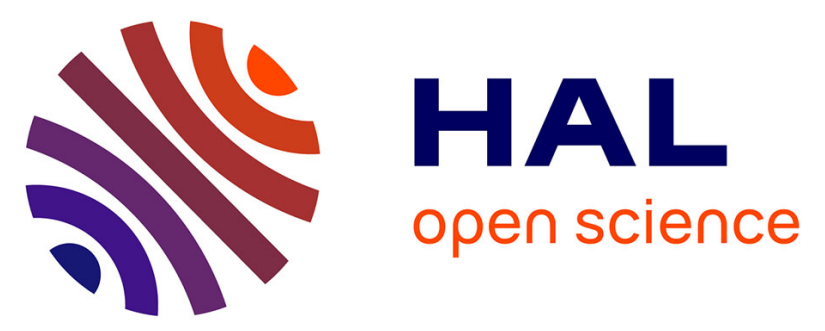

\title{
Myofiber metabolic type determination by mass spectrometry imaging
}

Laetitia Theron, Delphine Centeno, Annie Venien, Estelle Pujos-Guillot, Thierry Astruc, Christophe Chambon

\section{- To cite this version:}

Laetitia Theron, Delphine Centeno, Annie Venien, Estelle Pujos-Guillot, Thierry Astruc, et al.. Myofiber metabolic type determination by mass spectrometry imaging. SMMAP 2017 (Spectrométrie de Masse, Métabolomique et Analyse Protéomique), Oct 2017, Marne La Vallée, France. 476 p., 2017, Livre des résumés SMMAP 2017. hal-02734657

\section{HAL Id: hal-02734657 \\ https://hal.inrae.fr/hal-02734657}

Submitted on 2 Jun 2020

HAL is a multi-disciplinary open access archive for the deposit and dissemination of scientific research documents, whether they are published or not. The documents may come from teaching and research institutions in France or abroad, or from public or private research centers.
L'archive ouverte pluridisciplinaire HAL, est destinée au dépôt et à la diffusion de documents scientifiques de niveau recherche, publiés ou non, émanant des établissements d'enseignement et de recherche français ou étrangers, des laboratoires publics ou privés.

\section{(1) (1) $\$$}

Distributed under a Creative Commons Attribution - NonCommercial - NoDerivatives| 4.0 


\title{
SMMAP 2017
}

\author{
Conférence de \\ Spectrométrie de Masse, \\ Métabolomique et Fluxomique \& \\ Electrophorèse et Analyse Protéomique
}

\author{
Marne-la-Vallée, 2-5 octobre 2017
}

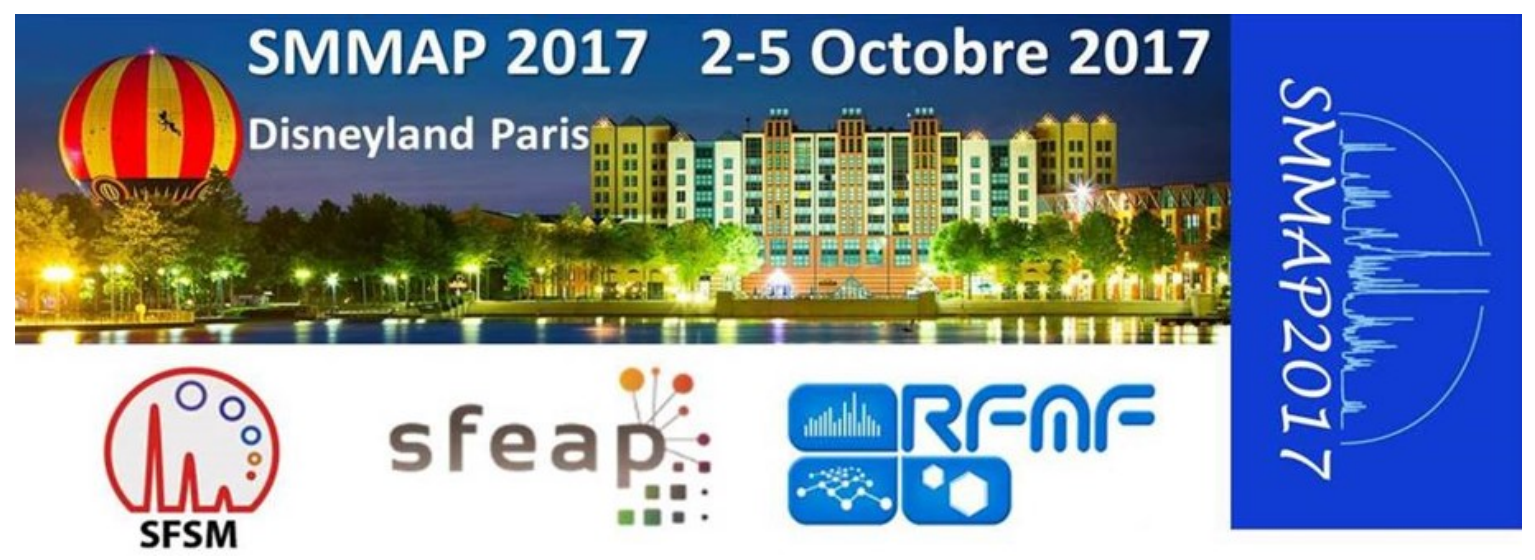

Société Française de Spectrométrie de Masse (SFSM)

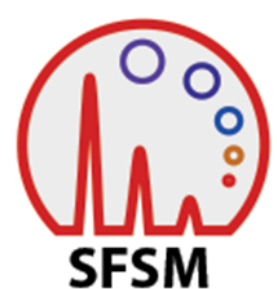

www.sfsm.fr
Société Française d'Electrophorèse et d'Analyse Protéomique (SFEAP)

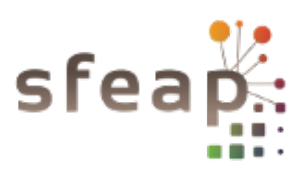

www.sfeap.fr
Réseau Francophone de Métabolomique et Fluxomique (RFMF)

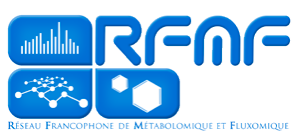

$\underline{\text { www.rfmf.fr }}$ 


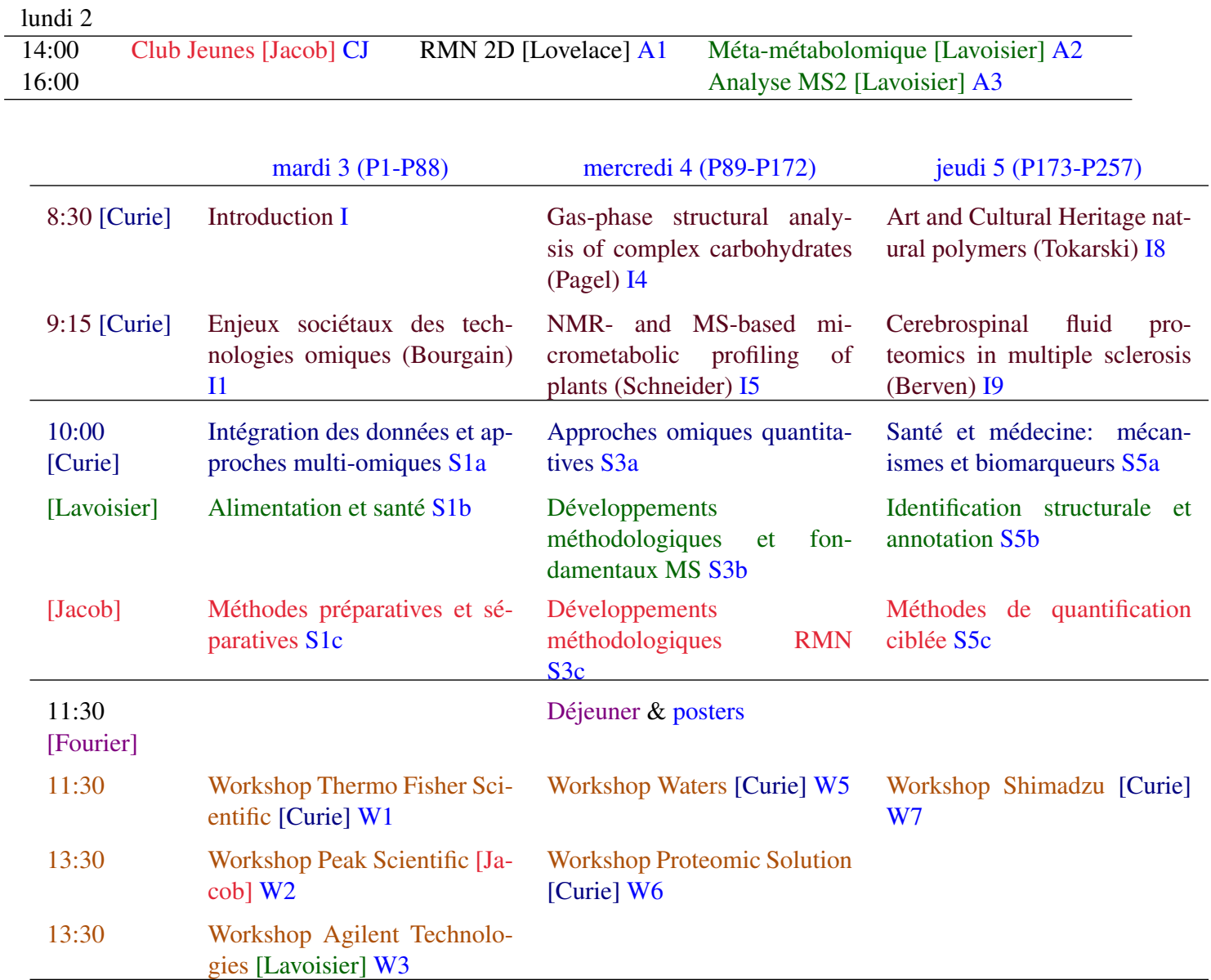

\begin{tabular}{|c|c|c|c|}
\hline $\begin{array}{l}13: 30 \\
{[\text { Curie }]}\end{array}$ & & & $\begin{array}{l}\text { Accurate lipidomic quantita- } \\
\text { tion: a case study of kidney } \\
\text { cancer (Holcapek) I10 }\end{array}$ \\
\hline $\begin{array}{l}14: 00 \\
{[\text { Curie }]}\end{array}$ & $\begin{array}{l}\text { Smart suspect screening in } \\
\text { real-world water samples } \\
\text { (Barceló) } \underline{\mathrm{I}} \underline{ }\end{array}$ & $\begin{array}{l}\text { Cancer cellular metabolism at } \\
\text { a spatio-temporal resolution } \\
\text { (Shlomi) I6 }\end{array}$ & $\begin{array}{l}\text { 14:15 Lauréats des prix Junior } \\
\text { et Docteurs } \underline{L}\end{array}$ \\
\hline $\begin{array}{l}14: 45 \\
{[\text { Curie }]}\end{array}$ & $\begin{array}{l}\text { The power and promise of a } \\
\text { thousand and one proteomes } \\
\text { (Martens) I3 }\end{array}$ & $\begin{array}{l}\text { Towards a functional plant } \\
\text { cell wall proteome } \\
\text { (Jamet) } \underline{17}\end{array}$ & \\
\hline $\begin{array}{l}15: 30 \\
\text { [Fourier] }\end{array}$ & & Pause café \& posters & \\
\hline $\begin{array}{l}16: 30 \\
{[\text { Curie }]}\end{array}$ & $\begin{array}{l}\text { Traitement et analyse statis- } \\
\text { tique des données } \underline{\mathrm{S} 2 \mathrm{a}}\end{array}$ & Clinique et diagnostic $\underline{\mathrm{S} 4 \mathrm{a}}$ & $\begin{array}{ll}\text { Modifications } & \text { post- } \\
\text { traductionnelles } \underline{\mathrm{S} 6 \mathrm{a}}\end{array}$ \\
\hline [Lavoisier] & $\begin{array}{l}\text { Imagerie in vitro et in vivo } \\
\underline{\mathrm{S} 2 \mathrm{~b}}\end{array}$ & Plantomics $\underline{\mathrm{S} 4 \mathrm{~b}}$ & Lipidomique $\underline{\mathrm{S} 6 \mathrm{~b}}$ \\
\hline [Jacob] & Environnement $\underline{\mathrm{S} 2 \mathrm{c}}$ & Fluxomique $\underline{\mathrm{S} 4 \mathrm{c}}$ & $\begin{array}{l}\text { Microbiologie : bactérie, } \\
\text { virus, champignon et méta- } \\
\text { omiques } \underline{\mathrm{S} 6 \mathrm{c}}\end{array}$ \\
\hline 18:00 & Workshop Bruker [Curie] W4 & AG des sociétés & Clôture du congrès \\
\hline 19:00 & Cocktail & & \\
\hline 20:00 & & Dîner de Gala & \\
\hline
\end{tabular}

$\underline{\text { Table des matières }}$ 


\section{Plan de centre de congrès de l'Hôtel New-York (Disney, Chessy - Marne-la-Vallée)}

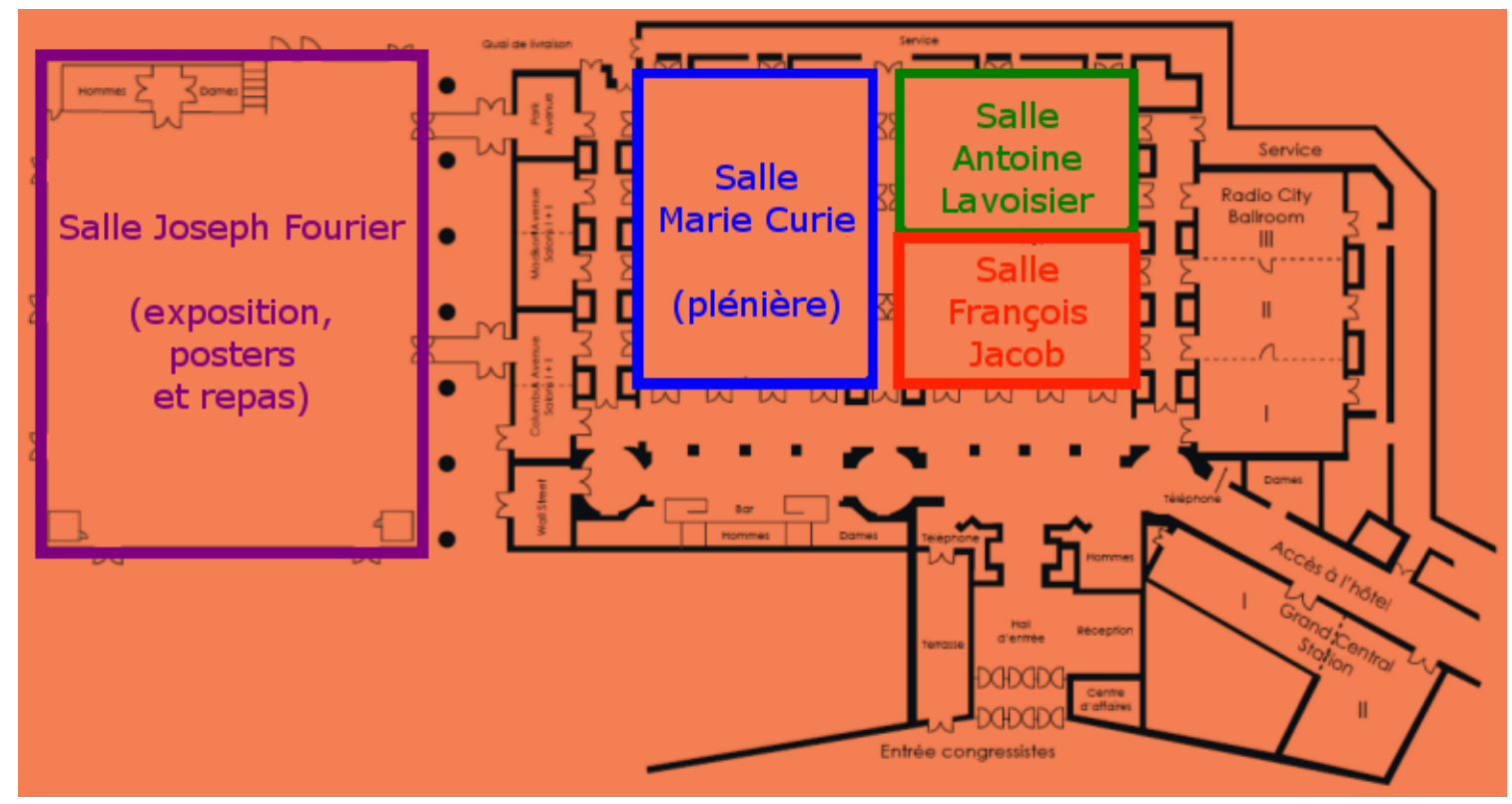

Plan de la salle d'exposition, posters et repas (Salle Joseph Fourier)

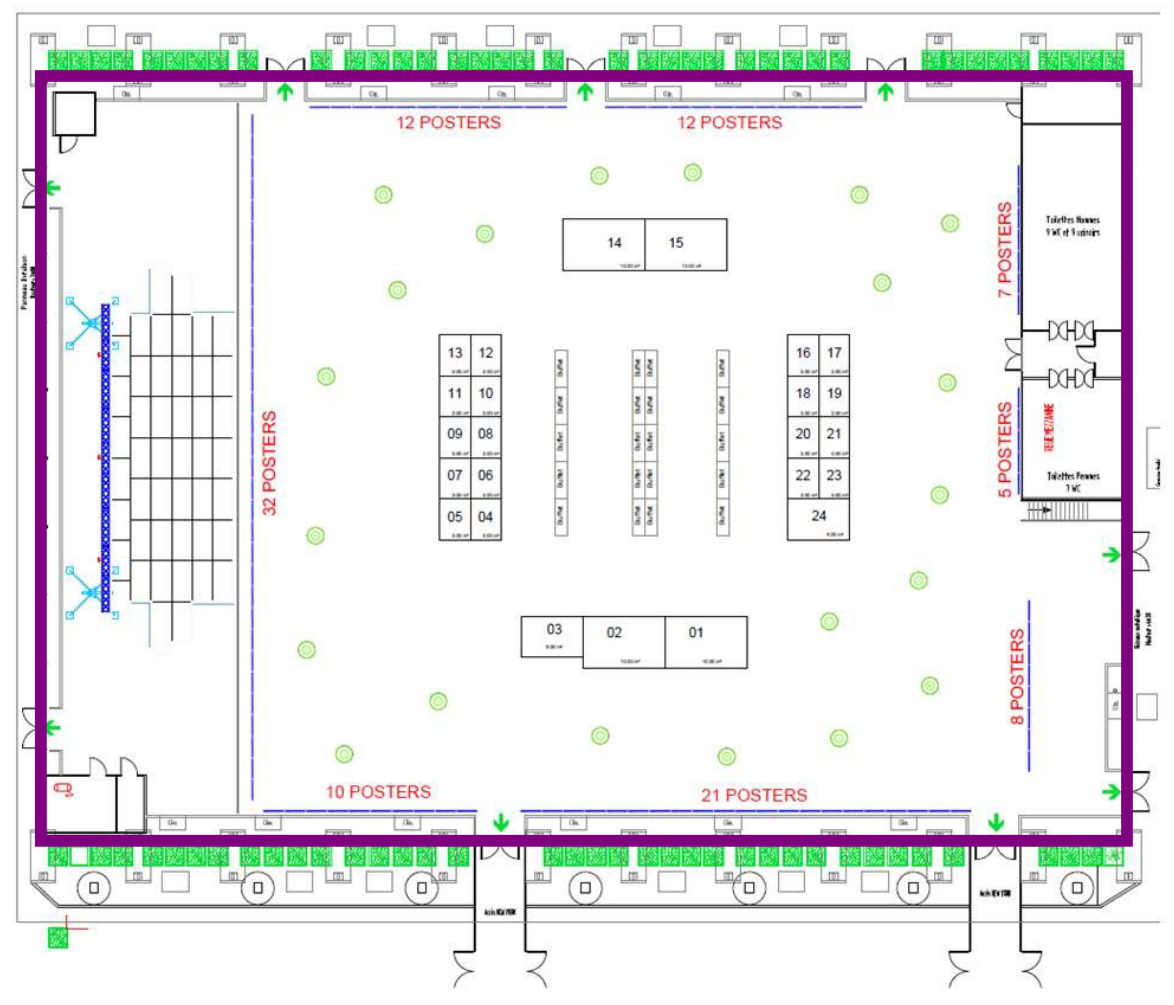

\begin{tabular}{|c|c|}
\hline $\mathrm{N}^{\circ}$ & Sociétés \\
\hline 1 & Waters \\
\hline 2 & Shimadzu \\
\hline 3 & Peak scientific \\
\hline 4 & MS Noise \\
\hline 5 & MS Vision \\
\hline 6 & LECO \\
\hline 7 & Chenomx \\
\hline 8 & Jeol \\
\hline 9 & Euriso-Top \\
\hline 10 & \begin{tabular}{|c|} 
Biotage $A B$ \\
\end{tabular} \\
\hline 11 & \begin{tabular}{|c|}
$\begin{array}{c}\text { Life sciences holdings France } \\
\text { sas (Sciex) }\end{array}$ \\
\end{tabular} \\
\hline 12 & \begin{tabular}{|c|} 
Proteingene \\
\end{tabular} \\
\hline 13 & Gengaz \\
\hline 14 & Bruker \\
\hline 15 & Thermo Fisher Scientific \\
\hline 16 & Anaquant \\
\hline 17 & La gazette du laboratoire \\
\hline 18 & $\mathrm{BCP}$ Instrument \\
\hline 19 & TGE FT-ICR \\
\hline 20 & RIC \\
\hline 21 & \\
\hline 22 & ProteinSimple \\
\hline 23 & Veolia \\
\hline 24 & Agilent Technologies \\
\hline
\end{tabular}




\section{Les partenaires}

\section{Platinum}

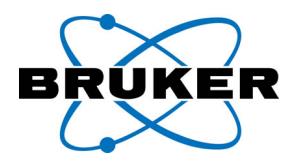

ФSHIMADZU

Thermofisher
$S$ C I E N T I F I C

Waters

THE SCIENCE OF

WHAT'S POSSIBLE.
Bruker

$\underline{\text { Shimadzu }}$

Thermo Fisher Scientific

$\underline{\text { Waters }}$

\section{Agilent Technologies \\ Peak Scientific}

$\underline{\text { Agilent Technologies }}$ 
Silver

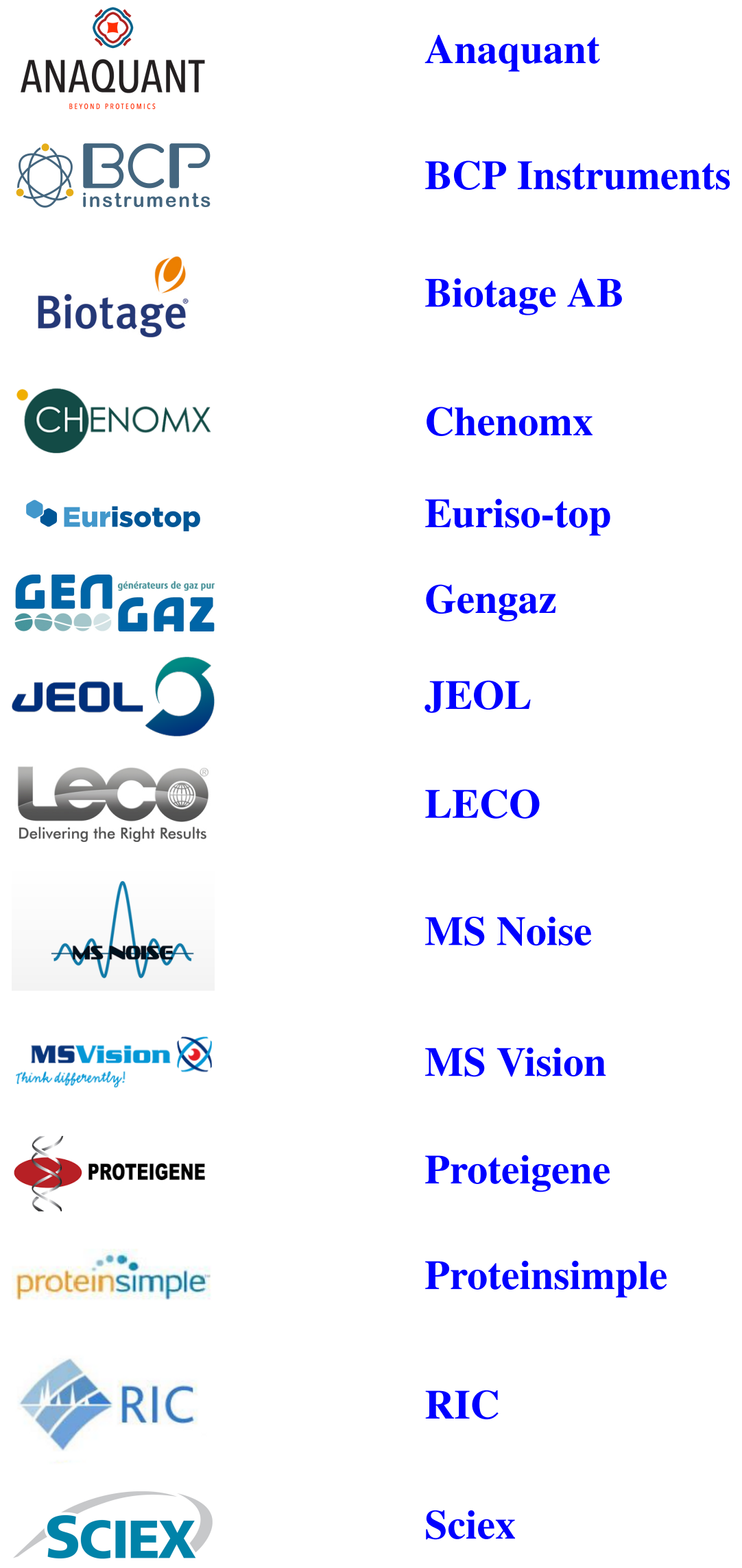


Institutionnels

Université d'Evry Val d'Essonne

METABOHUB MetaboHUB

unIversite

$\underline{\text { Université Paris-Saclay }}$

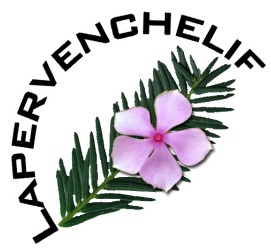

Association Lapervenchelif

cepa

Centre d'étude de la biodiversité amazonienne

Diffusion

\$) La gazette

LABORATOIRE

$\underline{\text { La gazette du laboratoire }}$

LAB RATOIRE Laboratoire.com

\section{Partenaire}

cortecnet $\quad \underline{\text { Biosolve-Nucleosyn }}$




\section{Introduction}




\section{Le mot des présidents}

Pour la première fois, la Société Française de Spectrométrie de Masse (SFSM), le Réseau Francophone de Métabolomique et Fluxomique (RFMF) et la Société Française d'Electrophorèse et Analyse Protéomique (SFEAP) sont heureux de vous présenter leur congrès joint SMMAP 2017 (Spectrométrie de Masse, Métabolomique et Analyse Protéomique 2017). Le comité local d'organisation vous accueillera à l'Hôtel New-York $®$ (Disneyland $囚$ Paris, Marne-la-Vallée-Chessy) du mardi 3 au jeudi 5 octobre 2017. Une journée satellite aura lieu le lundi 2 octobre afin d'accueillir les activités liées aux différents clubs jeunes, les formations ainsi que les tables rondes.

Cette édition unique, qui accueille plus de 510 scientifiques, sera placée sous le signe de l'interdisciplinarité et des échanges entre les communautés présentes habituellement à chacun des congrès annuels. Elle sera l'occasion d'approfondir nos connaissances, partager nos expériences et tisser de nouveaux liens scientifiques et humains. Ce congrès permettra aussi de rencontrer de nombreux industriels dans les domaines de l'instrumentation scientifique, la préparation d'échantillon ou le retraitement des données. Que la magie de Disney opère !

David Touboul, au nom du comité local d'organisation et du comité scientifique

Chers collègues, chers amis,

C'est avec un immense plaisir que nous nous retrouvons lors de la conférence annuelle de la Société Française de Spectrométrie de Masse (SFSM). Cette année, pour la première fois, notre société s'est jointe au Réseau Francophone de Métabolomique et Fluxomique (RFMF) et à la Société Française d'Electrophorèse et Analyse Protéomique (SFEAP) pour vous proposer une édition exceptionnelle, placée sous le signe de l'interdisciplinarité. SMMAP2017 sera ainsi l'opportunité pour tous de partager nos expériences et de tisser de nouveaux liens scientifiques et humains. Pour cette édition 2017, nous sommes heureux de vous accueillir à Disneyland $\mathbb{R}$ Paris, Marne-la-Vallée-Chessy et de vous proposer des thématiques variées qui, nous l'espérons, couvriront un large spectre de nos disciplines réciproques. Pour animer cet événement, le comité scientifique a fait appel à des orateurs de renommée internationale ainsi que de nombreux jeunes scientifiques garants de l'avenir et du dynamisme de nos sociétés. Cette année encore, nous avons une nouvelle fois la chance d'être accompagnés par des partenaires industriels fidèles sans qui cette manifestation ne pourrait pas être organisée.

SMMAP 2017, c'est l'occasion aussi pour la SFSM de faire partager avec ses membres les moments importants de la vie de la société. Comme chaque année, l'Assemblée Générale de la SFSM se tiendra lors de cette manifestation. La date retenue est le Mercredi 4 octobre à $18 \mathrm{~h}$ et nous espérons vous y retrouver nombreux. Nous profiterons de cette occasion pour vous annoncer la nomination de sept membres d'honneur au sein de notre société : Gérard Bolbach, Jeanine Tortajada, Jean-Claude Tabet, Christian Rolando, Alain Van Dorsselaer, Jean-Marie Schmitter, Bernard Monssarat, et Jean- François Gall. SMMAP2017 sera aussi pour nous l'occasion d'honorer nos jeunes membres en décernant le Prix de Thèse 2017 à Benoit Fatou de l’Université de Lille.

En espérant vous retrouver à SMMAP2017,

Aura Tintaru et Emmanuelle Leize-Wagner, Présidentes de la SFSM 
Au nom de la SFEAP, je vous souhaite la bienvenue au congrès SMMAP 2017, organisé conjointement avec la SFSM et, pour la première fois, le RFMF, et je vous remercie d'avoir été très nombreux à répondre présents à cette occasion. Cette organisation conjointe a permis d'élaborer un programme extrêmement riche qui, je l'espère, ne laisse de coté aucun aspect important de nos différentes disciplines et qui, à coté des conférences plénières avec des orateurs de renommée internationale, a permis d'offrir de très nombreuses opportunités de communications orales aussi bien aux jeunes scientifiques qu'aux leaders de nos trois communautés. Comme vous le constaterez, le programme scientifique met en avant de nombreuses convergences entre les champs disciplinaires couverts par nos trois sociétés et, j'en suis convaincu, créera de nombreuses opportunités de collaborations entre les membres de nos différentes communautés.

Je tiens également à remercier chaleureusement le comité local présidé par David Touboul et le comité scientifique pour la parfaite organisation précédent le congrès ainsi que les nombreux sponsors industriels sans qui l'organisation de cette manifestation ne serait pas possible, pour leur soutien et leur fidélité.

Bon congrès et bonne science à tous !

Philippe Marin, Président de la SFEAP

Chers collègues,

C'est avec grand plaisir que le Réseau Francophone de Métabolomique et Fluxomique (RFMF) se joint pour la première fois à la SFSM et à la SFEAP pour organiser ces journées scientifiques.

Le RFMF, créé en 2005, regroupe plus de 300 membres et s'est donné pour objectif de contribuer au développement de la métabolomique et de la fluxomique, de favoriser les échanges entre chercheurs du domaine, de promouvoir l'enseignement et la formation et d'accompagner les jeunes chercheurs dans leur début de carrière. Ces dernières années le périmètre de notre association s'est élargi aux pays francophones avec, comme concrétisation de cette intégration, la participation au conseil d'administration de collègues belges et suisses.

Les dernières éditions des journées scientifiques du RFMF ont montré que la métabolomique et la fluxomique doivent être appréhendées dans un contexte de biologie des systèmes, avec une intégration multiomique. SMMAP2017 sera l'occasion de renforcer ce lien avec d'autres approches "omiques" comme la protéomique. D'autre part, comme la protéomique, nos approches nécessitent le développement de méthodes originales en spectrométrie (de masse et RMN) qui sont notamment portées par les membres de la SFSM. Pour toutes ces raisons, nous sommes convaincus que SMMAP2017 sera l'occasion d'une émulation scientifique fructueuse entre nos communautés qui débouchera très certainement sur de nouvelles idées et collaborations.

Le RFMF met en avant, depuis son origine, le facteur humain dans la construction d'une société scientifique. Outre le slogan "bonne bouffe, bonne science" que nous portons haut et fort, nous avons toujours privilégié les échanges et la convivialité. Nous apprécions donc que le projet SMMAP2017 ait été construit dans cet esprit d'ouverture et d'échange. La part importante laissée aux jeunes chercheurs est aussi un point partagé par nos trois sociétés et qui donnera, à coup sûr, une belle dynamique à ces journées scientifiques. J'en profite pour remercier David Touboul, le comité d'organisation et le conseil scientifique de SMMAP2017 pour leur travail et leur investissement.

Bonne conférence à toutes et à tous. Métabolomiquement,

Fabien Jourdan, Président du RFMF 


\section{COMITÉ LOCAL D'ORGANISATION}

David Touboul (CNRS, Gif-sur-Yvette)

Stéphane Bouchonnet (Ecole Polytechnique)

Céline Boursier (Faculté de Pharmacie Chatenay-Malabry)

Alain Brunelle (CNRS, Gif-sur-Yvette)

Benoit Colsch (CEA, Saclay)

Jean-Nicolas Dumez (CNRS, Gif-sur-Yvette)

Florence Gonnet (Université Evry-Val d'Essonne)

Virginie Redeker (NeuroPSI, Gif-sur-Yvette)

Debora Scuderi (LCP, Université Paris Saclay)

Etienne Thévenot (CEA, Saclay)

Michel Zivy (INRA, Plateau du Moulon)

COMITÉ SCIENTIFIQUE

Frédéric Aubriet (Université de Lorraine)

Christine Carapito (IPHC, Strasbourg)

Patrick Giraudeau (Université de Nantes)

Fabien Jourdan (Président RFMF, INRA Toulouse)

Emmanuelle Leize-Wagner (Présidente SFSM, Faculté de Chimie de Strasbourg)

Philippe Marin (Président SFEAP, IGF, Montpellier)

Véronique Santoni (INRA, Montpellier)

Etienne Thévenot (CEA, Saclay)

David Touboul (CNRS, Gif-sur-Yvette)

Guillaume Van der Rest (Université Paris Saclay) 


\section{Informations générales}

\section{Ateliers}

La journée du lundi 2 octobre est consacrée aux ateliers scientifiques. L'inscription à ces ateliers est gratuite et doit se faire en suivant les instructions disponibles en ligne. Le programme proposé est le suivant :

- Réunion annuelle des trois clubs jeunes (Salle François Jacob, 14h-18h)

- Atelier 1: Méthodes rapides en RMN 2D pour l'analyse quantitative de mélanges (Salle Ada Lovelace, 14h-16h)

- Atelier 2: La métabolomique appliquée aux communautés (meta-métabolomique) (Salle Antoine Lavoisier, 14h-16h)

- Atelier 3 : Outils d'analyse des spectres de fragmentation pour l'identification des petites molécules (Salle Antoine Lavoisier, 16h-18h)

- Réunion ProFI (Salle Fred McLafferty, 15h30-18h)

- CA SFSM (Salle Ada Lovelace, 16h-18h)

- CA SFEAP (Salle Fred McLafferty, 14h-15h30)

- CA RFMF (Salle Ada Lovelace, 18h-20h)

\section{Sessions orales}

Les sessions orales auront lieu dans les salles Marie Curie, Antoine Lavoisier et François Jacob. Les conférences plénières auront lieu dans la salle Marie Curie.

Les supports visuels des oraux doivent être préparés en anglais et fournis aux modérateurs des sessions 30 minutes avant le début de la session. Seul le format pdf est disponible à la lecture sur les ordinateurs.

\section{Sessions posters}

Chaque poster sera affiché durant une journée complète de conférence. Les auteurs présentants devront se tenir près de leur poster durant toute la durée des sessions de présentation (pause déjeuner de $11 \mathrm{~h} 30$ à $14 \mathrm{~h}$ et pause-café de l'après-midi).

Les posters seront présentés les jours suivants :

$\begin{array}{ll}\text { Mardi } 3 \text { octobre } & \text { P1 à P88 } \\ \text { Mercredi } 4 \text { octobre } & \text { P89 à P172 } \\ \text { Jeudi } 5 \text { octobre } & \text { P173 à P257 }\end{array}$


Les posters doivent être préparés au format A0 vertical en français ou en anglais. Des supports de fixation seront fournis par les organisateurs. Les posters devront être mis en place au plus tard à $11 \mathrm{~h} 30$. Ils doivent être retirés au plus tard à $18 \mathrm{~h}$. Tout poster non détaché le lendemain matin sera détaché par l'équipe technique et ne sera pas récupérable. Pour les posters exposés le jeudi, ils devront être impérativement détachés après la pause-café de l'après-midi.

\section{Workshops}

Des workshops constructeurs sont organisés durant l'ensemble du congrès. Le programme est le suivant :

$\begin{array}{lll}\text { Mardi } 3 \text { octobre } & \begin{array}{l}11 \mathrm{~h} 30-12 \mathrm{~h} 30 \\ 13 \mathrm{~h} 30-14 \mathrm{~h}\end{array} & \begin{array}{l}\text { Thermo Fisher Scientific } \\ \text { Agilent Technologies }\end{array} \\ & \begin{array}{l}13 \mathrm{~h} 30-14 \mathrm{~h} \\ 18 \mathrm{~h}-19 \mathrm{~h}\end{array} & \begin{array}{l}\text { Peak Scientific } \\ \text { Bruker }\end{array} \\ & & \\ \text { Mercredi 4 octobre } & 11 \mathrm{~h} 30-12 \mathrm{~h} 30 & \text { Waters } \\ & 13 \mathrm{~h} 30-14 \mathrm{~h} & \text { Proteomic Solutions }\end{array}$

Jeudi 5 octobre $\quad$ 11h30-12h30 Shimadzu

\section{Déjeuners \& Pauses cafés}

Les déjeuners auront lieu dans la salle d'exposition de $12 \mathrm{~h}$ à $13 \mathrm{~h} 30$.

Les pause cafés auront lieu dans la salle d'exposition de $15 \mathrm{~h} 30$ à $16 \mathrm{~h} 30$.

\section{Bagagerie}

Une bagagerie sera mise en place tous les jours de $8 \mathrm{~h} 30$ à $18 \mathrm{~h}$.

\section{Badge}

Seuls les porteurs de badge seront admis aux sessions, repas, workshops et ateliers.

\section{Accès WI-FI}

Le centre de congrès sera équipé d'un accès WI-FI gratuit avec une bande passante réduite vous permettant de consulter vos emails. Les codes d'accès vous seront fournis durant la conférence.

\section{Cocktail de bienvenue}

Un cocktail de bienvenue sera organisé le mardi 3 octobre à 19h. Il aura lieu dans la salle d'exposition. Le cocktail est offert par le DIM Analytics (Région Ile-de-France). 


\section{Soirée de gala}

La soirée de gala aura lieu au restaurant King Ludwig's Castle dans une ambiance bavaroise. L'apéritif sera servi à partir de 19h30. Merci de vous munir de votre badge, un contrôle sera effectué à l'entrée.

$\underline{\text { Programme }}$

Table des matières 


\section{Programme détaillé}




\section{Mardi 3 octobre}

\section{8:45 Introduction - Présidents des trois sociétés organisatrices (SFSM, Marie SFEAP, RFMF) I \\ Curie}

9:15 Enjeux sociétaux des technologies omiques - Catherine Bourgain (INSERM, Paris Descartes, France) I1

10:00- Intégration des données et approches multi-omiques S1a (Modérateurs

10:00 > Metabolite imaging and shotgun proteomics to decipher the role of epididymis in sperm maturation - Karolina Modzelewska, PROTIM O1

10:30 > Identification d'une nouvelle classe de lanthibiotiques : utilisation combinée de l'exploration de données génomiques et de la spectrométrie de masse MALDI et HRMS - Sophie Tirat, Institut Charles Violette O2

10:50 > Modélisation du réseau métabolique des cellules de Leucémies Aiguës Myéloïdes pour comprendre les différences métaboliques liées à la mutation sur IDH1 - Nathalie Poupin, ToxAlim $\underline{\mathrm{O} 3}$

11:10 > Multiblock Omics data fusion: an efficient strategy to understand climatic effect on flaxseed (Linum usitatissimum) composition - Roland Molinié, Laboratoire de Biologie des Plantes et Innovation $\underline{\mathrm{O} 4}$

10:00- Alimentation et santé S1b (Modérateurs : Véronique Santé-Lhoutellier \&

10:00 > Input of proteomic analyses for understanding cellular responses to nanoparticles: toward mechanistic data and evidence for cross-toxic effects

- Thierry Rabilloud, Chemistry and Biology of Metals $\underline{\mathrm{O} 5}$

10:30 > Breast milk lipidome as a predictive component of postnatal growth trajectory in preterm infants. - Marie-Cécile Alexandre-Gouabau, Physiologie des Adaptations Nutritionnelles, Centre de Recherche en Nutrition Humaine Ouest $\underline{\mathrm{O} 6}$

10:50 > Découverte de marqueurs précoces de l'altération des ovoproduits au cours de leur procédé de fabrication par des approches de prises d'empreintes métabolomique utilisant des techniques combinées (RMN et MS) - Rémy Coat, Laboratoire de génie des procédés - environnement agroalimentaire $\underline{\mathrm{O} 7}$

11:10 > Shotgun polyphenomics of rosé wines: - Cédric Saucier, Université de Montpellier, UMR 1083 Sciences pour l'Enologie, INRA, Montpellier SupAgro 08 
10:00- Méthodes préparatives et séparatives S1c (Modératrices : Emmanuelle

11:30

Leize-Wagner \& Maud Fumex)

François

Jacob

10:00 > Characterization of monoclonal antibodies - receptor interaction using affinity liquid chromatography coupled to native mass spectrometry - Rabah Gahoual, Unité de Technologies Chimiques et Biologiques pour la Santé, Division of BioAnalytical Chemistry, Vrije Universiteit Amsterdam O9

10:30 > Flowers absolute fingerprint with SFC-HRMS non targeted method Cyrille Santerre, Institut Supérieur International du Parfum de la Cosmétique et de l'Aromatique Alimentaire $\underline{\mathrm{O} 10}$

10:50 > An online four-dimensional HICXSEC-IMxMS methodology for in-depth characterization of antibody drug conjugates - Anthony Ehkirch, Laboratoire de Spectrométrie de Masse BioOrganique $\underline{\mathrm{O} 11}$

11:10 > Analysis of Monoclonal Antibody Fc-glycosylation profiles using Capillary electrophoresis - mass spectrometry - Jeremie Giorgetti, Laboratoire de Spectrométrie de Masse des Interactions et des Systèmes $\underline{\mathrm{O} 12}$

11:30-

Déjeuner \& posters $\underline{[\mathrm{P} 1-\mathrm{P88}]}$

14:00

11:30- Workshop Thermo Fisher ScientificW1

Marie

$12: 30$

13:30- Workshop Peak Scientific W2

Curie

François

14:00

Jacob

13:30- Workshop Agilent Technologies W3

Antoine

14:00

Lavoisier

14:00 Smart Suspect Screening and Related HRMS Approaches for Detection Marie of Pharmaceuticals and their Transformation products in Real-World Curie Water samples - Damia Barceló (Catalan Institute of Water Research, Barcelone, Spain) $\underline{\mathbf{I}}$

14:45 The power and promise of a thousand and one proteomes - Lennart Martens (Université de Gent, Belgique) $\underline{\mathbf{I}}$ 
16:30- Traitement et analyse statistique des données S2a (Modérateurs : $\quad$ Marie

18:00 Etienne Thévenot \& Joanna Bons) Curie

16:30 > SpecOMS permet d'obtenir le profil des modifications portées par un échantillon analysé en MS/MS en quelques minutes - Dominique Tessier, Unité de recherche sur les Biopolymères, Interactions Assemblages $\underline{\mathrm{O} 13}$

17:00 > Combattre le feu par le feu: Comprehensive DIA spectral libraries improve phosphopeptide identification and quantification by DIA - Sebastian Vaca, Broad Institute of MIT and Harvard, Cambridge, MA, USA O14

17:20 > Complex designs combining ASCA/APCA-derived methods and mixed models - Manon Martin, Institut de Statistique, Biostatistique et Sciences Actuarielles $\underline{\mathrm{O} 15}$

17:40 > Two birds, one stone: ANOVA multiblock OPLS supports data analysis and method comparison in toxicant-induced neuroinflammation observed in 3D rat neural cell cultures - Víctor González-Ruiz, Analytical Sciences, School of Pharmaceutical Sciences, Swiss Centre for Applied Human Toxicology $\underline{\mathrm{O} 16}$

16:30- Imagerie in vitro et in vivo S2b (Modérateurs : Nicolas Desbenoit \&

Antoine Lavoisier Benoit Fatou)

16:30 > Analysis of Chemotherapeutic Drug Delivery at the Single Cell Level Using TOF-SIMS - Quentin Vanbellingen, Department of Chemistry and Biochemistry, Florida International University, Miami, FL, USA O17

17:00 > MetaSpace: A molecular annotation engine for metabolite imaging mass spectrometry - Régis Lavigne, PROTIM O18

17:20 > Development of a dual imaging strategy combining radio- and mass spectrometry -imaging to study the biodistribution of 14C-graphene oxide - Hélène Cazier, CEA-INRA UMR 0496/DRF/Institut Joliot/SPI/LEMM, Université Paris Saclay, MetaboHUB O19

17:40 > Characterization and localization of synthetic cannabinoid isomers in hair using MALDI-MSn imaging - Angéline Kernalléguen, Université AixMarseille, INSERM CRO2 UMR S-911, Marseille, France O20

16:30- Environnement S2c (Modérateurs : Frédéric Aubriet \& Arul Marie) 18:00

16:30 > Apport et limites des approches non ciblées de spectrométrie de masse à haute résolution pour la caractérisation de l'exposome : cas des pesticides Laurent Debrauwer, Metatoul Axiom platform - MetaboHUB, UMR 1331 Toxalim - INRA-ENVT-INP-EIP-UPS $\underline{\mathrm{O} 21}$
François Jacob 
17:00 > LC-HRMS based metabolomics to highlight biotransformation products and unexpected effects of diclofenac in Mytilus galloprovincialis Frédérique Courant, Hydrosciences Montpellier O22

17:20 > Ecotoxicity of sunlight irradiated marketed mixtures of acetamiprid and structural characterisation of unknown photoproducts - Edith Nicol, Laboratoire de chimie moléculaire $\underline{\mathrm{O} 23}$

17:40 > Intrinsic ion mobility peak width as an indicator of isomeric species distribution in petroleum using ion mobility - mass spectrometry - Carlos Afonso, Normandie Univ, FR 3038; IRCOF, (COBRA) - Université de Rouen, CNRS : UMR6014, INSA Rouen $\underline{\mathrm{O} 24}$

18:00- Workshop Bruker W4 
8:30 Gas-phase structural analysis of complex carbohydrates - Kevin Pagel Marie (Université libre de Berlin, Berlin, Allemagne) $\underline{I 4}$

9:15 NMR- and MS-based micrometabolic profiling of plants - Bernd Schneider (Max Planck Institute for Chemical Ecology Jena, Germany) $\underline{\mathbf{I}}$

10:00- Approches omiques quantitatives S3a (Modérateurs : Christine Carapito

10:00 > Proteomic analysis reveals strong secretion of IL-9 by group2 innate lymphoid cells upon IL-33/TL1A co-stimulation - Anne Gonzalez de Peredo, Institut de Pharmacologie et Biologie Structurale (IPBS), UMR5089 CNRS - Université de Toulouse $\underline{\mathrm{O} 25}$

10:30 > Carbon 12 metabolic labeling for high-throughput quantitative proteomics - Jean-Michel Camadro, Institut Jacques Monod O26

10:50 > Ultra-Short Column-Differential Mobility Spectrometry-Mass Spectrometry for Monitoring Oxidative Stress Markers in Human Whole Blood. Sophie Bravo-Veyrat, Université de Genève $\underline{\mathrm{O} 27}$

11:10 > Regulation of Metabolic Enzymes by Lysine Deacetylase Inhibitors in A549 Non-Small Cell Lung Cancer Cells - Sandrine Bourgoin-Voillard, LBFA et BEeSy, PROMETHEE Proteomic Platform O28

10:00 > Weighing intact viral capsids using nanomechanical resonators mass spectrometry. - Christophe Masselon, CEA Grenoble (DRF/BIG/BGE) O29

10:30 > Etude de la préservation des kératines de cheveux de momies par une approche protéomique spécifiquement dédiée - Armelle Charrié-Duhaut, Laboratoire de Spectrométrie de Masse des Interactions et des Systèmes (LSMIS), Université de Strasbourg, CNRS, CMC UMR 7140 O30

10:50 > Bridging the technological gap between mass spectrometry and spectroscopy for the structural resolution of isomers: application to glycomics Baptiste Schindler, Institut Lumière Matière [Villeurbanne] O31

11:10 > De la formation des ions sous ESI à leur dissociation: une histoire différemment perçue sous la haute résolution - Jean-Claude Tabet, CEA, iBiTec-S, SPI, LEMM CEA-Saclay et Sorbonne Universités, UPMC Univ Paris 06, CNRS, Institut Parisien de Chimie Moléculaire $\underline{\text { O32 }}$ 
10:00- Développements méthodologiques RMN S3c (Modérateurs :

François

$11: 30$

Jean-Nicolas Dumez \& Patrick Giraudeau)

Jacob

10:00 > The development of HR-MAS NMR towards g biospecimens - Alan Wong, Laboratoire de Structure et Dynamique par Résonance Magnétique $\underline{\mathrm{O} 33}$

10:30 > Mise en place d'une approche combinée MS-RMN pour aider à l'interprétation des données de stabilité des médicaments - Cécile Palaric, Technologie Servier, Plateforme analytique, Laboratoire de BIOlogie des Plantes et Innovation (BIOPI) $\underline{\mathrm{O} 34}$

10:50 > Recherche des marqueurs de la production de méthane chez la vache laitière - Bénédict Yanibada, Unité Mixte de Recherche sur les Herbivores $\underline{\mathrm{O} 35}$

11:10 > Développement d'un protocole de pré-traitement analytique pour l'analyse métabolomique par RMN d'échantillons rénaux congelés dans l'OCT (Optimal Cutting Temperature compound) - Justine Leenders, Centre Indisciplinaire de Recherche sur le Médicament (CIRM) $\underline{\mathrm{O} 36}$

11:30-

Déjeuner \& posters [P89-P172]

14:00

11:30- Workshop Waters W5

Marie

$12: 30$

Curie

13:30- Workshop Proteomic Solution W6

Marie

14:00

Curie

14:00 Cancer cellular metabolism at a spatio-temporal resolution - Tomer Marie Shlomi (Technion, Haifa, Israël) $\underline{\text { I6}}$

Curie

14:45 Towards a functional plant cell wall proteome atlas: from protein identification to characterization of post-translational modifications - Elisabeth Jamet (LRSV, Toulouse, France) $\underline{\mathbf{I}}$

15:30-

Pause café \& posters [P89-P172]

$16: 30$ 
16:30- Clinique et diagnostic S4a (Modératrices : Virginie Brun \& Justine Marie

18:00 Leenders) Curie

16:30 > Proteomic analysis of exosomes for biomarker research in rare genetic diseases. - Chiara Guerrera, Proteomics platform 3P5-Necker, Université Paris Descartes - Structure Fédérative de Recherche Necker $\underline{037}$

17:00 > MALDI-MSI based top down micro-proteomics: evidence of a hidden proteome - Julien Franck, Protéomique, Réponse Inflammatoire, Spectrométrie de Masse (PRISM), U1192, Université de Lille 1, France O38

17:20 > A Proton NMR Metabolomic Investigation of an Emerging Genetic Disease - Houda Boumaza, Université de Lyon, Institut des Sciences Analytiques, UMR 5280, CNRS, ENS de Lyon, Villeurbanne, France O39

17:40 > Proteomics investigation of Wilson's disease pathophysiology using the ATP7B-/- murine model - Maud Lacombe, CEA Grenoble $\underline{\mathrm{O} 40}$

16:30- Plantomics S4b (Modérateurs : Véronique Santoni \& Guillaume Meiffren)

16:30 > Caractérisations chimique et biologique de composés discriminants au sein du métabolome symbiotique Alnus viridis-Frankia - AnneEmmanuelle Hay, CESN, Laboratoire d'Écologie Microbienne O41

17:00 > ChloroKB: a web-application for the integration of knowledge related to chloroplast metabolic network - Myriam Ferro, Exploring the Dynamics of Proteomes (EDyP), BGE/U1038, INSERM/CEA/Université Grenoble Alpes $\underline{\mathrm{O} 42}$

17:20 > Description of developmental transitions of tomato fruit through Proteome and Metabolome quantitative analysis - Isma Belouah, Biologie du Fruit et Pathologie, Plateforme Métabolome Bordeaux (PMB-MetaboHUB), Université de Bordeaux, INRA, Villenave d'Ornon, France $\underline{\mathrm{O} 43}$

17:40 > Leaf ageing imprinting on metabolism and nitrogen nutrient recycling in oilseed rape (Brassica napus L.), a metabolomic and fluxomic view - Alain Bouchereau, Université de Rennes $1 \underline{\mathrm{O} 44}$

16:30- Fluxomique $\mathbf{S 4 c}$ (Modérateurs : Fabien Jourdan \& Floriant Bellvert)

16:30 > A novel approach for simultaneous absolute quantification and isotopic analysis of metabolome - Maud Heuillet, Metatoul - MetaboHUB, Laboratoire d'Ingénierie des Systèmes Biologiques et des Procédés $\underline{\mathrm{O} 45}$ 


\section{Mercredi 4 octobre}

17:00 > IDH mutation dictates a global redirection of catabolic and redox pathways towards $2 \mathrm{HG}$ biosynthesis leading to mitochondrial OxPHOS dependency and chemoresistance in acute myeloid leukemia - Lucille Stuani, Team ResistAML, Drug resistance \& oncometabolism in acute myeloid leukemia, CRCT $\underline{\mathrm{O} 46}$

17:20 > Study of sclareol biosynthesis for clary sage metabolic engineering Camille Chalvin, Institute of Plant Sciences Paris-Saclay O47

17:40 > Analyse multiplexe des flux protéiques par l'utilisation d'isotopes stables et de la LC-MS/MS : applications aux apolipoprotéines - Mikaël Croyal, Centre de Recherche en Nutrition Humaine $\underline{\mathrm{O} 48}$

18:00-

20:00

\section{AG des sociétés}

Diner de Gala 
8:30 Art and Cultural Heritage natural polymers by bottom-up and top- Marie down approaches - Caroline Tokarski (Université de Lille, France) I8 Curie

9:15 Cerebrospinal fluid proteomics in multiple sclerosis - Frode Berven (Université de Bergen, Norvège) $\underline{\underline{9}}$

10:00- Santé et médecine: mécanismes et biomarqueurs S5a (Modérateurs : Marie

11:50 Philippe Marin \& Blandine Chazarin) Curie

10:00 > On chip detection and proteomics of platelet-derived microparticles Géraldine Lucchi, Institut de Chimie Moléculaire de l'Université de Bourgogne $\underline{\mathrm{O} 49}$

10:30 > Metabolomic NMR studies \& Huntington's disease: models in transgenic drosophila - Marylène Bertrand, Centre de biophysique moléculaire O50

10:50 > Développement d'une approche multi-omique pour la recherche de biomarqueurs associés à la réponse au traitement dans les lymphomes - LucMatthieu Fornecker, Hôpitaux Universitaires de Strasbourg ; Laboratoire de Spectrométrie de Masse BioOrganique (LSMBO), IPHC, UMR7178, Strasbourg $\underline{051}$

11:10 > Combined laser microdissection and proteomic analysis for identification of tumor signatures - Anne-Aurélie Raymond, INSERM, UMR1053, BaRITOn Bordeaux, 9. Oncoprot, INSERM 1053, TBM-Core US 005 O52

11:30 > A native MS Study of RNA kissing complexes and their interaction with magnesium cations - Clémence Rabin, Université de Bordeaux (ARNA) $\underline{\mathrm{O} 53}$

10:00- Identification structurale et annotation S5b (Modérateurs : Marc-André 11:30 Delsuc \& Sandrine Aros-Calt)

Antoine

Lavoisier

10:00 > Elucidation of the Parkinsonism-associated protein DJ-1/Park7 function as a major protein and DNA deglycase - Thibaut Léger, Institut Jacques Monod $\underline{\mathrm{O} 54}$

10:30 > ASICS: an automatic method for identification and quantification of metabolites in complex 1D 1H NMR spectra - Rémi Servien, UMR Toxalim, Université de Toulouse $\underline{\text { O55 }}$

10:50 > Computer-aided dereplication of natural products: 13C NMR-based strategies - Ali Bakiri, Institut de Chimie Moléculaire de Reims, Soliance $\underline{\mathrm{O} 56}$ 
11:10 > Développement de stratégies analytiques originales pour l'étude des actifs volatils de Frullania tamarisci - Anais Pannequin, Laboratoire de Chimie des Produits Naturels, Université de Corse, UMR CNRS 6134, Campus Grimaldi, BP 52, 20250 Corte, France $\underline{\mathrm{O} 57}$

10:00- Méthodes de quantification ciblée S5c (Modératrices : Laetitia Fougère $11: 30$ \& Pauline Bros)

François Jacob

10:00 > Mass spectrometry and chemical labeling as a powerful tool for peptide quantitation in pharmacology - Christine Enjalbal, Institut des Biomolécules Max Mousseron [Pôle Chimie Balard] $\underline{058}$

10:30 > Top-down and bottom-up mass spectrometry approaches for Alphasynuclein analysis in biological fluids - Arthur Viodé, CEA Saclay, DRF/JOLIOT/SPI-INRA UMR 0496, Laboratoire d'Etude du Métabolisme des Médicaments $\underline{\text { O59 }}$

10:50 > Altered brain energy metabolism in Alzheimer disease: Linking peripheral and central metabolic changes - Tony Teav, Metabolomics Research Platform, Faculty of Biology and Medecine, University of Lausanne O60

11:10 > Identifying autoimmune beta-cell epitopes in type 1 diabetes by HLApeptidomics - Sergio Gonzalez Duque, Institut Cochin, Université Paris Descartes, INSERM U1016 - CNRS UMR 8104 / Diabetes and Autoimmunity Research Lab, ESPCI Paris, PSL, Spectrométrie de Masse Biologique et Protéomique (SMBP), CNRS O61

11:30-

Déjeuner \& posters [P173-P257]

$13: 30$

11:30- Workshop Shimadzu W7

Marie

$12: 30$

Curie

13:30- Accurate lipidomic quantitation: a case study of kidney cancer - Michal Marie

14:15 Holcapek (Université de Pardubice, République Tchèque) I10 Curie 
14:15-

Lauréats Junior \& Docteurs $\underline{\mathbf{L}}$

14:15 Prix de la présentation Junior O62

14:30 Development of microsampling tools by laser ablation and mass spectrometry for the characterization of biological tissues - Benoit Fatou, PRISM, Université Lille 1 (Prix de thèse SFSM) O63

14:50 De la classification moléculaire des gliomes à une nouvelle stratégie thérapeutique de réactivation des macrophages au sein de la tumeur - Marie Duhamel, PRISM, Université Lille 1 (Prix de thèse SFEAP) O64

15:10 Blandine Madji Hounoum, Université François-Rabelais, Tours (Prix de thèse RFMF) $\underline{\mathrm{O} 65}$

16:30- Modifications post-traductionnelles S6a (Modérateurs : Willy Bienvenut

16:30 > Intensive fractionation and Click chemistry as a powerful method for identification of O-GlcNAcylation sites - Caroline Cieniewski-Bernard, Unité de Recherche Pluridisciplinaire Sport, Santé, Société, Université Lille 1 $\underline{\mathrm{O} 66}$

17:00 > Quantitative analysis of redox modifications of protein cysteines in biofilm and planktonic Escherichia coli- Giovanni Chiappetta, Spectrométrie de Masse Biologique et Protéomique $\underline{067}$

17:20 > Large-scale proteomic analysis of SIRT1- and tissue-dependent acetylproteome in mouse liver, testis and muscle - Marie Locard-Paulet, Institut de pharmacologie et de biologie structurale $\mathrm{O68}$

17:40 > Proteomic study of histone acylations - Marion Crespo, CEA Tech Grenoble $\underline{\mathrm{O} 69}$

16:30- $\quad$ Lipidomique S6b (Modérateurs : Pauline Le Faouder \& Laurent

16:30 > Une approche combinée de lipidomique, d'imagerie MS et d'imagerie TEP-Scan révèle des différences de fonctionnement cérébral chez le raton selon le contenu lipidique de formules infantiles - Jean-Charles Martin, INRA UMR1260 $\underline{\mathrm{O} 70}$

17:00 > Two-dimensional mass spectrometry patterns as a tool for lipidomics: application to human blood plasma with different oxidation states - Fabrice Bray, Miniaturisation pour la Synthèse et l'Analyse Protéomique $\underline{\text { O71 }}$ 
17:20 > Multilevel statistics applied to NMR/MS lipidomics - Jérémy Marchand, LUNAM Université, Oniris, Laboratoire d'Etude des Résidus et Contaminants dans les Aliments (LABERCA), UMR INRA 1329, Chimie Et Interdisciplinarité : Synthèse, Analyse, Modélisation $\underline{\mathrm{O} 72}$

17:40 > Apport de la spectrométrie de masse dans la caractérisation structurale et l'analyse des phospholipides oxydés - Spiro Khoury, Unité de Nutrition Humaine UMR 1019 INRA / Université Clermont 1 Plate-forme d'Exploration du métabolisme PFEM $\underline{073}$

16:30- Microbiologie: bactérie, virus, champignon et méta-omiques S6c

18:00

(Modérateurs : Grégory Genta-Jouve \& Oriane Moyne)

François

Jacob

16:30 > Discrimination de biofilms marins par métabolomique - Gérald Culioli, MAPIEM $\underline{074}$

17:00 > Lysine modifications in Pseudomonas aeruginosa PA14 - Charlotte Gaviard, CNRS UMR $6270 \underline{\text { O75 }}$

17:20 > An integrated innovative top-down proteomics workflow for the rapid discrimination of enterobacterial pathogens - Mathieu Dupre, Unité de Spectrométrie de Masse Structurale et Protéomique, Institut Pasteur, Paris $\underline{\mathbf{O} 76}$

17:40 > NRPomics : Kendrick mass defect for molecular formula assignment of non ribosomal peptides (NRPs) - Mickael Chevalier, Univ. Lille, INRA, ISA, Univ. Artois, Univ. Littoral Côte d'Opale, Charles Viollette Institute $\underline{\mathrm{O} 77}$

18:00- Clôture du congrès - Présidents des trois sociétés (SFSM, SFEAP, Marie 
Ateliers, tables rondes et club jeunes 


\section{Club Jeunes : Réunion annuelle des trois clubs je- unes [CJ]}

Personnes animant l'atelier : Responsables des différents CJ (CJSFEAP : chazarin@ unistra.fr, RFMF junior : saros.calt@gmail.com, CJSM : clubjeunesm@gmail.com)

Public envisagé : La demi-journée est libre d'accès à toute personne souhaitant y participer

Contexte : Cette demi-journée est l'occasion pour nos membres de présenter leurs résultats et d'échanger entre jeunes chercheurs.

Un appel à communication vous sera adressé par vos CJ respectifs. Les CJ sélectionneront ensuite 3 propositions orales parmi celles reçues. Au total, la demi-journée comprendra donc 9 présentations de 15 minutes.

La meilleure présentation se verra attribuer un créneau pour une communication orale lors du congrès SMMAP2017.

Pour avoir plus d'information au sujet de cette demi-journée, nous vous encourageons à contacter le Club Jeune auquel vous appartenez.

Date et lieu : Lundi 2 octobre à 14h (Salle François Jacob).

$\underline{\text { http://cj.sfeap.fr/ http://www.rfmf.fr }}$ http://www.cjsm.sfsm.fr/

$\underline{\text { Programme }}$ 


\section{Atelier 1 : Méthodes rapides en RMN 2D pour l'analyse quantitative de mélanges [A1]}

Personnes encadrant la formation : Jean-Nicolas Dumez (jeannicolas.dumez@ cnrs.fr), Patrick Giraudeau (patrick.giraudeau@univ-nantes.fr)

Public envisagé et prérequis : Cet atelier s'adresse à toute personne désireuse d'appréhender l'intérêt de la RMN 2D pour l'analyse quantitative en métabolomique et fluxomique. Prérequis : connaissances de base en métabolomique par RMN 1D.

Objectif de la formation : L'objectif de la formation est d'initier les participants à l'acquisition et au traitement des données en RMN 2D pour l'analyse quantitative de mélanges complexes tels que ceux rencontrés en métabolomique et fluxomique. L'idée principale est de donner aux participants les moyens de choisir et de mettre en œuvre les expériences les plus appropriées à leur problématique. L'atelier sera centré sur les méthodes d'acquisition rapides en RMN 2D, en mettant l'accent sur les aspects quantitatifs relatifs ou absolus. Les étapes de traitement des données seront également abordées. L'atelier s'organisera autour de présentations interactives (questions/réponses) et de discussions.

Compétences acquises à la sortie de la formation :

Compréhension des aspects quantitatifs liés à la RMN 2D Compréhension des principales méthodes rapides (repliement, échantillonage non-uniforme, RMN ultrarapide) Connaissance des avantages et inconvénients des différentes méthodes, choix de la technique la plus appropriée à une problématique donnée Mise en œuvre des méthodes présentées (acquisition et traitement des données) Durée : 2 heures.

Date et lieu : Lundi 2 octobre à 14h (Salle Ada Lovelace).

$\underline{\text { Programme }}$ 


\section{Atelier 2 : La métabolomique appliquée aux com- munautés (meta-métabolomique) [A2]}

Personnes animant l'atelier : Cyril Jousse (cyril.jousse@uca.fr); Catherine Leblanc (catherine.leblanc@ @sbroscoff.fr)

Public envisagé et prérequis : Etudiants, ingénieurs et chercheurs avec des notions de métabolomique et d'écologie.

Contexte : Les outils de la métabolomique sont de précieux points de départ à ce type d'étude. Il reste cependant beaucoup à faire pour optimiser le rendu d'information métabolique en provenance de communautés, et particulièrement s'il s'agit d'évaluer l'impact d'effets (naturels, anthropiques ou autres) sur chacun des partenaires du système. Cet atelier a donc pour objectif de mener une réflexion autour des actions de recherche, des outils et des méthodologies nécessaires. Il s'agit d'un travail transdisciplinaire (chimie, biologie, écologie, biomathématiques, bioinformatique) qui fera sans doute appel à d'autres types de données d'intérêt (notamment d'autres "omiques").

Durée : 2 heures.

Date et lieu : Lundi 2 octobre à 14h (Salle Antoine Lavoisier).

$\underline{\text { Programme }}$ 


\section{Atelier 3 : Outils d'analyse des spectres de frag- mentation pour l'identification des petites molécules}

[A3]

Personnes animant l'atelier : Alexis Delabrière, (alexis.delabriere@cea.fr), Yann Guitton (yann.guitton@onirisnantes.fr), David Touboul (david.touboul@cnrs.fr)et Etienne Thévenot (etienne.thevenot@cea.fr)

Public envisagé et prérequis : L'atelier s'adresse aux chimistes, biologistes et bioinformaticiens qui utilisent ou développent des outils d'aide à l'identification structurale.

Contexte : Ces dernières années sont apparus plusieurs outils pour l'aide à l'identification à partir des spectres de fragmentation tels que la fragmentation combinatoire (MetFrag), la modélisation par fragmentation compétitive (CFM-ID), et la prédiction d'empreintes moléculaires (CSI:FingerID), mais aussi pour la visualisation des réseaux moléculaires (GNPS).

Objectif : L'objectif de l'atelier est de présenter ces outils et d'échanger sur leurs forces et limites en termes de prédiction et d'interprétation sur des jeux de données d'intérêt, et de discuter plusieurs développements en cours dans le domaine de l'aide à l'identification.

Durée de l'atelier : 2 heures.

Date et lieu : Lundi 2 octobre à 16h (Salle Antoine Lavoisier).

$\underline{\text { Programme }}$ 


\section{Conférenciers invités}




\title{
Enjeux sociétaux des technologies omiques [I1]
}

\author{
Catherine Bourgain $* \dagger$ \\ INSERM, Cermes 3, Villejuif, France
}

Médecine à plusieurs vitesse et déshumanisée, multiplication des formes de surveillance et de contrôle des corps et des modes de vie, artificialisation du vivant ... le spectre des menaces associées au développement des technologies omiques dans la société n'a d'égal que celui des promesses qui les accompagnent - développement de nouvelles thérapies antibiotiques ou anticancéreuses ; contrôle des pollutions environnementales ; compréhension des effets de l'alimentation sur la santé ; optimisation de la production agricole...

Pour aborder quelque uns des enjeux sociétaux associés à ces technologies en privilégiant l'analyse de pratiques actuelles plutôt que celle de projections plus incertaines, je partirai de trois dimensions qui les caractérisent. Au-delà de la diversité de leurs formes et de leurs usages, il s'agit en effet d'aborder le vivant, par l'entremise de technologies (1), permettant de quantifier des composés biologiques à des échelles toujours plus fines (2), et applicables de façon transversale dans un grand nombre de contextes (3).

Ce cadre permettra de présenter les acteurs (publics et privés) impliqués dans ces technologies et les effets sociétaux de leurs stratégies respectives ; d'interroger la quantification sous l'angle de ses conséquences sur les façons de penser, de représenter et d'influer sur le monde vivant; de discuter des effets de la standardisation des pratiques et des circulations nouvelles entre domaines de recherche très différents.

Ces éléments seront illustrés dans le contexte des technologies de la génomique, avec le souci de dégager des perspectives plus générales.

$\underline{\text { Programme }}$

\footnotetext{
${ }^{*}$ Intervenant

${ }^{\dagger}$ Auteur correspondant: catherine.bourgain@inserm.fr
} 


\title{
Smart Suspect Screening and Related HRMS Approaches for Detection of Pharmaceuticals and their Transformation products in Real-World Water samples [12]
}

\author{
Damia Barceló ${ }^{* \dagger}{ }^{1,2}$, Bozo Zonja ${ }^{1}$, Miren Lopez de Alda ${ }^{1}$ \\ ${ }^{1}$ Water and soil quality research group, IDAEA-CSIC, Barcelona, Spain \\ ${ }^{2}$ Catalan Institute of Water Research, ICRA, C/Emili Grahit, 101, edifici H2O Parc Científic i Tecnològic de la \\ Universitat de Girona, E-17003 Girona, Spain
}

\begin{abstract}
This presentation will discuss different approaches for the identification of transformation products (TPs) of pharmaceuticals. The classical approach for evaluation of transformation relies on the identification of TPs at lab-scale experiments and further detection of the identified TPs in environmental samples. However, new approaches based on HRMS using screening methods allow the detection of a large number of TPs without prior selection. However, the HRMS approaches presented in this talk focus on detection and identification rather than characterization. The classical approach for evaluation of these transformations is well illustrated in the example of photodegradation of an antiviral zanamivir with identification of its transformation products. Here first a set of lab-scale experiments is performed in order to determine whether the compound can be degraded using simulates sunlight. Its degradation products were identified using high resolution mass spectrometry (HRMS). Following structure elucidation, degradation pathways are proposed and a set of kinetic experiments at environmentally relevant concentration are performed. Finally, the outcome of this type of studies would be screening for the compound and its transformation products (TPs) in the aquatic environment with doubtful outcome whether they would be found or not. The talk will present some recent examples we have made in the attempt to appraoch this problematics. Examples shown will be (i) Detection based prioritisation of iodinated contrast media (ICM) photodegradates in surface water using HRMS, (ii) Suspec screening and transformations of an anticonvulsant lamotrigine and its human metabolite in WWTPs, and (iii) Smart Suspect Screening and data-dependent fragment ion search for detection of TPs, metabolites and related compounds of antihypertensive pharmaceuticals "sartans in wastewater.
\end{abstract}

Acknowledgements This study has been financially supported by the EU through the FP7 project SOLUTIONS (603437), and by the Generalitat de Catalunya (Consolidated Research Groups "2014 SGR 418-Water and Soil Quality Unit” and 2014 SGR 291-ICRA).

$\underline{\text { Programme }}$

\footnotetext{
* Intervenant

${ }^{\dagger}$ Auteur correspondant: dbcqam@cid.csic.es
} 


\title{
The power and promise of a thousand and one proteomes [I3]
}

\author{
Lennart Martens $\stackrel{* \dagger}{-}$ \\ VIB-UGent Center for Medical Biotechnology, VIB, Ghent, Belgium; Department of Biochemistry, Ghent \\ University, Ghent, Belgium
}

We now live in a world where an abundance of proteomics data is publicly available online, and that body of public proteomics data continues to grow and diversify every day. For a bioinformatician, this treasure of a thousand and one proteomes is like a fairy tale! But because the terasure is effectively bottomless, there should be no reason why only bioinformaticians have all the fun! In this talk, I'll therefore present the available data, the effect of the various types of contributions that are being made to these data, and the promise that it holds for different types of data re-use. In fact, we recently documented four major types of reuse (Vaudel et al., PROTEOMICS, 2016), each of which will be illustrated with a concrete example from my own lab.

We now live in a Golden Age for proteomics data re-use (Martens Vizcaino, Trends in Biochemical Sciences, 2017) and hopefully this talk can convince you of this, and inspire and motivate you to make the most of the endless gold that is available!

$\underline{\text { Programme }}$

\footnotetext{
*Intervenant

${ }^{\dagger}$ Auteur correspondant: lennart.martens@vib-ugent.be
} 


\title{
Gas-phase structural analysis of complex carbohydrates [I4]
}

\author{
E. Mucha ${ }^{1,2}$, J. Hofmann $^{1}$, A.I. González Flórez ${ }^{1}$, M. Marianski ${ }^{1}$, D.A \\ Thomas ${ }^{1}$, W. Hoffmann ${ }^{1,2}$, W.B. Struwe ${ }^{3}$, H.S. Hahm ${ }^{3}$, S. Gewinner ${ }^{1}$, W. \\ Schölkopf ${ }^{1}$, P.H. Seeberger ${ }^{4}$, G. von Helden ${ }^{1}$, Kevin Pagel ${ }^{* \dagger}+1,2$ \\ ${ }^{1}$ Institute of Chemistry and Biochemistry, Freie Universität Berlin, Takustraße 3, 14195 Berlin, Germany \\ ${ }^{2}$ Fritz Haber Institute of the Max Planck Society, Department of Molecular Physics, Faradayweg 4-6, 14195 \\ Berlin, Germany \\ ${ }^{3}$ Oxford Glycobiology Institute, Department of Biochemistry, University of Oxford, Oxford, UK \\ ${ }^{4}$ Max Planck Institute of Colloids and Interfaces, Department of Biomolecular Systems, Am Mühlenberg 1, \\ 14476 Potsdam, Germany
}

Currently, the vast majority of glycans are characterized using mass spectrometry-based techniques (MS). Measuring the molecular weight of a sugar, however, immediately poses a fundamental problem: entire classes of monosaccharide building blocks exhibit an identical atomic composition and, consequently, an identical mass. Therefore, glycan MS data can be highly ambiguous and often it is not possible to clearly assign a particular structure. A promising approach to overcome this limitation is to implement an additional gas-phase separation step using ion mobility-mass spectrometry (IM MS). Here, ions travel through a gas-filled cell aided by an electric field and are separated according to their collision cross section (CCS). Here, we demonstrate the potential of IM-MS to be used as a tool for the separation and identification of isomeric glycans and glycopeptides. First, six synthetic oligosaccharide isomers that differ with respect to their composition, connectivity, or configuration were analyzed. Our data reveal that linkage- and stereoisomers, which are difficult to distinguish using established techniques, can be separated and unambiguously identified on basis of their CCS (1). Second, we extended our investigations to glycopeptides. Our data show that glycopeptides, which merely differ in the regiochemistry of the attached glycan can be distinguished using fragmentation and subsequent IM-MS analysis (2). Finally, we recently assessed the potential of cold-ion spectroscopy for oligosaccharide analysis (3). Gas-phase IR spectra of a series of synthetically derived mono-, di- and trisaccharide standards were recorded. For each of these oligosaccharides, unique and highly diagnostic absorption patterns with a variety of well-resolved bands was obtained. In some cases, the line-width in the spectra was equal to the corresponding bandwidth of the laser radiation (FWHM $4 \mathrm{~cm}-1$ ). This unprecedented resolution reveals remarkable differences in the overall IR signatures and allows a simple, fingerprint-based discrimination between isomers, even if they merely differ in the stereochemistry of a single $\mathrm{OH}$ group.

(1) J. Hofmann, H. S. Hahm, P. H. Seeberger, K. Pagel, Nature 2015, 256, 241-244

(2) H. Hinneburg, J. Hofmann, W.B. Struwe, A. Thader, F. Altmann, D. Varón Silva, P.H. Seeberger, K. Pagel, D. Kolarich, Chem. Commun. 2016, 52, 4381-4384

(3) E. Mucha, A.I. González Flórez, M. Marianski, D.A. Thomas, W. Hoffman, W.B. Struwe, H.S. Hahm, S. Gewinner, W. Schöllkopf, P.H. Seeberger, G. von Helden, K. Pagel, Angew. Chem. Int. Ed. 2017, DOI: 10.1002/anie.201702896.

\footnotetext{
*Intervenant

${ }^{\dagger}$ Auteur correspondant: kevin.pagel@fu-berlin.de
} 


\title{
NMR- and MS-based micrometabolic profiling of plants [I5]
}

\author{
Bernd Schneider $* \dagger$ \\ Max Planck Institute for Chemical Ecology, Beutenberg Campus, Hans Knöll Str. 8, 07745 Jena, Germany
}

Metabolomics and metabolic profiling of special plant tissue, cell types, and single plant cells is of considerable interest in natural product chemistry, chemical ecology and other disciplines of plant sciences. The identification of specialized low-molecular natural products from microscopic plant samples, the composition of a mixture of metabolites and their temporal concentration changes are challenging for chemical analytics because of tiny amounts of material available. Mass spectrometry (MS) conventionally is the method of choice for studying such mass-limited samples. However, despite they are of moderate sensitivity, nuclear magnetic resonance (NMR) methods are also useful to precisely determine the spatio-temporal distribution of metabolites in plants and other organisms. This is feasible especially when NMR, using cryogenically cooled probes, is applied in combination with microscopic sampling methods such as laser-assisted microdissection. The combined application of laser microdissection, NMR and MS to analyze secondary metabolites in specialized cells will be discussed and examples from various plant species will be presented (1-5).

(1) Li et al., Planta 225, 771-779 (2007)

(2) Hölscher et al., Planta 225, 767-770 (2007)

(3) Li et al., ChemBioChem 13, 2702-2713 (2012)

(4) Fang et al., PloS ONE 7(10): e48006 (2012)

(5) Fang et al., Front. Plant Sci. 7:1743 (2016)

$\underline{\text { Programme }}$

\footnotetext{
${ }^{*}$ Intervenant

†Auteur correspondant: schneider@ice.mpg.de
} 


\title{
Cancer cellular metabolism at a spatio-temporal resolution [I6]
}

\author{
Tomer Shlomi $*_{\dagger} \dagger$ \\ Departments of Computer Science and Biology \& Lokey Center for Life Science and Engineering, Technion - \\ Israel Institute of Technology, Haifa 32000, Israel
}

The metabolism of cancer cells is altered to meet cellular requirements for growth, providing novel means to selectively target tumorigenesis. While extensively studied, our current view of cancer cellular metabolism is fundamentally limited by lack of information on variability in metabolic activity between distinct subcellular compartments and cells. We develop a spatio-temporal fluxomics approach for quantifying metabolic fluxes in distinct subcellular compartments as well as their cell-cycle dynamics, combining experimental and computational approaches - including LC-MS based isotope tracing, cell synchronization, rapid cellular fractionation, and computational deconvolution and metabolic network modelling. Temporal fluxomics reveals that TCA cycle fluxes are rewired as cells progress through the cell cycle with complementary oscillations of glucose versus glutamine-derived fluxes: Oxidation of glucose-derived flux peaks in late G1 phase while oxidative and reductive glutamine metabolism dominates $\mathrm{S}$ phase. Spatial fluxomics is applied to re-examine one of the emerging metabolic hallmarks of cancer cells - reductive glutamine metabolism, mediating fatty acid biosynthesis under hypoxia and in cells with defective mitochondria. Analyzing isocitrate dehydrogenase (IDH) activity in mitochondria and cytosol (as well as IDH isozymes within mitochondria) reveals that reductive glutamine metabolism is in fact the major producer of cytosolic citrate (rather than glucose oxidation) to support fatty acid biosynthesis also in standard normoxic conditions. We show that while the relative contribution of reductive glutamine metabolism to fatty acid biosynthesis increases in hypoxic cells and in cells with defective mitochondria, absolute reductive flux only increases in the latter case. Overall, the developed spatio-temporal fluxomics approach provides an essential tool for investigating how cells adapt their metabolism due to oncogenic mutations, providing novel means to target metabolic dysfunction in cancer.

$\underline{\text { Programme }}$

\footnotetext{
*Intervenant

†Auteur correspondant: tomersh@cs.technion.ac.il
} 


\title{
Towards a functional plant cell wall proteome atlas: from protein identification to characterization of post-translational modifications [I7]
}

\author{
Elisabeth Jamet $* \dagger$ \\ Laboratoire de Recherche en Sciences Végétales (LRSV), UMR 5546 UPS/CNRS, 31326 Castanet-Tolosan \\ cedex, France
}

Cell walls are complex structures surrounding plant cells. They provide not only mechanical support and protection against environmental changes, but also a mean for cell-to-cell communication. They are mainly constituted of polysaccharides (about $90 \%$ of their mass) and proteins. Cell wall proteins (CWPs) play critical roles because they contribute to the plasticity of the cell wall architecture during development and in response to environmental constraints, and to plant physiology. Their systematic identification has started in the 2000's with the sequencing of the genome of the Arabidopsis thaliana model plant and the development of mass spectrometry (MS) technologies. Since then, many other plants have been studied among which tomato and rice which are of agronomical interest. Today, the A. thaliana cell wall proteome remains the best characterized with more than 900 CWPs identified in different plant organs at various developmental stages, i.e. about half of the expected size. The description of cell wall proteomes has fully benefited not only from the improvement of MS technologies, but also from better sample preparation and peptide separation prior to MS analysis as well as from minor protein enrichment through chromatography on combinatorial peptide ligand library (CPLL). Moreover, posttranslational modifications (PTMS) such as proline hydroxylation and $\mathrm{N}$ - and O-glycosylations have been characterized thanks to the combined use of LC-MS/MS, MALDI-TOF MS and ETD-MS. New types of PTMs have been described including proline hydroxylation in new amino acid motifs and Oglycan motifs linked to hydroxyproline residues and specifically recognized by the peanut agglutinin lectin (PNA).

Programme

\footnotetext{
*Intervenant

${ }^{\dagger}$ Auteur correspondant: jamet@1rsv.ups-tlse.fr
} 


\title{
Art and Cultural Heritage natural polymers by bottom up and top down approaches [I8]
}

\author{
Caroline Tokarski $\stackrel{* \dagger}{*}$ \\ Miniaturisation pour la Synthèse, l'Analyse \& la Protéomique (MSAP), USR CNRS 3290, Université de Lille 1 \\ Sciences et Technologies, 59655 Villeneuve d'Ascq, France
}

Cultural Heritage material is challenging to study. Most pieces are made of more than one material, each containing many chemical components. The manufacturing process, artist's use, time and travel as well as exposure to light, humidity, heat and conservation treatments all affect these materials. How an artwork appears to us today is not the same as its original appearance: it is a culmination of all of the chemical changes driven by these events. Moreover, the change will continue, although more slowly, under museum conditions. To understand these chemical changes and how they relate to the conservation and preservation, the organic material has to be accurately identified and characterized (1).

Until recently, the organic compounds from Cultural Heritage samples were analyzed via their constitutive moieties (e.g. amino acids, fatty acids, monosaccharides) inducing a loss of information. In the early 2000s, we have successfully adapted proteomic and lipidomic methodologies to the study of few micrograms of historic art paintings and archaeological samples allowing for the first time the accurate structural identification as well as the identification of the biological species. These methodologies are currently used in the most famous international museums (e.g. Metropolitan Museum of Art, New York).

This conference will present our new biochemical approaches based on high resolution mass spectrometry for the study of ancient proteins, polysaccharides and lipids. It will also show how the top down methodology address the current challenges for analysis of Cultural Heritage samples. For example structural elucidation of biopolymers of unknown structures and/or their chemical modifications will be shown (e.g. historic art paintings and watercolors...). Another example is the combination of soft depolymerization experiments and very high resolution mass spectrometry to unravel the 3D networks formed by insoluble lipidic films (e.g. historic oil-paintings). The conference will be illustrated by the study of various outstanding samples from art but also from archaeological and paleontological sciences from the most famous museums and institutes of the world.

(1) Dallongeville S., Garnier N., Rolando C., Tokarski C.* Chemical Reviews 2016, 116, 2-79

$\underline{\text { Programme }}$

\footnotetext{
*Intervenant

†Auteur correspondant: Caroline.Tokarski@univ-lille1.fr
} 


\title{
Cerebrospinal fluid proteomics in multiple sclerosis [I9]
}

\author{
Frode Berven $* \dagger$
}

Proteomics Unit (PROBE), Department of Biomedicine, University of Bergen

In this presentation I will go through a biomarker discovery project focused on finding proteins in CSF affected by multiple sclerosis. In the first phase of the project several shotgun experiments were conducted using both TMT, iTRAQ and label-free approaches, allowing quantification of more than 2000 proteins in CSF. The results from some of these experiments will be covered. In order to gather all the data from our own experiments, and compare it to previously published data, we created an online database (CSF-PR 2.0) where 87 dataset containing quantitative CSF data from Multiple sclerosis (MS), Alzheimer's and Parkinson's disease were included. This database was used as a starting point for selecting most promising biomarker candidates for which PRM assays now are under developed. The process of using the database to select biomarker candidates and developing the PRM-assays towards absolute quantification quality will be described.

\section{Programme}

*Intervenant

†Auteur correspondant: Frode.Berven@uib.no 


\title{
Accurate lipidomic quantitation: a case study of kidney cancer [I10]
}

\author{
Michal Holčapek ${ }^{* \dagger}{ }^{1}$, Miroslav Lísa ${ }^{1}$, Robert Jirásko ${ }^{1}$, Eva Cífková ${ }^{1}$, Maria \\ Khalikova ${ }^{1}$, David Vrána ${ }^{2}$, Bohuslav Melichar ${ }^{2}$ \\ ${ }^{1}$ University of Pardubice, Department of Analytical Chemistry, Pardubice, Czech Republic \\ ${ }^{2}$ Department of Oncology, Faculty of Medicine and Dentistry, Palacký University, Olomouc, Czech Republic
}

The major requirement for the reliable and robust lipidomic quantitation is the use of non-endogenous internal standards (IS) for quantified lipid classes and also the coionization of lipid class IS and analytes using the lipid class separation approaches based on normal-phase or HILIC separation mechanisms or shotgun approaches without chromatographic separation. Tumor cells have different proteomic, metabolomics, and lipidomic composition (1-3) in comparison to normal cells. These changes could be also reflected in collectable body fluids, which may be used in the research of cancer biomarkers. Lipids are building blocks of cell membranes and intracellular compartments with important cell functions, therefore the study of their dysregulation in cancer is quite interesting. The series of MS based analytical methods mostly coupled with liquid-phase separation techniques (UHPLC and UHPSFC) has been developed and fully validated for the quantitation of a wide range of lipid species from multiple lipid categories (4-5). Several analytical methods are essential due to rather different physico-chemical properties of individual lipid classes and also their natural abundances starting from major components (e.g., phospholipids, sphingolipids and glycerolipids) up to ultratrace levels (e.g., oxylipins) but with important biological functions and possible relation to the disease onset and progress. The data from kidney cancer project are processed by our software LipidQuant and then the large data files are processed by the multivariate data analysis methods to differentiate between healthy and cancer groups using nonsupervised (PCA) and supervised (OPLS-DA) methods.

This work was supported by ERC CZ project No. LL1302 (MSMT, Czech Republic).

(1) E. Cífková et al., Rapid Commun. Mass Spectrom. 31 (2017) 253.

(2) E. Cífková, et al., Anal. Bioanal. Chem. 407 (2015) 991.

(3) E. Cífková, et al., J. Chromatogr. B 1000 (2015) 14.

(4) M. Lísa, M. Holčapek, Anal. Chem. 87 (2015) 7187.

(5) R. Jirásko et al., J. Amer. Mass Spectrom. Soc. 28 (2017) 1562.

$\underline{\text { Programme }}$

\footnotetext{
*Intervenant

†Auteur correspondant: Michal.Holcapek@upce.cz
} 


\section{Communications orales}




\section{Intégration des données et approches multi-omiques [S1a]}




\title{
Metabolite imaging and shotgun proteomics to decipher the role of epididymis in sperm maturation [01]
}

\author{
Karolina Modzelewska *† ${ }^{1}$, Régis Lavigne ${ }^{1}$, Andrew Palmer ${ }^{2}$, Blandine \\ Guével ${ }^{1}$, Emmanuelle Com ${ }^{1}$, Mélanie Lagarrigue ${ }^{1}$, Theodore Alexandrov ${ }^{2}$, \\ Charles Pineau ${ }^{1}$

\footnotetext{
${ }^{1}$ PROTIM - INSERM U1085 Irset - CS2407 Campus de Beaulieu 35042 Rennes cedex, France

2 Structural and Computational Biology Unit, European Molecular Biology Laboratory - EMBL, 69117

Heidelberg, Allemagne
}

Background: Infertility or subfertility is a widespread problem with approximately $25 \%$ of couples seeking medical help. For about half the cases it lies in the male partner. Male infertility is caused by problems that affect sperm production, maturation and/or transport. In this study the role played by the epididymis in the post-testicular maturation of spermatozoa during its transit through this organ was investigated using an innovative combination of FT-ICR imaging mass spectrometry of metabolites and shotgun proteomics.

Methods: Distribution of metabolites in the 3 regions of rat epididymis (caput, corpus and cauda) was monitored by high-resolution FT-ICR MALDI imaging. Protein expression along the epididymal tube was monitored in the same 3 regions by quantitative label-free proteomics. Correlation between metabolite and protein expression was performed using dedicated tools developed by the European consortium METASPACE (http://metaspace2020.eu).

Results: Large-scale metabolites and protein datasets were mapped and annotated in the 3 regions of the epididymis using KEGG Pathway. Molecular maps specific to each region of the organ could be drawn and are further explored to investigate the function of specific epididymal proteins in the maturation of the transiting spermatozoa. As a priority, focus is given on the study of proteins involved in glutathione metabolism, oxidoreductases, calcium ion binding proteins and transport regulation proteins that are key features of the epididymis biology.

Conclusion: To our knowledge this is the first time FT-ICR Imaging mass spectrometry of metabolites is coupled to quantitative shotgun proteomics to model in situ molecular maps and highlight metabolic pathways deserving further in-depth studies to understand the physiology of an organ.

Mots-Clés : Proteomics, MALDI imaging, Metabolomics, Epididymis, Sperm maturation, Epididymal maturation, Male infertility, Reproduction

\section{Programme}

\footnotetext{
*Intervenant

†Auteur correspondant: karolina.modzelewska@univ-rennes1.fr
} 


\title{
Identification d'une nouvelle classe de lanthibiotiques : utilisation combinée de l'exploration de données génomiques et de la spectrométrie de masse MALDI et HRMS [O2]
}

\author{
Sophie Tirat* ${ }_{-1}$, Guillaume Lesquame ${ }^{2}$, Guillaume Letellier ${ }^{2}$, Hugues \\ Mandavid $^{2}$, Marjorie Valenduc ${ }^{1}$, Vincent Wiebach ${ }^{3}$, Pascal Dhulster ${ }^{1}$, \\ Roderich Süssmuth ${ }^{3}$, Dominique Le Beller ${ }^{2}$
}

\footnotetext{
${ }^{1}$ Institut Charles Violette (ICV) - Univ. Lille, INRA, ISA, Univ. Artois, Univ. Littoral Côte d'Opale, EA, 7394 F-59000 Lille, 59655 Villeneuve d'Ascq, France

${ }^{2}$ Deinobiotics - Deinove - 1682 rue de la Valsière, ZAC Euromédecine II, 34790 Grabels, France

3 Technische Universität Berlin (TU Berlin) - Fakultät II - Institut für Chemie, Straße des 17. Juni 124, 10623

Berlin, Allemagne
}

\begin{abstract}
Développer de nouveaux antimicrobiens est primordial face à la menace imminente posée par la très forte augmentation du nombre de germes multi-résistants aux antibiotiques. Un screening de 600 souches rares a récemment permis d'isoler puis de caractériser trois molécules aux propriétés antibiotiques produites par Microbacterium arborescens. La caractérisation structurale de ces molécules par HRMS-MS et RMN a révélé une structure proche de celle des lanthipeptides. Ces trois molécules originales sont formées d'un double cycle peptidique et d'une chaine aliphatique portant à son extrémité une guanidine diméthylée. La découverte du cluster de gènes responsable de la biosynthèse de ces molécules a permis d'utiliser l'exploration des données génomique pour repérer d'autres souches bactériennes potentiellement productrices de molécules de la même famille. Une première sélection des souches les plus prometteuses a été réalisée, basée sur des analyses bioinformatiques et le repérage rapide de la production de métabolites grâce à des expériences MALDI réalisées directement sur les colonies bactériennes. Après fermentation et extraction des cultures bactériennes, les analyses HRMS-MS ont ensuite permis de caractériser une dizaine de nouveaux composés produits par le genre Nocardia. Les données obtenues grâce à l'exploration du génome ont permis un assignement rapide des spectres MSMS. Ces molécules originales constituent une nouvelle famille de composés antibiotiques, appelée "lipolanthines ". Ils diffèrent entre eux par la longueur et le nombre d'insaturations de la chaine aliphatique, par les acides aminés qui composent le double cycle peptidique, ainsi que par le degré de méthylation de la guanidine.
\end{abstract}

Mots-Clés : antimicrobiens, lanthibiotiques, génomique, MALDI, HRMS

$\underline{\text { Programme }}$

${ }^{*}$ Intervenant 


\title{
Modélisation du réseau métabolique des cellules de Leucémies Aiguës Myéloïdes pour comprendre les différences métaboliques liées à la mutation sur IDH1 [O3]
}

\author{
Laurent Fernando ${ }^{1}$, Lucille Stuani ${ }^{2,3}$, Tony Palama ${ }^{3}$, Tony Kaoma ${ }^{4}$, \\ Jean-Emmanuel Sarry ${ }^{2}$, Fabien Jourdan ${ }^{1}$, Nathalie Poupin ${ }^{* \dagger} 1$ \\ ${ }^{1}$ ToxAlim - INRA : UMR1331 - 180 Chemin de Tournefeuille, BP 9317331027 Toulouse Cedex 3 - France \\ 2 Team ResistAML, Chimiorésistance et oncométabolisme dans les LAM, CRCT - INSERM : UMR1037 - 2 \\ avenue Hubert Curien 31037 Toulouse cedex 01, France \\ ${ }^{3}$ Plateforme MetaToul Réseaux métabolique, LISBP - INSA (INSA) - Toulouse - 135 avenue de Rangueil 31077 \\ Toulouse cedex 04, France \\ ${ }^{4}$ Department of Oncology, Luxembourg Institute of Health - Luxembourg, Luxembourg
}

Les leucémies aigues myéloïdes (LAM) sont des maladies hématologiques liées à la transformation maligne de progéniteurs hématopoïétiques dans la moelle osseuse aboutissant à la destruction du tissu sanguin sain. Des mutations récurrentes ont été observées chez les patients atteints de LAM dont l'une sur des enzymes clés du métabolisme : les isocitrate déshydrogénases 1 et 2 (IDH1, IDH2). La mutation IDH1-R132H conférerait aux cellules LAM une flexibilité métabolique induisant des dépendances métaboliques et énergétiques spécifiques, qui seraient responsables de la chimiorésistance de ces cellules. Dans cette étude, nous avons utilisé une approche globale de modélisation in silico du réseau métabolique des cellules LAM, basée sur des données de transcriptomique et d'exométabolomique, afin d'identifier l'ensemble des voies métaboliques activées par la mutation IDH1-R132H dans ces cellules. À partir du réseau métabolique humain global (Recon2; Thiele et al., 2013) et des données d'expression de gènes obtenues sur des cellules LAM avec ou sans la mutation IDH1-R132H, nous avons utilisés des algorithmes d'optimisation permettant de générer des modèles de réseaux métaboliques représentant spécifiquement le réseau métabolique fonctionnel de cellules LAM avec et sans mutation, c'est-àdire les réactions du réseau global qui sont spécifiquement actives dans les cellules étudiées. Plusieurs algorithmes publiés visant à l'identification de réseaux tissu- ou cellule- spécifiques à partir de données de transcriptomique ont été testés et adaptés. Les données d'exométabolomique ont été utilisées, via des méthodes de modélisation sous contraintes, pour contextualiser les modèles cellules-spécifiques générés et rendre compte de la production ou consommation des métabolites mesurés. La comparaison des réseaux cellules-spécifiques générés a permis notamment de mettre en évidence que les voies du métabolisme des acides gras étaient différemment utilisées chez les cellules mutées ou non mutées. Les modèles générés pourront être utilisés pour identifier des dépendances métaboliques présentes spécifiquement dans les cellules LAM mutées.

Mots-Clés : réseaux métaboliques, modélisation, leucémie aiguë myéloiïde, transcriptomique, métabolomique

\footnotetext{
*Intervenant

${ }^{\dagger}$ Auteur correspondant: nathalie.poupin@inra.fr
} 


\title{
Multiblock Omics data fusion: an efficient strategy to understand climatic effect on flaxseed (Linum usitatissimum) composition [O4]
}

\author{
Roland Molinié ${ }^{*} 1$, Romain Roulard ${ }^{1}$, Jean-Xavier Fontaine ${ }^{1}$, Larbi Rhazi ${ }^{2}$, \\ Xavier Guillot ${ }^{-3}$, Reynald Tavernier ${ }^{4}$, Brigitte Thomasset ${ }^{5}$, Melha-Amel \\ Lazouk $^{5}$, Julien Boccard ${ }^{6}$, Emmanuel Petit ${ }^{1}$, François Mesnard ${ }^{1}$ \\ ${ }^{1}$ Laboratoire de Biologie des Plantes et Innovation (EA3900-BIOPI-UPJV) - Université de Picardie Jules Verne : \\ EA3900 - 80000 Amiens, France \\ ${ }^{2}$ Institut Polytechnique UniLasalle - Institut Polytechnique UniLasalle - Campus de Beauvais, Beauvais, France \\ ${ }^{3}$ LABOULET Semences - 80270 Airaines, France \\ ${ }^{4}$ Linéa - Semences de Lin - Linéa - Semences de Lin - 20 Avenue Saget 60210 Grandvilliers, France \\ ${ }^{5}$ Sorbonne Universités, UTC (CNRS FRE 3580 GEC) - Université de Technologie de Compiègne [Compiègne] \\ - Centre de Recherche de Royallieu, Compiègne, France \\ ${ }^{6}$ Geneva-Lausanne School of Pharmacy (EPGL) - University of Geneva, Geneva, Switzerland, Suisse
}

Flaxseed compounds (Linum usitatissimum) showed a growing interest in the last decade. Indeed, flaxseed contains large metabolites amounts (1) that can be valued in different industrial sectors. It is thus necessary to get information on the metabolites content in mature flaxseed and possible variations depending on the culture conditions during seed development. The present study concerns the composition of different varieties of oilseed flax grown in different regions in France between 2011 and 2015. $1 \mathrm{H}-\mathrm{NMR}$ was used to achieve a non-targeted metabolic profiling. Multiple seed characteristics and specific metabolites (lignans, mucilage, proteins, oils, omega-3...) were measured. The fusion of data from different sources is expected to provide a more complete view of complex systems (2). Multiblock multivariate analysis was performed taking into account the climatic conditions. It appears that rainfall would play a significant role on the flaxseed content of a certain type of metabolites such as oils, omega-3, phenolics or cyanogenic glycosides. The yield of mucilage and its sugar composition also seem to be affected by the climatic conditions. It was then possible to highlight the metabolic pathways appearing influenced by the climatic conditions.

(1) Hall C., Tulbek M.C. \& Xu Y. (2006). Flaxseed. Advances in food and nutrition research, 51, 197.

(2) Boccard J. \& Rutledge D.N. (2013). A consensus orthogonal partial least squares discriminant analysis (OPLS-DA) strategy for multiblock Omics data fusion. Analytica chimica acta, 769, 30-39.

Mots-Clés : Flaxseed, Linum usitatissimum, NMR, Multiblock multivariate analysis, climatic effect

$\underline{\text { Programme }}$

${ }^{*}$ Intervenant 
Alimentation et santé [S1b] 


\title{
Input of proteomic analyses for understanding cellular responses to nanoparticles: toward mechanistic data and evidence for cross-toxic effects [05]
}

\author{
Thierry Rabilloud * 1 \\ ${ }^{1}$ Chemistry and Biology of Metals (CBM) - CNRS : UMR5249 - CEA Grenoble, France
}

\begin{abstract}
Nanoparticles are recently-introduced industrial products which impact on the environment and on human health is intensely debated. Most of the toxicological research carried to date on NPs follows very classical tracks, so that little is known yet on their mechanisms of toxicity, apart their propensity to induce oxidative stress and sometimes cytokine release. Because of their major scavenging role, macrophages are one of the major cell types to study when working on nanoparticles. In order to gain new insights on the interaction of nanoparticles with macrophages, we carried out a proteomic screen on cells treated with different nanoparticles (e.g. copper oxide, zinc oxide, metallic silver or silica). Very different responses have been observed : Copper oxide induces mainly a mitochondrial response and a strong response at the glutathione level. Zinc oxide rather induces a proteasomal and a metabolic response (glucolysis and pentose phosphate pathways). Proteomics was followed by targeted studies aiming at validating the proteomic results and at investigating major functions of macrophages (e.g. phagocytosis and cytokine production). In this way, we could demonstrate a role of DNA repair pathways for zinc oxide and silica nanoparticles, as well as a critical role of glutathione and heme oxygenase for survival to a copper oxide challenge. Mitochondrial dysfunction is also prominent following exposure to zinc oxide or copper oxide, and much less important following exposure to silver or silica. Different changes in the actin cytoskeleton were also observed in response to the nanoparticles tested. In conclusion, this combined approach has provided new ideas on how nanoparticles can exert their toxic effect.
\end{abstract}

Mots-Clés : analyse protéomique, macrophages, nanoparticules, génotoxicité, cytosquelette, toxicologie

Programme

${ }^{*}$ Intervenant 


\title{
Breast milk lipidome as a predictive component of postnatal growth trajectory in preterm infants [06]
}

\author{
Marie-Cécile Alexandre-Gouabau * 1,2 , Thomas Moyon $^{3}$, Véronique Cariou ${ }^{4}$, \\ El Mostafa Qannari ${ }^{4}$, Mikaël Croyal ${ }^{3}$, Agnès David-Souchard ${ }^{3}$, Yann \\ Guitton ${ }^{5}$, Hélène Billard ${ }^{3}$, Jean-Philippe Antignac ${ }^{5}$, Clair-Yves Boquien ${ }^{2,3,6}$ \\ ${ }^{1}$ Physiologie des Adaptations Nutritionnelles (UMR PhAN) - INRA, Université Nantes - CHU Hôtel-Dieu \\ 44000 Nantes, France \\ ${ }^{2}$ Centre de Recherche en Nutrition Humaine Ouest (CRNH) - Université de Nantes - CHU Hôtel-Dieu 44000 \\ Nantes, France \\ ${ }^{3}$ Physiopathologie des Adaptations Nutritionnelles (UMR PhAN) - INRA : Angers-Nantes - CHU Hôtel-Dieu \\ UMR INRA PHAN - HNB1 44000 Nantes, France \\ ${ }^{4}$ Unité de Statistiques et de Chimiométrie (StatSC) - Université de Nantes - ONIRIS, INRA, 44322, Nantes \\ ${ }^{5}$ Laboratoire d'Etude des Résidus et Contaminants dans les Aliments (LABERCA) - Université de Nantes - \\ LUNAM Université, ONIRIS, LABERCA, USC INRA 1329, Nantes, France \\ ${ }^{6}$ Association des Banques de lait Européennes (EMBA) - Milan, Italie
}

Early nutrition of preterm infants (7\% of babies in France) is of utmost importance since early growth impacts not only brain development but also the risk of adult chronic diseases. Human milk, recommended for feeding preterm infants, is a highly complex mixture. The potential health benefits of human milk lipid species composition on infancy growth has still received little attention, merely limited to few trials, in term infants or in studies comparing breastfed and formula-fed infants.

The relationships between mass spectrometry-based lipidomics phenotyping of human breast milk and preterm babies' growth during their hospitalization was investigated in an observational, prospective mono-centric cohort, LACTACOL. Maternal milk lipidomic signatures were performed in two subgroups of 13 infants (gestational age: $30.6 \pm 1.5$ weeks, birth weight: $1.42 \pm 0.29 \mathrm{~kg}$ ), focusing on the bottom and top deciles for the difference of weight Z-score between discharge and birth in LACTACOLcohort. Lipidomics data were extracted, using the workflow4metabolomics Galaxy platform, combined to normalization of batch effects by fitting regression models to quality control samples. Factor growth effect, encompassing time and mother, was assessed by an in-home multivariate statistical analysis, AoVPLS combined to linear discriminant analysis, in the scope of biomarkers selection. The predictive ability of these biomarkers on the postnatal weight growth trajectory of the preterm infants was evaluated by multiple linear regression method, taking into account confounding factors such as infants' birth weight, gestational age, total parenteral feeding and mother's body mass index. Several relevant lipids biomarkers were annotated using online database searches on LIPID-Maps and an in-house reference databank. Several fatty acids, triacylglycerol and phospholipid species were identified as predictive biomarkers to evaluate the early growth rate of breast-fed preterm infants, leading to a comprehensive view of the mechanisms by which early gestational age impacts human milk composition and consequently trajectory growth's infants.

Mots-Clés : preterm, milk, lipidomique, phospholipids, growth trajectory

\footnotetext{
${ }^{*}$ Intervenant
} 


\title{
Découverte de marqueurs précoces de l'altération des ovoproduits au cours de leur procédé de fabrication par des approches de prises d'empreintes métabolomique utilisant des techniques combinées (RMN et MS) [O7]
}

\author{
Rémy Coat ${ }_{-}^{*}$, Jack Legrand ${ }^{1}$, Abdellah Arhaliass ${ }^{1}$, Olivier Goncalves ${ }^{1}$ \\ ${ }^{1}$ Laboratoire de génie des procédés - environnement - agroalimentaire (GEPEA) - Université Bretagne Loire, \\ IMT Atlantique Bretagne-Pays de la Loire, Oniris, CNRS : UMR6144, Université de Nantes - GEPEA - UMR \\ CNRS 6144 CRTT, 37 bd de l'Université BP 40644602 Saint-Nazaire Cedex - France
}

L'ovoproduit est une matrice biologique complexe, constituée de protéines, lipoprotéines, lipides et de nombreux micronutriments (vitamines, minéraux, etc.). Cependant, une fois cassé et homogénéisé l'ovoproduit entier liquide perd une part de ses propriétés de conservation, devenant ainsi pour certaines bactéries un excellent milieu de croissance. Ce développement bactérien non maitrisé provoque en plus des risques sanitaires, des altérations biochimiques modifiants fortement les qualités organoleptiques de l'ovoproduit. L'objectif de cette étude est d'étudier les mécanismes biochimiques impliqués par des approches de métabolomique combinées (non ciblées utilisant la MS et la RMN) afin de décrire et de comprendre ces mécanismes jusqu'alors peu ou pas caractérisés et d'identifier in fine des marqueurs précoces de ces altérations microbiologiques (projet région pays de la Loire - Bretagne : ALTOVOP). Des études cinétiques de la dégradation ont été réalisées sur des ovoproduits stériles préparés en laboratoire avec des espèces bactériennes modèles caractéristiques de deux types d'altération (1 et 2). L'analyse" multi-omique " des profils métaboliques MS et RMN indique que les métabotypes sont type d'altération dépendant que ce soit pour les phénotypes les plus contrastés ou les phénotypes proches temporellement. Les différences observées ont permis d'identifier des groupes de molécules (signatures métaboliques) propres à chaque type d'altération et à chaque temps de la cinétique pour une même altération. Des marqueurs individuels, en cours de résolution structurale, présentent le potentiel de détecter de manière précoce l'altération microbiologique des ovoproduits. Ils pourraient ainsi permettre un meilleur suivi qualité des produits sur les chaines de production en industrie.

Mots-Clés : empreintes métaboliques, agroalimentaire, RMN, MS, marqueurs précoces, altération, ovoproduits

$\underline{\text { Programme }}$

*Intervenant 


\title{
Shotgun polyphenomics of rosé wines [08]
}

\author{
Mélodie Gil ${ }^{1}$, Cédric Saucier * 1, Robert Sabatier ${ }^{2}$, Christelle Reynes ${ }^{2}$, \\ Guillaume Cazăls ${ }^{3}$, Christine Enjalbal ${ }^{3}$
}

\footnotetext{
${ }^{1}$ Université de Montpellier, UMR 1083 Sciences pour l'Enologie, INRA, Montpellier SupAgro - Université de Montpellier - 15 Avenue Charles Flahault, 34000 Montpellier, France

${ }^{2}$ Université de Montpellier, IGF, UMR 5203 CNRS INSERM - 15 Avenue Charles Flahault, 34000 Montpellier

${ }^{3}$ Université de Montpellier, PT-LMP, IBMM UMR 5247 CNRS - Pl. E. Bataillon, 34095 Montpellier Cedex 5
}

Wine is a widely consumed alcoholic beverage with a high commercial value. The worldwide consumption of rosé wine has increased by $20 \%$ since 2002 (1). But because of its high commercial value, it can become a subject of fraud, and authenticity control is necessarily required. Hundreds of molecules can be found in wines, including polyphenols which are key components defining color, taste and quality of wines. Their amount and composition depend on many different factors such as grape variety, winemaking and age of the wine. In this study, the influence of geographic origin of some rosé French wines was investigated. An original and very fast UPLC-QTOF-MS method was developed and used to predict the geographic origin authenticity of rosé wines.

60 rosés wines were divided into two sets, both containing 30 wines from 3 different regions of France (Bordeaux, Languedoc and Provence, 10 of each). They were analyzed in triplicate using an original and fast UPLC-high resolution MS method with a similar approach previously used for red wines (2).The goal of this 6 min shotgun analytical method was to give a rapid mass spectrometry fingerprint of these wines and be able to identify specific ions.

Statistical analyses were performed after 1) peak extraction in each spectrum, 2) peak alignment between all the 60 rosés wines and 3) specific peaks selection by applying a genetic algorithm 4) validation. The discrimination between the 3 regions was applied onto the described datasets and the chosen solution -involving only 8 molecules including 5 polyphenols- produced good classification results of $97 \%$ on the training set, $87 \%$ for the 2 -fold-cross-validation and $80 \%$ for validation.

(1) OIV Focus 2015, Le marché des vins rosés

(2) Delcambre, A. et al. Analytical chemistry 2013, 85, 9736-9741.

Mots-Clés : rosé wine, UPLC, QTOF, MS, origin discrimination, metabolomics

Programme

${ }^{*}$ Intervenant 
Méthodes préparatives et séparatives [S1c] 


\title{
Characterization of monoclonal antibodies - receptor interaction using affinity liquid chromatography coupled to native mass spectrometry [09]
}

\author{
Rabah Gahoual $* 1,2$, Anna-Katharina Heidenreich ${ }^{3}$, Govert Somsen ${ }^{4}$, Patrick \\ Bulau $^{3}$, Dietmar Reusch ${ }^{3}$, Manfred Wuhrer ${ }^{5}$, Markus Haberger ${ }^{3}$ \\ ${ }^{1}$ Unité de Technologies Chimiques et Biologiques pour la Santé (UTCBS) - CNRS : UMR8258, INSERM : U1022, \\ Université Paris Descartes - Paris 5 : Faculté de pharmacie - 4 avenue de l'observatoire 75006 Paris \\ 2 Division of BioAnalytical Chemistry, Vrije Universiteit Amsterdam - Vrije Universiteit Amsterdam, 1081 HV Amsterdam, \\ Pays-Bas \\ ${ }^{3}$ Roche Diagnostics GmbH - Roche Diagnostics GmbH, Penzberg 82377, Allemagne \\ ${ }^{4}$ Division of BioAnalytical Chemistry, vrije universiteit amsterdam (VU) - 1081 HV Amsterdam, The Netherlands, Pays-Bas \\ ${ }^{5}$ Center for Proteomics and Metabolomics, Leiden University Medical Center, 2333 ZA Leiden, Pays-Bas
}

Monoclonal antibodies (mAbs) and their related formats are meeting an important success as therapeutic treatments, mainly in oncology and treatment of inflammatory diseases. MAbs are highly complex glycoproteins derived from immunoglobulin $\mathrm{G}(\mathrm{IgG})$, potentially subject to a large variety of microheterogeneities which may influence dramatically receptor interactions.

In this work, affinity liquid chromatography (affinity LC) was directly coupled to electrospray ionization mass spectrometry, performed in native conditions to study the impact of mAbs post-translational modifications (PTMs) on FcRn interaction. The stationary phase used is composed of immobilized FcRn receptor, which interacts with IgG Fc fragment under $\mathrm{pH}$ mediated conditions. The conditions were finely optimized in order to meet the specific requirements of FcRn receptor affinity LC separation and native ESI-MS. Native FcRn affinity LC-ESI-MS analysis performed for mAbs stress samples demonstrated the possibility to separate mAbs variants exhibiting different affinities with the FcRn receptor followed by high resolution MS identification. The data achieved systematic identifications of the 5 major glycoforms and conservation of mAbs in pseudo native form. Results suggested the modification responsible for reduction of the affinity is a specific oxidation. In addition, different experiments allowed to confidently prove that the observed retention was originating from specific Fc fragment - FcRn receptor interactions.

The method was applied to a marketed mAbs exposed to different oxidative stress. Data were used to determine the oxidation level of the sample and compared to UPLC-MS peptide mapping analysis. Data correlation from both techniques allowed to identify unambiguously the oxidation of heavy chain Met252 to be responsible for the decrease of FcRn receptor - Fc fragment affinity.

This methodology implements for the first time online coupling of affinity LC and high resolution native ESI-MS. It enables to perform detailed investigations regarding the influence of PTMs on crucial receptor binding in an integrated analysis.

Mots-Clés : MS native, chromatographie d'affinité, anticorps monoclonaux, Récepteur FcRn, interactions anticorps, récepteur, couplage

*Intervenant 


\title{
Flowers absolute fingerprint with SFC-HRMS non targeted method [O10]
}

\author{
Cyrille Santerre $^{*}{ }^{1}$, David Touboul ${ }^{2}$, Nadine Vallet ${ }^{1}$ \\ ${ }^{1}$ Institut Supérieur International du Parfum de la Cosmétique et de l'Aromatique Alimentaire (ISIPCA) - CCIP - \\ 34-36 rue du parc de clagny 78000 Versailles, France \\ ${ }^{2}$ Institut de Chimie des Sunstances Naturelles (ICSN) - CNRS : UPR2301 - Avenue de la terrasse 91198 Gif sur \\ yvette cedex, France
}

Cosmetics and perfumes industries are very late for using supercritical fluids compared with pharmaceutical industry, for example. The protection and the environmental respect became a major subject of concern nowadays. Furthermore with the increasing interest of the professionals for the natural raw materials with the complexity of their compositions, Supercritical Fluid Chromatography (SFC) seems to be imperative to us as green chemistry tool. Hyphenation is very easy with Mass Spectrometry (MS) using various ionization sources (ESI, APPI, and APCI). Samples are flower absolutes from the market, and the aim of the study is to obtain quickly their "fingerprint". First step consists in stationary phase screening ( $\mathrm{Si}, \mathrm{C} 18$, Hypercarb...) using gradient mode (methanol, ethanol, isopropanol as modifier and various final percentage of modifier). Hypercarb was selected as the most retentive stationary phase for this type of analysis. Then chromatographic resolution has been improved by checking the effect of column temperature, $\mathrm{CO} 2$ back pressure. Ionization sources have been tested too and the better responses were obtained using APPI source and two ionization modes (positive and negative). Indeed volatile compounds of flower absolutes are already well known and described in the literature using Gas Chromatography (GC) coupled with MS but unvolatile fraction remains incompletely described. Two data processing methods were realized, one graphically using the EIC (Extracted-Ion Chromatogram) to obtain a chromatographic profile from compounds and a second statistical treatment to get PCA (Principal Component Analysis) representation.

Mots-Clés : SFC, HRMS, flower absolute, profiling

$\underline{\text { Programme }}$

*Intervenant 


\title{
An online four-dimensional HICxSEC-IMxMS methodology for in-depth characterization of antibody drug conjugates [O11]
}

\author{
Anthony Ehkirch * ${ }^{\text {, Valentina D' atri }}{ }^{2}$, Florent Rouvière ${ }^{3}$, Oscar \\ Hernandez-Alba ${ }^{1}$, A $\bar{l}$ exandre Goyon ${ }^{2}$, Olivier Colas ${ }^{4}$, Morgan Sarrut ${ }^{3}$, \\ Alain Beck ${ }^{4}$, Davy Guillarme ${ }^{2}$, Sabine Heinisch ${ }_{-}^{\dagger}{ }^{3}$, Sarah Cianferani ${ }_{-}^{\ddagger 1}$ \\ ${ }^{1}$ Laboratoire de Spectrométrie de Masse BioOrganique - Université de Strasbourg - CNRS, IPHC UMR 7178, 67000 \\ Strasbourg, France \\ ${ }^{2}$ School of Pharmaceutical Sciences - University of Geneva, University of Lausanne, CMU - Rue Michel-Servet, 1, 1206 \\ Geneva, Suisse \\ ${ }^{3}$ Univ Lyon - Université de Lyon, Université de Lyon - CNRS, Université Claude Bernard Lyon 1, Ens de Lyon, Institut des \\ Sciences Analytiques, UMR 5280, 69100 Villeurbanne, France \\ ${ }^{4}$ Centre d'Immunologie Pierre Fabre - CIPF - Saint-Julien-en-Genevois, France
}

Antibody Drug Conjugates (ADCs) are tripartite molecules consisting of a monoclonal antibody $(\mathrm{mAb})$ onto which highly cytotoxic small molecules are conjugated by cleavable or non-cleavable linkers. They show better efficiency than canonical unconjugated $\mathrm{mAbs}$, due to the synergic effect of $\mathrm{mAb}$ specificity for its target and the efficacy of the highly cytotoxic drug (1).

There are currently two main techniques allowing the analytical characterization of cysteine linked antibody drug conjugates under non denaturing conditions, namely hydrophobic interaction chromatography (HIC) and native high resolution mass spectrometry.

HIC is a chromatographic technique allowing the evaluation of drug load profile and calculation of average drug to antibody ratio (DAR) $(2,3)$. High resolution mass spectrometry (MS) offers a wealth of information on the biochemical and biophysical properties of ADCs, thanks to accurate mass measurement (4). On-line coupling of both techniques can potentially be of great interest, but the presence of large amounts of non-volatile salts in HIC mobile phases make them non compatible with MS.

Here, we present an innovative multidimensional analytical approach combining comprehensive on-line two dimensional chromatography (HICxSEC) to ion mobility and mass spectrometry (IM-MS) for performing analytical characterization of ADCs under non-denaturing conditions. Online hyphenation of non-denaturing 2D chromatography to 2D IM-MS enabled comprehensive and streamlined characterization of both native and stressed ADC samples.

(1) Ornes, S. Proc. Natl. Acad. Sci. 2013, 110, 13695-13695

(2) Rodriguez-Aller et al. J. Pharm. Biomed. Anal. 2016, 118, 393-403.

(3) Cusumano et al. J. Pharm. Biomed. Anal. 2016, 121, 161-173.

4. Debaene et al. Anal. Chem. 2014, 86, 10674-10683.

Mots-Clés : HIC, SEC, native MS, native IM, MS, Antibody drug conjugate, HICxSEC, IMxMS

\footnotetext{
*Intervenant

†Auteur correspondant: sabine.heinisch@univ-lyon1.fr

$¥$ Auteur correspondant: sarah.cianferani@unistra.fr
} 


\title{
Analysis of Monoclonal Antibody Fc-glycosylation profiles using Capillary electrophoresis - mass spectrometry [012]
}

\author{
Jeremie Giorgetti *1, Julie Canonge ${ }^{1}$, Valentina D'atri ${ }^{2}$, Davy Guillarme ${ }^{2}$, \\ Olivier Colas ${ }^{3}$, Elsa Wagner - Rousset ${ }^{4}$, Alain Beck ${ }^{4}$, Yannis-Nicolas \\ Francois ${ }^{1}$, Emmanuelle Leize-Wagner ${ }^{1}$ \\ ${ }^{1}$ Laboratoire de Spectrométrie de Masse des Interactions et des Systèmes (LSMIS) - UMR CNRS-UDS 7140 - \\ 1, rue Blaise Pascal, France \\ ${ }^{2}$ School of Pharmaceutical Sciences, University of Geneva, University of Lausanne - Boulevard d'Yvoy 20, \\ 1211 Geneva 4, Suisse \\ ${ }^{3}$ Centre d'Immunologie Pïerre Fabre (CIPF) - CIPF - Saint-Julien-en-Genevois, France \\ ${ }^{4}$ Centre d'Immunologie Pierre Fabre - CIPF - Saint-Julien-en-Genevois, France
}

Monoclonal Antibodies (mAbs) are considered as emergent therapeutic proteins thanks to their antiinflammatory action, anti-viral and anti-cancer efficiency. Nowadays, there are more than $50 \mathrm{mAbs}$ approved by the FDA and more than 30 in the last clinical evaluation. These molecules represent a real challenge for analytical sciences because of their structure complexity. The main obstacle is the wide range of micro-heterogeneities like Post-Translational Modifications (PTMs) and glycosylations. The glycosylation of a biologic is considered as a critical quality attribute (CQA) and is subject to intense scrutiny by both biopharmaceutical companies and regulatory agencies, and can be a major source of batch-to-batch heterogeneity in biologics production. Today, HILIC approach using fluorescence detection represents the reference method to determine the level of each glycoform [1]. At the moment, CE-ESI-MS has been proved to be a robust technique to characterize mAbs in terms of sequence coverage, PTMs characterization and glycoform structure elucidation in a single run [2]. The aim of this study was to validate the CE-ESI-MS method to quantitate relative abundance of each glycoform on mAbs. A bottom-up strategy have been adopted. Repeatability and reproducibility have also been studied. Indeed, three experimenters in the laboratory have made their own tryptic digestion of ten different mAbs to check the robustness of the method. These digests were run on CE-ESI-MS method in duplicates or triplicates to prove the repeatability of the technique. The CE-ESI-MS methodology has been performed on the ten $\mathrm{mAbs}$, and 15 different glycoforms on each one have been characterized. A relative quantitation of the glycoforms have been realized and results were systematically confronted with HILIC reference method. Comparison of N-Glycoform profiling of the ten mAbs demonstrated a good fit between the two methodologies and then validate the CE-ESI-MS methodology for relative quantitation of N-glycoform.

Mots-Clés : capillary electrophoresis, mass spectrometry, monoclonal antibodies, HILIC, glycoprofiling

Programme

*Intervenant 


\section{Traitement et analyse statistique des données [S2a]}




\title{
SpecOMS permet d'obtenir le profil des modifications portées par un échantillon analysé en MS/MS en quelques minutes [013]
}

\author{
Dominique Tessier ${ }^{*}$, Matthieu David ${ }^{1,2}$, Virginie Lollier ${ }^{1}$, \\ Guillaume Fertin ${ }^{2}$, Hélène Rogniaux ${ }^{1}$ \\ ${ }^{1}$ Unité de recherche sur les Biopolymères, Interactions Assemblages (BIA) - INRA : UR1268 - rue de la \\ géraudière, Nantes, France \\ ${ }^{2}$ LS2N UMR CNRS 6004 (LS2N) - Université Nantes - rue de la Houssinière, France
}

Le logiciel SpecOMS est capable d'identifier en quelques minutes des dizaines de milliers de spectres MS/MS sans appliquer de filtre de masse d'aucune sorte sur une station de travail standard. Il s'appuie pour cela sur une structure de données très performante (1) et met à profit la précision de mesure de masse des fragments obtenue par les spectromètres développés ces dernières années. SpecOMS est ainsi un logiciel particulièrement rapide - actuellement largement le plus rapide parmi toutes les approches proposées sans filtre de masse -, et peu gourmand en mémoire, ce qui rend son utilisation possible dans tous les laboratoires. De plus, nous montrerons sur des jeux de spectres extraits de PRIDE, qu'il est également très sensible. SpecOMS peut donc facilement être intégré dans un pipeline d'analyse pour (i) visualiser en un coup d'œil les principales modifications présentes dans un échantillon et éventuellement les ajouter en modification variable dans son outil préféré (ii) identifier les artefacts d'une expérience pour y pallier et /ou en maîtriser les conséquences, (iii) et enfin, bien sûr, mettre en évidence les modifications post traductionnelles et/ou les variants des peptides présents dans les échantillons.

Le développement des approches sans filtre de masse pour interpréter les spectres MS/MS est actuellement un domaine de recherche très dynamique. Cependant, l'utilisation de ces logiciels est encore aujourd'hui freinée par la difficulté et le temps nécessaire à l'interprétation complexe des résultats. Nous proposons une démarche et quelques représentations graphiques originales pour faciliter ce processus d'interprétation.

(1) David M., Fertin G. and Tessier D. 2016 SpecTrees: An efficient without a Priori Data Structure for MS/MS Spectra Identification. In: Frith M., Storm Pedersen C. (eds) Algorithms in Bioinformatics WABI 2016. Lectures Notes in Computer Science, vol 9838, 65-76; Springer.

Mots-Clés : : Bioinformatique, Interprétation des spectres MS/MS, Approche sans filtre de masse

Programme

${ }^{*}$ Intervenant 


\title{
Combattre le feu par le feu: Comprehensive DIA spectral libraries improve phosphopeptide identification and quantification by DIA [O14]
}

\author{
Sebastian Vaca $* \dagger 1$, Jarrett Egertson ${ }^{2}$, Brian Searle ${ }^{2}$, Sonia Ting ${ }^{2}$, Adam \\ Officer ${ }^{1}$, Karsten Krug ${ }^{1}$, Michael Maccoss ${ }^{2}$, Steven Carr ${ }^{1}$, Jacob D. Jaffe ${ }^{1}$ \\ ${ }^{1}$ Broad Institute of MIT and Harvard, Cambridge, MA, 02142 - 415 Main Street, Cambridge, MA-02142, \\ Etats-Unis \\ ${ }^{2}$ Department of Genome Sciences, University of Washington - Foege Building S-250, Box 3550653720 15th \\ Ave NE, Seattle WA 98195-5065, Etats-Unis
}

The mining of Data-Independent Acquisition (DIA) data usually requires the use of an MS/MS spectral library. Peptide identification and quantification highly depend on the quality and the completeness of this library. Typically, libraries are generated using Data-Dependent Acquisition (DDA) methods, which produce incomplete datasets due to the semi-stochastic nature of the parent ion selection. By promising to capture a signal for all peptides above the instrument's limits of detection, we wondered if DIA itself might be the best method to generate comprehensive high-quality spectral libraries.

To generate a comprehensive spectral library and obtain the largest diversity of phosphopeptides, we created a pool of 32 samples from PC3 cells that were perturbed with different drugs, lysed, digested, and phospho-enriched. The sample was analyzed on an Orbitrap mass-spectrometer using twelve separate DIA methods, each spanning $50 \mathrm{~m} / \mathrm{z}$ to cover the $400-1000 \mathrm{~m} / \mathrm{z}$ precursor ion space. In turn, each DIA method cycled through $25 \times 2 \mathrm{~m} / \mathrm{z}$ narrow-window isolation events. The data were analyzed with SpectrumMill for peptide identification and Percolator for validation and FDR control. The peptide quantification was performed with an automated pipeline using Skyline combinaed with EncyclopeDIA to identify peptides and align retention times. High quality and interference-free DIA signals are insured by a newly developed transition refinement tool.

The comprehensive mass spectrometry method presented here enabled the generation of a large phosphopeptide library termed the superlibrary. We demonstrated that DDA-like peptide identification approaches were compatible with our narrow-window DIA data since the approach generates significantly low false discovery rates. The use of narrow isolation windows and the untargeted analysis, characteristic of DIA, highly increased sensitivity and phosphoproteome coverage. More than 17400 phosphopeptides could be identified which represents a $60 \%$ improvement over classic DDA approaches. Additionally, by capturing the entire chromatographic profile of phosphosite-specific transitions, the number of confidently localized phosphopeptides increased by $30 \%$.

Mots-Clés : Data, Independent Acquisition, Chromatographic Libraries, Data Refinement, Phosphoproteomics

$\underline{\text { Programme }}$

\footnotetext{
${ }^{*}$ Intervenant

†Auteur correspondant: svaca@broadinstitute.org
} 


\title{
Complex designs combining ASCA/APCA-derived methods and mixed models [O15]
}

\author{
Manon Martin ${ }^{* \dagger}{ }^{1}$, Bernadette Govaerts ${ }^{1}$ \\ ${ }^{1}$ Institut de Statistique, Biostatistique et Sciences Actuarielles (ISBA) - Université Catholique de Louvain, Voie \\ du Roman Pays 20, 1348 Louvain-La-Neuve, Belgique
}

Omics data produce high-dimensional multivariate databases usually with a higher number of variables than samples and high biological variability that may impact the data. They also frequently involve complex experimental designs that should be considered during the data analysis to maximize their efficiency and accuracy. However, in practice, part of this information is often ignored and the analysis is resumed to a one-response (O)PLS-DA modelling. To be able to extract meaningful information from these data, one solution lies in a combination of multivariate dimension reduction methods and statistical modeling. This methodology allows to understand the effect of each experimental factor on the multivariate response and quantify or test their statistical significance.

Two popular approaches, namely ASCA and APCA combine the strengths of ANOVA and PCA in this context. They provide a powerful new framework to visualize the multivariate structures in the space of each effect related to the experimental design, yet lack generalization since they cannot handle more complex models than balanced fixed effects ANOVA. Extensions to circumvent their restrictive use are already been suggested to deal with unbalanced designs. The scope of this research is to extend further this methodology using mixed models with random factors in the statistical modeling, allowing to measure and test the significance of both fixed and random effects in such complex designs.

These methods will be applied on a longitudinal and an analytical variance components studies, to demonstrate their interest and encourage further work in this promising field of data analysis.

Mots-Clés : mixed models, APCA, complex experimental designs

$\underline{\text { Programme }}$

\footnotetext{
*Intervenant

†Auteur correspondant: manon.martin@uclouvain.be
} 


\title{
Two birds, one stone: ANOVA multiblock OPLS supports data analysis and method comparison in toxicant-induced neuroinflammation observed in 3D rat neural cell cultures [016]
}

\author{
Víctor González-Ruiz * 2,1, Julian Pezzatti ${ }^{2}$, Jenny Sandström ${ }^{3,1}$, Florianne \\ Monnet-Tschudi ${ }^{1,3}$, Julien Boccard ${ }^{2,1}$, Serge Rudaz ${ }^{1,2}$ \\ ${ }^{2}$ Analytical Sciences, School of Pharmaceutical Sciences - University of Geneva. 1, rue Michel Servet, CH 1211 \\ Genève, Suisse \\ ${ }^{1}$ Swiss Centre for Applied Human Toxicology (SCAHT) - University of Basel. Missionsstrasse 64, CH 4055 \\ Basel, Suisse \\ ${ }^{3}$ Department of Physiology, University of Lausanne, Switzerland - 7, rue du Bugnon CH-1005 Lausanne, Suisse
}

\begin{abstract}
Untargeted metabolomics becomes a useful approach without previous knowledge about the metabolic pathways altered in a biological experiment. Nevertheless, among the challenges associated to that strategy, it is first necessary to reliably assign identities to the detected features. Secondly, the large datasets obtained require a clever data analysis strategy to maximize the amount of useful information recovered from them. This is especially relevant when data originate from several analytical methods and when multiple experimental factors are varied simultaneously. These two issues can be tackled by combining the use of an in-house developed library of standards and a recently proposed approach of multivariate decomposition in PLS-based discrimination for structured experiments, i.e. AMOPLS (ANOVA Multiblock OPLS).

The most reliable metabolite identification can only be achieved by matching at least two orthogonal properties of an unknown compound to those of a reference standard, under the same analytical conditions and in the same lab. A high-throughput strategy has been deployed to create a library of properties covering over 600 standards under four different separation/ionization modes (RP+/-, HILIC+/-).

In the present study, rat 3D neural cell cultures were exposed to neurotoxicant trimethyltin following a design of experiments comprising three factors: cells maturation state, dose of toxicant and exposure time. Samples were submitted to RP+/- and HILIC+/- analyses and features were identified by means of the library of standards. Most existing multivariate analysis tools, such as PCA, fail to decompose the different sources of variation in the data using a single global model. On the contrary, AMOPLS analysis of data generated in the four modes allowed to quantify the contribution of each experimental factor to the total observed variability, as well as the ability of each analytical method to distinguish the effect of each factor.
\end{abstract}

Mots-Clés : multivariate analysis, multiblock, neurotoxicity, neuroinflammation, cell cultures, neurodegenerative diseases

$\underline{\text { Programme }}$

\footnotetext{
*Intervenant
} 


\section{Imagerie in vitro et in vivo [S2b]}




\title{
Analysis of Chemotherapeutic Drug Delivery at the Single Cell Level Using TOF-SIMS [017]
}

\author{
Quentin Vanbellingen ${ }^{* \dagger}{ }^{1}$, Anthony Castellanos ${ }^{1}$, Monica Rodriguez-Silva ${ }^{2}$, \\ Iru Paudel ${ }^{2}$, Jeremy Chambers ${ }^{2,3}$, Francisco Fernandez-Lima ${ }_{-}^{\ddagger 1,3}$ \\ ${ }^{1}$ Department of Chemistry and Biochemistry - AHC 4 Florida International University 11200 SW 8th St, Miami, \\ FL 33199, Etats-Unis \\ 2 Department of Cellular Biology and Pharmacology, Department of Neuroscience, Herbert Wertheim College of \\ Medicine - AHC4 Florida International University 11200 SW 8th St, Miami, FL 33199, Etats-Unis \\ ${ }^{3}$ Biomolecular Science Institute - AHC4 Florida International University 11200 SW 8th St, Miami, FL 33199, \\ Etats-Unis
}

Time-of-Flight Secondary Ion Mass Spectrometry (TOF-SIMS) is emerging as an imaging tool for biomedical studies on the sub-micrometer scale. In this study, semi-quantification of anticancer drug ABT-737 is demonstrated in vitro in human A-172 human glioblastoma cells.

Gold coated silicon wafers have been immerged in A-172 human glioblastoma culture. Samples have been treated with ABT-737 in a range of concentrations $(0,25,50$, and $100 \mu \mathrm{M})$ for four hours. After treatment, Samples were washed in $10 \mathrm{mM}$ ammonium acetate followed by freeze-drying. A commercial TOF-SIMS5 (ION-TOF GmbH) retrofitted by a $20 \mathrm{keV}$ GCIB and a $25 \mathrm{keV}$ bismuth LMIG has been used. Cell interrogation was performed using either High Mass Resolution mode (HMR) $\left(5 \mathrm{e} 12 \mathrm{ions} / \mathrm{cm}^{2}\right.$ dose density, $1.2 \mu \mathrm{m}$ pixel size) or High Spatial Resolution mode (HSR) (1e13 ions $/ \mathrm{cm}^{2}$ dose density, $195 \mathrm{~nm}$ pixel size).

In HMR analysis, the total targeted ion count was normalized to both the primary ion beam dose as well as to the surface, thus allowing for comparison between different cell samples. When comparing the relative abundance of secondary ions, it was found that the concentration of HP2O6- (nuclear marker), and $[\mathrm{C} 16: 0-\mathrm{H}]-$ (fatty acid) do not vary as a function of drug dosage. In contrast, the abundance of characteristic ions of ABT-737 were found to increase as a function of dosage, reaffirming that A-172 cells had internally incorporated the therapeutic agent.

HSR analyses reveal characteristic fragment ions of ABT-737 has been detected in cell, following a specific distribution different of nuclei and cytoplasm marker. This result is in agreement of the literature which describe ABT-737 is supposed to target proteins located in mitochondria membrane.

The workflow has demonstrated the possibility for the localization as well as semi-quantification of drug delivered into single cells using a TOF-SIMS.

Vanbellingen et al. J Am Soc Mass Spectrom 2016, 27, 2033-2040

Mots-Clés : TOF, SIMS, Mass Spectrometry Imaging, Quantification, Drug, Single Cell Analysis

Programme

\footnotetext{
* Intervenant

$\dagger$ Auteur correspondant: quentin.vanbellingen@ gmail.com

¥Auteur correspondant: franciscoalberto.fernandezlima@ fiu.edu
} 


\title{
MetaSpace: A molecular annotation engine for metabolite imaging mass spectrometry [018]
}

\author{
Régis Lavigne ${ }_{-}^{*}$, Consortium Metaspace ${ }^{2}$, Charles Pineau ${ }^{1}$, Theodore \\ Alexandrov ${ }^{3}$ \\ ${ }^{1}$ PROTIM - INSERM U1085 Irset, Université de Rennes I \\ CS2407 Campus de Beaulieu 35042 Rennes cedex, France \\ ${ }^{2}$ Consortium MetaSpace - http://metaspace2020.eu/, Allemagne \\ ${ }^{3}$ European Molecular Biology Laboratory (EMBL) - theodore.alexandrov@embl.de, Allemagne
}

\begin{abstract}
Imaging mass spectrometry (IMS) can be used for probing and analyzing in situ the spatial arrangement of a wide range of molecules, in particular metabolites. However, no algorithms exist for automated molecular annotation. A high-resolution imaging dataset for one tissue section has 10.000.000 individual ion images and manual interpretation covers up to $0.01 \%$ data only. This lack of global understanding of data is a bottleneck.

Our consortium has developed a big data analysis platform to answer this question. Based on efficient algorithms and big data technologies, this platform is able to translate millions of ion images to hundreds of molecular images. Hundreds of datasets provided to us by the IMS community, from various species, organs, conditions, and IMS technologies, have been processed using the METASPACE metabolite annotation engine (Palmer et al., 2016, Nature Methods). We performed FDR-controlled annotation of all these datasets against databases considering various adducts. We stored all metabolite and lipid annotations and indexed them for fast access to have a custom search engine for metabolite images.

METASPACE is an open-source platform for spatial metabolomics. High-throughput molecular annotation with a controlled level of confidence makes possible the extraction of molecular knowledge from different datasets in a reproducible way, enabling comparisons between replicates, users, and labs. Yet, the consortium received over 1000 datasets from more than 25 labs covering various species, organs, conditions, acquired with various sample preparation protocols, and various IMS technologies. All annotations are made public through the web interface, allowing searching in particular for specific datasets or compounds, and enable the clustering of datasets with similar molecular content that often matches either the type of tissue or the condition. This metabolite annotation will be illustrated in different examples. Mining all these big datasets enabled our consortium to create the first of its kind spatial metabolite knowledgebase.
\end{abstract}

Mots-Clés : MALDI Imaging, Computational Methods and Analysis, Metabolites, Lipids

$\underline{\text { Programme }}$

*Intervenant 


\title{
Development of a dual imaging strategy combining radio- and mass spectrometry -imaging to study the biodistribution of 14C-graphene oxide [O19]
}

\author{
Hélène Cazier * ${ }^{1}$, Dominique Georgin ${ }^{2}$, Carole Malgorn ${ }^{3}$, François \\ Fenaille ${ }^{1}$, Frédéric Taran ${ }^{2}$, Vincent Dive ${ }^{3}$, \\ Christophe Junot ${ }^{1}$, Benoit Colsch ${ }^{1}$
}

\author{
${ }^{1}$ CEA-INRA UMR 0496/DRF/Institut Joliot/SPI/LEMM, Université Paris Saclay, MetaboHUB - Centre de \\ Saclay, 91191 Gif-sur-Yvette, France \\ 2 CEA/DRF/Institut Joliot/SCBM, Université Paris Saclay - Centre de Saclay, 91191 Gif-sur-Yvette, France \\ ${ }^{3}$ CEA/DRF/Institut Joliot/SIMOPRO, Université Paris Saclay - Centre de Saclay, 91191 Gif-sur-Yvette, France
}

\begin{abstract}
Graphene success results from its versatile physicochemical and biological properties making it an attractive nanomaterial. Indeed, those nanoparticles such as carbon-nanotubes, nanodots or graphene oxide (GO) sheets can be used in multiple areas including therapeutics with bioengineering or drug delivery. Despite its great potential, special attention has to be paid concerning its bioactivity and safety. To this end, our approach aims to provide complementary analytical information on biodistribution of 14C-radiolabeled graphene in mouse tissue by combining radioimaging (CZARNY et al. ACS nano, 2014) and mass spectrometry imaging (MSI) (CHEN et al. Nature nanotech, 2015). Indeed, absolute quantification provided by radioimaging needs to be supplemented with structural analyzes to confirm graphene-specific biodistribution (for instance in mouse tissues).

Development of the MSI approach was performed on an UltraFleXtreme ${ }^{\mathrm{TM}}$ MALDI-TOF/TOF (Matrix assisted Laser Desorption Ionization - tandem Time Of Flight) mass spectrometer to detect labeled (14C) and unlabeled (12C) graphene oxide species. First, homogeneous suspensions of 12C-GO and 14C-GO were obtained in $0.05 \%$ Sodium DodecylBenzeneSulfonate (SDBS) and analyzed in negative ionization mode without any MALDI matrix addition. Specific signatures were reproducibly observed for both forms of GOs, with carbon cluster distributions ranging from C2-. $(\mathrm{m} / \mathrm{z} 23.93)$ to C9-. $(\mathrm{m} / \mathrm{z}, 108.03)$ and a base peak at $m / z 71.99$ corresponding to C6-. .

In addition, the limit of detection (LOD) was assessed by analyzing dilution series of 12C-GO on and out of tissue sections, in order to evaluate method sensitivity in both conditions and matrix effect. LODs were determined at $1 \mathrm{ng} / \mu \mathrm{L}$ after deposition on indium tin oxide (ITO) slides and $5 \mathrm{ng} / \mu \mathrm{L}$ on liver tissue sections.

After confirmation of ITO slides compatibility with both imaging techniques, future objectives aim to successively analyze $14 \mathrm{C}-\mathrm{GO}$ in an animal model by the implemented dual imaging approach. Those complementary results could be further exploited to study other carbon nanomaterials biodistribution.
\end{abstract}

Mots-Clés : Graphene, Biodistribution, Mass Spectrometry Imaging, Radioimaging

\section{Programme}

\footnotetext{
${ }^{*}$ Intervenant
} 


\title{
Characterization and localization of synthetic cannabinoid isomers in hair using MALDI-MSn imaging [O20]
}

\author{
Angéline Kernalléguen ${ }^{*}{ }^{1,2}$, Christine Enjalbal ${ }^{3}$, Georges Leonetti ${ }^{2}$, \\ Anne-Laure Pélissier-Alicot ${ }^{4}$, Daniel Lafitte ${ }_{-}^{\dagger} 1$ \\ ${ }^{1}$ Université Aix-Marseille, INSERM, CRO2, UMR S 911, PIT2 - Hôpital de la Timone [CHU - APHM] : U911, \\ INSERM : U911 - Faculté de Pharmacie - 27 Boulevard Jean Moulin 13385 Marseille cedex 05, France \\ ${ }^{2}$ Université Aix-Marseille, CNRS, EFS, ADES UMR 7268 (ADES) - Faculté de Médecine - 27 boulevard Jean \\ Moulin - 13385 Marseille cedex 05, France \\ ${ }^{3}$ Université de Montpellier, IBMM, UMR 5247 (IBMM) - CNRS : UMR5247, Ecole Nationale Supérieure de \\ Chimie de Montpellier - Faculté de Pharmacie - 15 Av. Charles Flahault - BP 14491 \\ 34093 Montpellier Cedex 5, France \\ ${ }^{4}$ Université Aix-Marseille, APHM, CHU Timone, Service de Médecine Légale - Hôpital de la Timone [CHU - \\ APHM] - Faculté de Médecine - 27 boulevard Jean Moulin - 13385 Marseille cedex 05, France
}

Hair strands analysis documents punctual or regular drugs of abuse (DOA) consumption. At the beginning of the 2000s, the hair analysis was associated with Matrix-Assisted Laser Desorption Ionization mass spectrometry (MALDI) and new opportunities appear, such as high-throughput profiling or drug monitoring. Mass spectrometry imaging (MSI) offers the unique possibility to map with high spatial resolution several tens of species into only one intact hair, such as synthetic cannabinoids (SCs). The SCs have multiple positional isomers but minor structural modifications lead to significant influence on SCs pharmacokinetic and their affinity for the cannabinoid CB1 and CB2 receptors, and thus on their potency in vivo. Drug-free hair samples were soaked overnight in a solution of JWH-007, JWH-019 and JWH-122, to simulate concomitant drug consumption. Intact hair samples were fixed onto ITO glass blade and sprayed with $\alpha$-cyano-4-hydroxycinnamic (CHCA) matrix. The JWH standard solutions and hair were analyzed and mapped using MALDI QIT-TOF (Nitrogen laser, $337 \mathrm{~nm}, 20 \mathrm{~Hz}$ ) and MALDI$7090^{\mathrm{TM}}$ TOF-TOF (Nd:YAG laser, $355 \mathrm{~nm}, 500 \mathrm{~Hz}$ ) mass spectrometers. Fragments ions were produced through high- (TOF-TOF) and low-energy (QIT) fragmentation process. This talk will demonstrate the high efficiency of the MALDI-MSn and imaging combination to decipher along human hair strands, three JWH synthetic cannabinoid isomers with a methyl group positional change on the SCs skeleton. The MALDI QIT-TOF provides on one hand identification of JWH isomers using MS3 and in the other hand, imaging in hair samples. The combination of MALDI-MS $n$ and imaging is a real improvement: without an extensive hair samples preparation, a high mapping resolution (laser pitch _ $100 \mu \mathrm{m}$ ) for a precise chronological consumption history and a MS3 fragmentation to determine exact composition of complex mixture, open new ways for precise elucidation of complex drugs in forensic issues using the potency of the QIT-TOF/MS $n$ fragmentation.

Mots-Clés : MALDI, Imaging, Hair analysis, Drugs monitoring, Isomers

Programme

\footnotetext{
*Intervenant

${ }^{\dagger}$ Auteur correspondant: daniel.lafitte@univ-amu.fr
} 


\section{Environnement [S2c]}




\title{
Apport et limites des approches non ciblées de spectrométrie de masse à haute résolution pour la caractérisation de l'exposome : cas des pesticides [021]
}

\author{
Emilien Jamin 1,2, Adéline Delcambre ${ }^{1,2}$, Jean-François Martin ${ }^{1,2}$, Nathalie \\ Bonvallot ${ }^{3}$, Emmanuelle Kesse-Guyot ${ }^{4}$, Jean Pierre Cravedi ${ }^{2}$, Laurent \\ Debrauwer* $* 1,2$ \\ ${ }^{1}$ Metatoul Axiom platform - MetaboHUB, INRA, 180 chemin de Tournefeuille, Toulouse, France \\ 2 UMR 1331 Toxalim - INRA-ENVT-INP-EIP-UPS, 180 chemin de Tournefeuille - Toulouse, France \\ ${ }^{3}$ EHESP-Irset (EHESP-Irset) - École des Hautes Études en Santé Publique [EHESP], INSERM - Avenue du Pr. Léon Bernard CS74312 - \\ 35043 - Rennes, France \\ ${ }^{4}$ Centre de Recherche Épidémiologie et Statistique Sorbonne Paris Cité - Université Paris 13, U.F.R de Santé, Médecine et Biologie Humaine, \\ INSERM, INRA, Université Paris Diderot - Paris 7, Université Paris Descartes - Paris 5, 74 rue Marcel Cachin, 93017 Bobigny cedex, France
}

L'exposition de l'Homme aux contaminants alimentaires et environnementaux (tels que les pesticides) est généralement estimée par des méthodes indirectes. Le bio-monitoring ciblé permet depuis les années 2000 d'améliorer l'estimation de l'exposition mais se heurte aux quantités d'échantillon souvent très faibles pour des analyses aussi rigoureuses et sensibles que possible. Ainsi, les risques pour la santé humaine associés à la multi-exposition aux mélanges complexes restent actuellement sous-explorés et les questions suivantes constituent toujours des défis : pouvons-nous évaluer l'exposition aux polluants à partir de bio-fluides de façon non ciblée ? Quelle est l'influence de ces expositions multiples sur le métabolome? Quels mécanismes pourraient être impliqués dans les perturbations métaboliques observées?

Pour tenter de répondre à ces questions, nous avons développé un workflow complet d'analyses métabolomiques non ciblées basées sur la spectrométrie de masse haute résolution (HRMS) et la RMN pour évaluer d'une part l'exposition des sujets aux pesticides et d'autre part les effets de cette exposition sur leur métabolisme général.

Ce workflow a été appliqué dans le cadre de deux études différentes. L'une a été menée à partir de 338 échantillons d'urine de femmes enceintes (cohorte PELAGIE, Bretagne), classifiés en 3 groupes selon la surface consacrée à l'agriculture céréalière dans leur commune de résidence. La seconde a concerné 300 échantillons urinaires issus de sujets (cohorte NUTRINET, France) consommant une alimentation issue majoritairement de l'agriculture dite biologique vs. l'agriculture dite conventionnelle.

Les résultats présentés tenteront de montrer que ces approches non ciblées peuvent apporter des informations non seulement sur l'exposition aux contaminants grâce à l'identification de métabolites urinaires de pesticides dans une démarche de " suspect-screening ", mais aussi sur l'impact potentiel de ces expositions complexes sur le métabolisme, en s'intéressant non plus aux contaminants eux-mêmes mais aux variations des concentrations en métabolites endogènes tels que révélées dans l'urine.

Mots-Clés : métabolomique, exposome, spectrométrie de masse, pesticides, métabolites

${ }^{*}$ Intervenant 


\title{
LC-HRMS based metabolomics to highlight biotransformation products and unexpected effects of diclofenac in Mytilus galloprovincialis [O22]
}

\author{
Bénilde Bonnefille , Elena Gomez, Mellis Alali , Hélène Fenet, \\ Frédérique Courant ${ }_{-}^{*}$ \\ ${ }^{1}$ Hydrosciences Montpellier (HSM) - Université de Montpellier (UM) - Faculté de Pharmacie, 15 Avenue \\ Charles Flahault, 34093 Montpellier Cedex 5, France
}

Diclofenac (DCF) has become a major contaminant of interest as shown by its inclusion in the EU Water Framework Directive (2015/495/EC). Relatively little is known regarding its biotransformation and unexpected effects (beyond the mechanism of action). Metabolomics seems to be a promising approach to investigate them. Indeed, metabolomics profiles acquired from aquatic organisms may reveal i) exposure through the detection of contaminants and their biotransformation products and ii) effects through the investigation of endogenous metabolites modulation after the exposure.

To demonstrate the approach feasibility, an experiment was carried out whereby marine mussels were exposed for 7 days to ethanol (<1॰/oo, vehicle) or to $100 \mu \mathrm{g} / \mathrm{L}$ DCF. Analytical methods relying on Liquid Chromatography-High Resolution Mass Spectrometry were developed to generate metabolic profiles from mussel's tissues. The obtained profiles for both groups (controls and exposed) were compared.

We highlighted DCF and 13 DCF metabolites in exposed mussels. Three of them were phase I metabolites such as 4'-hydroxy-diclofenac, and 10 were phase II metabolites such as amino acids conjugates. Five were reported for the first time in an aquatic organism. Regarding the effects, we evidenced the modulation of steroid hormone biosynthesis, dopaminergic and serotoninergic pathways. These three pathways are involded in spawning modulation in mussels (2-4). Moreover, steroid hormones have been described as involved in neurotransmitters activity modulation (5). Our results suggest a potential threat of DCF on mussel's reproduction. Metabolomics appears then to be an appropriate approach to highlight in a comprehensive manner biotransformation products and unexpected effects in mussels exposed to DCF.

(1) Holmes et al., Anal. Chem. 79, 2629 (2007).

(2) Wang \& Croll, Aquaculture 256, 423 (2006).

(3) Fong et al., J. Exp. Zool. 267, 475 (1993).

(4) Fong et al., J. Exp. Zool. 266, 79 (1993).

(5) Lafont \& M. Mathieu, Ecotoxicology 16, 109 (2007).

Mots-Clés : pharmaceuticals, non, targeted profiling, neurotransmitters, steroid hormones, reproduction

$\underline{\text { Programme }}$

\footnotetext{
${ }^{*}$ Intervenant
} 


\title{
Ecotoxicity of sunlight irradiated marketed mixtures of acetamiprid and structural characterisation of unknown photoproducts [023]
}

\author{
Edith Nicol ${ }^{* \dagger}{ }^{1}$, Caroline Berenger ${ }^{1}$, Ségolène De Vaugelade ${ }^{1,2}$, Svetlana \\ Vujovic $^{1}$, Sophie Bourcier ${ }^{1}$, Stéphane Bouchonnet ${ }^{1}$ \\ ${ }^{1}$ Laboratoire de chimie moléculaire (LCM) - Polytechnique - X, Université Paris-Saclay, CNRS : UMR9168 - \\ Ecole polytechnique 91128 Palaiseau Cedex, France \\ ${ }^{2}$ EXPERTOX Laboratory - EXPERTOX - 75011 PARIS, France
}

\begin{abstract}
One of the major issues of our time is the impact of pesticides on health and environment in terms of toxicity and ecotoxicity. The main concern is that most of their degradation products remain unknown, explaining the growing number of studies trying to clear up this topic. Crops treated with insecticides are directly exposed to sunlight irradiation, which may lead to compounds harmful for human and environment.

Studies about photodegradation of several fungicides have already been carried out, often showing an increased toxicity of the irradiated samples, and the ability of photoproducts to cross the skin of fruits. Very recently, photoreactions between the pesticide and the matrix have started to be considered and this work follows on this pathway.

Polysect and Roseclear are marketed mixtures directly sprayed on vegetables to protect them, among others, from aphids, cochineals, thirps or colorado potato beetles. They contain acetamiprid (the insecticide) and additives such as 1,2-benzisothiazoline-3-one for Polysect or a fungicide (triticonazole) for Roseclear, identified as preserver and having an antifungal activity.

UV-visible irradiation was performed first on acetamiprid, then on both marketed mixtures. These studies allowed the identification of the degradation products. Chemical interaction with the additives and their influence on the degradation rate of acetamiprid and the appearance of the photoproducts were also studied. All these investigations were carried out with LC-HR-MS/MS, to obtain precise identification of the structures and to propose photochemical and fragmentation mechanisms.

Experiments were performed to estimate the toxicity of the sample on several living organisms (TEST QSAR software) and to confirm the ecotoxicity estimated using in silico tests on Vibrio fisheri bacteria. The main photoproducts observed and their potential toxicities will be discussed, as well as the occurrence of intermolecular reactions within the marketed mixtures and their consequences on ecotoxicity and human health.
\end{abstract}

Mots-Clés : Ecotoxicity, acetamiprid, LC HR MS/MS, photodegradation, marketed mixtures

Programme

\footnotetext{
* Intervenant

†Auteur correspondant: edith.nicol@polytechnique.edu
} 


\title{
Intrinsic ion mobility peak width as an indicator of isomeric species distribution in petroleum using ion mobility - mass spectrometry [024]
}

\author{
Mathilde Farenc , Benoit Paupy ${ }^{1}$, Sabrina Marceau ${ }^{1}$, Eleanor Riches ${ }^{2}$, Carlos \\ Afonso ${ }_{-}^{*}$, Pierre Giusti ${ }^{1}$

\footnotetext{
${ }^{2}$ Waters Corporation - Stamford Avenue, Altrincham Road, Wilmslow, Cheshire. SK9 4AX, Royaume-Uni

${ }^{3}$ Normandie Univ, FR 3038; IRCOF, (COBRA) - Université de Rouen, CNRS : UMR6014, INSA Rouen - 1 rue

Tesnière, 76821 Mont St Aignan cedex, France
} \\ ${ }^{1}$ Total Raffinage Chimie (TRTG) - Département Analyse BP 27 - 76700 Harfleur, France
}

Ion mobility coupled with mass spectrometry was proved to be efficient way to characterize complex mixtures such as petroleum samples $(1,2)$. However, the identification of isomeric species is difficult owing to the molecular complexity of petroleum and no availability of standard molecules (3). This work proposes a new simple indicator to estimate the isomeric content of highly complex mixtures. This indicator is based on the full width at half maximum (FWHM) of the extracted ion mobility peak measured in millisecond or square angstrom which is corrected for instrumental factors such as ion diffusion (4). This value can be easily obtained without precisely identifying the number of isomeric species under the ion mobility peaks. Actually, considering the Boduszynski model, the ion mobility profile for a particular elemental composition is expected to be a continuum of various isomeric species. The drift time dependent fragmentation profile was studied and confirmed this hypothesis showing a continuous evolution of the fragmentation profile showing that the larger alkyl chain species were detected at higher drift time values. Finally, this new indicator was proved to be a fast and efficient method to compare vacuum gasoils for which no difference was found using other analytical techniques.

(1) Lalli, P.M., Jarvis, J.M., Marshall, A.G., Rodgers, R.P. Energy Fuels 31, 311-318 (2017).

(2) Maire, F., Neeson, K., Denny, R., McCullagh, M., Lange, C., Afonso, C., Giusti, P. Anal. Chem. 85, 5530-5534 (2013).

(3) Farenc, M., Corilo, Y.E., Lalli, P.M., Riches, E., Rodgers, R.P., Afonso, C., Giusti, P. Energy Fuels 30, 8896-8903 (2016).

(4) Jeanne Dit Fouque, K., Afonso, C., Zirah, S., Hegemann, J.D., Zimmermann, M., Marahiel, M.A., Rebuffat, S., Lavanant, H. . Anal. Chem. 87, 1166-1172 (2015).

Mots-Clés : ion mobility, mass spectrometry, petroleomics, isomers

$\underline{\text { Programme }}$

\footnotetext{
*Intervenant
} 
Approches omiques quantitatives [S3a] 


\title{
Proteomic analysis reveals strong secretion of IL-9 by group2 innate lymphoid cells upon IL-33/TL1A co-stimulation [025]
}

\author{
Anne Gonzalez De Peredo * 1 , Mylène Camus ${ }^{1}$, Corinne Cayrol ${ }^{1}$, Anaïs \\ Duval ${ }^{1}$, Odile Burlet-Schiltz ${ }^{1}$, Jean-Philippe Girard ${ }^{1}$ \\ ${ }^{1}$ Institut de Pharmacologie et Biologie Structurale (IPBS), UMR5089 CNRS - Université de Toulouse (IPBS) - \\ CNRS : UMR5089 - 205 route de Narbonne, 31077 Toulouse, France
}

Group 2 innate lymphoid cells (ILC2s) are key players of innate immunity, producing high amounts of Th2 cytokines IL-5 and IL-13. They are major targets of the epithelial cytokine interleukin-33 (IL-33), which is critically involved in allergic inflammation and asthma. However, the mechanisms of ILC2s' response to the stimulation by IL33 and other activators, such as the TNF-family cytokine TL1A, are not fully understood.

We used a large-scale quantitative mass spectrometry approach to characterize the proteome of ILC2s and its modulation following stimulation. Mouse ILC2s were isolated from lungs, stimulated in-vitro with IL-33 alone or in combination with other cytokines, and analyzed by nanoLC-MS/MS on a fastsequencing Orbitrap Fusion mass spectrometer, followed by label-free quantification.

We mined the proteome of ILC2s to a depth of more than 5000 proteins and detected about 200 proteins significantly modulated following IL-33 stimulation, including IL-5 and IL-13 but also several cell surface proteins and transcription factors. Interestingly, our unbiased proteomic approach revealed that stimulation of ILC2s with a combination of IL-33 and TL1A specifically induced a major up-regulation of IL-9, a key driver of allergic inflammation at mucosal surfaces. Further analysis by flow-cytometry, ELISA and RT-qPCR showed that IL-33 synergizes with TL1A to induce prodigious amounts of IL-9 secretion by ILC2s. The IL-9 production was transient and associated with a phenotypic shift characterized by upregulation of pSTAT5 and downregulation of the ILC2 master transcription factor GATA-3. Finally, in vivo experiments showed that the IL-33/TL1A co-stimulation induces IL-9 high ILC2s in lungs, and that these cells are potent inducers of allergic airway inflammation.

This is the first proteomic characterization of ILC2s and their response to IL-33 activation. Importantly, we describe for the first time stimulatory conditions that induce the secretion of IL-9 by ILC2s, up to levels significantly higher than previously described for Th9 cells.

Mots-Clés : large, scale proteomics, label, free quantification, immune cells, immunology, ILC2, IL33, cytokine

Programme

${ }^{*}$ Intervenant 


\title{
Carbon 12 metabolic labeling for high-throughput quantitative proteomics [026]
}

\author{
Thibaut Léger* ${ }_{-}$, Camille Garcia ${ }^{1}$, Bastien Morlet ${ }^{1}$, Laetitia Collomb ${ }^{1}$, \\ Jean-Michel Camadro $\stackrel{\dagger+1}{-1}$ \\ ${ }^{1}$ Institut Jacques Monod (IJM) - Université Paris Diderot - Paris 7, CNRS : UMR7592 - Université Paris \\ Diderot, Bât. Buffon, 15 rue Hélène Brion, 75205 Paris cedex 13, France
}

Many quantitative proteomics strategies rely on in vivo metabolic incorporation into proteins of amino acids with modified stable isotopes profiles. These methods give rise to multiple ions for each peptide, with possible distortion of the isotopologs distribution, making the overall analytical process complex. By reducing the isotopic composition of proteins in vivo we bring a new dimension to indepth, high resolution MS-based quantitative proteomics that alleviates these problems. We used U[12C]-glucose as the metabolic precursor of all amino acids in yeast. This substantially increased the peptide monoisotopic ion intensity in bottom-up analyses, greatly improving identification scores and protein sequence coverage. Multiplexing samples of $12 \mathrm{C}$ composition varying from natural abundance to $100 \% 12 \mathrm{C}$ makes it possible to address quantitative proteomics, keeping all the critical information within a single isotopologs cluster. We applied this method to measure for the first time protein turnover at the proteome scale in the pathogenic yeast Candida albicans.

Mots-Clés : quantitative proteomics, metabolic labeling, protein turnover, isotopes, Candida albicans

$\underline{\text { Programme }}$

\footnotetext{
*Auteur correspondant: thibaut.leger@ijm.fr

${ }^{\dagger}$ Intervenant

¥Auteur correspondant: jean-michel.camadro@ijm.fr
} 


\title{
Ultra-Short Column-Differential Mobility Spectrometry-Mass Spectrometry for Monitoring Oxidative Stress Markers in Human Whole Blood [O27]
}

\author{
Sophie Bravo-Veyrat ${ }^{* \dagger}{ }^{1}$, Gérard Hopfgartner ${ }_{-}^{\ddagger}$ \\ ${ }^{1}$ Université de Genève - 24 Quai Ernest Anserment 1211 Genève, Suisse
}

Stability of blood bag during the forty-two days of legal storage is of prime importance as it can affect the patient status. The analysis of thiols metabolites (e.g. reduced and oxidized glutathione, respectively GSH and GSSG) are used to determine the oxidative stress subjected to the red blood cells (RBCs) during storage. Beside many different methods LC-MS assay was found to be time consuming to allow the screening of large set of blood samples. In the present work Differential Ion Mobility spectrometry using modifiers coupled to tandem mass spectrometry (DMS-SRM/MS) was investigated as an alternative to LC-SRM/MS for quantitative high throughput analysis of oxidative stress markers using ultra-short LC-columns.

The metabolites were derivatized prior analysis with $N$-ethylmaleimide (NEM). Ultra-short LC-DMSSRM/MS method was developed on a 5500 QTrap from AB Sciex equipped with positive mode electrospray. Chemical modifiers (methanol, isopropanol, acetone, toluene) were added to the nitrogen transport gas. MRM transitions, separation voltage (SV) and compensation voltage $(\mathrm{CoV})$ were optimized for the separation of the thiol metabolites. Ultra-short columns $(2 \times 10 \mathrm{~mm})$ with different physicochemical properties were automatically screened with the PROSPEKT-2 using ballistic gradients.

Derivatization of the compounds was required for analyte stabilization and ESI signal enhancement (increase of GSH signal by at least 1000-fold). Signal suppression is divided by a factor of 2 thanks to the Ultra-short LC column enabled to reduced matrix suppression effect by at least a factor of 2-3. The Differential Ion Mobility was found to be essential to increase the selectivity to measure accurate concentrations. These results show that separation based on ultra-short LC - Differential Ion Mobility with modifiers allows the development of high-throughput assays (less than 1 minute) for thiols metabolites with good linearity, selectivity and accuracy. The Ultra-short LC-DMS-SRM/MS assay was crossvalidated with an LC-SRM/MS assay using a Hypercarb column.

Mots-Clés : Differential Mobility Spectrometry, Mass Spectrometry, Ultra short column, High throughput, Oxidative stress, Glutathione, Thiols

Programme

\footnotetext{
*Intervenant

†Auteur correspondant: sophie.veyrat@unige.ch

¥Auteur correspondant: gerard.hopfgartner@uinge.ch
} 


\title{
Regulation of Metabolic Enzymes by Lysine Deacetylase Inhibitors in A549 Non-Small Cell Lung Cancer Cells [028]
}

\author{
Alfonso Martin-Bernabe ${ }^{1,2}$, Josep Tarrago-Celada ${ }^{2,1}$, Valérie Cunin ${ }^{2}$, Sylvie \\ Michelland ${ }^{2}$, Roldan Cortes ${ }^{1}$, Martha Cascante ${ }^{1}$, \\ Sandrine Bourgoin-Voillard ${ }_{-}^{2}$, Michel Seve ${ }^{2}$
}

\footnotetext{
${ }^{1}$ Department of Biochemistry and Molecular Biology, IBUB, Faculty of Biology, Universitat de Barcelona and Institut d'Investigacions Biomèdiques August Pi i Sunyer (IDIBAPS), Barcelona, Espagne

${ }^{2}$ LBFA et BEeSy, PROMETHEE Proteomic Platform - Université Grenoble Alpes, Centre de Recherche INSERM, CHU Grenoble - Plate-forme de Protéomique Promethée Institut de Biologie et Pathologie, CHU de Grenoble - Boulevard la Chantourne, Grenoble, France
}

Metabolic reprogramming is nowadays known as a hallmark of cancer. It enables cancer cells to adapt their cellular metabolism to new environmental conditions of limited nutrient and oxygen supply that are characteristic in the tumor microenvironment. Protein lysine acetylation has also emerged recently as a metabolism-coordinating mechanism and growing evidence has shown that acetylation regulation of metabolic enzymes plays an essential role in cancer. Consequently, inhibitors of lysine deacetylases (KDACis) have drawn attention as promising strategies for therapeutic intervention. According to this statement, this study aimed to analyse the changes in the proteome of A549 non-small cell lung cancer (NSCLC) in response to hypoxia and KDACi treatments with a special focus on the proteins associated with metabolism. The quantitative proteomics approach was carried out by using the FASP (Filter Aided Sample Preparation) method combined with a dual protease digestion (Lys-C/ trypsin) before labelling the resulting peptides with iTRAQ 8-plex reagents. Then, the labelled peptides were fractionated in two dimensions (OFFGEL/RP nanoLC) prior MALDI-TOF/TOF mass spectrometry analysis. MS and MS/MS data were analysed by Protein Pilot software and quantitation was validated by the R package IsobarPTM. This proteomic approach led to the identification and quantitation of 834 proteins and evidenced the capacity of KDACis to reverse the tumor metabolic phenotype, an effect enhanced under hypoxia conditions, by changing metabolic enzyme expression profiles, especially in glycolysis and Krebs cycle. These enzyme expression changes were validated by Western Blot analysis. Moreover, glucose uptakes, production of lactate analysis and enzyme activity determination corroborated the implication of these enzymes in the reversion of the A549 NSCLC metabolic phenotype. Together, these results allow us to better understand how KDAC inhibitors control metabolic pathways under hypoxia in NSCLC.

Mots-Clés : Non small cell lung cancer, metabolic reprogramming, inhibitors of lysine deacetylases, quantitative proteomics

\section{Programme}

\footnotetext{
${ }^{*}$ Intervenant
} 


\section{Développements méthodologiques et fondamentaux MS [S3b]}




\title{
Weighing intact viral capsids using nanomechanical resonators mass spectrometry [O29]
}

\author{
Shawn Fostner ${ }^{1}$, Sergio Dominguez Medina ${ }^{2}$, Emeline Vernhes ${ }^{3}$, Marc \\ Sansa Perna ${ }^{1}$, Thomas Alava ${ }^{1}$, Ann-Kathrin Stark ${ }^{2}$, Pascale Boulanger ${ }^{3}$, \\ Sébastien Hentz ${ }^{1}$, Christophe Masselon ${ }^{* \dagger} 2$
}

${ }^{1}$ Laboratoire d'Electronique et des Technologies de l'Information - CEA : DRT/LETI, Université Grenoble Alpes [Saint Martin d'Hères] - MINATEC 17, rue des Martyrs, 38054, Grenoble Cedex 9, France

${ }^{2}$ CEA Grenoble (DRF/BIG/BGE) (Laboratoire de Biologie à Grande Echelle) - 17 Avenue Des Martyrs Grenoble 38054 Cedex 9, France

${ }^{3}$ Institut de Biologie Intégrative de la Cellule (I2BC) - Université Paris-Sud - Paris 11, CEA : DSV/I2BC, Université Paris-Saclay, CNRS : UMR9198 - Bâtiment 21, 1 avenue de la Terrasse, 91198 Gif/Yvette cedex, France

Knowing the mass of an intact virus can be an important quality control parameter in the development of new vaccines, as well as to provide complementary characterization of their protein capsids and genome contents. However, measuring the mass of large viruses of 10's to 100's of MDa is challenging for both micro-gravimetric techniques (Quartz-crystal microbalance) due to mass sensitivity issues, and for conventional mass spectrometry due to limitations in particle ionization and transfer. We have measured the inertial mass of intact viral capsids of the bacteriophage T5, a virus that infects $E$. Coli, using nano electromechanical resonators (NEMS). NEMS measure mass by detecting a change in their resonance frequency upon individual capsids landing on its surface, acting as both mass detector and analyzer. This measurement has been possible due to an improved three-stage mass spectrometer architecture that can transfer analytes with high efficiency from their liquid phase to a NEMS detector in vacuum across three stages: a nebulization source, a focusing interface and a detection chamber [US Patent application US20140250980 A1]. First, analytes in solution are nebulized using surface acoustic wave nebulization under ambient pressure. The nebulized droplets are introduced in a vacuum system and desolvated through a heated capillary inlet. Then, an aerodynamic lens composed of a series of apertures focuses the particle beam down to a spot of approximately $1 \mathrm{~mm}$ in diameter and onto the NEMS detector, without the need of ion guides. The system analyte transfer and focusing efficiency have been thoroughly characterized using polystyrene nanoparticles $(10-40 \mathrm{~nm})$ with similar density to those of the viral capsids, and a mass calibration method was developed. The high sensitivity of the system allowed capsids mass measurement starting from minute sample amounts (tens of $\mu \mathrm{g}$ corresponding to few picomoles).

Mots-Clés : Nano, electromechanical Systems, neutral mass spectrometry, viral particle, Megadalton

Programme

\footnotetext{
${ }^{*}$ Intervenant

†Auteur correspondant: christophe.masselon@ cea.fr
} 


\title{
Etude de la préservation des kératines de cheveux de momies par une approche protéomique spécifiquement dédiée [O30]
}

\author{
Armelle Charrié-Duhaut ${ }^{* \dagger}{ }^{1}$, Margaux Fresnais ${ }^{1}$, Pascale Richardin ${ }^{2}$, \\ Emmanuelle Leize-Wagner ${ }^{1}$
}
${ }^{1}$ Laboratoire de Spectrométrie de Masse des Interactions et des Systèmes (LSMIS), Université de Strasbourg, CNRS, CMC UMR 7140 (LSMIS - UMR 7140) - Institut Le Bel, 7 étage - 4, Rue Blaise Pascal 67081 Strasbourg Cedex, France
${ }^{2}$ Centre de Recherche et de Restauration des Musées de France (C2RMF) - Ministère de la Culture et de la Communication - Palais du Louvre - Porte des Lions 14, quai François Mitterrand 75001 Paris, France

Le cheveu étant un bioindicateur puissant utilisé dans les études toxicologiques et environnementales, l'analyse de sa structure moléculaire représente un enjeu crucial, mais constitue également un réel défi analytique du fait de sa complexité. Dans ces travaux, l'accent a été mis sur l'estimation de l'état de conservation des fibres capillaires au niveau moléculaire en s'appuyant sur un corpus de cheveux de 16 momies datées de 6500 av. J.-C. à 1500 ap. J.-C ainsi que sur différents cheveux actuels. En contexte archéométrique, ces données sont importantes pour notamment adapter les stratégies analytiques, s'assurer de la fiabilité des résultats obtenus et permettre la mise en place de protocoles de conservation de ces archéomatériaux grâce à une meilleure compréhension de la structure capillaire. Les cheveux de momies offrent également un modèle idéal pour étudier la dégradation des cheveux modernes.

Par une approche protéomique " bottom-up " développée spécifiquement au laboratoire (1), il a été prouvé que les kératines, protéines majoritaires des cheveux, pouvaient y être identifiées avec de bons scores d'identification et des taux de recouvrement élevés. Les analyses optiques (SEM) et structurelles (FTIR) montrent un degré de préservation relativement bon en surface. Différents indices moléculaires ont cependant été mis en évidence indiquant des modifications moléculaires.

Ainsi l'empreinte peptidique massique par MALDI-MS est clairement différente entre cheveux modernes et anciens. De même, l'identification des protéines par nanoLC-ESI-MS/MS suggère une dégradation préférentielle des protéines minoritaires (KAPs, cytokératines) par rapport aux kératines. L'étude de PTMs spécifiques comme par exemple la déamidation des asparagines et glutamines connue pour être une horloge biologique moléculaire (2) donne accès également à des marqueurs d'altération.

(1) Fresnais et al. 2017, Omics: J. Integrative Biol., in press

(2) Hurtado and O'Connor 2012, Anal. Chem., 82:3017-3025

Mots-Clés : archéométrie, kératines, protéomique, cheveux, momie, modifications post, traductionnelles

Programme

\footnotetext{
*Intervenant

${ }^{\dagger}$ Auteur correspondant: acharrie@unistra.fr
} 


\title{
Bridging the technological gap between mass spectrometry and spectroscopy for the structural resolution of isomers: application to glycomics [031]
}

\author{
Baptiste Schindler * 1, Loïc Barnes ${ }^{1}$, Gina Renois Predelus ${ }^{1}$, Stéphane

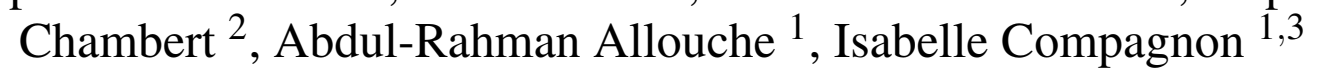 \\ ${ }^{1}$ Institut Lumière Matière [Villeurbanne] (ILM) - Université Claude Bernard Lyon 1, CNRS : UMR5306 - Domaine \\ Scientifique de La Doua Bâtiment Kastler, 10 rue Ada Byron 69622 Villeurbanne cedex, France \\ ${ }^{2}$ Institut de Chimie et Biochimie Moléculaires et Supramoléculaires (ICBMS) - Université Claude Bernard Lyon 1, INSA \\ Lyon, École Supérieure Chimie Physique Électronique de Lyon, CNRS : UMR5246 - Bâtiment CPE 43, Bld du 11 novembre \\ 191869622 Villeurbanne cedex, France \\ ${ }^{3}$ Institut Universitaire de France (IUF) - Ministère de l'Éducation nationale, de l'Enseignement supérieur et de la Recherche \\ - Maison des Universités 103 Boulevard Saint-Michel 75005 Paris, France
}

Spectroscopies (NMR, Raman ...) and Mass Spectrometry are two powerful structural tools and are commonly used for the identification of molecular structures. On one hand, Spectroscopies, which provide a detailed structural information, usually require high quantity and purity. On the other hand, Mass Spectrometry requires lesser sample and purity. Nonetheless, one of the key limitation of Mass Spectrometry is the disambiguation of isomers for which the MS/MS fingerprint obtained by various fragmentation techniques (CID, ETD...) could be insufficient. In this context, the development of hyphenated MS-based approaches is crucial to provide an additional dimension of structural information and methods like ion mobility and laser spectroscopy are particularly promising.

Our approach is to combine the best of Two Worlds: Mass Spectrometry and Spectroscopy. We have built an instrument coupling Mass Spectrometry and Vibrational Spectroscopy (InfraRed Multiple Photon Dissociation), dedicated to the structural characterization of biomolecules. This instrument requires typical MS conditions and offers the structural resolution of spectroscopic techniques.

In our group at Institut Lumière Matière, this instrument is dedicated to the structural elucidation of carbohydrates. This class of biomolecules is particularly difficult to characterize due to the frequent occurrence of isomerisms:

- the nature of the monosaccharide content

- the regiochemistry of the glycosidic bond linking two carbohydrate moieties

- the anomer stereochemistry ( $\alpha$ or $\beta$ ) - the structure of the monomeric ring (pyranose or furanose)

- the identification of the position of commonly observed modifications such as sulfation or acetylation In this presentation, we will focus on the potential of this hyphenated technique for carbohydrate analysis.

Mots-Clés : glycomics, IRMPD, vibrational spectroscopy, glycan, structural characterization

$\underline{\text { Programme }}$

\footnotetext{
${ }^{*}$ Intervenant
} 


\title{
De la formation des ions sous ESI à leur dissociation: une histoire différemment perçue sous la haute résolution [032]
}

\author{
Jean-Claude Tabet ${ }_{-}^{*}$ \\ ${ }^{1}$ CEA, iBiTec-S, SPI, LEMM CEA-Saclay et Sorbonne Universités, UPMC Univ Paris 06, CNRS, Institut \\ Parisien de Chimie Moléculaire, - Université Pierre et Marie Curie - Paris 6, CEA Saclay, Gif Sur Yvette, France \\ et 4 place Jussieu, 75005 Paris, France
}

\begin{abstract}
L'étude de la structure, et de la dissociation, d'espèces moléculaires monomériques ou multimériques (systèmes non-covalents: SNC) cationisées (ou non) préparées sous ESI a été un axe important de nos travaux. Dès 2000, étudiée sous basse résolution avec des tandems à faisceau ou à piégeage d'ions, la dissociation d'espèces cationisées avec métaux de transition permet la distinction de monosaccharides stéréoisomères par FeIII. De par sa capacité à se réduire en CuI, CuII conduit in situ aux radicaux sur des monomères cationisés permettant l'élimination de radicaux où la charge reste "spectatrice". Il résulte: (i) la localisation d'insaturation d'acides gras, (ii) la distinction de peptides isomères (L/I) et isobares (Q/K). La dissociation de complexes ternaires CuII/aminoacides permet d'attribuer la chiralité. Toutefois, la structure de SNC d'un complexe cationisé évolue durant son passage de sa forme solvatée à celles "dénudée".

L'ultra haute résolution en FT/MS a permis de comprendre le mécanisme de certains processus inattendus. Ainsi les dissociations détaillées de SNC (DNA/médicament ou DNA/peptides) montrent une compétition entre séparation directe des partenaires et clivage spécifique de liaisons covalentes. Cette différence est attribuée selon la charge à la formation de ponts salins (PS, liés aux zwitterions) plus stables que les liaisons hydrogène (LH). Toutefois, la compétition PS/LH entre phospho-hexoses et $\mathrm{R}$ est montrée dépendante de la désolvatation. Leurs dissociations complexes sont éclairées grâce aux échanges H/D (HDX) et effets de stéréochimie. Le futur sera tourné vers la mobilité d'ions pour fournir des preuves directes sur les conformations de tels complexes. Pour des systèmes simples comme l'anion aspartate, la HR associée aux HDX, et la compréhension instrumentale, montrent comment la sélection des ions influence les fragmentations. Finalement, la constitution de banque de données HRMS/MS contribuera à l'élucidation structurale de métabolites de novo grâce à une meilleure compréhension de l'instrumentation et des processus de dissociation.
\end{abstract}

Mots-Clés : Activation resonante/non résonante, complexe non covalent, cationisation, echange H/D, pont salin, calculs quantiques

Programme

*Intervenant 


\section{Développements méthodologiques RMN [S3c]}




\title{
The development of HR-MAS NMR towards $\mu \mathrm{g}$ biospecimens [O33]
}

\author{
Alan Wong $* \dagger 1$, Yusuke Nishiyama ${ }^{2}$ \\ ${ }^{1}$ Laboratoire de Structure et Dynamique par Résonance Magnétique (LSDRM) - NIMBE, CEA, CNRS, \\ Université Paris-Saclay, CEA Saclay 91191 Gif-sur-Yvette, France \\ 2 JEOL RESONANCE Inc. - 3-1-2 Musashino, Akishima, Tokyo 196-8558, Japon
}

\begin{abstract}
NMR has already proven to be a tremendous spectroscopic tool in the field of metabolomics in living specimens. Its major weakness is the low detection sensitivity that renders the analysis of microscopic quantities $(<1 \mathrm{mg}$-scale) impractical, time consuming and often impossible. The use of micro-size NMR detection coils is consider a cost effective approach; however, implementing a microcoil for heterogeneous biospecimens such as tissues, cells and organisms is a challenging task. This is because of the necessity of rapid sample rotation of the specimens at a specific angle, 54.74。, to the magnetic field. The technique denotes as Magic-Angle Spinning (MAS) NMR. It is commonly applied to solid materials. Depending on the diameter of the MAS detection coil, MAS can be applied to a wide range of sample mass from $500 \mathrm{mg}$ with a large coil diameter 7-mm probe, to For this reason, there are no suitable $\mu$ MAS probes for metabolomic studies prior to 2014. This talk will present the 'progress' of the MAS developments towards metabolomics of $\mu \mathrm{g}$ specimens. It will briefly outline (i.e. sensitivity, resolution and practicality) two different $\mu$ MAS approaches: (i) using a $\mu$-size inductively coupled resonator, HighResolution Magic Angle Coil Spinning (HRMACS); and (ii) the use of a specially designed standalone $\mu$ MAS probe, High-Resolution micro-Magic Angle Spinning (HR $\mu$ MAS).
\end{abstract}

Mots-Clés : HRMAS, $\mu$ MAS

Programme

\footnotetext{
${ }^{*}$ Intervenant

†Auteur correspondant: alan.wong@ @ea.fr
} 


\title{
Mise en place d'une approche combinée MS-RMN pour aider à l'interprétation des données de stabilité des médicaments [034]
}

\author{
Cécile Palaric ${ }^{*} 1,2,3$, Roland Molinié ${ }^{1}$, Jean Xavier Fontaine ${ }^{1}$, Dominique \\ Cailleu ${ }^{2}$, Serge Pilard ${ }^{2}$, Tristan Renaud ${ }^{3}$, Alain Petit ${ }^{3}$ \\ ${ }^{1}$ Laboratoire de BIOlogie des Plantes et Innovation (BIOPI) - Université de Picardie Jules Verne : EA3900 - 33 \\ Rue Saint Leu, 80000 Amiens, France \\ 2 Plateforme analytique (PFA) - Université de Picardie Jules Verne \\ 33 rue Saint-Leu, 80039 Amiens Cedex, France \\ ${ }^{3}$ Technologie Servier - Département Chimie Structurale - 25/27 rue Eugène Vignat, 45000 Orléans, France
}

Avant la mise sur le marché (AMM), les stabilités d'une spécialité pharmaceutique (PF) et de son principe actif (PA) doivent être étudiées selon les recommandations ICH. Ces études de dégradation (température, $\mathrm{pH}$, oxydation,...) conduisent souvent à des mélanges complexes qui sont analysés en première intention par couplage LC/UV/MS-MS (1). Les limites de cette approche sont l'absence de quantification précise et globale des composés détectés en UV et/ou MS et le caractère hypothétique des structures proposées à partir des spectres MS-MS. Dans ce cadre, la RMN n'est souvent utilisée que dans un second temps, après une ou plusieurs étapes de purification, pour confirmer la structure des composés majoritaires. Or, depuis quelques années, dans les domaines de la métabolomique et de la métabonomique, des travaux combinant plusieurs techniques spectrales ont été décrits et le traitement des données à l'aide de méthodes statistiques et d'outils de prédiction a été abordé (2). Dans le cadre de notre projet, une approche combinant des données MS et RMN a été développée sur des mélanges issus de la dégradation forcée $(\mathrm{HCl}$ et $\mathrm{NaOH})$ de l'Indapamide. L'objectif est de caractériser et de quantifier l'ensemble des composés présents dans les profils de dégradation. La stratégie utilisée a donc nécessité la mise en place d'une méthode générique de préparation des échantillons, l'optimisation des acquisitions MS et MSE et leur retraitement automatisé par le logiciel UNIFI(Waters) et également l'amélioration de la qualité des spectres RMN en terme de résolution et de sensibilité par l'acquisition de données mesurées avec un échantillonnage partiel (NUS) (3), permettant d'identifier les produits de dégradation présents jusqu'à $1 \%$.

(1) Attia et al., Anal Methods, 2016, 8 (8), 1836-1851.

(2) Bingol et al., Anal. Chem., 2015, 87 (7), 3864-3870.

(3) Le Guennec et al., Magn. Reson. Chem., 2015, 53 (11), 913-920.

Mots-Clés : produits de dégradation, mélanges complexes, approche combinée, RMN, MS.

Programme

${ }^{*}$ Intervenant 


\title{
Recherche des marqueurs de la production de méthane chez la vache laitière [035]
}

\author{
Bénédict Yanibada ${ }^{* \dagger}{ }^{1}$, Hamid Boudra ${ }^{\ddagger}$, Diego Morgavi ${ }^{1}$, Laurent \\ Debrauwer $^{2}$, Cécile Martin ${ }^{1}$, Roselyne Gautier ${ }^{2}$, Cécile Canlet ${ }_{-}^{\S} 2$ \\ ${ }^{1}$ Unité Mixte de Recherche sur les Herbivores (UMRH) - VetAgro Sup : UMR1213, INRA \\ [Auvergne/Rhône-Alpe] : UMR1213 - 63122 St-Genès-Champanelle, France \\ 2 Toxalim Axiom platform Metatoul MetaboHUB - UMR 1331 - INRA [Toulouse] - 180 chemin de \\ Tournefeuille, Toulouse, France
}

Le méthane, puissant gaz à effet de serre (GES), est produit dans le rumen des bovins par la fermentation microbienne anaérobie des aliments. Cette production est également responsable d'une perte d'énergie pour l'animal représentant $6 \%$ à $8 \%$ de l'apport alimentaire. Pour ces raisons, plusieurs travaux de recherches sont entrepris pour réduire ces émissions, en jouant sur la composition des aliments ou sur l'utilisation d'additifs alimentaires. La mesure des émissions de méthane se fait par différentes techniques. Cependant, ces méthodes présentent des inconvénients, notamment le coût ou encore la difficulté d'application à grande échelle sur le terrain. C'est pourquoi notre projet consiste à explorer la présence de marqueurs indirects de production de méthane par des approches métabolomiques. Le travail expérimental vise à établir une preuve de concept, en combinant l'utilisation d'un composé antiméthane spécifique avec une analyse des profils métaboliques de 4 matrices (le lait, l'urine, le sang et le jus de rumen) par une approche multiplateforme. Nous présentons ici les résultats de la mise au point de la préparation des échantillons de lait destinés à l'analyse des profils métaboliques par RMN (Résonance Magnétique Nucléaire). Pour cela, 8 méthodes de préparation d'échantillon ont été testées et évaluées en termes de qualité visuelle des spectres, de répétabilité, d'efficacité et de rendement d'extraction. Au terme de l'évaluation, l'extraction au méthanol a été retenue pour l'analyse des profils métaboliques. La méthodologie a été validée sur des échantillons de lait provenant d'une expérimentation utilisant 16 vaches laitières réparties en 2 groupes dont l'un a reçu un additif alimentaire qui réduit les émissions de méthane de $30 \%$ (Guyader, 2016). L'analyse statistique multivariée a montré une séparation des 2 groupes d'animaux et l'identification des marqueurs discriminants est en cours.

Mots-Clés : Ruminants, méthane, biomarqueurs, métabolomique

$\underline{\text { Programme }}$

\footnotetext{
${ }^{*}$ Intervenant

${ }^{\dagger}$ Auteur correspondant: benedict.yanibada@inra.fr

¥Auteur correspondant: $\overline{\text { abdelhamid.boudra@inra.fr }}$

$\S$ Auteur correspondant: cecile.canlet@inra.fr
} 


\title{
Développement d'un protocole de pré-traitement analytique pour l'analyse métabolomique par RMN d'échantillons rénaux congelés dans l'OCT (Optimal Cutting Temperature compound) [036]
}

\author{
Justine Leenders * 1, Pascal De Tullio ${ }_{-}^{1}$, François Jouret, Antoine Buemi , \\ Michel Mourad \\ ${ }^{1}$ Centre Indisciplinaire de Recherche sur le Médicament (CIRM) - Institut de Pharmacie Quartier HOPITAL - \\ Av. Hippocrate, 15 (Bât. B36) Sart-Tilman B-4000 Liège, Belgique
}

Les nombreuses biopsies stockées au sein des biobanques,représentent une mine d'information importante pour la compréhension de l'étiologie des pathologies et la recherche d'approches thérapeutiques personnalisées. Cependant, de par leur conservation dans des milieux de préservation tels que l'OCT (Optimal Cutting Temperature compound), ils ne sont que peu utilisables pour des analyses métabolomiques basées sur la RMN. En effet, la présence de signaux relatifs à l'OCT vient interférer de manière significative avec les données spectrales des métabolites. Afin de réduire l'impact de ces signaux et de rendre accessibles ces échantillons, nous avons développé et validé une méthode de prétraitement analytique capable d'éliminer l'OCT.

A cette fin, des échantillons rénaux provenant soit d'un modèle murin, soit de biopsies humaines ont été utilisés. Chez la souris, une ischémie rénale suivie d'une reperfusion est induite. Les reins ischémiés et non ischémiés sont coupés en deux fragments. L'un est congelé dans l'azote liquide (LN2) tandis que le second est placé dans l'OCT avant congélation. Chez l'homme, deux biopsies sont prélevées chez chaque patient avant transplantation et soit congelées dans l'azote liquide, soit placées dans l'OCT.

Différentes méthodes d'élimination de l'OCT par lavages des échantillons ont été évalués avant l'utilisation des échantillons. Un protocole optimisé a été obtenu permettant de réduire sensiblement l'OCT en minimisant la perte de métabolites. Afin d'évaluer l'impact de ce protocole sur les résultats métabolomiques, les données obtenues avec les échantillons " OCT " après lavage et LN2 ont été comparés via des méthodes statistiques multivariées. Cette comparaison montre clairement que le protocole développé n'affecte pas de manière significative les résultats tant au niveau murin qu'humain.

Le développement de ce protocole rend donc possible l'utilisation d'échantillons congelés dans des agents de cryoconservation pour des applications en métabolomique et ouvre de nouvelles perspectives d'analyse des nombreux échantillons présents dans les biobanques.

Mots-Clés : RMN, Rein, OCT, protocole, métabolomique

$\underline{\text { Programme }}$

\footnotetext{
${ }^{*}$ Intervenant

${ }^{\dagger}$ Auteur correspondant: p.detullio@ulg.ac.be
} 


\section{Clinique et diagnostic [S4a]}




\title{
Proteomic analysis of exosomes for biomarker research in rare genetic diseases [037]
}

\author{
Bourderioux Matthieu, Virginie Rollet-Cohen, Cerina Chhuon, Joanna \\ Lipecka, Vincent Jung, Thao Nguyen-Khoa, Alain Schmitt , Bertrand \\ Knebelmann, Aleksander Edelman , \\ Isabelle Sermet-Gaudelus, Guerrera Chiara * 1
} ${ }^{1}$ Proteomics platform 3P5-Necker, Université Paris Descartes - Structure Fédérative de Recherche Necker -
INSERM : US24, CNRS : UMS3633 - Paris, France

The discovery of exosomes (nanovesicles of 30-100nm) in body fluids has raised hope in the search for biomarkers. This study was designed to obtain the proof of concept that the exosomes analyses could help to evaluate the efficiency of treatment and the evolution / propagation in rare genetic diseases. We selected two genetic disorders. I) Cystinuria (Cys), due to mutations in cystine transporter in the kidney, leads to kidney stones and even chronic renal insufficiency. Predictive markers of the evolution of the renal disease have not yet been identified and might be discovered in the urinary exosomes as they derive from the renal epithelium. ii) Cystic fibrosis (CF), due to mutations on CFTR, causes early lung damage characterized by heterogeneous extension in the distal lung. The mechanisms are still unclear, but exosomes could be involved in the propagation of lung damage and inflammation.

Exosomes were isolated by differential centrifugations from urine (8 Cys patients and 10 controls) and broncho-alveolar lavage (BAL) (4 CF, 7 asthma, and 3 PCD patients). Exosomes were characterized by immunoelectron/immunogold microscopy, and western blot (WB). Exosomal proteins were analyzed by nanoRSLC-Q-Exactive Plus MS using label-free quantification.

In Cystinuria, hierarchical analysis of differential proteins allowed to clearly separate cystinuria patients from healthy individuals, and further separate patients according to severity. These proteins include known markers of kidney injury, and a neutrophil signature and were verified by WB (Bourderioux et al., 2014). In CF, hierarchical analysis of 14 proteins differential proteins could separate these three lung diseases, showing a closer relationship between $\mathrm{CF}$ and PCD. Two proteins implicated in redox balance were found higher in CF patients and were validated by WB.

In conclusion, exosomes are a suitable source of biomarkers in body fluids to follow the evolution and understand the propagation of genetic disease.

Mots-Clés : rare genetic disease, exosomes, biomarkers

$\underline{\text { Programme }}$

${ }^{*}$ Intervenant 


\title{
MALDI-MSI based top down micro-proteomics: evidence of a hidden proteome [O38]
}

\author{
Julien Franck $* 1$, Vivian Delcourt $* 1,2$, Jusal Quanico * 1 , Maxence

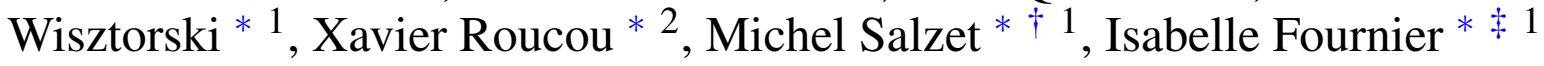 \\ ${ }^{1}$ Protéomique, Réponse Inflammatoire, Spectrométrie de Masse - INSERM : U1192 - Université Lille, Sciences \\ et Technologies Bat SN3, 1er étage 59655 Villeneuve d'Ascq Cedex, France \\ 2 Dept de Biochimie lab Z8-2001 - Université de Sherbrooke Faculté de Médecine et des Sciences de la Santé \\ Dept de Biochimie (lab Z8-2001; office Z8-2070) 3201 Jean Mignault, Sherbrooke QC J1E 4K8, Canada
}

MALDI-MSI is now widely applied to clinical molecular histology and to identify proteins as potential biomarkers. Recently, it was shown that the extraction of tryptic peptides from specific regions of a tissue section determined by MALDI-MSI allowed the identification of around 2000 groups of proteins from a region of $1 \mathrm{~mm} 2$. This strategy called mico-proteomics is mainly performed using a bottom-up approach. Top-Down proteomics gives great opportunities for better understanding the biological mechanisms as it gives informations on PTMs, intact molecular weight and truncated forms of proteins, which can be critical for biomarker hunting. This approach has been adapted to the micro-proteomics strategies in order to identified intact proteins and their PTMs as well as alternative proteins translated from alternative ORFs.

Rat brain investigation led to the identification of 156 reference proteins from different cellular compartments. 25 specific non redundant proteins have been identified from Corpus callosum, 22 from Medullar Oblongata and 33 from Hippocampus, Among the identified proteins, some constituted fragments of larger proteins either neuropeptide precursors or constitute proteins were identified. Similarly, some proteins display specific (PTMs) profiles linked the brain regions and their function.

Additionally, 237 proteins with some exhibiting PTMs have been isolated from ovarian cancerr biospies including 61 proteins specific to the tumor region, 44 to the necrotic-fibrotic region and 48 to the benign region.

Besides the reference proteome, a deeper analysis of the hidden proteome was also investigated from rat brain and ovarian cancer tissue sections. 9 alternative proteins issued from alternative ORFs were identified and were relied to the rat regions. 15 alternative proteins were also identified in the case of ovarian cancer. Expression of one of the 4 tumoral alternative protein, AltGNL1 which is translated from an AltORF nested within the GNL1 canonical coding sequence, has been demonstrated.

Mots-Clés : MALDI MSI, top, down, microproteomics, hidden proteome, PTM, ovarian cancer, alternative proteins

$\underline{\text { Programme }}$

\footnotetext{
* Intervenant

†Auteur correspondant: michel.salzet@univ-lille1.fr

$¥$ Auteur correspondant: isabelle.fournier@univ-lille1.fr
} 


\title{
A Proton NMR Metabolomic Investigation of an Emerging Genetic Disease [039]
}

\author{
Houda Boumaza * 1,2, Suzy Markossian ${ }^{* 2}$, Rautureau Gilles ${ }^{*}{ }^{1}$, Karine \\ Gauthier-Vanacker ${ }^{*} 2$, Frédéric Flamant ${ }^{2}$, Bénédicte Elena-Herrmann $* 1$ \\ ${ }^{1}$ Univ Lyon, CNRS, Université Claude Bernard Lyon 1, ENS Lyon, Institut des Sciences Analytiques, UMR \\ 5280 - 5 rue de la Doua, F-69100 Villeurbanne, France \\ ${ }^{2}$ Institut de Génomique Fonctionnelle de Lyon, INRA USC 1370, Université de Lyon, Université Lyon 1, CNRS \\ UMR 5242, ENS Lyon - 46, allée d'Italie 69364 Lyon cedex 07 France
}

Resistance to thyroid hormone $(\mathrm{RTH} \alpha)$ due to mutations in the thyroid hormone receptor alpha (TR $\alpha 1$ ), which is encoded by the THRA gene, is a recently discovered genetic disease. Patients present a high variability in clinical features (skeletal dysplasia, growth retardation, intellectual disability, etc...), and the absence of reliable biochemical markers make the diagnosis of this disease difficult. Since its first description in 2012, 25 cases of RTH $\alpha$ have been reported worldwide, corresponding to 14 different mutations of TR $\alpha 1$. In this context, a 1H nuclear magnetic resonance (NMR) metabolomic study was initiated, among a range of other phenotyping studies (including skeletal, blood and heart phenotype, neurodevelopment), to evaluate the impact of different mutations of TR $\alpha 1$ on the metabolism, and possibly identify biomarkers contributing to RTH $\alpha$ diagnostic in humans.

Considering that the mouse Thra and human THRA genes display extensive sequence similarities, mouse lines with Thra mutations are highly relevant animal models for RTH $\alpha$. We used CRISPR/Cas9 genome editing to introduce 5 different germline mutations in the mouse Thra gene: 4 frameshift and 1 missense mutation closely modeling the mutations found in RTH $\alpha$ patients. Urine and plasma samples from adult mice carrying these Thra mutations were analyzed by NMR with associated wild-type controls. Multivariate statistical analysis (OPLS-DA models) shows that samples collected from specific groups of mice carrying frameshift mutations can be discriminated from control samples collected from wild-type littermates, while mutations associated with minor phenotypic changes do not discriminate from controls. Our results reveal the presence of metabotype changes induced by Thra mutations, which provides a proof-of-principle that NMR metabolomics can be used to diagnose RTH $\alpha$.

Mots-Clés : metabolomics, RTH $\alpha$, Resistance to thyroid hormones, NMR, Multivariate statistical analysis, biomarkers, diagnosis

$\underline{\text { Programme }}$

*Intervenant 


\title{
Proteomics investigation of Wilson's disease pathophysiology using the ATP7B-/- murine model [040]
}

\author{
Maud Lacombe ${ }^{* \dagger}{ }^{1}$, Michel Jaquinod ${ }^{1}$, Lucid Belmudes ${ }^{1}$, Ninon Zala ${ }^{1}$, \\ Khémary Um ${ }^{2}$, Elisabeth Mintz ${ }^{2}$, Sandrine Miesh-Fremy ${ }^{1}$, Florence \\ Combes ${ }^{1}$, Thomas Burger ${ }^{1}$, Yohann Coute ${ }^{1}$, Virginie Brun \\ ${ }^{1}$ CEA Grenoble (BIG, Biologie à grande Echelle, EDyP) - INSERM U1038, Université Grenoble Alpes - 17 rue \\ des Martyrs 38054 Grenoble Cedex 9, France \\ ${ }^{2}$ CEA Grenoble (CEA, BIG, Laboratoire de chimie et biologie des métaux (LCBM)) - Université Grenoble \\ Alpes, CNRS UMR 5249 - 17 rue des Martyrs 38054 Grenoble Cedex 9, France
}

Wilson's disease is a rare genetic disorder triggered by mutations in the ATP7B gene. These mutations lead to the dysfunction of a transport protein (ATP7B) involved in copper excretion. This disease is characterized by defects in copper transport and by toxic copper overloads, primarily in the liver and the brain. Copper toxicity leads to liver injury and neuropsychiatric disorders which manifest either as acute (fulminant hepatitis) or chronic (cirrhosis) episodes. In this study, we explore the plasma and liver proteome modifications induced by disease development in the ATP7B-/-murine model for Wilson's disease.

The ATP7B-/-mouse was used as a preclinical model of Wilson's disease. Plasma and liver samples from ATP7B-/- and wildtype mice were collected at defined stages of the disease. Plasma and liver proteomes were characterized and compared using either a SUPER-SILAC or a label-free quantification strategy. Proteins identified as differentially abundant between ATP7B-/- and wildtype mice were quantified in a larger group of samples using LC-SRM and AQUA peptides. Skyline software was used for LC-SRM data analysis.

Proteomics discovery investigations using ATP7B-/- and wildtype mice at different stages of Wilson's disease led to the identification of 31 plasma proteins specifically regulated during disease progression. A larger group of plasma samples was investigated to validate differentially abundant protein using quantitative LC-SRM. In the liver, proteins involved in metal homeostasis, lipid metabolism, carbohydrate and energy metabolism were found to be regulated during Wilson's disease development.

Using discovery and targeted proteomics analyses in a mouse model of Wilson's disease, we could identify potential plasma biomarkers for disease progression. In the liver, we identified proteins that may play a major role in copper buffering during disease progression.

Mots-Clés : Wilson's disease, Proteomics, Biomarkers, Mass spectrometry

\section{Programme}

\footnotetext{
* Intervenant

†Auteur correspondant: maud.lacombe@cea.fr

$\ddagger$ Auteur correspondant: virginie.brun@cea.fr
} 


\section{Plantomics [S4b]}




\title{
Caractérisations chimique et biologique de composés discriminants au sein du métabolome symbiotique Alnus viridis-Frankia [041]
}

\author{
Dounia Dhaou , Rémy Marcellin-Gros , Aude Herrera-Belaroussi , Hasna \\ Boubakri , Marjolaine Rey, Anne-Emmanuelle Hay ${ }^{* \dagger}$
}

CESN, Laboratoire d'Écologie Microbienne - CNRS : UMR5557 - Villeurbanne, France

\begin{abstract}
L'association entre Alnus spp et l'actinobactérie Frankia s'inscrit dans le cadre des symbioses actinorhiziennes. Au cours de cette interaction, Frankia induit chez sa plante-hôte, la formation d'un nouvel organe au niveau racinaire, le nodule, au sein duquel ont lieu des échanges trophiques entre les deux partenaires. La bactérie fournit à l'hôte de l'azote réduit, grâce à sa capacité à fixer l'azote atmosphérique et bénéficie en retour des composés carbonés issu de la photosynthèse de la plante. Ces échanges trophiques à bénéfices réciproques entre les plantes actinorhiziennes et leur symbiote expliquent leur caractère de plantes pionnières, capables de coloniser des milieux instables. Cependant, les molécules et voies métaboliques impliquées dans cette symbiose restent à ce jour très peu décrites (Lundberg \& Lundquist, 2004 ; Berry et al., 2011). Récemment, une étude exploratoire globale des métabolites présents dans des nodules d'Alnus viridis et des racines associées a été réalisée au laboratoire (43 échantillons de nodules et racines prélevés sur 6 aulnaies géographiquement distinctes ont été analysés). L'objectif est de mettre en évidence et caractériser les métabolites spécifiquement exprimés dans chaque organe végétal associé (nodule) ou non (racine) à la bactérie. Les profils métaboliques des extraits polaires (Méthanol/Eau) de nodules et racines obtenus par UHPLC/UV/ESIMS, CPG/MS ou HPLC/UV-DAD ont permis de caractériser 48 métabolites secondaires (MII), 17 acides organiques/sucres et 20 acides aminés significativement différents entre les nodules et les racines. Dix MII ont pu être purifiés, caractérisés voire identifiés par RMN. Leurs effets stimulateurs ou inhibiteurs sur la croissance des bactéries et leur capacité à fixer l'azote ont été évalués pour certains d'entre eux.
\end{abstract}

Mots-Clés : Métabolome symbiotique, Alnus, Frankia, tests in, vitro (ARA, IRA), métabolites secondaires.

$\underline{\text { Programme }}$

\footnotetext{
*Intervenant

${ }^{\dagger}$ Auteur correspondant: hay.de-bettignies@univ-lyon1.fr
} 


\title{
ChloroKB: a web-application for the integration of knowledge related to chloroplast metabolic network [042]
}

\author{
Myriam Ferro * 1, Pauline Gloaguen ${ }^{1}$, Claude Alban ${ }^{2}$, Sylvain Bournais ${ }^{1}$, \\ Stéphane Ravanel ${ }^{2}$, Daphné Seigneurin-Berny ${ }^{2}$, Michel Matringe ${ }^{2}$, Marianne \\ Tardif ${ }^{1}$, Marcel Kuntz ${ }^{2}$, Bruley Christophe ${ }^{1}$, Norbert Rolland ${ }^{2}$, Yves \\ Vandenbrouck ${ }^{1}$, Gilles Curien ${ }^{2}$ \\ ${ }^{1}$ Exploring the Dynamics of Proteomes (EDyP), BGE/U1038, INSERM/CEA/Université Grenoble Alpes (EDyP) \\ - Université Joseph Fourier - Grenoble I - 17 Avenue des Martyrs, F-38054 Grenoble, France \\ ${ }^{2}$ Laboratoire de Physiologie Cellulaire et Végétale, UMR5168 CNRS/CEA/Université Grenoble Alpes/INRA \\ (PCV), INRA : UMR1417 - 17 Avenue des Martyrs, 38054 Grenoble, France
}

\begin{abstract}
Higher plants, as autotrophic organisms, are effective sources of molecules. They hold great promise for metabolic engineering, but the behavior of plant metabolism at the network level is still incompletely described. Although structural models (stoichiometry matrices) and pathway databases are extremely useful, they cannot describe the complexity of the metabolic context and new tools are required to visually represent integrated biocurated knowledge for use by both humans and computers. Here, we describe ChloroKB, a web-application (http://chlorokb.fr/) for visual exploration and analysis of the Arabidopsis thaliana metabolic network in the chloroplast and related cellular pathways. The network was manually reconstructed through extensive biocuration to provide transparent traceability of experimental data. Proteins and metabolites were placed in their biological context (spatial distribution within cells, connectivity in the network, participation in supramolecular complexes, regulatory interactions) using CellDesigner software. The network contains 1147 reviewed proteins (559 localized exclusively in plastids, 68 in at least one additional compartment and 520 outside the plastid); 122 proteins awaiting biochemical/genetic characterization; and 228 proteins for which genes have not yet been identified. The visual presentation is intuitive and browsing is fluid, providing instant access to graphical representation of integrated processes and to a wealth of refined qualitative and quantitative data. Thus, ChloroKB is a significant support for structural and quantitative kinetic modeling, for biological reasoning, when comparing novel data to established knowledge, for computer analyses, and for educational purposes. ChloroKB will be enhanced by continuous updates following contributions from plant researchers.
\end{abstract}

Mots-Clés : plant metabolism, Arabidopsis, chloroplast, biological network visualization, biocuration, knowledge base

Programme

*Intervenant 


\title{
Description of developmental transitions of tomato fruit through Proteome and Metabolome quantitative analysis [043]
}

\author{
Isma Belouah * , Annick Moing ${ }^{1,2}$, Stéphane Bernillon ${ }^{1,2}$, Stéphanie \\ Arrivault $^{3}$, Thierry Berton ${ }^{2,1}$, Salimata Diarrassouba ${ }^{1}$, Michel Zivy ${ }^{4}$, \\ Mélisande Blein-Nicolas ${ }^{4}$, Yves Gibon ${ }^{2}$, Sophie Colombie ${ }^{5}$ \\ ${ }^{1}$ Plateforme Métabolome Bordeaux (PMB-MetaboHUB) - INRA : UMR1332 - Centre INRA de \\ Bordeaux-Aquitaine, IBVM, CS 20032, 33140 Villenave d'Ornon, France \\ 2 Biologie du fruit et pathologie (BFP) - Université Sciences et Technologies - Bordeaux I, Université Victor \\ Segalen - Bordeaux II, INRA : UMR1332 - Centre INRA Bordeaux-Aquitaine 71 avenue Bourlaux BP81 \\ F-33883 Villenave d'Ornon, France \\ ${ }^{3}$ Max Planck Institute of Molecular Plant Physiology - Am Mühlenberg 1, \\ 14476 Potsdam, Brandenburg, Allemagne \\ ${ }^{4}$ UMR Génétique Quantitative et Evolution - Le Moulon (UMR GQE - Le Moulon) - INRA, CNRS, Université \\ Paris Sud - Paris XI, AgroParisTech - Ferme du Moulon, 91190 Gif-sur-Yvette, France \\ ${ }^{5}$ INRA : UMR1332 - Centre INRA, F-33883 Villenave d'Ornon, France
}

Tomato (Solanum lycopersicum) fruit presents two main research interests; first in the economical context it represents one of the most worldwide consumed fruit and secondly in the biological context it represents a model for fleshy fruit with a short life cycle and large genetic resources available: sequenced genome, mutant collections, transformants and introgression line. According to phenotype, physiology and cellular properties like the metabolites composition, the tomato fruit development can be divided into three principal stages: cell division, cell expansion, and maturation. Recently, by constraint-based modelling, we described and highlighted the respiration climacteric, a physiological event happening just before the ripening stage and characterized by an imbalance of metabolized carbon(Colombié,S et al 2016). To go further, we investigated the changes of proteins and metabolites throughout fruit development. At nine developmental stages, more than 50 targeted metabolites were quantified with complementary techniques and around 2500 proteins were quantified by label-free shotgun proteomics. Principal Component Analyses (PCA) performed on those data revealed a gap between cell expansion and maturation stages, so we identified the compounds and pathways involved in this transition. Moreover as previously observed for metabolome and activome(Oa,D et al 2009; Biais,B et al 2014) PCAs present a "boomerang-shaped" segregation of samples revealing similarities between the younger and older stages of development. Some variables describing this shaped segregation of stages point out the energy required for the synthesis of compounds. Finally, to get an almost complete overview of the system this integrative analysis will be complemented with transcriptome and activome data. In the future, another objective is to exploit proteomic and transcriptomic quantitative data into a translation model to predict a degradation rate for each protein.

Mots-Clés : tomato fruit, proteomic, metabolites, development

*Intervenant 


\title{
Leaf ageing imprinting on metabolism and nitrogen nutrient recycling in oilseed rape (Brassica napus L.), a metabolomic and fluxomic view [044]
}

\author{
Sylvain Déchaumet ${ }^{1}$, Solenne Berardocco ${ }^{2}$, Elise Bizouerne ${ }^{1}$, Carole Deleu \\ ${ }^{2}$, Pascal Faes ${ }^{3}$, Yann Guitton ${ }^{4}$, Catherine Jonard ${ }^{3}$, Françoise Le Cahérec ${ }^{2}$, \\ Patrick Leconte ${ }^{3}$, Laurent Leport ${ }^{2}$, Nathalie Marnet ${ }^{5}$, Nathalie Nesi ${ }^{3}$, \\ Anthoni Pellizzaro ${ }^{2}$, Marie-Françoise Niogret ${ }^{2}$, Sophie Rolland ${ }^{3}$, Alain \\ Bouchereau $* \dagger^{\dagger} 7$

\footnotetext{
${ }^{1}$ INRA - Agrocampus Ouest, Université de Rennes 1 - Domaine de la Motte, 35653 Le Rheu, France

${ }^{2}$ Université de Rennes 1 - INRA, Agrocampus Ouest, Université de Rennes 1 - Domaine de la Motte, 35653 Le Rheu, France

${ }^{3}$ INRA, Agrocampus Ouest, Université de Rennes I - Domaine de la Motte, 35653 Le Rheu, France

${ }^{4}$ Oniris - Ecole Nationale Vétérinaire, Agroalimentaire et de lálimentation Nantes-Atlantique, INRA - Atlanpole-La Chantrerie, Nantes 5 INRA - Domaine de la Motte, 35653 Le Rheu, France
} \\ ${ }^{6}$ Université de Rennes 1 (UMR IGEPP) - INRA, Agrocampus Ouest, Université de Rennes 1 - Domaine de la Motte, 35653 Le Rheu, France
}

Winter oilseed rape, the main European oleaginous crop, is mainly grown for its seeds and extraction of edible oil and biofuel, while the residual protein meal is also used for animal feeding. It is a very high nitrogen (N)-fertilizer consuming species characterized by a rather low $\mathrm{N}$ use efficiency (NUE). To meet the current challenges of agroecology and sustainable agriculture through input limitation, improvement of $\mathrm{N}$ remobilization efficiency during leaf senescence is likely to improve significantly the overall plant NUE, particularly in oilseed rape where organic $\mathrm{N}$ recycling between source and sink tissues is rather inefficient. Thus, metabolic profiling explorations have been undertaken in relation to leaf development and resource allocation at the whole plant level for the comprehensive understanding of sink and source metabolome and senescence-associated metabolic adjustments. Our study focused on quantitative analysis of primary $\mathrm{C}$ and $\mathrm{N}$ polar metabolites, as they are fundamental attributes of nutrient assimilation and recycling. Concurrently a holistic non-targeted metabolomic approach has been realized to decipher leaf ageing imprinting on leaf metabolic networks. The communication will relate and discuss recently acquired results after metabolite profiling data were integrated into exploratory multivariate statistical analyses. Leaf development-dependent metabolic signatures have been pointed out and clusters of metabolic indicators could be assigned to sink/source statues, senescence progression and culture conditions. At a targeted functional point of view proline and glutamate metabolism are also investigated as a reliable metabolic proxy to regulate organic nitrogen recycling and partitioning in oilseed rape. Overexpression of proline catabolic processes during leaf senescence has been recently postulated giving insight into putative roles of proline oxidation into nitrogen recycling/translocation towards sink tissues and energy production. To assess proline catabolism efficiency during leaf development, fluxomic investigations have been addressed through labelling experiments with stable isotopes into isolated plant tissues from young and old leaves.

Mots-Clés : Oilseed rape, nitrogen use efficiency, nutrient remobilization, leaf senescence, abiotic stress, metabolic profiling

\footnotetext{
${ }^{*}$ Intervenant

†Auteur correspondant: alain.bouchereau@univ-rennes1.fr
} 


\section{Fluxomique [S4c]}




\title{
A novel approach for simultaneous absolute quantification and isotopic analysis of metabolome [045]
}

\author{
Maud Heuillet * 1,2, Floriant Bellvert ${ }^{\dagger} 1,2$, Pierre Millard ${ }^{1}$, Madi Cissé ${ }^{3}$, \\ Laetitia Linares ${ }^{3}$, Laurent Le Cam ${ }^{3}$, Jean-Charles Portais ${ }^{1,2}$ \\ ${ }^{1}$ Laboratoire d'Ingénierie des Systèmes Biologiques et des Procédés (LISBP) - INSA, CNRS : UMR5504, \\ INRA : UMR0792 - 135 Avenue de rangueil 31077 Toulouse cedex 04, France \\ ${ }^{2}$ Metatoul - MetaboHUB - INRA : UMR792, CNRS : UMR5504, INSA, France \\ ${ }^{3}$ Institut de Recherche en Cancérologie de Montpellier (IRCM) - INSERM : U1194, Université de Montpellier, \\ Institut régional du Cancer de Montpellier - Campus Val d'Aurelle - Parc Euromédecine - 208, rue des \\ Apothicaires 34298 Montpellier, France
}

A relevant approach to study the topology and operation of metabolic networks is based on $13 \mathrm{C}$ isotope labeling strategies. In such experiments, biological interpretations are supported by two main type of information that can be measured by mass spectrometry: the incorporation of $13 \mathrm{C}$ atoms into metabolites (carbon isotopologue distribution, CID) and the absolute concentration of metabolites. The latter requires the use of an internal standard (IS), such as uniformly 13C-labeled cellular extracts which are currently considered as the gold standard. Since the 13C-IS cannot be resolved from the CIDs and impacts their measurements, two experiments must be conducted independently: one with an unlabeled substrate for absolute quantification and one with a 13C-labeled tracer for isotopic analyses. This increases the number of cultures and samples to collect and analyze and may thus be difficult to implement to investigate dynamic metabolic states or when biological material is limited. Moreover, current approaches impair data integration due to biological variability, and ultimately may bias biological interpretations. In order to circumvent these limitations we developed a method allowing simultaneous quantification of CIDs and metabolite pools based on a doubly-labeled IS. This new method was first designed for the analysis of intracellular amino acids, a crucial class of metabolites with a central role in metabolism, using a $15 \mathrm{~N}-13 \mathrm{C}$-IS. The $15 \mathrm{~N}$ isotope can be used to analyze a broad range of molecules (e.g. 56\% of E. coli metabolome contains at least one $\mathrm{N}$ atom), and other isotopes (such as $34 \mathrm{~S}$ ) can be exploited to analyze other classes of metabolites. Validation of the proposed approach demonstrates that it allows single-step, accurate measurement of both the CIDs and absolute intracellular concentrations of metabolites. We finally applied this approach in a dynamic 13C-labeled experiment to evaluate the impact of the ER-stress pathway on amino-acid metabolism in rat fibroblasts (Rat-1 Fv2E-PERK).

Mots-Clés : mass spectrometry, fluxomics, absolute quantification, isotopologue analysis, internal standard

Programme

*Auteur correspondant: maud.heuillet@insa-toulouse.fr

$\dagger$ Intervenant 


\title{
IDH mutation dictates a global redirection of catabolic and redox pathways towards $2 \mathrm{HG}$ biosynthesis leading to mitochondrial OxPHOS dependency and chemoresistance in acute myeloid leukemia [046]
}

\author{
Lucille Stuani ${ }_{-}^{*}$ \\ ${ }^{1}$ Team ResistAML, Drug resistance oncometabolism in acute myeloid leukemia, CRCT - INSERM : UMR1037, \\ CNRS : UMR5294, Université Paul Sabatier-Toulouse III - UPS \\ 2 avenue Hubert Curien 31037 Toulouse cedex 1, France
}

Metabolic reprogramming is now considered as one of the major characteristics of cancer cells. We and others have showed that energetic metabolism plays a key role in AML biology and therapeutic response and that targeting mitochondrial oxidative phosphorylation, glutaminolysis or $\beta$-oxidation are promising anti-leukemic approaches. Furthermore, recurrent mutations in key metabolic genes, isocitrate dehydrogenases, have been discovered in $15 \%$ of AML patients. Wild type IDH1 catalyzes the conversion of isocitrate to $\alpha$-ketoglutarate $(\alpha-\mathrm{KG})$ generating NADPH, in the cytosol. Mutant IDH1 generates an oncométabolite, 2-hydroxyglutarate (2HG), from $\alpha$-KG using NADPH. However, the contribution of IDH1 and its variants to AML metabolism has been overlooked thus far. Using a biological system-based approach combining transcriptomics, metabolomics, enzymatic assays, nutrients deprivations and metabolic pathways inhibitions, we established that IDH1 mutant cells acquired the capacity to use a broad range of substrates with higher rates, but are not dependent of any of them. Moreover, using C13-nutrients fluxomics, we also showed that this substrates flexibility is exacerbated to provide for $\alpha-\mathrm{KG}$, the precursor of $2 \mathrm{HG}$, which also leads to a higher mitochondrial activity, confirmed by in silico models. We then showed that not only these cells exhibit higher $\beta$-oxidation but also higher respiration, increased amounts of TCA cycle metabolites and mitochondrial ATP. Accordingly, they are more sensitive to OXPHOS inhibition by various drugs (metformin, ABT-199) but surprisingly, these inhibitors lead to increased amounts of $2 \mathrm{HG}$, which reveals an uncoupling between $2 \mathrm{HG}$ production and apoptosis. Altogether, our results indicate that IDH1 mutation in AML, through 2HG production, confers an extreme metabolic flexibility and increases their ability to consume nutrients and resist to drugs. This redirection induces a dependency to high OXPHOS metabolism and leads to higher resistance to genotoxics and more sensitivity to mitochondrial inhibitors. Thus, we propose a triple therapy combining IDH mutation inhibitor/OxPHOS inhibitor and AraC.

Mots-Clés : AML, metabolic flexibility, IDH, fluxomics

Programme

${ }^{*}$ Intervenant 


\title{
Study of sclareol biosynthesis for clary sage metabolic engineering [O47]
}

\author{
Camille Chalvin * 1, Stéphanie Drevensek ${ }^{\dagger}$, Françoise Gilard, Caroline \\ Mauve, Michel Dron, Abdelhafid Bendahmane, Adnane Boualem \\ ${ }^{1}$ Institute of Plant Sciences Paris-Saclay (IPS2) - Université Paris-Sud, Orsay, France - Bâtiment 630, plateau du \\ Moulon, rue Noetzlin, CS80004, 91192 Gif-sur-Yvette, France
}

Sclareol is a diterpene produced by floral organs of clary sage (Salvia sclarea). It is used for the

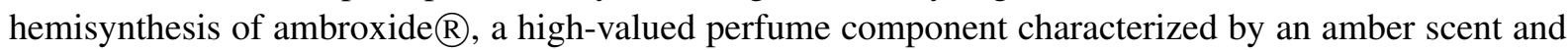
a high perfume fixation capacity. Sclareol used in perfume industry is extracted from clary sage, but the extraction yield is low. Enzymes responsible for sclareol biosynthesis have been characterized in vitro, but little is known about sclareol biosynthesis regulation in planta. Here, we study metabolic fluxes linked to sclareol biosynthesis and their regulation in order to get a better understanding of sclareol production in clary sage.

Isopentenyl-diphosphate (IPP) is a key intermediate of terpene biosynthesis. In plant cells, IPP can be synthesized via two different pathways: the mevalonate pathway and the methylerythritol-phosphate pathway. To determine the origin of IPP used for sclareol production, we fed clary sage inflorescences with [1-13C]-glucose and analyzed sclareol isotopic labeling by quantitative 13C-NMR. Sclareol labeling pattern indicates that IPP originates from the methylerythritol-phosphate pathway. Other feeding experiments will be conducted to go further into the analysis of terpene biosynthesis, particularly linalyl acetate biosynthesis, a major monoterpene of clary sage essential oil. This study will help highlighting key enzymes that could be targeted to increase sclareol production in clary sage.

In order to identify regulators of sclareol biosynthesis, we are conducting a comparative analysis of transcriptomic data and sclareol content (GC-MS) during clary sage calyx development. The function of candidate enzymes and regulators will then be investigated by reverse genetics (TILLING) on a population of 5000 clary sage genetic variants (EMS mutagenesis).

The originality of this work is the combination of metabolic flux analysis and high-throughput genomic tools to study the secondary metabolism of a perfume plant. This study is a first step toward the development of non-GMO clary sage lines with improved sclareol yield.

Mots-Clés : metabolic engineering, terpene, metabolic flux analysis, isotopic labeling, clary sage

\section{Programme}

\footnotetext{
*Intervenant

†Auteur correspondant: stephanie.drevensek@u-psud.fr

$¥$ Auteur correspondant: adnane.boualem@inra.fr
} 


\title{
Analyse multiplexe des flux protéiques par l'utilisation d'isotopes stables et de la LC-MS/MS : applications aux apolipoprotéines [048]
}

\author{
Mikaël Croyal $^{* 1}$, Karine Bernardeau ${ }^{2}$, Fanta Fall ${ }^{1}$, Valentin Blanchard ${ }^{1}$, \\ Aurélie Loussouarn ${ }^{1}$, Stéphanie Crossouard ${ }^{1}$, Audrey Aguesse ${ }^{1}$, Frédéric \\ Pecorari $^{2}$, Gilles Lambert ${ }^{3}$, Michel Krempf ${ }^{1}$ \\ ${ }^{1}$ Centre de Recherche en Nutrition Humaine (CRNH) - INRA : UMR1280 \\ 8 quai Moncousu, 44000 Nantes, France \\ 2 Production de Protéines recombinantes (P2R), CRCNA, INSERM U892, CNRS U6299 - Nantes, France \\ ${ }^{3}$ DéTROI - INSERM - Sainte-Clotilde, La Réunion, France
}

Les lipides sont insolubles dans les milieux biologiques aqueux. Afin d'être véhiculés de leurs sites de production et d'absorption vers les sites de stockage, d'utilisation et d'élimination, les lipides vont se complexer avec des entités protéiques, ou apolipoprotéines, pour former des édifices macromoléculaires complexes mais hydrophiles : les lipoprotéines. Les apolipoprotéines jouent un rôle clé dans le métabolisme lipidique et sont de nature et de structure très variées.

Les études cinétiques des protéines impliquent l'administration d'un acide aminé enrichi en isotopes stables telle que la 2H3-Leucine. Ce traceur exogène est administré aux patients et des prélèvements sanguins sont effectués au cours du temps. Les courbes cinétiques d'incorporation du traceur dans la séquence protéique permettent ensuite, par le biais de modélisations, d'accéder aux taux de catabolisme et de production de la protéine. L'étude statique et dynamique des protéines implique généralement la mise en place de différentes techniques expérimentales complexes.

L'émergence de nouvelles méthodologies, combinant la protéolyse enzymatique et la chromatographie liquide couplée à la spectrométrie de masse en tandem (LC-MS/MS), a récemment permis d'étendre le spectre des analyses protéiques. La LC-MS/MS permet en effet d'étudier simultanément les cinétiques de renouvellement de ces protéines, de les quantifier, mais aussi d'évaluer d'éventuelles altérations polymorphiques.

Notre laboratoire a ainsi développé une méthode multiplexe à haut-débit permettant d'analyser simultanément par LC-MS/MS douze apolipoprotéines majeures chez l'Homme. Cette méthode a été comparée aux méthodes standards couramment utilisées pour la quantification (ELISA) et les mesures cinétiques (électrophorèse, hydrolyse, GC-MS). Notre approche analytique s'est avérée fiable et reproductible pour l'étude de ces protéines, plaçant la LC-MS/MS comme un outil très puissant pour les analyses statiques, dynamiques et polymorphiques des apolipoprotéines plasmatiques.

Mots-Clés : apolipoproteines, lipoprotéines, LC, MS/MS, flux métaboliques, polymorphisme, biomarqueurs

\section{Programme}

\footnotetext{
*Intervenant
} 


\section{Santé et médecine: mécanismes et biomarqueurs [S5a]}




\title{
On chip detection and proteomics of platelet-derived microparticles [049]
}

\author{
Géraldine Lucchi ${ }^{* \dagger}{ }^{1}$, Sameh Obeid ${ }^{2}$, David Rageot ${ }^{1}$, Thierry Burnouf ${ }^{3}$, \\ Céline Elie-Caille ${ }^{2}$, Wilfrid Boireau ${ }^{2}$
}

\footnotetext{
${ }^{1}$ Institut de Chimie Moléculaire de l'Université de Bourgogne (CLIPP-ICMUB) - Université de Bourgogne, CNRS : UMR6302 - 15 Bd Maréchal de Lattre de Tassigny - Bat. Médecine B3 - 21000 Dijon, France

${ }^{2}$ Franche-Comté Électronique Mécanique, Thermique et Optique - Sciences et Technologies (CLIPP-FEMTO-ST) - CNRS : UMR6174, Université de Franche-Comté - 15B avenue des Montboucons 25030 Besançon cedex, France

3 Taipei Medical University (TMU) - No. 250, Wuxing Street, Xinyi District, Taipei City, Taïwan
}

Blood microparticles are small membrane vesicles derived from the plasma membrane of different cell types. Increased platelet microparticles (PMPs) formation has been reported to contribute to the inflammatory role of blood components used for transfusion. When PMPs formation results from thrombin activation, they are able to aggregate monocyte cells in vitro.

Our work aims to use surface plasmon resonance (SPR) method to detect and qualify the PMPs directly in their complex media, via their immunocapture onto the biochip-surface using specific ligands. An investigation by Atomic Force Microscopy (AFM) allowed the characterization of PMPs size subpopulations. We also engaged an "on chip" nanoLC-MS/MS analysis, in order to reveal a potential differential proteome between PMPs either produced from resting platelets (NPMPs) or from thrombinactivated platelets (TPMPs). A relative quantification analysis was performed with the Proline software.

SPR results showed a specific and differential immunocapture depending on the ligand nature. With anti-CD41 antibodies, SPRi signal with TPMPs was more than 3-times higher than with NPMPs, illustrating a greater concentration of TPMPs expressing CD41 markers or a greater density of these markers on the surface of the TPMPs.

AFM results concluded that more than $80 \%$ of the population of PMPs measures less than $100 \mathrm{~nm}$ in diameter and TPMP CD41+ vesicles were slightly smaller than NPMP CD41+ ones.

A correlation has been demonstrated between the SPRi signal, the surface density observed in AFM and the quantity of proteins identified. Differential quantitative proteomic was possible with only $500 \mathrm{ng}$ of PMPs captured on the biochip surface. All the targeted markers used in SPR (CD41, CD61, CD62P and CD9) have been identified by mass spectrometry. P-Selectin, the specific activation marker of thrombin induced PMPs has been found exclusively in TPMPs fraction. Differential analysis allowed to identify signalization pathways involved in platelet aggregation after thrombin activation.

Mots-Clés : On chip detection, microparticles, AFM, immunocapture, SPR, mass spectrometry, relative quantification

\footnotetext{
*Intervenant

†Auteur correspondant: geraldine.lucchi@ clipproteomic.fr
} 


\title{
Metabolomic NMR studies \& Huntington's disease: models in transgenic drosophila [050]
}

\author{
Marylène Bertrand ${ }^{* \dagger}{ }^{1}$, Hervé Meudal ${ }^{1}$, Serge Birman ${ }^{2}$, Martine Decoville ${ }^{3}$, \\ Céline Landon ${ }^{1}$ \\ ${ }^{1}$ Centre de biophysique moléculaire (CBM) - CNRS : UPR4301 - Rue Charles Sadron CS 80054, \\ 45071 Orléans cedex 2, France \\ ${ }^{2}$ Genes Circuits Rhythms and Neuropathology Group, CNRS Brain Plasticity Unit, ESPCI ParisTech - CNRS : \\ UMR8249 - 10 rue Vauquelin, 75231 Paris Cedex 05, France \\ ${ }^{3}$ Université d'Orléans - Ministère de l'Enseignement Supérieur et de la Recherche Scientifique - 6 Avenue du \\ Parc Floral, 45067 Orléans Cédex 2, France
}

This study is designed to identify metabolites at a pre-symptomatic stage of Huntington's disease modeled in Drosophila melanogaster. Transgenic flies have been obtained to express a pathogenic polyglutaminated huntingtin fragment (exon1 with 93 polyQ repeats). Pan-neuronal expression of this transgene ( $h t t-93 Q)$ induces neuropathology that recapitulates most of the characteristics of the human disease. In particular, the neuropathology is progressive, older flies having more severe symptoms. Therefore, 10-day and 16-day-old flies were sampled. The 10th day corresponds to the pre-symptomatic stage, the 16th day to the presence of the disease symptoms.

After sample preparation, 1H-NMR spectra of several sets of adult Drosophila, carrying the disease or not, sampled at 10 and 16 days, were performed on a BRUKER $700 \mathrm{MHz}$ NMR spectrometer with cryoprobe. For assignment purposes, COSY, TOCSY, 13C-HSQC and HMBC spectra were acquired. Multivariate statistical analyzes (Principal Component Analysis or PCA and predictive methods as PLS and OPLS) were performed with the 1D NMR spectra. The discriminant metabolites were hence detected. The biomarkers were identified with the 2D spectra: the glutamine, ATP and AMP are among the most discriminant biomarkers. A model, making the detection of the disease possible, was finally developed with the measurements of only a few metabolites.

We demonstrate in this study that the Huntington's disease could be identified by the analysis of only a few metabolites. These metabolites allow the prediction of the Huntington's disease even before the appearance of its symptoms. This study allows a better understanding of the metabolic pathways disrupted by the disease in order to consider future therapeutic targets.

Mots-Clés : metabolomics, NMR, huntington, drosophila

Programme

\footnotetext{
*Intervenant

${ }^{\dagger}$ Auteur correspondant: marylene.bertrand@cnrs-orleans.fr
} 


\title{
Développement d'une approche multi-omique pour la recherche de biomarqueurs associés à la réponse au traitement dans les lymphomes [051]
}

\author{
Luc-Matthieu Fornecker ${ }^{*}{ }^{1}$, Leslie Muller ${ }^{2}$, Raphaël Carapito ${ }^{3}$, Frédéric \\ Bertrand ${ }^{4}$, Nicodème Paul ${ }^{3}$, Siamak Barham ${ }^{3}$, Sarah Cianférani ${ }^{2}$, Christine \\ Carapito $^{2}$ \\ ${ }^{1}$ Service d'Hématologie, Hôpitaux Universitaires de Strasbourg, Strasbourg. Laboratoire de Spectrométrie de \\ Masse BioOrganique (LSMBO), Institut Pluridisciplinaire Hubert Curien (IPHC), UMR7178, Strasbourg. - \\ CNRS : UMR7178 - Hôpital de Hautepierre, 1 avenue Molière, 67000 Strasbourg. LSMBO, IPHC, 25 rue \\ Becquerel, 67087 Strasbourg Cedex 2, France \\ ${ }^{2}$ Laboratoire de Spectrométrie de Masse BioOrganique (LSMBO), Institut Pluridisciplinaire Hubert Curien \\ (IPHC), UMR7178, Strasbourg. - CNRS : UMR7178 - LSMBO, IPHC, \\ 25 rue Becquerel, 67087 Strasbourg Cedex 2, France \\ ${ }^{3}$ Laboratoire d'ImmunoRhumatologie Moléculaire, INSERM UMR S1109, Centre de Recherche d'Immunologie \\ et d'Hématologie, Faculté de Médecine, Fédération de Médecine Translationnelle de Strasbourg (FMTS), \\ Strasbourg. - INSERM : UMR S1109 - Centre de Recherche d'Immunologie et d'Hématologie, Hôpital Civil, 1 \\ place de l'Hôpital, 67000 Strasbourg, France \\ ${ }^{4}$ Institut de Recherche Mathématique Avancée, CNRS UMR 7501, Université de Strasbourg, Strasbourg. - \\ CNRS : UMR7501 - 7 rue René-Descartes, 67084 Strasbourg Cedex, France
}

\begin{abstract}
Introduction : Les traitements actuels des lymphomes B diffus à grandes cellules permettent d'obtenir un taux de guérison estimé globalement à $60 \%$. Le pronostic des patients en rechute ou réfractaires reste très péjoratif rendant nécessaire la mise en évidence de nouveaux biomarqueurs prédictifs de la réponse au traitement. Cette étude avait pour objectif d'identifier des biomarqueurs associés à la réponse au traitement en combinant des approches quantitatives protéomiques et transcriptomiques (RNAseq) à partir de tissu tumoral prélevé au diagnostic.

Matériels et méthodes : une cohorte de 20 patients a pu être constituée (chimiosensibles, $\mathrm{n}=12$; chimioréfractaires, $\mathrm{n}=8$ ) pour lesquels du matériel tumoral frais, congelé au diagnostic, était disponible. Les extractions d'ARN et de protéines ont été réalisées pour chaque patient sur le même matériel tumoral. Les analyses protéomiques ont été effectuées sur un couplage nanoLC-MS/MS (nanoAcquity - Waters - Orbitrap Q-Exactive Plus - Thermo Fisher Scientific). L'analyse quantitative sans marquage a été réalisée par extraction des courants d'ions à l'aide du logiciel MaxQuant. L'analyse par RNAseq a été réalisée par méthode AmpliSeq (ThermoFisher Scientific), associée à un séquençage de nouvelle génération.

Résultats : L'analyse protéomique a permis d'identifier 4774 protéines sur l'ensemble des 20 échantillons. Parmi elles, 3101 ont pu être quantifiées sur la base des intensités peptidiques selon une approche "ridge robust " (Goeminne L et al, Mol Cel Proteomics 2016). Au total, 586 protéines avaient une expression significativement différente entre les 2 groupes de patients. L'analyse par RNAseq a identifié 245 gènes différentiellement exprimés. L'analyse conjointe a montré une expression différentielle concordante pour 22 gènes/protéines, impliqués notamment dans la voie de signalisation du récepteur des lymphocytes B.

Conclusion : Cette étude préliminaire démontre la faisabilité d'une approche multi-omique réalisée sur un matériel tumoral commun pour la recherche de biomarqueurs associés à la réponse au traitement dans les lymphomes agressifs.
\end{abstract}

Mots-Clés : omiques, lymphomes, biomarqueurs

${ }^{*}$ Intervenant 


\title{
Combined laser microdissection and proteomic analysis for identification of tumor signatures [052]
}

\author{
Elodie Henriet ${ }^{1}$, Aya Abou Hammoud ${ }^{1}$, Jean-William Dupuy ${ }^{2}$, Benjamin \\ Dartigues ${ }^{3}$, Zakaria Ezzoukry ${ }^{1}$, Nathalie Dugot-Senant ${ }^{4}$, Thierry \\ Leste-Lasserre ${ }^{5}$, Nestor Pallares-Lupon ${ }^{1}$, Macha Nikolski ${ }^{6}$, Brigitte Le Bail \\ ${ }^{1,7}$, Jean-Frédéric Blanc ${ }^{8}$, Charles Balabaud ${ }^{1}$, Paulette Bioulac-Sage ${ }^{1}$, \\ Anne-Aurélie Raymond ${ }_{-}^{* 1,9}$, Frédéric Saltel*1 \\ ${ }^{1}$ INSERM, UMR1053, BaRITOn Bordeaux - INSERM : U1053 - Bordeaux, France \\ ${ }^{2}$ Plateforme Protéome, Centre de Génomique Fonctionnelle de Bordeaux - Université de Bordeaux, Bordeaux, France \\ ${ }^{3}$ Centre de Bioinformatique de Bordeaux, Centre de Génomique Fonctionnelle de Bordeaux - Université de Bordeaux, \\ Bordeaux, France \\ ${ }^{4}$ Plateforme d'histopathologie, TBM-Core US 005, Bordeaux, France \\ 5 INSERM, U1215, Neurocentre Magendie, Bordeaux, Bordeaux, France \\ ${ }^{6}$ Centre de Bioinformatique de Bordeaux, Centre de Génomique Fonctionnelle de Bordeaux, Université de Bordeaux - \\ Université de Bordeaux, Bordeaux, France \\ ${ }^{7}$ Service de Pathologie, Hôpital Pellegrin, CHU de Bordeaux, Bordeaux, France \\ ${ }^{8}$ Service Hépato-Gastroentérologie et oncologie digestive, centre médico-chirurgical Magellan, Hôpital Haut-Lévêque, CHU \\ de Bordeaux, Bordeaux, France \\ 9 9. Oncoprot, INSERM 1053, TBM-Core US 005, Bordeaux, France
}

\begin{abstract}
Currently, the identification of genomic abnormalities is still the main approach to establish tumors diagnosis, prognosis and to predict resistance to some chemotherapies proposing in the near future of individualized therapeutic approaches and better management of patients. However, proteins expression is the downstream result of these combined genomic anomalies and thus relevant to identify new biomarkers and pharmacological targets. That is why we implemented a method combining laser microdissection and mass spectrometry analysis, tailored to compare protein expression levels in T and NT tissue derived from the formalin-fixed and paraffin-embedded (FFPE) tissue sections from the same patient in order to identify new tumor biomarkers. Hepatocellular adenomas (HCA) are rare benign tumors divided into three main subgroups defined by patho-molecular features, HNF1A (HHCA), b-catenin (b-HCA) mutated and inflammatory (IHCA). In the case of unclassified HCA (UHCA), which are currently identified by default, a high risk of bleeding remains a clinical issue. The objective of this study was to explore UHCA proteome in the purpose of identifying specific biomarkers. We compared T and NT proteins expression levels in HCA, H-HCA, IHCA, b-HCA, UHCA and focal nodular hyperplasia (FNH). Using this methodology we searched for proteins specifically deregulated in UHCA. First, we demonstrated that proteomic profiles allow us to discriminate between known HCA subtypes by the identification of classical biomarkers of each HCA subgroup. We revealed specific upregulation of the synthesis of the arginine pathway associated with an overexpression of argininosuccinate synthase (ASS1) and arginosuccinate lyase (ASL) in UHCA. Moreover, arginine is the substrate for nitric oxide synthesis, a factor involved in vascular permeability. ASS1 immunohistochemistry identified all the UHCA, of which $64.7 \%$ presented clinical bleeding manifestations. Consequently, we demonstrated the power of mass spectrometry coupled with laser microdissection to identify tumoral signatures and robust biomarkers.
\end{abstract}

Mots-Clés : Laser capture, proteomics, liver cancer, tumor, biomarkers

\footnotetext{
${ }^{*}$ Intervenant
} 


\title{
A native MS Study of RNA kissing complexes and their interaction with magnesium cations [053]
}

\author{
Clémence Rabin * ${ }_{-}^{1}$, Louise Van Gheluwe ${ }^{1}$, Joséphine Abi Ghanem ${ }^{1}$, Valérie \\ Gabelica_ 1
}

\footnotetext{
${ }^{1}$ Université de Bordeaux (ARNA) - Université de Bordeaux, INSERM : U1212, CNRS : UMR5320, Laboratoire ARNA - IECB, 2 rue Robert Escarpit, 33607 Pessac, France
}

Magnesium is naturally presents in cells in the millimolar range. RNA often recruits $\mathrm{Mg} 2+$ cations to achieve its proper folding and to stabilize the structure. Here we propose a direct method to analyze the interaction between $\mathrm{Mg} 2+$ and RNA complexes using "native" mass spectrometry (MS). Native MS uses gentle conditions to maintain complexes from solution to gas phase. We started our investigations using different RNA kissing complexes (KC) models: the TAR RNA element of HIV-1 viral genome and its kissing complex with the aptamer R06, RNAIi and RNAIIi from E.Coli involved in the replication of the ColE1 plasmid.

ESI-MS allowed us to detect specifically RNA-RNA KC that are present in solutions doped with magnesium acetate up to $1 \mathrm{mM}$. We showed that adding $\mathrm{Mg} 2+$ in the solution helps to form larger amount of dimers. We can deduce the number of cation adducts preferentially bound to the loop-loop kissing motif, using reference sequences forming a duplex RNA of the same length and base pairs than the KC. By mathematical subtraction of the non-specific adducts contribution to the signal, we can deduce the number of preferential cations, and the quantities of complexes of each stoichiometry. Using titrations of one hairpin by the other, we can determine the concentration of each species and then determine binding constants for the formation of $\mathrm{KC}$. By combining all the data, we can decompose the apparent dimerization constants into individual thermodynamic constants of dimer formation and of binding of each preferential cation. We show here that $\mathrm{KC}$ can have different cation binding patterns and affinity. Tandem mass spectrometry and molecular dynamics will eventually allow us to determine the localization of divalent cations.

In summary, we developed a method to observe RNA complexes using native MS and present new insights into the role of magnesium cations in $\mathrm{KC}$.

Mots-Clés : native MS, RNA, kissing complexes, magnesium

Programme

\footnotetext{
*Intervenant

${ }^{\dagger}$ Auteur correspondant: valerie.gabelica@inserm.fr
} 


\section{Identification structurale et annotation [S5b]}




\title{
Elucidation of the Parkinsonism-associated protein DJ-1/Park7 function as a major protein and DNA deglycase [054]
}

\author{
Gilbert Richarme ${ }^{1}$, Thibaut Léger ${ }^{*}{ }^{1}$, Cailing Liu ${ }^{2}$, Mouadh Mihoub ${ }^{1}$, Jad \\ Abdallah ${ }^{1}$, Nicolas Joly ${ }^{1}$, Jean-Claude Liebart ${ }^{1}$, Ula V. Jurkunas ${ }^{2}$, Marc \\ Nadal $^{1}$, Philippe Bouloc ${ }^{3}$, Julien Dairou ${ }^{4}$, Aazdine Lamouri ${ }^{5}$ \\ ${ }^{1}$ Institut Jacques Monod (IJM) - Université Paris Diderot - Paris 7, CNRS : UMR7592 - Université Paris \\ Diderot, Bât. Buffon, 15 rue Hélène Brion, 75205 Paris cedex 13, France \\ ${ }^{2}$ Schepens Eye Research Institute - Massachusetts Eye an Ear Infirmary, Department of Ophtalmology, Harvard \\ Medical School, Boston, Massachusetts, États-Unis \\ ${ }^{3}$ Institut de Biologie Intégrative de la Cellule (I2BC) - Université Paris-Sud - Paris 11, CEA : DSV/I2BC, \\ Université Paris-Saclay, CNRS : UMR9198 - Bâtiment 21, 1 avenue de la Terrasse, 91198 Gif/Yvette cedex \\ ${ }^{4}$ Chimie et Biochimie Pharmacologiques et Toxicologiques, Université Paris Descartes, CNRS : UMR8601 - \\ Chimie et Biochimie Pharmacologiques et Toxicologiques, Université Paris Descartes-Sorbonne Paris Cité, UMR \\ 8601, 75270 Paris, France \\ ${ }^{5}$ Interfaces, Traitements, Organisation et Dynamique des Systèmes (ITODYS UMR7086) - Université Paris \\ Diderot, Bâtiment Lavoisier, 15 rue Jean de Baiff, case postale 7090, 75205 Paris Cedex 13, France
}

Glycation is an inevitable nonenzymatic covalent reaction between proteins or DNA and endogenous reducing sugars or dicarbonyls (methylglyoxal, glyoxal). Protein glycation results in protein inactivation whereas DNA glycation is associated with increased mutation, DNA strand breaks and cytotoxicity. Both protein and DNA glycations are implicated in a large number of diseases among which neurodegenerative pathologies, cancer and atherosclerosis. However, few mechanisms of protein glycation repair are described and how glycated DNA is repaired remains undetermined. DJ-1 was reported to be a multifunctional oxidative stress response protein with poorly defined function. By using different mutants for the protein DJ-1 (and its bacterial homologs Hsp31, YhbO and YajL) and LC-MS/MS analyses, we demonstrated that DJ-1 and its homologs could repair methylglyoxal- and glyoxal-glycated amino-acids (cysteine, arginine and lysine) (1) but also methylglyoxal- and glyoxal-glycated nucleotides and nucleic acids (2). These results establish that DJ-1 and its prokaryotic homologs are major anti-glycation and anti-aging proteins and constitute a major nucleotide repair system that we name Guanine Glycation Repair.

(1) Richarme, G., Mihoub, M., Dairou, J., Bui, L. C., Leger, T., and Lamouri, A. The Journal of biological chemistry (2015).

(2) Richarme, G., Leger, T., Liu, C., Mihoub, M., Abdallah, J., Joly, N., Liebart, JC., Jurkunas UV., Nadal, M., Bouloc, P., Dairou, J., Lamouri, A. Science (2017).

Mots-Clés : glycation, DNA, protein, repair, chemical modification, post, translationnal modification, deglycase

Programme

\footnotetext{
* Intervenant

${ }^{\dagger}$ Auteur correspondant: thibaut.leger@ijm.fr
} 


\title{
ASICS: an automatic method for identification and quantification of metabolites in complex 1D $1 \mathrm{H}$ NMR spectra [055]
}

\author{
Patrick Tardivel ${ }^{1}$, Cécile Canlet ${ }^{1,2}$, Gaëlle Lefort ${ }^{3}$, Laurent Debrauwer ${ }^{1,2}$, \\ Marie Tremblay-Franco ${ }^{1,2}$, Didier Concordet ${ }^{1}$, Rémi Servien * 1 \\ ${ }^{1}$ UMR Toxalim, Université de Toulouse - INRA - ENVT, INP-Purpan, UPS, F-31027 Toulouse, France., France \\ ${ }^{2}$ Axiom Platform - INRA - MetaToul-MetaboHUB, F-31027 Toulouse, France \\ ${ }^{3}$ Genphyse - INRA - Université de Toulouse, INRA, ENVT, Castanet Tolosan, France
}

One of the major challenges in NMR/mass spectrometry analysis of metabolic profiles relies on the identification and quantification of metabolites in complex biological mixtures. These features are mandatory to make metabolomics asserting a general approach to test a priori formulated hypotheses on the basis of exhaustive metabolome characterization rather than an exploratory tool dealing with unknown metabolic features. In this communication we propose a method, named ASICS, based on a strong statistical theory that handles automatically the metabolites identification and quantification in proton NMR spectra. A statistical linear model is built to explain a complex spectrum using a library containing pure metabolite spectra. This model can handle local or global chemical shift variations due to experimental conditions using a warping function. A statistical lasso-type estimator identifies and quantifies the metabolites in the complex spectrum. This estimator shows good statistical properties and handles peak overlapping issues. The performances of the method were investigated on known mixtures (such as synthetic urine) and on plasma datasets from duck and human (plasma NIST SRM1950) using a library of 175 pure metabolites. Results show noteworthy performances, outperforming current existing methods (namely MetaboHunter, BATMAN, Bayesil or Chenomx) for the identification and the quantification of metabolites. Furthermore, ASICS could easily be used routinely according to its reasonable computational time (no more than 3 minutes for the whole analysis of a complex spectrum). In conclusion, ASICS is a completely automated procedure for metabolites identification and quantification in $1 \mathrm{H}$ NMR spectra of biological mixtures. It will enable empowering NMR-based metabolomics by quickly and accurately helping experts to obtain metabolic profiles. ASICS is already available as a R function or within the more user-friendly Galaxy/W4M interface developed by the MetaboHUB infrastructure and IFB (French Institute of Bioinformatics).

Mots-Clés : Nuclear magnetic resonance, Identification of metabolites, Quantification of metabolites, Annotation

Programme

*Intervenant 


\title{
Computer-aided dereplication of natural products: 13C NMR-based strategies [056]
}

\author{
Ali Bakiri $* 2,1$ \\ ${ }^{2}$ Soliance - Pomacle - street of Bazancourt 51110, France \\ ${ }^{1}$ Institut de Chimie Moléculaire de Reims (ICMR) - Université de Reims - Champagne Ardenne, CNRS : \\ UMR7312 - UFR Sciences, BP1039, 51687 Reims Cedex 2, France
}

The emergence of dereplication strategies over the last decades has brought new perspectives to speed up natural product screening programs. Here is presented a 13C NMR-based dereplication method dedicated to the chemical profiling of natural metabolite mixtures, without need for any fractionation or purification steps [1]. It consists of a database searching approach that allows metabolite identification by comparing experimental 13C NMR data of the studied extract to a set of predicted 13C NMR data of known metabolites stored in a database. The comparison is performed by the mean of a developed algorithm that evaluates the quality of the matching between experimental and predicted data. The algorithm calculates a score value for each metabolite stored in the database and returns a list of metabolites that are the most likely to be present in the metabolite mixture. As an example, this method was applied on a crude alkaloid extract obtained from the leaves of Peumus boldus, resulting in the identification of eight major alkaloids including isocorydine, rogersine, boldine, reticuline, coclaurine, laurotetanine, $\mathrm{N}$-methylcoclaurine, and norisocorydine, as well as three monoterpenes including $p$-cymene, eucalyptol, and $\alpha$-terpinene. [1] A. Bakiri, J. Hubert, R. Reynaud, S. Lanthony, D. Harakat, J.-H. Renault, and J.-M. Nuzillard, "Computer-Aided 13 C NMR Chemical Profiling of Crude Natural Extracts without Fractionation," J. Nat. Prod., p. acs.jnatprod.6b01063, 2017.

Mots-Clés : natural product dereplication, 13C NMR, metabolomics

Programme

${ }^{*}$ Intervenant 


\title{
Développement de stratégies analytiques originales pour l'étude des actifs volatils de Frullania tamarisci [057]
}

\author{
Anais Pannequin *, Alain Muselli ${ }_{-}^{\dagger}$, Aura Tintaru ${ }^{2}$, Jean-Marie Desjobert, \\ Jean Costa
}

\footnotetext{
${ }^{1}$ Laboratoire de Chimie des Produits Naturels, UMR CNRS 6134, Campus Grimaldi, BP 52, 20250 Corte, France

${ }^{2}$ Aix-Marseille Université (Institut de Chimie Radicalaire) - CNRS : UMR7273 - Campus de Saint Jérôme, 13397 Marseille, France
}

L'analyse de mélanges complexes s'effectue classiquement par le couplage " en ligne "d'une technique chromatographique avec une technique d'identification spectrale. Cette procédure est privilégiée lors d'analyse "de routine", cependant, dès lors que l'étape d'identification se complexifie, la procédure nécessite un fractionnement de l'échantillon qui peut se poursuivre jusqu'à la purification d'un constituant afin d'aboutir à son élucidation structurale (1).

Dans le cadre de travaux de doctorat visant l'étude de la diversité chimique des Bryophytes de Corse, nous nous sommes intéressés aux métabolites volatils de Frullania tamarisci, une hépatique dont la particularité est de posséder des oléocorps riches en huile essentielle. Son huile essentielle est un mélange complexe riche en composés sesquiterpéniques dont l'identification et la quantification sont délicates (2).

Cette communication illustre des stratégies analytiques intégrant la chromatographie sur colonne ouverte, les couplages CPG-FID et CPG/SM, la RMN et les séquences d'hémi-synthèse mises en œuvre pour l'identification et la quantification des métabolites volatils de F. tamarisci dont les données spectrales ne sont pas disponibles ou sont décrites de façon incomplète. Ainsi, ces techniques ont été utilisées pour identifier/quantifier, le pacifigorgiol un sesquiterpène oxygéné totalement co-élué sur les colonnes de CPG avec le tamariscol, autre sesquiterpene au squelette pacifigorgiane. La combinaison des techniques d'analyse et la mise en œuvre d'hémi-synthèses ont permis l'identification de quatre lactones sesquiterpéniques, parmi lesquelles le dihydrofrullanolide dont la caractérisation complète par RMN n'avait jamais été décrite et le g-dihydrocyclocostunolide reporté pour la première fois en tant que nouveau composé naturel. Par ailleurs, l'action phytotoxique des actifs identifiés semble prometteuse.

(1) Mariott P.J., Shellie R., Cornwell C., J. Chromatogr. A., 2001, 936, 1-22.

(2) P. D. Y. Asakawa, D. A. Ludwiczuk, D. F. Nagashima, "Chemical Constituents of the Bryophyta" in Prog. Chem. Org. Nat. Prod., Springer Vienna, 2013, pp. 563-605.

Mots-Clés : Bryophyte, Hépatique, Frullania tamarisci, Cyclocostunolide, frullanolide, g, dihydrocyclocostunolide

\footnotetext{
*Intervenant

†Auteur correspondant: muselli@unive-corse.fr
} 


\section{Méthodes de quantification ciblée [S5c]}




\title{
Mass spectrometry and chemical labeling as a powerful tool for peptide quantitation in pharmacology [058]
}

\author{
Christine Enjalbal ${ }^{*}{ }^{1}$, Sonia Cantel ${ }^{1}$, Gilles Subra ${ }^{1}$, Jean Martinez ${ }^{1}$, Didier \\ Gagne ${ }^{1}$, Maxime Rossato ${ }^{1}$, Emmanuelle Cordeau ${ }^{1}$, Nolween Prache ${ }^{1}$, \\ Carine Arnaudguilhem ${ }^{2}$, Brice Bouyssiere ${ }^{2}$
}
${ }^{1}$ Institut des Biomolécules Max Mousseron [Pôle Chimie Balard] (IBMM) - CNRS : UMR5247, Université de Montpellier, Ecole Nationale Supérieure de Chimie de Montpellier - Faculté de Pharmacie - 15 Av. Charles Flahault - BP 14491 - 34093 Montpellier Cedex 5, France
${ }^{2}$ Laboratoire de Chimie Analytique Bio-inorganique et Environnement (LCABIE-IPREM, UMR5254) - Université de Pau et des Pays de l'Adour - Hélioparc, 2 av. Pr. Angot, 64053 Pau, France

Since peptides represent a class of biomolecules involved in many biological processes, they are extensively studied for pharmaceutical developments as well as diagnostic tools. We have developed an original approach to selectively detect Mass Spectrometry signals of targeted peptides thanks to a specifically designed covalent labeling. Both molecular and elemental mass spectrometry techniques were investigated. N-terminal peptide modification through reaction with a common MALDI matrix (HCCA) was explored for MALDI-MS quantitation $(1,2)$ whereas peptide selenium tagging was engaged for ICPMS measurement (3). This strategy based on quantitative MS associated with a specific peptide chemical labeling was applied to quantify ligands at very low concentrations from cell cultures in pharmacological experiments. The cornerstone of this analytical methodology relies on the production of very abundant signals in MALDI- or ICP-mass spectrometry related exclusively to the peptide of interest that was quantified according to appropriate standards (isotopic dilution protocols in MALDI-MS or external calibration in ICP-MS). The proof of concept will be illustrated on the vasopressin/AVP pharmacological model, the targeted labeled ligands (HCCA-derivatized AVP or selenium-containing AVP) being quantified in both saturation and competitive binding assays at sub-nanomolar concentration levels. These results indicate clearly that these two MS-based methods represent a viable alternative to radiolabeling which is still, up to now, the reference method commonly used in pharmacology laboratories despite the environmental and health hazards of manipulating and storing radioactive materials.

(1) D. Paramelle et al., Angew. Chem. Int. Ed. 2010, 49, 8240

(2) M. Rossato et al., Chem. Med. Chem. 2016, 11, 2582

(3) E. Cordeau et al., Plos One, 2016, 11(6): e0157943.

Mots-Clés : Peptide, Selective detection, Sensitive quantification, Covalent labeling, MALDI, MS, ICP, MS

Programme

${ }^{*}$ Intervenant 


\title{
Top-down and bottom-up mass spectrometry approaches for Alpha-synuclein analysis in biological fluids [059]
}

\author{
Arthur Viodé ${ }^{* \dagger}{ }^{1}$, Foudil Lamari ${ }^{2}$, Christophe Junot ${ }^{1}$, François Fenaille ${ }^{1}$, \\ François Becher 1
}

${ }^{1}$ CEA Saclay, DRF, Institut Joliot, Service de Pharmacologie et d'Immunoanalyse- CEA-INRA UMR 0496, Laboratoire d'Etude du Métabolisme des Médicaments (CEA) - 91191 Gif-sur-Yvette cedex, France

${ }^{2}$ UF Biochimie des Maladies Neurométaboliques Service de Biochimie Métabolique - Hôpital Pitié-Salpêtrière 47-83 boulevard de l'Hôpital 75013 PARIS, France

\begin{abstract}
Alpha-synuclein is a $14 \mathrm{kDa}$ protein that tends to aggregate and represents the main component of Lewy bodies (intracellular protein inclusion in neurons). These inclusions are characteristic of the socalled synucleinophathies that include Parkinson's disease (PD), dementia with Lewy bodies and multiple system atrophy. In France, Parkinson's disease is the second most frequent neurodegenerative disease after Alzheimer disease with about 100000 affected people.

There have been some discrepancies about whether or not total alpha-synuclein level in cerebrospinal fluid (CSF) is decreased in PD, suggesting it may be worth evaluating specific proteoforms (phosphorylated, nitrated and glycosylated) or truncated species rather than unmodified native $\alpha$-synuclein. Also, some studies have combined $\alpha$-synuclein with other biomarkers involved in neurodegenerative diseases such as tau and amyloid peptides with the aim of increasing its diagnostic power. In this context, the high specificity offered by high resolution mass spectrometry represents a definitive advantage.

We have first developed a top-down assay on a quadrupole-Orbitrap mass spectrometer instrument with an antibody free extraction protocol (protein precipitation step) for monitoring native $\alpha$-synuclein in various biological fluids (CSF, plasma and red blood cells (RBCs)). A stable-isotope-labeled version of synuclein was used as an internal standard. In the investigated matrices, synuclein concentrations ranged from hundreds of $\mathrm{pg} / \mathrm{mL}$ in CSF to tens of $\mu \mathrm{g} / \mathrm{mL}$ in RBCs. The method was first applied to RBCs and allowed the identification of intact $\alpha$-synuclein and several other truncated forms. However, in CSF and plasma, the method was not sensitive enough for detection of intact $\alpha$-synuclein. Therefore, a more sensitive bottom-up multiplexed quantification method was set-up and optimized for $\alpha$-synuclein keeping in mind the requirement of high sequence coverage to monitor distinct proteoforms. In addition, this method was further extended to the simultaneous quantification of synuclein and tau protein species in a single analytical run.
\end{abstract}

Mots-Clés : Proteins, Biomarkers, Neurodegenerative diseases, Top down, Bottom up, synuclein

$\underline{\text { Programme }}$

\footnotetext{
*Intervenant

$\dagger$ Auteur correspondant: arthur.viode@cea.fr

$\ddagger$ Auteur correspondant: francois.becher@cea.fr
} 


\title{
Altered brain energy metabolism in Alzheimer disease: Linking peripheral and central metabolic changes [060]
}

\author{
Tony Teav $* \dagger 1$ \\ ${ }^{1}$ Metabolomics Research Platform, Faculty of Biology and Medecine, University of Lausanne (MEP) - Quartier \\ UNIL-CHUV Rue du Bugnon 19, Suisse
}

Evolutionary emergence of unique cognitive skills in humans is associated with elevated metabolic gene expression and specific brain metabolic activities that are sensitive to changes in energy homeostasis. Neurodegenerative disorders, such as Alzheimer disease (AD), are thought to be associated with and perhaps even caused by alterations in central energy metabolic pathways. However, these metabolic alterations, beyond the reduced glucose metabolism, remain largely unexplored. Metabolomics, as phenotyping approach, in combination with orthogonal clinical approaches, has the potential to accelerate the understanding of mechanisms that underlie complex diseases such as AD. Here the untargeted UPLC-HRMS-based metabolomic profiling was combined with targeted quantification to unravel and validate the metabolic signatures associated with $\mathrm{AD}$ in peripheral blood plasma and CSF of cognitively impaired subjects with confirmed AD pathology (by CSF biomarkers) and healthy aged controls without cerebral AD pathology $(\mathrm{N}=72)$. Results revealed distinctive metabolic phenotypes of plasma and CSF with some shared patterns mainly outlining significant alterations in amino acid and acylcarnitine metabolism. Plasma profiles of AD patients mirrored significant depletion in the levels of basic (histidine, lysine), aromatic (tryptophan, phenylalanine) and branched chain amino acids (leucine and valine) while CSF profiles highlighted the accumulation of specific amino acid catabolites. Additionally, both, plasma and CSF of AD patients showed the accumulation of long-chain acylcarnitines. Revealed alterations imply amino acids's catabolism as a compensatory strategy for reduced glucose supply in $\mathrm{AD}$, as well as the perturbed energy production in mitochondria with regards to fatty acid oxidation. Observed changes at the metabolite and pathway level are being correlated with CSF markers (A $\beta 1$, tau, and P-tau), patient's gender, BMI and blood-brain-barrier permeability. The association of peripheral metabolic changes with central metabolism and clinical meta-data will allow for the identification of metabolic biomarker signatures of $\mathrm{AD}$ pathology and understanding of their impact on the clinical manifestation.

Mots-Clés : Metabolomics, Alzheimer, UHPLC, HRMS

Programme

\footnotetext{
*Intervenant

${ }^{\dagger}$ Auteur correspondant: tony.teav@unil.ch
} 


\title{
Identifying autoimmune beta-cell epitopes in type 1 diabetes by HLA-peptidomics [061]
}

\author{
Sergio Gonzalez Duque ${ }^{* \dagger 1,2}$, Yann Verdier $\$ 1$,

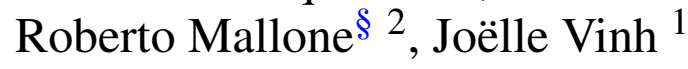 \\ ${ }^{1}$ ESPCI Paris, PSL Research University, Spectrométrie de Masse Biologique et Protéomique (SMBP), CNRS \\ USR 3149 - CNRS, UPMC, ESPCI - 10 Rue Vauquelin 75005 Paris, France \\ 2 Institut Cochin, Université Paris Descartes, INSERM U1016 - CNRS UMR 8104 / Diabetes and Autoimmunity \\ Research Lab - INSERM - 123 Bd de Port Royal 75014 Paris, France
}

Type 1 diabetes (T1D) is an autoimmune disease in which autoreactive CD8+ T-cells destroy pancreatic insulin-secreting beta-cells. This destruction is triggered by the recognition of peptide epitopes presented at the beta-cell surface in the pocket of HLA Class I molecules. We aimed at identifying these epitopes by HLA peptidomics. This strategy consists in purifying the peptide-HLA complexes from immortalized human beta-cell lines and to analyze the eluted peptides by nanoLC-MS/MS.

This workflow was validated based on: 1) the 8-12-aminoacid length of most (93\%) peptides identified, which fits the HLA pocket constraints; 2) the peptide signature, which reflects the HLA haplotype expressed by the beta-cells; and 3) the identification of several preproinsulin peptides already described as major CD8+ T-cell epitopes.

Thus we obtained a catalogue of 184 unique peptides derived from 109 beta-cell proteins. Fifty-two peptides were derived from known beta-cell protein antigens (preproinsulin, GAD, IA-2, ZnT8, IAPP and chromogranin-A), and novel candidate epitopes were identified within their sequences. The remaining 103 proteins represent novel candidate antigens. One recurrent feature shared by several known and putative antigens is their expression in insulin granules and their processing by proconvertases, which cleave protein precursors to obtain bioactive products. Intriguingly, several of the peptides identified map next to these proconvertase cleavage sites. The processing of protein precursors within the $\beta$-cell may thus represent a major source of autoimmune epitopes. The candidate epitopes identified may lead to the development of novel T-cell biomarkers.

Mots-Clés : Type 1 Diabetes, Biomarkers, T, cells, Epitopes, Peptidomics, Autoimmunity

$\underline{\text { Programme }}$

\footnotetext{
${ }^{*}$ Intervenant

${ }^{\dagger}$ Auteur correspondant: sergio.gonzalez-duque@espci.fr

† Auteur correspondant: yann.verdier@espci.fr

$\S$ Auteur correspondant: roberto.mallone@inserm.fr
} 


\section{Prix Junior et Doctorants [L]}




\title{
Compared effects of beta-hydroxybutyrate and bear serum on the proteome of human muscle cells [O62-P99]
}

\author{
Blandine Chazarin * 1, Stéphanie Chanon ${ }^{2}$, Guillemette Gauquelin-Koch ${ }^{3}$, \\ Stéphane Blanc, Etienne Lefai ${ }^{2}$, Fabrice Bertile ${ }^{1}$
}

${ }^{1}$ IPHC-DSA, LSMBO - CNRS, Université de Strasbourg - Laboratoire de Spectrométrie de Masse Bio-Organique (LSMBO) ECPM, Bât R5-0 25, rue Becquerel F - 67087 Strasbourg Cedex 2, France

2 Laboratoire CarMeN, INSERM U1060 / INRA 1397 - Université de Lyon - Faculté de Médecine Lyon-Sud 165 Chemin du Grand Revoyet 69600 Oullins, France

${ }^{3}$ Centre National d'études Spatiales - Centre national d'études spatiales - CNES

2 Place Maurice Quentin, 75001 Paris, France

\begin{abstract}
We recently showed that winter bear serum triggers changes in cultivated human myotubes that mimics a hibernation-like state. The identification of the active components in the bear serum would pave the way for innovative solutions to fight human muscle atrophy, one of the main deleterious characteristics of human ageing and physical inactivity. eta-hydroxybutyrate (betaOH) could be a good candidate as its concentration is markedly increased in winter bear serum and betaOH-supplemented diets have positive effects on human muscle mass preservation. Hence, human myotubes were incubated with either FCS or bear serum in the presence of various betaOH concentrations ( $\mathrm{N}=4 /$ condition). After extraction, proteins were separated on SDS-PAGE gels (4 bands) and tryspin-digested. Tryptic peptides were analyzed using a quantitative label-free-based method on a nanoUPLC-system (nanoAcquity, Waters) coupled to a Q-Exactive Plus (Thermo) before data analysis using MaxQuant (Swissprot Homo sapiens database). Quality controls (spiked iRT peptides and repeated analysis of a same sample pool) indicated very good reproducibility of retention times (median CV of $0.71 \%$ ) and quantitative data (median CV of $20.2 \%$ ). 3780 proteins (FDR 1\%) were quantified, of which a hundredth exhibited a differential abundance across groups (ANOVA+Tukey tests, $\mathrm{p}<0.05$ ). As expected, the bear serum induced the main effects, in line with a decreased protein turnover in human myotubes and possibly reflecting a pro-inflammatory status of muscle cells. The effects of betaOH, which may favor protein synthesis, were more marked when added in FCS, but remained limited. These data suggest that the known beneficial effects of betaOH on muscle mass preservation could be indirect, and that they could be masked by the already potent impact of the bear serum on human muscle cell protein balance.
\end{abstract}

Mots-Clés : label, free, bear, proteomic, quantitative, betaOH, muscle

Programme

${ }^{*}$ Intervenant 


\title{
Development of microsampling tools by laser ablation and mass spectrometry for the characterization of biological tissues [063]
}

\author{
Benoit Fatou * 1, Philippe Saudemont ${ }^{1}$, Maxence Wisztorski ${ }^{1}$, Cristian \\ Focsa $^{2}, \bar{M}$ ichel Salzet ${ }^{1}$, Michael Ziskind ${ }^{2}$, Isabelle Fournier ${ }^{1}$ \\ ${ }^{1}$ Laboratoire de Protéomique, Réponse Inflammatoire et Spectrométrie de Masse (PRISM) - INSERM : U1192 - \\ SN3, 1er étage, Cité Scientifique, Université de Lille 1, 59655 Villeneuve d'ascq Cedex, France \\ ${ }^{2}$ Physique des Lasers Atomes et Molécule (PhLAM) - CNRS : UMR8523 - Bât P5, Cité Scientifique, Université \\ de Lille 1, 59655 Villeneuve d'ascq Cedex, France
}

The characterization of biological tissues is an essential need to guide surgeons in their diagnosis and decision making for patient outcomes. Mass spectrometry (MS) is an essential and powerful tool for the characterization of samples to meet the clinical and pathological issues. Recent advanced ambient ionization sources facilitate the study of native samples, without any preparation required for MS analysis. In combination with sampling methods, they allow identification of biomolecules while retaining their histological localization. In this context, we first of all interested in the development and optimization of a $532 \mathrm{~nm}$ laser ablation strategy and capture the ablated material into a droplet solvent as an alternative method in micro-sampling biological tissue. We started by the detection of an ablation process not using the sample's absorption properties applied to the study of proteins and lipids derived from the ablation of tissue. The second point is the development of a new instrument called SpiderMass, for real-time analysis of biomolecules by laser ablation at $2940 \mathrm{~nm}$ coupled to MS for the characterization of biological tissue ex vivo and in vivo. First, the development of this instrument was made and optimized on the different parts that compose it. Molecular profiles generated in real-time show signals corresponding to metabolites and lipids. The low-invasive and virtually painless nature of the laser irradiation was obtained through in vivo studies on voluntary individual phalanxes. Finally, some of the developments made on the SpiderMass was dedicated for clinical application, which is ovarian cancer, to develop databases of molecular profiles corresponding to different grades of the disease.

Mots-Clés : mass spectrometry, laser ablation, proteomics, lipidomics, ambient ionisation sources, in vivo analysis, dermatology, cancer

Programme

${ }^{*}$ Intervenant 


\title{
De la classification moléculaire des gliomes à une nouvelle stratégie thérapeutique de réactivation des macrophages au sein de la tumeur [064]
}

\author{
Marie Duhamel ${ }_{-}^{*}$, Franck Rodet ${ }^{1}$, Maxence Wisztorski ${ }^{1}$, Isabelle \\ Fournier ${ }^{1}$, Michel Salzet ${ }^{1}$ \\ ${ }^{1}$ Laboratoire Protéomique Réponse Inflammatoire et Spectrométrie de Masse, INSERM U1192, Université de \\ Lille - Centre de Recherche INSERM : U1192 - Bâtiment SN3, Cité Scientifique \\ 59650 Villeneuve d'Ascq, France
}

Les tumeurs sont des régions très hétérogènes à la fois au niveau moléculaire et au niveau de la diversité cellulaire composant le microenvironnement tumoral. La classification des gliomes repose actuellement sur des critères histologiques qui sont enclins à de fortes subjectivités inter- et intra-observateurs ainsi que sur des marqueurs moléculaires utilisés en routine (mutation IDH1, co-délétion 1p/19q...). Au sein du même grade, des sous-groupes de tumeurs se différencient. Le but de ce projet est de réaliser une classification moléculaire des gliomes de haut grade en se basant sur des données protéiques permettant de localiser des biomarqueurs potentiels directement sur le tissu. Des sous-régions ayant des profils moléculaires différents ont été mises en évidence et les molécules les composants ont ensuite été identifiées de façon localisée. Les résultats démontrent que les annotations histologiques ne concordent pas forcément avec la classification moléculaire. Cette hétérogénéité est également retrouvée dans le microenvironnement des tumeurs où l'on retrouve des cellules immunitaires telles que les macrophages. Les macrophages sont détournés de leur fonction première par la tumeur pour lui permettre de se développer. Une stratégie thérapeutique pour contrer sa croissance est de réorienter le phénotype des macrophages vers un phénotype antitumoral. L'inhibition de la proprotéine convertase 1/3 s'est révélée être une stratégie prometteuse pour la réactivation des macrophages via les récepteurs TLR. Les facteurs sécrétés par ces macrophages ont un effet sur la viabilité et l'invasion de différentes cellules cancéreuses (gliomes, cancer de l'ovaire et cancer du sein) en fonction des ligands des récepteurs TLR utilisés. La première partie nous a permis d'identifier des sous-groupes de gliomes qui en fonction de leur profil moléculaire pourront, dans une perspective à long terme, recevoir des traitements plus personnalisés basés, par exemple, sur l'inhibition de proprotéines convertases en combinaison avec des ligands des récepteurs TLR.

Mots-Clés : Gliome, Imagerie par Spectrométrie de Masse, Microprotéomique, Classification, Proprotéine convertase 1/3, Macrophages, Récepteurs TLR, Oncoimmunologie

$\underline{\text { Programme }}$

${ }^{*}$ Intervenant 


\title{
Evaluation of metabolic alterations induced by glutamate in a cellular model of amyotrophic lateral sclerosis using a metabolomics approach [065]
}

\author{
Blandine Madji Hounoum * ${ }^{1}$, Cédric Raoul ${ }^{2}$, Lydie Nadal-Desbarats ${ }^{1,5}$, \\ Patrick Emond ${ }^{1,5}$, Philippe Corcia ${ }^{1,4}$, Christian R. Andres ${ }^{1,3}$, Sylvie Mavel ${ }^{1}$, \\ Hélène Blasco ${ }^{1,3}$
}

\footnotetext{
${ }^{1}$ Université François-Rabelais, INSERM U930 'Imagerie et Cerveau', CHRU de Tours, Tours France

2 The Neuroscience Institute Montpellier, INSERM U1051, Saint Eloi Hospital, Montpellier, France

${ }^{3}$ Laboratoire de Biochimie et de Biologie Moléculaire, Hôpital Bretonneau, CHRU de Tours, France

${ }^{4}$ Centre SLA, Service de Neurologie, CHRU de Tours, France

${ }^{5}$ Université François-Rabelais, Plateforme Scientifique et Technique 'Analyses des Systèmes Biologiques' PST-ASB, 37032 Tours Cedex 1- France
}

The selective degeneration of motoneurons that typifies amyotrophic lateral sclerosis (ALS) implicates non-cell-autonomous effects of astrocytes. However, mechanisms underlying astrocyte-mediated neurotoxicity remain largely unknown. According to the determinant role of astrocyte metabolism in supporting neuronal function, we have explored the metabolic status of astrocytes exposed to two ALSassociated conditions (mutation in the gene coding the superoxide dismutase-1 (SOD1); and excitotoxicity induced by glutamate). We investigated for the first time, the metabolism of astrocytes and motoneurons by LC-HRMS-based metabolomics approach completed by a 1H-NMR study of extracellular medium. The main aim of this study was to assess the effects of co-culture system on the metabolism of astrocytes and motoneurons. SOD1 astrocytes exposed to glutamate revealed a significant modification of the crosstalk between astrocytes and motoneurons. Pathway analysis of discriminating metabolites revealed interactive partners, involving metabolic dysregulation in both cell types. We found a significant metabolic dysregulation including purine, pyrimidine, lysine and glycerophospholipid metabolism pathways in SOD1 astrocytes when co-cultured with motoneurons. We observed that SOD1 mutation and stress-induced by glutamate impact the cellular shuttling of lactate between astrocytes and motoneurons. Based on a metabolomics strategy, all this work provides novel insight for understanding metabolic dysfunction of astrocytes and motoneurons in ALS and opens the perspective of therapeutics targets through focusing on these metabolic pathways

$\underline{\text { Programme }}$

*Intervenant 
Modifications post-traductionnelles [S6a] 


\title{
Intensive fractionation and Click chemistry as a powerful method for identification of O-GIcNAcylation sites [O66]
}

\author{
Barbara Deracinois , Luc Camoin , Matthias Lambert, Stéphane Audebert , \\ Erwan Dupont, Bruno Bastide, Caroline Cieniewski-Bernard * 1 \\ ${ }^{1}$ URePSSS (Unité de Recherche Pluridisciplinaire Sport, Santé, Société) - Université Lille I - Sciences et \\ technologies : EA7369 Activité Physique, Muscle, Santé - Bâtiment Eurasport 413 avenue Eugène Avinée
} 59120 LOOS, France

The O-linked N-acetyl- $\beta$-D-glucosaminylation (or O-GlcNAcylation), an atypical glycosylation, corresponds to the transfer of a unique GlcNAc moiety on serine and threonine hydroxyl group of a protein. Because of its dynamism, its reversibility and the swiftness of GlcNAc moieties transfer, OGlcNAcylation is akin to phosphorylation and responds rapidly to cell demands. This post-translational modification is involved in a large amount of cellular processes, and its dysregulation is closely associated to the etiology of several acquired pathologies, such as cardiovascular or neurodegenerative disorders. However, the precise function of O-GlcNAcylation remains often poorly understood because of the unawareness of the precise location of the modified sites. As for others post-translational modifications, mapping of O-GlcNAcylated site remains challenging nowadays, and several approaches were developed to determine directly or indirectly the serine or threonine amino acids which bear the O-GlcNAc moieties. In a context of understanding the potential role of O-GlcNAc in the skeletal muscle physiopathology, we attempt to localize O-GlcNAcylation sites on proteins isolated from $\mathrm{C} 2 \mathrm{C} 12$ skeletal muscle myotubes. Proteins were submitted to several fractionation steps (differential extraction, ammonium sulfate precipitation and fractionation according to the isoelectric point); each fraction was submitted to azide-alkyne Click chemistry, permitting the coupling of O-GlcNAcylated proteins to agarose beads. Peptides resulting from proteolysis of proteins linked to agarose beads, or released from beads through beta-elimination were sequenced on mass spectrometry, leading to the identification of proteins bearing O-GlcNAc moieties and the O-GlcNAc sites mapping. Thus, 1835 O-GlcNAcylated proteins were identified while 620 dehydrated peptides were sequenced, bearing one or more O-GlcNAc sites. This data lead to the identification of sites on signaling proteins, on structural proteins, and in particular, some sites corresponds to mutated site in muscular disorders. In conclusion, our approach, based on Click chemistry, is a promising and powerful approach for localization of O-GlcNAcylated sites.

Mots-Clés : O, GlcNAcylation, Click chemistry, O, GlcNAc site mapping, post, translational modification

$\underline{\text { Programme }}$

${ }^{*}$ Intervenant 


\title{
Quantitative analysis of redox modifications of protein cysteines in biofilm and planktonic Escherichia coli [O67]
}

\author{
Giovanni Chiappetta ${ }^{* \dagger}{ }^{1}$, Nicolas Barraud, Jean-Marc Ghigo, Joelle Vinh \\ ${ }^{1}$ Spectrométrie de Masse Biologique et Protéomique (SMBP) - ESPCI ParisTech, CNRS : USR3149 - 10 rue \\ Vauquelin, 75231 Paris Cedex 05, France
}

The growth of bacterial biofilms on surfaces often leads to steep oxygen gradients, rendering deep areas in the biofilm structure fully anaerobic. Redox signaling is likely to play important roles in the development and functioning of biofilms. For instance, the signaling molecule nitric oxide (NO) which is produced from anaerobic processes in mature biofilms has been found to trigger dispersal events and restart the biofilm life-cycle.

One major mechanism by which redox signaling, including $\mathrm{NO}$, can induce physiological responses is the posttranslational reversible oxidation of protein cysteine thiols to form disulfide (-S-S-), sulfenic acid (-SOH-) or $S$-nitroso (-SNO-). To determine if redox modification of proteins may play a role in bacterial biofilms development, we used a bottom-up proteomics approach, using a modified OcSILAC strategy. A biotin-switch method was adapted for the differential enrichment of oxidized and nitrosylated thiols in cysteines coupled to a stable isotope labelling with amino acids in culture strategy.

This method was applied to study the redoxome of biofilms. Quantitative data processing allowed to identify proteins with distinct redox modification profiles in Escherichia coli biofilms grown in microfermentor cultures compared to planktonic cultures under both aerobic and anaerobic conditions. The effects of oxygen availability on protein expression level and on the redox state of each protein were discriminated. This study furnishes also a real example of data mining to quantify post-translational modifications.

Mots-Clés : cysteine oxidation, ROS, S, Nitrosylation

Programme

\footnotetext{
*Intervenant

${ }^{\dagger}$ Auteur correspondant: giovanni.chiappetta@espci.fr
} 


\title{
Large-scale proteomic analysis of SIRT1- and tissue-dependent acetylproteome in mouse liver, testis and muscle [068]
}

\author{
Marie Locard-Paulet* ${ }^{*}$, Amitkumar Fulzele ${ }^{2}$, Emmanuelle Mouton-Barbosa \\ ${ }^{1}$, Marlène Marcellin ${ }^{\top}$, Odile Burlet-Schiltz ${ }^{1}$, Shaunak Deota ${ }^{2}$, Babukrishna \\ Maniyadath $^{2}$, Ullas Kolthur-Seetharam ${ }^{2}$, Anne Gonzalez De Peredo ${ }_{-}^{\dagger}$ \\ ${ }^{1}$ Institut de pharmacologie et de biologie structurale (IPBS) - Université Paul Sabatier - Toulouse 3, CNRS : \\ UMR5089 - 205 Route de Narbonne 31077 Toulouse cedex 4, France \\ 2 Tata Institute of Fundamental Research - Homi Bhabha Road, Colaba, Mumbai India 400005, Inde
}

\begin{abstract}
Background: SIRT1 (NAD-dependent protein deacetylase Sirtuin-1) regulates the expression of genes by deacetylating their transcription factors and co-regulators. These can be involved in a wide range of functions such as cell cycle, DNA damage, metabolism, aging and spermatogenesis. Sirtl is differentially expressed in tissues and its activity can be regulated through post-translational modifications or expression of tissue-specific isoforms. Furthermore, SIRT1 activity depends on NAD+ levels, which is altered by starvation and metabolic changes associated with caloric restriction. In order to identify substrates of SIRT1 in vivo and to gain insights into tissue- and diet-dependent regulations by SIRT1, we analysed SIRT1-dependent acetylations in liver, muscle and testis of fed and starved mice.
\end{abstract}

Methods: Tissues were harvested from fed and starved wild-type control mice or mice with conditional SIRT1-KO. After lysis and trypsin digestion, acetylated peptides were enriched by immuno-precipitation using a specific antibody targeting acetylations before being injected onto a Q-Exactive Plus for labelfree quantification. The proteome (peptides before acetyl-enrichment) and the acetylproteome data sets were then subjected to a statistical workflow developed for PTM analysis and integrated to identify potential substrates of SIRT1 and diet- and/or tissue-specific acetylation events.

Results: We identified over 1,600 acetylation sites belonging to 719 proteins and their statistical analysis uncovered potential tissue independent and tissue specific SIRT1 substrates. Our integration of the acetylome and proteome data sets shows major SIRT1-dependent changes of the acetylproteome upon nutrient restriction in the liver and muscle.

Conclusions: This work allowed the identification of global acetylation changes due to SIRT1 extinction in function of nutrient availability. We identified previously unreported potential substrates of SIRT1 providing clues on its cellular functions in different organs. Finally, the undergoing integration of our data set with similar studies of other Sirtuins should enlighten on their inter-dependencies in a tissue-specific fashion.

Mots-Clés : Sirt1, acetylation, PTM

\section{Programme}

\footnotetext{
${ }^{*}$ Intervenant

†Auteur correspondant: gonzalez@ipbs.fr
} 


\title{
Proteomic study of histone acylations [069]
}

\author{
Marion Crespo ${ }^{*}{ }^{1}$, Sara El Kennani ${ }^{1}$, Annelaure Damont ${ }^{2}$, Julie Cocquet $^{3}$, \\ Christophe Bruley ${ }^{1}$, François Fenaille ${ }^{2}$, Jérôme Govin ${ }^{1}$, Delphine Pflieger ${ }^{1}$ \\ ${ }^{1}$ CEA Tech Grenoble - CNRS : FR3425, Centre de Recherche INSERM, Université Grenoble Alpes, U1038 - 17 \\ rue des Martyrs 38054 Grenoble Cedex 9, France \\ ${ }^{2}$ CEA Saclay (CEA) - 91191 Gif-sur-Yvette cedex, France \\ ${ }^{3}$ Institut Cochin - CNRS : UMR8104, Centre de Recherche INSERM : U1016, Université Paris Descartes - Paris \\ 5 - 22, rue Mechain 75014 PARIS, France
}

Histones $\mathrm{H} 2 \mathrm{~A}, \mathrm{H} 2 \mathrm{~B}, \mathrm{H} 3$ and $\mathrm{H} 4$, organized in tetramers within chromatin, are decorated by a great diversity of post-translational modifications (PTMs) which contribute to numerous processes such as gene expression regulation, DNA damage repair, etc. Acetylation and methylations of Lys and Arg residues as well as phosphorylation of Ser and Thr have long been described and functional roles have been attributed to a number of these modified residues. Over the past decade, a range of PTMs whose structures are quite close to, but longer than acetylation, collectively referred to as acylations, were discovered by the group of Yingming Zhao (Sabari BR et al, Nat Rev Mol Cell Biol. 2017). Specific effects have started to be attributed to these acylations, such as the transcriptional active state marked by crotonylation in the post-meiotic phases of spermatogenesis (Tan M et al, Cell 2011). These new PTMs thus aroused an increasing interest, because they largely expand the refinement level of epigenetic regulation mechanisms. Our team works on yeast sporulation considered as a model for mammalian spermatogenesis. These processes share a meiosis step, followed by a progressive compaction of the genome that is accompanied by dramatic changes in histone PTMs, and end with the removal of histones (Govin J et al, Genes Dev 2010). We decided to study the acylations present on histones during yeast sporulation and mouse spermatogenesis, to assess their conservation level. Mass spectrometry analysis allowed pinpointing conserved and possibly specific sites modified with propionylation, butyrylation and crotonylation. Because histone variants emerged during evolution, we observe a very complex pattern of regulation during mouse spermatogenesis, combining diverse acylations and histone sequence variants that differ by a few amino acids only. These proteomic analyses are currently associated with metabolomics analyses of acyl-coAs to assess the correlation between the levels of PTMs and of metabolites.

Mots-Clés : Post translational modifications, acylations, histones, proteomics

$\underline{\text { Programme }}$

*Intervenant 


\section{Lipidomique [S6b]}




\title{
Une approche combinée de lipidomique, d'imagerie MS et d'imagerie TEP-Scan révèle des différences de fonctionnement cérébral chez le raton selon le contenu lipidique de formules infantiles [O70]
}

\author{
Jean-Charles Martin ${ }^{* \dagger}{ }^{1}$, Nacima Aidoud ${ }^{1}$, Bernadette Delplanque ${ }^{2}$, Nicole Masotti ${ }^{3}$, Brigite \\ Nicolini ${ }^{3}$, Cyrielle Garcia ${ }^{4}$, Dominique Darmaun ${ }^{5}$, Lucie Arnoux ${ }^{6}$, Samantha Fernandez ${ }^{7}$, Benjamin \\ Guillet ${ }^{7}$, Claudine Antona ${ }^{1}$, Farid Boubred ${ }^{6}$, Charlotte Baudry ${ }^{8}$, Pascale Le Ruyet ${ }^{8}$ \\ ${ }^{1}$ INRA, Aix-Marseille Université - AMU, INSERM - NORT, UMR INRA 1260, Marseille, France \\ 2 INSERM, INRA, Université de Paris-Sud Orsay - NMPA, U-Paris Sud Orsay, France \\ ${ }^{8}$ Lactalis R\&D, Retiers, France
}

Nous avons évalué l'impact de la qualité lipidique de formules infantiles sur la composition et le fonctionnement du cerveau dans un modèle de ratons allaités artificiellement avec des formules de sources lipidiques différentes : matière grasse végétale seule (MGV) ou en mélange avec des graisses laitières (MGLmix), supplémentées ou non en acide arachidonique (ARA) et DHA (ratio2:1). Les résultats ont été comparés à un groupe allaité (opérés Sham). Au sevrage ont été évaluées (i) l'activité fonctionnelle cérébrale en imagerie TEP-scan, (ii) la composition en acides gras et en espèces lipides du cerveau par lipidomique, (iii) la richesse en DHA des différentes régions cérébrales par imagerie en spectrométrie de masse.

Résultats : L'activité fonctionnelle cérébrale devient comparable aux allaités avec les formules DHA+ARA. La formule MGLmix induit des teneurs en DHA supérieures à la base végétale, mais inférieures aux témoins allaités. L'ajout de DHA+ARA dans les formules permet de normaliser le contenu cérébral en DHA, mais sa distribution dans les différentes zones du cerveau, déterminée par imagerie MS, reste différente des rats allaités : seule la formule MGLmix se rapproche au mieux des contrôles allaités. L'analyse lipidomique a permis d'identifier plus de 700 espèces lipidiques réparties dans 27 classes de lipides. La PC(18:0/22:6n-3) est la plus modifiée en présence de DHA+ARA et la mieux corrélée positivement avec l'activité cérébrale $(\mathrm{r} 2=0,25 ; \mathrm{P}<0.05)$. Au-delà de la composition en acides gras, les teneurs de certains lipides structuraux (LPC, céramides, sphingosine et cholestérol) sont modifiées par le type de formules administrées.

Conclusions : les matières grasses laitières, le DHA+ARA des formules modulent l'activité cérébrale post-natale. Le contenu en DHA cérébral peut être normalisé par l'ajout de DHA+ARA, mais non sa distribution dans les zones cérébrales. La qualité lipidique des formules est capable de moduler le contenu en certains lipides structuraux et fonctionnels du cerveau.

Mots-Clés : nutrition lipidique, lipidomique, imagerie MS, imagerie in vivo, nouveau, né

\footnotetext{
*Intervenant

${ }^{\dagger}$ Auteur correspondant: jean-charles.martin@univ-amu.fr
} 


\title{
Two-dimensional mass spectrometry patterns as a tool for lipidomics: application to human blood plasma with different oxidation states [071]
}

\author{
Fabrice Bray ${ }^{* \dagger}{ }^{1}$, Caroline Tokarski ${ }^{1}$, Christian Rolando ${ }^{2}$ \\ ${ }^{1}$ Miniaturisation pour la Synthèse et l'Analyse Protéomique (MSAP) - CNRS : USR3290 - Université Lille 1, \\ Sciences et Technologies Batiment C4 - Avenue Paul Langevin 59655 Villeneuve d'Ascq, France \\ ${ }^{2}$ USR 3290 MSAP, Université Lille 1, Sciences et Technologies - USR 3290 MSAP, Université Lille 1, Sciences \\ et Technologies - 59655 Villeneuve d'Ascq cedex, France
}

\begin{abstract}
Two-dimensional Fourier transform ion cyclotron resonance mass spectrometry (2D FT-ICR MS) is an innovative tandem mass spectrometry method that correlates precursor and fragment ions without requiring prior ion isolation. 2D FT-ICR MS is therefore very well adapted to the structural analysis of complex samples. Human blood triacylglycerols (TAGs) were extracted from one milliliter of human plasma using two solid phase extractions on $50 \mathrm{mg}$ DSC-NH2 columns. TAGs 50 microliter solution was then diluted 500 fold in methanol/chloroform $2: 1(\mathrm{v} / \mathrm{v})$ with $0.1 \%$ of lithium chloride. So the quantity required for an analysis may be reduced to a drop of blood as only 10 microliter of solution are required for the simpler analysis. Classical 1D MS analysis and bi-dimensional FT-ICR MS experiments were performed on an Apex 9.4 Tesla fitted with an Infinity cell using gas-free fragmentation method IRMPD as the lithiated TAG precursor ions are very cleanly fragmented by IMRPD allowing an easy determination of their fatty acids composition. Two set of parameters for 2D FT-ICR MS were used: in the first one unit resolution was achieved for the precursor selection and high resolution for the fragments using a fast acquisition ( $2 \mathrm{k}$ points, 60 minutes) whereas in the second one a high resolution for precursors was achieved using a non uniform sampling acquisition (256k points, NUS 1/16, overnight). From the low resolution 2D spectra, clear bidimensional patterns are obtained allowing to classify the oxidation by family according to the transfusion plasma treatment (methylene blue, Amotosalem, untreated) or the disease leading to an oxidative stress. From high resolution 2D spectra TAGs native and oxidized with a total carbon of 46 to 56 and unsaturation numbers from 1 to 5 may be identified and their individual fatty acid composition determined. The same information was obtained for the different families of lipids including phospholipids.
\end{abstract}

Mots-Clés : Triacylglycerols (TAGs), 2D FT, ICR, human plasma, IRMPD, pattern

Programme

\footnotetext{
${ }^{*}$ Intervenant

†Auteur correspondant: fabrice.bray@univ-lille1.fr
} 


\title{
Multilevel statistics applied to NMR/MS lipidomics [O72]
}

\author{
Jérémy Marchand ${ }^{*}{ }^{1,2}$, Yann Guitton ${ }^{2}$, Sébastien Déjean ${ }^{3}$, François Bartolo \\ ${ }^{4}$, Estelle Martineau ${ }^{1,5}$, Bruno Le Bizec ${ }^{2}$, Patrick Giraudeau ${ }^{1,6}$, Gaud \\ Dervilly-Pinel $^{2}$
}

${ }^{1}$ Chimie Et Interdisciplinarité : Synthèse, Analyse, Modélisation (CEISAM) - Université de Nantes, CNRS : UMR6230 - UFR des Sciences et des Techniques - 2 rue de la Houssiniere BP 92208 - 44322 Nantes Cedex 3

${ }^{2}$ LUNAM Université, Oniris, Laboratoire d'Etude des Résidus et Contaminants dans les Aliments (LABERCA), UMR INRA 1329 (ONIRIS-Laberca) - Ministère de l'alimentation de l'agriculture et de la pêche - Nantes

3 Institut de Mathématiques de Toulouse UMR5219 (IMT) - Université Toulouse 1 Capitole, INSA - Toulouse, Université Toulouse 2, Université Paul Sabatier - Toulouse 3, PRES Université de Toulouse, CNRS - UPS IMT, F-31062 Toulouse Cedex 9, France INSA, F-31077 Toulouse, France UT1, F-31042 Toulouse, France UT2,

F-31058 Toulouse, France

${ }^{4}$ Methodomics, SARL - 60 rue nationale 85290 Mortagne, France

${ }^{5}$ Spectromaîtrise, CAPACITÉS SAS, 26 Bd Vincent Gâche, 44200 Nantes, France

${ }^{6}$ Institut Universitaire de France (IUF) - Paris, France

Metabolomic -and by extent lipidomic- studies generate large amounts of data, which require tailored statistical methods. Multivariate statistical analyses, such as Principal Component Analysis (PCA) for data exploration, or Partial Least Square Discriminant Analysis (PLS-DA), for supervised analysis are therefore commonly used (1). However, when the experiment design includes repeated measurements (for instance several measurements acquired on the same individual at different time points), too few available exploratory solutions enable dealing with such characteristic, resulting in biological noise which hinders further interpretation. The so-called multilevel approaches, as included in the mixOmics $\mathrm{R}$ package, make an efficient use of these repeated measurements and after subsequent multivariate analysis, better reveal the differences between sample groups and relevant variables (2-3).

We will demonstrate that a two-factor multilevel approach, followed by PLS-DA, can greatly simplify the interpretation of the results from the statistical treatment of lipidomic data acquired with multiple analytical methods. We will present a simple and efficient solution for relevant variable selection. The strategy has been efficiently applied in a public health related project to highlight biomarkers of chemical exposure in food producing animals on two data sets respectively acquired by Mass Spectrometry and multidimensional Nuclear Magnetic Resonance fingerprinting. A distinct discrimination between the sample groups was obtained, allowing a simple selection of the relevant variables, thus highlighting potential biomarkers.

(1) F.Courant, J.-P. Antignac, G. Dervilly-Pinel, B. Le Bizec, Proteomics, 2014, 140: 2369-2388.

(2) J. Westerhuis, E. van Velzen, H. Hoefsloot, A. Smilde, Metabolomics, 2010, 6: 119-128.

(3) B. Liquet, K.-A. Lê Cao, H. Hocini, R. Thiébaut, BMC Bioinformatics, 2012, 13: 325.

Mots-Clés : lipidomics, food safety, data analysis, biomarkers, NMR/HRMS

\footnotetext{
*Intervenant

${ }^{\dagger}$ Auteur correspondant: jeremy.marchand@oniris-nantes.fr
} 


\title{
Apport de la spectrométrie de masse dans la caractérisation structurale et l'analyse des phospholipides oxydés [073]
}

\author{
Spiro Khoury ${ }^{* \dagger}{ }^{1}$, Corinne Pouyet ${ }^{1}$, Bernard Lyan ${ }^{1}$, Estelle Pujos-Guillot ${ }^{1}$
}

\author{
${ }^{1}$ Unité de Nutrition Humaine UMR 1019 INRA / Université Clermont 1 Plate-forme d'Exploration du \\ métabolisme PFEM - Centre de Clermont - Ferrand -Theix 63122 Saint Genès Champanelle, France
}

Les phospholipides (PLs) sont des biomolécules complexes, de structures très variées, et représentent une classe de métabolites d'intérêt pour évaluer les relations entre l'alimentation et le développement des maladies métaboliques. Vu leur richesse en acides gras insaturés, les PLs donnent lieu à la formation d'un grand nombre de produits d'oxydation. Ainsi, les phospholipides oxydés (PLs-Ox) sont de plus en plus reconnus non seulement comme des marqueurs de stress oxydant, mais aussi des marqueurs de différentes pathologies associées à l'inflammation, telles que le diabète. L'objectif de ce travail est d'acquérir de nouvelles connaissances structurales concernant les PLs-Ox afin de proposer une stratégie analytique permettant d'analyser ces composés dans les matrices biologiques.

Étant donné la faible disponibilité commerciale des PLs-Ox, une méthode de synthèse, en auto-oxydation (1), a été mise en place à partir d'espèces moléculaires, de structures variées, de Phosphatidylcholines et Phosphatidyléthanolamines. Une méthode d'analyse par spectrométrie de masse (MS), en basse et haute résolution, utilisant une source d'ionisation electrospray, a été développée pour caractériser la grande diversité structurale des formes oxydées. Le couplage avec la chromatographie liquide (LC) par Injection en Flux Continu a permis la mise au point d'une méthode LC-MS.

La cinétique de formation des produits d'oxydation a été évaluée et l'effet de la structure des PLs sur la nature des formes oxydées a été investigué. L'étude de la fragmentation des formes oxydées, à chaine courte et longue, en MSn, a contribuée à générer davantage d'informations structurales, à confirmer les structures proposées, ainsi qu'à localiser le site d'oxydation sur la chaine d'acide gras insaturée. Ces résultats permettent d'envisager la mise en place d'une stratégie d'analyse lipidomique de ces composés, et l'enrichissement des bases de données existantes par l'annotation proposée.

(1) Spickett, C.M., A. Reis, and A.R. Pitt, Free Radic Biol Med, 2011. 51(12): p. 2133-49.

Mots-Clés : Phospholipides oxydés, Spectrométrie de masse, Identification, Fragmentation

Programme

\footnotetext{
*Intervenant

${ }^{\dagger}$ Auteur correspondant: spiro.khoury@inra.fr
} 


\section{Microbiologie: bactérie, virus, champignon et méta-omiques [S6c]}




\title{
Discrimination de biofilms marins par métabolomique [074]
}

\author{
Gérald Culioli $_{-}^{*}$, Laurie Favre ${ }^{1}$, Annick Ortalo-Magné ${ }^{1}$ \\ ${ }^{1}$ MAPIEM - Université de Toulon - CS 60584, 83041 Toulon Cedex 9, France
}

En milieu marin, les surfaces immergées sont sujettes à la colonisation par de nombreux organismes (biofouling). Le développement de biofilms constitue une étape-clé de ce phénomène. La composition des populations microbiennes (bactéries, diatomées, ...) formant ces biofilms est complexe et varie en fonction des conditions environnementales et des propriétés physico-chimiques des surfaces. Les principales études menées à ce jour dans ce domaine ont porté sur la structure des communautés bactériennes mais le questionnement scientifique en lien avec la "dimension chimique " des biofilms a été éludé.

Dans ce contexte, les travaux menés par notre équipe visent, d'une part, à développer des protocoles d'analyse métabolomique (LC-MS) applicables aussi bien à des biofilms de bactéries modèles formés in vitro qu'à des biofilms naturels et, d'autre part, à discriminer des biofilms marins collectés sur diverses de surfaces artificielles. Ce dernier volet nécessite la mise en œuvre d'approches pluridisciplinaires liant l'analyse métabolomique à des études d'écologie microbienne (communautés), de chimie de l'environnement (paramètres environnementaux), de chimie des matériaux (physico-chimie des surfaces) ainsi que de biochimie (matrice exopolymérique).

Des protocoles dédiés spécifiquement à l'analyse par métabolomique de biofilms marins ont été développés à partir de cultures d'une sélection de bactéries. Les résultats montrent que le profilage par LC-MS lié à des analyses multivariées permet de différencier les souches étudiées au niveau spécifique et ce, quel que soit le milieu, le temps ou le mode de culture (planctonique/biofilm). En outre, la construction de réseaux moléculaires a conduit à la caractérisation de biomarqueurs de type aminolipides $(1,2)$. Pour les biofilms formés in situ, une nette discrimination est observée en fonction des surfaces et/ou des sites d'immersion, et peut être corrélée aux résultats obtenus par le biais des autres approches.

(1) Favre et al. J. Proteome Res. 2017 16: 1962.

(2) Favre et al. Biofouling soumis.

Mots-Clés : Biofilms marins, métabolomique, LC/MS, bactéries marines, réseaux moléculaires, amino, lipides

$\underline{\text { Programme }}$

\footnotetext{
*Intervenant
} 


\title{
Lysine modifications in Pseudomonas aeruginosa PA14 [075]
}

\author{
Charlotte Gaviard ${ }^{* \dagger}{ }^{1}$, Isabelle Broutin ${ }^{2}$, Pascal Cosette ${ }^{1}$, Emmanuelle Dé ${ }^{1}$, \\ Thierry Jouenne ${ }^{1}$, Julie Hardouin ${ }^{1}$
}

\author{
${ }^{1}$ CNRS UMR 6270 - Université de Rouen - Plateforme PISSARO, IRIB, Mont-Saint-Aignan, France \\ ${ }^{2}$ Laboratoire de cristallographie et RMN biologiques (LCRB) - CNRS : UMR8015, Université Paris V - Paris \\ Descartes - Faculté de Pharmacie 4 Avenue de l'Observatoire 75270 PARIS cedex 06, France
}

Post-translational modifications (PTMs) are crucial for regulating, on short timescales, almost all cellular functions in various organisms. Hundreds of PTMs have been so far reported but, in contrast to eukaryotes, PTM discovery in bacteria is quite recent. PTM diversity suggests their involvement in important bacterial mechanisms (virulence, resistance...) to rapidly respond to both internal and external signals, and thus allowing bacteria to adapt to its environment.

Pseudomonas aeruginosa is a Multi-Drug Resistant human pathogen largely involved in nosocomial infections. However, effective antibacterial agents lacked. Explore its physiology at the PTM level may contribute to the renewal of combat tactics. Although phosphorylation(1) and acetylation(2) are the most studied, the recent discovery of lysine succinylation(3) appears to be an interesting PTM.

Here, we will present the characterization of succinylated and acetylated proteins in $P$. aeruginosa PA14 in different carbon sources. We used a 2 dimensional immunoaffinity approach with high resolution/accuracy mass spectrometry.

Overall, a total of 1530 succinylated sites (617 proteins) and 1109 lysine sites (526 proteins) were identified. Citrate was the carbon source in which we identified the higher number of succinylated proteins.

Interestingly, we noticed that 622 sites (312 proteins) can be either acetylated or succinylated on the same lysine. The addition of these PTMs changes the residue charge that can affect the 3D structure. The protein function/interactions can thus be affected too. Some of these proteins have interesting functions like two-component regulatory systems, chemotaxis... So, we are looking to the structure of proteins of interest to investigate the possible involvement of the modified lysine residue in a conformational change.

This work provides the first repertory of succinylated proteins in PA14, a promising starting point for further investigations on the biological role of lysine succinylation in $P$. aeruginosa.

Mots-Clés : Pseudomonas aeruginosa, Post translational modifications, Succinylation

Programme

\footnotetext{
* Intervenant

${ }^{\dagger}$ Auteur correspondant: charlotte.gaviard1@ @univ-rouen.fr
} 


\title{
An integrated innovative top-down proteomics workflow for the rapid discrimination of enterobacterial pathogens [076]
}

\author{
Mathieu Dupre ${ }^{* \dagger}{ }^{1}$, Diogo Borges Lima ${ }^{1}$, Christian Malosse ${ }^{1}$, Magalie \\ Duchateau ${ }^{1}$, Dominique Clermont ${ }^{2}$, Paulo Costa Carvalho ${ }^{3}$, Julia \\ Chamot-Rooke ${ }^{1}$ \\ ${ }^{1}$ Unité de Spectrométrie de Masse Structurale et Protéomique, Institut Pasteur (USMSP) - 25-28 rue du Docteur \\ Roux F-75724 Paris Cedex 15, France \\ ${ }^{2}$ Collection de l'Institut Pasteur (CIP) - Institut Pasteur - Département Microbiologie - 25-28 rue du Docteur \\ Roux F-75724 Paris Cedex 15, France \\ ${ }^{3}$ Computational Mass Spectrometry and Proteomics Group, Carlos Chagas Institute - Rua Prof. Algacyr Munhoz \\ Mader, 3775 - CIC 81350-010 Curitiba/PR, Brésil
}

Pathogen identification is crucial to confirm bacterial infections and guide antimicrobial therapy. Although MALDI-TOF mass spectrometry (MS) has proved a powerful tool for microbial identification, clinical laboratories need more reliable methods since some bacteria remain difficult to identify (absence of specific profile, lack of appropriate references in the database, no differentiation of sub-species).

Top-down proteomics (TDP) is an emerging technology based on the analysis of intact proteins using very high-resolution MS. The major advantage of TDP, in comparison to the more usual bottom-up MS approach, is its ability to address protein variations, characterize proteoforms arising from alternative splicing, allelic variation, or post-translational modification, and negate the problem of protein inference.

Here, we developed a unique integrated approach, combining large-scale LC-MS/MS TDP with an innovative software tool, able to discriminate bacterial pathogens. As a proof of concept, we focused on enterobacterial species that are difficult to unambiguously identify with MALDI-TOF. Briefly, 12 different bacterial strains of E. coli, Shigella and Salmonella species were cultured. Following a lysis step, intact proteins were extracted and analyzed by LC-MS/MS on an Orbitrap Fusion Lumos mass spectrometer using EThcD fragmentation. All data were processed with Prosight PD 2.1 and Diagno-TOP, a new software tool developed in-house, which clusters spectra according to their similarity, without any database search or protein identification.

In total, our dataset comprised 36 LC-MS/MS runs containing 200,744 MS/MS spectra corresponding to 93,372 spectra clusters. From these data, Diagno-TOP pinpointed many spectral clusters shared by several species. Besides those, specific spectral cluster were also identified. For instance, 1,605, 1,226 and 2,705 spectral clusters were respectively found as unique for E. coli, Shigella and Samonella. Taken together, all species were correctly classified. Such discrimination would have been impossible with MALDI-TOF.

Mots-Clés : Bacterial infection, virulence, resistance, mass spectrometry, proteomics, diagnosis, DiagnoTop

\footnotetext{
*Intervenant

${ }^{\dagger}$ Auteur correspondant: mathieu.dupre@ pasteur.fr
} 


\title{
NRPomics : Kendrick mass defect for molecular formula assignment of non ribosomal peptides (NRPs) [077]
}

\author{
Mickael Chevalier ${ }^{*} \dagger 1$, Emma Ricart ${ }^{2}$, Emeline Hanozin ${ }^{3}$, Frederique \\ Lisacek $^{2}$, Maude Pupin ${ }^{4,5}$, Philippe Jacques ${ }^{6}$, Nicolas Smargiasso ${ }^{3}$, Edwin \\ De Pauw ${ }^{3}$, Valerie Leclère ${ }^{1}$, Christophe Flahaut ${ }^{1}$ \\ ${ }^{1}$ Univ. Lille, INRA, ISA, Univ. Artois, Univ. Littoral Côte d'Opale, Charles Viollette Institute (ICV) - \\ Université Lille I - Sciences et technologies : EA7394 - F-59000 Lille, France \\ ${ }^{2}$ Proteome informatics Group, Swiss Institute of bioinformatics (SIB) - Geneva, Suisse \\ ${ }^{3}$ Mass Spectrometry Laboratory (MS LAB) - Institut de Chimie, Bat. Bc B-4000 Liège, Belgique \\ ${ }^{4}$ Univ Lille, CNRS, Centrale Lille, UMR9189 - CRIStAL- Centre de Recherche en Informatique Signal et \\ Automatique de Lille (CRIStAL) - Université Lille I - Sciences et technologies - F-59000 Lille, France \\ ${ }^{5}$ Bonsai team (INRIA) - Institut National de Recherche en Informatique et en Automatique - F-59655 \\ Villeneuve d'Ascq Cedex, France \\ ${ }^{6}$ TERRA Research Centre, Microbial Processes and Interactions (MiPI) - Gembloux Agro-Bio Tech University \\ of Liege, B-5030 Gembloux, Belgique
}

Among the key analytical techniques dedicated to the high-throughput analysis of microbial secondary metabolites and, more particularly, of non-ribosomal peptides (NRPs), the mass spectrometry (MS) generally coupled to separative techniques, remains a tool of choice. As suggested by their names, the NRPs structure cannot be read directly from the genome hence the protein databases contain very little structural information about the NRPs. NRPs are, by nature, metabolites containing building blocks, called monomers, including proteogenic and non-proteogenic amino acids and derivatives, aliphatic chains, chromophores, fatty acids....Nowadays, more than 500 monomers... have been founds in NRPs composition in the NORINE database that currently gathers more than 1200 NRPs structures (Caboche et al., 2007; Flissi et al. 2016). The NRP synthesis occurs a long large enzymatic complexes called non ribosomal peptide synthetases (NRPS) and lead to linear, cyclic, semi-cyclic or branched structures of masses between 500 and 2,000 Da. NRPs have various activities ranging from anti-bacterial, antifungal, anti-inflammatory, surfactants, siderophore and so one. According to their mass range, NRPs do not fully belong to metabolomics or proteomics fields and the analytical methods developed in its respective fields are not fully transposable for the "NRPomics" (defined as the systematic study of NRPs). Here, we will illustrate that the combination of NORINE database information, the measurement accuracy using FTICR mass spectrometer and the Kendrick mass defect (Kendrick, 1963) is an relevant way to recover the molecular composition of NRPs and to propose potential structures for new NRPs, based on the NRPs family phylogeny.

Mots-Clés : nonribosomal peptides

\footnotetext{
*Intervenant

†Auteur correspondant: mickael.chevalier1@ polytech-lille.fr
} 


\section{Workshops}




\title{
Thermo Fisher Scientific : Orbitrap MS- repousser les limites de la recherche Omics [W1]
}

\author{
Présentation 1 : Accelérer la recherche de biomarqueurs : \\ workflows (HRAM)MS pour la proteomique translationnelle
}

Claire Dauly $\stackrel{* \dagger}{*}$

Thermo Fisher Scientific - Courtaboeuf cedex, France

Les maladies comme le Cancer sont complexes - et requièrent un autre niveau de discipline dans les mesures analytiques. Aprés avoir été reconnues comme un standard pour la recherche de biomarqueurs avec l'obtention de profils proteomiques complets, les dernières avancées de la technologie Orbitrap et les worflows associés permettent l'analyse à large échelle au travers d'un grand nombre d'échantillons . Lors de ce séminaire nous partagerons les nouvelles technologies et approches qui permettent d'atteindre sensibilité, précision, débit d'analyse, robustesse et reproductibilité nécessaires pour des résultats qui comptent.

\section{Présentation 2 : Chromatographie Ionique couplée à la spectrométrie de masse: un outil puissant pour l'analyse du métabolisme}

\author{
Floriant Bellvert $\$ \S$
}

Plateforme MetaToul, LISBP - INSA de Toulouse, France

L'étude du métabolisme central et énergétique requiert des séparations chromatographiques qui ne sont possibles qu'en chromatographie ionique, en particulier la séparation des hexoses phosphates. Couplé à un spectrométre de masse haute résolution Orbitrap, il est possible d'accéder à la fois à la quantification absolue des metabolites et à l'analyse des isotopologues obtenus aprés marquage, deux éléments essentiels dans les analyses métaboliques des flux.

\section{Programme}

\footnotetext{
${ }^{*}$ Intervenant

$\dagger$ Auteur correspondant: claire.dauly@thermofisher.com

${ }^{\ddagger}$ Intervenant

$\S$ Auteur correspondant: floriant.bellvert@insa-toulouse.fr
} 


\title{
Optimisez le cœur de votre laboratoire grâce à un générateur de gaz Peak Scientific [W2]
}

\author{
Sylvie Dos Reis ${ }^{* \dagger}$ \\ Peak Scientific France, Parc Gutenberg Bât 2B, 2 bis voie la Cardon, 91120 Palaiseau, France
}

Que se passe-t-il à ce moment précis où vous n'avez plus de gaz dans votre laboratoire ?

Le gaz devrait être la dernière chose dont vous vous souciez lorsqu'il alimente vos équipements analytiques. Avec un générateur de gaz Peak Scientific dans votre laboratoire, vous pouvez être tranquille.

L'alimentation en gaz constitue le cœur de votre laboratoire, permettant à vos instruments d'analyse d'effectuer et d'atteindre les résultats dont vous avez besoin. Nos générateurs, de par leurs différents types de technologies, offrent une alternative plus stable, plus pratique et plus sécuritaire à la bouteille de gaz. Ils travaillent à la demande et peuvent être activés ou désactivés en fonction de vos besoins.

Après plus de 20 ans d'expérience dans le secteur du gaz, une marque unique et un service aprèsvente inégalé, vous pouvez compter sur Peak pour une solution pratique et sans contrainte pour votre laboratoire.

\section{$\underline{\text { Programme }}$}

\footnotetext{
*Intervenant

†Auteur correspondant: sdosreis@ @eakscientific.com
} 


\title{
Agilent 6545XT AdvanceBio LC/Q-TOF: Designed for BioPharma Workflows [W3]
}

\author{
Jérémy Jeudy, $\mathrm{PhD}$ *† \\ LC/MS Field Applications Specialist, Agilent Technologies Parc Technopolis - ZA Courtaboeuf, 3 avenue du \\ Canada, CS 90263, 91978 Les Ulis Cedex
}

Les applications BioPharma imposent de nouveaux challenges analytiques, et des verrous technologiques qu'il est nécessaire de lever. Devant des échantillons toujours plus complexes et des limites de quantifications toujours plus basses, découvrez comment le nouvel Agilent 6545XT LC/Q-TOF s'inscrit dans les solutions BioPharma. Au-delà des innovations techniques qui seront présentées, différentes applications axées sur l'analyse des macromolécules viendront illustrer ses performances.

$\underline{\text { Programme }}$

*Intervenant

†Auteur correspondant: jeremy.jeudy@agilent.com 


\title{
Workshop Bruker [W4]
}

\section{TimsTOF $^{\mathrm{TM}}$ et technologie $\mathrm{PASEF}^{\mathrm{TM}}$, nouveaux horizons en analyse protéomique}

\author{
Pierre-Olivier Schmit $* \dagger$
}

Proteomics market area manager - Bruker Daltonics

L'échelle de temps nécessaire à la mesure d'une masse avec un analyseur à temps de vol rend cette technologie compatible avec une séparation additionnelle par mobilité ionique via la technologie $\operatorname{Tim}^{\mathrm{TM}}$ Trapped Ion Mobility, introduites par Bruker en 2016. Aboutissement de 8 années de recherches et de collaboration dans le domaine du couplage LC-TIMS -MS/MS, le TimsTOF ${ }^{\mathrm{TM}}$ et la stratégie PASEF ${ }^{\mathrm{TM}}$ (Parallel Accumulation Serial Fragmentation - PASEF, Meier et al., JPR 2015, PMID: 26538118) permettent d'offrir un potentiel inégalé pour la recherche protéomique, avec des acquisitions dépendantes des données de spectres MS/MS cinq à dix fois plus rapides. Nous illustrerons le potentiel de cette technologie avec les premiers résultats obtenus à partir de mélanges complexes de protéines digérées.

\section{Clinical metabolomics by NMR}

\author{
Martial Piotto $\stackrel{\ddagger}{\sharp}$ \\ Application specialist, Bruker Biospin France
}

NMR is a powerful technique to analyze the metabolic profile of bio-fluids like urine, serum and plasma. Analyzing such samples in a reliable manner requires the standardization of the NMR platform as well as the introduction of well-defined protocols for sample preparation, data acquisition and data analysis. The AVANCE IVDr platform is a $600 \mathrm{MHz}$-based NMR system that can achieve such a high degree of standardization and automation.

In this presentation, we will describe two methods that have been implemented on the IVDr platform and that can be used in full automation:

1) Metabolites quantification in human urine specimens. This method, based on the analysis of 1D NMR spectra (and optionally 2D J-Resolved spectra) can detect and quantify up to 150 metabolites automatically.

2) Lipoprotein subclass analysis in human serum/plasma specimens.

This method is based on the analysis of 1D NMR spectra of serum/plasma specimens and can provide the

\footnotetext{
${ }^{*}$ Intervenant

${ }^{\dagger}$ Auteur correspondant: pierre-olivier.schmit@bruker.fr

†ntervenant

$\S$ Auteur correspondant: martial.piotto@bruker.fr
} 
lipids concentration (cholesterol, free cholesterol, phospholipids, and triglycerides) and the apolipoproteins concentration (Apo-A1, Apo-A2 and Apo-B) in the following lipoprotein classes and subclasses:

- Plasma and Serum

- VLDL, IDL, LDL and HDL

- VLDL subclasses (VLDL-1 to VLDL-6)

- LDL sub-classes (LDL-1 to LDL-6)

- HDL-subclasses (HDL-1 to HDL-4) 


\title{
Workshop Waters [W5]
}

\section{Caractérisation des biomolécules avec la plateforme Vion IMS QTof et UNIFI}

\author{
Christophe Siroit $* \dagger$ \\ MS Specialist, Waters, BP 608, 78056 St Quentin en Yvelines, France
}

La spectrométrie de masse haute résolution seule n'est pas toujours suffisante pour répondre aux défis de la caractérisation des biomolécules les plus complexes. En incorporant une cellule de mobilité dans un spectromètre de masse, il est non seulement possible d'isoler les spectres des molécules d'intérêt des interférences de la matrice mais aussi d'observer les changements potentiels dans la conformation des protéines induites par une modification ou un lien avec un ligand. En plus de cette extra-sélectivité, la mobilité ionique permet de traiter les valeurs de CCS (Collision Cross Section) de chaque ion comme critère physico-chimique additionnel. La mesure simultanée en routine des CCS en plus des masses précises des protéines intactes, réduites et digérées permet d'obtenir des données plus fiables, indépendantes de la matrice et de l'instrument réduisant ainsi le risque d'erreur d'identification. Au travers d'exemples applicatifs, découvrez les stratégies de caractérisation de vos protéines, de leur structure 3D jusqu'à l'échelle des peptides et glycanes, grâce à la géométrie innovante du spectromètre Vion IMS QTof combinée à la plateforme informatique UNIFI.

\section{Du profilage non ciblé à la quantification hautement sensible}

$$
\text { Freddy Drouyé } \$ \S
$$

MS Specialist, Waters, BP 608, 78056 St Quentin en Yvelines, France

Panorama des solutions de Waters pour le screening et la quantification mettant en œuvre le spectromètre de masse Xevo G2-XS QTof et le nouveau tandem quadripôle Xevo TQ-XS. Alternatives innovantes aux techniques d'ionisation conventionnelles, les nouvelles sources UniSpray et APGC montrent des gains en efficacité d'ionisation qui permettent d'étendre la couverture des composés détectables en couplage LC et GC.

\section{Programme}

\footnotetext{
${ }^{*}$ Intervenant

†Auteur correspondant: christophe_siroit@waters.com

†Intervenant

§Auteur correspondant: freddy_drouye@waters.com
} 


\title{
The benefits of targeted, standardized procedures in metabolomics [W6]
}

\author{
Carmen Ludwig-Papst, $\mathrm{PhD}$ \\ Biocrates Life Sciences AG 220414 p. Eduard-Bodem-Gasse 86020 Innsbruck Austria
}

Application of Metabolomics in Biomedical has experienced exponential growth in recent years. The technology has proven to be a powerful tool to provide unique and relevant information. - on its own and in combination with other "Omic" approaches, for example NGS. Standardized, quantitative assays have increasingly been desired in metabolomics to enable large-scale, multi-center and longitudinal studies and required for clinical applications.

As metabolites are very diverse with regard to their properties (e.g. concentration, polarity) no single analytical technology can cover the whole metabolome. Therefore it is of high importance to carefully plan a metabolomics project.

Targeted Metabolomics enables hypothesis driven selection of metabolites that are known to be relevant in a given pathophysiological process of interest. Biocrates has been a leader in Targeted Metabolomics for more than 15 years, providing a range of Metabolomics kits for Triple Quad MS instruments and analytical and statistical services. The kits are designed to provide highly accurate and reproducible results across instrument platforms, and have contributed to hundreds of scientific publications.

In collaboration with ThermoFisher Scientific ${ }^{\mathrm{TM}}$, Biocrates has developed the AbsoluteIDQ $\mathbb{R} 400$ HR Kit, bringing the benefits of standardized Metabolomics kits to High Resolution Mass Spectrometry.

The talk will address considerations for Metabolomics study design and analysis of Metabolomics data. It will also highlight the benefits of standardization in Targeted Metabolomics as well as Biocrates' solutions to major challenges in Metabolomics.

\section{Programme}

\footnotetext{
${ }^{*}$ Intervenant

${ }^{\dagger}$ Auteur correspondant: carmen.ludwig-papst@biocrates.com
} 


\title{
Workshop Shimadzu [W7]
}

\author{
Thierry Legoupil *† ${ }^{*}$, Raphaël Delépée ${ }^{2-4}$
}

\author{
${ }^{1}$ Responsable Développement Biotech \& Techniques MS, Shimadzu France - Le Luzard II, Bât. A. Bd Salvador \\ Allende. 77448 Marne La Vallée Cedex 2, France \\ 2 Normandie Univ, UNICAEN, ABTE, 14000 Caen, France \\ ${ }^{3}$ Centre de Lutte Contre le Cancer François Baclesse, UNICANCER, 14076 Caen, France \\ 4 PRISMM, SF ICORE, 14000 Caen, France
}

Ce workshop permet aujourd'hui à Shimadzu de présenter des solutions uniques et performantes dédiées aux secteurs de la protéomique, métabolomique ou lipidomique.

Les chercheurs ont besoins de nouveaux outils comme nos spectromètres de masse de dernières générations avec la technologie «Ultra-Fast MS», pour la confirmation et la quantification des molécules d'intérêts à faible concentration.

Nous introduirons à cette occasion nos dernières nouveautés comme le mode d'acquisition «MRM Spectrum», l'automate de préparation en ligne avec le module LCMS CLAM-2000, la SFE-SFC-MS/MS, l'imagerie Maldi...

Nous aurons également le plaisir d'avoir un retour d'expérience de nos technologies avec un utilisateur : le Pr Raphaël Delépée, autour de l'analyse de biomarqueurs génotoxiques chez l'homme.

$\underline{\text { Programme }}$

\footnotetext{
*Intervenant

${ }^{\dagger}$ Auteur correspondant: tl@ shimadzu.fr
} 


\section{Communications affichées}


Mardi 3 octobre [P1-P88] 


\section{Intégration des données et approches multi-omiques [P1-P5]}




\title{
Integrated proteomic and transcriptomic approaches towards the high-throughput discovery of new bioactive molecules in venoms [P1]
}

\author{
Julien Giribaldi *† 1 , Nicholas Casewell ${ }^{2}$, Loïc Quinton ${ }^{3}$, \\ Christine Enjalbal ${ }^{1}$, Sébastien Dutertre ${ }^{4}$ \\ ${ }^{1}$ Institut des Biomolécules Max Mousseron, UMR 5247, Université de Montpellier - CNRS : UMR5247, Ecole \\ Nationale Supérieure de Chimie de Montpellier : UMR5247 - Montpellier, France \\ ${ }^{2}$ Alistair Reid Venom Research Unit, Parasitology Department, Liverpool School of Tropical Medicine - \\ Liverpool, Royaume-Uni \\ ${ }^{3}$ Laboratory of Mass Spectrometry- MolSys, Department of Chemistry, University of Liege - Liège, Belgique \\ ${ }^{4}$ Institut des Biomolécules Max Mousseron, UMR 5247, Université de Montpellier - CNRS - CNRS : \\ UMR5247, Ecole Nationale Supérieure de Chimie de Montpellier : UMR5247 - Montpellier, France
}

Venomous animals produce potent venom made of diverse bioactive molecules comprising small peptides, which is used to rapidly neutralize preys or deter predators. This lead to the evolution of toxins that act with high selectivity and affinity towards key biological targets including ions channels, G-protein coupled receptors, transporters and enzymes. Given these attractive properties, some toxins are widely employed as pharmacological tools or even drug leads. However, the traditional activity-guided fractionation method is time-consuming and consequently not adapted for high throughput discovery of new compounds. In recent years, integrated approaches coupling mass spectrometry instruments, in particular those running soft ionization methods, with transcriptomics databases and high throughput pharmacological screening assays have emerged to accelerate the discovery of venom derivative drugs. Moreover, the advances in mass spectrometry and bioinformatic softwares now allow the identification of more and more sequences with greater accuracy and reliability in very short time, which is highly beneficial to the high-throughput discovery of new sequences of interest. Here we report the first whole venom analysis of the common European adder (Vipera aspis), including some proteomic study by LC-MS/MS analysis (Q-exactive and SYNAPT-G2) and fully validated transcriptomic sequences using PEAKS software. The many sequence variants of various toxin classes as well as the putative novel toxins identified provide new opportunities for the discovery of bioactives of interest.

Mots-Clés : Venom, peptides, proteomic, transcriptomic, PEAKS.

$\underline{\text { Programme }}$

\footnotetext{
*Intervenant

${ }^{\dagger}$ Auteur correspondant: julien.giribaldi@gmail.com
} 


\title{
Evaluation de méthodes statistiques pour l'intégration de données métabolomiques, cliniques et alimentaires [P2]
}

\author{
Marion Brandolini-Bunlon ${ }^{*}{ }^{1}$, Mélanie Petera ${ }^{1}$, Stéphanie Monnerie ${ }^{2}$, \\ Charlotte Joly ${ }^{1}$, José Morais ${ }^{3}$, Hélène Payette ${ }^{4,5}$, Pierrette Gaudreau ${ }^{6,7}$, \\ Blandine Comte ${ }^{2}$, Julien Boccard ${ }^{8}$, Estelle Pujos-Guillot ${ }^{1,2}$ \\ ${ }^{1}$ Université Clermont Auvergne, INRA, UNH, Plateforme d'Exploration du Métabolisme, MetaboHUB Clermont - INRA : UMR1019 - \\ F-63000 Clermont-Ferrand, France \\ ${ }^{2}$ Université Clermont Auvergne, INRA, UNH - INRA : UMR1019 - F-63000 Clermont-Ferrand, France \\ ${ }^{3}$ Division of Geriatric Medicine, McGill University - Montreal, Canada \\ ${ }^{4}$ Centre de recherche sur le vieillissement, Centre intégré universitaire de santé et de services sociaux de Sherbrooke - Sherbrooke, Canada \\ ${ }^{5}$ Faculté de médecine et des sciences de la santé, Université de Sherbrooke - Sherbrooke, Canada \\ ${ }^{6}$ Département de médecine, Université de Montréal - Montréal, Canada \\ ${ }^{7}$ Centre de Recherche du Centre hospitalier de l'Université de Montréal - Montréal, Canada \\ ${ }^{8}$ School of Pharmaceutical Sciences, University of Lausanne, University of Geneva - Geneva, Suisse
}

Du fait de la prévalence croissante des maladies métaboliques chroniques, la compréhension de leurs mécanismes et du rôle de la nutrition dans leur développement et leur prévention est aujourd'hui un enjeu majeur. Leur complexité (maladies de systèmes) requiert une approche populationnelle, intégrée et multifactorielle. L'objectif de ce travail est de proposer une stratégie d'intégration de données afin de construire des modèles multidimensionnels, descriptifs ou discriminants de pathologies pour la découverte de biomarqueurs, et de contribuer à une meilleure compréhension des processus physiopathologiques impliqués.

Pour cela, cette étude s'est basée sur des données et échantillons biologiques de sujets de la cohorte NuAge du Réseau Québécois de Recherche sur le vieillissement : 123 hommes (68-82 ans) ont été sélectionnés pour une étude cas/témoins (61/62 sujets) du syndrome métabolique. Ils ont été suivis annuellement avec des prélèvements biologiques, la mesure de paramètres cliniques et le recueil de données par questionnaires. Des analyses métabolomiques ont été réalisées par spectrométrie de masse sur des échantillons de sérum collectés en 2003-2005 (T1) et 3 ans plus tard (T4). Trois blocs de données ont ainsi été identifiés : métabolomiques (863 ions), cliniques (29 variables) et alimentaires (41 variables), par temps et par groupe de sujets. Ils ont été analysés avec le logiciel R, simultanément ou deux à deux, après normalisation UV ou Pareto, par des méthodes d'analyses multiblocs, à des fins descriptives (ACP multiblocs et Analyse Factorielle Multiple (AFM)) ou discriminantes (PLS multiblocs). Les résultats sont comparés sur la base de critères statistiques (pourcentage de variance expliquée, $\mathrm{Q}^{2}, \mathrm{R}^{2}$, matrice de confusion...) et de leur adéquation aux objectifs biologiques : discrimination cas/témoins, identification de marqueurs, découverte de sous-groupes, adéquation aux connaissances du domaine...

Ce travail a permis d'établir une stratégie d'intégration de données pour mettre en œuvre une approche multidimensionnelle d'étude des pathologies systémiques.

Mots-Clés : intégration de données, ACP multiblocs, PLS multiblocs, AFM, maladies métaboliques chroniques, nutrition, spectrométrie de masse, biomarqueurs

\footnotetext{
*Intervenant

${ }^{\dagger}$ Auteur correspondant: marion.brandolini-bunlon@inra.fr
} 


\title{
ProteoRE, a Galaxy-based infrastructure for interpreting and exploring mass spectrometry-based proteomics data [P3]
}

\author{
Lien Nguyen ${ }^{1}$, Maud Lacombe ${ }^{1}$, Sandra Derosier ${ }^{2}$, Florence Combes ${ }^{3}$, Lisa \\ Perus ${ }^{1}$, Olivier Rué ${ }^{2}$, Christophe Caron ${ }^{4}$, Virginie Brun, Valentin Loux ${ }^{2}$, \\ Yves Vandenbrouck ${ }^{* \dagger} 1$
${ }^{1}$ Exploring the Dynamics of Proteomes (EDyP), BGE/U1038, INSERM/CEA/Université Grenoble Alpes (BIG) - INSERM : U1038, CEA - Grenoble, Université Joseph Fourier, 17 rue des Martyrs, F-38054 Grenoble, France
2 Mathématiques et Informatique Appliquées du Génome à l'Environnement (MaIAGE) - INRA : UR1404 - Bâtiment 210-233 Domaine de Vilvert 78350 Jouy en Josas Cedex, France
${ }^{3}$ CEA Grenoble (BIG, Biologie à grande Echelle, EDyP) - INSERM U1038, Université Grenoble Alpes - 17 rue des Martyrs 38054 Grenoble Cedex 9, France
${ }^{4}$ Ingenum - INRA - Toulouse, France

Background: Concurrently with the increased simplicity associated with producing MS-based proteomics data, the bottleneck in many laboratories has shifted to reliable and reproducible interpretation of the data to extract meaningful knowledge. The ProteoRE (Proteomics Research Environment) project is a joint effort between the French proteomics infrastructure (ProFI) and the French bioinformatics Institute (IFB). Its primary aim is to centrally provide the proteomics community with an online research service enabling biologists/clinicians without programming expertise to explore their proteomics data through the Web in a reproducible manner. ProteoRE is built upon the Galaxy framework, a well-maintained software platform, providing simple interfaces to tools and online access to computational resources in a collaborative and transparent way.

Methods: Starting from proteome software output files (e.g. MaxQuant, Proline), various components have been designed driven by expertise and needs from our collaborators. These modules embedded into Galaxy components have been implemented either by reusing tools (from the Galaxy Tool Shed) or by wrapping Bioconductor packages and external code, and further beta-tested.

Results: We have set up two use cases scenarios derived from our own research projects: the first case consists in interpreting a large proteins identification list while the second entails selection of biomarkers candidates based on biochemical criteria. Current components include customary data manipulation (e.g. filtering, sorting, and ranking), annotation (e.g. information retrieval from public resources), downstream analysis (e.g. cross-comparison and enrichment analysis) and graphical representation. A first ProteoRE instance integrating these components and tools, is now deployed for ergonomics assessment before public release in early 2018.

Conclusions: While Galaxy-based tools offer services for primary proteomics data analyses (e.g. MS data conversion, protein database tools, search algorithms), tools focusing on downstream analysis are still lacking. The ProteoRE platform proposes to fill this gap with the hope of promoting proteomics data in the Life Science community.

Mots-Clés : Computational workflow, Proteomics data, Bioinformatics, Annotation, Galaxy.

\footnotetext{
*Intervenant

†Auteur correspondant: yves.vandenbrouck@cea.fr
} 


\title{
Omics meets metabolic engineering for the production of light olefins by recombinant microorganisms : a highway to renewable plastics, synthetic rubber and fuels [P4]
}

\author{
Samia Boudah $* \dagger 1$ \\ ${ }^{1}$ Global bioenergies - Strain Construction Unit - Global Bioenergies \\ 5 rue Henri Desbruères, 91000 , Evry, France
}

Light olefins (ethylene, propylene, linear butylene, isobutylene and butadiene) are the core of the petrochemical industry. However, these volatile compounds are not naturally produced by microorganisms and no bioprocess to convert renewable resources to these molecules has been industrialized so far. This limits the scope of industrial biology, and prevents the access to many of the chemistry's largest markets.

The purpose of Global Bioenergies is to develop innovative metabolic pathways for the production of light olefins from renewable resources, by direct fermentation. To achieve this, Global bioenergies has developed artificial metabolic pathways including all the necessary enzymatic reactions from feedstock to isobutene. In contrast with most former approaches, the metabolic route leading to isobutene includes non-naturally occurring reactions as key steps.

Nevertheless, designing efficient "cell factories" involves understanding the complex interactions that occur between heterologous and native pathways in the host organism. To elucidate this, integrated genomics, transcriptomics, proteomics, metabolomics analyzes and genome-scale models of Escherichia coli metabolism were conducted. Samples are collected at multiple fermentation time points to follow up ARN, proteins (analyzed by LC/MS/MS bottom up approach) and intracellular metabolites (using LC/HRMS fingerprinting). All together, these data enable to identify (i) relevant differences between strains by highlighting perturbed metabolic nodes i.e. rate limiting enzymes, metabolites imbalance/ toxicity and (ii) the role of candidate genes, pathways, and biochemical reactions in observed experimental phenomena. These approaches help to gain insights into strain characteristics i.e. glucose consumption, growth rate, product titer and strain stability ensuring a rationally construction of more efficient industrially mutant strain with increased bio-base isobutene yield. This facilitates the process scale up, from laboratory bioreactors ( 1 to 10 liters) to our several cubic meters pilot plants (located in France and in Germany).

Mots-Clés : Synthetic biology, metabolic engineering, LC/HRMS, metabolome, proteome

Programme

\footnotetext{
${ }^{*}$ Intervenant

†Auteur correspondant: samia.boudah@global-bioenergies.com
} 


\title{
Patchwork evolution of metabolic pathways in red and brown macroalgae [P5]
}

\author{
Gabriel Markov* ${ }^{*}$, Jean Girard, Camille Trottier, Cédric Leroux, Elodie \\ Lacroix , Ludovic Delage , Jonas Collen , Simon Dittami , Erwan Corre , \\ Catherine Boyen, Anne Siegel, Catherine Leblanc
}

${ }^{1}$ Station Biologique de Roscoff - UMR8227 (CNRS) - CNRS : UMR8227, Université Pierre et Marie Curie [UPMC] - Paris VI - Place Georges Teissier 29600 Roscoff, France

Genome-scale reconstruction of metabolic network is necessary to properly model biomass accumulation and to infer synthesis pathways for signalling molecules that can regulate growth. Using an integrative approach combining both genomic and metabolomic data in the model red alga Chondrus crispus, and adding new metabolic data for the model brown alga Ectocarpus siliculosus, we show that even quite conserved metabolic pathways undergo substantial turnover in terms of enzymes, catalytic activities for orthologous enzymes, and succession of steps necessary to form final metabolites. This is consistent with findings from other areas of evolutionary biology, indicating that a given phenotype can be conserved even if the underlying mechanisms are changing.

Mots-Clés : macroalgae, genome, scale metabolic network, pathway evolution, targeted metabolic profiling

Programme

${ }^{*}$ Intervenant 
Alimentation et santé [P6-P17] 


\title{
Transgénèse et leurs effets sur la santé humaine [P6]
}

\author{
Yamina Bouatrous $* 1$ \\ ${ }^{1}$ Université Biskra Algérie - Université Mohamed Khider, Biskra, Algérie
}

La transgénèse est le transfère d'un gène ou plus d'un organisme à l'autre de nature différente pour obtenir les OGM.

Les OGM sont impliqués dans l'agriculture pour l'amélioration des espèces végétales vis-à-vis des contraintes biotiques et abiotiques. L'utilisation des OGM soulèvent certaines inquiétudes quant aux risques potentiels qu'ils peuvent présenter pour la santé : on parle de réaction allergique lorsque le système immunitaire réagit de façon inappropriée ou exagérée à l'absorption de substances dites " allergènes". Certains allergènes peuvent être nocifs pour les humains. Les allergies peuvent se manifester sous forme d'asthme ou par une chute importante de la pression artérielle dans les cas sévères.

Les toxines et les allergènes sont des substances naturellement produites par les végétaux et certains animaux. Les toxines, pour leur part, jouent un rôle dans les mécanismes naturels de défense de tous les organismes vivants. Or, un aliment avec OGM pourrait contenir une plus grande quantité de toxines ou d'allergènes par suite des réactions possibles de la plante à l'insertion d'un ou de plusieurs gènes introduits dans son génome, y compris pour ce qui est de la production de la ou des protéines.

Mots-Clés : : OGM, transgénèse, santé, toxine

Programme

*Intervenant 


\title{
Application d'une stratégie non ciblée par LC-HRMS pour l'identification d'interférences aux fluoroquinolones dans le miel révélées lors du dépistage immunochimique [P7]
}

\author{
Sophie Mompelat *† ${ }^{1}$, Céline Hédou, Valérie Gaudin , Dominique \\ Hurtaud-Pessel \\ ${ }^{1}$ Laboratoire de Fougères, Laboratoire National et Européen de Référence pour les Résidus de Médicaments \\ Vétérinaires dans les Denrées Alimentaires d'Origine Animale (ANSES) - Anses - 10B rue Claude Bourgelat, \\ 35306 Fougeres France
}

Les quinolones (Qs) et fluoroquinolones (FQs) d'origine synthétique forment une classe d'antibiotiques dédiée à des usages vétérinaires et humains. Dans le miel, ces antimicrobiens sont considérées comme des substances interdites car il n'existe aucune limite maximale réglementaire, ni recommandation émise dans le rapport SANCO/2006/3228. Afin de garantir les qualités sanitaires des productions de miel, des Plans de Surveillance et de Contrôle (PSPC) sont donc mis en œuvre annuellement pour contrôler l'absence de contamination d'antibiotiques.

En France, la stratégie analytique de contrôle des antibiotiques dans le miel repose sur un dépistage immunochimique suivi d'une analyse de confirmation par spectrométrie de masse sur les échantillons suspects. Au laboratoire, lors du PSPC de 2013, le test immunochimique de dépistage (AM II kit

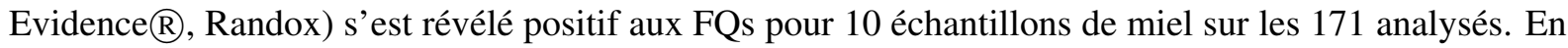
revanche, la présence de FQs dans ces échantillons n'a pas été confirmée lors des analyses LC-MS/MS subséquentes.

L'objectif de cette étude est donc de rechercher voire si possible d'identifier la(les) molécules(s) qui génère(nt) des faux positifs lors du dépistage des FQs dans le miel par la méthode immunochimique. L'étude a consisté en la comparaison d'un groupe d'échantillons de miel faux positifs aux FQs avec un groupe d'échantillons de miel témoin de même origine florale. La procédure d'extraction des échantillons a été développée afin de pouvoir extraire la(les) molécule(s) inconnues et d'obtenir un extrait analysable par Chromatographie Liquide couplée à la Spectrométrie de Masse Hautement Résolutive (LC-HRMS) et par analyse immunochimique. Le traitement statistique uni- et multivariée des empreintes acquises par LC-HRMS en mode full-scan a permis de démontrer la présence de signaux discriminants. Une identification des composés à l'origine de réponses croisées en immunochimie permettrait de contribuer à une meilleure maîtrise des techniques de dépistage pour le contrôle des résidus dans le miel.

Mots-Clés : Médicaments vétérinaires, Controle sanitaire, Recherche non ciblée, spectrométrie de masse haute résolution

\footnotetext{
*Intervenant

†Auteur correspondant: sophie.mompelat@anses.fr
} 


\title{
Towards a foodomics approach of food chemical safety assessment [P8]
}

\author{
Grégoire Delaporte ${ }^{*}$, Mathieu Cladière ${ }^{1}$, Delphine Jouan-Rimbaud \\ Bouveresse ${ }^{1}$, Valérie Camel_- \\ ${ }^{1}$ UMR Ingénierie Procédés Aliments (GENIAL) - INRA : UMR1145, AgroParisTech, Université Paris-Saclay - \\ 1 avenue des Olympiades, F-91744 Massy, France
}

\begin{abstract}
Chronic exposure to small doses of chemicals is an important today's public health issue, food being known to be an important contributor to the presence of exogenous hazardous substances in body burden. Monitoring food chemical contamination currently relies on selective targeted approaches. The need for more global untargeted approaches ("foodomics" approaches) has recently emerged, but their development raises many analytical challenges, namely trace concentrations (down to $\mu \mathrm{g} / \mathrm{kg}$ ) structural diversity of contaminants, and above all, the need for data treatment tools to work "blindly" (without any structural information on potential contaminants).

In this context, we have developed a foodomics approach dedicated to food chemical contamination assessment. Our methodology combines pillars from analytical chemistry, metabolomics and chemometrics: (i) broad-range analytical method based on UHPLC-HRMS and minimal sample treatment; (ii) feature detection based on XCMS (iii) blind discrimination of sample groups by Independent Component Analysis; (iv) powerful data mining strategies for annotation and suspect variables highlighting.

Tea has been chosen as a development food matrix since it is the most consumed beverage over the world, offering a high diversity and complexity as well. In addition, tea is regularly the subject of alerts on food safety networks, mainly due to chemical contamination issues. Samples were spiked with a mix of contaminants (pesticides, mycotoxins, process-induced toxicants and packaging contaminants) in the range 10 to $100 \mu \mathrm{g} / \mathrm{kg}$. Blind discrimination between control and spiked sample groups was achieved at levels as low as $10 \mu \mathrm{g} / \mathrm{kg}$. Annotation step appears to be the main challenge, but in-house data mining tools make it possible to reduce data complexity and also provide the user a quick feedback about potential identity of unexpected compounds. Our foodomics approach has been first developed on green tea, being further applied to other types of tea (respectively black tea and smoked green tea) for its validation.
\end{abstract}

Mots-Clés : Chemical contaminants, Tea, Untargeted approach, UHPLC, HRMS, Chemometrics, Independent Components Analysis

$\underline{\text { Programme }}$

\footnotetext{
*Intervenant

†Auteur correspondant: valerie.camel@agroparistech.fr
} 


\title{
Peptidomic approach to evaluate meat digestion in elderly conditions using combined in vitro mastication and gastric digestion [P9]
}

\author{
Thierry Sayd ${ }^{* \dagger}{ }^{1}$, Christophe Chambon ${ }^{*}{ }^{1}$, Marie-Agnès Peyron ${ }^{2}$, Jeremy \\ Pinguet ${ }^{* 3}$, Damien Richard $*^{3}$, Veronique Santé-Lhoutellier ${ }^{4}$ \\ ${ }^{1}$ INRA : UR370 - INRA, UR370 Qualité des Produits Animaux, F-63122 Saint Genès Champanelle, France \\ 2 INRA : UMR1019 - Unité de Nutrition Humaine, CRNH Auvergne, F-63000 Clermont-Ferrand, France \\ ${ }^{3} \mathrm{CHU}$ - centre hospitalier universitaire [clermont ferrand] - CHU Clermont-Ferrand, Service de Pharmacologie \\ Médicale, F-63003 Clermont-Ferrand, France \\ ${ }^{4}$ INRA : UR370 - UR370 Qualité des Produits Animaux, F-63122 Saint Genès Champanelle, France
}

As regards demography, more than $20 \%$ of the population will be over 65 by 2030 in developed countries. With age, muscle mass decreases, and one of the nutritional strategies to limit its size is to consume protein that is rapidly digested and of high nutritional value. Meat is precisely the food that fulfills these two conditions. Meat is known to be a source of protein of good nutritional quality in terms of composition in essential amino acids and digestibility. In elderly, masticatory function often presents failure in oral tasks due to impairment such as decline in muscular force, malocclusion or saliva production. Moreover, in elderly physiological digestive conditions are changed with reduced gastric acidification and digestive enzymes secretion.

Therefore, it was important to combine mastication and digestion to evaluate the fate of food in various physiological conditions representing adult and elderly.

The main objective of this work was to identify and quantify the peptides generated in the gastric phase after in vitro mastication mimicking food oral processing defiency. The meat model was frankfurter. Two in vitro masticatory conditions were tested using the mastication simulator AM2: normal / deficient. Two in vitro gastric physiological conditions of digestion were applied using DIDGIC : adult / elderly. Three repetitions of each coupling mastication/digestion were done. Five sampling were realized in gastric phase to analyze the kinetic peptide production. Identification and quantification of peptides generated by gastric digestion of meat model were performed using LC/MS analyses (Q Exactive plus) and Progenesis QI. A total of 632 unique peptides from 80 proteins were identified. The different kinetics of meat protein digestion were studied and discussed across the different masticatory and physiological digestion.

This combined approach was used for the first time to assess the consequences of masticatory deficiency associated with aging for meat proteins digestibility.

Mots-Clés : peptidomic, label free, meat, digestion, gastric

Programme

\footnotetext{
*Intervenant

${ }^{\dagger}$ Auteur correspondant: thierry.sayd@inra.fr
} 


\title{
Organoleptic properties of dark chocolates investigated by direct-injection mass spectrometry (PTR-ToF-MS) and GC-MS-Olfactometry [P10]
}

\author{
Jean-Luc Le Quéré ${ }^{*}{ }^{1}$, Zoé Deuscher ${ }^{1}$, Isabelle Andriot ${ }^{1}$, Karine Gourrat ${ }^{1}$, \\ Elisabeth Guichard ${ }^{-}$, Marie Repoux ${ }^{2}$, Sébastien Preys ${ }^{3}$, Renaud Boulanger ${ }^{4}$, \\ Hélène Labouré ${ }^{1}$, Etienne Sémon ${ }^{1}$ \\ ${ }^{1}$ Centrte des Sciences du Goût et de l'Alimentation (CSGA) - CNRS : UMR6265, INRA : UMR1324, Université \\ de Bourgone, Agrosup Dijon - Dijon, France \\ 2 Valrhona - F-26600 Tain-l'Hermitage, France \\ ${ }^{3}$ Ondalys - Ondays - 34830 Clapiers, France \\ ${ }^{4}$ CIRAD - 34000 Montpellier, France
}

\begin{abstract}
Organoleptic properties and particularly aroma of dark chocolate depend on cocoa origin, cocoa variety and fabrication process. A sensory analysis performed on 206 dark chocolates produced from cocoa beans of different varieties and origins but with the same fabrication process classified them into four sensory categories.

The objectives of this work were i) to assess whether the aromatic composition of the chocolates determine the sensory category they belong to and ii) to identify the key odorants that allow the dark chocolates discrimination.

For this, volatile organic compounds (VOCs) emitted from the samples were analyzed by dynamic headspace coupled to a direct-injection mass spectrometry method using a Proton Transfer Reaction - Time of Flight - Mass Spectrometer (PTR-ToF-MS). The average areas under the curves obtained for 314 significant ions present in the mass spectra during $2 \mathrm{mn}$ release time were used to perform supervised and unsupervised multivariate data analyses.

We showed this headspace PTR-MS analyses allowed retrieving the classification of the 206 samples into the four sensory categories previously determined.

In a second time, to determine the key aroma of each sensory category, a Gas Chromatography-Olfactometry (GC-O) study of extracts representative of each subset of chocolates was undertaken. Twelve samples (3 samples per sensory category) among the 206 were selected. The chocolates extracts were submitted to GC-O using the detection frequency method. The odour events identified by a panel of 12 assessors were grouped into olfactive areas (OAs).

On average $50 \mathrm{OAs}$ were found in the extracts and the most frequent associated olfactory descriptors were floral, fruity, butter, sugary, cotton candy and peanuts. A correspondence analysis (CA) conducted on the complete set of GC-O data allowed to distinguish samples and the sensory categories. The OAs were further identified using GC-MS, with a particular emphasis on those allowing samples discrimination.
\end{abstract}

Mots-Clés : chocolate, PTR, MS, direct, injection mass spectrometry, GC, MS, GC, Olfactometry, classification

$\underline{\text { Programme }}$

\footnotetext{
${ }^{*}$ Intervenant
} 


\title{
Consequences of sunlight-induced aging on a personal care emulsion containing $\alpha$-tocopherol as antioxidant [P11]
}

\author{
Ségolène De Vaugelade * ${ }^{1}$, Edith Nicol ${ }^{1}$, Sophie Bourcier ${ }^{1}$, Svetlana \\ Vujovic ${ }^{1}$, Stéphāne Pirnay ${ }^{2}$, Stéphane Bouchonnet ${ }_{-}^{\dagger 1}$ \\ ${ }^{1}$ Laboratoire de chimie moléculaire (LCM) - Polytechnique - X, Université Paris-Saclay, CNRS : UMR9168 - \\ Ecole polytechnique 91128 Palaiseau Cedex, France \\ 2 - EXPERTOX - 14 rue Godefroy Cavaignac, 75011 Paris, France
}

Vitamine $\mathrm{E}$ is a well-known mixture of eight forms, including four tocotreiols and four tocopherols with high antioxydative proprieties. On a biological point of view, the most active component is $\alpha$ tocopherol, which can be found in significant amount in cereals, vegetables, seeds, fruits and of course, in their respective oils. Because of its antioxidant activity, $\alpha$-tocopherol is widely used as an additive in foods, cosmetics, and pharmaceuticals products.

The structural elucidation of by-products arising from UV-visible photodegradation of $\alpha$-tocopherol has been investigated by gas chromatography coupled with mass spectrometry and by liquid-chromatography coupled with ultrahigh resolution tandem mass spectrometry. Their potential toxicities were estimated using in silico calculations based on a QSAR (Quantitative Structure-Activity Relationship) approach and by in vitro bioassays conducted on Vibrio fischeri bacteria.

Photolysis experiments were performed with a Q-sun test chamber equipped with a xenon arc lamp and a natural light filter. Both model systems (solutions of $\alpha$-tocopherol and $\alpha$-tocopherol-d9 in acetonitrile) and a cosmetic emulsion were irradiated up to $180 \mathrm{~min}$.

Twenty-five photoproducts were detected, corresponding to nine isomer families. Six of them, corresponding to the major ones, were separated and identified using LC-HR-MS/MS while the three minor ones were characterized by GC-MS. Their chemical structures were elucidated on the basis of mass spectra interpretation and isotopic labeling, which also permitted to suggest photo-induced degradation pathways. Most photoproducts are different from those reported in previous studies devoted to degradation of tocopherol.

Finally, two photoproduct families were detected, after irradiance, in the cosmetic emulsion spiked with $3000 \mu \mathrm{g} / \mathrm{mL}$ of $\alpha$-tocopherol.

In silico toxicity predictions showed that all photoproducts are potentially more toxic than the parent compound with lower oral rat LD50 values. In vitro assays on Vibrio fischeri bacteria showed that the ecotoxicity of the solution significantly increases with irradiation time.

Mots-Clés : Alpha tocopherol, Antioxidant, Photodegradation, In vitro tests, In silico tests

\section{Programme}

\footnotetext{
*Intervenant

†Auteur correspondant: stephane.bouchonnet@polytechnique.edu
} 


\title{
Identification of food intake biomarkers using metabolomics in the Metabo-Breast cancer project [P12]
}

\author{
Céline Dalle ${ }^{*} 1$, Lucie Lecuyer ${ }^{2}$, Mélanie Petera ${ }^{3}$, Delphine Centeno ${ }^{3}$, \\ Bernard Lyan ${ }^{3}$, Stéphanie Durand ${ }^{3}$, Estelle Pujos-Guillot ${ }^{3}$, Pierre Micheau ${ }^{1}$, \\ Christine Morand ${ }^{1}$, Pilar Galan ${ }^{2}$, Serge Hercberg ${ }^{2,4}$, Valentin Partula ${ }^{2}$, \\ Mélanie Deschasaux ${ }^{2}$, Bernard Srour ${ }^{2}$, Paule Latino-Martel ${ }^{2}$, Emmanuelle \\ Kesse-Guyot ${ }^{2}$, Mathilde Touvier ${ }^{2}$, Claudine Manach ${ }^{1}$

\begin{abstract}
${ }^{1}$ Unité de Nutrition Humaine - Clermont Auvergne (UNH) - Université Clermont Auvergne : UMR1019, INRA [Auvergne/Rhône-Alpe] : UMR1019 - Centre de Recherches INRA de Clermont-Fd/Theix / 63122 St Genès Champanelle, France

${ }^{2}$ Equipe de recherche en Epidémiologie Nutritionnelle (EREN) - Centre de Recherche INSERM : U1153, INRA : UR1125, Université

Paris-Nord - Paris XIII, Université Paris Diderot - Paris 7, Université Paris Descartes - Paris 5, Université Sorbonne Paris Cité (USPC), Conservatoire National des Arts et Métiers (CNAM) - 74, rue Marcel Cachin 93017 Bobigny Cedex, France

${ }^{3}$ Université Clermont Auvergne, INRA, UNH, PFEM, MetaboHUB Clermont - INRA : UMR1019 - F-63000 Clermont-Ferrand, France
\end{abstract} \\ ${ }^{4}$ Département de Santé Publique - Hôpital Avicenne - Bobigny, France
}

The work presented is part of the Metabo-Breast cancer project (2015-2017, INCa, P.I. M. Touvier), which aims at: discovering predictive biomarkers of breast cancer and biomarkers of the quality of the usual diet and of specific foods using metabolomics, then relating these biomarkers to enhance our understanding of the role of nutrition on breast cancer. Here we focus on the objective of discovering biomarkers of food intake by the exploration of the food metabolome in serum samples from the SU.VI.MAX cohort.

SU.VI.MAX female subjects who filled at least ten $24 \mathrm{~h}$ dietary records were stratified in deciles according to their level of adherence to the guidelines of the French Programme National Nutrition Santé. 80 women was randomly selected in the 10th decile of the PNNS-GS distribution and 80 women matched for age, BMI and others factors were selected in the 1st decile.

Plasma samples collected at baseline in the SU.VI.MAX study were analyzed using UPLC-ESI-QToF. Metabolic profiles were acquired in positive and negative modes (scan range 50-1,000m/z). Data were pre-processed using Galaxy (Workflow4Metabolomics). 1575 and 601 ions were detected (positive and negative mode). Metabolomics profiles were compared using univariate and multivariate statistical methods to select the ions associated with the consumption of 58 foods/food groups.

84 and 30 ions (positive and negative mode) were found correlated with specific foods/food groups $(\mathrm{r}>0.3$, p-value with $\mathrm{BH}<0.1)$. A few of them were known as biomarkers like proline-betaine for orange intake discovered in previous metabolomics studies. This demonstrates the relevance of our strategy. The identification of the other candidate biomarkers is ongoing (online database, literature and LC-MS/MS on LTQ-OrbiTrap).

This work will contribute to provide new biomarkers of food intake that are needed to improve the quality of dietary assessment in epidemiological studies.

Project grant: INCa_8085, PhD grant: INCa_11323 for L. Lecuyer

Mots-Clés : Metabolomics, UPLC QToF, Epidemiology, Food intake biomarkers

\footnotetext{
${ }^{*}$ Intervenant
} 


\title{
One-Dimensional and Two-Dimensional LC-MS Applied to the Characterization of Monoclonal Antibodies and Antibody-Drug Conjugates [P13]
}

\author{
Vandenheede Isabel ${ }^{1}$, Mieke Steenbeke ${ }^{1}$, Emmie Dumont ${ }^{1}$, Alexia Ortiz ${ }^{* \dagger}{ }^{1}$, \\ Gerd Vanhoenacker ${ }^{1}$, Pat Sandra, Koen Sandra ${ }_{-}{ }^{1}$ \\ ${ }^{1}$ Research Institute for Chromatography (RIC) - Kennedypark 26 B-8500 Kortrijk, Belgique
}

\begin{abstract}
Monoclonal antibodies (mAbs) have emerged as important therapeutics for the treatment of lifethreatening diseases like cancer and autoimmune diseases. The knowledge that the top-selling mAbs are, or will become, available to the market in the near future as "generics" has driven an explosion of interest in biosimilars. The successes of $\mathrm{mAbs}$ have furthermore triggered the development of various next generation formats. In oncology, antibody-drug conjugates (ADCs) are particularly promising, since they synergistically combine a specific mAb linked to a biologically active cytotoxic drug via a stable linker. The promise of ADCs is that highly toxic drugs can selectively be delivered to tumor cells thereby substantially lowering side effects as typically experienced with classical chemotherapy. Monoclonal antibodies have a complexity far exceeding that of small molecule drugs, hence, unraveling this complexity represents an analytical challenge. This challenge becomes even bigger in case ADCs are considered since the heterogeneity of the initial antibody is superimposed with the variability associated with the cytotoxic drug conjugation strategy. The current lecture will highlight the power of one and two-dimensional liquid chromatography in hyphenation to high resolution mass spectrometry for the characterization of mAbs, ADCs and biosimilars.
\end{abstract}

Mots-Clés : monoclonal antibodies, antibody, drug conjugates, biosimilars, characterization, LC MS, 1D/2D LC

Programme

\footnotetext{
*Intervenant

†Auteur correspondant: alexia.ortiz@ richrom.com

†Auteur correspondant: koen.sandra@ richrom.com
} 


\title{
Liquid chromatography coupled to high resolution mass spectrometry based metabolomics profiling of serum responses to dietary supplementation [P14]
}

\author{
Alexis Ripoche ${ }^{* \dagger}{ }^{1}$, Anna Gadaj ${ }^{1}$, Mark Mooney ${ }^{1}$ \\ ${ }^{1}$ Institute for Global Food Security (IGFS) - School of Biological Sciences, Queen's University Belfast, BT9 \\ 5 AG Belfast, Northern Ireland, Royaume-Uni
}

Previous studies have demonstrated that diets supplemented with saturated fatty acids (FA) can be beneficial to both humans and animals, and FAs are known to play important roles in the regulation of physiological and pathological functions such as intestinal mucosal defence and inflammation, energy metabolism and immune regulation, and generally contribute to improved overall health and performance. However, little is known about the molecular mechanisms involved in these effects and the aim of the present study was to determine if untargeted high resolution mass spectrometry-based metabolomics could be used as a tool to identify serum markers associated with responses to supplementation. An animal experiment was carried out on 24 sows during pregnancy and lactation, half of which were fed with a diet enriched in fatty acids, and the other half fed normal non-supplemented diet. Serum was collected from piglets at four weeks after birth during pre-weaning. Serum samples ( $n=12$ per group) were deproteinized by ice-cold methanol and analysed in a randomized order by LC-MS positive ionisation mode using an Acquity UPLC I Class System coupled to Xevo G2-S QTof. Chromatographic separation was performed employing an Acquity HSS T3 analytical column $(1.8 \mu \mathrm{m} 2.1 \times 100 \mathrm{~mm})$. Generated LC-ESI(+)-HRMS data was processed with Progenesis software, and data analysed employing multivariate analysis including Principal Component Analysis (PCA) and Orthogonal Partial Least Square - Discriminant Analysis (OPLS-DA) that were applied to build descriptive and predictive models. PCA score plot showed a good grouping of pool injections and the fitness of the OPLS-DA model was $\mathrm{R} 2 \mathrm{X}(\mathrm{cum})=0.832$, Q2 $(\mathrm{cum})=0.996$ and CV-ANOVA $(p$-value $=5.16 \times 10-30)$ confirming the robustness of the established model. Ongoing work is focused on the identification and biological interpretation of selected metabolite markers utilised within constructed models.

Mots-Clés : LC, HRMS metabolomics, serum, fatty acids

$\underline{\text { Programme }}$

\footnotetext{
*Intervenant

${ }^{\dagger}$ Auteur correspondant: a.ripoche@qub.ac.uk
} 


\title{
Capacité de l'huile d'olive à extraire les molécules bioactives de différentes espèces végétales alimentaires et non alimentaires : Cas particulier de l'absinthe (Artemisia absinthium) [P15]
}

\author{
Taous Allane $\underset{-}{*}$, Salem Benamara $\stackrel{*}{\dagger} 1$ \\ ${ }^{1}$ Laboratoire de Recherche en Technologie Alimentaire,Université M'Hamed Bougara, Boumerdès - Avenue de \\ l'Indépendance, Boumerdès, 35000, Algérie
}

Cette communication concerne l'étude de la capacité de l'huile d'olive (HO) à extraire les molécules bioactives des différentes parties constitutives (feuilles, tiges, pelure...) de 56 plantes alimentaires et non alimentaires. Pour cela, le pouvoir réducteur d'infusions végétales à base d'HO a été d'abord déterminé. Des 56 espèces analysées, les feuilles d'absinthe (Artemisia absinthium) présentent le PR le plus élevé (_ 70 mg BHT.g-1 de masse sèche (ms)) suivi de la pelure d'arbouse (Arbutus unedo) avec un RP d'environ 53 mg BHT.g-1 de masse fraiche (mf)). Pour rendre compte des molécules extraites par l'HO, un screening par spectrométrie de masse est en cours de réalisation sur l'infusion d'absinthe ainsi que, à des fins de comparaison, sur l'huile d'olive brute chauffée et non chauffée. Notons que les données complètes de cette étude mais sans l'analyse spectrométrique est soumise pour éventuelle publication à la revue "Indian Journal of Traditional Knowledge".

Mots-Clés : Huile d'olive, absinthe (Artemisia absinthium), pouvoir réducteur, spectrométrie de masse.

Programme

\footnotetext{
*Intervenant

†Auteur correspondant: sbenamara2001@yahoo.fr
} 


\title{
I knew you were trouble: Expanding LC methods to include difficult GC compounds using a Novel Ionization Technique [P16]
}

\author{
Freddy Drouyé ${ }^{* \dagger}+1$, Susan Leonard $\underset{-}{*}$, Eimear Mc Call $\stackrel{*}{\S}$ \\ ${ }^{1}$ Waters Corporation - Waters Corporation - Saint Quentin en Yvelines, France
}

Screening food samples for contaminants such as pesticides requires the use of GC-MS and LC-MS techniques. In order to cover a full suite of regulated compounds, several LC and GC methods are usually required that separately incorporate large suites of compounds, single residues and 'troublesome' compounds. We assessed the use of a novel LCMS ionization technique (UNISPRAY) that has potential to bridge the barrier between LC and GC amenable pesticides. This aids in a reduction of the number of methods required to monitor a suite of compounds and offers advantages with certain compound matrix pairs, such as captan in chlorophyll containing matrices. The evaluation was performed in various food commodities. Spiked extracts of food samples were assessed by ESI and UNISPRAY using a UPLC separation with a BEH C18 $1.7 \mu \mathrm{m}, 2.1 \times 100 \mathrm{~mm}$ column. The data was acquired using multi reaction monitoring methods on a tandem quadrupole mass spectrometer. The data was first acquired in ESI+ mode and then in UNISPRAY mode to show the utility of the new ionization technique and compared with relevant GC-MS/MS data. Multiple classes of compounds were targeted, including contaminants from agricultural processes such as pesticides. Initial results show that traditional GC amenable compounds can be added to LC acquisition methods, thus expanding the compound coverage of the method for food screening. Linearity, reproducibility and robustness were assessed to ensure the methods met local regulations.

Mots-Clés : contaminants, pesticides, GCMS, LCMS, ionization

$\underline{\text { Programme }}$

\footnotetext{
${ }^{*}$ Intervenant

†Auteur correspondant: freddy_drouye@waters.com

† Auteur correspondant: susan_leonard@waters.com

§ Auteur correspondant: Eimear_McCall@waters.com
} 


\title{
Exposition de la levure Saccharomyces cerevisiae à la sélénométhionine : caractérisation des acides aminés séléniés incorporés dans les protéines et agrégation des protéines [P17]
}

\author{
David Cornu $^{* \dagger}{ }^{1}$, Myriam Lazard ${ }^{2}$, Virginie Redeker ${ }^{3}$ \\ ${ }^{1}$ Institute for Integrative Biology of the Cell (I2BC) - CEA, CNRS, Univ. ParisSud, Université Paris-Saclay - \\ 91198, Gif-sur-Yvette, France \\ ${ }^{2}$ Laboratoire de Biochimie, Ecole Polytechnique - CNRS : UMR7654 - 91128 Palaiseau, France \\ ${ }^{3}$ Paris-Saclay Institute of Neuroscience (Neuro-PSI) - CNRS, Université Paris-Saclay \\ 91198, Gif-sur-Yvette, France
}

Les séléno-metabolites organiques comme la sélénométhionine (SeMet) et la sélénocystéine (SeCys), fréquemment utilisés dans les compléments alimentaires administrés à l'homme et aux animaux, présentent une toxicité à fortes doses. L'accumulation d'agrégats protéiques corrélée à cette toxicité a été observée chez Saccharomyces cerevisiae exposée à des teneurs élevées en SeMet. L'incorporation de SeMet n'étant pas connue pour être un facteur majeur de cytotoxicité, le mécanisme sous-jacent de cette cytotoxicité suggérait la possibilité d'une métabolisation de la SeMet en SeCys et une incorporation de SeCys à la place des Cys lors de la traduction, pouvant entrainer la formation d'adduits covalents avec des thiols ou sélénols, susceptibles alors d'induire des repliements protéiques erronés à l'origine des processus d'agrégation.

Pour vérifier ce mécanisme, à partir d'une protéine "reporter" nous avons identifié la nature des acides aminés séléniés effectivement incorporés et mis en place une méthode de quantification par spectrométrie de masse du taux de substitution moyen. La protéine EF1- $\alpha$ contenant un nombre significatif de Cys et de Met a été exprimée et purifiée à partir de Saccharomyces cerevisiae cultivée en présence de quantités élevées en SeMet, puis protéolysée et analysée par nanoLC-MS/MS. L'identification de peptides contenant des SeCys en place des résidus équivalents soufrés a confirmé le mécanisme d'incorporation aléatoire de SeCys issu de SeMet metabolisée. Les taux de remplacement des acides aminés soufrés ont été calculés en tenant compte des différentes modifications possibles (oxydations des Met et SeMet et conversion des SeCys en dehydroalanine) ainsi qu'en corrigeant les intensités des peptides (XIC) soufrés et séléniés par l'abondance naturelle respective des isotopes 32S et 80Se. Le taux de substitution moyen mesuré pour la SeMet (_ 17\%), proche du ratio extracellulaire de SeMet/Met (_ 20\%), a permis de valider la méthode de quantification utilisée dans ce travail.

Plateau, P. et al.. Sci. Rep.7, 44761; doi: 10.1038/srep44761 (2017).

Mots-Clés : sélénométhionine, sélénocystéine, quantification, agrégation des protéines

\footnotetext{
*Intervenant

${ }^{\dagger}$ Auteur correspondant: david.cornu@i2bc.paris-saclay.fr
} 
Méthodes préparatives et séparatives
[P18-P30] 


\title{
Evaluation of different Stage Tip fractionation strategies to increase proteome coverage at low cost [P18]
}

\author{
Marie Meziere ${ }^{*} 1$, Thibault Chaze $* \dagger 1$, Quentin Giai Gianetto ${ }^{1}$, Julia \\ $\bar{C}$ hamot-Rooke ${ }^{2,3}$, Mariette Matondo ${ }^{1}$ \\ 1 proteomics platform - Institut Pasteur de Paris - 28 rue du Docteur Roux 75015 Paris, France \\ ${ }^{2}$ MS bio - Institut Pasteur de Paris - 28 rue du Docteur Roux 75015 Paris, France \\ ${ }^{3}$ USR 2000 - CNRS : USR2000 - 28 rue du Docteur Roux 75015 Paris, France
}

In shotgun proteomics the depth of the analysis is a crucial parameter to properly address biological questions. While the race for the 'one hour proteome' using a single LC-MS/MS run is fascinating (1), not all proteomics labs are equipped with the latest generation of instrumentation to perform such analyses. To circumvent this limitation, we compare herein different simple Stage Tip fractionations, to increase proteome coverages at low cost both in protein consumption and equipment.

An E. coli digest was used to set-up the different fractionation strategies. Different types of home-made Stage Tips were tested $(2,3)$. We used different EmporeTM SPE discs (C18, SDB-XC, SDB-RPS, SCX) and different bead types (C18AQ, Dr Maish; PolyHATM, PolyLC). For all conditions, the total digest was eluted into 4 fractions that were further analysed using a C18 nanoLC column coupled to an Orbitrap LTQ Velos. Data were acquired using CID with a $2 \mathrm{~h}$ acquisition method. The total digest was analysed - over a $2 \mathrm{~h}$ or $4 \mathrm{~h}$ gradient using the same parameters. Data analysis was performed with MaxQuant, Perseus and R.

Each strategy was evaluated using the following three parameters: its complexity, efficiency, and instrument time. Preliminary results show that fractionation with SDB phases gives the best combination. A gain of $106 \%$ in peptide number and $70 \%$ in protein number was achieved using SDB-RPS Stage Tip in a mix-mode solvent/salt elution compared to the total digest.

We compared a wide variety of fractionation methods based on a Stage Tip strategy and using the LC/MS instrumentation, which is the most commonly found in proteomics labs (Source: ProteomeExchange). Our data showed that deep proteome coverage could be reached at low cost and easily implemented in many laboratories.

(1) Hebert AS. et al,. MCP 2014

(2) Rappsilber J. et al., Nat Protoc, 2007

(3) Ishihama Y., et al., JPR, 2006

Mots-Clés : Peptide Fractionation, Stage tipping, deep proteome coverage

$\underline{\text { Programme }}$

\footnotetext{
*Intervenant

†Auteur correspondant: thibault.chaze@ pasteur.fr
} 


\title{
Top-down and middle-down approach by fraction collection enrichment using Off-line capillary electrophoresis - mass spectrometry coupling: application to monoclonal antibody $\mathrm{Fc} / 2$ charge variants [P19]
}

\author{
Michael Biacchi ${ }^{1}$, Nassur Said ${ }^{1}$, Alain Beck ${ }^{2}$, Emmanuelle Leize-Wagner ${ }^{3}$, \\ Yannis Francois $* \dagger 1$ \\ ${ }^{1}$ Laboratoire de Spectrométrie de Masse des Interactions et des Systèmes (LSMIS) - UMR 7140 CNRS-UDS - 1 \\ rue Blaise Pascal 67000 Strasbourg, France \\ ${ }^{2}$ Centre d'Immunologie Pierre Fabre - CIPF - Saint-Julien-en-Genevois, France \\ ${ }^{3}$ Laboratoire de Spectrométrie de Masse des Interactions et des Systèmes (LSMIS) - UMR 7140 CNRS-UDS - 1 \\ rue Blaise Pascal, France
}

The characterization of complex protein mixtures represents one of the biggest challenge in many research fields such as biological or biopharmaceutical sciences. Out of all categories, monoclonal antibodies (mAbs) and related products drawn the most interest due to their strong therapeutic potency and specificity. Because of their intrinsic complexity due to a large number of micro-heterogeneities, there is a crucial need for analytical methods to provide comprehensive in-depth characterization of these proteins. In this work, we developed a methodology using CE-UV/MALDI-MS to perform top-down or middle-down characterization after fraction collection enrichment applied to intact protein and mAbs samples. The performance of the method was evaluated with the rapid separation of three intact protein mixture. Good robustness of CZE separation and quality of MALDI-MS spectra and MALDI-ISD spectra of each protein confirms the usefulness of sample enrichment to obtain adequate quantity of deposed protein for top-down analysis and the proof of principle of the method. In a second step, the method was applied to the middle-down characterization of $\mathrm{Fc} / 2$ cetuximab variants. Identification of around $9 \%$ sequence coverage of $\mathrm{Fc} / 2$ cetuximab fragments allows to conclude on the feasibility of the strategy for middle-down characterization of Fc/2 cetuximab variants using CE-UV/MALDI-MS. Moreover, MALDI-ISD fragmentation of Fc/2 cetuximab variants confirm separation phenomenon based on the formation of $\mathrm{Fc} / 2$ dimers with and without $\mathrm{C}$-terminal truncation.

Mots-Clés : Capillary Electrophoresis, Mass spectrometry, MALDI, ISD, Enrichment, Monoclonal antibody, Top, down, Middle, down

\section{Programme}

\footnotetext{
${ }^{*}$ Intervenant

†Auteur correspondant: yfrancois@unistra.fr
} 


\title{
A low-molecular-weight color pI markers to monitor on-line the peptide focusing process in OFFGEL fractionation [P20]
}

\author{
Sylvie Michelland* ${ }^{1}$, Sandrine Bourgoin-Voillard ${ }^{\dagger}{ }^{1}$, Valérie Cunin ${ }^{1}$, Axel \\ Tollance $^{1}$, Pascal Bertolino ${ }^{2}$, Karel Slais ${ }^{3}$, Michel Seve ${ }^{1}$
}

${ }^{1}$ LBFA et BEeSy, PROMETHEE Proteomic Platform, Grenoble, France - Université Grenoble Alpes, Centre de Recherche INSERM, CHU Grenoble - CHU Grenoble alpes, Institut de Biologie et de Pathologie, PROMETHEE Proteomic Platform, Boulevard de la Chantourne, 38700 La tronche, France

${ }^{2}$ GIPSA-lab, Grenoble, France - Université Grenoble Alpes, Université Grenoble Alpes - 11 rue des Mathématiques, Grenoble Campus BP46, F-38402 Saint Martin d'Hères cedex, France

${ }^{3}$ Institute of Analytical Chemistry of the Academy of Sciences of the Czech Republic - Institute of Analytical Chemistry IACH Academy of Sciences of the Czech Republic, 60200 Brno, Czech Republic

High-throughput mass spectrometry-based proteomic analysis requires peptide fractionation to simplify complex biological samples and increase proteome coverage. OFFGEL fractionation technology became a common method to separate peptides or proteins using isoelectric focusing in an immobilized $\mathrm{pH}$ gradient. However, the OFFGEL focusing process may be further optimized and controlled in terms of separation time and $\mathrm{pI}$ resolution. Here, we evaluated OFFGEL technology to separate peptides from different samples in the presence of low-molecular-weight (LMW) color pI markers to visualize the focusing process. LMW color $\mathrm{pI}$ markers covering a large $\mathrm{pH}$ range were added to the peptide mixture before OFFGEL fractionation using a 24-wells device encompassing the $\mathrm{pH}$ range 3-10. We also explored the impact of LMW color pI markers on peptide fractionation labeled previously for iTRAQ. Then, fractionated peptides were separated by RP_HPLC prior to MS analysis using MALDI-TOF/TOF mass spectrometry in MS and MS/MS modes. Here we report the performance of the peptide focusing process in the presence of LMW color pI markers as on-line trackers during the OFFGEL process and the possibility to use them as $\mathrm{pI}$ controls for peptide focusing. This method improves the workflow for peptide fractionation in a bottom-up proteomic approach with or without iTRAQ labeling.

Mots-Clés : iTRAQ labeling, low, molecular, weight color pI markers, Peptides OFFGEL fractionation

Programme

\footnotetext{
*Auteur correspondant: SMichelland@chu-grenoble.fr

${ }^{\dagger}$ Intervenant
} 


\title{
Comparaison de différentes sources d'ionisation sous vide en GC-MS haute résolution pour l'analyse de derivés de gaz de combat [P21]
}

\author{
Valentin Baillet $*_{-}^{1}$, Carlos Afonso ${ }_{-}^{\dagger 1}$, Corinne Loutelier-Bourhis ${ }_{-}^{\ddagger 2,3,4}$ \\ ${ }^{1}$ Normandie Univ, FR 3038; IRCOF, (COBRA) - Université de Rouen, CNRS : UMR6014, INSA Rouen - \\ Université de Rouen, CNRS : UMR6014 - 1 rue Tesnière, 76821 Mont St Aignan cedex, France \\ ${ }^{2}$ INSA de Rouen - INSA Rouen - avenue de l'Université, 76800 St Etienne du Rouvray, France \\ ${ }^{3}$ CNRS, Délégation Normandie - CNRS : FR3038 - 14 rue A. Kastler 14052 Caen, cedex, France \\ ${ }^{4}$ Université de Rouen, UMR CNRS 6014, COBRA, FR3038 - Université de Rouen, CNRS : UMR6014 - rue \\ Tesnière, 76821 Mont St Aignan cedex, France
}

La chromatographie en phase gazeuse couplée avec la spectrométrie de masse (GC/MS) reste actuellement une des techniques de référence pour l'analyse des produits chimiques liés à la Convention sur les armes chimiques (CAC) (1). L'ionisation électronique (EI) et l'ionisation chimique (CI) sont les deux techniques d'ionisation les plus utilisées. Cependant, ces méthodes présentent certaines contraintes ou limites : nombreuses fragmentations en EI rendant difficile la détection de l'ion moléculaire et discrimination en CI. Ces dernières années, de nouvelles méthodes d'ionisation dédiées au couplage GC-MS se sont développées sur des instruments commerciaux telles que l'ionisation par champ (FI) (2). Ce mode d'ionisation a pour avantage d'être universel et permet la détection des espèces ioniques intactes. De telles sources d'ionisation sont particulièrement pertinentes quand elles sont associées à un analyseur à haute ou très haute résolution. Ces instruments sont intrinsèquement plus sensibles et permettent donc la mise en évidence de composés à l'état de trace. Nous avons cherché à comparer trois différents modes d'ionisation : l'ionisation électronique (EI), l'ionisation chimique (CI) et l'ionisation par champs (FI) associées à la spectrométrie de masse à haute résolution (TOF) pour l'analyse de molécules liées à la défense telles que des impuretés de synthèse d'agents de guerre chimique, leurs composés de dégradation ainsi que des produits simulant leurs propriétés physiques et chimiques. La FI étant relativement récente, peu de travaux ont été reportés sur l'analyse d'agents de guerre chimiques par GC-FI-MS, contrairement aux études GC-EI-MS ou GC-CI-MS. Le présent travail reporte nos résultats obtenus pour trois concepts de sources : une source EI, une source combinée EI/CI et une source combinée EI/FI.

(1) Savel'eva, E. I. et al. Russian Journal of Applied Chemistry 2014, 87 (8), 1003-1012.

(2) Beckey, H. Symposium on Mass Spectroscopy, 2013; pp 1-24.

Mots-Clés : GC, MS, EI, CI, FI, Composés Organophosphorés

Programme

\footnotetext{
*Intervenant

†Auteur correspondant: carlos.afonso@univ-rouen.fr

† Auteur correspondant: $\overline{\text { corinne.loutelier@univ-rouen.fr }}$
} 


\title{
Apport de l'électrophorèse capillaire couplée à la spectrométrie de masse pour l'étude de la N-glycosylation [P22]
}

\author{
Coralie Ruel ${ }^{* \dagger}+1,2$, Marco Morani ${ }^{1}$, Laura Sola ${ }^{3}$, Marcella Chiari ${ }^{3}$, Myriam \\ Taverna ${ }^{1}$, Christophe Junot ${ }^{4}$, François Fenaille ${ }^{2}$, Thuy Tran ${ }^{1}$ \\ ${ }^{1}$ Institut Galien Paris-Sud (IGPS) - Université Paris-Sud - Paris 11, CNRS : UMR8612 - Faculté de Pharmacie - Chatenay \\ Malabry 5 Rue J.B Clément 92296 CHATENAY MALABRY cedex, France \\ ${ }^{2}$ Laboratoire d'Etude du Métabolisme des Médicaments, MetaboHUB-Paris - CEA Saclay - DRF/IBITEC-S/SPI, 91191 \\ Gif-sur-Yvette Cedex, France \\ ${ }^{3}$ Instituto di Chimica del Riconoscimento Molecolare (CNR) - Via Mario Bianco, 920131 Milano, Italie \\ ${ }^{4}$ Service de Pharmaco-Immunologie (SPI), DRF/iBiTec-S, MetaboHUB Paris - CEA - CEA-Saclay, 91191 Gif-sur-Yvette, \\ France
}

La glycosylation est l'une des principales modifications post-traductionnelles des protéines et peut être fortement modifiée lors de diverses pathologies comme le cancer, la polyarthrite rhumatoïde ou les "Congenital disorders of glycosylation". Ainsi, la nature et les proportions relatives des oligosaccharides liés aux protéines peuvent être utilisées comme biomarqueurs de pathologies. Leur étude requiert la séparation d'espèces de structures très proches (glycoformes ou glycannes) nécessitant l'utilisation d'une méthode de séparation avec un pouvoir de résolution élevé telle que l'électrophorèse capillaire (EC). Cependant, leur identification précise n'est possible que lors de l'utilisation du couplage de l'EC avec la spectrométrie de masse (EC-SM/Q-TOF).

L'étude par SM des N-glycannes est souvent limitée par leur faible sensibilité de détection. Nous avons donc étudié la dérivation des $\mathrm{N}$-glycannes libérés après clivage enzymatique (PNGaseF) de la liaison sucre-protéine par un nouveau fluorophore. Ce réactif, le Rapifluor-MS $\AA$, permet grâce à son amine tertiaire, une détection par SM avec une sensibilité accrue comparativement aux fluorophores traditionnellement utilisés en EC-SM. L'optimisation des paramètres de séparation et d'ionisation, afin d'obtenir les résolution et sensibilité maximales, nous a permis d'établir des profils $\mathrm{N}$-glycanniques de référence pour différentes glycoprotéines standards. Nous avons ainsi démontré, pour la première fois, la pertinence de ce fluorophore pour l'analyse de N-glycannes par EC-SM.

L'adsorption des glycoprotéines sur le capillaire est un problème majeur en EC qui provoque une perte de résolution. Afin de prévenir cela, nous avons exploré les potentialités d'utilisation d'une nouvelle famille de revêtement de capillaire semi-permanent en EC-SM. Ce revêtement est composé d'un polymère poly(DMA-GMA-MAPS) fonctionnalisé à façon avec des immobilines de pKa variable, permettant d'ajuster l'état de charge du capillaire et donc le flux électroosmotique généré. L'optimisation des paramètres de séparation s'est avérée nécessaire pour démontrer l'apport de ce nouveau revêtement facile de mise en oeuvre pour la séparation de glycoformes en EC-SM.

Mots-Clés : Glycosylation, électrophorèse capillaire couplée à la spectrométrie de masse, revêtement de capillaire, RapiFluor, MS

\footnotetext{
*Intervenant

${ }^{\dagger}$ Auteur correspondant: coralie.ruel@u-psud.fr
} 


\title{
Detection of human insulins in horse plasma samples by MSIA technology and nLC-QEx [P23]
}

\author{
Patrice Garcia * 1 , Benjamin Chabot ${ }^{1}$, Pierre Remy ${ }^{1}$, Marie-Agnès Popot ${ }^{1}$, \\ Benoit Loup ${ }^{1}$, Yves Bonnaire ${ }^{1}$, Ludovic Bailly-Chouriberry ${ }^{1}$
}

${ }^{1}$ Laboratoire des Courses Hippiques (LCH) - FNCH - 15 rue de Paradis, 91370 Verrières le Buisson, France

Insulin is a 51 amino acids peptide hormone with two chains (A- and B- chain) linked by two disulfide bridges. Due to its properties (carbohydrate metabolism regulation, anabolic and anti-catabolic), the misuse of insulin is reported in human sports to improve their physical performances. Due to these effects and the availability of pharmaceutical products, insulin can be considered as a potential doping molecule in equines. The available human insulins $(5807 \mathrm{Da})$ are slightly different from the equine insulin $(5748 \mathrm{Da})$ by two amino acids allowing thus an unequivocal discrimination between the two analogs. The detection of human insulin can be made by different approaches: immunoassay methods (ELISA) or mass spectrometry analyses. In the field of doping control screening and confirmatory methods are required. Currently the method applied to plasma sample is as follows: extraction using weak anion exchange cartridge and analysis of the intact protein by LC-MS/MS on a triple quadrupole mass spectrometer (Quantiva, Thermo Scientific). However, the method performances of are not consistent with a reliable doping control.

In order to improve insulin detection the screening method would be performed by means of an ELISA test using a commercial kit from Mercodia (Uppsala, Sweden) with the perspective to detect $100 \mathrm{pg} / \mathrm{mL}$ of human insulin. Concerning the confirmatory method, new developments are ongoing using antiinsulin antibodies monolith micro column from Thermo Scientific (MSIA technology) linked to LCHRMS analysis on a Q-Exactive mass spectrometer using a monolith column (Proswift) for chromatographic separation. This method allows detecting insulin at $100 \mathrm{pg} / \mathrm{mL}$ and confirming the presence of the protein at $500 \mathrm{pg} / \mathrm{mL}$.

In order to report a positive case for horseracing doping control laboratories, improvements of performances are still needed. Consequently, the new sample preparation using monolith micro columns will be combined with nano-LC-HRMS analysis in order to improve the limit of confirmation.

Mots-Clés : insulin, equine, doping, MSIA, nano, LC, QExactive

$\underline{\text { Programme }}$

${ }^{*}$ Intervenant 


\title{
Ionic liquids as super-solvent to improve metabolic extraction? [P24]
}

\author{
Alexandre Farigoule ${ }^{1}$, Lise Boberieth ${ }^{1}$, Mélissa Colombo ${ }^{1}$, Cynthia \\ Moreira ${ }^{1}$, Marion Vallet ${ }^{1}$, Marie Lagrée ${ }^{1}$, Cyril Jousse ${ }^{* \dagger}{ }^{1}$ \\ ${ }^{1}$ Institut de Chimie de Clermont-Ferrand - Clermont Auvergne (ICCF) - SIGMA Clermont, Université Clermont \\ Auvergne : UMR6296, CNRS : UMR6296 - 24 Avenue des Landais / 63177 Aubière Cedex, France
}

The metabolome could be considered as a complex mixture, sum of catabolic and anabolic processes, full of molecules picturing a wide scheme of physico-chemical properties and presenting various concentrations. In order to optimize metabolites' harvesting from biological samples to analytical ones, it must be useful to deal with different and/or novel extraction methods (Ser et al., 2015; Mushtaq et al., 2014; Choi \& Verpoorte, 2014).

During Xtract'LI project, we try to improve extraction using ionic liquids (Kerton, 2009). Ionic liquids are non-conventional solvents mostly used to replace toxic and or dangerous ones. Pure ionic liquids are salts with melting point below $100 \circ \mathrm{C}$, from ions usually in a solid state at room temperature. According to $\log$ Kow and CMC parameters, we could have access to interesting physico-chemical, then extractive, properties.

Using prokaryotic and eukaryotic strains, we performed conventional extraction and ionic liquid - assisted ones. All extracts have been analyzed on LC/MS and NMR (Metabolic Profiler(C)). Profiles were compared after binning or bucketing, according to qualitative and quantitative results.

Finally, through advantages and drawbacks, the interest of ionic liquid is discussed, as super-solvent or co-solvent.

Ser, Zheng, Xiaojing Liu, Ngoc Nu Tang, et Jason W. Locasale. " Extraction parameters for metabolomics from cultured cells". Analytical Biochemistry 475 (15 avril 2015): 22-28. doi:10.1016/j.ab.2015.01.003.

Mushtaq, Mian Yahya, Young Hae Choi, Robert Verpoorte, et Erica G. Wilson. " Extraction for Metabolomics: Access to The Metabolome". Phytochemical Analysis 25, no 4 (1 juillet 2014): 291-306. doi:10.1002/pca.2505.

Choi, Young Hae, et Robert Verpoorte. " Metabolomics: What You See Is What You Extract ". Phytochemical Analysis 25, no 4 (1 juillet 2014): 289-90. doi:10.1002/pca.2513.

Kerton, Francesca M. " Chapter 6: Room Temperature Ionic Liquids and Eutectic Mixtures ". In Alternative Solvents for Green Chemistry, 118-42, 2009. doi:10.1039/9781847559524-00118.

Acknowledgement: INCa project PLBIO14 and ANR-11-INBS-0010 MetaboHUB.

Mots-Clés : Ionic liquids, extraction, optimization, LC/MS, NMR

\footnotetext{
*Intervenant

${ }^{\dagger}$ Auteur correspondant: cyril.jousse@uca.fr
} 


\title{
Méthode monophasique pour l'extraction simultanée des lipides polaires et non polaires d'un homogénat de cerveau avant leur analyse par chromatographie liquide couplée à la spectrométrie de masse [P25]
}

\author{
Olivier Berdeaux ${ }^{* 1}$, Spiro Khoury ${ }^{1}$, Elodie Masson ${ }^{1}$ \\ ${ }^{1}$ Centre des Sciences du Goût et de lÁlimentation [Dijon] (CSGA) - INRA : UMR1324, Université de \\ Bourgogne, Institut National Supérieur des Sciences Agronomiques, de lÁlimentation et de lÉnvironnement, \\ CNRS : UMR6265 - Université de Bourgogne - Bât. CSG - 9E Bd Jeanne dÁrc - 21000 Dijon, France
}

L'analyse des lipides constitue un challenge important du fait de leurs structures extrêmement hétérogènes qui couvrent un large éventail de polarités, degré d'insaturation et abondance dans un tissu donné.

Nous proposons une méthode d'extraction monophasique qui utilise un mélange $\mathrm{CHCl} / \mathrm{MeOH} / \mathrm{H} 2 \mathrm{O}$ afin d'extraire simultanément tous les lipides d'un cerveau de rat, qu'ils soient hautement polaires ou non polaires. L'efficacité et les rendements de cette méthode ont été comparés à la méthode de référence de Bligh-and-Dyer. Nous avons aussi testé la purification des gangliosides sur une colonne "Phree Phospholipid Removal ". L'analyse globale des extraits lipidiques a été réalisée avec un Orbitrap FUSION après une séparation par HPLC en phase inverse. Les analyses ciblées de certaines classes de lipides (gangliosides, phospholipides et céramides) ont été obtenues en utilisant un QqQ TSQ Quantum Ultra après une séparation par HPLC (HILIC pour les phospholipides et gangliosides; phase inverse pour les céramides). Les profiles en acides gras et en cholestérol ont été obtenus par GC-FID.

Notre méthode permet une extraction rapide, directe et efficace de tous les lipides. L'efficacité de l'extraction est beaucoup plus élevée que la méthode de Bligh-and-Dyer pour les lipides particulièrement polaires tels que les gangliosides et lysophospholipides, et similaire pour les différentes classes de phospholipides, céramides et cholesterol ou pour le profile en acides gras. L'analyse quantitative des gangliosides a révélé un effet de suppression d'ions importante des GM3 (jusqu'à 90\%) en raison de leur co-élution avec les phosphatidylcholines. L'élimination des phospholipides est indispensable pour l'analyse précise des gangliosides par LC/MS et la colonne " Phree Phospholipid Removal " apparait comme un outil puissant pour réaliser cette étape de purification.

Cette stratégie d'extraction monophasique pour une analyse globale ou ciblée permet donc des analyses détaillées des lipides sur une large gamme de polarités et d'abondances sans nécessiter de multiples extractions spécifiques à chaque classe.

Mots-Clés : extraction, analyse, lipides, lipidomique, spectrométrie de masse

Programme

*Intervenant 


\title{
Analytical Coverage Investigation of a Database of Reference Compounds for Metabolomic Studies [P26]
}

\author{
Julian Pezzatti * 1, Víctor González-Ruiz ${ }^{2,1}$, Nicolas Drouin ${ }^{1}$, Yoric \\ Gagnebin ${ }^{1}$, Serge Rudaz ${ }^{\dagger}, 1$ \\ ${ }^{1}$ Analytical Sciences, School of Pharmaceutical Sciences - University of Geneva \\ Michel Servet 11211 Genève, Suisse \\ ${ }^{2}$ Swiss Centre for Applied Human Toxicology - University of Basel Missionsstrasse 644055 Basel, Suisse
}

Metabolomic sciences aim at the study of low molecular weight molecules in different biological matrices. Although the investigation of the whole metabolic content can be achieved by means of untargeted approaches, the annotation of relevant metabolites is necessary for an optimal interpretation of the biological information present in the studied systems (1). In order to make possible the identification of features, a chemical library containing above 630 standard metabolites (Mass Spectrometry Metabolite Library of Standards from Sigma-Aldrich), was investigated in our laboratory with generic HILIC and RPLC methods hyphenated to MS in positive and negative acquisition modes.

LC methods were developed on a Waters H-Class Acquity system, using Waters Acquity UPLC $\mathbb{R}$ BEH Amide (HILIC) and Phenomenex $₫$ Kinetex C18 (RPLC) stationary phases. MS analysis was conducted on a Bruker maXis $3 \mathrm{G}$ QTOF. Both methods were chosen owing to their orthogonal retention properties (2). The quality of the chemical information delivered by each method was carefully evaluated, as well as the overlap among them based on Derringer's desirability functions, established on different criteria such as retention, sensitivity and peak shape.

Computed scores allowed to spot the best method(s) for the analysis of every detected compound. Furthermore, the coverage and complementarity of the methods was further evaluated. As a result, the combination of all LC methods and ionization modes led to an overall coverage of $80 \%$ of the proposed library. It was found that when only two or three out of the four analytical methods were carefully chosen, the obtained coverage decreased by only $10 \%$.

Finally, the most informative set of LC methods and ionization modes was applied to the investigation of biological matrices, and the annotation of metabolites was carried out by using the constructed database.

(1) C. Virgiliou, I. Sampsonidis, H.G. Gika, N, Raikos, G.A. Theodoridis, Development and validation of a HILIC-MS/MS multitargeted method for metabolomics applications, Electrophoresis 36 (2015) 2215-2225.

(2) A. Periat, I.S. Krull, D. Guillarme, Applications of hydrophilic interaction chromatography to amino acids, peptides, and proteins, Review Article, J. Sep. Sci. 38 (2015) 357-367.

Mots-Clés : Metabolomics, LC, HRMS, RPLC, HILIC, Database

\footnotetext{
*Intervenant

†Auteur correspondant: Serge.Rudaz@unige.ch
} 


\title{
An in-solution digestion method to improve Proteome coverage from small samples of Extracellular Matrix and Membrane extracts [P27]
}

\author{
Haddad Iman ${ }^{* \dagger}{ }^{1}$, Anne Joutel ${ }^{2,3}$, Joelle Vinh ${ }^{1}$ \\ ${ }^{1}$ Spectrométrie de Masse Biologique et Protéomique (SMBP) - CNRS : USR3149, ESPCI Paris, PSL Research \\ University : USR3149 - 10 rue vauquelin 75005 Paris, France \\ ${ }^{2}$ Genetics and Pathogenesis of Cerebrovascular Diseases (UMR 1161 INSERM) - Université Paris Diderot - \\ Paris 7 - 10 avenue de Verdun 75010 Paris, France \\ ${ }^{3}$ Hôpital Lariboisière (APHP) - DHU NeuroVasc Sorbonne - 10 avenue de Verdun; 75010 Paris, France
}

Sample preparation is a key step for proteomics, both in discovery and in targeted modes. It could deeply modify the range of information provided by mass spectrometry, even when using the latest technologies. Indeed the sample preparation must be designed within the analytical constraints according to the biological question to be addressed. In the present study, a bottom-up proteomic strategy was developed to characterize the extracellular matrix (ECM) composition of tissues, involving enrichment of ECM components in protein extracts and subsequent nanoLC-MS/MS analysis.

ECM is a complex meshwork of cross-linked proteins that are important regulators of cell proliferation, survival, differentiation, and migration (1). Proteomic analyses of ECM and membrane proteins are particularly difficult due to their poor solubility and their proteolysis-resistant nature. We first focused on the optimization of a digestion method in order to increase the coverage of ECM proteins, but also to enhance the robustness of the treatment. Then, we tested the reproducibility and the repeatability, which are a pre-requisite for a label free quantitative analysis.

Five protocols have been tested on very small amounts of murine tissue with minimal handling for a label free robust quantification. The best protocol provided more than 2000 proteins identifications from a single pial artery and in a single 3 hour gradient run, $50 \%$ of which are membrane proteins and $12 \%$ of which are ECM proteins.

This type of protocol opens the way towards a relatively simple, rapid and robust way to identify membrane proteins with adverse biochemical and physicochemical characteristics, and that are generally difficult to identify and yet very important for cellular metabolism.

(1) Joutel A, Haddad I, Ratelade J, Nelson MT. Perturbations of the cerebrovascular matrisome: A convergent mechanism in small vessel disease of the brain? J Cereb Blood Flow Metab. 2016 Jan;36(1):14357.

Mots-Clés : proteolysis, extracellular matrix, membrane protein, label, free quantification

\footnotetext{
*Intervenant

†Auteur correspondant: iman.haddad@espci.fr
} 


\title{
CE-MS for metabolomic analysis [P28]
}

\author{
Nicolas Drouin* ${ }_{-}$, Julian Pezzati $\dagger 1$, Yoric Gagnebin \pm 1 , Victor Gonzalez \\ Ruiz ${ }^{1}$, Julie Schāppler ${ }^{1}$, Serge Rudaz ${ }^{1}$ \\ ${ }^{1}$ Analytical Sciences, School of Pharmaceutical Sciences, University of Geneva, University of Lausanne - Rue \\ Michel-Servet 1, 1211 Genève, Suisse
}

In capillary electrophoresis (CE), compounds are separated according to their charge and their hydrodynamic radius ratio, upon application of an electric field. Although CE is an efficient approach for the separation of charged polar compounds, CE-MS is still considered as marginal method for metabolomics analysis mainly because of the numerous experimental conditions needed for a best coverage.

In this study, we have developed a new method for the analysis of basic, neutral and acidic compounds using a single condition of capillary type, buffer composition, ESI mode, and sheath liquid composition. Normal and reverse CE polarity modes were used for basic/neutral and acidic compounds, respectively. A slight positive pressure was applied at the inlet of the capillary to obtain a cathodic electroosmotic flow in reverse polarity mode and reduce analysis time in normal polarity mode. Using a sheath liquid composed of ammonium acetate in $\mathrm{PrOH}: \mathrm{H} 2 \mathrm{O}$, only ESI in the positive mode was required, as acidic compounds were detected as ammonium adducts.

Using this new CE-Q-TOF/MS method, 600 compounds were analysed and 74.7\% of them detected. Metabolites' coverage was compared to that obtained with conventional RPLC and HILIC conditions. CE-MS appeared more efficient for the analysis of very polar charged compounds such as amino acids, organic acids and phosphorylated compounds.

Mots-Clés : CE, MS, metabolomics

$\underline{\text { Programme }}$

\footnotetext{
*Auteur correspondant: nicolas.drouin@ unige.ch

${ }^{\dagger}$ Intervenant
} 


\title{
Evaluation de l'intérêt de la FAST-GC pour le screening des anabolisants dans l'urine de cheval [P29]
}

\author{
Elodie Mirmont ${ }^{1}$, Natali Stojiljkovic ${ }^{1}$, Marie Collard * 1, Béatrice Georges ${ }^{1}$, \\ Patrice Garcia ${ }^{*}{ }^{1}$, Marie-Agnès Popot ${ }^{1}$, Yves Bonnaire ${ }^{1}$, Ludovic \\ Bailly-Chouriberry ${ }^{1}$
}

${ }^{1}$ Laboratoire des Courses Hippiques (LCH) - FNCH - 15 rue de Paradis, 91370 Verrières le Buisson, France

La GC-MS/MS reste la méthode de choix pour la détection de l'administration d'anabolisants stéroïdiens dans l'urine de cheval pour la plupart des laboratoires de contrôle antidopage des chevaux comme le Laboratoire des Courses Hippiques, même si la LC-MS/MS est également utilisée. Compte tenu du nombre croissant d'anabolisants à détecter et d'échantillons à analyser lors du contrôle antidopage de routine, l'intérêt de la FAST-GC pour cette problématique a été évalué.

Les performances de cinq colonnes capillaires commercialisées par trois fournisseurs différents ont été testées et comparées à la colonne GC utilisée quotidiennement au laboratoire (DB-5MS-UI $30 \mathrm{~m}$ x 0,25 $\mathrm{mm} \times 0,25 \mu \mathrm{m}$, Agilent Technologies). Quatre colonnes avec les mêmes caractéristiques $20 \mathrm{~m}$ x 0,18 $\mathrm{mm} \times 0,18 \mu \mathrm{m}$ (DB-5MS-UI (Agilent Technologies), TG-5MS (Thermo Scientific) ainsi que ZB-5MSPLUS et ZB-5MSi (Phenomenex)) ainsi qu'une colonne plus courte, la ZB-Drug-1 ont été évaluées (10 $\mathrm{m} \times 0,18 \mathrm{~mm} \times 0,18 \mu \mathrm{m}$, Phenomenex). L'influence de la température de la ligne de transfert, du temps de splitless ainsi que des gradients en température ont été testés à partir des conditions initiales de routine. 47 anabolisants ont été sélectionnés pour cette étude. Le protocole de routine a été appliqué à des urines de chevaux testées négatives lors du screening et ensuite supplémentées avec le pool de 47 molécules. Ce protocole comprend une étape d'hydrolyse enzymatique suivie d'étapes d'extractions sur phase solide, d'une solvolyse et d'une dérivation des extraits avec ITMS/MSTFA avant analyse en GC-MS/MS.

L'exploitation des données à ce stade de l'étude indique que le transfert de la méthode actuelle vers une méthode FAST-GC permet d'obtenir un gain en sensibilité ainsi qu'un gain de temps. L'intérêt de cette étude sera présenté avec les résultats obtenus pour des échantillons supplémentés mais aussi pour des échantillons urinaires issus d'une administration de 4-chlorotestosterone acétate (Steranobol).

Mots-Clés : FAST, GC, GC, MS/MS, anabolisants, urine, cheval

$\underline{\text { Programme }}$

${ }^{*}$ Intervenant 


\title{
Laser capture and mass spectrometry combination for subcellular proteomics [P30]
}

\author{
Zakaria Ezzoukhy ${ }^{1}$, Elodie Henriet ${ }^{1}$, Fabrice Cordelieres ${ }^{2}$, Jean-William \\ Dupuy $^{*} 3$, Marlène Maitre ${ }^{4}$, Violaine Moreau ${ }^{1}$, \\ Anne-Aurélie Raymond ${ }^{*} \uparrow 1,5$, Frédéric Saltel ${ }^{1}$ \\ ${ }^{1}$ INSERM, UMR1053, BaRITOn Bordeaux - INSERM : U1053 - Bordeaux, France \\ ${ }^{2}$ Bordeaux Imaging Center (BIC) - Institut François Magendie, INSERM : US4 - 146 rue Léo Saignat 33077 \\ Bordeaux Cedex, France \\ ${ }^{3}$ Plateforme Proteome Bordeaux - Université de Bordeaux - 146, rue Leo Saignat université de Bordeaux 33076 \\ Bordeaux Cedex, France \\ ${ }^{4}$ Neurocentre Magendie U1215, INSERM - INSERM : UMS3420 - Institut Francois Magendie 146, rue leo \\ saignat 33077 Bordeaux cedex, France \\ 5 9. Oncoprot, INSERM 1053, TBM-Core US 005 - INSERM : US005 - Bordeaux, France
}

The challenge of deciphering the proteome of subcellular complexes is crucial to better understand cellular processes and, on a broader level physiology and pathologies. Currently, the main difficulties concern the conservation of the integrity and the isolation of the protein complex of interest. Indeed, classical biochemical methods to purify them provide contamination and consequently difficulties for analyses and validation of the data. To solve these problems we decided to combine laser capture and mass spectrometry analysis. Laser microdissection allowed the isolation of subcellular complexes on their native state. Once collected, proteins were extracted and the fixation reversed. The proteins Were then digested by trypsin in-gel and the peptides analyzed by LC-MS/MS on a Q-exactive mass spectrometer, (Thermo) whose sensitivity is compatible with such small quantities of material. Database searching with $13 \mathrm{C}(6)(\mathrm{K})$ or $13 \mathrm{C}(6)(\mathrm{R})$ labeling as fixed modification uniquely identifies proteins coming from microdissected elements. Finally, in order to confirm the enrichment of identified proteins in comparison with the total cellular proteome and thus the significant presence of these proteins in the compartment of interest, we performed a relative label free quantification between the microdissected fraction and a total extract of labeled cells. This original association of several advanced technologies is geared to the needs of lower the level of contaminations and increase the level of sensitivity for subcellular proteomics. As a proof of concept we applied this strategy on invadosomes, a F-actin based structures involved in extracellular matrix degradation and cell invasion. Using this new methodology we identified components already known of this structure. And in addition, we highlighted that invadosomes concentrated mRNA and exhibit their own translation activity.

Mots-Clés : Subcellular proteomics, Laser capture microdissection

Programme

\footnotetext{
${ }^{*}$ Intervenant

${ }^{\dagger}$ Auteur correspondant: anne-aurelie.raymond@inserm.fr
} 


\section{Traitement et analyse statistique des données [P31-P44]}




\title{
Protein identification using MS/MS data under $\mathbf{R}$ [P31]
}

\author{
Sara El Jadid ${ }^{* \dagger}{ }^{1}$, Rajaa Touahni ${ }^{1}$, Ahmed Moussa ${ }_{-}^{\ddagger}$ \\ ${ }^{1}$ Laboratory of Telecommunication Systems and Decision Engineering (LaSTID) - Faculty of Sciences, Ibn \\ Tofail University, Kenitra, Morocco, Maroc \\ ${ }^{2}$ System and Data Engineering Team (SDET) - National School of Applied Sciences, Abdelmalek Essaadi \\ University, Tangier, Morocco, Maroc
}

Proteomics has made a massive advance and reached enough fullness previously reserved only for genomics. Therefore, it generates a flood of data that presents significant challenges for their interpretation. With the emergence of mass spectrometers that allow the study of proteins in a large-scale, the analysis of complex protein samples became possible. However, the correct identification of all proteins present in a sample are of utmost matter to provide the suitable biologically interpretation.

Many bioinformatics algorithms, in different programming languages, dedicated to this purpose have emerged, but they differ in terms of ease of use. Nevertheless, for researchers with low or fair programming skills, using such tools could be a significant challenge.

In addition, most pipelines are proprietary, inducing to a black box aspect which makes the test, examination or modification of the process leading to results an impossible task.

The subject of this tutorial is protein identification by database searching using tandem Mass Spectrometry (MS/MS) data. Here we present how the famous open source programming language and environment for statistical computing, R, can be a user-friendly tool for protein identification.

We use in this tutorial rTANDEM, a Bioconductor package that encapsulates in R the popular algorithm $\mathrm{X}$ !Tandem excluding the independent installation of the search engine and eliminating the black box phenomenon.

The package makes possible the performance of MS2 spectra identification in the R environment and takes advantage of R's data processing efficiencies to investigate results.

Some strong aspects of rTANDEM are emphasized, such as supplying extended syntax and functions to streamline launching analyses, besides functions to convert parameters, taxonomy or results files to/from $\mathrm{R}$.

The main goal of this tutorial is to make $\mathrm{R}$ a powerful and user-friendly framework for tandem mass spectrometry data analysis to the proteomists' community just like it is for the genomists' community.

Mots-Clés : Mass Spectrometry data, Protein Identification, R, data analysis.

$\underline{\text { Programme }}$

\footnotetext{
*Intervenant

${ }^{\dagger}$ Auteur correspondant: eljadidsara@gmail.com

$¥$ Auteur correspondant: amoussa@uae.ac.ma
} 


\title{
Exploitation de données HRMS via W4M pour la comparaison de signatures en entrée/sortie d'un traitement tertiaire [P32]
}

\author{
Aurélie Fildier ${ }^{*}$, Audrey Buleté ${ }^{1}$, Alexandre Berge ${ }^{1}$, Christelle \\ Bonnefoy ${ }^{*}{ }^{1}$, Claire Bordes ${ }^{1}$, Romain Mailler ${ }^{2}$, Johnny Gasperi ${ }^{3}$, Fabrice \\ Nauleau ${ }^{4}$, Vincent Rocher ${ }^{4}$, Emmanuelle Vulliet $*^{\dagger}+1$ \\ ${ }^{1}$ Institut des Sciences Analytiques (ISA) - CNRS : UMR5280, École Normale Supérieure (ENS) - Lyon, \\ Université Claude Bernard - Lyon I (UCBL) - 5 rue de la Doua, 69100 Villeurbanne, France \\ ${ }^{2}$ SIAAP - Direction du Développement et de la Prospective - 82 avenue Kléber, 92700 Colombes, France \\ ${ }^{3}$ Université Paris Est (UMR MA 102) - Université Paris-Est, agroparis tech, Université Paris-Est - Université \\ Paris-Est Créteil, 61 avenue du Général de Gaulle, 94010 Créteil Cedex, France \\ ${ }^{4}$ SAUR, Direction de la Recherche et du Développement - SAUR \\ 1 rue Antoine Lavoisier, 78064 Guyancourt, France
}

La présence de micropolluants à l'état de traces dans le milieu aquatique suscite un intérêt croissant. Afin de réduire leur présence et ainsi restaurer le bon état écologique et chimique des eaux souterraines et superficielles imposé par la Directive Cadre sur l'Eau (2000/60/CE), des efforts importants sont consentis ces dernières années pour accroître l'efficacité des filières de traitement des eaux usées. Ainsi, l'adsorption sur charbon actif apparaît comme une technique prometteuse pour réduire les rejets de micropolluants.

Si de nombreuses méthodes analytiques ont été développées ces dernières années pour la détection sélective et sensible de polluants organiques dans les matrices environnementales, aujourd'hui une technique analytique centrée sur quelques contaminants ou familles de contaminants ne suffit plus pour une analyse complète d'une matrice complexe. L'utilisation de la Spectrométrie de Masse à Haute Résolution (HRMS) et l'opportunité qu'elle offre d'effectuer l'analyse de molécules non-ciblées ou inconnues s'avère nécessaire.

Dans ce contexte, l'étude propose de comparer les signatures chimiques en entrée et sortie du traitement

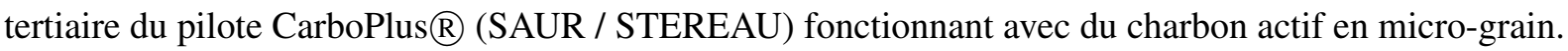
Plus précisément, le couplage de la chromatographie liquide avec la HRMS à temps de vol (QToF Maxis Plus, Bruker®) a été utilisé pour l'analyse de 8 campagnes hebdomadaires de 2 prélèvements en entrée et sortie du pilote. Avant injection, ces prélèvements ont été extraits par extraction sur phase solide.

Ainsi, les données brutes obtenues en MS ont été investiguées sur la plateforme Galaxy Workflow4Metabolomics. Les outils chimiométriques disponibles ont permis de réaliser le prétraitement des données ainsi que leur analyse statistique. Les résultats en analysant simultanément ou individuellement toutes les séquences ont été confrontés. Cette démarche a permis la mise en évidence de nombreuses molécules abattues par charbon actif mais aussi certaines molécules non éliminées, dont l'identification par des analyses MS/MS est en cours.

Mots-Clés : analyse non, ciblée, LC, QToF, identification

\footnotetext{
*Intervenant

†Auteur correspondant: emmanuelle.vulliet@isa-lyon.fr
} 


\title{
Exploitation de données HRMS via Galaxy pour la mise en évidence de métabolites chez Gammarus fossarum exposé à 2 composés pharmaceutiques [P33]
}

\author{
Aurélie Fildier ${ }^{*}{ }^{1}$, Aurélie Cortéjade ${ }^{1}$, Audrey Buleté ${ }^{1}$, Christelle \\ Bonnefoy ${ }^{*}{ }^{1}$, Claire Bordes ${ }^{1}$, Jeanne Garric ${ }^{2}$, Emmanuelle Vulliet ${ }^{*} \uparrow 1$ \\ ${ }^{1}$ Institut des Sciences Analytiques (ISA) - CNRS : UMR5280, École Normale Supérieure (ENS) - Lyon, \\ Université Claude Bernard - Lyon I (UCBL) - 5 rue de la Doua, 69100 Villeurbanne, France \\ ${ }^{2}$ Irstea-Lyon - Institut national de recherche en sciences et technologies pour l'environnement et l'agriculture - \\ IRSTEA - 5 rue de la Doua, 69100 Villeurbanne, France
}

La large contamination des poissons dans les milieux par les substances pharmaceutiques a été largement démontrée. De plus, de récents travaux ont montré la bioconcentration et la bioaccumulation de plusieurs substances pharmaceutiques dans les invertébrés benthiques, organismes à la base des chaines trophiques, échantillonnés en aval de rejet de station d'épuration. L'amphipode Gammarus fossarum est fréquemment utilisé comme espèce sentinelle de la qualité de l'eau, car elle est très répandue en Europe occidentale et sa physiologie est parfaitement connue.

L'objectif principal de ce travail de métabolomique environnementale est d'étudier l'exposition de $G$. fossarum à 2 composés pharmaceutiques (l'anxiolytique oxazépam et l'antiépileptique carbamazépine) en conditions de laboratoire (1000 ng.L-1), individuellement ou en mélange, sur des individus de sexe et de stade de développement différents, susceptibles de conduire à des différences de sensibilités toxicologiques. Les gammares ont été analysés à l'échelle d'un seul individu grâce à une méthode incluant une extraction de type $\mu \mathrm{QuEChERS} \mathrm{suivie} \mathrm{d'une} \mathrm{analyse} \mathrm{par} \mathrm{nanochromatographie} \mathrm{liquide} \mathrm{couplée} \mathrm{à} \mathrm{la}$ spectrométrie de masse haute résolution nanoLC-HRMS à temps de vol (QToF Maxis Plus, Brukerß). Ainsi, les empreintes moléculaires obtenues en MS ont été investiguées à l'aide de la plateforme Galaxy Workflow4Metabolomics. Les outils chimiométriques disponibles ont permis de réaliser le prétraitement des données ainsi que leur analyse statistique.

Cette démarche d'approche globale a permis de comparer les empreintes moléculaires de chaque individu et de les classer suivant leur nature ou leur condition d'exposition. Des composés discriminants correspondant aux potentiels métabolites ou biomarqueurs responsables de modifications du métabolome de G. fossarum ont été mis en évidence. Leur identification par des analyses MS/MS est en cours. Cette étude contribue au besoin de développer des stratégies analytiques permettant l'identification de métabolites et de voies métabolomiques pouvant être modifiées en réponse à une perturbation biologique et donc de faire avancer la métabolomique environnementale.

Mots-Clés : métabolomique environnementale, pharmaceutiques, invertébrés, LC, HRMS, W4M

\footnotetext{
*Intervenant

${ }^{\dagger}$ Auteur correspondant: emmanuelle.vulliet@isa-lyon.fr
} 


\title{
Data-Independent Acquisition workflow optimizations: from chromatographic conditions to data processing [P34]
}

\author{
Joanna Bons ${ }^{* \dagger}{ }^{1}$, Gauthier Husson ${ }^{1}$, Sarah Cianferani ${ }^{1}$, Christine Carapito ${ }^{1}$ \\ ${ }^{1}$ Laboratoire de Spectrométrie de Masse Bio-Organique (IPHC) - Université de Strasbourg, CNRS : UMR7178 - \\ 25 rue Becquerel 67087 Strasbourg Cedex 2, France
}

Since its introduction a few years ago, data-independent acquisition (DIA) has gained a real interest in quantitative proteomics, thanks to its ability to quantify all extracted signals from a highly complex sample (Gillet et al., 2012). It circumvents the main drawbacks of the current quantitative methods limited dynamic range and undersampling effect in label-free quantification, and limited quantified protein number in targeted approaches.

Nevertheless, two bottlenecks remain challenging in DIA: (i) the robustness and maintained sensitivity of the instrument to reproducibly quantify complex, high dynamic range proteomes, (ii) the performant and automated data extraction and interpretation of MS/MS ion chromatograms.

For this study, two calibrated samples were set up: a series of UPS1 standard (Merck) ranging from 0.5 to $25 \mathrm{fmol}$ spiked into $0.8 \mu \mathrm{g}$ of yeast lysate background (YLB), and another series of 1 to $200 \mathrm{fmol}$ UPS1 spiked into $8 \mu \mathrm{g}$ of YLB. Additionally, a series of heavy-labeled synthetic peptides corresponding to proteotypic peptides of the 48 UPS1 standard proteins were spiked into the samples. Both sample series were analysed on quadrupole-time-of-flight mass spectrometers (TripleTOF 5600+ and TripleTOF 6600 , Sciex). These DIA-SWATH experiments aim to quantify the highest number of UPS1 proteins along these ranges, while maintaining the YLB constant. In parallel, MRM-HR experiments were conducted on the same samples and instruments targeting a subset of UPS1 proteotypic peptides.

Using the generated datasets, extraction and integration performed by four programs, Spectronaut (Reiter et al., 2011), PeakView (Gillet et al., 2012), Skyline (MacLean et al., 2010) and DIA-Umpire (Tsou et $a l ., 2015)$, were evaluated, regarding key parameters: extraction window width, XIC width, transition number and FDR threshold.

In addition, performances between the nano- and the micro-range systems were evaluated to estimate benefits-losses of a chromatographic upscaling. Finally, MRM-HR quantification was compared to DIASWATH quantification thanks to isotope dilution.

Mots-Clés : Quantitative proteomics, Data, independent Acquisition, SWATH, Skyline, PeakView, DIA, Umpire

$\underline{\text { Programme }}$

\footnotetext{
*Intervenant

†Auteur correspondant: joanna.bons@etu.unistra.fr
} 


\title{
MS-Angel: a solution for real-time proteomics workflows [P35]
}

\author{
Julie Poisat ${ }^{* \dagger}{ }^{1}$, David Bouyssié ${ }^{1}$, Alexandre Burel ${ }^{2}$, Christophe Bruley ${ }^{3}$, \\ Sarah Cianferani ${ }^{2}$, Jérôme Garin ${ }^{3}$, Odile Burlet-Schiltz ${ }^{1}$
}

\footnotetext{
${ }^{1}$ Institut de pharmacologie et de biologie structurale (IPBS) - Université Paul Sabatier - Toulouse 3, CNRS : UMR5089 - 205 Route de Narbonne 31077 Toulouse cedex 4, France

${ }^{2}$ Laboratoire de Spectrométrie de Masse BioOrganique (LSMBO) - CNRS UMR7178 - Université Strasbourg ECPM Bat R5-0, 25, Rue Becquerel, 67087 Strasbourg Cedex 2, France

${ }^{3}$ Laboratoire de Biologie à Grande Échelle (BGE - UMR S1038) - CEA : DSV/IRTSV, Université Grenoble Alpes [Saint Martin dH́ères], INSERM : U1038 - CEA -Grenoble/IRTSV Laboratoire Biologie à Grande Echelle 17 Rue des Martyrs 38054 Grenoble cedex 9, France
}

Search engines are major tools to identify proteins through the mass spectrometry-based proteomic analysis of peptide mixtures. While they were often used in stand-alone applications, today it becomes common to see complex data processing workflows involving multiple search engines. Indeed, software like OpenMS, Proteome Discover and SearchGUI allow the submission of peaklist files to several search engines simultaneously. However, these tools are lacking a useful Mascot Daemon feature, which is able to monitor the creation of acquisition files to trigger automatically their processing in background.

To satisfy this need we decided to create MS-Angel, an open-source software managing the automated detection of newly created files and their processing. MS-Angel workflows include a lot more operations than the proteins identification. It is possible to combine in a single batch the conversion of files (e.g. into peaklists), the submission of spectra to search engine(s), the execution of custom scripts... MS-Angel is designed to work with Mascot, and SearchGUI is being integrated to support many open source search engines.

Moreover, MS-Angel has been developed to be coupled to Proline, an open-source software suite dedicated to the processing of mass spectrometry data, especially target/decoy validation and label-free quantitation. Using MS-Angel, users can schedule the import of the MS/MS search result files into Proline as soon as they are created; then validate and quantify the data altogether.

MS-Angel is thus a new free, fully automated solution for the management of raw files and the submission of searches in databases. Combined to Proline, it offers a fairly comprehensive and easy-to-use pipeline for the analysis of LC-MS/MS data.

The first public version is available at http://proline.profiproteomics.fr/download. The next version, embedding SearchGUI, should be released with Proline 2.0 (end of 2017). A standalone version coming without Proline - providing limited features - is planned.

Mots-Clés : MS/MS search engines, workflow, automation, real, time monitoring

\footnotetext{
${ }^{*}$ Intervenant

${ }^{\dagger}$ Auteur correspondant: julie.poisat@ipbs.fr
} 


\title{
Visualisation of Residual Bioorganic Compounds in an Archaeological Mollusc Shell Sample using Imaging Mass Spectrometry [P36]
}

\author{
Sebastiaan Van Nuffel ${ }_{-}^{*}$, Carole Fritz ${ }^{2}$, Gilles Tosello ${ }^{2}$, Philippe Walter ${ }^{3}$, \\ Alain Brunelle $\_1$ \\ ${ }^{1}$ Institut de Chimie des Substances Naturelles (ICSN) - CNRS : UPR2301 - Avenue de la terrasse 91198 Gif sur \\ Yvette cedex, France \\ ${ }^{2}$ Centre de Recherche et d'Etude pour l'Art Préhistorique (CREAP) - CNRS : UMR5608 - Maison des Sciences \\ de l'Homme de Toulouse (USR 3414), 5 allées Antonio Machado, 31058 Toulouse, France \\ ${ }^{3}$ Laboratoire d'Archéologie Moléculaire et Structurale (LAMS) - Sorbonne Universités, UPMC Univ Paris 06, \\ CNRS, UMR 8220 - 5 Place Jussieu 75005 Paris, France
}

Time-of-flight secondary ion mass spectrometry (ToF-SIMS) is a powerful surface analysis technique that allows the characterisation of both organic and inorganic molecules and their spatial distribution. Its high spatial resolution and sensitivity make ToF-SIMS especially suited for the study of art or archaeological artefacts (1). The artefact investigated here is a Charonia lampas conch found in the Marsoulas Cave, located in the southwest of France and well known for its archaeological wealth. The conch was excavated in 1931 and likely stems from the Upper Paleolithic. Its remarkable size $(31 \times 18$ $\mathrm{cm}$ ) and its excavation site suggest the conch was utilised by early modern humans.

A small fragment of the conch was first embedded in a polyester resin and subsequently polished in order to obtain a flat sample surface for ToF-SIMS analysis. The ToF-SIMS analyses were executed using an ION-TOF TOF-SIMS IV instrument (Muenster, Germany), equipped with a Bi liquid metal ion gun (LMIG) and Ar gas cluster ion beam (GCIB). Prior to 2D ToF-SIMS imaging, Ar1500+ cluster ions were used to clean the sample surface. Bi3+ primary ions were subsequently used to analyse an area of $400 \times 400 \mu \mathrm{m}^{2}$ with $1024 \times 1024$ pixels in both positive and negative polarity. To facilitate data interpretation and image processing, principal component analysis was performed on the mass spectral data using in-house Matlab scripts (2).

Several mass peaks that correspond with calcium carbonate are detected, which is consistent with the calcite or aragonite composition of mollusc shells. The presence of fluorine and several fluorine containing ions indicate a fossilisation process whereby the calcium carbonate is replaced by fluorite. More interestingly, fatty acid ions are present as well and constitute a clear biosignature.

(1) M. Noun, et al. Journal of Mass Spectrometry, 51, 2016, 1196-1210.

(2) S. Van Nuffel, et al. Analyst, 141(1), 2016, 90-95.

Mots-Clés : imaging mass spectrometry, bioanalytical mass spectrometry, ToFSIMS, multivariate analysis, archaeology

\section{$\underline{\text { Programme }}$}

\footnotetext{
*Intervenant

${ }^{\dagger}$ Auteur correspondant: alain.brunelle@cnrs.fr
} 


\title{
Proline label free quantification algorithm evaluation and abundance measurement accuracy [P37]
}

\author{
David Bouyssié ${ }^{1}$, Véronique Dupierris ${ }^{2}$, Anne-Marie Hesse ${ }^{2}$, Emmanuelle \\ Mouton-Barbosa ${ }^{1}$, Christine Carapito ${ }^{3}$, Anne Gonzalez De Peredo ${ }^{1}$, Odile \\ Burlet-Schiltz ${ }^{1}$, Sarah Cianferani ${ }^{3}$, Jérôme Garin , Christophe Bruley * 2
}

${ }^{1}$ Institut de Pharmacologie et Biologie Structurale (IPBS), UMR5089 CNRS - Université de Toulouse (IPBS) 205 route de Narbonne, 31077 Toulouse, France

${ }^{2}$ Laboratoire de Biologie à Grande Échelle (BGE - U1038 INSERM/CEA/UGA) - CEA : DRF/BIG, Université Grenoble Alpes [Saint Martin dH́ères], 17 Rue des Martyrs 38054 Grenoble cedex 9, France

${ }^{3}$ Laboratoire de Spectrométrie de Masse Bio-Organique (IPHC) - Université de Strasbourg, CNRS : UMR7178 25 rue Becquerel 67087 Strasbourg Cedex 2, France

Mass-spectrometry based proteomics has evolved in the past few years in such a way that a majority of proteomics experiments do not only aim at identifying proteins but mostly try to reach a more comprehensive understanding of the dynamic of biological processes. This evolution leads to complex experimental designs in which label-free MS-based quantitative approaches are broadly used to provide protein expression information. Matching MS signal of a same identified peptide ion across all runs is an ideal result that is not always realized because peptides are not systematically identified by MS/MS in every run. Hence, a peptide ion not identified in some runs generates missing quantitative values and cross assignment is necessary to recover these values. This step is probably the most error-prone in label-free methods. Indeed, the signals that must be cross-assigned between the runs may be very close in $\mathrm{m} / \mathrm{z}$ and/or time dimensions to the signals of some interfering species and the algorithms must be clever enough to avoid the cross assignment of an ion that is really not present in a sample. We will show through a spiked standard sample [1] that Proline implements an efficient cross assignment procedure, which makes it possible to reach out a low level of missing values rate without adversely affecting the coefficient of variation of measured ions. The accuracy of the final protein abundance measurement is investigated by using the same dataset but focusing on the spiked UPS1 proteins, whose theoretical relative abundances in the different samples are known. We will demonstrate that the observed ratios are close to the expected ones, combined with a limited dispersion around the median values. [1] Ramus et al. (2016). Benchmarking quantitative label-free LC-MS data processing workflows using a complex spiked proteomic standard dataset. Journal of Proteomics 132, 51-62.

Mots-Clés : label, free quantification, data processing, bioinformatics, software

\section{Programme}

\footnotetext{
${ }^{*}$ Intervenant
} 


\title{
mzScope: fast MS data visualization and exploration tool based on the mzDB file format [P38]
}

\author{
Christophe Bruley ${ }_{-}^{*}$, Anne-Marie Hesse ${ }^{1}$, Véronique Dupierris ${ }^{1}$, Bouyssié \\ David $^{2}$ \\ ${ }^{1}$ Laboratoire de Biologie à Grande Échelle (BGE - U1038 INSERM/CEA/UGA) - CEA : DRF/BIG, Université \\ Grenoble Alpes [Saint Martin dH́ères], 17 Rue des Martyrs 38054 Grenoble cedex 9, France \\ ${ }^{2}$ Institut de pharmacologie et de biologie structurale (IPBS) - Université Paul Sabatier - Toulouse 3, CNRS : \\ UMR5089 - 205 Route de Narbonne 31077 Toulouse cedex 4, France
}

The mzDB format is an efficient file format for large mass spectrometry (MS) datasets relying on the SQLite lightweight database management system. Vendor's raw file can easily be converted into mzDB by using a freely available converter. mzScope is a visualization and exploration tool written in Java allowing users to visualize scans and chromatograms extracted from mzDB file. Usual features such as MS1 chromatogram extraction from a user's specified mass over charge ratio $(\mathrm{m} / \mathrm{z})$ value or from a mass range selected from an MS scan or from a list of precursor's $\mathrm{m} / \mathrm{z}$ values are provided. Moreover extraction can be applied to a single mzDB file or to a set of MS files simultaneously. Thanks to the mzDB format, chromatogram extraction is usually performed in few hundred of milliseconds over a 2 or $3 \mathrm{~h}$ gradient time range. In addition to zooming and panning vertically or horizontally, the extracted chromatograms can be visualized through multiple synchronized views or stacked in a single view to be easily compared. Fragmentation events matching to the extracted $\mathrm{m} / \mathrm{z}$ can also be overlaid. The software can also perform elution peaks detection by using the algorithm implemented in the Proline software or peak grouping into MS features through the Proline deisotoping algorithm. Since mzDB format support DIA MS data, mzScope also provides MS2 chromatogram extraction within a selected isolation window that can be performed on user supplied $\mathrm{m} / \mathrm{z}$ values or from ion fragment masses imported from a spectral library. Finally, the software supplies various metrics computed from the raw MS data that can be used as identification-free quality control of the coupling of chromatography with MS instrumentation. Those features combined with the efficiency of the mzDB format make mzScope a suitable tool for MS data visualization and exploration or for raw MS signal comparison.

Mots-Clés : mass spectrometry data, visualization, software

Programme

\footnotetext{
${ }^{*}$ Intervenant
} 


\title{
Understanding MALDI through 3D ToF-SIMS Imaging [P39]
}

\author{
Nicolas Elie ${ }_{-}^{*}$, Sebastiaan Van Nuffel ${ }^{1}$, Julius Nouet ${ }^{2}$, Pierre Chaurand ${ }^{3}$, \\ Alain Brunelle_t \\ ${ }^{1}$ Institut de Chimie des Substances Naturelles (ICSN) - CNRS : UPR2301 - Avenue de la terrasse \\ 91198 Gif sur Yvette cedex, France \\ ${ }^{2}$ Géosciences Paris Sud (GEOPS) - Université Paris-Sud - Paris 11, CNRS : UMR8148 - Université Paris Sud, \\ bâts. 504 510, 91405 ORSAY Cedex, France \\ ${ }^{3}$ Departement de Chimie, Universite de Montreal - Montreal, Quebec, Canada 3HC 3J7, Canada
}

Imaging mass spectrometry (IMS) has become a powerful tool to characterise the spatial distribution of biomolecules in thin tissue sections. In the case of matrix-assisted laser desorption ionisation (MALDI) IMS, homogeneous matrix deposition is critical to produce high quality ion images and sublimation in particular has shown to be an excellent matrix deposition method for the imaging of phospholipids. Matrix deposition by sublimation is however a completely solvent-free system as opposed to more conventional spray methods. The analytes within the tissue section are therefore never resolubilised, which prevents the formation of matrix/analyte co-crystals presumed to be necessary for laser desorption ionisation. To understand the desorption-ionisation process after matrix deposition by sublimation, it is necessary to study the matrix-tissue interface prepared for MALDI IMS.

Here, liver tissue sections were first mounted on conductive indium tin oxide coated microscope slides and then 2,5-dihydroxybenzoic acid matrix was applied to the tissue by either spray or sublimation. Combined with atomic force microscopy measurements and advanced multivariate image analysis using principal component analysis, 3D Time-of-Flight (ToF) SIMS measurements in dual-beam mode allowed the spatial distribution of biomolecules in the matrix and tissue layers to be visualised with nanometric depth resolution.

Aside from major differences in surface morphology between the matrix layers generated by either sublimation or spray deposition, different 3D spatial distributions were observed for different biomolecules such as cholesterol, glycerides and phosphatidylcholines, suggesting analyte migration from the section to the matrix. These spatial distributions were also corroborated by successive MALDI MS laser ablations measurements.

Our conclusions are that after matrix deposition by sublimation, there is a privileged molecular migration from the tissue section to the matrix layer. Desorption is then induced by laser ablation and ionisation occurs by proton or cation exchange presumably in the gas phase.

Mots-Clés : MALDI, TOF, SIMS, spray, sublimation, imaging, statistics, matrix

Programme

\footnotetext{
*Intervenant

${ }^{\dagger}$ Auteur correspondant: alain.brunelle@cnrs.fr
} 


\title{
EN-TerPred: A new tool for predicting protein $\mathrm{N}$-terminal modifications and plastid transit-peptide cleavage sites [P40]
}

\author{
Willy Bienvenut ${ }^{* \dagger}{ }^{1}$, Pierre-Albert Charbit ${ }^{1}$, Jean-Pierre Scarpelli ${ }^{1}$, Thierry \\ Meinnel ${ }^{1}$, Carmela Giglione ${ }^{1}$
}

${ }^{1}$ Institut de Biologie Intégrative de la Cellule (I2BC) - Université Paris-Sud - Paris 11, CEA : DSV/I2BC, Université Paris-Saclay, CNRS : UMR9198 - Bâtiment 21, 1 avenue de la Terrasse

91198 Gif/Yvette cedex, France

\begin{abstract}
Proteins N-terminus is a major criteria involved in protein fate and half-life. Some of the most frequent co-translational N-terminal modifications are associated to initial methionine excision or protein $\mathrm{N}$-terminal acetylation. Some others occur post-translationally such as the excision of the transit peptide observed for nuclear-encoded proteins targeting the mitochondrion or plastids. Few prediction tools are currently available such as TermiNator 3 for the prediction of protein $\mathrm{N}$-terminal modifications (at positions 1-2) and the prediction tools suite TargetP/ChloroP/SignalP for the subcellular localization (mostly mitochondria, plastid and secreted proteins) jointly with the prediction of the transit-peptide cleavage site. Unfortunately, these tools suffer from minor inconsistencies (e.g. NatC substrates prediction for TermiNator3) to major drawbacks (e.g. transit-peptide cleavage-site accuracy for the TargetP suite).

Our large-scale $\mathrm{N}$-terminomics analyses provide highly relevant data integrated in a dedicated database (eNergiome $D B$ ). Subcellular localization, protein $\mathrm{N}$-terminus status and mature $\mathrm{N}$-terminal start position are checked and validated for all collected data. This essential step benefit of data redundancy and annotations available in various databases such as PPDB, SUBA, At_Chloro, UniprotKB, etc. The eNergiomeDB contains almost 250,000 mature experimental $\mathrm{N}$-termini related to more than 6,000 distinct non-redundant proteins (2,538 from A. thaliana, 3507 from H. Sapiens). More than 175,000 validated peptides (associated to 1,925 proteins) were used to improve the existing $\mathrm{N}$-terminus prediction tools and to develop new ones.

These validated data provide a strong and highly valuable basis for the development of a new prediction tool: EN-terPRED. This new tools (i) integrates newly identified NTA inhibitory effects, and (ii) improves NTA modification yields especially for NatC substrates. Furthermore, EN-terPRED provides also a subcellular localization prediction based on protein primary sequence and cleavage sites of plastid transit peptide for the $A$. thaliana nuclear-encoded proteins. These newer functionalities and their possible use on alternative species will be discussed.
\end{abstract}

Mots-Clés : Mature N, terminal prediction, N, terminal acetylation, chloroplast targeting proteins.

\section{Programme}

\footnotetext{
${ }^{*}$ Intervenant

†Auteur correspondant: willy.bienvenut@i2bc.paris-saclay.fr
} 


\title{
True or False Experience: Going after well-behaved features and biologically relevant information in metabolomics data [P41]
}

\author{
Florence Mehl ${ }^{* 1}$, Hector Gallart-Ayala ${ }^{1}$, Tony Teav ${ }^{1}$, Carl Brunius ${ }^{2}$, \\ Julijana Ivanisevic ${ }_{-}^{\dagger} 1$
}

\footnotetext{
${ }^{1}$ Plateforme de Métabolomique, Faculté de Biologie et Medecine, Université de Lausanne (UNIL) Metabolomics Platform Quartier UNIL-CHUV Rue du Bugnon 19 CH-1005 Lausanne, Suisse

2 Department of Biology and Biological Engineering, Chalmers University of Technology - Department of Biology and Biological Engineering, Chalmers University of Technology, Göteborg, Suède
}

Liquid chromatography coupled to high resolution mass spectrometry (LC-HRMS) is the most versatile and widely used technique in metabolomics that allows us to measure thousands of metabolite features from minimal amounts of biological sample. However, the back end data processing and analysis, including the efficient correction of signal intensity drift, removal of chemical noise and redundancy, feature annotation and metabolite identification remains a tedious and error-prone task thus limiting the potential of reaching biologically relevant conclusions. Here we demonstrate a complete workflow of translation of spectral feature changes to biologically significant information in an untargeted LC-MS based analysis of cell lysates. Raw, centroid or profile LC-HRMS data were pre-processed with XCMS software to produce a peak area table containing metabolite features defined and aligned by accurate $\mathrm{m} / \mathrm{z}$ (AM) and retention time (RT) across multiple samples. Following the peak detection and alignment a cluster-based feature intensity correction was applied using pooled quality control (QC) samples to correct the intensity drift - a consequence of an inherent and systematic LC-MS analysis variation. The processed data was mined using univariate and multivariate statistics to extract the significant differences or regulated features that drive sample clustering in group comparison. To translate these selected spectral feature changes to metabolites and pathways, Accurate-Mass and Retention-Time (AMRT) matching was performed against in-house and open-access metabolite databases (HMDB, MassBank and LipidMaps) and subsequently, pathway databases (KEGG, BioCyc). The total set of detected features in a respective analysis mode (after signal correction and noise filtering) was defined as the reference metabolome for pathway analysis. Finally, the validation of putative metabolite IDs, by MS/MS fragmentation pattern matching against METLIN, was pathway-guided, focusing on metabolites involved in significantly enriched pathways.

Mots-Clés : LC, MS, signal correction, metabolomics workflow, pathway analysis, metabolite identification

Programme

\footnotetext{
*Intervenant

${ }^{\dagger}$ Auteur correspondant: Julijana.Ivanisevic@unil.ch
} 


\title{
Integration and provenance of proteomics data using SWOMed, a Product Lifecycle Management framework for biomedical research [P42]
}

\author{
Amel Raboudi $* \dagger 1,2$, Marianne Allanic ${ }^{1}$, Pierre-Yves Hervé ${ }^{1}$, Daniel \\ Balvay ${ }^{3}$, Joevin Sourdon ${ }^{3}$, Philippe Boutinaud ${ }^{1}$, Bertrand Tavitian ${ }^{4}$ \\ ${ }^{1}$ Fealinx - company - 37 rue Adam Ledoux 92400 Courbevoie, France \\ 2 Paris-Centre de Recherche Cardiovasculaire (PARCC) - INSERM : U970 \\ 56 rue Leblanc 75015 Paris, France \\ ${ }^{3}$ Paris-Centre de Recherche Cardiovasculaire (PARCC) - Université Paris Descartes - Paris 5 : U970, INSERM : \\ U970 - 56 rue Leblanc 75015 Paris, France \\ ${ }^{4}$ Paris-Centre de Recherche Cardiovasculaire (PARCC) - Hôpital Européen Georges Pompidou [APHP] : U970, \\ Université Paris Descartes - Paris 5 : U970, INSERM : U970 - 56 rue Leblanc 75015 Paris, France
}

Product Lifecycle Management (PLM) was developed to provide collaborative, secure, and reliable tools for industrial manufacturing. It provides traceability, versioning, access rights and data integrity to complex data, originating from multiple, geographically distributed sources, in multiple formats.

SWOMed is a biomedical PLM system developed during the interdisciplinary research project BIOMIST (ANR-13-CORD-0007) It provides a collaborative framework for biomedical data lifecycle management, with a focus on cohort imaging and human cognitive neuroscience studies (Allanic, M. et al., Front. ICT $3,35,2017)$.

In the context of the DRIVE-SPC research project, an extension of SWOMed is being developed in order to support and integrate complex preclinical imaging, biological and omics data, including proteomics. DRIVE-SPC needs to handle a wider range of data types, including different modalities of in vivo (PET, CT, ultrasound) and in vitro (histology, immunohistochemistry, western blotting...) imaging modalities, proteomics (Mass spectrometry), transcriptomics (qRT-PCR) and metabolomics (processed using Metexplore). All related to small groups $(n=5-10)$ of laboratory animals undergoing different pharmacological treatments.

In this presentation, we will describe how proteomics data are integrated in the SWOMed framework, together with other biomedical data, and how we ensure its provenance, processing and management. First, data are curated, following the FAIR (Findable, Accessible, Interoperable, Reusible) guidelines (Wilkinson, M. D. et al., Sci. Data 3, 160018 (2016)), with the use of proteomics standards and domain ontologies so as to guarantee interoperability with other data sources (e.g. biosharing.org). Then, we show that proteomics data can be integrated into the SWOMed framework, using data from a study exploring the cardiotoxicity of an anti-angiogenic anticancer treatment in mice (Sourdon, J. et al., Theranostics, in press). In addition, proteomics data are mediated with other modalities, and processed using multiple workflows while maintaining end-to-end traceability.

Mots-Clés : Data integration, Data management, Data processing, Provenance, Ontologies

\footnotetext{
*Intervenant

${ }^{\dagger}$ Auteur correspondant: amel.raboudi@inserm.fr
} 


\title{
Workflow4Metabolomics : new services and contributions for the metabolomics community [P43]
}

\author{
Yann Guitton ${ }^{*}$, Cécile Canlet $^{2}$, Alexis Delabriere ${ }^{3}$, Christophe Duperier ${ }^{4}$, \\ Franck Giacomoni ${ }^{4}$, Gildas Le Corguillé ${ }^{5}$, Natacha Lenuzza ${ }^{3}$, Jean-Francois \\ Martin ${ }^{2}$, Pierrick Roger-Mele ${ }^{3}$, Mélanie Pétéra ${ }^{4}$, Etienne Thévenot ${ }^{3}$, Marie \\ Tremblay-Franco ${ }^{2}$, Christophe Caron ${ }^{\dagger} 6$ \\ ${ }^{1}$ Oniris, Laboratoire d'Etude des Résidus et Contaminants dans les Aliments (LABERCA), - Université Nantes Angers Le Mans - Nantes \\ 2 INRA Toxalim Axiom MetaToul MetaboHUB - Université de Toulouse - INRA : UMR1331, INRA : UMR1331 - 180 chemin de \\ Tournefeuille 31027 Toulouse, France \\ ${ }^{3}$ CEA, LIST, Laboratory for Data Analysis and Systems' Intelligence, MetaboHUB - F-91191 Gif-sur-Yvette, France \\ ${ }^{4}$ UMR1019 - MetaboHUB - PFEM - INRA - 63122, Saint Genes Champanelle, France \\ ${ }^{5}$ FR2424, ABiMS, Station Biologique - UPMC et CNRS - 29680, Roscoff, France \\ ${ }^{6}$ Institut Français de Bioinformatique - INRA - IFB, 1 avenue de la Terrasse, 91198 Gif-sur-Yvette, France
}

Metabolomics data analysis is a complex, multistep process, which is constantly evolving with the development of new analytical technologies, mathematical methods, and bioinformatics tools and databases. The Workflow4Metabolomics reference platform (workflow4metabolomics.org) provides an on-line, user-friendly and collaborative environment to build, run and share analysis workflows for the Metabolomics community. The Workflow4Metabolomics (W4M) Core Team aims to develop full pipelines using Galaxy framework for data analysis including preprocessing, normalization, quality control, statistical analysis and annotation steps to cover the main technologies: LC/MS, GC/MS, FIA/MS and NMR. In addition to providing expert and reference workflows, the W4M infrastructure is fully open to community contributions. These contributions should take different forms: i) a complete integration, including standardized input/output formats or ii) a showcase for external developers as a functional version of a tool publicly available on the platform. The W4M Core Team provides also annual training courses with tutored session to help each participant to analyze their own dataset.

Meanwhile, we foster the current version by developing new services. First of all, we continuously add new tools to expand data processing, analysis, and annotation possibilities. In addition to our Workflow4Experimenters courses focusing on tutoring, we aim to develop online training sessions using new e-Learning technologies. To this end, we are building in particular a "Metabolomics and Bioinformatics Open Course" on data analysis with W4M. Ongoing development projects include visualization components to converge with proteomics tools and community.

Finally, we are going to develop collaboration with other national and international infrastructures (ELIXIR, Phenomenal...). These collaborations bring to W4M more complete workflows, scientific visibility and offers long term sustainability. Workflow4Metabolomics thus not only offers a unified, evolving environment for metabolomics data analysis, but also should become the reference repository for shared workflows.

Mots-Clés : workflow, metabolomics, galaxy, statistics, analysis

\footnotetext{
*Intervenant

${ }^{\dagger}$ Auteur correspondant: christophe.caron@inra.fr
} 


\title{
Leading tool: a "proteinGroups.txt" post-processing file to highlight representative 'leading" proteins among protein groups [P44]
}

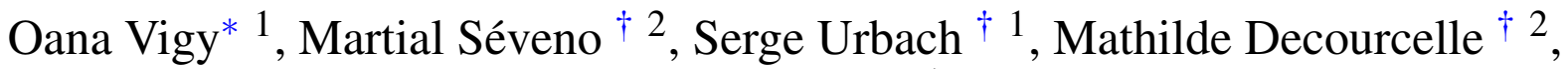 \\ Philippe Marin ${ }^{1}$ \\ ${ }^{1}$ Functional Proteomics Platform (FPP) - CNRS : UMR5203 - c/o Institut de Génomique Fonctionnelle (IGF), \\ CNRS, INSERM, Univ. Montpellier, F-34094 Montpellier, France \\ ${ }^{2}$ Functional Proteomics Platform (FPP) - CNRS : UMS3426 BioCampus - c/o Institut de Génomique \\ Fonctionnelle (IGF), CNRS, INSERM, Univ. Montpellier, F-34094 Montpellier, France
}

The MaxQuant software generates several output files that contain information about identified and quantified peptides and proteins. The "proteinGroups.txt" file is dedicated to identified proteins: each single row collapses into protein groups, all proteins that cannot be distinguished based on the identified peptides.

Starting from our first use of MaxQuant in 2009, questions were about "how to obtain a list of identified proteins as less redundant as possible to perform further analysis", in other words, "which protein should be kept from its protein group?".

To address this issue, we have developed an in-house bioinformatics tool that allows automatic selection of a representative protein ID in each protein group - based on the following criteria:

- first, proteins with the most numerous identified peptides are isolated in a so called "match group" (proteins from the "Protein IDs" column with the maximum number of "peptides counts (all)").

- the "leading" protein is then defined as the best annotated protein. As we perform MaxQuant analysis mainly with UniProtKB databases, manually reviewed proteins are picked, i.e. SwissProt entries rather than TrEMBL ones.

Particular cases (reverse, contaminants, isoforms, etc.) are also handled.

This tool automatically detects the leading protein in the majority of protein groups. Remaining cases wherein several proteins cannot be automatically distinguished are compiled and enriched with additional annotations to help the end-user in choosing the more representative protein.

The "leading" tool, developed in Perl-CGI, has been improved over the past years to facilitate the post-treatment of "proteinGroups" files and to provide users a simple and friendly graphical interface (HTML5/CSS3) that allows data and log file exports. Leading proteins obtained with this tool can then be used for data analysis and merging in Perseus.

Further developments are planned to better manage multi-species analysis.

Mots-Clés : MaxQuant, Postprocessing, Match group, UniProtKB, Bioinformatics

\footnotetext{
*Auteur correspondant: oana.vigy@fpp.cnrs.fr

$\dagger$ Intervenant
} 


\section{Imagerie in vitro et in vivo [P45-P50]}




\title{
A new image of cereal cell walls provided by MALDI MS imaging [P45]
}

\author{
Fanuel Mathieu * 1, David Ropartz ${ }^{1}$, Dusan Velickovic ${ }^{2}$, Luc Saulnier ${ }^{1}$, \\ Fabienne Guillon ${ }^{1}$, Hélène Rogniaux ${ }_{-}^{\dagger}$ \\ ${ }^{1}$ Unité de recherche sur les Biopolymères, Interactions Assemblages (BIA) - INRA : UR1268 - F-44316 \\ NANTES, France \\ ${ }^{2}$ Current position: Pacific Northwest National Laboratory - Richland, Washington 99352, États-Unis
}

Although cell walls in wheat grain endosperm account only for 2-4\% of dry weight, they have a significant effect on grain end-uses (milling, baking, brewing, animal feeding, biofuel production, etc.). The two main wall components in the wheat grain endosperm are arabinoxylans (AX) and $\beta$-glucans (BG) (1). Because the variability of $\mathrm{AX}$ and $\mathrm{BG}$ in composition plays a significant role into the functional properties of the wheat grain, it is of deep interest to get better insight into the occurrence and spatial distribution of these biopolymers across the endosperm. This needs to couple chemical information to spatial information, and techniques which are until now used for this purpose are either time consuming or require appropriate antibody for each polysaccharide feature (2). Imaging by MS (MSI) provides a means of resolving, in intact tissue sections, both the spatial distribution of molecules and their molecular structure without the need of any specific probe (3).

In this work, we thus used MSI for analysing distribution and chemical variability of AX and BG in cross sections of wheat endosperm (Triticum aestivum). Samples were treated with appropriate enzymes and after that coated with a generic and efficient matrix for rapid and automated detection of released oligosaccharides $(4,5)$. Recently, we attempted 3D reconstruction of AX signals. From successive cross sections, the 3D visualization allows to obtain an overall and simultaneous view of the distribution of the walls polymers along both transversal and longitudinal axes of the wheat grain.

(1) Saulnier L. et al. J Cereal Sci., 50, 312-317 (2009).

(2) Burton, R. et al. Front Plant Sci. 2014, 5.

(3) Spengler, B. Anal. Chem. 2015, 87, (1), 64-82.

(4) Velickovic, D. et al. J Exp Bot 2014, 65, (8), 2079-91.

(5) Velickovic, D. et al. J. Agric. Food Chem 2016, 64, (32), 6249-56.

Mots-Clés : MALDI imaging, biopolymers, cereal cell walls

$\underline{\text { Programme }}$

\footnotetext{
${ }^{*}$ Intervenant

${ }^{\dagger}$ Auteur correspondant: Helene.rogniaux@inra.fr
} 


\title{
2.5 D whole sheep brain representation combining in vivo 3D Magnetic Resonance Imaging and ex vivo 2D Mass Spectrometry Imaging and lipidomic in selective areas [P46]
}

\author{
Valérie Labas ${ }^{* \dagger}{ }^{1}$, Ana-Paula Teixeira-Gomes ${ }^{2}$, Richard Eloy ${ }^{1}$, Charles \\ Banliat ${ }^{1}$, Lucie Combes-Soia ${ }^{1}$, Frédéric Andersson ${ }^{3}$, Martine Batailler ${ }^{4}$, \\ Hans Adriaensen ${ }^{5}$, Martine Migaud ${ }^{4}$, Elodie Chaillou ${ }^{4}$

\footnotetext{
${ }^{1}$ Plate-forme CIRE (Chirurgie-Imagerie-Recherche-Enseignement)-Pôle d'Analyse et d'Imagerie des Biomolécules (PAIB) (PAIB-CIRE) INRA, CNRS : UMR7247, Université François Rabelais - Tours, Institut Francais du Cheval et de l'Equitation - Centre de Recherches INRA de Nouzilly 37380 Nouzilly, France

2 Plate-forme CIRE (Chirurgie-Imagerie-Recherche-Enseignement)-Pôle d'Analyse et d'Imagerie des Biomolécules (PAIB) (CIRE-PAIB) INRA UMR 1282 Infectiologie et Santé Publique, France

${ }^{3}$ INSERM U930 Imagerie et Cerveau (INSERM U930) - INSERM : U930 - Université François Rabelais de Tours, F-37000 Tours, France

${ }^{4}$ UMR Physiologie de la Reproduction et des Comportements (PRC) - INRA : UMR85, CNRS : UMR7247, Université François Rabelais Tours, Institut Français du Cheval et de lÉquitation [Saumur] - Centre INRA Val de Loire, 37380 Nouzilly, France

${ }^{5}$ Plate-forme CIRE (Chirurgie-Imagerie-Recherche-Enseignement) (CIRE) - INRA, CNRS : UMR7247, Université François Rabelais -
} \\ Tours, Institut Francais du Cheval et de l'Equitation - Centre de Recherches INRA de Nouzilly 37380 Nouzilly, France
}

Sheep is a relevant model in neurosciences because its brain is large and highly circumvoluted with a cortical organization close to those of human. This conceives the sheep brain as a model of choice to explore the molecular distribution of lipids throughout it. In order to view the topology of the biomolecules in the sheep brain, we combined in vivo 3D Magnetic Resonance Imaging (MRI) and ex vivo 2D Mass Spectrometry Imaging (MSI). From the resulting 2.5 D representation of a sagittal MSI-image realigned on the 3D T1-weighted image, we localized 7 Regions Of Interest (ROI): cortical white/grey matters, corpus callosum, fimbria, cerebellum white matter, hippocampus, pineal gland. To achieve a large descriptive analysis of sheep brain, we performed MSI in positive and negative ion modes using CHCA and DHB matrices. From the whole sections and ROIs, $504 \mathrm{~m} / \mathrm{z}$ (non-redundant) were detected. In order to increase our inventory in the ROIs, qualitative analysis were performed using LESA and TLC-MALDI MS. Thus, we showed that lipid separations provided a more complete coverage of the molecular species possibly observed by MALDI ( $749 \mathrm{~m} / \mathrm{z} \mathrm{nr}$ ). In order to identify the major lipids, after macro-dissection of ROIs and lipid extraction from tissues, the samples were directly infused into a high-resolution mass spectrometer, analysed by spectral stitching in positive and negative ion mode and fragmented by HCD. Thus, a total of $1391(+)$ and $1327(-) \mathrm{m} / \mathrm{z}$ were detected and $181 \mathrm{~m} / \mathrm{z}$ were already identified as glycerophospholipids, sphingolipids, sterol lipids and fatty acyls. In this work, we showed, for the first time, that 2.5D lipid cartography in an entire mammalian brain combined to global/targeted lipidomic can yield enormous information around the occurrence of specific lipids in cerebral regions which could be used for neuroscience studies.

Mots-Clés : IRM, MSI, whole brain sheep, lipidomic

\footnotetext{
*Intervenant

${ }^{\dagger}$ Auteur correspondant: valerie.labas@inra.fr
} 


\title{
Muscle Mass Spectrometry Imaging for myofiber metabolic type determination [P47]
}

\author{
Laetitia Theron ${ }^{* \dagger}{ }^{1}$, Delphine Centeno, Annie Vénien, Estelle Pujos-Guillot, \\ Thierry Astruc, Christophe Chambon \\ ${ }^{1}$ Plateforme d'Exploration du Métabolisme, MetaboHUB Clermont (PFEM) - Université Clermont Auvergne, \\ INRA UNH, F-63000 Clermont-Ferrand, France
}

In muscle imaging, myofiber type determination is of great importance to better understand biological mechanisms related to skeletal muscle changes associated with pathologies. However, reference methods (histo-enzymology and immunohistochemistry) require serial-cross sections, and several days from the sampling to the results of image analysis. In this work, a strategy based on MALDI-Mass Spectrometry Imaging was developed as an alternative to the classical methods for myofiber metabolic type determination.

The spectra were acquired on an Autoflex Speed MALDI-TOF/TOF mass spectrometer with a Smartbeam laser (Bruker Daltonics) in positive linear mode at a mass range of $\mathrm{m} / \mathrm{z} 2,000-20,000$ and a rastering of $100 \mu \mathrm{m}$. Spectra were baseline-subtracted, smoothed and peak picking was applied to the TIC spectra. The different tissue classes were determined so that every myofiber was correctly assigned: oxidative (OM) versus glycolytic metabolic (GM) type myofibers, accordingly to the immunofluorescence typology. A predictive model was then built in SCILS Lab software to discriminate the metabolic myofiber types using the MALDI spectral data, and used to classify spectral data acquired on tibialis muscle sections (intermediate metabolism).

The performance of the model was evaluated through the percentage of correct assignment into each myofiber metabolic type class (internal validation of 96\%). Myofiber type determination using MALDI-MSI tibialis spectra revealed that $11 \%$ of the myofibers belonged to the OM class and $89 \%$ of the myofibers belonged to the GM one. The successful classification of MALDI spectra acquired on tibialis muscle section was confirmed since the myofiber type determination using immunohistofluorescence showed that $9 \%$ of the myofibers belonged to the OM class and $91 \%$ of the myofibers belonged to the GM one.

This approach can be successfully applied to any organisms, to perform both MALDI-MSI of proteins and myofiber type determination, saving considerable time and expenses.

Accepted for publication in JMS

Mots-Clés : Imagerie, Modèle prédictif, Muscle

Programme

\footnotetext{
*Intervenant

${ }^{\dagger}$ Auteur correspondant: laetitiathrn@gmail.com
} 


\title{
Biomarker Monitoring by Quantitative MALDI Imaging: Application to the Tryptophan-Kynurenine Pathway in Immuno-Oncology [P48]
}

\author{
Edma Fontaine , Mathieu Gaudin $* \dagger 1$, Rima Ait-Belkacem ${ }^{\ddagger 1}$, Vanesa Bol ${ }^{2}$, \\ Bruno Gomes ${ }^{2}$, Gregory Hamm ${ }^{1}$, Jonathan Stauber ${ }^{1}$ \\ ${ }^{1}$ ImaBiotech - ImaBiotech - 885 avenue eugene avinée, France \\ 2 iTeos Therapeutics SA - Gosselies, Belgique
}

\begin{abstract}
Tryptophan (Trp) is an amino acid for cell proliferation and survival that is metabolized through different pathways, a major route being the kynurenine (Kyn) pathway. The first, rate-limiting enzyme is the indoleamine-2,3-dioxygenase 1 (IDO1); an endogenous molecular mechanism of immune suppression. Inhibition of T-cell functions, activation of its regulatory, and inhibition of Natural Killer cells are among the important immunosuppressive effects of IDO1. IDO1 is proposed to have a therapeutic potential in immunodeficiency-associated abnormalities, including cancer. The standard quantification methods are based on the total level of Tryptophan and its metabolites determined by LC-MS/MS in plasma and tumors. We describe the setup and application of a MSI method to localize and quantify Tryptophan and Kynurenine in the microenvironment of tumors. This method allows both the study of the sub-tissular localization and the detection/quantitation of metabolites of interest in tumor tissues. An experimental tumor model overexpressing IDO1 and its wild-type counterpart were implanted in mice. Tissue sections of different tumors were realized and used for MSI analysis. MALDI FTICR high resolution imaging followed by data analysis enabled an absolute on tissue quantitation. Internal standards of tryptophan and kynurenine metabolites were used for normalization. Results showed an increase of Kyn in parallel to a decrease of Trp amount in IDO1-positive tumors. Immunostainings of IDO1 and Trpdepletion sensor (GCN2) pathways were carried. Overlaying images between the immunostainings and the molecular MS images allowed co-localization studies and underlined both the biology and the tumor heterogeneity. This allowed us to highlight key metabolites of the Trp pathway that are responsible for the immunosuppressive tumor microenvironment. The development of immunotherapies such as IDO1 inhibitors requires a deep understanding of the interplay between the immune system and cancer cells, these immune endogenous metabolites can now be followed by quantitative imaging and as biomarkers towards enhancing immunotherapies efficiency.
\end{abstract}

Mots-Clés : Oncology Mass spec Imagingg

Programme

\footnotetext{
*Intervenant

†Auteur correspondant: gaudin.mathieu@imabiotech.com

†Auteur correspondant: ait-belkacem.rima@imabiotech.com
} 


\title{
Mass spectrometry imaging: a game changer in the pharmaceutical industry [P49]
}

\author{
Edma Fontaine ${ }^{1}$, Mathieu Gaudin ${ }_{-}^{*}{ }^{1}$, David Bonnel ${ }_{-}^{\dagger}{ }^{1}$, Jonathan Stauber ${ }^{1}$ \\ ${ }^{1}$ ImaBioteh - ImaBiotech - 885 avenue eugene avinée, France
}

Developing a drug requires to demonstrate its efficacy in preclinical and clinical studies but also to characterize its pharmacokinetic properties. Among them, absorption, distribution, metabolism and elimination benefit from the more and more widespread use of MALDI Mass Spectrometry Imaging in the pharmaceutical industry.

If Quantitative Whole-Body Autoradiography is still a gold standard to support the design of radiolabelled clinical studies, its lack of molecular specificity limits the understanding of the distribution of the drug and its metabolites. On the contrary, the use of high resolution mass spectrometers such as FT-ICR MS allows a quantitative characterization of the metabolic profile of the drug at the tissue level in order to further understand its behaviour in the organism.

As Mass Spectrometry Imaging does not require the long and costly synthesis of a radiolabelled drug, this label-free technique offers a unique opportunity to gain information about the drug and metabolite distribution in the earliest stages of research, making distribution a new tool for target validation or drug selection.

Quantitative MSI allows pharmaceutical researchers to understand quickly drug pharmacokinetics at the tissue level and not only at the blood level, but also contributes to the mechanistic characterization of the drug by imaging at the same time the distribution of potential endogenous biomarkers supporting target engagement and PK/PD studies.

There is no restriction in term of sample and QMSI can be applied in almost all therapeutic fileds. Oncology, neurology or dermatology are among the most promising areas where MSI has demonstrated its game changing place.

In this communication, we propose to illustrate the potential of MALDI-FT-ICR MSI associated to dedicated Multimaging software solution to understand target engagement, efficacy, toxicity or drug formulation selection.

Mots-Clés : mass spectrometry imaging, $\mathrm{PK} / \mathrm{PD}$, toxicity

$\underline{\text { Programme }}$

\footnotetext{
*Intervenant

†Auteur correspondant: bonnel.david@imabiotech.com
} 


\title{
Label-free multimodal imaging for biological applications: toward a molecular investigation without a priori [P50]
}

\author{
Nicolas Desbenoit ${ }^{* \dagger}{ }^{1}$, Rico Scheier ${ }^{2}$, Martin Loeder ${ }^{3}$, Heiner Schmidt ${ }^{2}$, \\ Andreas Roempp ${ }^{2}$, Marc Bonneu ${ }^{1}$, Jean-Marie Schmitter ${ }^{1}$ \\ ${ }^{1}$ CBMN, Université de Bordeaux - CNRS : UMR5248 - CGFB, 146 rue Leo Saignat, \\ 33076 Bordeaux Cedex, France \\ ${ }^{2}$ University of Bayreuth, Chair of Bioanalytical Sciences and Food Analysis \\ 95326 Kulmbach, Allemagne \\ ${ }^{3}$ University of Bayreuth, Chair of Animal Ecology I \\ 95440 Bayreuth, Allemagne
}

\begin{abstract}
Nowadays, in a public health context, multimodal imaging becomes an emerging strategy. Such an approach is required to elucidate the complex spatial distribution of biomolecules in tissues, to collect complementary structure information, as well as to compensate for the limitations of each imaging technique. For this purpose, the promising combination of vibrational spectroscopies such as FourierTransformed Infra-Red (FTIR), and Raman, with mass spectrometry based on Matrix-Assisted Laser Desorption/Ionization (MALDI) opens the way for a molecular view of the anatomical structure of biological tissues. These label-free techniques provide access without $a$ priori to the spatial distribution of a wide range of biomolecules directly from thin sections of tissues in a single run, and to the evaluation of subtle biochemical changes within these tissues. With a spatial resolution limited only by the diffraction limit, FTIR and Raman allow characterizing the overall distribution of lipids, and of biomolecules difficult to identify via other spectroscopic methods, such as carbohydrates and proteins. Besides, MALDI mass spectrometry can readily identify the structure of imaged molecular species. Combining these imaging methodologies is highly beneficial only if datasets from different imaging platforms can be correlated. For this purpose, data have to be converted to a common format file, called "imzML", and displayed using a unique software with identical settings for visualization. The consistency of the strategy makes it a powerful and very promising tool to understand the molecular complexity of tissue section.
\end{abstract}

Mots-Clés : Multimodal Imaging, MALDI, MS, FT, IR, Raman.

$\underline{\text { Programme }}$

\footnotetext{
*Intervenant

${ }^{\dagger}$ Auteur correspondant: n.desbenoit@ cbmn.u-bordeaux.fr
} 


\section{Environnement [P51-P66]}




\title{
La dynamique quotidienne des polluants émergents en amont de station d'épuration par UHPLC/MRM [P51]
}

\author{
Laëtitia Fougere $^{* 1}$, Thomas Thiebault ${ }^{2}$, Maxime Rety ${ }^{2}$, Jérémy Jacob ${ }^{2}$, \\ Cédric Morio ${ }^{3}$, Emilie Destandau ${ }^{1}$ \\ ${ }^{1}$ Institut de Chimie Organique et Analytique (ICOA) - CNRS : UMR7311, Université d'Orléans - F-45067 \\ Orléans, France \\ 2 ISTO - CNRS : UMR7327, INSU, Université d'Orléans, BRGM, INSU - Orléans, France \\ ${ }^{3}$ Aménagement et développement durable - Direction du cycle de l'eau et de l'énergie \\ Exploitation, Orléans, France
}

Depuis 1950 nous sommes entrés dans l'anthropocène, époque marquée par l'activité de l'homme qui a un impact significatif sur l'écosystème. Un de ces effets est la présence de polluants émergents (drogues illicites ou composés pharmaceutiques) dans les eaux. L'étude développée vise à évaluer s'il existe une corrélation entre l'évolution du métabolisme urbain et le monitoring des flux de polluants dans les réseaux d'assainissement. Ceci permettrait de d'évaluer l'impact sociétal sur l'environnement et plus particulièrement sur les eaux usées afin de pouvoir mettre en place des procédés de traitement mieux adaptés à notre époque comme l'incite la directive Cadre sur l'Eau.

Dans ce cadre, des eaux usées ont été automatiquement collectées sur 24h à l'entrée d'une STEP de 90000 habitants quotidiennement pendant 85 jours consécutifs. Les composés ont été concentrés par SPE avant quantification par UHPLC/MRM. Ainsi une cinquantaine de polluants et leurs métabolites ont été suivis. Les concentrations ont été converties en charges de masse par population équivalente, en fonction du débit, de la partition solide/liquide et du taux d'excrétion des résidus cibles.

Les estimations de la consommation journalière de produits pharmaceutiques avec notre approche sont en accord avec la littérature. De plus, les ratios d'antibiotiques co-consommés comme le sulfaméthoxazole et le triméthoprime sont constants au cours de l'étude et permettent des estimations similaires pour leur consommation. Il peut être mis en évidence des voies de transformations des drogues durant le trajet consommation-collecte. Cette étude a également permis de suivre des logiques journalières et évènementielles de la consommation. Ainsi la distinction semaine/week-end est exprimée pour la cocaïne et l'ecstasy, tandis que les taux de carbamazépine sont constants.

Notre étude révèle que la surveillance des produits pharmaceutiques et des drogues illicites dans les eaux usées peut apporter des informations sur l'évolution des pratiques de consommation dans les zones urbaines.

Mots-Clés : Drogues illicites, composés pharmaceutiques, UHPLC/MRM, Eaux usées

Programme

\footnotetext{
${ }^{*}$ Intervenant
} 


\title{
Profils isoprostanoiques de mollusques lamellibranches marins exposés à un contaminant émergeant, le diclofénac [P52]
}

\author{
Vigor Claire ${ }^{* \dagger}{ }^{1}$, Grégoire Debise ${ }^{1}$, Bénilde Bonnefille ${ }^{2}$, Guillaume \\ Reversat ${ }^{1}$, Amandine Rocher ${ }^{1}$, Camille Oger ${ }^{1}$, Jean-Marie Galano ${ }^{1}$, Joseph \\ Vercauteren ${ }^{1}$, Thierry Durand ${ }^{1}$, Frédérique Courant ${ }^{2}$ \\ ${ }^{1}$ Institut des Biomolécules Max Mousseron [Pôle Chimie Balard] (IBMM) - CNRS : UMR5247, Université de \\ Montpellier, Ecole Nationale Supérieure de Chimie de Montpellier - Faculté de Pharmacie - 15 Av. Charles \\ Flahault - BP 14491 - 34093 Montpellier Cedex 5, France \\ ${ }^{2}$ Hydrosciences Montpellier (HSM) - Institut de Recherche pour le Développement, Université Montpellier 2 - \\ Sciences et Techniques, Université de Montpellier, CNRS : UMR5569 - Département Sciences de \\ l'Environnement et Santé Publique, UMR Hydrosciences, Faculté de pharmacie 15, Avenue Charles Flahault \\ 34060 Montpellier cedex 2 - France
}

Contexte : Les mollusques lamellibranches marins présentent une aptitude extrême à accumuler les contaminants environnementaux. Nous savons par ailleurs que la production d'espèces réactives de l'oxygène peut être stimulée par les contaminants du milieu aquatique. L'objectif de notre étude est de faire la preuve de l'intérêt des métabolites oxygénés non enzymatiques des acides gras poly-insaturées (AGPIs) comme marqueurs de pollution environnementale dans un modèle, la moule méditerranéenne.

Etude expérimentale : A partir de mollusques Mytilus galloprovincialis, nettoyés puis acclimatés pendant 7 jours dans des bassins, sont formés 3 groupes de 15 individus: 1 groupe contrôle, 1 groupe exposé à 1 microg.L-1de Diclofénac, 1 groupe à 100 microg.L-1 de Diclofénac. Après 7 jours, les individus sont disséqués, les glandes digestives ainsi que les branchies sont prélevées, le tissu restant est congelé, lyophilisé puis broyé. Ce dernier constitue la matrice support de l'étude. Après avoir comparé puis développé une méthode efficace d'extraction et de pré-concentration des métabolites d'intérêts, une analyse chromatographie liquide couplée à la spectrométrie de masse (LC-Q-Trap) par suivi MRM est menée sur ces derniers.

Résultats préliminaires : 27 isoprostanoides ont été détectés pour la première fois dans la moule méditerranée, dont 6 phytoprostanes, 3 phytofuranes, 9 isoprostanes, 2 isofuranes et 7 neuroprostanes. La concentration en ces métabolites, à l'état basal, varie de 9 pg.g-1 à 5532 pg. g-1. Dans le cas d'une exposition au Diclofénac à 100 microg.L-1, une augmentation de la teneur de 12 d'entre eux a été observée. Les augmentations les plus notables concernent majoritairement les IsoPs (7 des 9) avec notamment la 5F3t-IsoP pour laquelle la teneur augmente de $41 \%$. Ainsi, une exposition forte au Diclofénac induit une modification quantitative du profil en métabolites oxygénés des AGPI. Le modèle expérimental (moule + dosage des isoprostanoides) semble répondre positivement à la problématique environnementale posée.

Mots-Clés : Mytilus galloprovincialis, contaminant émergeants, diclofénac, isoprostanoides

$\underline{\text { Programme }}$

\footnotetext{
* Intervenant

${ }^{\dagger}$ Auteur correspondant: claire.vigor@umontpellier.fr
} 


\title{
Metabolomic and proteomic investigations of impacts of titanium dioxide nanoparticles on Escherichia coli [P53]
}

\author{
Gaspard Huber* 1, Mariane Planchon ${ }^{1}$, Olivier Spalla ${ }^{1}$, Thibaut Leger ${ }^{2}$, \\ Roselyne Ferrari ${ }^{\dagger} 3$
}

\begin{abstract}
${ }^{1}$ Nanosciences et Innovation pour les Matériaux, la Biomédecine et l'Énergie (NIMBE) - Commissariat à l'énergie atomique et aux énergies alternatives, Université Paris-Saclay, Centre National de la Recherche Scientifique - NIMBE, CEA, CNRS, Université Paris-Saclay, CEA Saclay 91190 Gif sur Yvette, France

${ }^{2}$ Institut Jacques Monod - CNRS : UMR7592, Université Paris Diderot - Paris 7 : UMR7592 - Plateforme Protéomique Structurale et Fonctionnelle Institut Jacques Monod - CNRS et Université Paris-Diderot Bâtiment Buffon - AileB -piece 657B- 6ème étage 15, rue Hélène Brion 75205 PARIS cedex 13, France

${ }^{3}$ Laboratoire Interdisciplinaire des Energies de Demain (LIED) - Université Paris Diderot - Paris 7 : UMR8236, CNRS : UMR8236, 11 rue Alice Domon et Léonie Duquet Bât. Condorcet, case postale 7040, 75205 Paris cedex 13, France
\end{abstract}

The ecotoxicological impact of manufactured titanium oxide (TiO2) on Escherichia coli in a natural environmental medium, Seine River water, has been established through colony-forming unit technique and is closely related to the presence of little aggregates. Proteomic analyses by mass spectrometry and metabolomic analyses by NMR have been performed on water extracts. The influence of $\mathrm{TiO} 2$ concentration and ultraviolet irradiation on metabolomic profiles has been investigated. Processing metabolomics through Principal Components Analysis, together with an original method for processing proteomics data, revealed the up-regulation of proteins and the increase of fraction of metabolites related to energy and growth metabolism while other proteins are down-regulated and the fraction of other metabolites decreases. Moreover, the ATP content gradually rises in relation with the nano-TiO2 concentration in the medium, indicating a dramatic release of ATP by the damaged cells. These apparently contradictory results accredit the thesis of a heterogeneity of the bacterial population. This heterogeneity is also confirmed by Scanning Electron Microscopy images which show that while some bacteria are fully covered by nano-TiO2, the major part of the bacterial population remains free from nanoparticles, resulting in a difference of proteome and metabolome. The poster will particularly focus on the methodology used for metabolomics.

Mots-Clés : metabolomics, proteomics, TiO2 Nanoparticles, Escherichia coli, nuclear magnetic resonance, mass spectrometry

Programme

\footnotetext{
${ }^{*}$ Intervenant

${ }^{\dagger}$ Auteur correspondant: roselyne.ferrari@gmail.com
} 


\title{
Analysis of perfluorocarbons compounds (PFCs), potent greenhouses gases by action spectroscopy [P54]
}

\author{
Suzie Douix ${ }^{* \dagger}{ }^{1}$, Héloïse Dossmann ${ }_{-}^{\ddagger 2}$, Laurent Nahon ${ }_{-}^{\S}$, Alexandre \\ Giulianit 1 \\ ${ }^{1}$ Synchrotron SOLEIL (SOLEIL) - CNRS : UMRUR1 - L'Orme des Merisiers Saint-Aubin - BP 4891192 \\ Gif-sur-Yvette cedex, France \\ ${ }^{2}$ Institut Parisien de Chimie Moléculaire (IPCM) - CNRS : UMR7201, Université Pierre et Marie Curie - Paris \\ VI - F 75252 Paris Cedex 05, France
}

Perfluorocarbons (PFCs) are potent greenhouse gases and possess extremely long lifetimes. They have been manufactured for 50 years.

The atmospheric removal processes and their atmospheric lifetimes are presently not well understood. Indeed, these molecules are not volatile enough to be probed by the usual gas phase spectroscopic methods and very little information is available about their absorption spectroscopy.

Our main objective in this project is to gain insight into spectroscopic properties of these pollutants using ion action spectroscopy in the UV range.

A novel experimental technique for tandem mass spectrometry and ion spectroscopy of electrosprayed ions using vacuum-ultraviolet (VUV) synchrotron radiation has been used on the perfluorooctane carboxylic acid (PFOA). This compound is widely dispersed in the environment, and has been found to be one of the final compounds of degradation of the majority of PFCs.

Experiments of photo activation have been done in the VUV range (6 to $12 \mathrm{eV}$ ). This energy domain permits to study excited states of molecular ions up to his fragmentation threshold, and thus to study photo-induced processes in a layer of valence. Moreover, this is the region of interest for atmospheric chemistry.

Photodissociation experiments have been done and have revealed abundant fragments, which are specifics to the PFOA form, and provided information on the channel fragmentation. Photodissociation is an important atmospheric removal process for many ozone depleting substances (ODSs) and halogenated degradation products, and depends of the absorption.

A recently developed procedure to determine absolute cross section has been applied and absolute differential oscillator strengths have been derived for each individual fragmentation channels. Specific absorption features are reported and their origins are discussed.

These experiments provide information about the photo stability of the PFOA compound in relation with its atmospheric lifetime and photo degradation.

Mots-Clés : Ion, spectroscopy, absorption, gas phase, mass spectrometry, photo activation, photodissociation: cross section, atmisphere

\footnotetext{
*Intervenant

†Auteur correspondant: suzie.douix @ synchrotron-soleil.fr

† Auteur correspondant: heloise.dossmann@upmc.fr

$\S$ Auteur correspondant: laurent.nahon@ synchrotron-soleil.fr

IIAuteur correspondant: alexandre.giuliani@synchrotron-soleil.fr
} 


\title{
Toxicologie des contaminants émergents : étude du métabolisme in vitro et de la modulation du métabolome des cellules hépatiques HepaRG par les bisphénols A chlorés [P55]
}

\author{
Nicolas Cabaton $*{ }^{*}$, Cécile Canlet ${ }^{* 2}$, Marie Tremblay-Franco ${ }^{2}$, Roselyne \\ Gautier $^{2}$, Elisabeth Perdu ${ }^{2}$, Daniel Zalko ${ }^{1}$ \\ ${ }^{1}$ INRA Toxalim - Université de Toulouse (Research Centre in Food Toxicology) - INRA : UMR1331 - 180 \\ chemin de Tournefeuille 31027 Toulouse, France \\ ${ }^{2}$ INRA Toxalim Axiom MetaToul MetaboHUB - Université de Toulouse (Research Centre in Food Toxicology) - \\ INRA : UMR1331 - 180 chemin de Tournefeuille 31027 Toulouse, France
}

Les bisphénols halogénés suscitent aujourd'hui un questionnement sociétal en toxicologie environnementale et alimentaire. La présence d'analogues halogénés du BPA, perturbateur endocrinien (PE) modèle, dans l'environnement et dans l'alimentation, en particulier les produits de la mer, ont déjà été rapportée dans plusieurs publications et certains de ces bisphénols ont été détectés dans le sang et le tissu adipeux de femmes, ainsi que dans le placenta. Parmi ces analogues structuraux chlorés du BPA, le tétrachloro-bisphenol A (TCBPA) est produit à raison de 10000 t/an. Ce niveau de production n'explique peut-être pas à lui seul la présence des bisphénols chlorés dans l'environnement, ni la contamination humaine. Il est bien plus probable que la mise en évidence répétée d'analogues chlorés du BPA dans l'environnement, au cours de ces dernières années, prend son origine dans la chloration du BPA. Le développement d'approches globales en toxicologie est extrêmement prometteur pour répondre aux préoccupations des agences d'évaluation du risque qui ont à gérer le problème des contaminants émergents, et celui de multiples composés de type PE, pouvant exercer des effets à faible dose, avec un différentiel dose-dépendant sur de nombreuses cibles, y compris des cibles impactant le métabolisme endogène. Dans un premier temps, une étude du métabolisme (biotransformation) du TCBPA, ainsi que des 3 intermédiaires : mono-chloro, di-chloro et trichloro-BPA a été réalisé sur la lignée cellulaire hépatique humaine HepaRG, métaboliquement compétente avec des propriétés fonctionnelles de métabolisation très proches des hépatocytes humains. En parallèle, une approche par métabolomique globale par 1H-RMN sur des extraits aqueux de cellules HepaRG exposées à de faibles concentrations de TCBPA (10-6, 10-9 et 10-12 M a permis une discrimination très nette des différents groupes de cellules exposées. L'identification des métabolites discriminants suggère, après reconstruction du réseau métabolique, une modulation du métabolisme énergétique et des protéines.

Mots-Clés : Métabolomique RMN, Bisphenol A chlorés, métabolisme, perturbateur endocrinien

Programme

\footnotetext{
*Intervenant

${ }^{\dagger}$ Auteur correspondant: nicolas.cabaton@inra.fr
} 


\title{
Preliminary metabolomic approach on cyanobacterial co-cultures: Chemically mediated interactions between Microcystis and Planktothrix [P56]
}

\author{
Florence Mondeguer *† ${ }^{1}$, Manoella Sibat-Dubois ${ }^{1}$, Sébastien Reubrecht ${ }^{2}$, \\ Zouher Amzil ${ }^{1}$, Myriam Bormans ${ }^{2}$, Philipp Hess ${ }^{1}$, Enora Briand ${ }^{2}$ \\ ${ }^{1}$ Ifremer, Laboratoire Phycotoxines (PHYC) - Institut Français de Recherche pour l'Exploitation de la Mer \\ (IFREMER) - Rue de l'île d'Yeu, 44311 Nantes, France \\ ${ }^{2}$ Ecosystèmes, biodiversité, évolution [Rennes] (ECOBIO) - Universite de Rennes 1, INEE, Observatoire des \\ Sciences de l'Univers de Rennes, CNRS : UMR6553 - Bâtiment 14 - Université de Rennes 1 - Campus de \\ Beaulieu - CS 74205 - 35042 Rennes Cedex - France
}

Cyanobacterial proliferation is one of the most harmful hazards, in both freshwater and marine ecosystems. Cyanobacteria are well known for their ability to produce a wide variety of bioactive compounds, some of which have been described as allelochemicals. There is growing evidence that these secondary metabolites play an important role in shaping community composition through biotic interactions; however, for the most part, their biological role and mode of regulation of the production are poorly understood. In temperate eutrophic freshwaters, Microcystis and Planktothrix often co-occur, with Planktothrix being an early colonizer and Microcystis appearing subsequently. By integrating LCMS/MS molecular networking and an innovative experimental design, we tested if the production of cyanopeptides by co-existing species could be regulated through interspecifc interactions. We investigated chemically mediated interactions between two cyanobacteria, a toxic M. aeruginosa strain and a non-toxic $P$. agardhii strain, using a combined approach of co-cultures and metabolomic profiling. More precisely, we evaluated changes in growth, morphology and metabolites production and release by both interacting species. Interestingly, culturing Microcystis with Planktothrix resulted in a reduction of the growth of Planktothrix together with a decrease of its filament size and alterations in the morphology of its cells. Ours untargeted metabolomic profiling allow to observe that the production of specific intracellular compounds by Planktothrix was not different between mono and co-culture conditions. Concerning Microcystis, the number of specific intracellular compounds was higher under co-culture condition than under monoculture. In general, Microcystis produced a lower number of intracellular compounds under monoculture than Planktothrix, and a higher number of compounds than Planktothrix under co-culture condition. These results suggest that specific compounds produced by Microcystis in the presence of Planktothrix have been specifically produced as potential allelochemicals. Identification of compounds specifically involved in the observed physiological and morphological changes of Planktothrix cells is still in progress.

Mots-Clés : Cyanobacteria, Cyanotoxins, Plankton interactions, Co_culture, LC_HRMS, Molecular Network, Metabolomics

\footnotetext{
*Intervenant

${ }^{\dagger}$ Auteur correspondant: florence.mondeguer@ifremer.fr
} 


\title{
Proteome modulation as an early marker of gamma irradiation effect on Caenorhabditis elegans egg hatchability? [P57]
}

\author{
Cecile Dubois $* 1$ \\ ${ }^{1}$ Institut de Radioprotection et de Sûreté Nucléaire (IRSN) - Université Montpellier I - Centre de Cadarache - \\ Bât 186 - BP3 13115 Saint-Paul-Lez-Durance, France
}

Non-human species exposure to ionizing radiation (IR) is a major environmental concern whereas underlying toxicity mechanisms remain unclear. Radiosensitivity of environmental species covers 5 orders of magnitude and the responses to IR for a same dose may change depending on the exposure duration (chronic or acute). To better understand the ecotoxic effects of IR and elucidate these differences, subcellular level studies, allowing the identification of earlier and more sensitive markers, need to be performed. Thus, modulation of protein expression, oxidation (via carbonylation assessment) and proteolytic activity were assessed after acute and chronic exposure of C. elegans.

C. elegans were exposed to different acute and chronic doses of $\gamma$ rays (137Cs) from 0 to 200Gy. Then, reproduction was monitored (number of offspring, hatchability) and samples were prepared for protein carbonylation assessment (carbonyls derivatization), proteasomal activity (native-PAGE) and proteomic study (DiGE approach). Spots of interest were analyzed by mass spectrometry.

A significant decrease of offspring number was observed after chronic and acute exposure from 3.3Gy and 30Gy, respectively, whereas an hatchability decrease was only observed after acute irradiation from 30Gy. At the molecular level, protein carbonylation and proteolytic activity appeared to be differentially modulated depending on the mode of irradiation. Moreover, after acute exposure, 5 proteins were identified as repressed, 7 as overexpressed with respect to the control, some as early as $0.5 \mathrm{~Gy}$. After chronic exposure, however, only act- 4 was shown to be slightly repressed, from $0.5 \mathrm{~Gy}$. Finally, all these proteins are involved in the processes of reproduction, reproductive system development or hatching, which could be linked to the observed reproduction decline.

These results highlight that protein modulation could be an predictive marker to assess radiation-induced toxicity molecular mechanisms. A label free proteomic approach is in progress to extend and refine the low number of targets likely to be differentially modulated after chronic exposure.

Mots-Clés : proteome modulation, Caenorhabditis elegans, gamma irradiation, chronic and acute exposure

Programme

\footnotetext{
*Intervenant
} 


\title{
Localisation and quantification of Chlordecone in a rat model of prostatic adenocarcinoma by MALDI imaging [P58]
}

\author{
Mélanie Lagarrigue *1, Karine Rondel ${ }^{1}$, Régis Lavigne ${ }^{1}$, Maureen Scipion ${ }^{1}$, \\ Gaëlle Fromont-Hānkard ${ }^{2}$, Jean-Pierre Thomé ${ }^{3}$, Luc Multigner ${ }^{4}$, François \\ Laurent ${ }^{5}$, Charles Pineau ${ }^{1}$ \\ ${ }^{1}$ PROTIM - INSERM U1085 Irset, Université de Rennes I - CS2407 Campus de Beaulieu \\ 35042 Rennes cedex, France \\ ${ }^{2}$ Hôpital Bretonneau - CHRU Tours - 2 boulevard Tonnellé, 37044 Tours, France \\ ${ }^{3}$ Laboratoire d'écologie animale et d'écotoxicologie - Université de Liège Quartier Agora Allée du six Aout 11 B-4000 Liège \\ (Sart-Tilman), Belgique \\ 4 Team 3ERD - INSERM U1085 Irset, Université de Rennes I - 9 Avenue du Professeur Léon Bernard, \\ 35000 Rennes, France \\ ${ }^{5}$ Laboratoire Ecologie Fonctionnelle et Environnement - ECOLAB (ECOLAB) - CNRS : UMR5245 - 180 chemin de \\ Tournefeuille (bâtiment A) BP 9317331027 Toulouse Cedex 3, France
}

Chlordecone is an organochlorine pesticide extensively used in the French West Indies to fight weevils in banana plantations from 1973 to 1993 . This has led to a persistent pollution of the environment and to the contamination of the local population for several decades with effects demonstrated on human health. Chlordecone was thus positively associated with increased risk of prostate cancer.

The aim of this project was to localize and quantify Chlordecone in a rat model of prostatic adenocarcinoma by MALDI imaging by using a transgenic rat model of prostatic adenocarcinoma (TRAP rat). Quantitative MALDI imaging experiments were thus performed with a MALDI-FT-ICR mass spectrometer on the prostates of TRAP rats exposed weekly to Chlordecone via gavage at the dose of 1,15 or 20 $\mathrm{mg} / \mathrm{kg} / \mathrm{bw}$. The superposition between MALDI images of Chlordecone and optical images obtained from serial sections stained with hematoxylin and eosin $(\mathrm{H} \& \mathrm{E})$ revealed that Chlordecone is clearly located in tumor foci of prostatic adenocarcinomas but absent in the connective tissue of the stroma. H\&E staining does not differentiate the lesions observed on the prostates of TRAP rats exposed to Chlordecone from the lesions observed on the prostates of associated controls. Therefore, immunohistochemical experiments will be performed with three antibodies directed against specific markers (Cytokeratin 5, Ki-67 and Chromogranin-A) to provide information about the link between tumor progression and Chlordecone exposure and to refine the annotation of MALDI images of Chlordecone in the prostatic adenocarcinomas.

Concentrations of Chlordecone determined from molecular images after 15 or 20 gavages are very similar, suggesting a saturation of prostatic tissues. Chlordecone present in prostates analyzed by MALDI imaging was quantified by GC. A correlation coefficient of 0.97 was obtained between Chlordecone concentrations determined by GC and MALDI imaging, confirming the results obtained.

Mots-Clés : Imagerie MALDI, quantification, pesticide, chlordécone

${ }^{*}$ Intervenant 


\title{
Insights into biomineralization and environmental adaptation of bivalves through shell matrix proteins [P59]
}

\author{
Arul Marie * 1, Jaison Arivalagan ${ }^{2,3}$, Sophie Berland ${ }^{4}$, \\ Benjamin Marie ${ }^{5}$, Gerard Bolbach ${ }^{6}$, Lucrèce Matheront ${ }^{6}$, \\ Giovanni Chiappetta ${ }^{7}$, Joëlle Vinh ${ }^{7}$

\footnotetext{
${ }^{1}$ Plateforme de spectrométrie de masse - CNRS : UMR7245, Museum National d'Histoire Naturelle - 63, rue Cuvier 75005 Paris, France ${ }^{2}$ Molécules de Communication et Adaptation des Micro-Organismes (MCAM) - CNRS : FRE3206, Museum National d'Histoire Naturelle 63, rue Cuvier 75005 Paris, France

${ }^{3}$ Biologie des Organismes et Ecosystèmes Aquatiques (BOREA) - Muséum National d'Histoire Naturelle (MNHN), Université Pierre et Marie Curie (UPMC) - Paris VI, Institut de recherche pour le développement [IRD], CNRS : UMR7208 - 43, rue Cuvier, CP 32, 75231 Paris Cedex 05, France

${ }^{4}$ Biologie des Organismes et Ecosystèmes Aquatiques (BOREA) - Museum National d'Histoire Naturelle, CNRS : UMR7208 - 7, rue Cuvier, CP 32, 75231 Paris Cedex 05, France

${ }^{5}$ UMR 7245 MCAM - Musée National d'Histoire Naturelle - MNHN (France) - CP 54, 57 Rue Cuvier Paris 75005, France

${ }^{6}$ Plateforme de spectrométrie de masse et protéomique - Université Pierre et Marie Curie, case courrier 41 IBPS FR3631, Bât A, 6ème étage 7-9, Quai Saint-Bernard 75005 Paris, France

${ }^{7}$ Plateforme de Spectrométrie de masse Biologique et Protéomique - ESPCI - 10 rue Vauquelin, 75005 Paris, France
}

Marine calcifiers defend themselves against predation and environmental stressors via their exoskeletons (shells) and are composed of $\mathrm{CaCO} 3(95 \%)$ and organic molecules such as proteins, polysaccharides, lipids, etc. $(<5 \%)$. A suite of proteins exported to the shell matrix space plays a significant role in controlling the mineralogy and microstructure features, in addition to underpinning some of the physical properties of the shell itself.

Proteomics approach is used to identify the shell matrix proteins (SMPs) of four highly divergent bivalves (Crassostrea gigas, Mytilus edulis; Mya truncata, Pecten maximus) to identify the " basic proteome tool kit " required for shell formation in bivalves. In addition, protein domains controlling the crystal layers specific to aragonite and calcite were also identified. Intriguingly, a significant number of the identified SMPs contained domains related to immune functions; these are unique to each species implying environmental adaptation. This suggests that the SMPs are selectively exported in a complex mix to endow the shell with both mechanical protection and biochemical defense.

The capacity to produce structurally efficient shells of many calcifiers under a changing environment is severely altered in many species leading to the formation of thin, small and fragile shells. Label free proteomics approach was used to investigate the modulation of SMPs in mussels living in different habitats. Variations in the shell characteristics could be correlated to the differential expression of SMPs and also to the mechanism of biochemical defense. Shell proteomics is a powerful tool to understand the biological control in shell formation (biomineralization) and adaptation of marine calcifiers to its environment.

Mots-Clés : Shell proteomics, Label free quantification, bivalves, environmental adaptation

\footnotetext{
${ }^{*}$ Intervenant
} 


\title{
Étude de la composition de particules du courant principal de fumée de cigarette en fonction de la nature de la cigarette par LDI-FTICRMS [P60]
}

\author{
Adama Kamissoko $_{-}^{*}$, Vincent Carré $^{1}$, Frédéric Aubriet ${ }^{1}$ \\ ${ }^{1}$ Laboratoire de Chimie et Physique - Approche Multi-échelle des Milieux Complexes (LCP-A2MC) - \\ Université de Lorraine : EA4632 - Université de Lorraine, ICPM, 1 boulevard Arago, CP 87811, \\ 57078 Metz Cedex 3, France
}

La fumée de cigarette produite par combustion/pyrolyse d'une cigarette est constituée d'une phase gazeuse et d'une phase particulaire. Cette dernière contient plusieurs milliers de composés dont certains sont toxiques et qui n'est que peu documentée.

Une machine à fumer associée à un dispositif de prélèvement sur filtre quartz permet de produire et de collecter la phase particulaire du courant principal de la fumée de cigarette. L'aérosol de six cigarettes (2 réplicats) d'une même marque mais d'origine différente (France, Italie, Egypte, Qatar, Indonésie, Bali) a été analysé par LDI-FTICRMS. Les ions produits par LDI à $355 \mathrm{~nm}$ sont dirigés vers la cellule FTICR par un guide optimisé pour le transfert des ions de m/z 150 à 500. Un spectre final est obtenu en moyennant 50 spectres individuels, chacun résultant de l'accumulation des ions produits par 8 tirs laser. Après calibration, une précision sur la mesure de masse inférieure à $1 \mathrm{ppm}$ est obtenue avec une résolution de _ 400 000 et_ 600000 à m/z 250, en mode de détection positif et négatif, respectivement.

Les composés détectés sont principalement protonés ou déprotonés et dans une moindre mesure radicalaire. Typiquement, près de 300 signaux sont observés en (+) LDI et près de 1000 en (-) LDI. Majoritairement, on observe des espèces azotées C10-25H8-22N1-3 et peu oxygénées C11-23H10-20N1-2O en (+) LDI et une plus grande diversité de composition en (-) LDI avec l'observation d'espèces C926H7-20N1-3O1-3 et C7-24H6-30O1-6. Ces dernières résultent de la pyrolyse de la cellulose du tabac. L'analyse (-) LDI renseigne sur des composés présentant une DBE moyenne pondérée de _ $\sim 13.7$, plus insaturés que ceux obtenus par l'analyse (+) LDI (DBE moyenne pondérée _ 11.2).

La comparaison des aérosols issus des différentes cigarettes montre des différences notables qui ont pu être associées à une différence de morphologie du filtre de la cigarette et à l'origine géographique.

Mots-Clés : Fumée de cigarette, aérosol, pollution, LDI FTICRMS, combustion/pyrolyse

$\underline{\text { Programme }}$

\footnotetext{
${ }^{*}$ Intervenant
} 


\title{
Evaluation of the environmental impact of a natural herbicide, Myrigalone and its extract from Myrica gale using Environmental Metabolic Footprinting (EMF) [P61]
}

\author{
Rahul Suryawanshi*, Delphine Raviglione, Yuxiang Zhou, Marie-Virginie \\ Salvia $\stackrel{\dagger \neq}{\dagger}$, Cédric Bertrand $\pm \underline{\S} 1$ \\ ${ }^{1}$ CRIOBE USR3278, Université de Perpignan Via Domitia - Univ de Perpignan Via Domitia \\ 58 Avenue Paul Alduy 66860 Perpignan Cedex, France
}

Increased use of chemical pesticides to protect crop plants may have significant negative impacts on the environment. To put a step ahead, France has aimed to reduce the use of chemical pesticides by half by 2025, through ECOPHYTO II plan; In this context, biocontrol products (botanical substances for instance), thought as having less impact, could be considered as alternatives.

However we have to banish the preconceptions and we must have the same requirements in terms of safety with these new substances than with chemical pesticides. Tools must be developed in order to evaluate their environmental impact. To date, the half-life, $\mathrm{t} 1 / 2$, was often employed in order to study the environmental fate of pesticides. It can indicate whether or not the compound will persist in the environment. However, this value does not describe all the phenomena occurring following the pesticide application such as the formation of by-products and the effect on biodiversity. Besides, biocontrol products are really complex and this complexity yields chromatograms that are extremely difficult to interpret, which precludes the $t 1 / 2$ from being considered as a viable tool. A new metabolomics approach, the "Environmental Metabolic Footprinting" (EMF) (Patil et al., 2016), was developed in the laboratory. It brings a new integrative proxy, the resilience time that both reflects all the previously described phenomena and can be usable for complex mixtures.

This innovative procedure using LC-MS was employed in order to evaluate the environmental impact of pure Myrigalone and its extract on soil. Indeed, Myrigalone (Patent EP 2320726 A2) can minimize use of chemical herbicides as extract of Myrica gale have been proved to have herbicidal activity on selected broadleaf and grass weed (Popovici et al, 2010). A well-known herbicide, Sulcotrione, was also studied for comparison.

Mots-Clés : Herbicide, Myrigalone, Sulcotrione, soil, LC, MS, Metabolomics

$\underline{\text { Programme }}$

\footnotetext{
*Auteur correspondant: rahulsurya85@gmail.com

†ntervenant

† Auteur correspondant: marievirginie.salvia@univ-perp.fr

$\S$ Auteur correspondant: cedric.bertrand@univ-perp.fr
} 


\title{
Modulation and resilience of the metabolome of Pseudomonas graminis, a cloud bacterium, facing H2O2 atmospheric stress [P62]
}

\author{
Nolwenn Wirgot ${ }^{1}$, Marie Lagrée ${ }^{* \dagger}{ }^{1,2}$, Mounir Traïkia ${ }^{1,2}$, Isabelle Canet ${ }^{1}$, \\ Martine Sancelme ${ }^{1}$, Cyril Jousse ${ }^{\ddagger 1,2}$, Bernard Lyan ${ }^{3}$, Pierre Amato ${ }^{1}$, \\ Ludovic Besaury ${ }^{1}$, Anne-Marie Delort ${ }^{1,2}$ \\ ${ }^{1}$ Université Clermont Auvergne, CNRS, Sigma-Clermont, Institut de Chimie de Clermont-Ferrand F-63000 \\ Clermont-Ferrand, France - Université Clermont Auvergne, CNRS \\ 24 Avenue Blaise Pascal 63178 Aubière, France \\ ${ }^{2}$ Université Clermont Auvergne, Plateforme d'Exploration du Métabolisme, Clermont-Ferrand, France - \\ Université Clermont Auvergne, CNRS - 24 Avenue Blaise Pascal 63178 Aubière, France \\ ${ }^{3}$ Université Clermont Auvergne, Plateforme d'Exploration du Métabolisme, Clermont-Ferrand, France - INRA - \\ Inra UNH 63122 Saint-Genès Champanelle, France
}

In cloud waters microorganisms are metabolically active although they are exposed to very strong stresses, especially due to the presence of reactive oxygenated species, including $\mathrm{H} 2 \mathrm{O} 2$ and radicals. In order to understand how microorganisms can modulate their metabolism facing $\mathrm{H} 2 \mathrm{O} 2$ stress, we have investigated by a metabolomics approach the response of a Pseudomonas graminis strain, isolated from cloud waters, to hydrogen peroxide exposure. For this purpose $P$. graminis cells were incubated in microcosms containing artificial cloud waters in the presence or absence of $\mathrm{H} 2 \mathrm{O} 2$. Metabolites were extracted at two time points (50 min and $24 \mathrm{~h}$ ) that were important regarding the evolution of ATP cellular content and $\mathrm{H} 2 \mathrm{O} 2$ degradation over time. These bacterial extracts were analyzed by LC-MS and 1H-NMR using the Metabolic Profiler $\AA$ facility (Bruker). Metabolic profiles were converted into matrices and statistical analyses (PCA, PLS-DA) were performed; key markers of this oxidative stress were identified by 2D NMR and LC-MS-Orbitrap. At time $50 \mathrm{~min}$, when $\mathrm{H} 2 \mathrm{O} 2$ was still present in the incubations, the bacteria adapted and modulated their metabolome facing this stress. The major metabolic pathways of Pseudomonas graminis (13b-3) impacted by the presence of hydrogen peroxide were the carbohydrate pathway, glutathione, energy, lipid and amino-acid metabolisms. Unexpectedly, the concentration of a few dipeptides containing mainly Ala, Val, Leu (Ile) was also highly modified in the presence of $\mathrm{H} 2 \mathrm{O} 2$. These dipeptides are reported here for the first time as biomarkers of oxidative stress. Interestingly, at time $24 \mathrm{~h}$, when $\mathrm{H} 2 \mathrm{O} 2$ has been completely biodegraded by the cells, no more significant difference was observed between the metabolites of exposed and non-exposed cells to $\mathrm{H} 2 \mathrm{O} 2$. This shows the resilience of this bacterium metabolome after $\mathrm{H} 2 \mathrm{O} 2$ stress exposure. These results are discussed in terms of impacts on cloud chemistry.

Mots-Clés : Environnement, métabolomique, microorganismes, nuage

\footnotetext{
*Intervenant

${ }^{\dagger}$ Auteur correspondant: marie.lagree@uca.fr

† Auteur correspondant: cyril.jousse@uca.fr
} 


\title{
Composition chimique du brouillard de Titan par spectrométrie de masse haute résolution [P63]
}

\author{
Isabelle Schmitz-Afonso ${ }_{-}^{*}$, Julien Maillard ${ }^{1}$, Nathalie Carrasco ${ }^{2,3}$, \\ Carlos Afonso ${ }^{1}$
}

\author{
${ }^{1}$ Normandie Univ, FR 3038; IRCOF, (COBRA) - Université de Rouen, CNRS : UMR6014, INSA Rouen - 1 rue \\ Tesnière, 76821 Mont St Aignan cedex, France \\ ${ }^{2}$ Laboratoire Atmosphères, Milieux, Observations Spatiales (LATMOS) - Université de Versailles \\ Saint-Quentin-en-Yvelines : UMR8190, Université Pierre et Marie Curie - Paris 6, CNRS : UMR8190 - 11 \\ boulevard d'Alembert, Quartier des Garennes 78280 - Guyancourt, France \\ ${ }^{3}$ Institut Universitaire de France (IUF) - Ministère de lÉducation nationale, de l'Enseignement supérieur et de la \\ Recherche - Maison des Universités 103 Boulevard Saint-Michel 75005 Paris, France
}

Titan est le plus grand satellite glacé de la planète Saturne. Il est le siège d'une chimie atmosphérique s'apparentant à des processus qui ont eu lieu sur la Terre Primitive. Cette chimie aboutit à la formation d'un brouillard organique photochimique orangé d'un intérêt essentiel pour l'exobiologie. La composition chimique de ce brouillard reste à ce jour très mal connue, et ce malgré la mission spatiale Cassini en cours dans le système planétaire de Saturne.

Pour progresser à la fois sur notre connaissance de la composition chimique du brouillard, et sur les performances nécessaires des instruments d'analyse requises pour percer sa complexité moléculaire, le LATMOS a mis au point un système expérimental de production d'analogues d'aérosols de Titan, appelés " tholins ". La partie soluble de ces tholins a déjà été étudiée en introduction directe[1] et par couplage chromatographie liquide[2] avec la spectrométrie de masse haute résolution. Ces études ont donné une première approche des compositions élémentaires grâce à l'utilisation de diagrammes de Van Krevelen et la comparaison avec des standards.

Au vu de l'extrême complexité des échantillons, le couplage de la mobilité ionique avec la spectrométrie de masse haute résolution a été testé sur ces analogues des aérosols organiques de l'atmosphère de Titan et a permis de séparer les espèces en phase gazeuse pour approfondir l'identification moléculaire. Au vu de la complexité des échantillons et de la résolution insuffisante du temps de vol couplé à la mobilité ionique, cette étude a été faite en parallèle avec des analyses à ultra-haute résolution pour mettre en évidence différentes familles moléculaires.

(1) Gautier T., Schmitz-Afonso I., Touboul D., Szopa C., Buch A., Carrasco N.; Earth and Planetary Science Letters, 404, 2014, 33-42.

(2) Gautier T., Carrasco N., Schmitz-Afonso I., Touboul D., Szopa C., Buch A., Pernot P.; Icarus, 275, 2016, 259-266.

Mots-Clés : Titan, mobilité ionique, FTICR, spectrométrie de masse

${ }^{*}$ Intervenant 


\title{
L'imagerie par spectrometrie de masse MALDI appliquée à l'étude des metabolites des lichens [P64]
}

\author{
Audrey Geairon * 1 , Pierre Le Pogam ${ }^{2}$, Anne-Cécile Le Lamer ${ }^{2,3}$, Béatrice \\ Legouin $^{2}$, Hélène Rogniaux ${ }^{1}$, Joël Boustie ${ }^{2}$ \\ ${ }^{1}$ Unité de recherche sur les Biopolymères, Interactions Assemblages (BIA) - INRA : UR1268 - Rue de la \\ Géraudière, 44316 Nantes, France \\ ${ }^{2}$ Institut des Sciences Chimiques de Rennes (ISCR) - UMR CNRS 6226, Université de Rennes 1, Universite de \\ Rennes 1 - PNSCM, 2 avenue du Professeur Léon Bernard, 35043 Rennes, France \\ ${ }^{3}$ Université de Toulouse III -Université Paul Sabatier (UPS) - Université Paul Sabatier (UPS) - Toulouse III - \\ 118 Route de Narbonne, 31062 Toulouse Cedex 09, France
}

L'imagerie par spectrométrie de masse est aujourd'hui une stratégie puissante permettant d'avoir accès à des distributions spatiales de métabolites dans des systèmes biologiques variés.

Les lichens, organismes composés résultant d'une symbiose entre au moins un champignon hétérotrophe et des cellules microscopiques possédant de la chlorophylle (algue verte ou cyanobactérie), sont largement répandus sur la planète. Les lichens sont une composante importante de la biodiversité. Ils sont une source de nourriture pour certains animaux (rennes, caribous, chenilles...), contribuent à l'épuration des milieux et au recyclage des éléments par captation des particules de l'air et des pluies (leur présence est un indicateur de pollution lors d'accumulation d'éléments toxiques).

La structure des métabolites secondaires majoritaires du lichen Ophioparma ventosa (lichen présent sur les roches alpines acides) ayant été étudiée auparavant, nous nous sommes intéressés à leurs distributions spatiales à partir de coupes fines de $40 \mu \mathrm{m}$. Les cycles aromatiques présents dans les structures étudiées permettent l'auto-ionisation des molécules par LDI-MS (MALDI sans matrice). Les images chimiques observées avec une distribution spatiale spécifique pour chaque métabolite nous permettent d'établir un lien avec les fonctions écologiques ou nutritives de cette variété de lichen. Cette technique pourrait être largement utilisée pour éclairer les processus métaboliques mal connus au cœur de ces symbioses, et en faire un outil privilégié pour mieux comprendre leur signification écologique.

Le Pogam, P. et al. Spatial mapping of lichen specialized metabolites using LDI-MSI : chemical ecology issues for Ophioparma ventosa. Sci. Rep. 6, 37807; doi: 10.1038/srep37807 (2016)

Mots-Clés : Spectrométrie de masse, MALDI, Lichens, Métabolites

$\underline{\text { Programme }}$

\footnotetext{
${ }^{*}$ Intervenant
} 


\title{
Etude de l'impact d'une formulation commerciale de glyphosate sur Trachemys scripta elegans par profilage métabolomique non ciblé [P65]
}

\author{
Remi Pagnon ${ }^{1}$, Delphine Raviglione ${ }^{2}$, Lauirent Hériter ${ }^{3}$, \\ Olivier Verneau ${ }^{4,5}$, Cédric Bertrand ${ }_{-}^{*}, 6$ \\ ${ }^{1}$ Centre de Formation et de Recherche sur les Environnements Méditérranéens (CEFREM) - Université de \\ Perpignan Via Domitia : UMR5110, Université de Perpignan Via Domitia : UMR5110 - Univ. Perpignan Via \\ Domitia, F-66860, Perpignan, France \\ ${ }^{2}$ CRIOBE USR3278, Université de Perpignan Via Domitia - Univ de Perpignan Via Domitia - 58 Avenue Paul \\ Alduy 66860 Perpignan Cedex, France \\ ${ }^{3}$ Centre de Formation et de Recherche sur les Environnements Méditérranéens (CEFREM) - CNRS : UMR5110, \\ Université de Perpignan Via Domitia : UMR5110, Université de Perpignan Via Domitia : UMR5110 - Univ. \\ Perpignan Via Domitia, F-66860, Perpignan, France \\ ${ }^{4}$ Univ. for Environmental Sciences and Management - ZA-2520, Potchefstroom, Afrique du Sud \\ ${ }^{5}$ Centre de Formation et de Recherche sur les Environnements Méditérranéens (CEFREM) - Université de \\ Perpignan Via Domitia : VIADOMITIA - UPVD (FRANCE), CNRS : UMR5110 - 52, Avenue Paul Alduy, \\ 66860 Perpignan Cedex. France \\ ${ }^{6}$ Laboratoire d'Excellence CORAIL - CNRS : USR3278 - Université de Perpignan, France
}

Les analyses physico-chimiques qui ont été réalisées depuis le début des années 2000 par les laboratoires départementaux ont conduit à révéler la présence de nombreux pesticides, tels que le glyphosate et son produit de dégradation l'acide amino méthyl phosphonique (AMPA), dans certains cours d'eau du sud de la France. Ces composés qui sont présents en forte concentration dans certaines rivières du département des Pyrénées-Orientales, pourraient présenter une réelle toxicité pour les organismes aquatiques et semi-aquatiques. Il a été montré en effet que les eaux contaminées de la Fosseille, l'un des cours d'eau les plus pollués, pouvaient induire un stress oxydatif chez une espèce de tortue semi-aquatique patrimoniale, l'émyde lépreuse Mauremys leprosa, à travers une modulation de l'expression et de l'activité de deux enzymes impliquées dans les processus de détoxification oxydative, la Catalase et la Superoxide Dismutase. C'est pourquoi nous envisageons maintenant d'étudier les variations des métabolites de cette espèce face à ces changements environnementaux. Comme il est impossible d'expérimenter sur cette espèce, classée Vulnérable sur la liste rouge des espèces menacées de France, nous avons testé l'approche par profilage métabolomique non ciblé sur Trachemys scripta elegans, espèce invasive. L'objectif était de caractériser les variations du métabolome chez des animaux au contact du glyphosate. Pour se faire, dix tortues ont été exposées à une solution concentrée de glyphosate préparée à partir de la formulation commerciale Clinic $\AA$, et les réponses métaboliques ont été comparées à celles d'un groupe contrôle. Les analyses ont été réalisées à partir d'échantillons sanguins analysés sur un système UPLC/QTOF. Les profils métabolomiques, interprétés sous le logiciel R, ont permis de mettre en évidence des métabolites discriminants entre les individus du groupe contrôle et ceux du groupe exposé. Ce travail préliminaire doit permettre à moyen terme l'étude d'impact des pesticides en milieu naturel.

Mots-Clés : Métabolomique, Glyphosate, Tortues d'eau douce

*Intervenant 


\title{
High resolution LCMS analysis of metabolic cycles in the intertidal bivalve Mimachlamys varia [P66]
}

\author{
Pascaline Ory ${ }^{*}$, Antoine Bonnet $\stackrel{*}{*}$ Emmanuel Dubillot ${ }^{*}$, Marianne Graber $*$ \\ 1
}

${ }^{1}$ LIttoral ENvironnement et Sociétés [La Rochelle] (LIENSs) - CNRS : UMR7266, Université de La Rochelle Bâtiment Marie Curie Avenue Michel Crépeau 17042 La Rochelle cx1 - Bâtiment ILE 2, rue Olympe de Gouges $17000 \mathrm{La}$ Rochelle, France

\begin{abstract}
Mimachlamys varia, commonly known as the variegated scallop, is a marine bivalve mollusk in the famility Pectinidae. Due its relative abundance along the coasts and also because this species has been shown to have a high pollutants bioaccumulation capacity, it has been proposed as a potential ecotoxicological biomonitoring species within the marine environment (Milinkovitch et al., 2015). This species occurs at depths ranging from the low intertidal to about $100 \mathrm{~m}$ in depth and it is mostly byssally attached to rocks or among rough ground. In order to use $M$. varia as sentinel species for contaminant monitoring, samples of these scallops are taken in situ on the shore at low tide and oxidative stress biomarkers are assayed among others to evaluate the sub-lethal effects of pollutants. During this period of low tide, bivalves may experience short time of aerial exposure, with a low availability of dissolved oxygen, as they have only a small reserve of seawater inside their closed shell. In order to provide normalized sampling methods to assess the health of this aquatic organism, it is important to exactly know if energetic metabolism is modified during emersion period. Indeed little is known about the air-breathing capacity of scallops upon emersion, nor about their ability to shift towards an anaerobic metabolism, as oysters and mussels do, during prolonged emersion. To clarify this point, scallops were grown in aquaria with a simulated intertidal environment and a metabolomics study was performed during 6 complete tidal cycles, with successive $10 \mathrm{~h}$ immersion and $2 \mathrm{~h}$ emersion periods. It was shown that M.varia exhibited alternating phases of fermentation at low tide, with an accumulation of carnitine-conjugated metabolites and aerobic metabolism at high tide. These findings have to be taken into account to homogenize sampling during campaigns of environmental monitoring, by taking only immersed bivalves.
\end{abstract}

Mots-Clés : metabolomics, energetics, marine environment, monitoring

$\underline{\text { Programme }}$

${ }^{*}$ Intervenant 


\section{Identification structurale et annotation [P67-P88]}




\title{
Hydride shifts in gas phase ions influence the release of hydroxide as $\mathrm{H2O}, \mathrm{CO}$ and $\mathrm{H2CO}$ [P67]
}

\author{
Ulli M. Hohenester ${ }_{-}{ }^{1}$, Diego P. Morgavi ${ }^{1}$, Bernard Lyan ${ }^{2}$, Hamid Boudra ${ }^{1}$ \\ ${ }^{1}$ UMR1213 Herbivores, INRA, VetAgro Sup - INRA Clermont-Ferrand-Theix - 63122 \\ Saint-Genès-Champanelle, France \\ 2 PlateForme d'Exploration du Métabolisme (PFEM), UMR 1019 Unité de Nutrition Humaine, INRA \\ Clermont-Ferrand-Theix - 63122 Saint-Genès-Champanelle, France
}

\begin{abstract}
Ruminal microbiome is responsible for the production of the greenhouse gas methane and its reduction is an important challenge. Linseed and garlic essential oil as food additive reduce methane production of lambs by $10 \%$. Rumen fluid samples were analysed by hydrophilic interaction liquid chromatography coupled with mass spectrometry. Multivariate data analyses showed a clear separation between animals (control vs treatment). More than 50 metabolites could be ascribed to the antimethanogenic treatment. Some of them with high VIP were annotated (choline, pipecolic acid and 3-deoxycarnitine) as well as seven unknown with similar molecular formula showing extraordinary alike fragmentation behaviour.

In ruminal samples seven molecules, with similar formula and fragmentation pattern, were observed which release terminal hydroxide as $\mathrm{H} 2 \mathrm{O}, \mathrm{CO}$ and $\mathrm{H} 2 \mathrm{CO}$ after ion activation. These special fragmentation pattern were addressed to a 4-pyridyl-alkane-1,2-dihydroxide substructure, where hydride shifts leads to different transition states. These transitions states can be induced by the loss of the hydroxylgroup on beta-position, leading to a carbocation in beta-position to the terminal hydroxide. Without hydride shift $\mathrm{H} 2 \mathrm{CO}$ will be released whereas $\mathrm{CO}$ loss requires it. Another possibility is protonation of the pyridine nitrogen followed by resonance stabilization, with a carbocation at position 4 as boundary structure, and hydride shift (generating a carbocation in beta-position) leading to direct $\mathrm{H} 2 \mathrm{CO}$ release. Furthermore the terminal hydroxide can be directly released as H2O. MS3 spectra acquired from these molecules support our structural proposition.
\end{abstract}

Choline was addressed as methane source whereas 3-deoxycarnitine and pipecolic acid might be markers for protozoa population.

Hydride shifts in activated ion species can lead to different transition states resulting in different neutral loss from the same functional group. Molecules with 4-pyridyl-alkane-1,2-dihydroxid substructure, found in rumen fluid, showing this behaviour after HCD and CID fragmentation.

Mots-Clés : LC, HRMS, fragmentation, Hydride shift

Programme

\footnotetext{
*Intervenant
} 


\title{
Benchmarking mAb bioconjugation strategies using a combination of native MS and peptide mapping approaches [P69]
}

\author{
Stéphane Erb ${ }_{-}^{* 1}$, Steve Hessmann ${ }^{*}{ }^{1}$, Igor Dovgan ${ }^{2}$, Alain Wagner ${ }^{2}$, \\ Sarah Cianferani $i_{-1}^{1}$
}

\footnotetext{
${ }^{1}$ Laboratoire de Spectrométrie de Masse BioOrganique (LSMBO, IPHC) - Université de Strasbourg, CNRS : UMR7178 - 25 rue Becquerel, 67087 Strasbourg, France

${ }^{2}$ Laboratoire des Systèmes Chimiques Fonctionnels (LSCF, CAMB) - Université de Strasbourg, CNRS : UMR7199 - 74 route du Rhin, 67400 Illkirch-Graffenstaden, France
}

Antibody-drug conjugates (ADCs) are $\tilde{1} 54 \mathrm{kDa}$ tripartite molecules comprising a recombinant monoclonal antibody $(\mathrm{mAb})$, which specifically targets the cancer cell, attached to a highly cytotoxic drug (payload) that inhibits cancer cell growth. This specificity expands the therapeutic window needed on oncology therapy in comparison to the unconjugated mAb. ADCs are mostly generated via reactions on either lysine side-chain amines (Kadcyla $($ ) $)$ or cysteine thiol groups (Adcetris $($ ) resulting in heterogeneous populations with a variable number of drug loads per antibody (DAR, drug to antibody ratio)(1). To control the position and the number of drug loads, new conjugation strategies aiming at the generation of more homogeneous site-specific conjugates are under development.The analytical characterization of ADCs is still challenging. State-of-the art mass spectrometry (MS) methods like MS in non-denaturing conditions can play a pivotal role in next-generation ADC characterization (2). Here we present the analytical workflow we have developed to screen the average number of attached reagent as well as heterogeneity of the sites of attachement to evaluate the efficiency of new bioconjugation strategies (plug-and-play strategy) (3). This approach combines high-resolution non-denaturing mass spectrometry (HR-nativeMS) followed by an automatic DAR calculation using BioPharmaFinder 2.0 (Thermo Fisher Scientific). Classical peptide mapping strategies is further used to determine the different sites of conjugation on the mAb scaffold. Altogether, HR-nativeMS combined to peptide mapping provide a fast, accurate and straightforward MS-based analytical workflow for benchmarking new bioconjugation strategies for the development next generation ADCs.

(1) A. Beck, L. Goetsch, C. Dumontet, N. Corvaia, Nat Rev Drug Discov 2017, 16, 315-337.

(2) A. Beck, G. Terral, F. Debaene, E. Wagner-Rousset, J. Marcoux, M. Janin-Bussat, O. Colas, A. Van Dorsselaer, S. Cianférani, Expert Review of Proteomics 2016, 13, 157-183.

(3) I. Dovgan, S. Ursuegui, S. Erb, C. Michel, S. Kolodych, S. Cianférani, A. Wagner, Bioconjugate Chem 2017, 28, 1452-1457.

Mots-Clés : Antibody Drug Conjugates, Drug to Antibody Ratio, mass spectrometry

Programme

\footnotetext{
${ }^{*}$ Intervenant

${ }^{\dagger}$ Auteur correspondant: sarah.cianferani@unistra.fr
} 


\title{
Epitope characterization of anti-JAM-A antibodies using orthogonal Mass Spectrometry and Surface Plasmon Resonance approaches [P70]
}

\author{
Guillaume Terral ${ }^{1}$, Thierry Champion ${ }^{2}$, François Debaene ${ }^{1}$, Olivier Colas ${ }^{2}$, \\ Elsa Wagner-Rousset ${ }^{2}$, Nathalie Corvaïa ${ }^{2}$, Alain Beck ${ }^{2}$, Sarah Cianferani ${ }^{*} 1$ \\ ${ }^{1}$ Laboratoire de Spectrométrie de Masse BioOrganique (LSMBO) - CNRS UMR7178 - Université Strasbourg - \\ Laboratoire de Spectrométrie de Masse BioOrganique (LSMBO) ECPM Bat R5-0 25, Rue Becquerel 67087 \\ Strasbourg Cedex 2 , France \\ ${ }^{2}$ IRPF - Centre d'Immunologie Pierre-Fabre (CIPF) (IRPF) - Aucune - IRPF - Centre d'Immunologie \\ Pierre-Fabre (CIPF), Saint-Julien-en-Genevois, France
}

Junctional adhesion molecule-A (JAM-A) is an adherens and tight junction protein expressed by endothelial and epithelial cells and associated with cancer progression. We present here the extensive characterization of immune complexes involving JAM-A antigen and three antibodies, including hz6F42 a humanized version of anti-tumoral $6 \mathrm{~F} 4 \mathrm{mAb}$ identified by a functional and proteomic approach in our laboratory. A specific workflow that combines orthogonal approaches has been designed to determine binding stoichiometries along with JAM-A epitope mapping determination at high resolution for these three mAbs. Native mass spectrometry (MS) experiments revealed different binding stoichiometries and affinities, two molecules of JAM-A being able to bind to Hz6F4-2 and F11 Fab (Fragment antigen-binding), while only one JAM-A was bound to J10.4. Surface plasmon resonance (SPR) indirect competitive binding assays revealed epitopes located in a close proximity for hz6F4-2 and F11. Finally, hydrogen-deuterium exchange mass spectrometry (HDX-MS) was used to precisely identify epitopes for all mAbs. Altogether results obtained by orthogonal biophysical approaches showed a clear correlation between determined epitopes and JAM-A binding characteristics, allowing for the first time to settle the basis for molecular recognition of JAM-A by Hz6F4-2. Taken together, our results highlight the power of MS-based structural approaches for epitope mapping and $\mathrm{mAb}$ conformational characterization.

Mots-Clés : HDX, MS, surface plasmon resonance, monoclonal antibody, epitope mapping

Programme

*Intervenant 


\title{
Deep metabolome annotation and the necessity of a thought experiment [P71]
}

\author{
Pierre-Marie Allard ${ }^{1}$, Jonathan Bisson ${ }^{2}$, Mehdi Beniddir ${ }^{3}$, Grégory \\ Genta-Jouve ${ }^{* \dagger} 4$ \\ ${ }^{1}$ Université de Genève (UNIGE) - 24 rue du Général-Dufour CH - 1211 Genève 4, Suisse \\ ${ }^{2}$ College of Pharmacy - University of Illinois at Chicago - 833 S. Wood Street (781) \\ Chicago, IL 60612, États-Unis \\ ${ }^{3}$ Université Paris Sud - CNRS : UMR8076 - Faculté de Pharmacie Université Paris-Sud 5, rue J-B Clément \\ 92296 Châtenay-Malabry cedex, France \\ ${ }^{4}$ Université Paris Descartes (COMETE) - CNRS : UMR8638 - 4 Avenue de l'observatoire, France
}

\begin{abstract}
The metabolome of an organism consists in the totality of the small molecules present in an organism at a given time. Unlike genome, transcriptome or proteome, it represents the real time content of the a living organism at the metabolic level. In order to understand the most complex biological interactions between cells, tissues, organs or individuals in a specific ecosystem, it is fundamental to first identify all the components, i.e. all the molecules that can be encountered. Over the last decade, identification of small biologically generated compounds, the metabolites, has emerged as the main issue in the field of metabolomics and despite all the great efforts of the community during the last years only a relatively small number of compounds have been referenced in accessible databases, and often with only hypothetical structures. Herein we propose to discuss the philosophical aspects of the important question "what is a known natural product?" in order to move forward to a new paradigm in metabolite identification: identifying the real from the possible. This approach based on available tools of in silico metabolisation and MS/MS spectra prediction and data annotation will lead to the characterisation of new natural products with a limited amount of available biological material at a higher discovery rate. These improvements will enable new challenges to arise and be solved in a wide range of biological systems encountered in domains such as chemical ecology, drug discovery and traditional medicine studies.
\end{abstract}

Mots-Clés : metabolites identification, natural products, in silico metabolisation

$\underline{\text { Programme }}$

\footnotetext{
*Intervenant

${ }^{\dagger}$ Auteur correspondant: gregory.genta-jouve@ parisdescartes.fr
} 


\title{
RNA Aptamers and their ligand complexes: Shape and KD determination by native mass spectrometry [P72]
}

\author{
Stefano Piccolo ${ }_{-}^{* 1}$, Valérie Gabelica ${ }_{-}^{\dagger}$ \\ ${ }^{1}$ Université de Bordeaux (ARNA) - INSERM : U1212, CNRS : UMR5320, Université de Bordeaux - Institut \\ Européen de Chimie et Biologie (IECB), 2 rue Robert Escarpit, 33607 Pessac, France
}

Native electrospray ionization mass spectrometry (ESI-MS) allows to gently ionize and preserve non-covalent complexes, in order to separate them in vacuo and quantify each species. As a label-free technique, it can provide RNA-ligand stoichiometry and KD values in vitro. Furthermore, ESI-MS coupled to ion mobility spectrometry (IMS) gives access to binding and shape information at the same time. Well-characterized RNA aptamers will be our starting point. Malachite Green, Neomycin and FMN aptamers, purchased from IDT, are dissolved in Nuclease-Free water. Before use, the stock solutions are prepared in NH4OAc or TMAA $100 \mathrm{mM}$ buffers, easily tolerated by the spectrometer. Specific cations $(\mathrm{Mg} 2+)$ are also tested. To allow proper hairpins folding, RNAs are heated at $85 \circ \mathrm{C}$ then immediately cooled on ice. An Agilent 6560 ESI-IMS-Q-TOF mass spectrometer in negative mode is used for all the experiments.

We are currently validating the quantification using internal standards to correlate MS signals to concentrations in solution, defining the lower and higher KD limits attainable, and establishing a protocol for $\mathrm{KD}$ determination. In KDs calculation, maximum error propagation is also taken into account.

With IMS, we did not observe significant conformational changes upon binding for these aptamers, but our lab has now evidence that duplex structures at low charge states collapse in the gas phase (1). So we focused our attention on higher charge states and on more diverse structural models as Tetracycline and Cocaine aptamers, where both ligand and buffer are influencing their shape.

The poster will explain in what respects our results are in line with or different from the published data.

This work is funded by the EU H2020 (Marie Curie ITN "MetaRNA")

(1) Porrini, Rosu, Rabin, Darré, Gomez, Orozco \& Gabelica, Compaction of Duplex Nucleic Acids upon Native Electrospray Mass Spectrometry, ACS Cent. Sci. (2017), DOI: 10.1021/acscentsci.7b00084

Mots-Clés : nativeMS, Ion Mobility, RNA, Aptamer

Programme

\footnotetext{
*Intervenant

†Auteur correspondant: valerie.gabelica@inserm.fr
} 


\title{
M+2 Relative Isotopic Abundance on Orbitrap Fusion: input of 180/13C2 separation on annotation for metabolomics [P73]
}

\author{
Pierre Barbier Saint Hilaire ${ }^{*}$, Benoit Colsch ${ }^{2}$, \\ Christophe Junot $^{2}$, François Fenaille ${ }^{2}$ \\ ${ }^{1}$ CEA-INRA UMR 0496/DRF/Institut Joliot/SPI/LEMM, Université Paris Saclay, MetaboHUB - CEA Saclay, \\ Batiment 136, 91191 Gif sur Yvette, France
}

\begin{abstract}
Even with cutting-edge mass spectrometers, the identification of observed signals in metabolomics is still challenging. If accurate mass measurement can lead to few possible elemental compositions, this number highly increases with mass. Exploiting the Relative Isotopic Abundance (RIA) can be an efficient way to reduce the number of elemental compositions proposals. In this work, we evaluate the ability of Orbitrap Fusion to perform accurate RIA measurement in order to improve the relevance of metabolite identification.

A pool of 50 molecules was analyzed by LC-MS on an Orbitrap Fusion instrument (ThermoFisher). Molecules were chosen with masses between 109Da and 774Da. Emphasis was placed on multi-oxygenated species to facilitate the observation of $\mathrm{M}+2$ isotopes. A $5-\log$ concentration range $(1 \mathrm{ng} / \mathrm{mL}$ to $10 \mu \mathrm{g} / \mathrm{mL})$ was studied. The impact of resolution was studied through three resolving powers (RP): 120k, 240k, $500 \mathrm{k}$.

Higher RP reached on the Orbitrap Fusion can allow separation of the two main M+2 isotopes in metabolomics, i.e. $18 \mathrm{O}$ and $13 \mathrm{C} 2$ (spaced by $2.46 \mathrm{mDa}$ ). This gives access to specific RIA. At RP $120 \mathrm{k}, 240 \mathrm{k}$ and $500 \mathrm{k}$, isotopes resolution was determined to be efficient for masses up to $\mathrm{m} / \mathrm{z} 250,350$ and 550, respectively.

The RIA was calculated when both peaks were separated. A clear impact of resolution on RIA measurements was evidenced, with more accurate values for RP 240k. In these rather ideal conditions, the mean RIA errors are $-14 \%$ for $13 \mathrm{C} 2$ and $-20.6 \%$ for $18 \mathrm{O}$ detected signals. Moreover, $75 \%$ of $13 \mathrm{C} 2$ and $55 \%$ of 180 detected signals present an RIA error within $-25 \%$ and $+10 \%$, i.e. the safety factor for an efficient use of RIA in elemental composition determination (defined by Nagao et al., Anal. Chim. Acta 813,70-76(2014))
\end{abstract}

This first specific 180 RIA measurement on an Orbitrap technology instrument will allow refining mass formulas attribution in upcoming studies.

Mots-Clés : Relative Isotopic Abundance, 18O, 13C2, HRMS, Elemental composition, Annotation

Programme

*Intervenant 


\title{
Characterization by mass spectrometry of plant adhesives from the Iron Age discovered on the site "Cité d'Affrique" (Messein, France) [P74]
}

\author{
Armelle Charrié-Duhaut ${ }^{* \dagger}{ }^{1}$, Marc Leroy ${ }^{2}$, Sylvie Deffressigne ${ }^{3}$ \\ ${ }^{1}$ Laboratoire de Spectrométrie de Masse des Interactions et des Systèmes (LSMIS), Université de Strasbourg, \\ CNRS, CMC UMR 7140 (LSMIS - UMR 7140) - Université de Strasbourg, CNRS - Institut Le Bel, 7 étage - 4, \\ Rue Blaise Pascal 67081 Strasbourg Cedex, France \\ ${ }^{2}$ Laboratoire de Métallurgies et Cultures Institut de Recherches sur les Archéomatériaux - IRAMAT (UMR \\ 5060) Musée de l'Histoire du Fer / Laboratoire d'archéologie des métaux (LMC) - CNRS : UMR5060 - 1, \\ avenue du général de Gaulle 54140 Jarville-La-Malgrange, France \\ ${ }^{3}$ INRAP, ARTeHIS, UMR 6298, Université de Bourgogne - INRAP - Bâtiment Equinoxe - 5 rue Fernand \\ Holweck 21000 Dijon, France
}

Mass spectrometry has become a key tool to study organic archeomaterials. Beyond the identification of natural substances, it allows to define markers of anthropogenic transformations (manufacturing processes) and of natural ageing (for better preservation). Equally important, interdisciplinary collaboration with Humanities partners brings an historical value to the chemical results leading to a better knowledge of past civilizations.

We will detail here the study of materials collected during excavations on a fortified settlement from the Iron Age, called "Cité d'Affrique", occupied between the 6th and the 4th century BC (Messein, 54, France). Among the residues found, small individual black pellets as well as a black macroresidue in the cabochon of bronze fibulae were characterized.

Organic lipidic extracts of the black materials were analyzed by GC-MS revealing the presence in all samples, of triterpenic components belonging to the lupane family, more specifically to the betuline family. These compounds are biomarkers from birch bark tar, a substance produced by controlled thermal process. Markers of anthropogenic degradation and natural ageing have also been identified.

These chemical data confirm that the black substance in the cabochon of fibulae is a plant adhesive used by metallurgist/jeweler craftsmen to fix the decorative elements on these fibulae. The presence of pellets of the same tar indicates that they are work-residues and provides further evidence of such crafts on the site.

Plant tar was used for its adhesive properties since the Middle Paleolithic for hafting, pottery repair or jewelry (1). Why such properties? MALDI-MS and ESI-MS analyses show the presence of a polymer. This can be probably paralleled with bioadhesives based on condensed tannins formulated since the 80's. But the study of these tannins, especially their mass distribution, remains a challenge (2).

(1) Charrié-Duhaut, Leprovost 2012 Spectra Analyse 285:32-39.

(2) Mouls et al. 2011 Anal. Bioanal. Chem. 400:613-623.

Mots-Clés : archaeometry, birch bark tar, Iron Age, Cité d’Affrique, triterpenes

\footnotetext{
${ }^{*}$ Intervenant

†Auteur correspondant: acharrie@ unistra.fr
} 


\title{
Size-exclusion chromatography coupled to native ion mobility mass spectrometry (SEC-native IM-MS) for therapeutic protein aggregation studies [P75]
}

\author{
Oscar Hernandez Alba ${ }_{-}^{*}$, Anthony Ehkirch ${ }^{1}$, Sarah Cianferani ${ }_{-}^{\dagger} 1$ \\ ${ }^{1}$ Laboratoire de Spectrométrie de Masse BioOrganique - Université de Strasbourg, université de Strasbourg - \\ CNRS, IPHC UMR 7178, Strasbourg, France
}

\begin{abstract}
Monoclonal antibodies (mAbs) have emerged as a very promising class of therapeutic proteins for clinical use against a large number of diseases such as cancer, infection and immune disorders (1). Advances in $\mathrm{mAb}$ production and analytical characterization are both required in order to market pure, stable and active therapeutic proteins. MAb aggregation is a common issue that can impair the efficiency of the protein-based drug. Healthy risks like immune responses to the therapeutic protein product and lowered therapeutic efficacy can be attributed to mAb aggregation (2). Aggregation can occur during manufacturing process or sample purification, as a consequence of stress factors such as temperature, exposure to light or ionic strength (3).

Size Exclusion Chromatography is commonly used to evaluate the degree of aggregation of therapeutic proteins4. In parallel, MS performed in non-denaturing conditions has considerably evolved in the past five years and is now adapted for routine analyses of mAbs. We have developed the on-line coupling of SEC to native (IM)-MS for aggregation studies. In this work, several mAbs were subjected to stress conditions and their aggregates were amazed by on-line SEC-IM-MS in non-denaturing conditions. SEC chromatography affords size-based separation of all species forms while IM-MS allows straightforward identification and conformational characterization of all SEC-separated species. Altogether this new methodology provides all-in-one separation, unambiguous identification through accurate mass measurement and conformational characterization of oligomers generated upon environmental stress in less than one hour. The benefits of the presented SEC-IM-MS method in non-denaturing conditions could be further generalized to the characterization of protein oligomers.
\end{abstract}

(1) Beck, A., et al., Nature Reviews Drug Discovery 2017, 16 (5), 315-337.

(2) Ahmadi, M., et al., Pharmaceutical Research 2015, 32 (4), 1383-1394.

(3) Beck, A., et al., Expert Review of Proteomics 2016, 13 (2), 157-183.

(4) Goyon, A., et al., Journal of Chromatography A 2017, 1498, 80-89.

Mots-Clés : SECIMMS, native mass spectrometry, aggregates, mAbs

Programme

\footnotetext{
${ }^{*}$ Intervenant

${ }^{\dagger}$ Auteur correspondant: sarah.cianferani@unistra.fr
} 


\title{
Insights from native mass spectrometry approaches for top- and middle- level characterization of site-specific antibody-drug conjugates [P76]
}

\author{
Thomas Botzanowski ${ }^{1}$, Stéphane Erb ${ }^{1}$, Oscar Hernandez Alba ${ }^{*}$, Anthony \\ Ehkirch ${ }^{1}$, Olivier Colas ${ }^{2}$, Elsa Wagner-Rousset ${ }^{2}$, David Rabuka ${ }^{3}$, Alain \\ Beck $^{2}$, Penelope Drake ${ }^{3}$, Sarah Cianferani ${ }^{\dagger}$ \\ ${ }^{1}$ Laboratoire de Spectrométrie de Masse BioOrganique - Université de Strasbourg, université de Strasbourg - \\ CNRS, IPHC UMR 7178, Strasbourg, France \\ ${ }^{2}$ Centre d'Immunologie Pierre-Fabre - Saint-Julien-en-Genevois, France \\ ${ }^{3}$ Catalent Biologics West - 5703 Hollis Street, Emerville, California, États-Unis
}

Antibody-drug conjugates (ADCs) have emerged as a family of compounds with promise as efficient immunotherapies (1). First-generation ADCs were generated mostly via reactions on either lysine sidechain amines or cysteine thiol groups after reduction of the interchain disulfide bonds (2), resulting in heterogeneous populations with a variable number of drug loads per antibody. To control the position and the number of drug loads, new conjugation strategies aiming at the generation of more homogeneous site-specific conjugates have been developed (3-5).

We report here the first multi-level characterization of a site-specific ADC by state-of-the-art mass spectrometry (MS) methods, including native MS and its hyphenation to ion mobility (IM-MS). We demonstrate the versatility of native MS methodologies for site-specific ADC analysis, with the unique ability to provide several critical quality attributes within one single run, along with a direct snapshot of ADC homogeneity/heterogeneity without extensive data interpretation. The capabilities of native IM-MS to directly access site-specific ADC conformational information are also highlighted. Finally, the potential of these techniques for assessing an ADC's heterogeneity/homogeneity is illustrated by comparing the analytical characterization of a site-specific DAR4 ADC to that of first-generation ADCs.

Altogether, our results highlight the compatibility, versatility, and benefits of native MS approaches for the analytical characterization of all types of ADCs, including site-specific conjugates. Thus, we envision integrating native MS and IM-MS approaches, even in their latest state-of-the-art forms, into workflows that benchmark bioconjugation strategies.

(1) Beck, A., et al., Nature Reviews Immunology 2010, 10 (5), 345-352.

(2) Beck, A., et al., MAbs 2012, 4 (6), 637-47.

(3) Rabuka, D., et al., Nature Protocols 2012, 7 (6), 1052-1067.

(4) Agarwal, P., et al., Bioconjugate Chemistry 2013, 24 (6), 846-851.

(5) Kudirka, R., et al., Chemistry \& Biology 2015, 22 (2), 293-298.

Mots-Clés : Antibody, drug conjugate (ADC), ion mobility mass spectrometry (IM, MS), middle level, native mass spectrometry, site, specific bioconjugation, top level

\footnotetext{
*Intervenant

${ }^{\dagger}$ Auteur correspondant: sarah.cianferani@unistra.fr
} 


\title{
Assessing chemical labeling of proteins by mass spectrometry: MALDI-TOF to the rescue of ESI-HRMS [P77]
}

\author{
Guillaume Gabant ${ }_{-}^{1}$, Martine Cadène ${ }_{-}^{\dagger} 2$ \\ ${ }^{1}$ Centre de Biophysique Moléculaire (CBM) - CNRS : UPR4301 - Rue Charles Sadron CS80054 45071 \\ ORLEANS Cedex 02, France \\ ${ }^{2}$ Centre de biophysique moléculaire (CBM) - CNRS : UPR4301 - Rue Charles Sadron \\ 45071 Orléans cedex 2, France
}

\begin{abstract}
The chemical labeling of proteins is of great interest both for fundamental research and patient care. Applications range from structural characterization of proteins, e.g. for assessing the solvent accessibility of residues, to pharmaceutical industry, e.g. for covalent drugs or for the development of antibody-drug conjugates (ADCs), a new class of anti-cancer therapies. To tune the reaction, a chemist or biochemist needs to know the extent of labeling on the intact protein which, in the case of ADCs, is measured as the drug-to-antibody ratio (DAR). Mass spectrometry, especially high resolution instrumentation, is a unique tool to answer these questions, by allowing for the dissection of heterogeneity on increasingly large proteins in an accurate and reliable manner.

Most of the time, the chemical labeling of a protein targets several residues and is incomplete, thus increasing the protein heterogeneity, especially in the case of two-step addition processes and/or instability of chemical groups. This heterogeneity can then combine with microheterogeneity due to posttranslational modification (PTM) of the protein of interest. The resulting distributions of proteoforms may cause mass spectral peaks to overlap or fuse, leading to uninterpretable spectra, and consequently, loss of information. This difficulty can be overcome by HPLC. However, the HPLC separation efficiency of proteoforms is still challenging and remains protein- and modification-dependent. In this context, we show that HRMS is the best methodology to assess protein chemical labeling in low to moderate heterogeneity cases, but fails when the heterogeneity is too high. In this case MALDI-TOF MS analysis may be relevant and allows for the estimation of the average number of labels per protein. Biochemical tools to remove reversible PTMs may also be helpful.

In conclusion, depending on the heterogeneity of the protein of interest, ESI-HRMS and MALDI-TOF MS appear as complementary techniques for assessing its degree of chemical labeling.
\end{abstract}

Mots-Clés : chemical labeling, modification, proteoforms, ADC, DAR, covalent, ESI, HRMS, MALDI, TOF MS

Programme

\footnotetext{
${ }^{*}$ Intervenant

†Auteur correspondant: martine.cadene@cnrs-orleans.fr
} 


\title{
Identification de l'extrémité $\mathrm{N}$-terminale des protéines par marquage chimique [P78]
}

\author{
Laila Sago ${ }_{-}^{*}{ }^{1}$, Eslande Hercul ${ }^{1}$, Charles Bou Nader ${ }^{2}$, Virginie Redeker ${ }^{3,1}$, \\ David Cornu ${ }^{1}$
}

\author{
${ }^{1}$ Institut de Biologie Intégrative de la Cellule (I2BC) - Université Paris-Sud - Paris 11, CEA, Université \\ Paris-Saclay, CNRS : UMR9198 - Bâtiment 21, 1 avenue de la Terrasse, 91198 Gif/Yvette cedex, France \\ ${ }^{2}$ Laboratoire de chimie des Processus Biologiques, Collège de France - CNRS : UMR8229 - 11 Place Marcelin \\ Berthelot, 75231 Paris, France \\ ${ }^{3}$ Institut des Neurosciences de Paris-Saclay (Neuro-PSI) - Université Paris-Sud - Paris 11, CNRS : UMR9197 - \\ Université Paris-Sud bât 32, 1 avenue de la Terrasse, 91198 Gif/Yvette Cedex, France
}

Les caractérisations des extrémités $\mathrm{N}$ - et $\mathrm{C}$-terminales de protéines purifiées et/ou isolées sur gel SDS-PAGE correspondent à des demandes d'utilisateurs en progression sur la plateforme de protéomique SICaPS (Service d'Identification et de Caractérisation des Protéines par Spectrométrie de masse). Ces caractérisations ont pour objectif d'identifier les sites de protéolyses générés in vivo ou in vitro afin d'obtenir des informations structurales sur les protéines d'intérêts. L'identification des sites de protéolyses ménagées générés in vitro permet d'identifier des domaines structuraux ou des surfaces accessibles de protéines. L'identification des sites de protéolyses générés in vivo renseignent sur les maturations de type post-traductionnelles par clivage protéolytique ou les dégradations protéolytiques des protéines.

Les approches indirectes habituellement utilisées sur la plateforme pour identifier les extrémités des protéines sont basées sur l'utilisation d'une combinaison d'endoprotéases, seules ou en mélanges pour effectuer une digestion totale des polypeptides à caractériser, et l'identification des peptides générés par spectrométrie de masse pour établir un recouvrement de séquence le plus complet possible et ainsi délimiter les extrémités $\mathrm{N}$ - et $\mathrm{C}$-terminales des polypeptides. Cette approche consommatrice en temps peut présenter des limites en raison soit du manque de spécificité de certaines enzymes habituellement utilisées, soit en raison des séquences en acides aminés $\mathrm{N}$ - ou C-terminales trop riches en sites de digestion, soit en raison d'une hétérogénéité des produits de protéolyses.

Les méthodes de marquages chimiques des extrémités sont une alternative intéressante. La dérivatisation chimique ciblée de l' amine $\mathrm{N}$-terminale par le groupement TMPP-Ac-OSu ( $N$-Succinimidyloxycarbonylmethyl) tris (2,4,6-trimethoxyphenyl) phosphonium bromide ) permet de fixer une charge positive et d'augmenter l'hydrophobicité des peptides N-terminaux, et ainsi d'améliorer leurs détections et leurs caractérisations. L'apport de l'utilisation du marquage N-terminal au TMPP, seule ou en combinaison avec les approches classiques de recouvrement de séquence, a été évalué. Ce travail sera présenté et discuté.

Mots-Clés : caractérisation N-terminale, spectrométrie de masse, marquage chimique

Programme

\footnotetext{
*Intervenant
} 


\title{
MineMS2: detection of chemical patterns to mine MS/MS spectral libraries and facilitate de novo spectrum elucidation [P79]
}

\author{
Alexis Delabrière ${ }^{* \dagger}{ }^{1}$, Emilien Jamin ${ }^{2}$, Thaïs Hautbergue ${ }^{2}$, Marie-Françoise \\ Olivier ${ }^{3}$, Annelaure Damont ${ }^{3}$, Jean-Claude Tabet ${ }^{4}$, Anna Warnet ${ }^{4}$, \\ Christophe Junot ${ }^{3}$, François Fenaille ${ }^{3}$, Etienne A. Thévenot \\ ${ }^{1}$ CEA, LIST, Laboratoire Analyse de Données et Intelligence des Systèmes, MetaboHUB, 91191 Gif-sur-Yvette \\ 2 ToxAlim - INRA : UMR1331 - 180 chemin de tournefeuille 31300 Toulouse, France \\ ${ }^{3}$ Laboratoire d'Etude du Métabolisme des Médicaments, MetaboHUB, CEA Saclay, DRF/IBITEC-S/SPI, 91191 \\ Gif-sur-Yvette Cedex, France \\ ${ }^{4}$ Institut Parisien de Chimie Moléculaire (IPCM) - Université Pierre et Marie Curie - Paris 6, CNRS : UMR8232, \\ 4 place Jussieu 75252 Paris Cedex 05 Bâtiment F/74, France
}

Metabolite structure elucidation is a major challenge in metabolomics. Tandem mass spectrometry (MS/MS) is a powerful method to obtain fragmentation fingerprints from charged molecular species from compounds, and libraries of MS/MS spectra from standard compounds or biological matrices of interest are generated by metabolomics laboratories and platforms. Characterizing the structural content of such spectral databases is of major interest since it would 1) provide new metrics for spectral matching (based on structural patterns), and 2) facilitate the interpretation of results. Recently, approaches such as GNPS (Wang et al. 2014) and Mass2Motifs (Van Der Hooft et al. 2016) have been developed to provide the user with a global overview of a (set of) acquisition(s). These methods, however, are based on fragment ions only. In contrary, the concepts of fragmentation tree or graph (which are used by the top performing identification methods, as CSI:FingerID - Shen et al. 2014) are closer to the gas phase ion chemical process.

We have therefore developed a graph mining approach to extract recurrent neutral loss patterns from a collection of low energy collision spectra: each spectrum is first converted into a graph where each edge is a neutral loss and each node is a fragment ion; the algorithm then identifies common edge patterns (including at least two neutral losses) between the graphs.

We applied our software module to mine two distinct MS/MS datasets: 1) a library of $500 \mathrm{CID} / \mathrm{HCD}$ spectra from endogenous and exogenous compounds of interest for metabolomics studies of human biofluids; 2) a collection of spectra from the pathogenic fungus Penicillium verrucosum. We show that meaningful chemical patterns can be extracted, which are useful to mine the content of the databases and interpret new product ion spectra of unknown compounds. The results will be presented and discussed during the workshop 3 (Monday 2 October).

Mots-Clés : annotation, pattern mining, MS/MS

\footnotetext{
*Intervenant

${ }^{\dagger}$ Auteur correspondant: alexis.delabriere@cea.fr

¥Auteur correspondant: etienne.thevenot@ cea.fr
} 


\title{
Isolation of anti-chikungunya diterpenoids from Euphorbia pithyusa extract: premyrsinane, myrsinane and tigliane diterpene analogues annotated by molecular networking [P80]
}

\author{
Mélissa Esposito ${ }^{1,2}$, Louis-Félix Nothias-Scaglia ${ }^{1,2}$, Pascal Retailleau ${ }^{1}$, Jean \\ Costa $^{2}$, Fanny Roussi ${ }^{1}$, Johan Neyts ${ }^{3}$, Pieter Leyssen ${ }^{3}$, David Touboul ${ }^{1}$, \\ Marc Litaudon_ ${ }_{-}^{*}$, Julien Paolini $+\$ 2$ \\ ${ }^{1}$ Institut de Chimie des Substances Naturelles (ICSN) - CNRS : UPR2301 - Avenue de la terrasse \\ 91198 Gif sur Yvette cedex, France \\ ${ }^{2}$ Laboratoire de Chimie des Produits Naturels, Université de Corse - UMR CNRS 6134 - Corte, 20250, France \\ ${ }^{3}$ Laboratory of Virology - Rega Institute for Medical Research, University of Leuven, Belgique
}

\begin{abstract}
The aim of the present investigation was to search for new antiviral diterpenoids by means of a bioassay-guided purification procedure from an EtOAc extract of $E$. pithyusa aerial parts. To gain more insight in the structural diversity of the diterpenoid content of $E$. pithyusa, extract and fractions were analyzed by LC-MS/MS-based molecular networking.

In this work, six new premyrsinol esters and one new myrsinol ester were isolated from the aerial parts of Euphorbia pithyusa, together with two known dideoxyphorbol esters, following a bioactivity-guided purification procedure using a chikungunya virus (CHIKV) cell-based assay. The structure of the seven new compounds was elucidated by MS and NMR spectroscopic data interpretations. The evaluation of the isolated compounds against Chikungunya virus (CHIKV) replication showed that the most active compound was a dideoxyphorbol ester, with an EC50 value of $4.0 \pm 0.3 \mu \mathrm{M}$ and a selectivity index of 10.6. To gain more insight into the structural diversity of diterpenoids produced by $E$. pithyusa, the extract and fractions were analyzed by molecular networking. The generated data were annotated using molecular networking and revealed that dozens of unknown premyrsinane, myrsinane, and tigliane analogues were contained.
\end{abstract}

The present results show the capability of MS/MS molecular networking for efficient annotation of $E u$ phorbia diterpene esters, allowing us to capture the diversity of diterpene esters produced by E. pithyusa, and guiding a hypothesis on its bioactive constituents.

Mots-Clés : Diterpene, molecular networking, LC-MS/MS, Euphorbia sp., antiviral activity

Programme

\footnotetext{
*Auteur correspondant: Marc.LITAUDON@cnrs.fr

${ }^{\dagger}$ Intervenant

$\ddagger$ Auteur correspondant: paolini@univ-corse.fr
} 


\title{
Investigation of the conformational dynamics of the human prion protein and its interaction with the A $\beta$ peptide by ion mobility mass spectrometry [P81]
}

\author{
Jan Bohl ${ }^{* \dagger}$ 1, Frédéric Halgand, Human Rezaei , \\ Guillaume Van Der Rest $*$ \\ ${ }^{1}$ Laboratoire de Chimie Physique (LCP) - CNRS : UMR8000, Université Paris Sud - Paris XI - Bâtiments \\ 349/350 avenue Georges CLEMENCEAU 91405 ORSAY cedex, France
}

Interactions between $\mathrm{A} \beta$ peptides and prion proteins ( $\mathrm{PrP})$, as well as their biological consequences in Alzheimer disease have been already studied intensively over the past and important information about the consequences of an interaction between both molecules could be obtained. This interaction could provide the organism with some control on the accumulation of $\mathrm{A} \beta$ fibrils involved in progression of Alzheimer's disease and/or in the control of the accumulation of PrP oligomers and fibrils. Nevertheless, few studies have tried to understand the molecular basis of the interaction between $\mathrm{A} \beta$ and $\operatorname{PrP}$ and the consequence on the folding landscape of the respective partners. Indeed, the biochemical mechanisms of how PrP could transduce structural information upon $\mathrm{A} \beta$ binding remain vague. Recent results of the lab indicated the great potential of ion mobility mass spectrometry (IMS MS) in the analysis of the broad conformational landscape of PrP by the separation of isobaric conformers followed by mass analysis. Where classical structural characterization methods were limited by the inhomogeneous PrP samples containing multiple species at one time, IMS MS allows to specifically track the structural changes introduced to PrP conformers.

To study this interaction human $\operatorname{PrP}$ and $\mathrm{A} \beta(1-40)$ were overexpressed and purified. Proofing the interaction between $\operatorname{PrP}$ and the $\mathrm{A} \beta$ peptide remained elusive: no direct formation of $\operatorname{PrP} / \mathrm{A} \beta$ complexes was observed by MS, and indirect measurements based on global H/D exchange were not successful. The methodologies that were applied (based on SEC/IMS and H/D exchange) for this approach will be presented in this poster. Future work will be focused on further optimizing experimental conditions for complex formation and establishing methods for local H/D exchange to better understand the conformational landscape of the molecules of interest.

Mots-Clés : IMS, MS, Prion, Abeta, H/D exchange

\section{Programme}

\footnotetext{
*Intervenant

$\dagger$ †uteur correspondant: jan.bohl@u-psud.fr

† Auteur correspondant: guillaume.van-der-rest@u-psud.fr
} 


\title{
Analyses métabolomiques non ciblées par GC-QToF : de la basse à la haute résolution [P82]
}

\author{
Carole Migné ${ }^{* \dagger}{ }^{1}$, Nils Paulhe ${ }^{1}$, Yann Guitton ${ }^{2}$, Franck Giacomoni ${ }^{1}$, \\ Mélanie Petera ${ }^{1}$, Stéphanie Durand ${ }^{1}$, Estelle Pujos-Guillot ${ }^{1}$ \\ ${ }^{1}$ Université Clermont Auvergne, INRA, UNH, Plateforme d'Exploration du Métabolisme, MetaboHUB \\ Clermont - INRA - F-63000 Clermont-Ferrand, France \\ ${ }^{2}$ LUNAM Université, Oniris, Laboratoire d'Etude des Résidus et Contaminants dans les Aliments (LABERCA), \\ UMR 1329 (ONIRIS-Laberca) - Ministère de l'alimentation de l'agriculture et de la pêche \\ F-44307 Nantes, France
}

Les approches métabolomiques non ciblées par GC-MS ont pu évoluer grâce au développement de nouveaux instruments de plus haute résolution, comme le GC-QToF. Cette approche est utilisée au laboratoire dans le cadre de projets scientifiques pour la recherche de biomarqueurs permettant la caractérisation de phénotypes métaboliques.

Une méthode d'analyse non ciblée pour la détermination de profils métaboliques de biofluides par GCQToF a été adaptée d'une méthode basse résolution (Gao et al (1)) basée sur une double dérivation oximation /silylation.

Cette technique, plus sensible et plus résolutive, nécessite des outils de traitement des données spécifiques dédiés. Aussi, nous avons dû adapter des outils développés par notre laboratoire pour le traitement de données métabolomiques à ce type de données. Ces outils comprennent l'extraction des données par xcms sous la plateforme Galaxy (W4M, (2)), ainsi que tout le workflow conduisant à l'annotation des ions extraits après filtration et correction des effets batch.

Parallèlement, nous déployons une stratégie de déconvolution, à partir d'outils constructeurs afin de compléter les résultats obtenus sous Galaxy.

A ce jour, les bibliothèques GC-MS (NIST, Golm, Massbank) restent très utilisées pour l'identification des métabolites mais ne contiennent aucun spectre avec des masses précises bien que certains proviennent de GC-EI-ToF. Par conséquent, nous constituons une bibliothèque interne en haute résolution avec des standards purs et en matrices biologiques qui alimentera la base de données PeakForest de l'infrastructure française MetaboHUB.

La mesure des masses précises ainsi que le développement de nouveaux outils d'automatisation du traitement de données devraient permettre de lever certains verrous rencontrés dans la recherche de biomarqueurs concernant l'identification des métabolites.

(1) Gao X, Pujos-Guillot E, Sébédio JL. Development of a quantitative metabolomic approach to study clinical human fecal water metabolome based on trimethylsilylation derivatization and GC/MS analysis. Anal Chem. 2010 Aug 1;82(15):6447-56.

(2) W4M : http://workflow4metabolomics.org/

Mots-Clés : metabolomique, GC, QTof, Galaxy

\footnotetext{
${ }^{*}$ Intervenant

${ }^{\dagger}$ Auteur correspondant: carole.migne@inra.fr
} 


\title{
Structural characterization of distinct Tau strains [P83]
}

\author{
Emilie Caroux ${ }_{-}^{*}$, Karine Madiona $^{1}$, Luc Bousset ${ }^{1}$, Ronald Melki ${ }^{1}$, \\ Virginie Redeker $* \dagger 1$ \\ ${ }^{1}$ Paris-Saclay Institute of Neuroscience (Neuro-PSI) - CNRS : UMR9197, Université Paris-Saclay \\ 91198, Gif-sur-Yvette, France
}

Intracellular deposits of fibrillar assemblies of microtubule-associated protein tau are the common hallmark of several neurodegenerative diseases collectively named "tauopathies", including Alzheimer's disease (AD) (Lee et al Annu Rev Neurosci. 2001, 24:1121). Distinct tauopathies are distinguished by the 3R and 4R tau isoform composition of intracellular fibrillar tau deposits (Sergeant et al , Biochim Biophys Acta. 2005, 1739:179; Kovacs GG, Neuropathol Appl Neurobiol. 2015, 41: 3) and might be defined as distinct tau strains propagating distinct fibrillar conformations (Sanders et al Neuron. 2014, 82:1271; Clavaguera et al Neuropathol Appl Neurobiol. 2015, 41:47; Frost et al J Biol Chem. 2009, 284:3546). In order to identify isoform-specific conformational epitopes of distinct tau assemblies that allow discriminating between distinct tauopathies, we assembled the six full-length tau isoforms in vitro into fibrils. Using structural proteomic methods, we identified isoform-specific peptide sequences reflecting conformational and molecular signatures of distinct tau assemblies. The strategy we followed and the findings we made will be presented and discussed. Identification of specific isoform-conformational epitopes will be valuable tools to design new tau isoform epitope-specific antibodies in order to develop novel typing and early diagnostic method of distinct tauopathies.

Mots-Clés : Structural Proteomics, Protein aggregates, Alzheimer

Programme

\footnotetext{
${ }^{*}$ Intervenant

${ }^{\dagger}$ Auteur correspondant: virginie.redeker@cnrs.fr
} 


\title{
UVPD as a unique fragmentation tool for complete structure determination and substructure identification of small molecules [P84]
}

\author{
Marie-Pierre Pavageau * 1, Romain Huguet, Seema Sharma , Christopher \\ Mullen, Canterbury Jesse, Mark Berhow, \\ Zabrouskov Vlad, Tim Stratton \\ ${ }^{1}$ Thermo Fisher Scientific - Thermo Fisher Scientific - Courtaboeuf cedex, France
}

\begin{abstract}
Plant and fungus secondary metabolites are involved in many functions such as pigmentation, UV filtration, and defense mechanisms. These polyphenolic antioxidants have been incorporated for thousands of years in Eastern medicine but have yet to be utilized in Western therapeutics despite their phenomenal record in providing health benefits.

Here we investigate the molecular structures of several phenylpropanoids using various fragmentation techniques (CID, HCD and UVPD) available on an Orbitrap TM Fusion TM Lumos TM Tribrid TM mass spectrometer modified with a $213 \mathrm{~nm}$ UV-photodissociation (UVPD) source and a higher mass resolving power capability $(1,000,000$ at $\mathrm{m} / z 200)$. We performed CID, HCD and UVPD fragmentation experiments on these molecules for structural investigation. The data acquired from the different fragmentation techniques were used to reveal the molecular structures of each flavonoid using mzCloud and Xcalibur Qual Browser.
\end{abstract}

The structural diversity of conjugated flavanoids is extremely large, with the total number of combinations of conjugate sugars on different cores and their linking positions being unknown. We investigate here the fragmentation behavior of several flavonoids and their conjugates to determine diagnostic fragmentation using CID, HCD, and UVPD. When subjected to UVPD, flavone and flavanone both produce unique fragment ions from radical fragmentation channels not observed in either CID or HCD. A detailed UVPD study of luteolin and several of its mono glycosides showed that fragmentation of the core structure could be obtained concurrently with the losses of the glycosides typically observed by other fragmentation techniques. UVPD also provided unique fragmentation channels in both low and high mass range, since UVPD does not suffer the same low mass cut-off observed with CID. These results reveal that UVPD could be a powerful technique for the structural elucidation of conjugated flavonoid structures.

Mots-Clés : Orbitrap Fusion Lumos, UVPD, Flavonoids

Programme

${ }^{*}$ Intervenant 


\title{
Towards a faster localization of non-covalent ligand binding sites using an original footprinting method [P85]
}

\author{
Teddy Bijot ${ }^{*}{ }^{1}$, Guillaume Gabant ${ }^{1}$, Martine Cadène ${ }^{\dagger} 1$ \\ ${ }^{1}$ Centre de biophysique moléculaire (CBM) - CNRS : UPR4301 - Rue Charles Sadron \\ 45071 Orléans cedex 2, France
}

\begin{abstract}
Cancer is a disease with increasing impact worldwide. The pathophysiology of cancer is still poorly understood, especially the transition from the primary tumor to the advanced stage of metastasis. Yet, the main cause of lethality in cancer disease is metastasis. At this time, there is no treatment specifically targeting the spread of metastasic cells. Our project consists in providing a molecular basis for future preventative and curative treatments by studying the SK3, a Ca2+-activated potassium channel. This channel promotes invasion, particularly in bone metastasis, by associating with the Orai1 $\mathrm{Ca} 2+$ channel in lipid rafts. Ohmline, a glycerophospholipid derived from Edelfosine, can inhibit SK3's promoter activity. The finality of this work is to improve on the specificity and activity of Ohmline as a drug candidate. Ohmline is thought to stop the interplay between Orai1 and SK3 either through an indirect effect such as the disruption of lipid rafts, and/or through direct interaction with a lipid-binding domain on SK3 that would break up the Orai1/SK3 complex. We are developing a new footprinting method to determine the site of ligand binding on the protein. This method, based on limited proteolysis in single-hit statistics conditions using MALDI-TOF MS, generates a molecular cleavage ladder and its complementary ladder. The cleavage sites obtained in the control without ligand and the sample with ligand are compared. If a cleavage is not detected in the presence of ligand, it means that the cleavage site is masked by the ligand. In comparison with existing footprinting methods, our approach has the potential to make interpretation of the data faster and easier. Ultimately, the binding data combined with the protein $3 \mathrm{D}$ structure allows for modelization of the interaction, thus providing a basis for rational ligand design. This methodology could be extended to different kinds of protein/ligand systems in the future.
\end{abstract}

Mots-Clés : Foot printing, Localization, non, covalente interaction

$\underline{\text { Programme }}$

\footnotetext{
*Intervenant

†Auteur correspondant: martine.cadene@cnrs-orleans.fr
} 


\title{
Etude des mécanismes impliqués dans la photodégradation d'un polluant organique, le cyprodinil, par LC-HR MS/MS [P86]
}

\author{
Xuan Zuo, Christophe Genty, Stéphane Bouchonnet, \\ Edith Nicol, Sophie Bourcier* ${ }_{-}$ \\ ${ }^{1}$ Laboratoire de chimie moléculaire (LCM) - Polytechnique - X, Université Paris-Saclay, CNRS : UMR9168 - \\ Ecole polytechnique 91128 Palaiseau Cedex, France
}

Le développement industriel et urbain de la seconde moitié du 20ième siècle s'est accompagné de l'émergence de milliers de composés chimiques anthropogènes dans notre environnement. Leur toxicité n'est, le plus souvent, pas caractérisée. Si de nombreuses études analytiques et écotoxicologiques examinent l'impact de ces composés sur les populations aquatiques et terrestres, ces études portent essentiellement sur les molécules répertoriées dans les directives régissant la qualité de l'environnement aquatique. Or ces composés ne sont pas inertes chimiquement et en fonction de leur environnement, évoluent et conduisent à la formation de produits de transformation (TPs) qui peuvent être non seulement plus persistants que leurs précurseurs et présenter une toxicité plus importante. Des études au laboratoire de modélisation de la dégradation par photolyse de polluants dans l'eau, ont permis de le mettre en évidence. Dans ce travail, nous souhaitons appréhender les phénomènes mis en jeu dans la formation des TPs en faisant varier le solvant de dilution de la solution photolysée en présence ou pas d'eau. La caractérisation structurale est réalisée par combinaison des résultats obtenus en LC-HR/MS et LC-MS/MS sur la molécule ciblée et son analogue deutéré. Les résultats montrent que de nombreuses réactions ont lieu lors du processus de photodégradation : hydroxylation, addition d'une partie du solvant pour les alcools, isomérisation. Les mécanismes mis en jeu sont très dépendants de l'environnement de la molécule. Ces études pourraient nous permettre de mieux prédire la nature des composés formés. Leur toxicité potentielle est évaluée avec des tests in silico qui utilisent des calculs de type QSAR (Quantitative Structure Activity Relationship). Cette approche analytique a pour double objectif d'apporter des éléments pour mieux comprendre les mécanismes impliqués dans la photodégradation afin de caractériser des polluants émergents qui pourront être détectés avec des méthodes sélectives de spectrométrie de masse dans des matrices environnementales.

Mots-Clés : Pesticides, Photodégradation, Caractérisation de photoproduits, LC, HR/MS/MS

Programme

*Intervenant 


\title{
Native Ion Mobility Mass Spectrometry for the Characterization of Biotherapeutics [P87]
}

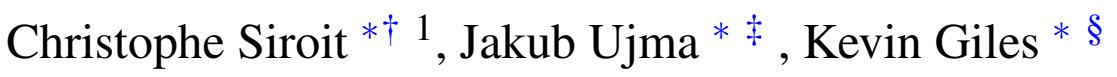 \\ ${ }^{1}$ Waters Corporation - Waters Corporation - Saint Quentin en Yvelines, France
}

Biopharmaceutical products provide a complex analytical challenge to the modern pharma industry. Not only must laboratories characterize the primary structure of protein species, but also the tertiary and quarternary (higher order) structure. One method often used in research laboratories for higher order structure analysis is native ion mobility spectrometry-mass spectrometry (IMS-MS). Due to the expansion of the biopharmaceutical industry and the broadening range of drugs being investigated, instrumentation is required to carry out advanced experiments in a routine manner. We describe a method to carry out native IMS-MS on a routine high resolution LC-IMS-MS platform. We also describe investigations into the applicability of high resolution-IMS-MS (HR-IMS-MS) for biopharmaceutical analysis using a cyclic IMS-enabled research platform.

Mots-Clés : IMS, biotherapeutics, ion mobility

Programme

\footnotetext{
${ }^{*}$ Intervenant

†Auteur correspondant: christophe_siroit@waters.com

¥Auteur correspondant: Jakub_Ujma@ waters.com

$\S$ Auteur correspondant: kevin_giles@ waters.com
} 


\title{
Structure elucidation and validation of small molecules: the LSD and CASA software [P88]
}

\author{
Jean-Marc Nuzillard ${ }_{-}^{*}$, Bertrand Plainchont \\ ${ }^{1}$ Institut de Chimie Moléculaire de Reims (ICMR) - CNRS : UMR7312, Université de Reims \\ Champagne-Ardenne - UFR Sciences, BP1039, 51687 Reims Cedex 2, France
}

The validation of a molecular organic structure on the basis of 1D and 2D HSQC, COSY and HMBC NMR spectra is proposed as an alternative to the methods that are mainly based on chemical shift prediction. The CASA software was written for this purpose. The tentative matching between the structure and the NMR data of a triterpene unexpectedly lead to the hypothesis of an incorrect structure. The LSD software was used to find an alternative structure that improved the 2D NMR data interpretation and the carbon-13 chemical shift matching between experimental values and those produced by the nmrshiftdb2 prediction tool.

The LSD software proposes the structures of small organic molecules that fit with structural constraints from 1D and 2D NMR spectroscopy. Its initial design introduced limits that needed to be eliminated in order to extend its scope and help its users choose the most likely structure among those proposed. The LSD software code has been improved, so that it recognizes a wider set of atom types to build molecules. More flexibility has been given in the interpretation of 2D NMR data, including the automatic detection of very long-range correlations. A program named pyLSD was written to deal with problems in which atom types are ambiguously defined. It also provides a carbon-13 NMR chemical shift-based solution ranking algorithm. PyLSD was able to propose the correct structure of hexacyclinol, a natural product whose structure determination has been highly controversal. The solution was ranked first within a list of ten structures that were produced by pyLSD from literature NMR data.

$\underline{\text { www.univ-reims.fr/LSD/JmnSoft }}$

Mots-Clés : Analyse structurale automatique, vrification de structure, métabolites secondaires

Programme

*Intervenant 
Mercredi 4 octobre [P89-P172] 


\section{Approches omiques quantitatives [P89-P100]}




\title{
Utilisation d'une approche métabolomique pour l'analyse des composés organiques volatils du cacao fermenté séché en provenance de Côte d'Ivoire [P89]
}

\author{
Mathieu Lazarus ${ }_{-}^{*}{ }^{1,2}$, Cédric Bertrand ${ }^{1}$, Sabine Quintana ${ }^{2}$, \\ Nathalie Tapissier ${ }^{1}$ \\ ${ }^{1}$ Centre de Recherches Insulaires et Observatoire de l'Environnement (CRIOBE) - École Pratique des Hautes \\ Études [EPHE], CNRS : USR3278 - 52 Av. Paul Alduy, 66100 Perpignan, Bat T, France \\ ${ }^{2}$ Service qualité, recherche et développement cacao (QRD cacao) - Cémoi - 2980 Avenue Julien Panchot, \\ 66000 Perpignan, France
}

L'arôme du cacao dépend des facteurs génétiques (cultivar) mais aussi des pratiques culturales ou des méthodes de fermentation, [...]. Une partie de ces arômes sera créée lors de la torréfaction. Cependant, une large part des notes florales et fruitées apparaissent lors des étapes de transformation précédant la torrefaction. En Côte d'Ivoire, l'entreprise Cemoi a mis en place un système de classement du cacao fermenté séché reposant sur les caractéristiques organoleptiques des lots.

Nous présenterons ici le résultat d'une étude portant sur 21 échantillons de cacao fermenté séché prélevés en Côte d'Ivoire et répartis en 3 classes organoleptiques. L'analyse de la fraction volatile du cacao par Headspace-SPME-GC-MS et le traitement des résultats avec des outils de statistiques multivariées nonsupervisées ont permis de faire émerger des biomarqueurs de la qualité du cacao. Les différences observées sont probablement imputables au climat, aux méthodes agronomiques ou encore aux traitements post-récolte utilisés ; ces variables étant elles-mêmes largement dépendantes de la région, de l'année et la saison.

Pour essayer de démontrer l'existence d'effets terroirs, millésimes ou récoltes en Côte d'Ivoire, une étude à grande échelle a été initiée en mai 2016. Sur 3 ans, des échantillons en provenance de centres de fermentation répartis sur l'ensemble du territoire Ivoirien seront analysés. Pour traiter un nombre aussi considérable d'échantillons, une méthode automatisée d'extraction et d'analyse a été développée : des séries de 24 échantillons (12 échantillons, 6 contrôles qualités, 6 blancs) sont analysés avant d'être traités avec XCMS, via la plateforme workflow4metabolomics, afin d'intégrer les pics et de corriger la dérive intra et inter-séquence.

Jusqu'à maintenant, 154 lots issus de la production de 10 centres de fermentation de fèves de cacao ont étés évalués. Le traitement statistique de l'intégralité de ces données a d'ors et déjà permis de mettre en évidence des biomarqueurs de l'origine géographique en Côte d'Ivoire.

Mots-Clés : Headspace, GC, MS, Molécules Volatiles, Cacao, Metabolomique

$\underline{\text { Programme }}$

*Intervenant 


\title{
Impact des Botryosphaeriaceae sur la production de métabolites de la vigne [P90]
}

\author{
Mary-Lorène Goddard ${ }^{* \dagger}{ }^{1,2}$, Kim Wilhelm ${ }^{1,2}$, Hélène Laloue ${ }^{2}$, \\ Peter Nick ${ }^{3}$, Céline Tarnus ${ }^{1}$, Christophe Bertsch ${ }^{2}$, Julie Chong ${ }^{2}$ \\ ${ }^{1}$ Laboratoire de Chimie Organique et Bioorganique, Université de Haute-Alsace 3bis, rue Alfred Werner \\ 68093 Mulhouse Cedex, France \\ ${ }^{2}$ Laboratoire Vigne, Biotechnologies et Environnement, Université de Haute-Alsace, 33, rue de Herrlisheim \\ 68000 Colmar, France \\ ${ }^{3}$ Botanical Institute, Molecular Cell Biology, Karlsruhe Institute of Technology, Karlsruhe, Allemagne
}

Le Botryosphaeria Dieback, une des principales maladies du bois de la vigne, a un impact considérable sur la production et la pérennité du vignoble français et mondial. A ce jour, aucun traitement n'est disponible pour limiter la progression de cette maladie. Elle est associée au développement de champignons de la famille des Botryosphaeriaceae, dont Neofusicoccum parvum and Diplodia seriata, qui produisent des enzymes dégradant le bois ainsi que des métabolites phytotoxiques. Leur lien avec les symptômes foliaires caractéristiques de la maladie n'est pas encore clairement établi. De même, les réponses de la vigne suite à cette infection fongique sont encore peu décrites, en particulier les changements induits au niveau de son métabolisme. Nous avons réalisé à la fois une étude métabolomique ciblée pour quantifier par GC-MS les métabolites primaires chez la vigne (sucres, acides aminé et acides organiques) ainsi qu'une étude non ciblée des métabolites secondaires par LC-MS/MS. Notre étude s'est également focalisée sur la production de phytoalexines de la famille des stilbènes, connues pour être impliquées dans les défenses de la plante suite à un stress biotique, qui se trouve impactée par les champignons de la famille des Botryosphaeriaceae. Nous avons notamment pu montrer une production de d-viniférine, dimère de resvératrol, suite à la présence de matériel fongique (champignon inoculé sur des sarments ou même simple contact entre des cellules de vigne et les protéines fongiques extracellulaires).

Mots-Clés : Botryosphaeriaceae, vigne, métabolites, stilbènes, GCMS, LCMS/MS

$\underline{\text { Programme }}$

\footnotetext{
*Intervenant

†Auteur correspondant: mary-lorene.goddard@uha.fr
} 


\title{
Overcoming Gefitinib Resistance By HDAC Inhibition In Mutant KRAS Lung Adenocarcinoma [P91]
}

\author{
Sylvia G. Lehmann ${ }^{1,2}$, Michel Seve ${ }^{1}$, Laetitia Vanwonterghem ${ }^{3}$, Sylvie \\ Michelland ${ }^{1}$, Valérie Cunin ${ }^{1}$, Jean-Luc Coll ${ }^{3}$, Amandine Hurbin'³, \\ Sandrine Bourgoin-Voillard

\begin{abstract}
${ }^{1}$ LBFA et BEeSy, PROMETHEE Proteomic Platform - Université Grenoble Alpes, Centre de Recherche INSERM, CHU Grenoble - Plate-forme de Protéomique Prométhée Institut de Biologie et Pathologie, CHU de Grenoble Boulevard la Chantourne 38700 La Tronche, France

2 ISTerre - Université Grenoble Alpes, CNRS : UMR5275 - Université Grenoble Alpes ISTerre, Grenoble

${ }^{3}$ Institute for Advanced Biosciences - Centre de Recherche INSERM : U1209, Université Grenoble Alpes, CNRS : UMR5309 - Institut Albert Bonniot Centre de recherche UGA / INSERM U 1209 / CNRS UMR 5309

Site santé - Allée des Alpes 38700 La Tronche, France
\end{abstract}

Since the last decades, EGFR-TKI treatments such as gefitinib have emerged to target specific nonsmall cell lung cancer (NSCLC) molecular pathways. Although, these molecules are highly efficient for some NSCLC patients, others show resistance including patients with mutant KRAS lung adenocarcinoma. In this context, we previously demonstrated that deacetylase inhibitors significantly sensitized mutant KRAS adenocarcinoma cells to gefitinib. The aim of this study is to use the mutant KRAS lung adenocarcinoma $\mathrm{H} 358$ cell line, to identify protein biomarkers of the restored sensitivity to gefitinib by deacetylase inhibitors treatment and also to provide new therapeutic targets for this subset of NSCLC. To achieve this goal, a comparative quantitative proteomic analysis of $\mathrm{H} 358$ cells treated with gefitinib and deacetylase inhibitors (TSA and NAM) versus gefitinib alone was performed. The quantitative proteomic approach was carried out by a subcellular fractionation (nuclear and cytoplasmic fractions) followed by trypsin enzymatic digestion, iTRAQ labeling, 2D peptide fractionation (OFFGEL/RP nanoLC) and MALDI-TOF/TOF mass spectrometry analysis. MS and MS/MS data were analyzed by Protein Pilot software $\mathrm{v} 4$ prior a validation of quantitative results by the R package IsobarPTM. Eighty-six proteins were found significantly dysregulated between the two conditions. Gene ontology and pathway analysis was performed and revealed that several signaling pathways, including Interferon type I and II, androgen receptor, TGF-beta and EGF/EGFR, were modified between the two conditions. Also network analysis showed that most of dysregulated proteins identified were upstream neighbors of apoptosis and then could be interesting therapeutic targets. Subcellular localization and changes of expression of three interesting proteins were further validated by western blot and confirmed the proteomic results. Finally, our study highlighted the impact of these three proteins on proliferation and apoptosis induction by conducting siRNA transfection in NSCLC cells.

Mots-Clés : Non small cell lung cancer, EGFR TKI, resistance, gefitinib, inhibitors of lysine deacetylases, quantitative proteomics

\footnotetext{
*Auteur correspondant: amandine.hurbin@univ-grenoble-alpes.fr

${ }^{\dagger}$ Intervenant

¥Auteur correspondant: sandrine.bourgoin@univ-grenoble-alpes.fr
} 


\title{
Host Cell Proteins accurate quantification using MS-based assay coupled to label-free strategy [P92]
}

\author{
Tanguy Fortin * ${ }_{-}^{1}$, Mathieu Trauchessec ${ }^{1}$, Quentin Enjalbert ${ }^{1}$ \\ ${ }^{1}$ ANAQUANT, 5 rue de la Doua, 69100 Villeurbanne, France
}

In the context of the use of biotherapeutics, Host Cell Proteins (HCPs) can present a safety risk to patients. Therefore HCPs identification and quantification must be monitored for consistency purpose. Currently, HCPs levels are typically measured with classical biochemical or immunological techniques, such as ELISA assays. Considering the time needed and the difficulty to develop specific antibodies, it appeared inconceivable to guarantee coverage of all every possible HCPs. In order to assay HCPs in biotherapeutics samples, mass spectrometry appears as a orthogonal tool to overpass limitations of other techniques. Also, stable isotope dilution strategy doesn't appear judicious for high throughput quantification, label-free MS-based absolute quantification strategy was thus developed. This strategy consisted in performing titration curves with Escherichia coli protein standards accurately calibrated by the AAA-MS method. An 1/x linear regression was performed considering iBAQ values of each standard protein. Standards quantities were calculated from the best fit equation and plotted against added amount to assess accuracy and precision of the method. To go further, BSA obtained from the NIST was added in the sample as an internal standard. Once the performances benchmarked, all detected HCPs can be quantified in a single MS and label-free analysis, based on their iBAQ values. In spite of labelfree aspect, performances assessment demonstrated highly accurate and precise results with high throughput potential. To go further we are currently testing the same approach with top3 strategy, to overpass protein standards limitations, and take advantage of peptides properties, particularly better stability. Associated with READYBEADS technology, it provides the first universal HCPs quantification kit. By adding one bead in the sample it becomes possible to quantify all HCPs present in the sample, in a single MS run.

Mots-Clés : HCPs, quantification

$\underline{\text { Programme }}$

*Intervenant 


\title{
NMR-based metabolomic in study on fruit-oils: Determination of optimal treatment on fruits and differences on oil composition [P93]
}

\author{
Covadonga Lucas-Torres $*^{*} 1,2$, Andrés Moreno ${ }^{2}$, José Emilio Pardo ${ }^{3}$, \\ Manuel Álvarez-Ortí ${ }^{3}$ \\ ${ }^{1}$ Laboratoire de Structure et Dynamique par Résonance Magnétique (LSDRM) - add this : CEASACLAY - \\ NIMBE, CEA, CNRS, Université Paris-Saclay, CEA Saclay 91191 Gif-sur-Yvette, France \\ ${ }^{2}$ Facultad de Ciencias y Tecnologías Químicas, Universidad de Castilla-La Mancha, Ciudad Real, Spain - \\ Universidad de Castilla-La Mancha, Ciudad Real, Espagne \\ ${ }^{3}$ ETSIAM, Universidad de Castilla-La Mancha, Albacete, Spain \\ Universidad de Castilla-La Mancha, Albacete, Espagne
}

Introduction: This research aims to study several vegetable oils (tiger nut, pistachio), to understand how different treatments on the fruit can improve the oil composition. Besides, the major and minor metabolites in walnut oils from different varieties are also included in this study.

Methodology: a) Multinuclear NMR analysis

$1 \mathrm{H}, 13 \mathrm{C}$ and 31P NMR experiments were carried out by triplicate on the oil samples.

b) NMR data processing and statistical analysis

After processing each spectrum, the NMR data matrices were used to record statistical analysis in terms of Linear Discriminant Analysis (LDA).

Results and discussion: $1 \mathrm{H}$ and 31P NMR experiments show differences in the profile of the different oils.

On the basis of 13C NMR quantification of the unsaturated fatty acid content in each sample, only the pistachio oil samples from fruits submitted to toasted treatments show a slight decrease in oleic acid and an increase in linoleic acid with temperature and time. To carry out the LDA, groups of samples were generated in terms of the toasted treatments. Using the 1H NMR data, although the separation is not extreme, the distinct groups can be easily differentiated from each other suggesting a correct interpretation of the results on the composition.

The 13C NMR analysis of the different walnut varieties help to differentiate the samples by their content in linoleic acid, which is the major component. They can be categorised into four groups according to the decreasing content in linoleic acid and subsequent increase in oleic and linolenic acids. The LDA on the $1 \mathrm{H}$ NMR data shows a strong separation between these pre-defined groups.

Conclusion: We herein report an efficient analysis of metabolites of different vegetable oils by NMR spectroscopy and statistical tools, constituting a valid approach for sample characterization in terms of fruit pre-treatment and varieties.

Mots-Clés : NMR, fruit ois, metabolomics, LDA

\footnotetext{
*Intervenant

†Auteur correspondant: Covadonga.Lperez@gmail.com
} 


\title{
Monitoring of Host Cell Proteins clearance through therapeutic monoclonal antibodies purification process [P94]
}

\author{
Séverine Clavier ${ }_{-}^{*}$, Bruno Genet ${ }^{1}$, Dawid Bugnazet ${ }^{1}$, Florence Cordier ${ }^{1}$ \\ ${ }^{1}$ Sanofi BioAnalytics Department - SANOFI Recherche - 13 Quai Jules Guesdes 94400 Vitry-sur-Seine, France
}

\begin{abstract}
Host cell proteins (HCPs) are bioprocess-related impurities arising from death or secretion of cells used for monoclonal antibody (mAbs) production. Clearance of thousands of HCPs through downstream purification (DSP) is required to produce safe and stable therapeutic proteins. DSP of mAbs utilizes a series of orthogonal chromatographic steps, the first of which is most often a protein A capture step, followed by one or two polishing steps. Following purification, low residual levels of HCP impurities can remain in the final drug substance. As HCPs might represent potential safety risks for patients including immunogenicity, adjuvant activity, proteolytic activity and direct biological activity, it is necessary to identify and quantify HCPs along the purification steps. This represents a major analytical challenge due to the parts-per-million ( $\mathrm{ppm}$ ) sensitivity and high dynamic range required to detect a given HCP in the presence of the $\mathrm{mAb}$ product. Following identification by an exploratory approach, quantification can be achieved with targeted approaches (MRM/PRM) and help DSP team better understand and improve HCPs clearance. In Sanofi, HCP profiling was performed for several mAb samples collected at the different steps of the DSP. This work allowed identifying "hitchhiker" HCPs that tend to copurify with $\mathrm{mAb}$ and that are thus particularly important to monitor. Based on this HCP profiling a list of "usual suspects" was built and labelled synthetic surrogate peptides were obtained in order to quantify the corresponding HCPs along DSP. Analytical strategies used for both the identification and quantification of HCP will be described with a focus on the challenge of sensitivity for the detection of these low levels impurities.
\end{abstract}

Mots-Clés : Host Cell Proteins, Monoclonal antibodies, PRM, MS, MRM, MS

Programme

${ }^{*}$ Intervenant 


\title{
Performance evaluation of Data Independent Acquisition and Data Dependent Acquisition workflows [P95]
}

\author{
Alexandra Kraut*1, Christophe Bruley $* 1$, Christophe Masselon $* 1$, Virginie \\ Brun $^{*} 1$, Yohann Couté ${ }^{1}$, Anne-Marie Hesse $* \nmid 1$ \\ ${ }^{1}$ Exploring the Dynamics of Proteomes - Large Scale Biology Laboratory BGE UMR S 1038 (EDyP) - \\ Université Grenoble Alpes,CEA - Grenoble : CEA/DRF/BIG/BGE, INSERM : U1038 - 17, rue des Martyrs \\ 38054 Grenoble cedex 9, France
}

In discovery proteomics experiments, tandem mass spectrometry and Data-Dependent Acquisition (DDA) are classically used to identify peptides and proteins through database searching. This strategy suffers from different limitations like under-sampling and irreproducible precursor ion selection leading to a non-exhaustive analysis of large datasets. Data-Independent Acquisition (DIA) based on the fragmentation of all precursors contained in predetermined isolation windows has the potential to overcome these limitations. In particular exhaustive MS/MS spectral library combined to effective targeted MS2 data extraction and scoring is expected to improve proteome coverage, enhance the quantification reproducibility and decrease missing value frequency.

We present here an evaluation and comparison of DDA and DIA strategies in terms of detection sensitivity, proteome coverage, dynamic range, quantification reproducibility and false discovery proportion. We acquired data on complex protein lysates (like E. coli or yeast extracts) on a QExactive HF instrument from Thermo Scientific with a two-hours gradient using either a DDA or DIA acquisition mode. DIA data were processed with Spectronaut whereas DDA data were processed with Maxquant software.

From the obtained results, we show that DIA is more sensitive than DDA. Indeed, we were able to quantify respectively 3000 and 500 additional peptides and proteins with DIA from a $10 \mathrm{ng}$ E. coli digest. For more complex samples, using an exhaustive library, DIA allowed to quantify $25 \%$ more proteins than DDA. To test false discovery proportion at the identification level using DIA, we processed data using a library from another specie. Interestingly, it did not generate more false identifications than DDA data analysis through database searching. The dynamic range and the quality of quantification results will be illustrated with yeast samples spiked with known amount of protein standards. All together, these results support DIA as an exquisite strategy for the identification and quantification of proteins in complex biological systems.

Mots-Clés : Label free Quantification, Shotgun, Data Independent Acquisition, Library

Programme

\footnotetext{
${ }^{*}$ Intervenant

${ }^{\dagger}$ Auteur correspondant: anne-marie.hesse@cea.fr
} 


\title{
Quantitative analysis of the cysteine redoxome by iodoacetyl tandem mass tags [P96]
}

\author{
Shakir Shakir ${ }_{-}^{\dagger}{ }^{1}$, Giovanni Chiappetta ${ }_{-}^{\ddagger}$, Joëlle Vinh ${ }_{-}^{\S 1}$ \\ ${ }^{1}$ ESPCI Paris, Spectrométrie de Masse Biologique et Protéomique. (SMBP) - PSL Research University, CNRS : \\ USR3149, PSL Research University - 10 rue Vauquelin, 75231 Paris Cedex 05, France
}

The redox conditions that reign inside a cell have a determining effect on many biological processes. Reactive Oxygen Species (ROS) and Reactive Nitrogen Species (RNS) are key redox players and have been linked to several pathologies. They have also been shown to play an important regulating role in cell signaling events. On the proteome level, thiol groups of cysteinyl side chains constitute the major targets of ROS and RNS. A few analytical techniques based on mass spectrometry have been developed to characterize the cysteine redoxome, often facing technical challenges, mostly related to the lability, heterogeneity and low abundance of the oxidized forms. Furthermore, any posttranslational modification (PTM) quantification method needs to take the parent protein's expression level into account.

While taking all these limitations into consideration, we have developed a quantitative analytical strategy named OxiTMT (1), based on chemical labeling with iodoacetyl isobaric tandem mass tags (iodoTMT). OxiTMT allowed the generation of quantitative redox data that could be normalized by the protein's expression profile in up to three different conditions. The method was tested and validated on $E$. Coli with or without an oxidative treatment. Results showed the method to be adequate for the analysis of cysteine PTMs with a good coverage of the cysteine redoxome, especially for the low abundant oxidized species. Furthermore, this study has allowed us to assess some of the challenges that face reporter ion quantification of PTMs by mass spectrometry. The study also opens some interesting perspectives, notably the use of tandem mass tags for the study of redox PTMs in tissues and sera.

(1) Shakir S, Vinh J, Chiappetta G. Quantitative analysis of the cysteine redoxome by iodoacetyl tandem mass tags. Anal Bioanal Chem. 2017 Jun;409(15):3821-3830

Mots-Clés : proteomics, cysteine, redoxom, TMT, quantification, oxidative stress

$\underline{\text { Programme }}$

\footnotetext{
${ }^{*}$ Intervenant

${ }^{\dagger}$ Auteur correspondant: shakir.shakir@espci.fr

¥Auteur correspondant: giovanni.chiappetta@espci.fr

$\S$ Auteur correspondant: joelle.vinh@espci.fr
} 


\title{
Scanning quadrupole data independent acquisition: a novel workflow for discovery and targeted quantitative proteomics [P97]
}

\author{
Sarah Lennon * 1 , Ute Distler ${ }^{2}$, Jörg Kuharev ${ }^{2}$, Oliver M. Bernhardt ${ }^{3}$, Lukas \\ Reiter ${ }^{3}$, Hanñes Roest ${ }^{4}$, Keith Richardson ${ }^{1}$, Chris Hughes ${ }^{1}$, Johannes Pc \\ Vissers ${ }^{1}$, Gushinder Kaur-Atwal ${ }^{1}$, Stefan Tenzer ${ }^{2}$ \\ ${ }^{1}$ Waters corporation - Stamford Avenue Altrincham Road Wilmslow SK9 4AX UK, Royaume-Uni \\ ${ }^{2}$ University Medical Center of the Johannes Gutenberg - Mainz, Allemagne \\ ${ }^{3}$ Biognosys - Zurich, Suisse \\ ${ }^{4}$ Stanford University School of Medicine - California, États-Unis
}

\begin{abstract}
Data independent analysis (DIA) has become increasingly popular in the field of quantitative proteomics. Here we describe and evaluate a DIA mode of operation called SONAR, developed and implemented on a hybrid quadrupole/oa-time-of-flight (Q-TOF) mass spectrometer. Briefly, data are collected using a continuously scanning quadrupole, isolating specific $\mathrm{m} / \mathrm{z}$ regions prior to oa-TOF analysis. MS scans alternate between precursor (low energy) and CID product ions (high energy). This method enhances duty-cycle and produces highly specific and unbiased multi-dimensional data sets, which can be searched using a traditional discovery proteomics workflow with a SwissProt database or using a targeted spectral library approach.

To evaluate the quantitative performance of SONAR, the metaproteome quantification standards were used, which consist of tryptic digests from three different proteomes (Human, yeast and E.coli) mixed at different levels. Data were processed using ProteinLynx Global Server 3.0.3 (Waters) with a reviewed SwissProt database. Additionally, we interrogated the data with spectral library-based analysis workflows using OpenSWATH (ETH Zurich) and Spectronaut (Biognosys). The LFQbench software (Mainz University) was used to determine both precision and accuracy of the SONAR label-free quantification results at peptide and protein level. Overall, data acquired with SONAR showed high technical reproducibility and excellent quantification accuracy with over 4 orders of magnitude dynamic range.
\end{abstract}

Mots-Clés : Quantitative proteomics, SONAR, Data Independant Acquisition, spectral library search

$\underline{\text { Programme }}$

*Intervenant 


\title{
Evolution des histones au cours de l'érythropoïèse murine [P98]
}

\author{
Marjorie Leduc ${ }_{-}^{*}{ }^{1}$, Emilie-Fleur Gautier ${ }^{1}$, François Guillonneau ${ }^{1}$, \\ Patrick Mayeux ${ }^{1}$
}

13 P5 proteomics facility - INSERM U1016, Université Paris Descartes, Sorbonne Paris Cité - Paris, France

L'érythropoï̀se est le processus physiologique aboutissant à la formation des érythrocytes. On distingue 2 grandes phases : l'érythropoï̀se précoce et la différenciation érythroïde terminale. Lors de cette seconde phase, la taille des noyaux diminue fortement et la chromatine se condense. Selon certains auteurs, cette condensation pourrait être associée à une expulsion partielle des histones du noyau (Hattangadi 2014 et Zhao 2016) et/ou à des Modifications Post-traductionnelles (MPTs) (Popova 2009).

Cette étude protéomique a pour but de suivre les histones nucléaires selon 3 aspects : l'évolution de leur quantité totale par cellule, celle de l'expression de leurs différentes isoformes et variants ainsi que les MPTs.

Pour cela, une lignée érythrö̈de murine appelée FRIEND a été marquée SILAC et sert de référence. Des aliquots de cette référence ont été mélangés avec un nombre constant de cellules de FRIEND non marquées à différents temps de différenciation. Puis, les histones nucléaires ont été purifiées et 3 digestions ont été menées parallèlement afin d'obtenir un maximum de couverture : trypsine précédée ou non d'une propionylation et LysC.

Parmi la trentaine d'histones identifiée, seules les 5 plus intenses influencent significativement la quantité totale d'histone dans les noyaux. Contrairement aux observations de Hattangadi, les ratios obtenus au cours de la différenciation, n'indiquent pas de diminution majeure de la quantité totale d'histone nucléaire. Par ailleurs, on note une importante augmentation de H1F.0 (une histone linker connue pour être surexprimée dans des cellules différenciées). Enfin, cette analyse a permis la quantification d'une quinzaine de MPTs dont 6 ne sont pas référencées dans Swissprot. C'est le cas de la méthylation de H3R84. Cette arginine participe à l'une des interactions entre ADN et nucléosome. Les quantifications du site H4K13 confirment la désacétylation mise en évidence par Popova en 2009. Enfin, deux acétylations présentent une variation notable : H3K19 et H3K24.

Mots-Clés : Histones, SILAC, Erythropoï̀se

$\underline{\text { Programme }}$

\footnotetext{
*Intervenant
} 


\title{
Revolutionary Proteome Profiling and Quantitation without Compromising Speed, Sensitivity, and Selectivity [P100]
}

\author{
Claire Dauly * 1, Yue Xuan, Oleksandr Boychenko, Remco Swart, Alexander \\ Harder, Thomas Moehring \\ ${ }^{1}$ Thermo Fisher Scientific - Courtaboeuf cedex, France
}

For large cohort studies in translational proteomics research, data independent acquisition (DIA) methods are used to provide a global view of protein abundance changes among the samples. Here, a novel high resolution MS1 based quantitation DIA (HRMS1) method was developed on the Thermo Scientific $^{\mathrm{TM}} \mathrm{Q}$ Exactive ${ }^{\mathrm{TM}} \mathrm{HF}-\mathrm{X}$ mass spectrometer to optimize usage of scan speed, ion injection time (sensitivity), and high resolution (selectivity). Conventional DIA quantitation is based on the intensities of fragments in MS2 scans. Instead of quantifying the peptides on MS2 intensitities, MS1 scans offer potentially higher sensitivity since the peptide precursor is not fragmented into multiple fragments. High resolution detection removes interferences from analytes of interest, achieving accurate and precise quantitation.

The samples consisted of three separate proteomes (HeLa, Yeast, and E. coli). For high-throughput analysis, an UltiMate 3000 RSLC system equipped with capillary flow configuration was used to separate tryptic peptides with 1-hour run time. The Q Exactive HF-X system enables collection of a higher number of ions per time can be collected. The HRMS1 method uses MS2 scans only for identification while the MS1 scan rate is kept constant across the LC peak for precise quantitation. In this case, a narrower isolation window width was applied to increase the selectivity and dynamic range. Separation of the tryptic peptides in complex proteomes was performed with 1-hour total run time allowing for the identification and quantification of $>4400$ proteins and $>30,000$ peptide precursors $\left(\_-15 \%\right.$ more peptide precursors than on the QE HF). Different resolution settings on the MS1 scans were evaluated. With higher resolution, _ 10\% more peptide precursors are identified with $1 \%$ FDR, and $\sim 20 \%$ more peptide precursors are quantified with CV\% $<20 \%$. This result shows that high resolution is the key to achieve accurate and precision quantitation by removing interferences.

Mots-Clés : QE HF, X, DIA, capLC, MS

$\underline{\text { Programme }}$

*Intervenant 


\section{Développements méthodologiques et fondamentaux MS [P101-P117]}




\title{
Identification and evaluation of antibacterial agents present in lipophilic fractions isolated from date seeds and pollen of Phoenix dactilyfera L [P101]
}

\author{
Najla Bentrad $_{-}^{*}$, Rabéa Gaceb-Terrak ${ }^{1}$, Fatma Rahmania ${ }^{1}$ \\ ${ }^{1}$ Faculty of Biological Sciences - University of Sciences and Technology Houari Boumediene (USTHB), BP 32, \\ 16111 El-Alia, Bab Ezzouar, Algérie
}

In this work, we have analyzed the biochemical composition of naturals extracts isolated from date seeds and pollen. Then, we have tested the antibacterial effect of fatty acids and volatile compounds found in subproducts of Ph.dactylifera $\mathrm{L}$, in order to determine their industrial and nutritional values. The vegetable powder was extracted by Soxhlet extractor and the solutions were analyzed by GC-MS to determine their chemical compositions.

The results in seeds cultivars revealed that the main fatty acids in Deglet Nour seeds is oleic acid $(42.06 \%)$ followed by capric acid (24.16\%), Takerbucht seeds oil contains mostly oleic acid (40.59\%) and palmitic acid (20.19\%) while Bent Kbala seed oil is rich in cis-vaccenic acid (52.09\%) followed by capric acid (16.71\%). Pollen is rich in 14-methyl palmitic acid (33.31\%). In fact, two essential fatty acids, linoleic acid $(31.16 \%)$ and linolenic acid $(25.78 \%)$ were identified for the first time in pollen extract. These elements seem to have a significant effect against some bacteria.

Given the results, the fatty acids composition present in seeds and pollen are suitable for nutritional purposes and represent an important source for pharmaceutical and food industries or for the production biodiesel fuels. However, due to the presence of some organic volatils compounds, the security of these oils should be tested before human consumption.

Mots-Clés : Antibacterial activity, GC, MS, lipophilic fractions, Phoenix dactylifera L, sub, products.

$\underline{\text { Programme }}$

*Intervenant 


\title{
VUV study of the electronic effects of phosphine ligands bound to a Molybdenum complex [P102]
}

\author{
Héloïse Dossmann ${ }^{*}{ }^{1}$, Denis Lesage ${ }^{1}$, David Gatineau ${ }^{2}$, Hervé Clavier ${ }^{3}$, \\ Antony $\overline{\text { Memboeuf }}{ }^{4}$, Anne Milet ${ }^{5}$, Yves Gimbert ${ }^{6}$ \\ ${ }^{1}$ Institut Parisien de Chimie Moléculaire (IPCM) - CNRS : UMR8232, Université Pierre et Marie Curie [UPMC] \\ - Paris VI - F 75252 Paris Cedex 05, France., France \\ ${ }^{2}$ Institut Parisien de Chimie Moléculaire - Université Pierre et Marie Curie [UPMC] - Paris VI, CNRS : \\ UMR8232 - F 75252 Paris Cedex 05, France \\ ${ }^{3}$ Institut des Sciences Moléculaires de Marseille (iSm2 - UMR CNRS 7313) - Aix-Marseille Université - AMU : \\ EA1, Ecole Centrale de Marseille - Campus de St Jérôme 13997 Marseille Cedex 20, France \\ ${ }^{4}$ Chimie, électrochimie moléculaires et chimie analytique (CEMCA) - CNRS : UMR6521, Université de \\ Bretagne Occidentale (UBO), Institut Supérieur des Sciences et Technologies de Brest (ISSTB) - 6 Av Victor Le \\ Gorgeu - BP 80929285 Brest cedex, France \\ ${ }^{5}$ Département de Chimie Moléculaire (DCM) - CNRS : UMR5250, Université Joseph Fourier - Grenoble I - \\ 301, rue de la Chimie 38041 Grenoble cedex 9, France \\ ${ }^{6}$ Département de Chimie Moléculaire UJF-CNRS (DCM) - CNRS : UMR5250 - Université Joseph Fourier 301 \\ rue de la chimie BP 5338041 Grenoble Cedex 9, France
}

An important feature of metal catalysts lies in the crucial role of ancillary ligands on the electronic structure of the metal center. Determining how those ligands affect the reactivity of the metal center and quantifying this effect is thus of paramount importance. Various methods have been proposed to evaluate the electron donating/accepting property of ligands as, for instance, the popular Tolman Electronic Parameter method. This technics nevertheless lacks of a correct description of the electronic effects implied. The electronic environment of the metal center is indeed affected by the nature of its ligands by means of s-donation and $\pi$-back donation. In this context, a collaborative work was initiative from various fields (organometallic chemistry and catalysis, theoretical chemistry, mass spectrometry) with the objective of studying the connections existing between steric and electronic properties of ligands of interest for catalytic processes, and reactivity of the metal-based catalyst to which they are bound. Our objective is to build a new electronic properties scale for ligands bound to a given metal which will help chemists to rationalize the effect of ligands on the performance of catalysts. To this end, various experimental technics have been employed, in particular VUV-spectroscopy. We will present here the results obtained for several Molybdenum complexes, $\mathrm{Mo}(\mathrm{CO}) 5 \mathrm{~L}$, with $\mathrm{L}=\mathrm{PR} 3(\mathrm{R}=$ alkyl, MexPhy or PyrxPhy) and studied by means of VUV spectroscopy at the synchrotron SOLEIL facility center and density-functional theory (DFT) calculations. Photoionization process of the complexes gives precious information concerning the electronic interaction between the ligand and the metal. The vertical ionization energies IEvert that are measured on the photoionization spectra are indeed related to the molecular orbitals of the complexes and allows thus a detailed description of P-back-bonding and s-acceptor characters of the ligand.

Mots-Clés : Spectroscopy, organometallic, retrodonation, vertical ionization energy

$\underline{\text { Programme }}$

*Intervenant 


\title{
Collision Cross Sections of Polyoxometalates : linking experimental and theoretical values [P103]
}

\author{
Sébastien Hupin ${ }^{1}$, Hélène Lavanant ${ }^{* \dagger}{ }^{1}$, Madeleine Piot ${ }^{2}$, Guillaume Izzet ${ }^{2}$, \\ Vincent Tognetti ${ }^{\top}$, Carlos Afonso ${ }^{1}$ \\ ${ }^{1}$ Normandie Univ, UNIROUEN, INSA Rouen, CNRS, COBRA - Université de Rouen, CNRS : UMR6014, \\ INSA Rouen, Normandie Univ - 1 rue Tesnière, 76821 Mont St Aignan cedex, France \\ 2 Institut Parisien de Chimie Moléculaire UMR CNRS 8232, Sorbonne Universités, UPMC-Paris 6, France. - \\ CNRS : UMR8232 - 4 Place Jussieu,75005 Paris, France
}

Polyoxometalates (POM) are a remarkable class of nanoscale oxoclusters with an unmatched diversity of structures and properties. They are built from the connection of $\{\mathrm{MOx}\}$ polyhedra $(\mathrm{M}$ is Mo VI or W VI) and form compact negatively charged structures.

To develop how ion mobility - mass spectrometry (IM-MS) and collision cross sections (CCS) could be used to obtain structural information for polyoxometalate-derived molecules, we studied a set of three POM anions (Linqvist Mo6O19 2-, Keggin PW12O40 3- and Dawson [P2W12O62 +H] 5-) with and without tetrabutylammonium (TBA) counterions and worked on linking experimental and calculated values of CCS.

Starting from crystal structures, Gaussian 09 was used for density functional theory (DFT) calculations to optimize geometries of the POM alone or with TBA in the gas phase, and to obtain atomic charges fitted on the electrostatic potential (HLY ESP). We used the $\Omega$ B97XD exchange-correlation functional and 6-31G(d) basis set for atom from $\mathrm{H}$ to $\mathrm{P}$ and Stuttgart/Dresden (SDD) pseudopotential and associated basis set for Mo and $\mathrm{W}$ atoms. We then calculated the CCS with the trajectory method (MOBCAL : Mesleh et al., J. Phys. Chem., A. 1997).

The atomic charges were found to affect significantly the calculated CCS(N2), with values ranging from $198 \AA^{2}$ to $130 \AA^{2}$ for Mo6O192- with or without ESP atomic charges, respectively. Other types of atomic charges (uniform, NPA, APT) were also tested but all values were found lower than the experimental drift tube measurement of $219 \AA^{2}$.

Using ESP atomic charges for theoretical CCS calculations, we derived new scaling factors to be used on the universal force field atomic parameters for the Lennard-Jones parameters in the trajectory method in $\mathrm{He}$ and N2. With this new set of parameters, experimental and theoretical values of CCS in $\mathrm{He}$ and $\mathrm{N} 2$ could be matched for the three tested structures.

Mots-Clés : polyoxometalates, ion mobility, collision cross section

\section{Programme}

\footnotetext{
*Intervenant

†Auteur correspondant: helene.lavanant@univ-rouen.fr
} 


\title{
Study of DNA i-motif folding in gas phase by ion mobility spectrometry coupled to native mass spectrometry [P104]
}

\author{
Sandrine Livet* ${ }_{-}^{1}$, Samir Amrane ${ }^{1}$, Frédéric Rosu ${ }^{2}$, Valérie Gabelica ${ }_{-}^{\dagger}$ \\ ${ }^{1}$ Laboratoire ARNA, IECB - Université de Bordeaux, INSERM : U1212, CNRS : UMR5320 - 2 rue Robert \\ Escarpit, 33607 Pessac, France \\ ${ }^{2}$ Institut de Chimie et de Biologie (IECB) - CNRS : UMS3033, INSERM : US001, Université de Bordeaux - 2 \\ rue Robert Escarpit, 33607 Pessac, France \\ ${ }^{3}$ Laboratoire ARNA, IECB - Université de Bordeaux, INSERM : U1212, CNRS : UMR5320 - 2 rue Robert \\ Escarpit, 33607 Pessac, France
}

At acidic $\mathrm{pH}, \mathrm{C}$-rich DNA sequences can fold into the i-motif structure, consisting in two anti-parallel duplexes connected by intercalated hemiprotonated $\mathrm{C} \bullet \mathrm{C}+$ base pairs. The i-motif's potential role in vivo motivates studying its folding in vitro. Here we seeked to determine whether ion mobility spectrometry (IMS-MS) could reveal intramolecular folding into i-motif.

The experiments were performed as a function of the solution $\mathrm{pH}$, and with mutant control sequences unable to form i-motifs. The folding in solution was verified using NMR spectroscopy, UV melting and circular dichroism.

For the telomeric sequence d(CCCAAT)3CCC, we found that the most abundant charge states (4-, 5) produced from native conditions are compact, independently of the prior solution folding. However, charge state 6- (visible using $15 \mathrm{mM}$ NH4OAc, or by supplementing $150 \mathrm{mM}$ NH4OAc with sulfolane) is sensitive to prior folding, and to activation conditions.

Collision induced unfolding experiments(obtained by varying the trap entrance grid delta voltage in the trapping region of our Agilent 6560 IMS-Q-TOF) provide a fingerprint of i-motif structure, with a conformational transition from compact forms to unfolded forms. The fractions folded deduced from IMS-MS experiments on charge state 6- reflect accurately the results obtained by solution spectroscopy techniques.

In conclusion, ion mobility can be used to probe intramolecular folding of nucleic acids in solution, and the choice of the charge state to be monitored is critical for the success.

Mots-Clés : imotif, ion mobility, collision induced unfolding, nucleic acids, native mass spectrometry

$\underline{\text { Programme }}$

\footnotetext{
*Intervenant

${ }^{\dagger}$ Auteur correspondant: valerie.gabelica@inserm.fr
} 


\title{
Optimization of the design of cyclic peptides scaffolds for characterization by MALDI-TOF/TOF mass spectrometry [P105]
}

\author{
Benjamin Zagiel , Gérard Bolbach, Lucrèce Matheron, Gilles Clodic , Roba \\ Moumne, Emmanuelle Sachon $* \dagger 1,2$
}

\footnotetext{
${ }^{1}$ Plateforme de spectrométrie de masse et protéomique (IBPS UPMC) - Université Pierre et Marie Curie [UPMC] - Paris VI - 7-9 Quai Saint Bernard, 75005 Paris, France

${ }^{2}$ Laboratoire des Biomolécules, UMR 7203 - Université Pierre et Marie Curie [UPMC] - Paris VI, CNRS : UMR7203, École normale supérieure [ENS] - Paris - 4 place Jussieu, 75252 PARIS Cedex 05, France
}

Mimicking protein-protein interactions using small "drug-like" compounds able to target such interactions is a challenging task. In an innovative strategy, small folded cyclic peptide scaffolds are derivatized thanks to dynamic combinatorial chemistry (DCC). This dynamic functionalization would allow rapid access to a large and complex library of well-ordered protein mimetics in equilibrium with each other, which can then be screened in a single step toward a relevant protein hit. This strategy requires dedicated analytical methodologies to detect, quantify and characterize all cyclic peptide of the library. In this work, we report the rational design of such peptide scaffolds, taking into considerations all the experimental conditions required for a sensitive HPLC-UV detection coupled to an optimal identification and characterization of the synthesized compounds using MALDI-TOF/TOF mass spectrometry.

Mots-Clés : MALDI, TOF/TOF, cyclic peptide, characterization, thioester

Programme

\footnotetext{
*Intervenant

†Auteur correspondant: emmanuelle.sachon@upmc.fr
} 


\title{
New innovations implemented on the Q Exactive HF mass spectrometer [P106]
}

\author{
Tabiwang Array ${ }^{1}$, Eugen Damoc ${ }^{1}$, Erik Couzijn ${ }^{1}$, Jens Grote ${ }^{1}$, Olivier Lange \\ ${ }^{1}$, Christian Thoeing ${ }^{1}$, Kerstin Strupat ${ }^{1}$, Catherina Crone ${ }^{1}$, Anastassios \\ Giannakopulos ${ }^{1}$, Thomas Moehring ${ }^{1}$, Alexander Harder ${ }^{1}$, Sega Ndiaye ${ }^{* \dagger} 2$ \\ 1 Thermo Fisher Scientific - Bremen, Allemagne \\ 2 Thermo Fisher Scientific - Thermo Fisher Scientific - Villebon sur Yvette, France
}

\begin{abstract}
Orbitrap mass spectrometers are increasingly being used for many different applications. Each application imposes special requirements on the mass spectrometer. Modern instruments have improved sensitivity, accuracy, high resolution, and/or increased scanning speed.Though we have come this far, further technical improvements or next-generation mass spectrometers are desired by the mass spectrometric community. To further address existing and new requirements from a broad field of applications, new technological developments and performance improvements on the existing Q Exactive ${ }^{\mathrm{TM}} \mathrm{HF}$ instrument were undertaken. On the modified Q Exactive HF instrument, a brighter source was implemented with improved ion transmission. Using our standard positive calibration mixture at a flow rate of $5 \mathrm{uL} / \mathrm{min}$, we observed up to fourfold improvement in ion transmission; injection times were approximately 2.5 times shorter and electrometer currents correspondingly higher relative to the unmodified Q Exactive HF instrument. The modified instrument also showed reduced solvent cluster formation in the bent flatapole relative to the unmodified version. Through optimization of the electronics switching times and the measurement strategy, combined with a resolution setting of 7,500@ m/z 200, a maximum scan speed of over $40 \mathrm{~Hz}$ can be attained. The productivity of this resolution setting was verified using a HeLa digest sample. We could perform a full scan (6,'000 resolution @ m/z 200) and 40 MS/MS (7,500 resolution @ $\mathrm{m} / \mathrm{z} 200$ ) in one second on the modified instrument. On average, 25,000 unique peptides were identified in $30 \mathrm{~min}$ (58 min total run time); the same number of identified peptides could only be achieved on the unmodified Q Exactive HF using a 60 min gradient. A comparison with a 60 min gradient on the modified instrument afforded approximately $39 \%$ more identified peptides. In another experiment, mAbs were analyzed in their native form on both the modified instrument and the unmodified Q Exactive HF.
\end{abstract}

Mots-Clés : Q Exactive HF, mass spectrometer, Biopharma, proteomics, Orbitrap, Lipidomics, High Field

$\underline{\text { Programme }}$

\footnotetext{
*Intervenant

${ }^{\dagger}$ Auteur correspondant: sega.ndiaye@ thermofisher.com
} 


\title{
Étude in vitro et in vivo chez le cheval du métabolisme du FG4592 (Roxadustat), un stabilisateur du facteur induit par l'hypoxie 1 alpha (HIF1- $\alpha)$, dans le contexte de la lutte anti-dopage [P107]
}

\author{
Stéphane Trévisiol *1, Yves Moulard, Murielle Jaubert, Benoit Loup , Patrice \\ Garcia ${ }_{-}^{\dagger}$, Marie-Āgnès Popot, Yves Bonnaire , Ludovic Bailly-Chouriberry_
}

${ }^{1}$ Laboratoire des Courses Hippiques (LCH) - Laboratoire des Courses Hippiques - 15 rue de Paradis 91370 Verrières-le-Buisson, France

Les facteurs induits par l'hypoxie (HIF) sont des protéines se comportant comme des capteurs du taux de l'oxygène permettant une adaptation physiologique aux conditions d'oxygénation (normoxie ou hypoxie). Le HIF1- $\alpha$ régule de manière directe la production d'érythropoïétine (EPO) endogène.

Le FG4592, ou Roxadustat, est un stabilisateur du HIF1- $\alpha$ développé pour traiter l' anémie et les maladies rénales chroniques. Ce médicament, actuellement en phase III d'essai clinique, est déjà disponible sur le marché noir. Ses propriétés d'agent stimulant de l'érythropoï̀se (ESA) ont incité des tricheurs à le détourner de son usage à des fins de dopage pour augmenter leur endurance.

Dans le contexte du contrôle antidopage équin, cette molécule est interdite en toutes circonstances. Il est donc primordial de développer des outils de détection de l'usage du FG4592. Pour ce faire, il a été nécessaire d'étudier le métabolisme du FG4592 chez le cheval afin d'identifier et de caractériser les molécules les plus pertinentes à cibler (FG4592 et/ou ses métabolites) dans l'urine et le sang.

Cette étude du métabolisme du FG4592 a été réalisée dans un premier temps in vitro à l'aide de fractions microsomales d'hépatocytes équins (S9) puis in vivo sur trois chevaux via deux modes d'administration (orale et sous cutanée). Les réactions in vitro et les échantillons de sang et d'urine collectés ont été analysés par LC-HRMS ou LC-SRM.

Les résultats in vitro obtenus ont montré que le FG4592 était très peu métabolisé. Ces résultats ont été ensuite confirmés avec les échantillons in vivo. Il a ainsi été démontré que le contrôle de l'administration du FG4592 doit être basé sur la recherche de la molécule administrée, laquelle est détectée pendant plusieurs jours dans le plasma (LOD $5 \mathrm{pg} / \mathrm{mL}$ ) et dans l'urine (LOD $10 \mathrm{pg} / \mathrm{mL}$ ). Dans le cas de la matrice urinaire, un métabolite hydroxylé peu abondant a aussi été identifié.

Mots-Clés : Cheval, control anti, dopage, LC, MS, métabolisme, agent stimulant de l'érythropo'lèse

\footnotetext{
*Intervenant

†Auteur correspondant: p.garcia@1chfrance.fr

¥Auteur correspondant: 1.bailly@lchfrance.fr
} 


\title{
Optimization of source and acquisition parameters for HILIC-HRMS metabolomic analysis of human plasma [P108]
}

\author{
Fanta Fall $* 1,2$, Natacha Lenuzza ${ }^{3}$, Jean-Claude Alvarez ${ }^{1,2,4}$, \\ Etienñe Thévenot ${ }^{3}$, Grassin-Delyle Stanislas ${ }^{\dagger} 1,2,5$ \\ ${ }^{1}$ Plateforme de spectrométrie de masse MasSpecLab - Université Versailles - Saint Quentin en Yvelines, UFR \\ Sciences de la Santé Simone Veil - 2, avenue de la source de la Bièvre, 78180, Montigny le Bretonneux, France \\ ${ }^{2}$ INSERM UMR1173 - 2 avenue de la source de la Bièvre, 78180 Montigny le Bretonneux, France \\ ${ }^{3}$ CEA, LIST, Laboratoire Analyse de Données et Intelligence des Systèmes, MetaboHUB - CEA - Digiteo \\ Saclay (bâtiment 565), Point Courrier 192, F-91191 Gif-sur-Yvette, Cedex, France \\ ${ }^{4}$ Laboratoire de Pharmacologie - Toxicologie, Hôpital Raymond Poincaré, Assistance publique - Hôpitaux de \\ Paris (AP-HP) - 104 boulevard Raymond Poincaré, 92380 Garches, France \\ ${ }^{5}$ Departement des maladies des voies respiratoires - Hôpital Foch, Suresnes, France
}

Rationale: Untargeted metabolomics is of increasing interest in medical research to explore pathophysiology, find disease biomarkers or for the understanding of the mechanism of action of drugs. However, several contaminants are known to cause interferences in LC-MS analysis and the instrumental method may thus be optimized for each matrix. Our objective was to evaluate the influence of contaminants as well as to optimize source and acquisition parameters to reduce those interferences and enhance the detection of metabolites in human plasma.

Methods: Human plasma samples were processed with liquid/liquid extraction. Extracted samples and blank mobile phase samples were analyzed with HILIC-high resolution mass spectrometry (Q-Exactive, Thermofisher) with electrospray ionization in the positive mode. Contaminants were identified in blank mobile phase. Four sets of values (low, medium, high and mixed) were tested for each of the following source parameters: sheath and auxiliary gas, spray voltage, S-lens level and heater temperature. For the acquisition, a single full-scan range (60-900) and a method split in 3 ranges (60-101; 105-213 and $215-900 \mathrm{~m} / z$ ) to exclude the main interferences were compared. The data was analyzed with Worklow4Metabolomics.

Results: Three major interferences were identified in blank mobile phase, including 2 compounds with $\mathrm{m} / \mathrm{z}$ corresponding to triethylamine and n-butylbenzenesulfonamide, accounting up to $80 \%$ of the signal intensity. With the mixed source settings, 7311 features were detected with the full-scan method, whereas up to 44610 features were detected when the scan range was split. With the low, medium and high sets of source parameters, 24168, 41583 and 48578 features were detected, respectively. Within each scan range, the median $\mathrm{m} / \mathrm{z}$ was identical with all the 4 parameter sets.

Conclusion: Interferences may seriously impact the detection of metabolites in human plasma. Optimizing source and acquisition parameters may enable to detect up to 6.6-fold more features in HILIC-HRMS plasma metabolomic analysis.

Mots-Clés : mass spectrometry, liquid chromatography, metabolomics

\footnotetext{
*Intervenant

${ }^{\dagger}$ Auteur correspondant: stanislas.grassin-delyle@uvsq.fr
} 


\title{
Analysis of sterols and steroids using HPTLC- MS: influence of ionization parameters [P109]
}

\author{
David Da Silva ${ }^{1}$, Laëtitia Fougere ${ }^{*}$, Cyrille Guimaraes ${ }^{2}$, Caroline \\ Goupille $^{2}$, Benoit Maunit ${ }^{1}$, Stephān Chevalier ${ }^{2}$, Michelle Pinault ${ }^{2}$ \\ ${ }^{1}$ Institut de Chimie Organique et Analytique (ICOA) - CNRS : UMR7311, Université d'Orléans \\ F-45067 Orléans, France \\ ${ }^{2}$ Nutrition, Croissance et Cancer (N2C) - INSERM : U1069, Université de Tours - Faculté de Médecine \\ 37032 Tours, France
}

The potential of MALDI, ESI or APCI-MS for the direct analysis of TLC plates has been demonstrated by several research groups. These techniques have been used for analysis of variety of small (polar or non-polar) molecules. The main goal of this work is to develop a method involving a direct coupling of these different mass spectrometers (MALDI-Time-of-flight, ESI/APCI-Triple Quadripole) to HPTLC for characterization of nonderivatized sterol and steroid standards.

In this work, we have evaluated the influence of these HPTLC- MALDI, ESI and APCI ionization methods on sterol and steroid standard compounds (cholesterol, campesterol, desmosterol, stigmasterol, cortisone, estradiol, testosterone, progesterone, etc). The HPTLC separation has been realized according to the conditions routinely used in $\mathrm{N} 2 \mathrm{C}$ group for the sterols and steroids screening from tissues. HPTLC plates are analyzed thanks to TLC-adapted target for MALDI-TOFMS (Bruker Daltonik) and with the TLC-MS interface I (Camag) for TQMS (Thermofisher scientific). Positive and negative ionization modes were carried out on mass spectrometers.

Although the APCI ionization produced one common type of rearrangement (the alcohols can lose a molecule of water) for each standards, the high sensitivity and ability to ionize sterol compounds avoiding significant fragmentation (e.g. detection of stigmasterol $\mathrm{m} / z 395$ corresponding to $[\mathrm{M}-\mathrm{H} 2 \mathrm{O}+\mathrm{H}]+$ ion) were obtained by this coupling in positive mode in comparison to ESI and MALDI. For the MALDI ionization, the automated analysis of the entire TLC plate, the non-destruction of spots, and ability to ionize steroid compounds are major advantages of this TLC-MS coupling.

This optimized TLC-MS coupling proves its interest through fast characterization of sterol and steroid in complex extracts. Although mass is a powerful tool, a good separation is necessary to have a richer representation (isomer like 22-OH-cholesterol and 24-OH-cholesterol) of mixture standards or extract.

Mots-Clés : TLC/MS, Stéroides

Programme

*Intervenant 


\title{
2D-precursor selection for trapped ion mobility with parallel accumulation - serial fragmentation (TIMS-PASEF) [P110]
}

\author{
Pierre-Olivier Schmit $* \dagger{ }^{\dagger}$, Scarlett Beck ${ }^{*} 2$, Markus Lubeck ${ }^{2}$, \\ Oliver Raether ${ }^{2}$, Florian Meier ${ }^{3}$ \\ ${ }^{1}$ Bruker Daltonique (Bruker) - Bruker France SAS - 34, rue de l'industrie, 67160 Wissembourg, France \\ 2 Bruker Daltonik GmbH (BDAL) - Bremen, Allemagne \\ ${ }^{3}$ Max Planck Institute of Biochemistry (MPIB) - Martinsried, Allemagne
}

Background: With the previously introduced "Parallel Accumulation - Serial Fragmentation" method (PASEF, Meier et al., JPR 2015, PMID: 26538118) for ion mobility (IMS) quadrupole time of flight (QTOF) instruments, five to ten times faster data dependent acquisition of fragment ion spectra became possible. This approach requires a fast two-dimensional (2D) precursor selection algorithm using mass as well as ion mobility information.

Methods: In TIMS-PASEF mode peptide ions elute from the IMS device as a condensed packages. For most efficient MSMS acquisition the quadrupole isolation window needs to switch its isolation position exactly synchronized to these elution times in the fastest possible order. The corresponding algorithm was developed and evaluated using tryptic digests of human cancer cell lysates (HeLa), separated by 90min nanoLC gradients. Data were analyzed using DataAnalysis (Bruker), Mascot (www.matrixscience.com), and MaxQuant (Cox group, MPI of Biochemistry).

Results: The precursor selection algorithm detects $\mathrm{m} / \mathrm{z}$ and mobility positions of all precursors in the MS1-IMS scan. Then they are scheduled for measurement across multiple (ten to twenty) consecutive IMS experiments aiming for most efficient utilization of measurement time. Low intensity precursors are measured multiple times to achieve sufficient spectra quality. Elution length of an individual precursor ion is dependent on IMS resolution which is a function of mobility scan time. For tryptic peptides, mobility scan times of 25, 50, 100 and 200 ms resulted in average mobility resolutions between 20 and up to 80 and elution lengths between 1.8 and $10.6 \mathrm{~ms}$. With a $100 \mathrm{~ms}$ IMS separation up to 900000 individual PASEF-MSMS spectra can be acquired during a 90 min Hela nanoLC-run, resulting in about 200000 unique MSMS spectra after combining repetitive measurements.

Conclusion: We developed a 2D-precursor selection algorithm for TIMS-PASEF that determines and schedules precursors in complex samples within 100-200 ms, well suited for an LC timescale.

Mots-Clés : PASEF, ion mobility, shotgun proteomics, identifications

Programme

\footnotetext{
*Intervenant

${ }^{\dagger}$ Auteur correspondant: pierre-olivier.schmit@bruker.com
} 


\title{
microDIA acquisition combined to a novel software tool enables direct identification of peptides in pseudo-SRM MS/MS spectra from sequence databases [P111]
}

\author{
Pierre-Olivier Schmit ${ }^{* \dagger} 1^{1}$, Michael Heaven ${ }^{2}$, Thomas Kosinski ${ }^{3}$, \\ Archie Cobbs ${ }^{2}$, Gary Kruppa ${ }^{4}$ \\ ${ }^{1}$ Bruker Daltonique (Bruker) - Bruker France SAS - 34, rue de l'industrie, 67160 Wissembourg, France \\ 2 Vulcan Analytical (Vulcan Analytical) - LLC, Birmingham, AL, USA, États-Unis \\ ${ }^{3}$ Bruker Daltonik GmbH (BDAL) - Bremen, Allemagne \\ ${ }^{4}$ Bruker Daltonics (BDAL) - Billerica, États-Unis
}

Background: Typical data independent acquisition (DIA) approaches use wide isolation windows that produce noisy MS/MS data and require sample specific spectral libraries to be generated for confident peptide identification. Large DIA isolation windows have the drawback of complicating peptide modification analyses - especially when modified and unmodified versions of the peptides are co-isolated. To address these limitations, we developed the microDIA workflow that uses sequentially overlapping precursor isolation windows combined with an automated MS/MS spectrum deconvolution It produces highly specific MS/MS spectra with $\pm 1 \mathrm{~m} / \mathrm{z}$ mass-isolation windows across the precursor range spanning most detectable tryptic peptides in a single shot analysis. The workflow is implemented in the Protalizer $^{\mathrm{TM}}$ software platform, that enables direct peptide and protein identification without requiring a spectral library.

Methods: We acquired data using $6 \mathrm{~m} / \mathrm{z}$ wide DIA windows, each overlapping $2 \mathrm{~m} / \mathrm{z}$ and covering a $430-910 \mathrm{~m} / \mathrm{z}$ mass range with a $37 \mathrm{~Hz}$ rate using an Impact II UHR-Q-TOF coupled to a nano Elute UHPLC (Bruker Daltonics). Hela tryptic digest or mixtures of Hela, Yeast and E.Coli lysates triptic digests -mixedaccording to Navarro et al (2016) have been separated with a $2 \mathrm{~h}$ gradient. Protalizer ${ }^{\mathrm{TM}}$ software (Vulcan Analytical) was used to identify peptides and proteins using a hybrid Swiss-Prot reference database of Yeast, E. coli, and Human proteomes. Quantification was performed via MS2 chromatograms

Results: We increased the number of protein ID's by $64 \%$ compared to a standard shotgun workflow and with a $1 \%$ Protein FDR level Median CV values observed on replicates of the three proteome mixtures were below $10 \%$. Details illustrating the quantitation and comparative dynamic range accessible with shotgun and microDIA approaches will be given.

Conclusion: Our results illustrate the ability to perform in-depth protein identification and quantification from a DIA experiment without the need to create a spectral database beforehand.

Mots-Clés : DIA, database, shotgun proteomics

\footnotetext{
*Intervenant

${ }^{\dagger}$ Auteur correspondant: pierre-olivier.schmit@bruker.com
} 


\title{
Paléoprotéomique pour retracer l'introduction de petits bovidés en Afrique australe [P112]
}

\author{
Louise Le Meillour* 1, Antoine Zazzo ${ }^{1}$, Sophie Cersoy ${ }^{1}$, Arul Marie ${ }^{2}$, \\ Matthieu Lebon ${ }^{3}$, Joséphine Lesur ${ }^{1}$, Chrystelle Le Danvic ${ }^{4}$, David \\ Pleurdeau ${ }^{3}$, Patricia Nagnan-Le Meillour ${ }^{5}$, Séverine Zirah ${ }^{6}$ \\ ${ }^{1}$ Archéozoologie, Archéobotanique : sociétés, pratiques et environnements (AASPE) - Sorbonne Universités, \\ Muséum National d'Histoire Naturelle (MNHN), CNRS : UMR7209 - CP 56, 55 rue Buffon, F-75005 Paris \\ 2 Plateforme de spectrométrie de masse - CNRS : UMR7245, 63, rue Cuvier 75005 Paris, France \\ ${ }^{3}$ Histoire naturelle de l'Homme préhistorique (HNHP) - Sorbonne Universités, Muséum National d'Histoire \\ Naturelle (MNHN), UPVD, CNRS : UMR7194 - 17 Place du Trocadéro, F-75116 Paris, France \\ ${ }^{4}$ Unité de Glycobiologie Structurale et Fonctionnelle (ALLICE) - Allice - Cité Scientifique, avenue Mendeleiev \\ - 59655 Villeneuve d'Ascq cedex, France \\ ${ }^{5}$ Unité de Glycobiologie structurale et fonctionnelle - UMR 8576 CNRS/Univ. Lille1/USC INRA 1409 (UGSF) \\ - CNRS : UMR8576, Université Lille I - Sciences et technologies - Bâtiment C9 Cité Scientifique, avenue \\ Mendeleiev - 59655 Villeneuve d'Ascq cedex, France \\ ${ }^{6}$ Molécules de Communication et Adaptation des Micro-Organismes (MCAM) - Sorbonne Universités, Muséum \\ National d'Histoire Naturelle (MNHN), CNRS : UMR7245 - CP 54, 57 rue Cuvier, F-75005 Paris, France
}

Les traces de domestication animale en Afrique australe font état d'une arrivée des pratiques d'élevage de caprinés il y a environ 2000 ans. Les similarités morphologiques, l'état d'usure et la fragmentation des restes archéologiques de caprinés et de petits antilopinés rendent délicate l'identification claire des espèces. La spectrométrie de masse apparaît comme une approche alternative pour identifier ces espèces en utilisant les séquences des protéines extraites des restes archéologiques. L'approche ZooMS (Zooarchaeology by mass spectrometry), qui consiste à générer des empreintes peptidiques diagnostiques de certaines espèces animales, s'est révélée particulièrement efficace sur le collagène (1). Nous avons conduit une étude paléoprotéomique sur des restes osseux et dentaires issus de deux sites d'Afrique australe considérés comme ayant livré les plus anciens restes caprinés de la région : Toteng (Botswana) et Leopard Cave (Namibie). Des échantillons modernes de caprinés et antilopinés ont également été analysés afin d'établir un référentiel protéique d'espèces africaines. Nous avons utilisé une stratégie bottom-up avec digestion à la trypsine des protéines, extraites selon trois protocoles différents plus ou moins rudes. Les digests ont été analysés par chromatographie liquide spectrométrie de masse (U-HPLC-MS) sur un instrument de type électrospray - temps de vol (ESI-Q-TOF) en mode autoMSMS dépendant des données. Parmi les protéines identifiées, le collagène de type I et la glycoprotéine HS alpha 2 ont révélé des peptides distinguant les caprinés des antilopinés. Alors qu'à Toteng, la présence du mouton est confirmée, nos résultats montrent qu'à Leopard Cave les restes initialement attribués à des caprinés appartiennent en fait à des antilopinés. Ces résultats démontrent tout le potentiel de la paléoprotéomique dans l'identification de restes provenant d'environnements arides, et ouvrent de nouvelles perspectives concernant l'étude des modalités de la diffusion de l'élevage sur le continent africain.

(1) Buckley M et al. Rapid. Commun. Mass Spectrom. 23:3843-54 (2009)

Mots-Clés : archéologie, Afrique, ZooMS, protéines structurales, UHPLC, MS/MS

*Intervenant 


\title{
Identification de fibres animales archéologiques par protéomique [P113]
}

\author{
Clara Azémard * 1,2, Antoine Zazzo ${ }^{2}$, Arul Marie ${ }^{1}$, Régis Debruyne ${ }^{3}$, Elise \\ Dufour $^{2}$, Nicolas Goepfert ${ }^{4}$, Corinne Debaine-Francfort ${ }^{5}$, Séverine Zirah ${ }^{1}$ \\ ${ }^{1}$ Molécules de Communication et Adaptation des Micro-Organismes (MCAM) - Museum National d'Histoire \\ Naturelle, CNRS : FRE3206 - 57 rue Cuvier 75005 ParisCNRS/MNHN, France \\ ${ }^{2}$ Archéozoologie, archéobotanique : sociétés, pratiques et environnements (AASPE) - Museum National \\ d'Histoire Naturelle, CNRS : UMR7209 - Muséum national dH́istoire naturelle - Case postale 56 - 55 rue Buffon \\ - 75005 Paris, France \\ ${ }^{3}$ Service de Systématique Moléculaire (OMSI) - Muséum National d'Histoire Naturelle (MNHN), CNRS : \\ UMS2700 - 43, rue Cuvier, CP26, 3ème étage, 75005 Paris, France \\ ${ }^{4}$ Archéologie des Amériques (AA) - Université Panthéon-Sorbonne, CNRS : UMR8096 - 21 Allée de lúniversité \\ 92023 Nanterre cedex, France \\ ${ }^{5}$ Archéologies et Sciences de l'Antiquité (ArScAn) - Université Paris I - Panthéon-Sorbonne, CNRS : \\ UMR7041, Université Paris X - Paris Ouest Nanterre La Défense - Maison René Ginouvès Boîte 3 21, allée de \\ l'université 92023 Nanterre cedex, France
}

L'industrie textile est l'une des premières développées par l'humanité. Les textiles archéologiques représentent une grande quantité d'informations sur les savoir-faire techniques, l'élevage et les échanges commerciaux entre les sociétés du passé. Ceux-ci sont malheureusement souvent dégradés au cours des siècles et l'identification des fibres animales qui les composent sur une base anatomique peut s'avérer complexe. Depuis quelques années, l'analyse par spectrométrie de masse des protéines anciennes est proposée comme une approche alternative pour identifier des espèces animales. Cette méthode a d'abord été développée pour le collagène et est depuis peu appliquée aux kératines de type I et II ainsi que des protéines associées à la kératine (KAPs) formant les fibres. La similarité de certaines espèces et l'état de conservation entraine le développement d'une méthodologie adaptée au contexte archéologique.

Nos échantillons de poils et textiles archéologiques proviennent de deux contextes différents : des sites de l'âge du Bronze et du Fer de la vallée de la Keriya (Xinjiang, Chine) ainsi que des sites précolombiens de la côte nord du Pérou.

Les échantillons ont été analysés sur un ESI-QTOF en mode U-HPLC-MS/MS automatique avec une approche bottom-up après digestion par la trypsine. L'utilisation des logiciels PEAKS et Proteinscape et des bases de données Swissprot et NCBI ont permis d'identifier certaines espèces, en prenant en considération les dégradations pouvant subvenir au cours des siècles. L'absence de certaines espèces des bases de données (lama, guanaco, vigogne), ou leur proximité (mouton et chèvre) nous ont amené à rechercher des marqueurs sur fibres modernes marqueurs et à séquencer après PCR certaines kératines et KAPs d'intérêt. Notre étude a ainsi permis de dégager une nouvelle séquence isomorphe permettant la distinction mouton-chèvre. Ces résultats ouvrent de nouvelles perspectives concernant l'analyse des tissus anciens.

Mots-Clés : protéomique, kératine, fibres animales, archéologie, textiles

${ }^{*}$ Intervenant 


\title{
Optimized Protein Digestion for Immunoprecipitation Samples [P114]
}

\author{
Vincent Jung ${ }_{-}^{*}{ }^{1}$, Joanna Lipecka ${ }^{1}$, Chhuon Cerina ${ }^{1}$, Chiara Guerrera ${ }^{1}$ \\ ${ }^{1}$ Proteomics platform 3P5-Necker, Université Paris Descartes - Structure Fédérative de Recherche Necker (3P5 \\ Necker) - CNRS : UMS3633, INSERM, Université Paris V - Paris Descartes - 14 rue Maria Helena Vieira Da \\ Silva 75014 Paris, France
}

One of the major challenges in sample preparation of low abundance samples is to remove rapidly and efficiently the detergents from the protein mixtures prior digestion while preserving high yield. Typically, proteins eluted after immunoprecipitation, are both detergent rich and low abundance. We have recently shown that Filter Aided Sample Preparation, or FASP (Lipecka et al. Proteomics 2016), can be a valid method to prepare low abundance samples. However, at high concentration of SDS, this may require additional detergent removal step from the peptides. The S-Trap is another and more recent method developed by Protifi (www.protifi.com/s-trap) consisting of a column capturing proteins and allowing to wash contaminant and detergents.

The aim of the present study is to compare FASP and S Trap for low abundance, high detergent samples.

Tests were performed on HeLa cells lysate in SDS 5\% and 2\%, Laemmli buffer 1X. The proteins obtained have been digested using S-Trap (according to the manufacturer) or FASP (Lipecka et al. Proteomics 2016). A detergent removal step (DR columns, Pierce) had been added after FASPs. Sample preparation time was 5 hours for the S-Trap and 23 hours for the FASP. The peptides have been analyzed by nanoRSLC- Q-Exactive Plus MS.

Results obtained with S-Trap and FASP were compared in order to evaluate sensitivity, robustness, retention of low molecular weight proteins. We conclude that the S-Trap is a robust and reproducible preparation method for protein samples issued from immunoprecipation. Furthermore, the experiment time is five times lower with S-trap.

Mots-Clés : STrap, FASP, protein digestion, immunoprecipitation, Filter Aided Sample Preparation, detergent removal, SDS

$\underline{\text { Programme }}$

*Intervenant 


\title{
In-Depth Characterization Of Intact Protein Standards Using Top Down Mass Spectrometry With Multiple MSMS Strategies [P115]
}

\author{
Claire Dauly *1, Romain Huguet, Helene Cardasis, Mullen Chris, \\ Zabrouskov Vlad, Kelleher Neil ${ }^{2}$ \\ ${ }^{1}$ Thermo Fisher Scientific - San Jose, États-Unis \\ ${ }^{2}$ Northwestern University - Chicago, IL, États-Unis
}

\begin{abstract}
Complete and accurate characterization of intact proteins by mass spectrometry is possible today thanks to the latest technological development. We developed a standard mixture for LCMS quality control and method development. Here we present the top-down analysis of this mixture using various fragmentation techniques and MSn capabilities available on a modified Orbitrap Fusion Lumos Tribrid. We performed direct infusion experiments and LC-MS experiments using a Pierce intact protein standard mix ranging from _ $\sim 9 \mathrm{kDa}$ to _ $70 \mathrm{kDa}$ MW on an Orbitrap Fusion Lumos Tribrid MS modified with a $213 \mathrm{~nm}$ UVPD source and coupled with a Vanquish UHPLC system. Intact proteins were separated using $2.1 \mathrm{~mm}$ by $50 \mathrm{~mm}$ Acclaim columns with a $4 \mu \mathrm{m}$ particle size. We performed CID, HCD, ETD, EThcD and UVPD fragmentation MSn experiments for structural investigation. Intact Protein spectra were deconvoluted with ReSpect or Xtract in Biopharma Finder 2.0. MS/MS spectra were analyzed with ProSightPC 4.1 and the ProSightPD node in Proteome Discoverer 2.1.
\end{abstract}

Optimal dissociation parameters were determined as a function of ProSight P score. It was determined, for example, that UVPD reaction times spanned from 15 to $50 \mathrm{~ms}$ for proteins ranging from $9-68 \mathrm{kD}$. ETD reaction times ranged from 20 to $10 \mathrm{~ms}$ for proteins ranging $9-68 \mathrm{kD}$ To test consistency between infusion and LCMS, these optimized settings were translated to LCMS methods. These data not only confirms the translatability of these results and the value of these standards to optimize conditions during MS method development, but also intact protein LC method development and quality control. We will present here the range of optimized values in each fragmentation mode for proteins across the MW range, and discuss theoretical reasoning behind these experimentally determined settings.

Mots-Clés : Orbitrap Fusion Lumos, UVPD, Intact Protein Standard

Programme

*Intervenant 


\title{
Two-dimensional (2D) FT-ICR MS at high resolution on both precursor and fragment ions [P116]
}

\author{
Fabrice Bray ${ }^{1}$, Julien Bouclon ${ }^{2,3}$, Marc-André Delsuc ${ }^{4}$, \\ Christian Rolando $* \dagger 3$
}

\begin{abstract}
${ }^{1}$ Miniaturisation pour la Synthèse et l'Analyse Protéomique (MSAP) - CNRS : USR3290 - Université Lille 1, Sciences et Technologies Batiment C4 - Avenue Paul Langevin 59655 Villeneuve d'Ascq, France

${ }^{2}$ UMR 7203 Département de Chimie, Ecole Normale Supérieure - Ecole Normale Supérieure de Paris - ENS Paris -24 rue Lhomond, Paris 75005, France

${ }^{3}$ USR 3290 MSAP, Université Lille 1, Sciences et Technologies - USR 3290 MSAP, Université Lille 1, Sciences et Technologies - 59655 Villeneuve d'Ascq cedex, France

${ }^{4}$ Institut de Génétique et de Biologie Moléculaire et Cellulaire (IGBMC) - CNRS : UMR7104, INSERM : U964, université de Strasbourg - Parc D’Innovation 1 Rue Laurent Fries - BP 1014267404 ILLKIRCH cedex, France
\end{abstract}

Although mass information of all compounds is acquired at the same time leading to high throughput parallel acquisition, the structural information (MS/MS spectrum) is obtained sequentially leading to slow serial acquisition. Furthermore, most of modern mass spectrometers use quadrupole analyzer isolation with a selection window in the range of one $\mathrm{m} / \mathrm{z}$ to the best as the transmission is decreasing fast beyond. We demonstrated that two-dimensional (2D) FT-ICR solve problem of obtaining all structural information as it records the correlations, in only one experiment, regardless of the complexity of the sample. We developed also non-uniform sampling (NUS) acquisition for 2D FT-ICR MS which consists in skipping points randomly on the first dimension which give access to a higher resolution in the same amount of time. Nevertheless, the maximum delay between the two encoding pulse is equal to the recording time of the free induction decay (FID). This maximum delay increases as the resolution and reaches 1 second using for a 2Megapoints acquisition with a 0.5 microsecond dwell corresponding on a 9.4 Tesla instrument to a resolution of 380,000 at $\mathrm{m} / \mathrm{z} 200$. Obtaining sounded 2D FT-ICR implies that ions stays in place without drifting during this time with a precision better than the ECD or IRMPD beam. We will describe here the optimization of the acquisition and of the treatment which allow us to obtain square 2D spectra. Currently we are routinely recording 2D of size F1 (precursor) 256k and size F2 (fragments) 256k points which allows us to reach a resolution of 65,000 at $\mathrm{m} / \mathrm{z} 200$ for precursors and fragments. The acquisition is performed with a NUS ratio $1 / 16$ which means a physical size of $16 \mathrm{k}$ which can be recorded overnight. Examples will be presented in different fields (proteomics, lipidomics, metabolomics).

Mots-Clés : FT, ICR, two, dimensionnal, 2D

$\underline{\text { Programme }}$

\footnotetext{
*Intervenant

${ }^{\dagger}$ Auteur correspondant: Christian.Rolando@univ-lille1.fr
} 


\title{
Conformational Dynamics in Ion Mobility Data [P117]
}

\author{
Salomé Poyer ${ }^{1}$, Clothilde Comby-Zerbino ${ }^{*}{ }^{2}$, Changmin Choi ${ }^{3}$, Luke \\ Macaleese ${ }^{3}$, Claire Deo, Nicolas Bogliotti , Juan Xie , Jean-Yves Salpin ${ }^{1}$, \\ Philippe Dugourd ${ }^{3}$, Fabien Chirot ${ }^{\dagger} 4$
}

\footnotetext{
${ }^{1}$ Laboratoire Analyse et Modélisation pour la Biologie et l'Environnement (LAMBE - UMR 8587) - CEA, CNRS : UMR8587, Université d'Evry-Val d'Essonne - Bât. Mapertuis 1 étage bd François Mitterrand 91025 EVRY cedex, France

${ }^{2}$ Institut Lumière Matière (ILM) - Université Claude Bernard Lyon 1, CNRS : UMR5306 - UMR5306 CNRS Université Claude Bernard Lyon 1, 5 rue de la Doua, 69100 Villeurbanne, FRANCE, France

${ }^{3}$ Institut Lumière Matière (ILM) - CNRS : UMR5306, Université Claude Bernard - Lyon I (UCBL) - UMR5306 CNRS Université Claude Bernard Lyon 1, 5 rue de la Doua, 69100 Villeurbanne, FRANCE, France

${ }^{4}$ Institut des Sciences Analytiques (ISA) - CNRS : UMR5280, PRES Université de Lyon, ENS Lyon, Université Claude Bernard - Lyon I (UCBL) - 5 rue de la Doua, 69100 Villeurbanne, France
}

The spectral features in arrival time distributions (ATDs) recorded by ion mobility spectrometry (IMS) can often be interpreted in terms of the co-existence of different isomers. However, interconversion between co-existing species also participates to shape the ATD $(1,2)$. Overlooking interconversion may then lead to misinterpretation of experimental data. Unfortunately, only few works have addressed this problem so far. We present an analytical model that allows simulating ATDs resulting from interconverting species. This model is used to reproduce experimental data obtained on a bi-stable system, and to interpret discrepancies between measurements on different types of instruments. We show that the proposed model can be further exploited to extract kinetic and thermodynamic data from tandem-IMS measurements (3).

(1) Wyttenbach, T.; Pierson, N. A.; Clemmer, D. E.; et al. Annu. Rev. Phys. Chem. 2014, 65, 175196.

(2) Dugourd, P.; Hudgins, R. R.; Jarrold, M. F. Chem. Phys. Lett. 1997, 267 (1-2), 186-192.

(3) Poyer, S.; Comby-Zerbino, C.; Choi, C. M.; et al. Anal. Chem. 2017, 89 (7), 4230-4237.

Mots-Clés : Ion mobility, Dynamics, Model

$\underline{\text { Programme }}$

\footnotetext{
*Intervenant

${ }^{\dagger}$ Auteur correspondant: fabien.chirot@univ-lyon1.fr
} 


\title{
Exclusion en temps réel de précurseurs MS en fonction de la signature des protéines identifiées [P117.1]
}

\author{
David Rombaut ${ }^{* \dagger}{ }^{1}$, François Guillonneau ${ }^{1}$, Patrick Mayeux ${ }^{1}$ \\ ${ }^{1}$ Plateforme protéomique 3P5 - Inserm U1016, Université Paris Descartes, Sorbonne Paris Cité - 22 rue \\ Méchain, 75014 Paris France
}

Pour les échantillons de protéines en mélange complexe ou à forte gamme dynamique, les limitations techniques des spectromètres de masses ne permettent pas de cibler tous les peptides d'intérêts détectables sur une analyse en tandem. Une très forte augmentation de la vitesse de traitement et de la sensibilité serait nécessaire pour analyser la majorité des précurseurs d'intérêts, dans un contexte où les échantillons sont de moins en moins purs biochimiquement, en raison des coûts et du temps nécessaire au traitement. Ainsi, les résultats d'analyses sont fréquemment redondants sur une proportion de protéines abondantes, occupant un temps d'analyse non négligeable.

Une méthode "intelligente" a été mise en place par la création d'une base de données des résultats des analyses effectuées sur la plateforme. Un outil de contrôle en temps réel d'un spectromètre de masse, supporté par une API, a été développé dans le but d'exploiter cette base de données afin de réaliser l'identification en temps réel de protéines analysées, par comparaison des évènements MS et MS/MS. Cette identification permet de mettre à jour à la volée la liste d'exclusion du spectromètre de masse, de façon à exclure les peptides prédits et concentrer le temps machine sur des molécules moins intenses et moins connues.

Mots-Clés : Protéomique, spectrométrie de masse en tandem, optimisation temps-machine, C\#, SQLite, Perl, programmation orientée objet

\section{Programme}

\footnotetext{
${ }^{*}$ Intervenant

${ }^{\dagger}$ Auteur correspondant: david.rombaut@inserm.fr
} 


\section{Développements méthodologiques RMN [P118-P120]}




\title{
Stability-indicating HILIC Method for Determination of Citicoline and Characterization of its Degradation Products by LC-MS/TOF [P118]
}

\author{
Saliha Guermouche ${ }_{-}^{* 1,2}$ \\ ${ }^{1}$ Faculté de chimie (USTHB) - Faculté de chimie USTHB BP 32 El-Alia, Alger, Algérie \\ ${ }^{2}$ USTHB - Laboratoire de chromatographie, Faculté de chimie, USTHB, BP 32, El-Alia, Bab-Ezzouar \\ 16133 Alger, Algérie
}

\begin{abstract}
Citicoline is chemically is a psychostimulant/nootropic agent. Studies suggest that CIT supplements increase dopamine receptor densities.

Hydrophilic interaction liquid chromatography (HILIC) is an alternative high-performance liquid chromatography (HPLC) mode for separating polar compounds such as peptides, nucleic acids and other polar compounds. HILIC uses a polar stationary phase eluted with aqueous/organic mobile phases.

In this work, A stability-indicating HILIC-HPLC method was developed for analysis of Citicoline (CIT) in the presence of the degradation products (DPs). It was performed by using Atlantis HILIC Si column $(50 * 4.6 \mathrm{~mm}, 3 \mu$ particle size). The optimal mobile phase was selected by measuring classical chromatographic parameters of CIT (retention factor, plate number, tailing factor, resolution between CIT and its DPs). CIT was subjected to oxidative, acidic, basic, hydrolytic, thermal and UV light stress condition. The column effluents were monitored at $270 \mathrm{~nm}$ by photodiode array and mass detectors. Depending on the stress, three degradation products (DPA, DPB and DPC) appeared; DPA after acidic and photolytic action, DPB by $\mathrm{NaOH}$ reaction and DPC with oxidative stress. LC-ESI-MS/TOF and $1 \mathrm{H}$ and $13 \mathrm{C}$ NMR were used to characterize them. The most probable formation mechanisms of the impurities identified were proposed. The developed method was validated for specificity, limit of detection, linearity, accuracy, and precision). The proposed method can be used for determination of CIT in dosage forms.
\end{abstract}

Mots-Clés : citicolin HILIC MS, TOF NMR

$\underline{\text { Programme }}$

${ }^{*}$ Intervenant 


\title{
Ultrafast 2D NMR on a benchtop spectrometer for high-throughput foodomics [P119]
}

\author{
Boris Gouilleux ${ }^{1}$, Jérémy Marchand ${ }^{1,2}$, Benoît Charrier ${ }^{1}$, Gérald Remaud ${ }^{1}$, \\ Patrick Giraudeau $* \dagger 3,4$
}

\footnotetext{
${ }^{1}$ Chimie Et Interdisciplinarité : Synthèse, Analyse, Modélisation (CEISAM) - Université de Nantes, CNRS : UMR6230 - UFR des Sciences et des Techniques - 2 rue de la Houssiniere BP 92208 44322 Nantes Cedex 3, France

${ }^{2}$ Laboratoire d'Etude des Résidus et Contaminants dans les Aliments (LABERCA) - Ecole Nationale Vétérinaire, Agroalimentaire et de lálimentation Nantes-Atlantique - Nantes, France

${ }^{3}$ Chimie Et Interdisciplinarité : Synthèse, Analyse, Modélisation (CEISAM) - CNRS : UMR6230, Université de Nantes - UFR des Sciences et des Techniques - 2 rue de la Houssiniere BP 92208 44322 Nantes Cedex 3, France

${ }^{4}$ Institut Universitaire de France - Paris, France
}

The detection of adulteration of high priced edible oils with cheaper substitutes is a long-standing concern, both from for economic and safety reasons. Characterizing fatty acid profiles is an efficient strategy to screen and classify the different varieties of edible oils. High-field NMR (HF-NMR) is an efficient tool to determine fatty acid profiles. However, HF-NMR is not generally regarded as a candidate technique for routine applications due to practical and economic reasons.

By contrast, low-field NMR spectroscopy (LF-NMR) is relatively inexpensive and emerges as a relevant alternative to candidate as a low-cost and accessible screening tool for food authentication issues. Since benchtop spectrometers operate in the $40-80 \mathrm{MHz}$ range, resolution and sensitivity are critical and the 1D 1H NMR spectra of edible oils suffer from numerous peaks overlaps making the accurate characterization of the lipid fingerprint far more difficult.

To outmatch these overlapping issues, we recently developed an Ultrafast (UF) 2D NMR approach on a $43 \mathrm{MHz}$ benchtop system. UF COSY experiments are applied in the context of food science, on a panel of different edible oil samples. The resulting 2D-peak volumes are submitted to multivariate chemometric analysis. The resulting PCA analysis highlight the clear discrimination of olive, hazelnut, sesame, rapeseed, corn and sunflower oils. This UF 2D strategy provides a real benefit for the authentication of edible oils compared to a 1D NMR approach. Furthermore, this method combined with a partial least squares (PLS) model enables the detection of hazelnut oil into olive oil - a common fraud in food industry - at the level of $13.46 \%(\mathrm{w} / \mathrm{w})$.

As a fast approach, i.e., 2.4 min of experiment duration, this spatially encoded 2D experiment is compatible with high-throughput analysis so that its implementation on benchtop NMR apparatus leads to a versatile and rapid screening tool.

Mots-Clés : NMR, Ultrafast, Lipids, Edible oils, Authentication

\footnotetext{
*Intervenant

${ }^{\dagger}$ Auteur correspondant: patrick.giraudeau@univ-nantes.fr
} 


\title{
Spatially encoded diffusion-ordered NMR spectroscopy [P120]
}

\author{
Ludmilla Guduff $^{1}$, Ilya Kuprov ${ }^{2}$, Dennis Kurzbach ${ }^{3}$, Daniel Abergel ${ }^{3}$, \\ Carine Van Heijenoort ${ }^{1}$, Jean-Nicolas Dumez ${ }^{* \dagger}{ }^{1}$
}

\author{
${ }^{1}$ Institut de Chimie des Substances Naturelles (ICSN) - CNRS : UPR2301 - Avenue de la terrasse \\ 91198 Gif sur Yvette cedex, France \\ 2 School of Chemistry - University of Southampton University Road, \\ Southampton SO17 1BJ, Royaume-Uni \\ ${ }^{3}$ Laboratoire des Biomolécules (LBM) - CNRS, École normale supérieure [ENS] - Paris, Université Pierre et \\ Marie Curie (UPMC) - Paris VI - 24, rue Lhomond - 75005 Paris, France
}

NMR is a powerful tool for the analysis of complex mixtures, with applications in the fields of metabolomics and natural-product research. Diffusion-ordered spectroscopy (DOSY) is a widely used NMR approach to analyse mixtures. With DOSY, the ND spectra (with N typically 1 or 2 ) of components in a mixture are sorted according to their diffusion coefficients. Such separation, however, usually requires an incremented diffusion-encoding dimension that increases experiments' duration significantly. We show that the diffusion-based separation of multidimensional spectra of small molecules can be accelerated dramatically using a spatial encoding (SPEN) of the diffusion-encoding dimension. The SPEN DOSY sequence, originally designed to separate 1D spectra (1), is simplified with a systematic gradientbased coherence-selection scheme along orthogonal axes. The resulting scheme is generalised to 3D experiments, with the example of DOSY COSY (2). With this approach, COSY spectra of components in a mixture are separated with an experiment acquired in $\sim 10 \mathrm{~min}$, compared to the $14 \mathrm{~h}$ required for the conventional implementation. In order to understand and optimise spatially encoded experiments, we also carry out numerical simulations based on the Fokker-Planck formalism. These simulations are essential to design a model to extract accurate diffusion coefficients from the SPEN DOSY data.

A significant benefit of single-scan multidimensional experiments is the possibility to collect an entire data set with single-shot hyperpolarisation techniques, such as dynamic nuclear polarisation (D-DNP). As a first demonstration we show that the SPEN approach can be used with D-DNP to obtain hyperpolarised 13C DOSY spectra, which would take much longer to obtain otherwise for sensitivity reasons.

(1) (a) M. J. Thrippleton, N. M. Loening and J. Keeler, Magn. Reson. Chem., 2003, 41, 441; (b) Y. Shrot and L. Frydman, J. Magn. Reson., 2008, 195, 226.

(2) L. Guduff, I.Kuprov, C. van Heijenoort and J.-N. Dumez, Chem. Commun., 2017, 53, 701.

Mots-Clés : NMR, hyperpolarization, multidimensional NMR

$\underline{\text { Programme }}$

\footnotetext{
*Intervenant

†Auteur correspondant: jeannicolas.dumez@cnrs.fr
} 
Clinique et diagnostic [P121-P129] 


\title{
Multiplatform metabolomics study of urine in autism spectrum disorders in a Middle Eastern population [P121]
}

\author{
Tania Bitar ${ }^{* 1,2}$, Sylvie Mavel ${ }^{1}$, Patrick Emond ${ }^{1,3}$, Lydie Nadal-Desbarats ${ }^{1}$, \\ Antoine Lefèvre ${ }^{1}$, Hanna Mattar ${ }^{4}$, Michel Soufia ${ }^{4}$, Hélène Blasco ${ }^{1,3}$, Patrick \\ Vourc'h $^{1,3}$, Walid Hleihel ${ }^{2}$, Christian R. Andres ${ }^{1,3}$

\footnotetext{
${ }^{1}$ Université François-Rabelais, INSERM U930, Equipe neurogénétique et neurométabolomique, France Université François Rabelais - Tours - 10 Boulevard Tonnellé 37032 Tours, France

${ }^{2}$ Faculty of Science-Holy Spirit University of Kaslik (USEK) - B.P. 446 Jounieh Mont Liban Jounieh Liban

${ }^{3}$ Laboratoire de Biochimie et Biologie moléculaire, CHRU de Tours, France - CHRU Tours - Boulevard Tonnellé 37000 Tours, France

${ }^{4}$ Faculty of Medicine and Medical Sciences-Holy Spirit University of Kaslik (USEK), Lebanon - B.P. 446 Jounieh - Mont Liban Jounieh Liban
}

We analyzed for the first time the metabolic profile of Lebanese children affected by autistic disorder to compare this profile to other metabolomics studies and to identify the associated metabolic disturbances. Urine samples were analyzed using nuclear magnetic resonance and liquid chromatography coupled to high resolution mass spectrometry. Multivariate analysis on analytical data fusion were conducted on the training set of 50 urine samples, and then validated with a test set of 30 samples. The obtained model was also evaluated using a receiver operating characteristic curve showing a specificity and a sensitivity of $86 \%$ and $80 \%$ respectively. We found metabolic perturbations including amino acids, carbohydrates and oxidative stress pathway which added value for the contribution of known metabolic disturbances in ASD.

Mots-Clés : targeted metabolomics, metabolic pathways, LC, MS, 1H and 1H, 13C HSQC NMR.

$\underline{\text { Programme }}$

*Intervenant 


\title{
De la caractérisation à la quantification de Méthyle- $\beta$-Cyclodextrine dans des échantillons biologiques de souris [P123]
}

\author{
Laëtitia Fougere * 1, Emilie Destandau ${ }^{1}$, Anne Laure Gassner ${ }^{2}$, Serge \\ Rudaz $^{2}$, Fabrizio Montecucco ${ }^{3,4,5}$, Claire Elfakir ${ }^{1}$ \\ ${ }^{1}$ Institut de Chimie Organique et Analytique (ICOA) - CNRS : UMR7311, Université d'Orléans - UFR Sciences \\ Rue de Chartres - BP 675945067 Orléans cedex 2, France \\ ${ }^{2}$ School of Pharm. Sciences -1211 Geneva, Suisse \\ ${ }^{3}$ First Clinic of Int. Medecine - 16132 Genoa, Italie \\ ${ }^{4}$ Division of Cardiology - 1211 Geneva, Suisse \\ ${ }^{5}$ Division of Lab. Medicine - 1205 Geneva, Suisse
}

La Méthyle- $\beta$-Cyclodextrine (Me- $\beta$-CD) $($ Crysmeb $囚)$ a été envisagée en tant que principe actif, pour le traitement de l'athérogènèse, afin d'encapsuler les lipides qui s'accumulent sur les parois des artères. La Crysmeb $\mathbb{R}$ est synthétisée par méthylation partielle de la $\beta$-Cyclodextrine. Ce produit est un mélange complexe de dérivés de degré de méthylation (DM) varié. Son suivi cinétique après injection péritonéale dans différents organes vitaux de la souris a nécessité une stratégie analytique permettant de répondre à deux exigences différentes : d'une part caractériser la composition chimique de la cyclodextrine injectée et d'autre part disposer d'une méthode rapide et fiable pour évaluer l'efficacité de l'absorption de la $\mathrm{CD}$ après son administration.

L'analyse directe en Maldi-TOF-MS a permis d'obtenir l'empreinte spectrale spécifique de 7 dérivés de Me- $\beta$-CD différant par leur DM avec une distribution gaussienne autour du DM de 5.

Une analyse en HPLC/MS a permis de caractériser plus finement la complexité de ce lot en révélant la présence de plusieurs isomères de position par DM, permettant de faire l'assurance qualité des lots. Cette méthode permet de montrer que la répartition des DM était identique lors du passage de la CD par la membrane biologique.

Finalement une analyse par UHPLC/MRM a été développée afin d'obtenir un pic chromatographique unique par DM permettant une simplification du chromatogramme et une quantification de chacun des dérivés dans les différents échantillons biologiques (Rate, Aorte et Sérum) de la souris en vue du suivi

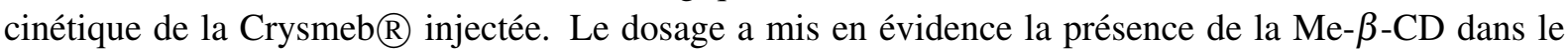
sérum et la rate jusqu'à $1 \mathrm{~h}$ après l'injection tandis qu'aucune trace de ces dérivés n'est détectée sur les parois de l'aorte thoraco-abdominale. Ainsi les analyses ont permis de confirmer que les CD passaient bien dans le sang, sans que le mélange ne se dégrade.

Mots-Clés : Cyclodextrine, UHPLC/MRM, Échantillons biologique, Athérogènèse

$\underline{\text { Programme }}$

${ }^{*}$ Intervenant 


\title{
A pharmacometabolomics approach in ALS: proof of concept in a clinical trial of olesoxime [P124]
}

\author{
Hélène Blasco *† 1 , Franck Patin , Amandine Descat, Guillaume Garcon , \\ Patrick Gele, Philippe Corcia, Timothee Lenglet, Vincent Meininger, \\ Gossens Jean Francois ${ }^{*}$, Pierre Francois Pradat ${ }^{2}$ \\ ${ }^{1}$ Imagerie et cerveau - Université François Rabelais - Tours, INSERM : U930, CNRS : ERL3106 - Hôpital \\ Bretonneau 1 Bd Tonnelle 37044 Tours, France \\ ${ }^{2}$ UPMC Univ Paris 06, CNRS, INSERM, Laboratoire d'Imagerie Biomédicale - APHP, Pitié-Salpêtrière \\ university hospital, Sorbonne Université UPMC Paris VI - PARIS, France
}

Background: As a proof of concept of pharmacometabolomics in Amyotrophic Lateral Sclerosis (ALS), we analysed some plasma samples collected during the therapeutic trial of TRO19622 (olesoxime) in ALS. The main objective was to investigate the link between metabolome modifications, from the early beginning of the study, and late clinical outcomes.

Material and methods: Patients included in the trial received riluzole and were randomized to one of two groups: Group $\mathrm{O}$ receiving olesoxime $(\mathrm{n}=38)$ and Group $\mathrm{P}$ receiving placebo $(\mathrm{n}=36)$. The metabolome was assessed at one (V1) and 12 months (V12) after the initiation of the treatment. High performance liquid chromatography coupled with tandem mass spectrometry was used to quantify 188 metabolites (Biocrates $\AA$ commercial kit). Multivariate analysis based on different learning machine methods (i.e. Biosigner algorithm) was performed.

Results: Metabolome profiles at V1 and V12 and variation of metabolomes between V1 and V12 correctly discriminated between Groups $\mathrm{O}$ and $\mathrm{P}\left(\mathrm{p}<5{ }^{\prime} 10-6\right)$, with glycine, kynurenine and citrulline/arginine as the most discriminant metabolites. Changes in metabolome profiles were closely linked with clinical progression, with a significant correlation between glutamine levels in Group P and amino acids, lipids and spermidine levels in Group O. Multivariate models correctly predicted disease progression from the V1 metabolome, including the discriminant role of sphingomyelins (SM C22:3 or SM C24:1) when pooling data from both groups.

Conclusion: This study provides proof of concept that the metabolome may be of use in assessing the biological effect of an investigational drug and of interest as a secondary outcome measure in clinical trials.

Mots-Clés : pharmacometabolomics, neurodegenerative diseases, prognostic biomarkers

$\underline{\text { Programme }}$

\footnotetext{
*Intervenant

${ }^{\dagger}$ Auteur correspondant: heleneblasco@yahoo.fr
} 


\title{
Empreintes métabolomiques par RMN sur la cirrhose et ses complications [P125]
}

\author{
Philippe Savarin *1, Mohamed Triba , \\ Nadia Bouchemal, Laurence Le Moyec \\ ${ }^{1}$ Laboratoire Chimie, Structures, Propriétés de Biomatériaux et d'Agents Thérapeutiques (CSPBAT) - Université \\ Paris-Nord - Paris XIII - 74 rue Marcel Cachin, 93037, Bobigny, France
}

Les maladies chroniques du foie sont définies par une atteinte hépatique supérieure à 6 mois, un phénomène d'inflammation et un prognostic incertain. Les maladies chroniques hépatiques suite à une stéatose hépatique ou à une hépatite virale conduisent à des changements morphologiques du foie (impliquant l'inflammation, l'activation de cellules souches hépatiques conduisant à une fibrogénèse, une angiogénèse et des lésions). La plupart des maladies chroniques hépatiques sont asymptomatiques jusqu'à la détection de la cirrhose qui peut provoquer une décompensation importante. Les complications de la cirrhose sont multiples (insuffisance hépatique chronique grave, carcinome hépatocellulaire, encéphalopathie hépatique...). Le but de cet exposé est de montrer sur un certain nombre d'études que des empreintes sériques, par RMN ou spectrométrie de masse peuvent être obtenues. Il a ainsi été possible de déterminer une signature métabolique sérique par RMN du carcinome hépatocellulaire (CHC) sur des patients cirrhotiques. Une meilleure caractérisation métabolique de l'insuffisance hépatique chronique grave, qui est une pathologie mal décrite, sera également présentée. Une étude RMN a également permis de montrer que la signature métabolique sérique du développement du CHC dépendait de l'étiologie, ce qui était validé par un suivi longitudinal à différents temps. Enfin, chez des patients atteints d'un CHC suite à une hépatite virale (VHC), des biomarqueurs métaboliques permettant de prédire la récurrence suite à une ablation par radiofréquence seront proposés.

Mots-Clés : RMN métabolomique $\mathrm{CHC}$ cirrhose

Programme

${ }^{*}$ Intervenant 


\title{
Hyphenation of Online Supercritical Fluid Extraction - Supercritical Fluid Chromatography with SWATH Mass Spectrometry for Metabolomics [P126]
}

\author{
Laura Akbal ${ }^{* \dagger}{ }^{1}$, Gérard Hopfgartner \\ ${ }^{1}$ University of Geneva - University of Geneva, Life Sciences Mass Spectrometry, Department of Inorganic and \\ Analytical Chemistry, 24 Quai-Ernest-Ansermet, CH-1211 Genève 4, Suisse
}

Introduction: Metabolite identification and quantification in metabolomics can be challenging i) due to chemical space of metabolites and ii) due to interferences from comedications in patient samples. Commonly applied generic sample preparation procedures such as protein precipitation or liquid-liquid extraction are not adequate for analytes fractionation.

Supercritical Fluid Extraction (SFE) allows the specific tuning of the extraction to selectively isolate analytes of interest or reduce interferences by removing matrix compounds during extraction.

The Data Independent Acquisition (DIA) (SWATH) has emerged as a powerful tool for comprehensive qualitative and quantitative data analysis and the present work investigates its hyphenation with SFE-SFC/HRMS for polar and apolar metabolites.

Methods: SFE extractions and SFC analyses of biological samples were carried out on the Nexera UC system (Shimadzu Corporation, Kyoto, Japan) coupled with a TripleTOF 5600 mass spectrometer (SCIEX, Concord, ON, Canada). The SFE parameters such as pressure, temperature or percentage of modifier were tuned to selectively optimize the extraction. Moreover, a comparison with a validated methanol extraction of Dried Paper Spots (DPaS) procedure was performed for endogenous metabolites and protease inhibitors, representative classes for metabolomics and pharmaceutical studies.

Results: Online SFE-SFC has been carried out for the extraction and analysis of endogenous metabolites and protease inhibitors in biological samples from DPaS. The SFE-SFC analysis of DPaS on high resolution mass spectrometer using data independent acquisition allows metabolomics identification of almost 100 metabolites from plasma samples. Extractions of protease inhibitors from DPaS by SFE and by methanol extraction have been compared to show the potential of the online SFE-SFC system.

Mots-Clés : SFC, MS, High Resolution, SWATH, Metabolomics, Supercritical Fluid Extraction, Biological Samples

$\underline{\text { Programme }}$

\footnotetext{
*Intervenant

${ }^{\dagger}$ Auteur correspondant: laura.akbal@unige.ch

¥Auteur correspondant: gerard.hopfgartner@uinge.ch
} 


\title{
Targeted MS and power ultrasound sample treatment allow robust and rapid amyloidosis diagnosis [P127]
}

\author{
Emmanuelle Demey-Thomas ${ }^{* \dagger}{ }^{1}$, Sophie Liuu ${ }^{1}$, Joëlle Vinh ${ }^{1}$ \\ ${ }^{1}$ Laboratory of Biological Mass Spectrometry and Proteomics, CNRS USR3149, ESPCI Paris, PSL Research \\ University - ESPCI ParisTech, CNRS : USR3149 - 10 rue Vauquelin, 75231 Paris cedex 05, France
}

\begin{abstract}
Amyloidosis is a group of rare protein folding diseases. It induces clinical disorders resulting from intracellular or extracellular deposition of specific and insoluble fibrillary protein aggregates, called amyloid deposits, ending in progressive organ damage. Accurate identification of fibrillary proteins is fundamental for proper medical care. The gold-standard approach involves immunofluorescence under polarized light or immunohistochemical methods (IHC) on affected tissues after biopsy or surgery. However, it requires suitable and specific antibodies, and suffers from limitations due to cross-reactivity, post-translational modifications, or mutations. Furthermore, practical experience in IHC is a key factor for successful diagnosis.

Recently, the identification of the protein composition of amyloid deposits has been addressed by mass spectrometry. We have shown that targeted mass spectrometry analysis of samples (using parallel reaction monitoring, PRM) can lead to specific and sensitive results. Combined with ultrasonic assisted proteolysis, we significantly improved protein quality digestion and reduce preparation time. This treatment has been used for the completion of enzymatic proteolysis on raw, fixed or from LCM amyloid biopsy samples on several tissues (kidney, spleen, lung, salivary gland, testis, seminal vesicle...). Comparison with mass spectrometry results reveals good subtyping correlation among the IHC results.

Our work shows how amyloidosis diagnosis and subtyping directly from clinical samples can be completed by targeted proteomics analysis in a reproducible way. This approach greatly minimized preparation time, reduced sample quantity and decreased analysis duration.
\end{abstract}

Mots-Clés : Mass spectrometry, Targeted, PRM, Amyloidosis, Ultrasonic proteolysis, Diagnosis

Programme

\footnotetext{
*Intervenant

${ }^{\dagger}$ Auteur correspondant: demey.usr3149.espci@ hotmail.com
} 


\title{
Shedding new light on Spinal Cord injury [P128]
}

\author{
Michel Salzet $* 1$ \\ ${ }^{1}$ INSERM, CHRU Lille, Université des Sciences et Technologies de Lille - Lille I - INSERM U-1192, \\ Laboratoire de Protéomique, Réponse Inflammatoire, Spectrométrie de Masse (PRISM), Université Lille 1, Cité \\ Scientifique, 59655 Villeneuve D’Ascq, France
}

Spinal cord injury (SCI) belongs to currently incurable disorders of the CNS and is accompanied by permanent health consequences-disability. In order to mimic a SCI, a balloon-compressive technique was used at thoracic Th8-9 spinal level in adult rat. Shot-gun proteomic was used to identify proteins in each spinal cord segment-derived conditioned medium along the rostral-caudal axis after SCI with time course. 3D MALDI Imaging, tissue microproteomics were undertaken combined with confocal imaging. In-vitro and in-vivo tests were realized. We established the spatial and temporal events occurring in acute phase after SCI. Caudal segment has clearly been detected as the therapeutic target. We assessed in a rat SCI model the in vivo impact of a sustained RhoA inhibitor administered in situ via functionalizedalginate scaffold. In order to decipher the underlying molecular mechanisms involved in such a process, an in vitro neuroproteomic-systems biology platform was developed in which the pan-proteomic profile of the dorsal root ganglia (DRG) cell line ND7/23 DRG was assessed in a large array of culture conditions using RhoAi and/or conditioned media obtained from SCI ex-vivo derived spinal cord slices. A fine mapping of the spatio-temporal molecular events of the RhoAi treatment in SCI was performed. The data obtained allow a better understanding of regeneration induced above and below the lesion site. Results notably showed a time-dependent alteration of the transcription factors profile along with the synthesis of growth cone-related factors (receptors, ligands, and signaling pathways) in RhoAi treated DRG cells. Furthermore, we demonstrate the inflammatory response process involvement via immunoglobulins by binding to their C16/CD32 receptors on the DRG cells upon neurite outgrowth initiation and thus modulating the neurite outgrowth process. We then validate our results by an in vivo proteomic studies along the spinal cord segments. Taken together, we shed new light on Spinal Cord injury

Mots-Clés : spinam cord injury, 3D MALDI imaging, mircroproteomic, lipidomic, microglial cells, macrophages, antibodies, RhoA inhibitors

$\underline{\text { Programme }}$

\footnotetext{
*Intervenant
} 


\title{
MALDI-TOF MS analysis of serum N-glycans and glycoproteins: an essential analytical tool in the diagnosis scheme of congenital disorders of glycosylation [P129]
}

\author{
Arnaud Bruneel ${ }^{1,2}$, Sophie Cholet ${ }^{3}$, Coralie Ruel $^{3,4}$, Thuy Tran-Maignan ${ }^{4}$, \\ Stéphanie Yen-Nicolaÿ ${ }^{5}$, Nathalie Seta ${ }^{2}$, François Fenaille $* \dagger 3$ \\ ${ }^{1}$ INSERM UMR-1193 « Mécanismes cellulaires et moléculaires de l'adaptation au stress et cancérogenèse », Université Paris-Sud - \\ INSERM - Chatenay-Malabry, France \\ ${ }^{2}$ AP-HP, CHU Bichat-Claude Bernard, Biochimie métabolique et cellulaire ; Groupe d'étude des glycopathies - Assistance publique - \\ Hôpitaux de Paris (AP-HP) - Paris, France \\ ${ }^{3}$ CEA/Institut Joliot/Service de Pharmacologie et Immunoanalyse, UMR 0496, Laboratoire d’Etude du Métabolisme des Médicaments, \\ MetaboHUB Paris - CEA Saclay, Gif sur Yvette, France \\ ${ }^{4}$ Institut Galien Paris Sud, UMR8612, Protein and Nanotechnology in Analytical Science (PNAS), CNRS, Univ. Paris-Sud, Université \\ Paris-Saclay - Université Paris Sud - 5 rue Jean Baptiste Clément, 92290 Châtenay-Malabry, France \\ ${ }^{5}$ Plateforme Trans-Prot, activité protéomique, UMS IPSIT, Université Paris Saclay - Université Paris Sud - Faculté de Pharmacie de \\ Châtenay-Malabry, France
}

Glycosylation is one of the most prominent and complex types of post-translational modifications, with more than $50 \%$ of human proteins being glycosylated. Protein glycosylation is usually N- or Olinked depending on the site of attachment to the protein backbone. Congenital disorders of glycosylation (CDGs) are rare inherited diseases sharing very diverse and variable clinical symptoms related to genetic defects in the $\mathrm{N}$ - and/or O-glycosylation process. CDGs with abnormal protein N-glycosylation are classically sub-grouped as type I (CDG-I) or type II (CDG-II) according to transferrin glycoforms patterns. In CDG-I, the defect alters the lipid-linked oligosaccharide synthesis/transfer to proteins in endoplasmic reticulum leading to partial non-occupancy of N-glycosylation sites. In CDG-II, the defect alters the maturation of protein-linked oligosaccharide in the Golgi apparatus with alterations of N-glycans motifs. Matrix-assisted laser desorption/ionization time-of-flight mass spectrometry (MALDI-TOF MS) profiling of enzymatically-released plasma $\mathrm{N}$-glycans is regarded as a powerful analytical tool for the characterization of CDG-II related N-glycosylation defects. Furthermore, we also show that MALDITOF MS of intact serum apolipoprotein C-III (apoC-III) can be used to screen for associated mucin core 1 $\mathrm{O}$-glycosylation defects. In an integrated view also implying clinical evaluation, first line electrophoretic methods for CDG screening and increasing whole exome sequencing data, we show that MS can greatly help diagnosing CDGs by accurately highlighting and characterizing abnormal glycan structures thereby pinpointing deficient proteins (glycosyl transferases, sugar transporters, ATPases...) and related gene mutations. In this presentation, we present key examples gathered from a number of relevant and illustrative clinical samples to definitively demonstrate the usefulness of MALDI-TOF MS for the diagnosis of CDGs, through $\mathrm{N}$-glycans and apoC-III analyzes.

Mots-Clés : CDG, MALDITOF, Nglycans, ApoCIII

\footnotetext{
${ }^{*}$ Intervenant

${ }^{\dagger}$ Auteur correspondant: francois.fenaille@cea.fr
} 


\section{Plantomics [P130-P153]}




\title{
Platform Metabolism-Metabolome : various analytical techniques based on stable isotopes and metabolomics for plant biology [P130]
}

\author{
Françoise Gilard ${ }^{* \dagger}$ 1, Caroline Mauve, Florence Guérard, Marlène \\ Lamothe-Sibold, Valérie Cantonny, Bertrand Gakière \\ ${ }^{1}$ Platform Metabolism-Metabolome - Institut of Plant Sciences Paris Saclay (IPS2) - CNRS : UMR9213 - IPS2 - \\ Bâtiment 630 - Rue Noetzlin Université Paris Sud 91405 Orsay Cedex, France
}

The main goal of this facility is to offer expertise to develop new protocols and to carry out the measurement and analysis of plant metabolites using a combination of isotopic and metabolomic techniques. We have the tools and know-how to undertake the rapid metabolic phenotyping of plant lines to help understand the consequences of specific genetic mutations with respect to metabolite contents, and to allow the determination of carbon, nitrogen and water use efficiencies as well as fluxes in plant organs and terrestrial vegetation. Such an association of devices allows to combine metabolomics and fluxomics for an improved understanding of plant cell metabolic networks. The facility is not only involved in local research projects since it is open to other laboratories whether they are public or private, local, national or international. This is achieved either as a service or collaboration and in both cases the Platform offers expertise from the experimental design to a statistical analysis of the data.

Mots-Clés : plant, metabolomics, primary metabolites, secondary metabolites, profiling, stable isotopes, metabolic tracing

Programme

\footnotetext{
*Intervenant

${ }^{\dagger}$ Auteur correspondant: francoise.gilard@u-psud.fr
} 


\title{
Développement d'une méthode de profilage par LC-HRMS/MS du lipidome total des extraits lipidiques de Serenoa repens (W.B. Bartram) Small (ARECACEAE) [P131]
}

\author{
Aurélien Amiel ${ }^{* \dagger}$ 1, Nicolas Fabre $^{1}$, Philippe Joulia ${ }^{2}$, Bernard Fabre ${ }^{2}$, \\ Christel Fiorini-Puybaret ${ }_{-}^{\ddagger 2}$, Guillaume Marti ${ }_{-}^{\S} 1$ \\ ${ }^{1}$ UMR 152 Pharma Dev, Université de Toulouse, IRD (PHARMA-DEV) - Université Paul Sabatier-Toulouse III - UPS, \\ Institut de recherche pour le développement [IRD] : UMR152 - 35 Chemin des Maraîchers \\ 31400 Toulouse, France \\ ${ }^{2}$ Laboratoire des Produits Végétaux, Institut de Recherche Pierre Fabre (IRPF) - PIERRE FABRE - 3 Avenue Hubert Curien, \\ 31100 Toulouse, France
}

La composition des extraits lipidiques de Serenoa repens disponibles dans le commerce dépend du solvant d'extraction utilisé (Hexane, $\mathrm{CO} 2 \mathrm{SC}$ ou Ethanol). Ces extraits, dont celui du produit leader, le médicament Permixon $\mathbb{R}$ obtenu à partir d'une extraction hexanique des drupes de la plante, sont utilisés en phytothérapie pour traiter l'hyperplasie bénigne de la prostate. Chaque extrait présente une complexité qualitative et quantitative importante qui rend leur comparaison difficile et ne permet pas de les différencier. L'objectif est dans un premier temps de développer une méthode d'analyse globale des composés lipidiques par LC-HRMS et dans un second temps, de comparer les différents extraits disponibles sur le marché afin de définir leur niveau de similarité.

Le développement de la méthode a été réalisé à partir d'échantillons industriels ayant subi une séparation liquide-liquide afin d'obtenir une phase hexanique (lipides apolaires) et acétonitrile (lipides polaires). Pour chaque phase, une méthode de séparation spécifique par UHPLC a été optimisée. Plusieurs paramètres de détection en masse haute résolution (LTQ Orbitrap XL) ont été évalués tel que la source d'ionisation (ESI ou APCI) et l'énergie de fragmentation. Les pics chromatographiques ont été annotés par interrogation des bases de données de fragmentation in silico tels que LipidBlast et LipidMaps. Cette méthode nous a permis d'identifier une dizaine de classes de lipides différents. Ainsi parmi les 300 pics détectés, le 2,3-dihydroxypropyl-dodecanoate et le 1-O-tetradecanoylglycerol caractéristiques de l'espèce ont été identifiés. Enfin, des réseaux moléculaires ont été construits pour avoir une vue globale de la composition qualitative de chaque extrait.

L'approche développée dans cette étude permet d'obtenir une empreinte globale du lipidome d'un extrait lipidique de Serenoa repens et peut être appliquée dans le cadre d'un contrôle qualité de la matière première ou d'identification d'actifs. De plus, cette méthode peut être implémentée à l'analyse d'autres extraits lipophiles d'origine végétale.

Mots-Clés : Lipidomique, Serenoa repens, LC, HRMS, Déréplication, Réseaux moléculaires

\footnotetext{
* Intervenant

$\dagger$ Auteur correspondant: aurelien.amiel@univ-tlse3.fr

†Auteur correspondant: christel.fiorini.puybaret@pierre-fabre.com

$\S$ Auteur correspondant: guillaume.marti@univ-tlse3.fr
} 


\title{
Métabolomique ciblée par UHPLC/MRM pour l'aide à la sélection variétale de plante piège [P132]
}

\author{
Laëtitia Fougere $_{-}^{*}{ }^{1}$, Emilie Destandau ${ }^{1}$, Béatrice Rhino ${ }^{2,3}$, Claire Elfakir ${ }^{1}$ \\ ${ }^{1}$ Institut de Chimie Organique et Analytique (ICOA) - CNRS : UMR7311, Université d'Orléans \\ F-45067 Orléans, France \\ ${ }^{2}$ Centre de coopération internationale en recherche agronomique pour le développement [CIRAD] \\ F-97285 Le Lamentin, Martinique, France \\ ${ }^{3}$ CAEC - CAEC - Lamentin, Martinique, France
}

\begin{abstract}
Des associations de plantes offrent une alternative écologique aux pesticides pour protéger les plantes des ravageurs. Aux Antilles, une étude a montré que le maïs doux peut être une plante piège pour la noctuelle Helicoverpa zea de la tomate (1). Les larves se nourrissent de soies contenant des flavones$\mathrm{C}$-glycosylées qui réduisent leur croissance et limite leur prolifération. Toutefois sur le terrain, l'effet d'antibiose sur $H$. zea varie selon les variétés de maïs.

Dans ce contexte, une étude phytochimique a été menée pour évaluer la composition moléculaire en flavonoïdes des soies de maïs de différentes variétés, et évaluer si ces métabolites permettent de les discriminer. La caractérisation et la quantification de ces éliciteurs dans les différentes variétés de soies de maïs ont été effectuées en parallèle du travail d'observation sur le terrain mené par le CIRAD pour identifier la variété présentant le meilleur effet d'antibiose.
\end{abstract}

Une première étude sur la fragmentation de standards de flavonoïdes $\mathrm{C}$ et O-glycosylés menée par UHPLC/MS ${ }^{2}$ a permis de caractériser une soixantaine de flavonoïdes dans les soies de maïs. À partir de cette étude, des transitions spécifiques ont pu être sélectionnées pour développer une méthode par UHPLC/MRM afin de réaliser une quantification relative de ces différents flavonoïdes dans 5 variétés de maïs (Java, Garrison, Sugar Jean, Nova et Golden Bantam). Le traitement statistique (Anova, ACP et PLS-DA) des données a montré une surexpression de certains flavones-C-glycosylés, comme la maysine, dans la variété Java par rapport aux autres variétés testées. Les observations sur le terrain ont montré que la variété Java s'était avérée la plus efficace dans la mortalité des nymphes.

L'étude de la signature moléculaire des soies de maïs s'avère une approche pertinente et complémentaire des observations en champ pour guider le choix de la variété la plus efficace en tant que plante piège.

(1) Int. J. of Pest Management 62 (2016) 3-10.

Mots-Clés : Métabolomique ciblée, UHPLC/MRM, Sélection variétale, Soies de maïs

Programme

${ }^{*}$ Intervenant 


\title{
Antioxydants and proteome analysis of root response to salt stress in the plant model Medicago truncatula Gaertn [P133]
}

\author{
Adel Amar Amouri * ${ }_{-}$, Esther M. González, Seghir Hadjadj Aoul \\ ${ }^{1}$ Laboratoire d'écologie végétale - Département de Biologie. Faculté des Sciences de la nature et de la vie. \\ BP1524. Université d'Oran1 Ahmed Ben Bella. 31000 Oran., Algérie
}

\begin{abstract}
Legumes are very important plants both ecologically and agriculturally because they are able to interact symbiotically with rhizobia for biological nitrogen fixation and soil fertilization. Medicago truncatula Gaertn. is an important model legume rich in protein. Salinity represents, today, the major cause of land degradation and crop productivity limitation around the world and it's an important abiotic stress which significantly affects seedling growth. In this study, we analyzed the physiological and biochemical responses of rootlets in two contrasting ecotypes of Medicago truncatula (Tru 131, tolerant and Jemalong, sensitive) to different level of $\mathrm{NaCl},(68,102$ and $137 \mathrm{mM})$. Results showed that the tolerant ecotype has a lower water potential than Jemalong. Root protein content of Jemalong was decreased than Tru131, this can be explained by accumulation of protein oxidation in the sensitive genotype. Moreover, $\mathrm{NaCl}$ increased guaiacol peroxidase activity GPX in rootlets of Tru 131, this enzyme has a protective role against the molecules ROS accumulated during oxidative stress. On the other hand, under salt stress the total content of ascorbate (ASC +DHA) and Glutathione (GSH+GSSG) was increased in the tolerant genotype Tru 131 compared to Jemalong. These results show how the tolerant genotype activate the antioxidative defense system at root level against damages caused by oxidative stress under salinity.
\end{abstract}

Mots-Clés : Medicago truncatula Gaertn., salt stress, root, antioxydants, proteome, capillary electrophoresis

$\underline{\text { Programme }}$

${ }^{*}$ Intervenant 


\title{
Differential protein expression in potato tubers infected with pectobacterium atrosepticum pathogen induced by chitosan treatment [P134]
}

\author{
Lila Mahious $* \dagger 1$, Sabrina Bousbata ${ }^{2}$, Andy Polomé, Rachida Yahiaoui-Zaidi
}

\footnotetext{
${ }^{1}$ Laboratoire de Microbiologie Appliqué, Département de Biologie Physico-Chimique, Université A. Mira de Béjaia, Algérie - Route de Traga Ouzemmour, 06000, Bejaia, Algérie

${ }^{2}$ Laboratoire de microbiologie, plateforme de protéomique, IBMM, Université Libre de Bruxelles, Belgique Rue des professeurs Jenneer et Brachet, Charleroi, Belgium, Belgique
}

Potato (Solanum tuberosum L.) is the fourth most frequently grown crop plant in the world, and after wheat and rice it is the third crop in order of importance for human consumption. In turn, potato tuber susceptibility to pathogens infection (specifically Pectobacterium atrosepticum) during harvesting and storage is one such complex trait of high agronomic interest. In response to this infection, defense mechanisms must be strongly induced to prevent important economic losses.

Chitosan is one of the potential elicitor of several plant defense responses including lignifications, production of phytoalexins, and synthesis of proteinase inhibitors.

A proteomic approach is valuable in understanding regulatory networks because it deals with identifying new proteins in relation to their function. The aim of this work was to focus attention on the early events possibly triggered by chitosan at the proteome level. Then, chitosan effect on potato tubers infected with $P a$ was examined by analyzing and comparing their proteomic profiling in order to understand the molecular mechanisms implicated in potato defense response induced by the elicitor. Furthermore, differentially abundant proteins were identified after performing 2-fluorescence difference gel electrophoresis (2-DIGE) experiments. We compared potato tuber proteome response to infection with Pectobacterium atrosepticum in two groups of infected potato tubers with or without pre-treatment by chitosan. Differentially expressed proteins were identified by mass spectrometry and investigated for molecular and enzymatic studies.

Mots-Clés : proteomics, potato, chitosan, DIGE, mass spectrometry

\section{Programme}

\footnotetext{
${ }^{*}$ Intervenant

${ }^{\dagger}$ Auteur correspondant: lila_mahious@ hotmail.fr
} 


\title{
Fast discrimination of chocolates from mass spectrometry fingerprints of cocoa polyphenols [P135]
}

\author{
Noémie Fayeulle ${ }^{* \dagger}{ }^{1}$, Soraya Chapel ${ }^{1}$, Anna Vallverdu-Queralt ${ }^{1}$, Florine \\ Grolet ${ }^{\top}$, Jean-Claude Boulet ${ }^{1}$, Jean-Michel Roger ${ }^{2}$ \\ ${ }^{1}$ Plateforme Polyphénols, UMR SPO, INRA, Montpellier Supagro, Université de Montpellier - Montpellier \\ SupAgro - 2 place Pierre Vialla, Bâtiment 28, 34060 Montpellier, France \\ ${ }^{2}$ UMR ITAP, IRSTEA - Institut national de recherche en sciences et technologies pour l'environnement et \\ l'agriculture - IRSTEA (France) - 361 rue J.F. Breton, BP 5095, 34196 Montpellier, France
}

Polyphenolics compounds are largely found in cocoa beans and are assumed to play an important role in chocolate taste. The hypothesis is that the variation in the polyphenolic compound composition of cocoa may be a good indicator of the taste of the future chocolate. Fifty-six cocoa samples have been attributed to four different sensory groups by sensory analysis of the corresponding chocolates. The aim of this study was to discover polyphenolic bio-markers enabling a fast discrimination of the sensory groups with mass spectrometry and chemometrics. The polyphenols have been extracted from the ground and defatted cocoa beans and analysed by UHPLC-ESI-IT-MS. The average mass spectrum recorded on the whole UHPLC profile was used as unique fingerprint for each sample. PCA analysis of these data showed that the IT-MS is sensitive and quantitative enough to discriminate the sensory groups without prior selection of target compounds, i.e polyphenolic bio-markers, leading to a fast unsupervised discrimination method. A chemometrics treatment was applied to select the most relevant molecules for the discrimination. Results show that only 32 molecules, mostly flavanols and tannins, are needed to differentiate the sensory groups in the cocoa samples. Therefore, the variable selection is relevant and provides a targeted discrimination method. Indeed, the differentiation of sensory group is similar on a PCA with the whole signal set from the average spectrum or with the selected variables only. Both methods allow taste prediction from the cocoa polyphenol composition.

Mots-Clés : cocoa, mass spectrometry, discrimination, taste prediction, variable selection

Programme

\footnotetext{
*Intervenant

${ }^{\dagger}$ Auteur correspondant: noemie.fayeulle@inra.fr
} 


\title{
Chemical diversity and antiviral potential of tropical euphorbiaceae [P136]
}

\author{
Simon Remy ${ }^{* \dagger}{ }^{1}$, Florent Olivon ${ }^{1}$, Pierre-Marie Allard ${ }^{2}$, Cécilia Eydoux ${ }^{3}$, \\ Jean-Luc Wolfender ${ }^{2}$, Jean-Claude Guillemot ${ }^{3}$, David Touboul ${ }_{-}^{\ddagger}$, Marc \\ Litaudon -1
}

\author{
${ }^{1}$ Institut de Chimie des Substances Naturelles (ICSN) - CNRS : UPR2301 - Avenue de la terrasse \\ 91198 Gif sur Yvette cedex, France \\ ${ }^{2}$ Université de Genève (UNIGE) - 24 rue du Général-Dufour CH - 1211 Genève 4, Suisse \\ ${ }^{3}$ Architecture et fonction des macromolécules biologiques (AFMB) - CNRS : UMR7257, Université de la \\ Méditerranée - Aix-Marseille II, Université de Provence - Aix-Marseille I - 31 Chemin Joseph Aiguier 13402 \\ Marseille cedex 20, France
}

Euphorbiaceae family is characterized by the production of various diterpenoid skeletons endowed with a wide range of biological activities (Vasas and Hohmann, 2014). In this study, 311 extracts from endemic Euphorbiaceae species of New Caledonia and French Guiana were screened for their inhibitory effects on ZIKV and DENV NS5 RNA-dependent RNA-polymerase (NS5 RdRp; Godoy et al., 2017). Dengue (DENV) and Zika (ZIKV) are arthropod-borne viruses associated with severe morbidity and responsible for massive epidemics. In a first study, based on the molecular networking approach (Wang et al., 2016), we will focus on the identification of natural dual inhibitors of DENV and ZIKV NS5 RdRp. The screening was performed using a newly developed fluorescent assay. To target original scaffolds, the biological activities were mapped on the global molecular network generated from LC-MS2 data. In a second study, seasonal variation in diterpenoid production will be investigated using LC-MS2 in two Euphorbiaceae species native from French Guiana i.e Sandwithia guyanensis and Sagotia racemosa. A set of 20 original macrocyclic diterpenoids and polycyclic diterpenoids has already been isolated from S. guyanensis. These compounds will be used as chemical markers in order to better understand the the relative quantitative and qualitative variations related to biotic and abiotic stress.

Vasas, A. and J. Hohmann, Chem. Rev. (2014). 114(17), 8579-612

Andre S. Godoy et al. Nat. Commun. (2017), 8, 14764

Wang M., et al. Nat. Biotechnol. (2016) 34(8), 828-837

Mots-Clés : Zika, Dengue, diterpenoid, Euphorbiaceae, molecular networking, LC, MS2, dereplication, French Guiana, New, Caledonia

$\underline{\text { Programme }}$

\footnotetext{
${ }^{*}$ Intervenant

$\dagger$ Auteur correspondant: simonremy0610@gmail.com

¥Auteur correspondant: $\overline{\text { david.touboul@icsn.cnrs-gif.fr }}$

$\S$ Auteur correspondant: Marc.LITAUDON@cnrs.fr
} 


\title{
Interactomics reveals novel regulatory mechanisms of plant aquaporins [P137]
}

\author{
Jorge Bellati ${ }^{1}$, Chloé Champeyroux ${ }^{1}$, Sonia Hem ${ }^{1}$, Valérie Rofidal ${ }^{1}$, Gabriel \\ Krouk ${ }^{1}$, Christophe Maurel ${ }^{1}$, Véronique Santoni ${ }_{-}^{* 1}$ \\ ${ }^{1}$ Lab. Biochimie et Physiologie Moléculaire des Plantes. INRA-CNRS-SupAgro-UM - INRA - 2 place Viala \\ 34060 Montpellier, France
}

In plants, aquaporins play a crucial role in regulating water transport in response to environmental cues. Our group identified stimuli that modulate Arabidopsis root hydraulic conductivity ( $L \mathrm{pr})$ and showed that the phosphorylation status of plasma membrane intrinsic proteins (PIPs), a sub-class of aquaporins, was positively correlated to (Lpr) [Di Pietro et al. Mol. Cell. Proteomics 2013 (12)]. Proteins that molecularly interact with PIPs were searched to get additional insights into regulatory mechanisms of root water transport. Immuno-purification of PIPs combined to protein identification and quantification by mass spectrometry allowed building a thorough PIP interactome of about 400 interacting proteins. Such interactome revealed PIPs to behave as a platform for recruitment of a wide range of transport activities and provided novel insights into regulation of PIP cellular trafficking by osmotic and oxidative treatments. This work also pointed to a role of lipid signaling in PIP function and revealed novel protein kinases involved in PIP regulation. In particular we show that two members of the receptor-like kinase (RLK) family (RKL1 and Feronia) differentially modulate PIP activity through distinct molecular mechanisms [Bellati et al. Mol. Cell. Proteomics 2016 (15)]. The overall work opens novel perspectives in understanding PIP regulatory mechanisms and their role in adjustment of plant water status. Work supported by French Research National Agency and Syngenta

Mots-Clés : aquaporin, interactomics, kinase, plant

$\underline{\text { Programme }}$

${ }^{*}$ Intervenant 


\title{
The impact of interactions between environment, cultural management and rapeseed oil varieties on health promoting molecules using a metabolomic approach [P138]
}

\author{
Djawed Bennouna ${ }_{-}^{*}$, Ljubica Svilar ${ }^{2}$, Célia Pontet , Frédéric Fine , Xavier \\ Pinochet, Jean-Charles Martin \\ ${ }^{1}$ Nutrition, obésité et risque thrombotique (NORT) - INRA, UMR A1260, Aix Marseille Université, Institut National de la Santé et de la \\ Recherche Médicale, U1062 - Faculté de Médecine Timone - 27 Bd Jean Moulin 13385 Marseille Cedex 5, France \\ ${ }^{2}$ CriBioM - Aix-Marseille Université - AMU - 27 Bd Jean Moulin Faculté de médecine, La Timone, France \\ ${ }^{3}$ UMR INRA 1260 / INSERM 1025 - Universités Aix Marseille - 27 Bvd Jean Moulin faculté de médecine de la Timone 13385 Marseille, \\ France
}

Rapeseed is grown for its use in the food industry (1), as well as its applicability in green chemistry as a biofuel (2). To improve the nutritional quality of rapeseed, various strategies have been implemented by the food industry to reduce the rate of anti-nutritional metabolites such as glucosinolates (3). Among them, the combination of crop cultivars with environmental conditions and culture management can be a lever of action to improve the nutritional quality of plants. In order to achieve this goal, 8 rapeseed varieties, grown in 8 regions of France were compared with a non-targeted metabolomics approach. In contrast to classical biochemistry analysis, Metabolomics has the advantage of giving an overview of all the metabolites and allows the study of interactions between different metabolic pathways in a single analysis. The raw data obtained from the analysis by LC/MS were processed to extract information prior to statistical analyses.

The multivariate data analysis using a combination of hierarchical clustering with principal component score analysis and correlation network analysis highlighted the' metabolomics' distance and closeness between the samples according to both genotypes and geographical regions. A major environmental impact on crop seeds metabolome was observed with different trends, depending on the varieties. In fact, some varieties were very sensitive to environment whereas others are less responsive. The comparison of the most impacting environment on seeds metabolome has shown a dramatic effect between the balance in the molecules of interest such as polyphenols and glucosinolates.

Lastly, the identified secondary metabolites were mapped into the KEGG pathway database to reveal the most sensitive gene targets that could be sensitive to the environmental influence. We thus identified a gene (gene X) in the biosynthesis of polyphenols that could be rate limiting/promoting in this pathway according to the environmental condition.

(1) Liu Q, Wu L, Pu H, Li C, Hu Q. Profile and distribution of soluble and insoluble phenolics in Chinese rapeseed (Brassica napus). Food Chem. nov 2012;135(2):616 22.

(2) Kortesniemi M, Vuorinen AL, Sinkkonen J, Yang B, Rajala A, Kallio H. NMR metabolomics of ripened and developing oilseed rape (Brassica napus) and turnip rape (Brassica rapa). Food Chem. avr 2015;172:63 70.

(3) Fenwick GR, Spinks E, Wilkinson AP, Heaney RK, Legoy MA. Effect of processing on the antinutrient content of rapeseed. J Sci Food Agric. 1986;37(8):735-741.

Mots-Clés : metabolomics, LC, MS, rapeseed, environnement, polyphenols, glucosinolates

\footnotetext{
*Intervenant

${ }^{\dagger}$ Auteur correspondant: jean-charles.martin@univ-amu.fr
} 


\title{
How nano-LC-MS/MS methods improve plasmodesmata proteome knowledge [P139]
}

\author{
Françoise Immel ${ }_{-}^{*}$, Magali Grison ${ }^{1}$, Mathieu Fouché ${ }^{1}$, Stéphane Claverol ${ }^{2}$, \\ Emmanuelle Bayer ${ }^{1}$
}

\footnotetext{
${ }^{1}$ Laboratory of Membrane Biogenesis, UMR5200 CNRS, University of Bordeaux, (LBM) - CNRS : UMR5200, Université de Bordeaux - 71 Avenue Edouard Bourlaux, 33883 Villenave d'Ornon cedex, France

2 Proteome Platform, Functional Genomic Center of Bordeaux (CGFB Protéome) - Université de Bordeaux - 146 rue Léo Saignat, 33076 Bordeaux cedex, France
}

In plants, plasmodesmata (PD) are cellular junctions which allow cell to cell communication. These connections between plant cells are critical for plant development and plant stress responses, diffusion of molecules, proteins and nucleic acid active transport and finally, spread of virus and fungi. PD pores exhibit a varying diameter of 20-40nm and electron microscopy observations revealed in their center a tubule of endoplasmic reticulum called the desmotubule. In this way, they establish a continuity of the cytoplasm (symplasm), the plasma membrane and the endoplasmic reticulum throughout the whole plant body. Finally, a dynamic regulation of the flux through the PD leads to a finely controlled cell to cell communication.

To elucidate their structure and function, proteomic analysis of PD enriched fractions have been performed. The difficulty was to isolate PD from a cell wall fraction. The first protocol was established in 1995 with a cellulase treatment [1] and according to these recommendations, the first major PD proteome was determined by the laboratory of A. Maule [2] in 2011. Their approach was based on performing a nanoLC-MS/MS method using an LTQ-OrbitrapTM mass spectrometer. They identified 1341 proteins but after a data mining, they established that at least $34 \%$ were contaminant proteins. Furthermore, this method didn't provide any information on protein relative abundance.

In 2015, our laboratory improved PD isolation protocol [3] from Arabidopsis thaliana suspension culture cells and a new strategy of proteomic analysis of PD enriched fraction was developed. Protein relative abundances were evaluated using a label-free method. Peptide mixture from different sub-cellular fractions (i.e. PD, total cell extract, plasma membrane, microsomes and cell wall) were analyzed with the Ultimate 3000 nanoLC system (Dionex) coupled to the LTQ-Orbitrap XL mass spectrometer (ThermoFinnigan). Finally, protein enrichment ratios were calculated and allow us to establish a new refined PD proteome.

Mots-Clés : plant, plasmodesmata, proteomics, label free method, Arabidopsis thaliana

\section{Programme}

\footnotetext{
${ }^{*}$ Intervenant
} 


\title{
Genome wide association study for protein expression under normal and water deficit conditions in maize leaves [P140]
}

\author{
Mélisande Blein-Nicolas ${ }^{*}{ }^{\dagger}{ }^{1}$, Sandra Negro ${ }^{1}$, Thierry Balliau ${ }^{1}$, Llorenc \\ Cabrera-Bosquet ${ }^{2}$, Hélène Corti ${ }^{1}$, Stéphane Nicolas ${ }^{1}$, Alain Charcosset ${ }^{1}$, \\ François Tardieu $^{2}$, Welcker Claude ${ }^{2}$, Michel Zivy ${ }^{1}$
}

${ }^{1}$ UMR Génétique Quantitative et Evolution - Le Moulon (UMR GQE - Le Moulon) - INRA, CNRS, Université Paris Sud - Paris XI, AgroParisTech, AgroParisTech - Ferme du Moulon, 91190 Gif-sur-Yvette, France ${ }^{2}$ Laboratoire d'Ecophysiologie des Plantes sous Stress Environnementaux (UMR759 LEPSE) - INRA, Montpellier SupAgro - Place Viala, F-34060 Montpellier Cedex 1, France

Maize is one of the main crops worldwide, but its yield can be severely affected by drought. Drought tolerance in maize is genotype-dependent, indicating that this trait can be genetically improved. This study aimed to identify genetic determinants of drought tolerance by using genome wide association study (GWAS) to identify pQTLs for protein abundance that colocalize with QTL for ecophysiological traits. A panel of 251 maize genotypes was grown in the high-throughput phenotyping platform PhenoArch (Montpellier) under water deficit (WW) and well-watered (WD) conditions and in two replicates. Several ecophysiological parameters were measured during plant growth and analyzed elsewhere (Alvarez Prado et al., submitted). At the pre-flowering stage, 1004 samples were taken on the last ligulated leaf and analyzed by shotgun proteomics. Protein identification and inference were performed using X!TandemPipeline (Langella et al., 2017, J. Proteome Res., 16:494-503). A total of 1950 proteins were quantified either by extracted ion current using MassChroq (Valot et al., 2011, Proteomics 11:3572-77) or by peak counting. GWAS was performed for 3900 molecular phenotypes (=1950 proteins $x$ conditions) using FaST-LMM (Lippert et al., 2011, Nature Methods, 8:833-835). Most proteins showed significant abundance variations in response to water deficit and to genotype. Drought responsive proteins, like dehydrins, were highly induced under WD, while proteins of energy metabolism were down-regulated. pQTLs were detected for most proteins, confirming the high genetic variability of their abundances. The most strongly associated pQTLs were located close to the protein encoding genes. Forty seven pQTL/QTL colocalizations, involving 5 ecophysiological traits and 58 proteins, were identified, mostly in WD. These results show the potential of high-throughput quantitative proteomics to decipher the determinisms of protein abundance regulation and to discover candidate genes and proteins potentially involved in the variation of plant phenotypic traits.

Mots-Clés : Zea mays, drought, shotgun proteomics, quantitative genetics

$\underline{\text { Programme }}$

\footnotetext{
*Intervenant

†Auteur correspondant: melisande.blein-nicolas@inra.fr
} 


\title{
Volatilomics in the vineyard [P141]
}

\author{
Christelle Lemaitre-Guillier * 1, Xavier Daire ${ }^{1}$, Nicolas Aveline ${ }^{2}$, Antonin \\ Douillet $^{2}$, Agnès Chartier ${ }^{3}$, Christelle Dufresne ${ }^{3}$, Marielle Adrian ${ }^{1}$ \\ ${ }^{1}$ Agroécologie (UMR 1347), AgroSup Dijon, CNRS ERL 6003, INRA, Université Bourgogne Franche-Comté, \\ 17 rue de Sully, F-21000 Dijon, France \\ ${ }^{2}$ Institut Français de la Vigne et du Vin, 39 rue Michel Montaigne, F33290 Blanquefort, France \\ ${ }^{3}$ Institut de Chimie Organique et Analytique (ICOA-UMR 7311), Université d'Orléans, rue de Chartres \\ F-45067 Orléans, France
}

Elicitors are natural compounds able to activate plant defense reaction against pathogens. Therefore they can be used as plant protectants in agriculture to reduce the use of fungicides. This strategy is particularly attractive in viticulture where heavy fungicides applications are needed to control fungal diseases, such as downy mildew. Several time-consuming approaches like transcriptomics, proteomics and metabolomics have been already performed to understand the action mode of numerous elicitors and to uncover potential induced-markers of the grapevine resistance $(1,2)$. However, elicitors usually provide inconsistent efficacy in field conditions. In order to improve the effectiveness of the elicitation, we then need fast and non-destructive tools enabling to check whether the plant has actually mounted a defense after the treatment.

In greenhouse, we recently correlated the emission of Volatile organic compounds VOCs (alpha-farnesene and beta-ocimene) with elicitor induced resistance to downy mildew (3). In an attempt to validate this observation in real conditions, we set up experiments using 2 commercial elicitors in 2 French vineyards (Burgundy and Bordeaux). Preliminary tests were performed to select the best devices and conditions for VOC sampling (SPME fibers or SBSE Twisters). Results presented will cover VOC emission in the two vineyards during three successive periods of the grapevine life cycle. Power and limitations of their use as markers of induced resistance in the field will be discussed.

(1) Lemaitre-Guillier C. et al. (2017). Proteomics towards the understanding of elicitor induced resistance of grapevine against downy mildew. J. Proteomics. 156:113-125

(2) Adrian M. et al. (2017). Metabolic fingerprint of PS3-Induced Resistance of grapevine leaves against Plasmopara viticola revealed differences in elicitor-triggered defenses. Front. Plant Sci. 8: art 101 (14p.)

(3) Chalal M. et al. (2015). Sesquiterpene volatile organic compounds (VOCs) are markers of elicitation by sulfated laminarine in grapevine. Front. Plant Sci. 6(350).

Mots-Clés : elicitation, VOC, volatilome, grapevine, plant resistance

$\underline{\text { Programme }}$

*Intervenant 


\title{
Activité antimicrobienne des huiles essentielles du genre Thymus numidicus et Thymus algériensis vis-à-vis les souches bactériennes responsables des infections nosocomials [P142]
}

\author{
Aicha Touhami ${ }_{-}^{*}$, Abbes Bookhari ${ }^{1}$, Ismail Fadel ${ }^{1}$ \\ ${ }^{1}$ Laboratoire de synthèse Organique, Modélisation, Optimisation et Procédé chimique (LOMOP) - Faculté des \\ Sciences, Département de Chimie, Université Badji Mokhtar Annaba, B. P. 12, 23000, El-Hadjar, Algérie
}

L'organisme humain possède un système complexe de défense qui lui permet de rencontrer ou d'héberger les agents pathogènes (virus, bactéries, champignons etc) sans leur permettre d'envahir ses tissus (Hill et al 1964). Cependant, dans certaines conditions ces derniers peuvent être responsables de maladies plus ou moins graves. (Heart et al 2006, Persidis et al 1999). La prise en charge de ces maladies diffère selon la nature de l'agent infectieux en cause : virus, champignons, parasites ou bactéries.

Les infections nosocomiale sont acquissent dans un établissement de soins, et apparaissent après un délai de $48 \mathrm{H}$ de l'admission, la gravité de ces infections réside dans les difficultés thérapeutiques qu'elles posent. Cela s'explique par le fait qu'elles résistent aux antibiotiques couramment utilisées. Le recours aux ressources naturelles, en général et aux plantes médicinales en particulier devient alors une des plus importantes et intéressantes pistes à explorer, pour la recherche de nouveaux produits antibactériens plus efficaces (Wright et al 2007).

Notre travail consiste à étudier l'activité antimicrobienne des huiles essentielles de Thymus numidicus et Thymus ciliatus vis-à-vis quelques souches bactériennes responsables des infections nosocomiales notamment :Klebsiella oxytoca, Acinitobacter baumanii, Satphylococus ATCC 25923 et Pseudomonas ATCC 27853.

Les résultats obtenus sont très satisfaisant, les souches bactériennes testées se sont révèlent très sensibles avec nos huiles essentielles, avec des diamètres d'inhibitions de 26 à $28 \mathrm{~mm}$ pour la souche Kelbsiella.o, de 32 à $35 \mathrm{~mm}$ pour l'Acinitobacter.b et de 38 à $54 \mathrm{~mm}$ pour Satphylococus ATCC 25923. Cette activité se traduit par la composition chimique des huiles essentielles qui est riche phénoliques, ces derniers ont un large spectre d'activité antimicrobienne en entrainent des lésions irréversibles sur les membranes bactériennes (Trombetta et al 2002, Setrani et al 2008).

Mots-Clés : huiles essentielles, T. numidicus, T. ciliatus, GCMS, infections nosocomiale

Programme

${ }^{*}$ Intervenant 


\title{
Etude protéomique des parois de grains de blé au cours du développement [P143]
}

\author{
Mehdi Cherkaoui ${ }^{* \dagger}{ }^{1}$, Audrey Geairon ${ }^{1}$, Virginie Lollier ${ }^{1}$, Hélène \\ Rogniaux ${ }^{1}$, Colette Larre ${ }^{1}$, Fabienne Guillon ${ }^{1}$, Mathilde Francin-Allami ${ }_{-}^{\ddagger 1}$ \\ ${ }^{1}$ Unité de recherche sur les Biopolymères, Interactions Assemblages (BIA) - INRA : UR1268 - Rue de la \\ Géraudière, 44316 Nantes, France
}

Les parois cellulaires sont les éléments structurels qui font la particularité des cellules végétales. Bien qu'elles ne représentent que 2 à $4 \%$ de la matière sèche du grain de blé elles ont un impact majeur sur les procédés de transformation du grain ainsi que la qualité nutritionnelle du produit consommable en termes de source de fibres alimentaires. Elles sont essentiellement constituées de polysaccharides tels que la cellulose, les hémicelluloses et les pectines qui sont assemblés à partir d'oligosaccharides, synthétisés dans le Golgi (hormis pour la cellulose) et transportés vers la paroi. Les protéines représentent une fraction non négligeable des constituants pariétaux et sont, pour certaines, impliquées dans les évènements d'assemblage et de remodelage des polysaccharides pariétaux qui ont lieu au cours du développement du grain.

L'objectif de cette étude est d'appréhender ces évènements d'assemblage et de remodelage des polysaccharides pariétaux à différents stades de développement en identifiant les protéines pariétales (CWP) dans deux tissus du grain : les enveloppes et l'albumen.

Pour réaliser cette étude, nous avons disséqué les albumens et les enveloppes de grains de blé récoltés à deux stades clé du développement à savoir un stade précoce de développement $(150 \circ \mathrm{J})$ et un stade de début d'accumulation des réserves $(250 \circ \mathrm{J})$. Les parois cellulaires ont ensuite été isolées et les protéines pariétales extraites pour être analysées par spectrométrie de masse couplée à la chromatographie liquide (LC-MS). Nous présentons ici les résultats d'identification et de quantification par label-free de ces protéines pariétales. Les résultats obtenus sont comparés d'un stade et d'un tissu à l'autre afin d'appréhender le remodelage des polysaccharides pariétaux d'un point de vue spatiale et temporelle au cours du développement du grain de blé.

Mots-Clés : blé, protéines pariétales, LC, MS, polysaccharides

$\underline{\text { Programme }}$

\footnotetext{
*Intervenant

$\dagger$ Auteur correspondant: mehdi.cherkaoui@inra.fr

$¥$ Auteur correspondant: $\overline{\text { mathilde.francin-allami@ } i n r a . f r}$
} 


\title{
Extraction et analyse de phytohormones par U-HPLC-MS : rôle des phytohormones dans la symbiose mycorhizienne [P144]
}

\author{
Simon Pons ${ }^{1,2}$, Adeline Bascaules Bedin ${ }^{2}$, Virginie Puech Pages ${ }^{1,2}$, Saïda \\ Danoun ${ }^{1,2}$, Sylvie Fournier $* \dagger 1,2$ \\ ${ }^{1}$ Plateau MetaToul-Métabolites végétaux (MetaToul-MV) - Université Paul Sabatier-Toulouse III - UPS, CNRS \\ - LRSV, 24, chemin de Borde Rouge - Auzeville, B.P. 42617, 31326 Castanet-Tolosan, France \\ ${ }^{2}$ Laboratoire de Recherche en Sciences Végétales (LRSV) - Université Paul Sabatier - Toulouse 3, CNRS : \\ UMR5546 - 24 Chemin de Borde-Rouge BP 42617 Auzeville 31326 Castanet-Tolosan cedex, France
}

Les phytohormones sont des substances végétales qui agissent à faibles concentrations, à différents stades du développement des plantes. Différentes familles de phytohormones ont été identifiées (auxines, cytokinines, salicylates, jasmonates, gibbérellines,...). Il s'agit de métabolites secondaires de natures chimiques très diverses avec des propriétés physico-chimiques très différentes.

L'analyse des phytohormones est réalisée en LC-ESI-MS grâce à un Q-Exactive Plus haute résolution couplé à une chaîne chromatographique UHPLC (Thermo Scientific). Dans un premier temps, à l'aide de standards de phytohormones, la séparation chromatographique a été optimisée en jouant sur différents paramètres (phases mobiles, température de colonne...). Les paramètres de spectrométrie de masse ont également été optimisés en faisant varier les paramètres de source ainsi que les paramètres d'acquisition. Dans un second temps, un protocole d'extraction inspiré de la littérature, a été optimisé afin d'extraire les phytohormones ciblées à partir de racines et de champignons. Ce protocole consiste en une extraction liquide-solide suivie d'une SPE hydrophobe et d'une SPE en échange d'ions.

Les phytohormones sont aussi produites par les plantes en tant que molécules "signal" en réponse à divers stress abiotiques et biotiques, notamment dans la symbiose mycorhizienne, une interaction bénéfique plantes-champignons. Le protocole d'extraction et d'analyse optimisé a été appliqué au dosage des hormones végétales dans les racines mycorhizées versus non mycorhizées et dans le champignon seul. Ces résultats permettront de mieux comprendre leurs rôles dans le développement de la symbiose mycorhizienne.

Mots-Clés : phytohormones, LC, MS, racines

$\underline{\text { Programme }}$

\footnotetext{
*Intervenant

${ }^{\dagger}$ Auteur correspondant: fournier@1rsv.ups-tlse.fr
} 


\title{
Identification of specific molecules of two Mentha species by a converging metabolomics/molecular networking approach [P145]
}

\author{
Axelle Aimond ${ }_{-}^{* 1,2}$, Grégory Genta-Jouve ${ }^{1}$, Coralie Audoin ${ }^{2}$ \\ ${ }^{1}$ Université Paris Descartes - Université Paris V - Paris Descartes - 4 rue de l'Observatoire, 75006 Paris, France \\ ${ }^{2}$ Laboratoires CLARINS - Laboratoires CLARINS - 5 rue Ampère, 95300 Pontoise, France
}

\begin{abstract}
Herbaceous plants belonging to the Mentha genus are commonly used as natural ingredients in cosmetics (1). Although better known for their oil, the more polar fractions have gained interest as they contain less toxic compounds such as pulegone and other terpenes. The Mentha genus is widely spread through several species which differentiate from each other by their macroscopic appearance and their molecular composition and the aim of this study is to highlight molecular differences between two selected species, Mentha piperita and Mentha arvensis. These two species are used in cosmetic products for their antioxidant, antimicrobial and calming properties (2). After an ethanolic extractions, the samples have been analyzed by UPLC-MS/MS on a Waters Xevo G2-XS QTof. The acquired data has been processed using two different approaches: a classical metobolomics workflow in order to identify the features of interest and a second one based on the molecular networking to putatively annotate the clusters containing the features identified in the first step. Through this convergent approach, some of the differences between the chemical composition of M. piperita and M. arvensis have been identified.
\end{abstract}

(1) Nair B.'Final report on the safety assessment of Mentha Piperita (Peppermint) Oil, Mentha Piperita (Peppermint) Leaf Extract, Mentha Piperita (Peppermint) Leaf, and Mentha Piperita (Peppermint) Leaf Water." International journal of toxicology. 20 Suppl 3 (pp 61-73), 2001

(2) Antioxidant, antimicrobial, cytotoxic and analgesic activities of ethanolic extract of Mentha arvensis L. , Nripendra Nath Biswas, Subarna Saha, Mohammed Khadem Ali, Asian Pacific Journal of Tropical Biomedicine, Volume 4, Issue 10, October 2014, Pages 792-797

Mots-Clés : molecular networking, metabolomics, Mentha species

$\underline{\text { Programme }}$

*Intervenant 


\title{
Does wild plant metabolomic diversity correlate with neutral genetic diversity? [P146]
}

\author{
Florence Souard ${ }^{* 1,2}$, Cédric Delporte ${ }^{2}$, Olivier Hardy ${ }^{2}$, Jérôme Duminil ${ }^{2}$, \\ Anais Gore $^{\overline{2}}$, Jean-Louis Doucet ${ }^{2}$, Jean-Francois Martin ${ }^{3}$, Marie \\ Tremblay-Franco ${ }^{3}$, Pierre Van Antwerpen ${ }^{2}$, \\ Caroline Stévigny ${ }^{2}$, Nausicaa Noret
}

\author{
${ }^{1}$ Université Grenoble Alpes - Département de Pharmacochimie Moléculaire, UMR 5063 CNRS, Université \\ Grenoble Alpes, 470 rue de la chimie, F-38400 Saint-Martin d'Hères, France \\ ${ }^{2}$ Laboratoire de Pharmacognosie, de Bromatologie et de Nutrition Humaine, Faculté de Pharmacie, Université \\ Libre de Bruxelles, Campus Plaine, CP 205/09, B-1050 Brussels, Belgium \\ ${ }^{3}$ INRA Toxalim Axiom MetaToul MetaboHUB - Université de Toulouse (Research Centre in Food Toxicology) - \\ INRA : UMR1331 - 180 chemin de Tournefeuille 31027 Toulouse, France
}

Overexploitation of African tropical forests is leading to a loss of intraspecific diversity. To counter biodiversity erosion, populations with high neutral genetic diversity (as assessed by microstallites) become areas of in situ conservation. There is however a lack of knowledge regarding the relationship between neutral genetic diversity on the one hand, and the diversity of adaptive measurable traits on the other hand. One example of plant measurable traits is highlighted by the metabolome, which includes both primary and secondary metabolites. Our work focuses on two wild species of the tropical trees Erythrophleum (Caesalpiniaceae), E. suaveolens and E. ivorense. Erythrophleum contains original secondary metabolites named cassaine diterpenes, a subfamily of the cassane diterpenes.

Plants from 5 populations (native from Cameroon, Republic of the Congo, Gabon) were cultivated in 4 plots located in a Cameroonian forest concession since 2011. Mature leaflets of 44 trees were collected in January 2016; samples were analyzed for both metabolomic and neutral genetic markers. Nine microstallite markers were used to assess neutral genetic diversity, based on individual heterozygosity and allelic richness of populations. An untargeted LC-(HR)MS metabolomics approach was used to examine metabolomic diversity. PCA and PLS-DA performed on the workflow4metabolomics collaborative platform (http://workflow4metabolomics.org) show that the two species have very distinct metabolic profiles even if sometimes hardly differentiated in the field. The experimental plot where plants grew has no influence on the metabolome. The geographically restricted E. ivorense has a lower metabolomic diversity compared with the widespread $E$. suaveolens. Statistical analyses were also conducted to link metabolomic and genetic diversity.

Mots-Clés : Erythrophleum, plant metabolomics, diversity, ecology

Programme

*Intervenant 


\title{
Coffee's leaf: an untargeted metabolome profiling determined by LC-HRMS [P147]
}

\author{
Florence Souard * 1,2 Cédric Delporte $^{2}$, Piet Stoffelen ${ }^{2}$, Etienne Thévenot ${ }^{3}$, \\ Nausicaa Noret ${ }^{2}$, Bastien Dauvergne ${ }^{2}$, Jean-Michel Kauffmann ${ }^{2}$, Pierre Van \\ Antwerpen ${ }^{2}$, Caroline Stévigny

\footnotetext{
${ }^{1}$ Université Grenoble Alpes - Département de Pharmacochimie Moléculaire, UMR 5063 CNRS, Université Grenoble Alpes, 470 rue de la chimie, F-38400 Saint-Martin d'Hères, France

${ }^{2}$ Laboratoire de Pharmacognosie, de Bromatologie et de Nutrition Humaine, Faculté de Pharmacie, Université Libre de Bruxelles, Campus Plaine, CP 205/09, B-1050 Brussels, Belgique

${ }^{3}$ CEA, LIST, Laboratoire Analyse de Données et Intelligence des Systèmes, MetaboHUB - Digiteo Saclay, F-91191 Gif-sur-Yvette, Cedex, France
}

Monitoring food quality is crucial and needs to be further developed in order to maintain/improve the standard of life. Untargeted methods such as metabolomics fingerprinting provide a global picture based on the overall content in small compounds and will thus highlight incoherent concentration ratios or matrix perturbations resulting from an adulteration.

Coffee seeds are used as beverage but also in cosmetic and pharmaceutical industries for their caffeine, chlorogenic acids ... contents. The three most studied and sailed coffee species are Arabica (Coffea arabica L.), Robusta (Coffea canephora Pierre ex Froehner), and Liberian coffees (Coffea liberica Bull.). Infusions of leaves are also consumed all around the world for medical purposes essentially. Few studies have described the metabolic compositions of Coffea leaves. We focused on coffee species for which there is a potential interest for cultivation and consumption. A detailed knowledge of chemical composition of leaves is important to contribute to a better understanding of the biosynthetic pathways as to improve the composition of future supplements. The wild diversity in the genus Coffea ( $>120$ coffee species) is large and could offer new opportunities and challenges.

All the plants studied were grown in tropical greenhouses and mature leaves were collected every 1.5 month (approximately) from January to November over a one year period. Metabolomics analysis of the mature leaves of 9 Coffea species (and sub-species) has been undertaken by LC-HRMS. Metabolic profiles were compared by univariate and statistical analyses using Workflow4Metabolomics online infrastructure (http://workflow4metabolomics.org) and a annotation analysis thanks to Biosigner algorithm. The study has permitted to highlight specific and original compositions. We have particularly explored the content of various xanthines, chlorogenic acids and toxic actractyl derivates. In a surprising way, caffeine was only present in C. arabica with seasonal variations.

Mots-Clés : coffee leaf metabolome, caffeine, actractylgenine

\section{Programme}

\footnotetext{
${ }^{*}$ Intervenant
} 


\title{
Plants with increased yield: from metabolomic to field [P148]
}

\author{
Théophile Kazmierczak * ${ }^{1}$, Florence Guérard ${ }^{\dagger}{ }^{1}$, Jingfang Hao ${ }^{1}$, \\ Mickael Hodges ${ }^{1}$, Françoise Gilard ${ }^{1}$, Bertrand Gakière ${ }^{1}$ \\ ${ }^{1}$ Institute of Plant Sciences Paris Saclay - Université Paris Sud - Paris XI - IPS2 - Bâtiment 630 - Rue Noetzlin \\ Université Paris Sud 91405 Orsay Cedex, France
}

The couple $\mathrm{NAD}(\mathrm{P}) / \mathrm{NAD}(\mathrm{P}) \mathrm{H}(\mathrm{NAD})$ is an energetic cofactor essential to a lot of metabolic reactionss. Its synthesis is fine-tuned and starts with L-aspartate oxidase (L-AO), the first committed enzyme in the NAD de novo biosynthesis in a pathway.

In this project, we looked at the effect of an increased NAD content in Arabidopsis thaliana plants displaying a higher L-AO activity (lao+). GC-MS experiments allowed us to compare the metabolome of these plants compaired to non-transformed plants (wt: wild-type) or plants deficient to L-AO activity (lao-). This approach highlight an accumulation of metabolites associated to a putative better plant growth in lao+ plants. Greenhouse experiments confirmed our hypothesis, a better biomass production was observed on lao+ plants whereas lao- plants are severaly impaired in their development and present a different metabolome profile.

This work present a first step to evaluate the transfer of our genetic approach to improve NAD production in crop species and the identification of metabolomics markers of high energy-content plants.

Mots-Clés : plants, metabolomics, translational biology

$\underline{\text { Programme }}$

\footnotetext{
*Intervenant

${ }^{\dagger}$ Auteur correspondant: florence.guerard@u-psud.fr
} 


\title{
Metabolic profile of phloem sap of tomato plants in response to phytoplasma infection [P150]
}

\author{
Federica De Marco *1, Françoise Vilaine ${ }^{1}$, \\ Marie Laure Martin-Magniette ${ }^{2}$, Catherine Jonard ${ }^{3}$, Sandrine Eveillard ${ }^{4}$, \\ Brigitte Batailler ${ }^{4}$, Rozenn Le Hir ${ }^{1}$, Sylvie Dinant ${ }^{1}$
}
${ }^{1}$ Institute Jean-Pierre Bourgin (IJPB), UMR 1318 INRA-Agro-ParisTech, Labex Saclay Plant Science, Versailles, France - INRA : UMR1318 - Versailles, France
${ }^{2}$ Institute of Plant Sciences - Paris Saclay (IPS2), INRA-CNRS-Université Paris Sud, Labex Saclay Plant Science, Orsay, UMR 518 INRA AgroParisTech Mathématiques et Informatique appliquées (MIA), Paris. France. - INRA : UMR518 - Orsay, France
${ }^{3}$ Metabolic Profiling and Metabolomic Platform, Rennes, France - Université de Rennes I - Rennes, France
${ }^{4}$ UMR 1332 Biologie du Fruit et Pathologie, INRA et Université de Bordeaux, CS20032, 33882 Villenave d'Ornon Cedex, France - INRA : UMR1332 - Villenave d'Ornon, France

In higher plants, phloem and xylem are the vascular tissues that permit the transport of photosynthates, water and other nutrients among the organs. Carbon is mainly fixed in photosynthetic leaves through the conversion of light into carbohydrates that are thus transported via the phloem into sink organs. The phloem sap content is mainly composed of sugars, such as sucrose, in addition to amino acids, organic acids and a range of secondary metabolites involved in signaling and defense. Phloem functions can be altered by plant pathogens. Notably phytoplasmas, which are phloem-restricted pathogens, can induce a switch in the source-sink balance between organs altering the normal pattern of sugar partitioning. Phytoplasmas affect many crops on which they cause severe diseases. Interactions between tomato and 'Candidatus Phytoplasma solani', which belongs to stolbur group 16SrXII, have been investigated in order to determine the effects of phytoplasmas infection on carbon allocation, using several approaches. In particular we set up an EDTA-facilitated exudation method to collect the phloem sap from tomato leaves. Sap metabolite contents were analyzed by Gas Chromatography (GC-FID). We were able to detect more than 50 metabolites, including sugars, amino acids and organic acids. Due to the high biological variability among plant samples we have developed a method of normalization before performing statistical analysis on data. Comparing phloem saps from healthy and infected plants, we observed significant changes in few metabolites belonging to different classes of compounds. For example, the rate of exudation of some organic acids such as glyoxylate has been found to be increased in infected plants while sucrose flow was found decreased. Profiling phloem sap content has appeared as an interesting tool to monitor plant status in the case of disease.

Mots-Clés : phloem, tomato, phytoplasma, GC

\section{Programme}

\footnotetext{
${ }^{*}$ Intervenant
} 


\title{
Développement d'une méthode haut débit pour le profilage métabolomique non ciblé par LC-HRMS [P151]
}

\author{
Thierry Berton * 1,2, Olivier Fernandez ${ }^{1}$, Benjamin Brachi ${ }^{3}$, Stéphane \\ Bernillon ${ }^{1,2}, \overline{\text { Nicolas Langlade }}{ }^{4}$, Yves Gibon ${ }^{1}$, Annick Moing ${ }^{1,2}$ \\ ${ }^{1}$ Biologie du fruit et pathologie (BFP) - Université Sciences et Technologies - Bordeaux I, Université Victor \\ Segalen - Bordeaux II, INRA : UMR1332 - Centre INRA Bordeaux-Aquitaine 71 avenue Bourlaux BP81 \\ F-33883 Villenave d'Ornon, France \\ 2 Plateforme Métabolome Bordeaux (PMB-MetaboHUB) - INRA : UMR1332 - Centre INRA de \\ Bordeaux-Aquitaine, IBVM, CS 20032, 33140 Villenave d'Ornon, France \\ ${ }^{3}$ Biodiversité, Gènes Communautés (BioGeCo) - INRA : UMR1202, Université de Bordeaux - Site de \\ recherche Forêt - Bois de Pierroton - 69, route d'Arcachon F-33612 Cestas Cedex France \\ ${ }^{4}$ Laboratoire des interactions plantes micro-organismes (LIPM) - INRA, CNRS : UMR2594 - Chemin de \\ Borde-Rouge - BP 2731326 Castanet Tolosan cedex, France
}

L'adaptation au changement climatique représente un défi, notamment dans le domaine de l'agriculture. Le manque d'eau qui en résulte représente un stress abiotique majeur pour les plantes d'intérêt agronomique, ce qui affecte leur croissance, les rendements et la qualité des produits. Maintenir une production satisfaisante impose donc de sélectionner les génotypes en identifiant des marqueurs de tolérance au stress hydrique constitutifs ou induits et d'adapter les pratiques culturales.

C'est dans ce contexte que nous avons réalisé des études métabolomiques pour prédire la tolérance de plusieurs centaines de génotypes et identifier les plus résistants en fonction des conditions climatiques. Il devenait donc indispensable d'adapter nos stratégies analytiques, notamment la spectrométrie de masse, au haut débit.

L'objectif était de passer d'un design expérimental initialement de l'ordre de la centaine d'échantillons au millier d'échantillons. L'ensemble des étapes du protocole analytique a donc été optimisé pour diminuer le temps d'analyse et automatiser le plus d'étapes possible. Différents solvants d'extraction ont été testés sur plusieurs matrices afin de remplacer le méthanol initialement utilisé par un solvant moins toxique, ce qui a permis de robotiser l'extraction. L'ensemble du protocole analytique (pesée, extraction, centrifugation, filtration, analyse LC-MS) est désormais réalisé en format microplaques de 96 puits, ce qui permet d'augmenter le débit de préparation des échantillons. Le gradient chromatographique a également été réduit de 51 minutes à 18 minutes et l'extraction des données via XCMS a été externalisée sur un mésocentre de calcul pour accélérer le retraitement des données.

Ce protocole a été appliqué à 540 échantillons de feuilles d'un panel de diversité de tournesol, soumise ou non à un stress hydrique, dans le cadre du projet SUNRISE. Des analyses statistiques ont ensuite été réalisées en combinant les données métabolomiques et des données de phénotypage pour identifier des métabolites marqueurs de tolérance dans les différents génotypes étudiés.

Mots-Clés : LC, HRMS, métabolomique, haut débit, tournesol, stress hydrique

${ }^{*}$ Intervenant 


\title{
Towards proteomics of single-starch granules [P152]
}

\author{
Stanislas Helle ${ }^{* \dagger}{ }^{2}$, Fabrice Bray ${ }^{2}$, Christophe D’hulst, Caroline \\ Tokarski ${ }^{2}$, Christian Rolando ${ }^{3}$, Nicolas Szydlowski
}

\author{
${ }^{1}$ Unité de Glycobiologie structurale et fonctionnelle (UGSF) - CNRS, Université de Lille, France \\ ${ }^{2}$ Miniaturisation pour la Synthèse et l'Analyse Protéomique (MSAP) - CNRS : USR3290 - Université Lille 1, \\ Sciences et Technologies Batiment C4 - Avenue Paul Langevin 59655 Villeneuve d'Ascq, France \\ ${ }^{3}$ USR 3290 MSAP, Université Lille 1, Sciences et Technologies - USR 3290 MSAP, Université Lille 1, Sciences \\ et Technologies - 59655 Villeneuve d'Ascq cedex, France
}

Starch granules display a broad structural and morphological heterogeneity. Moreover, the abundance of starch associated proteins is likely under the control of regulatory mechanisms related to the initiation and biosynthesis of the granules. To decipher these mechanisms and avoid biases due to intra-sample heterogeneity, the work reported here aimed at identifying starch-bound proteins and determining their stoichiometry in miniaturized samples. Granules from potato are the largest among common starch sources, with a diameter reaching up to $100 \mu \mathrm{m}$. Theoretical calculations show that the amount of the various proteins in a single $100 \mu \mathrm{m}$ starch granule from potato lies between $178 \mathrm{fmol}$ and $75 \mathrm{amol}$ inside a starch granule which is within the detection limit of nanoLC-nanoESI-MS/MS shotgun mass spectrometry. In our experimental workflow, starch granules are surface stripped with SDS 2\%, prior to glucan denaturation by heat. Then, the proteins are reduced, alkylated and digested by trypsin using the eFASP method. Finally, peptides were analyzed on a Q-Exactive Orbitrap mass spectrometer and raw data are faced to several potato databanks. Protein relative quantification is realized using emPAI score. Analyses have been realized on $300 \mathrm{mg}$ of granules (around $10^{6}$ granules) fractionated according to their size $(<11 \mu \mathrm{m} ; 11-31 \mu \mathrm{m} ; 31-50 \mu \mathrm{m}$ and $50-100 \mu \mathrm{m})$. Then we miniaturized the protocol to analyze the proteome of 30 granules and of a single starch granule. First data allow us to identify new proteins associated to potato tuber starch, and to establish protein stoichiometry inside the starch granule. The development on 30 granules analysis allowed identifying and quantifying the 3 most abundant proteins. This level of sensitivity is about 600 times higher than in previously reported proteomic analysis of potato starch, and allows studying highly limited starch samples. After future optimization, this work will lead to the analysis of a single starch granule.

Mots-Clés : starch, single, granule, proteomics, mass spectrometry, Aqua peptides

$\underline{\text { Programme }}$

\footnotetext{
*Intervenant

${ }^{\dagger}$ Auteur correspondant: stanislas.helle@outlook.fr

†Auteur correspondant: Nicolas.Szydlowski@univ-lille1.fr
} 


\title{
Les réseaux moléculaires comme moyen d'exploration rapide du contenu phytochimique d'extraits hydro-alcooliques de plantes [P153]
}

\author{
Ludivine Valois ${ }^{* \dagger}{ }^{1}$, Eric Marchioni ${ }^{1}$ \\ ${ }^{1}$ Equipe de Chimie Analytique des Molécules BioActives, Université de Strasbourg, CNRS, IPHC UMR 7178 \\ (Institut Pluridisciplinaire Hubert Curien) - CNRS : UMR7178 - 74 route du Rhin
}

67400 Illkirch-Graffenstaden, France

\begin{abstract}
Aujourd'hui, les techniques d'analyse des mélanges complexes sont de plus en plus performantes ce qui génère un très grand nombre d'informations à interpréter. Ainsi, il est nécessaire de mettre en place des outils rapides de traitement de larges sets de données. Les réseaux moléculaires constituent une approche récente et innovante pour la représentation des données MS/MS. Cet outil de visualisation permet de regrouper les ions parents selon la ressemblance de leurs spectres de fragmentation. On obtient ainsi des groupes au sein desquels sont rassemblés des composés apparentés ayant des schémas de fragmentation communs. On peut ainsi déterminer si des composés de structures proches sont présents dans un ou plusieurs échantillons. Pour notre étude, cette nouvelle approche a été utilisée pour explorer le contenu polyphénolique de six extraits hydro-alcooliques de plantes choisies comme modèles et appartenant à différentes familles botaniques. Il s'agit de Calendula officinalis, Chamaemelum nobile, Ribes nigrum, Citrus $x$ limon, Juniperus communis et Camellia sinensis. Un réseau moléculaire a été généré à partir des données LC-HRMS/MS. Ce réseau contient 4 principaux groupes de molécules. Par comparaison des ions détectés expérimentalement aux données bibliographiques des plantes modèles, il a été possible d'attribuer une identification à plusieurs de ces composés. Le réseau obtenu forme ainsi une " carte moléculaire " comportant 4 familles de composés polyphénoliques : les flavonols, les acides phénoliques, les dérivés de catéchine, et les flavones. Cette carte moléculaire réalisée à partir des plantes modèles a pour but d'être utilisée par la suite comme un outil rapide d'aide à l'identification du contenu en polyphénols d'autres extraits de plantes moins étudiées.
\end{abstract}

Mots-Clés : plantes, polyphénols, réseaux moléculaires

Programme

\footnotetext{
*Intervenant

†Auteur correspondant: ludivine.valois@unistra.fr
} 


\section{Fluxomique [P154-P155]}




\title{
A 15N-NMR based approach for amino acids based 13C-metabolic flux analysis of microbial metabolism [P154]
}

\author{
Lindsay Peyriga * 1,2, Pierre Millard ${ }^{\dagger}$, Edern Cahoreau ${ }^{1,2}$, \\ Maud Heuillet ${ }^{5}$, Jean-Charles Portais ${ }^{2,4}$, Guy Lippens ${ }^{5}$ \\ ${ }^{1}$ Laboratoire d'Ingénierie des Systèmes Biologiques et des Procédés (LISBP) - INSA - 135 Avenue de rangueil \\ 31077 Toulouse cedex 04, France \\ ${ }^{2}$ Metatoul - MetaboHUB - INRA : UMR792, CNRS : UMR5504, INSA - National Infrastructure of \\ Metabolomics \& Fluxomics (ANR-11-INBS-0010), France \\ ${ }^{3}$ Plateforme MetaToul Réseaux Métaboliques, LISBP - INSA Toulouse - 135 avenue de Rangueil 31077 \\ Toulouse cedex 04, France \\ ${ }^{4}$ Laboratoire d'Ingénierie des Systèmes Biologiques et des Procédés (LISBP) - INSA, CNRS : UMR5504, INRA \\ : UMR0792 - 135 Avenue de Rangueil 31077 Toulouse cedex 04, France \\ ${ }^{5}$ LISBP - CNRS : UMR5504, INRA : UMR792, INSA - 135 Avenue de Rangueil \\ 31077 Toulouse Cedex 4, France
}

Fluxomics, aims at measuring actual metabolic reaction rates within biological networks, has become a powerful tool for functional studies of metabolic systems for metabolic engineering, biotechnology or biomedical research. Typical NMR techniques for isotopomer quantification of amino acids exploit the $1 \mathrm{H}$ and $13 \mathrm{C}$ nuclei. They are based on non-decoupled experiments such as $1 \mathrm{H}, 1 \mathrm{H}-\mathrm{TOCSY}$ or $1 \mathrm{H}, 13 \mathrm{C}$ HSQC experiment, but J-resolved heteronuclear experiments have equally been proposed. Nevertheless, these experiments suffer from several drawbacks: overlaps, long relaxation delays for quantitatification, and carbonyl carbons are inaccessible as they have no attached proton. In protein NMR, most experiments exploit the favorable dispersion of the amide $15 \mathrm{~N}$ frequency, making the $1 \mathrm{H}, 15 \mathrm{~N}-\mathrm{HSQC}$ the workhorse of the myriad of n-dimensional NMR experiments for structural and dynamic protein analysis. We explore here how a similar approach can be used advantageously in the field of metabolomics and fluxomics to overcome some of the aforementioned shortcomings of NMR. We present novel HISQCTOCSY and HNCA experiments that allow deriving the same information as traditional experiments with increased efficiency. These experiments mostly exploit the NH3+ magnetization term as starting vector, rely on the good separation of the $15 \mathrm{~N}$ frequency, and yield accurate information on the $13 \mathrm{C}$ labelling of both the $\mathrm{C} \alpha$ and $\mathrm{CO}$ positions for the different amino acids. Combined with a novel $\mathrm{H} \alpha-\mathrm{CO}$ experiment, they allow quantifying the four isotopomers for the two-carbon block $(\mathrm{C} \alpha, \mathrm{CO})$ of the different amino acids. To evaluate our approach, a biologically-produced sample containing $15 \mathrm{~N}$-labeled metabolites with fully predictable 13C-labelling patterns was used as reference material. Results show excellent agreement between measured and expected isotopomer abundances for the three NMR experiments. Hence, exploiting the $15 \mathrm{~N}$ labelling of a cellular sample increases the coverage of isotopomers that can be quantified and largely accelerates subsequent analysis of biomass hydrolysates, making it a promising tool for high-throughput 13C-fluxomics studies.

Mots-Clés : Fluxomics, NMR, 15N, isotopomers, high, throughput

\footnotetext{
*Intervenant

${ }^{\dagger}$ Auteur correspondant: millard@insa-toulouse.fr
} 


\title{
High Resolution Orbitrap Mass Spectrometry for the Analysis of Deuterium-Labeled Lipids in E. Coli [P155]
}

\author{
Marie-Pierre Pavageau * 1, Anastasia Kalli, Neubauer Cajetan, David Peake, \\ Huhmer Andreas \\ ${ }^{1}$ Thermo Fisher Scientific - Thermo Fisher Scientific - Courtaboeuf cedex, France
}

\begin{abstract}
Mass spectrometry (MS) is a powerful analytical tool to advance our knowledge of lipid structures and their biosynthesis. However, lipid flux analysis has been challenging due to isobaric overlap of deuterium labels with the prevalent natural abundance of 13C. Orbitrap technology has now advanced to allow the resolving power required to differentiate the natural 13C isotopes and label-derived deuterium on a scale compatible with high pressure liquid chromatography. Here we demonstrate the efficacy of ultra-high resolution LC- MS/MS for analysis of deuterated glycerophospholipids in E.coli lipid extract. The extracts were separated by reverse-phase chromatography using an AccucoreTM C30 column and subjected for MS/MS analysis. Data were acquired in data-dependent mode on a Thermo Scientific ${ }^{\mathrm{TM}}$ Orbitrap Fusion Lumos TM mass spectrometer operated at a resolution of 120, 000 to 500, 000 (FWHM at $\mathrm{m} / \mathrm{z} 200$ ). Analysis of phosphatidylglycerol and cardiolipin molecular species showed that ultra-high resolution is a prerequisite for successful baseline separation of deuterium and $13 \mathrm{C}$ isotopes and therefore for accurate analysis of labeled lipid species. These results highlight the potential of ultra-high resolution MS and stable isotope labelling in establishing a more comprehensive view of lipid metabolism in vivo.
\end{abstract}

Mots-Clés : Orbitrap Fusion Lumos, Lipidomics, Fluxomics

$\underline{\text { Programme }}$

${ }^{*}$ Intervenant 


\title{
Visualization of metabolic subnetwork with MetExploreViz [P155.1]
}

\author{
Maxime Chazalviel *1, Florence Vinson ${ }^{2}$, Clément Frainay ${ }^{2}$, Benjamin \\ Merlet $^{2}$, Yoann Gloaguen ${ }^{3}$, Sanu Shameer ${ }^{4}$, Ludovic Cottret ${ }^{5}$, \\ Nathalie Poupin ${ }^{2}$, Fabien Jourdan ${ }^{2}$ \\ ${ }^{1}$ MedDay Pharmaceuticals, Paris, France \\ ${ }^{2}$ Toxalim, Université de Toulouse, INRA, Toulouse, France \\ ${ }^{3}$ Glasgow Polyomics, University of Glasgow, 120 University Place, Glasgow G12 8TA \\ ${ }^{4}$ Department of Plant Sciences, University of Oxford, South Parks Road, Oxford, OX1 3RB \\ ${ }^{5}$ LIPM, Université de Toulouse, INRA, CNRS, Castanet-Tolosan, France
}

The metabolic network of an organism gathers all the biochemical reactions that can occur in this organism, regardless of the conditions. In order to visualize those networks we introduce MetExploreViz, a free and open source javascript library which can easily be embedded into a webpage. One of the aims of MetExploreViz is to allow the extraction of sub-networks of interest based on a list of metabolites obtained from metabolomics experiments. To do so, a lightest-path based algorithm is used to identify the sub-networks linking the metabolites of interest and to highlight them in the network representation.

Within MetExploreViz, imported omics data can also be pinpointed on the network representation using mapping functions. Moreover, many features have been implemented in order to facilitate visual mining of the network. Especially, MetExploreViz offers a dynamic display of the network (contrary to the static traditional maps), allowing users to move nodes and automatically rearrange the layout to avoid node overlappings. Users can also choose to hide over-linked side compounds (e.g. H20, H+ ...) in order to reduce the amount of edges in the network and facilitate the visualization. Cellular compartments can be highlighted using color schemes, and a contextual menu allows displaying information from MetExplore database on compounds or reactions. MetExploreViz also enables users to save their network drawings and sessions in order to resume their work. Finally, publication ready images can be exported in various formats (jpeg, png or svg).

MetExploreViz will be integrated in the e-infrastructure developed in the framework of PhenoMeNal project (EC-654241).

$\underline{\text { Programme }}$

*Intervenant 
Géochimie / pétroéolomique / astrochimie
[P156] 


\title{
Determination of the efficiency of two deoxygenation catalysts for the upgrading of pyrolysis bio-oil by petroleomic approach [P156]
}

\author{
Jasmine Hertzog ${ }^{* \dagger} 1^{1}$, Vincent Carré ${ }^{1}$, Logan Colin Mackay ${ }^{2}$, \\ Liangyuan $\overline{\mathrm{Jia}}^{3}$, Ludovic Pinard ${ }^{4}$, Ondřej Mašek ${ }^{5}$, \\ Anthony Dufour ${ }^{6}$, Frédéric Aubriet \\ ${ }^{1}$ Laboratoire de Chimie et Physique - Approche Multi-échelle des Milieux Complexes (LCP-A2MC) - Université de Lorraine : EA4632 - \\ ICPM, 1 boulevard Arago, CP 87811, 57078 Metz Cedex 3, France \\ ${ }^{2}$ School of Chemistry - University of Edinburgh (SIRCAMS), Joseph Black Building The King's Buildings West Mains Road Edinburgh EH9 \\ 3JJ, Royaume-Uni \\ ${ }^{3}$ Laboratoire Réactions et Chimie des Procédés (LRGP) - UMR 7274 - LRGP - Laboratoire Réactions et Génie des Procédés - UMR 72741 \\ rue Grandville - BP 2045154001 Nancy Cedex, France \\ ${ }^{4}$ Institut de Chimie des Milieux et Matériaux de Poitiers (IC2MP) - Université de Poitiers, CNRS : UMR7285 - IC2MP - SFA Bâtiments \\ B27, B28 et B35 4, rue Michel Brunet - TSA 5110686073 Poitiers cedex 9, France \\ ${ }^{5}$ School of Geosciences - University of Edinburgh - UK Biochar Research Centre School of Geosciences Crew Building, The King's \\ Buildings University of Edinburgh Edinburgh, EH9 3FF, Royaume-Uni \\ ${ }^{6}$ Laboratoire Réactions et Génie des Procédés (LRGP) - Université de Lorraine, CNRS : UMR7274 - Université de Lorraine - ENSIC, 1 rue \\ de Grandville BP 20451, 54001 Nancy Cedex, France
}

Bio-oils from lignocellulosic biomass pyrolysis are promising alternatives to fossil fuels. However, their chemical properties do not allow to use them directly as fuel. In fact, bio-oils contain thousands of oxygenated species which are responsible of a poor energy density and corrosiveness issues. Therefore, upgrading processes are required to decrease the oxygen amounts by deoxygenation (DO) treatment and to convert bio-oil into "green petroleum" whose properties are close to crude oil ones and which may be refined to produce common fuels.

Raw and DO bio-oils from oak pyrolysis were investigated. DO bio-oils were produced with two different zeolite-based catalysts. The raw and the two upgraded bio-oils were characterized by non-targeted analysis in order to assess the efficiency of the treatment in respect with the nature of the catalyst. Thus, Fourier transform ion cyclotron resonance mass spectrometry coupled to electrospray ionization and atmospheric pressure photoionization (ESI/APPI FT-ICR MS), in positive ion mode, was used and ensured a petroleomic approach to be applied.

For all investigated samples, $\mathrm{CxHyOz}$ and $\mathrm{CxHyNnOz}$ species represent $90-100 \%$ and $0-10 \%$ of the signal, respectively. The comparison of the different bio-oils requires the use of specific data treatment such as the Van Krevelen diagram in which each $\mathrm{CxHyOz}$ compound is represented by a dot whose $\mathrm{x}$ and $\mathrm{y}$ coordinates are $\mathrm{O} / \mathrm{C}$ and $\mathrm{H} / \mathrm{C}$ ratio, respectively. The position of the dot in the diagram ensures to classify the bio-oil components as lipids, sugar or lignin derivatives. Thus, (+) ESI evidences the elimination of the sugaric derivatives and (+) APPI demonstrates the formation of less oxygenated compounds when DO treatments are used. Moreover, this approach allows the efficiency of both catalysts to be compared and the catalyst deactivation to be accessed.

Mots-Clés : Bio oil, petroleomic approach, ESI FTICR MS, APPI FTICR MS

\footnotetext{
*Intervenant

$\dagger$ Auteur correspondant: jasmine.hertzog@univ-lorraine.fr

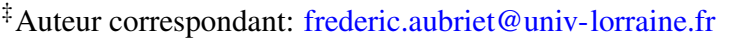




\section{Interactions intra- et inter-moléculaires [P157-P164]}




\title{
Affinity capillary electrophoresis hyphenated to mass spectrometry to study synthetic sulfated peptides and their non-covalent interactions with the chemokine SDF-1 [P157]
}

\author{
Maud Fumex * 1, Denis Servent, Gilles Mourier, \\ Régis Daniel ${ }^{1}$, Florence Gonnet ${ }^{\dagger} 1$ \\ ${ }^{1}$ Laboratoire Analyse et Modélisation pour la Biologie et l'Environnement (LAMBE - UMR 8587) - CEA, \\ CNRS : UMR8587, Université d'Evry-Val d'Essonne - Bât. Mapertuis 1 étage bd François Mitterrand \\ 91025 Evry cedex, France
}

Sulfation is one of the most important post-translational modifications of proteins. The known sulfated proteins are mostly cell receptors and among them, CXCR4 attracts growing attention because of its involvement in numerous physio-pathological processes (immune response, HIV infection). The extracellular domain of CXCR4, containing three tyrosine residues known to be sulfated, is important for the interaction with its specific ligand, the SDF-1/CXCL12 chemokine (Stromal cell-derived factor-1). The role of sulfation in this interaction remains to be established.

The 38 amino-acid peptide P38 corresponding to the extracellular domain of the CXCR4 receptor was chemically synthesized and sulfated on the three different tyrosine residues, 7, 12, and 21 respectively, and at different levels (mono-, di- or tri-sulfated). The impact of both sulfate distribution and position of sulfate groups on the interaction between P38 and SDF-1 is studied by affinity capillary electrophoresis (ACE) hyphenated to electrospray mass spectrometry (ESI-MS). ACE allows the detection of non-covalent complexes freely formed in solution and without partner immobilization and enables the determination of dissociation constants. The ACE-MS coupling in non-denaturing conditions allows the characterization of non-covalent complexes (stoichiometry).

An interaction between P38 and SDF- $1 \alpha$ was highlighted by ACE. It was strongly enhanced by the increase of P38 sulfation degree. The complex stoichiometry was then determined using ACE on-line coupled to ESI-MS.

Sulfation seems to have an important role in the affinity between the SDF- $1 \alpha$ chemokine and its receptor CXCR4. Higher is the P38 sulfation degree and stronger is the binding between the two partners. Other analytical tools will be considered such as hydroxyl-radical protein footprinting to determine the complex interaction sites.

Mots-Clés : Mass spectrometry, affinity capillary electrophoresis, sulfation, SDF, 1/CXCR4 complex

Programme

\footnotetext{
*Intervenant

${ }^{\dagger}$ Auteur correspondant: florence.gonnet@univ-evry.fr
} 


\title{
Properties of different forms of small size cationized non-covalent systems formed by phospho-hexose and basic compounds in gas phase: interest for D labeling [P158]
}

\author{
Ekaterina Dariy ${ }_{-}^{*}{ }^{1}$, Jean-Claude Tabet ${ }_{-}^{\dagger}$ \\ ${ }^{1}$ CEA - Fontenay-aux-Roses (UGRA / SETA) - 92265 Fontenay-aux-Roses Cedex, France
}

\begin{abstract}
Understanding properties of small (NCC) is important for MS analysis of complex mixtures. Our work is focused on the gas phase (GP) study of deprotonated/cationized non-covalent complexes (NCC) between hexose-phosphates (HexP) and arginine (R) or arginine dipeptide (RR) desorbed in negative ESI mode. Stabilization of small size NCC in GP mainly involves interactions such as:
\end{abstract}

(i) hydrogen bond (HB) formally constituted by two monocharged anions solvating proton,

(ii) salt bridge (SB) between two functional groups with opposite charges possible if one partner is as zwitterion and

(iii) solvated salt (SS) where the metallic cation of salt is solvated by a second partner.

HB systems are characterized by the absence of free charge and dissociate under CID conditions yielding free charged partners in competition which is not the case of SB and SS systems. SS/SB forms carry free charge and dissociate under CID by covalent bond cleavages (CBC). The D labeled cationized NCC with alkali and earth-alkali were used for exploration of inter/intra H/D exchange (HDX) of dissociation mechanisms of $\mathrm{HB} / \mathrm{SB} / \mathrm{SS}$ systems under resonant excitation conditions. For this purpose very high resolution was chosen and LTQ-Orbitrap FT/MS was used.

Negative ESI mass spectra of HexP and R (or RR) mixtures in D2O display only expected HDX for deprotonated/deuterated free partners (i.e., d5, d6 and d11, respectively) and NCC systems (d12, and d17) corresponding to the mobile proton number in anions. Alkali/one $\mathrm{D}$ and earth alkali/2D exchanges take place. Under CID conditions, NCC parent ions with complete deuterium labeling yield fragment ions with expected and unexpected residual labeling. This is probably due to covalent bond cleavages (CBC) promoted by free charge carried by NCC within SS or SB forms. The incorporation of additional D in sugar rings takes place due to intermolecular HDX between HexP and RR RR before complex dissociation.

Mots-Clés : non, covalent interactions in gas phase, $\mathrm{H} / \mathrm{D}$ exchange, fragmentation under CID

$\underline{\text { Programme }}$

\footnotetext{
* Intervenant

${ }^{\dagger}$ Auteur correspondant: jean-claude.tabet@ courriel.upmc.fr
} 


\title{
Enrichment strategies for improvement of mass spec analysis of chemical cross-linked peptides [P159]
}

\author{
Sega Ndiaye ${ }^{*}$, , Rosa Viner ${ }^{2}$, Ryan Bomgarden ${ }^{3}$, Kratika Singhal $^{3}$, \\ Sergei Snovida ${ }^{3}$, Craig Gutierrez ${ }^{4}$ \\ ${ }^{1}$ Thermo Fisher Scientific - Thermo Fisher Scientific - Villebon sur Yvette, France \\ 2 Thermo Fisher Scientific - San Jose CA, États-Unis \\ ${ }^{3}$ Rockford, IL - Rockford, IL, États-Unis \\ ${ }^{4}$ UC Irvine - Irvine, CA, États-Unis
}

Chemical cross-linking in combination with mass spectrometry is a powerful method to determine protein-protein interactions. This method has been applied to recombinant and native protein complexes and, more recently, to whole cell lysates or intact unicellular organisms in efforts to identify proteinprotein interactions on a global scale. However, this method suffers from low identification rates without enrichment/fractionation, as the typical yield of cross-linked peptides is less than $1 \%$ of total identified peptides. In this study, we evaluated multiple, widely used enrichment/fractionation techniques andbenchmarked newly developed SCX spin columns for cross-linked peptide analysis using an Orbitrap Fusion Lumos mass spectrometer.

Different amine-reactive, homobifuctional crosslinkers including DSS, DSSO and BuUrBu were used to crosslink protein and protein complex standards. Cross-linked samples were reduced, alkylated and digested with trypsin for MS analysis. Protein and peptide concentrations were determined using the Pierce $^{\mathrm{TM}}$ BCA Protein Assay Kit and the Pierce ${ }^{\mathrm{TM}}$ Quantitative Colorimetric Peptide Assay, respectively. Cross-linked peptides were pre-fractionated on SCX stage tips, SCX spin columns and SEC Superdex Peptide PC column (GE Health). Enriched samples were separated using a $50 \mathrm{~cm}$ Thermo Scientific $^{\mathrm{TM}}$ EASY-Spray ${ }^{\mathrm{TM}}$ column and an EASY-nLC ${ }^{\mathrm{TM}} 1200$ UPLC system in $60 \mathrm{~min}$ gradient, followed by detection on the Thermo Scientific ${ }^{\mathrm{TM}}$ Orbitrap $^{\mathrm{TM}}$ Fusion Lumos ${ }^{\mathrm{TM}}$ mass spectrometer. Data were analyzed using Thermo Scientific ${ }^{\mathrm{TM}}$ Proteome Discoverer ${ }^{\mathrm{TM}} 2.2$ software and XlinkX node.

We identified on average 40-50 crosslinked products in BSA without any enrichment using DSSO or BuUrBu mass spec cleavable crosslinkers. Using commercially available SCX Stage Tips and the recommended gradient of ammonium acetate as eluent, we identified up to 80 crosslinked peptides in 5 fractions. For SEC based fractionation, we also identified similar numbers of crosslinked peptides in 5 fractions using BSA as the model protein. For newly developed SCX spin columns, we identified a similar number of crosslinked peptides in only 2 fractions.

Mots-Clés : Cross, Link, XlinkX, Orbitrap, Fusion, Fusion Lumos, Q, Exactive, MS, cleavable crosslinkers, crosslinked peptide

$\underline{\text { Programme }}$

${ }^{*}$ Intervenant 


\title{
New biochip functionalizations for the SPR-MS coupling [P160]
}

\author{
Anastasiia Halushkina ${ }^{* \dagger} 1^{1}$, William Buchmann ${ }^{\ddagger}$, Diane Lebeau ${ }^{1,2}$, Nathalie \\ Jarroux ${ }^{\top}$, Florence Gonnet ${ }^{1}$, Régis Daniel ${ }_{-}^{\S} 1$
}

${ }^{1}$ Laboratoire Analyse et Modélisation pour la Biologie et l'Environnement (LAMBE - UMR 8587) - CEA : DEN/DPC, Université d'Évry-Val-d'Essonne, Université Paris-Saclay, CNRS : UMR8587 - Bât. Mapertuis 1 étage bd François Mitterrand 91025 EVRY cedex, France

${ }^{2}$ CEA Saclay - 91191 Gif-sur-Yvette cedex, France

Coupling of Surface Plasmon Resonance Imaging (SPRi) with Mass Spectrometry (MS) offers a very promising multidimensional analysis. This system takes advantages of the two well-established techniques: SPR that allows to analyse biomolecular interactions through the determination of kinetic and thermodynamic constants, and MS that can determine biological structures from mass measurements and fragmentation experiments. The ability of the SPR device for affinity-based enrichment of specific ligands, followed by the structural identification of captured ligands by MS, offers new opportunities in proteomics, bio-diagnostics and medicine (thanks to the identification of biomarkers and protein variants related to diseases).

With regards to multiplexing capacity, combining the principles of SPR with a powerful imaging system (so-called SPRi) allows preparation of assay surface in an array format that opens the way to multiplexed analyses. The recent introduction of SPRi compatible with MS detection offers the advantage of a multiplexed SPR-MS analysis, but the development of this coupling is limited due to the lack of MS sensitivity. The chemical functionalization of the biochip surface, the nature of the receptors and the grafting process are key factors that can influence the sensitivity of the on-chip MS detection. We report new biochip functionalizations of the SPR-MS biochip using aptamers as an alternative to commonly used antibodies, and the effects of these grafted new receptors on the MS detection sensitivity.

Mots-Clés : SPR, SPRi, MS, MALDI, MS, interactions

Programme

\footnotetext{
${ }^{*}$ Intervenant

$\dagger$ Auteur correspondant: galnastia@gmail.com

† Auteur correspondant: william.buchmann@univ-evry.fr

$\S$ Auteur correspondant: regis.daniel@univ-evry.fr
} 


\title{
Ion mobility spectrometry of foldamers and foldaxanes. Optimization of parameters used for theoretical CCS calculation [P161]
}

\author{
Frederic Rosu ${ }_{-}^{*}$, Yann Ferrand, Victor Maurizot, Ivan Huc, \\ Valérie Gabelica \\ ${ }^{1}$ CNRS, Université de Bordeaux (UMS 3033) - 2, rue Robert Escarpit, 33607, Pessac, France
}

Introduction: Quinoline-derived oligoamide foldamers are synthetic organic molecules that can fold into specific tridimensional structures. Foldaxanes are helix-rod host-guest complexes, which form upon winding aromatic oligomers around an alkylcarbamate rod. Characterizing the folding and the selfassembly is important to link the structure with a desired function. On these very rigid and monomorphic model structures, we determined collision cross section (CCS) by drift tube IMS in helium, and compare the experimental CCS with calculations in order to improve the empirical parametrization of ion-buffer gas interaction parameters of the EHSS model. IMS-MS is then applied to grasp the conformational dynamics of more complex and multi-modular foldaxanes.

Methods: Ion mobility spectrometry experiments were carried out with an Agilent 6560 ESI-IMS-QTOF (drift tube ion mobility cell and adapted for accurate CCS determination in helium). Theoretical collision cross sections in helium were calculated using the exact hard-sphere scattering (EHSSrot) method and TM. BOMD (PM7) calculations were carried out with Gaussian 16.

Results: The folded structure of monotonous quinoline oligoamine foldamers is kept in vacuo. The collision cross section (CCS) distribution is a narrow single peak. The width of the CCS distribution approaches the diffusion limit, and the CCS increases linearly with the foldamer mass.

We detect non-covalent assemblies of stacked helical aromatic oligoamides bound around a long rod-like alkylcarbamate oligomers (Nature Nanotech., 2017, 12, 447)

These artificial molecules (up to $25 \mathrm{kDa}$ ) allow us to refine the parameters used to calculate CCS values. To optimize the empirical parameters for each atom-Helium gas interaction in the EHSS model, we used foldamers bearing different exposed functional groups on the surface of the helix (isobutyl, carboxylic acid, phosphate and NH2). The experimental CCS are compared with candidates structures obtained using ab-initio molecular dynamics. Refined parameters for EHSS model are $\mathrm{R}(\mathrm{H}-\mathrm{He})=1.50 \AA$, $\mathrm{R}(\mathrm{C}-\mathrm{He})=2.40 \AA, \mathrm{R}(\mathrm{N}-\mathrm{He})=2.45 \AA, \mathrm{R}(\mathrm{O}-\mathrm{He})=2.47 \AA, \mathrm{R}(\mathrm{P}-\mathrm{He})=2.90$.

Mots-Clés : ion mobility, foldamer, stuctural chemistry, non, covalent complexes, CCS, calibration

$\underline{\text { Programme }}$

\footnotetext{
${ }^{*}$ Intervenant

${ }^{\dagger}$ Auteur correspondant: valerie.gabelica@inserm.fr
} 


\title{
Measurement of energy resolved collision induced dissociation and collision induced unfolding in a TWIMS device: critical parameters that need to be assessed [P162]
}

\author{
Felindra Sakthivelou ${ }^{1}$, Jan Bohl ${ }^{1}$, \\ Frédéric Halgand ${ }^{1}$, Guillaume Van Der Rest ${ }_{-} 1$ \\ ${ }^{1}$ Laboratoire de Chimie Physique (LCP) - CNRS : UMR8000, Université Paris Sud - Paris XI - Bâtiments \\ 349/350 avenue Georges Clémenceau 91405 Orsay cedex, France
}

In the course of work carried on in the laboratory on the binding of protein and peptides observed in the gas phase, it came to be of interest to measure the gas phase binding or structuring properties of systems by inducing fragmentation or unfolding using collisional activation prior to ion mobility separation. Two systems were more specifically investigated: a peptide dimer, for which we previously showed that a strong intermolecular binding was observed and the prion protein $(\mathrm{PrP})$, for which we showed that several conformations can coexist for a single charge state. The first system included studying several variants displaying varying gas phase interaction energies.

From this series of experiments, it became obvious that: a) Pressure conditions in the Tri-wave system are interconnected. It is not possible to keep conditions identical in one section of the system (trap, helium cell, nitrogen cell, transfer) without affecting the other regions. Furthermore, a change in gas flow in one section, notably the helium cell, not only changes the pressures but also likely affects the gas composition. Thus, distinguishing between mobility in helium or in nitrogen makes little sense in a device were both flows mix together. b) The activation of the IMS mode, which increases gas pressures throughout the system, leads to reduced fragmentation of weakly bound systems (presumably in the trap stacked ion ring), allowing their observation. c) Care should be taken when interpreting dissociation induced unfolding experiments, as changes in ion mobilities can easily be artefacts of overlapping peaks. Despite these limitations, conclusions can also be reached on the appearance of unfolded states of PrP which extend unfolded conformations observed at higher charge states, as well as reaching conclusions on the link between peptide binding and folding in peptide dimers.

Mots-Clés : ion mobility, collision induced dissociation, peptide interactions, protein conformers

$\underline{\text { Programme }}$

*Intervenant 


\title{
Interactome analysis of the RLTPR protein reveals its essential role in $T$ cells $[P 163]$
}

\author{
Luc Camoin * 1, Romain Roncagalli, Margot Cucchetti, Stéphane Audebert ${ }^{2}$, \\ Emilie Baudelet ${ }^{2}$, Marisa Goncalves Menoita, Stéphane Durand, Frédéric \\ Fiore, Marie Malissen, Bernard Malissen \\ ${ }^{1}$ Marseille Protéomique - Centre de Recherche en Cancérologie de Marseille (MaP-CRCM) - Centre de \\ Recherche INSERM : U1068, CNRS : UMR7258, Aix Marseille Université (Aix-en-Provence) : UM105 - AMU \\ UM105 27 Bd Leï Roure - CS 3005913273 Marseille Cedex 09, France \\ ${ }^{2}$ Centre de Recherche en Cancérologie de Marseille, UMR1068 INSERM, UMR 7258 CNRS, Institut \\ Paoli-Calmettes, Aix-Marseille Université, Marseille - CRCM-Marseille - 27 Boulevard Lei Roure 13009 \\ Marseille, France
}

Background: The RLTPR cytosolic protein, also known as CARMIL2, is essential for CD28 costimulatory functions in mouse T lymphocytes, but its importance in human $\mathrm{T}$ cells and mode of action remain elusive. The RLTPR interactome identification can help to understand the mechanism of action of RLTPR during CD28 co-stimulation in mouse and human T cells.

Methods: We developed mice that bear a genetic tag (one-STrEP-tag; OST) allowing affinity purification - mass spectrometry analysis (LTQ Velos Orbitrap) of RLTPR interactome in primary T cells. Thymocytes containing high levels of RLTPR were used to determine RLTPR interactome at different time of stimulation using pervanadate, a potent chemical component mimicking early molecular events induced during the $\mathrm{T}$ cell activation. Three independent biological experiments, each involving five different conditions corresponding to no stimulation and to four time points after stimulation were analysed by AP-MS.

Results: We showed that known molecular components of the CD28 signaling pathway, such as CD28 itself, GRB2, VAV1 and CARMA1, physically associate with RLTPR after activation. Additionally, we also identified uncharacterized molecular elements potentially relevant to elucidate the RLTPR CD28dependent co-stimulatory function. These results suggested that RLTPR acts as a scaffold protein, bridging CD28 to downstream effectors allowing the specific receptor transduction in T cells.

Conclusions: 19 proteins were determined as the RLTPR interactome of thymocytes. Among these proteins, we identified a large spectrum of functional activities, including phosphatases, adaptors and proteins involved in the actin dynamic assembly. Whereas some of these proteins are constitutively associated with RLTPR, a majority of interactors showed a dynamic interaction with the bait after T cell activation.

Mots-Clés : RLTPR, CARMIL2, Interactome, AP, MS, T cells

\section{Programme}

\footnotetext{
${ }^{*}$ Intervenant
} 


\title{
Chemical cross-linking and Mass spectrometry for the structural characterization of retinoic acid receptor complexes [P164]
}

\author{
Noëlle Potier*1,2, Natacha Rochel, Sangeetha Covindarassou, \\ Emmanuelle Leize \\ ${ }^{1}$ Laboratoire de Spectrométrie de Masse des Interactions et des Systèmes (LSMIS) - UMR 7140 CNRS-UDS - 1 \\ Rue Blaise Pascal, 67008 Strasbourg, France \\ ${ }^{2}$ Université de Strasbourg - CNRS - CNRS : UMR7140 - 4 rue B. Pascal 67081 Strasbourg, France
}

Strategy: It is now well establish that proteins carry out their function through their interaction with other partners. Therefore, structure determination of protein complexes is one key in understanding protein action and in the resulting modulation of cellular dysfunction. Our project aims to develop a global strategy to extend the potential of cross-linking approaches to the characterization of heterodimer interfaces of Nuclear Receptors / DNA and associated coregulators. In particular, we want to investigate whether the dimerization interface is modified upon partner (DNA or coactivator) interactions. For this, we will elucidate the molecular architecture of various complexes by cross-linking - Mass Spectrometry (XLMS).

Methodology: Cross-linking relies on the introduction of a covalent bond between functional groups of amino acids that are nearby in space. Cross-linking has been performed on Retinoid Acid Receptor / Retinoid X Receptor (RAR/RXR dNTD). Taking advantage from our experience, bis[sulfosuccinimidyl] suberate (BS3) has first been used for performing the cross-linking reaction. The reaction conditions were optimized to minimize perturbation on structure and the cross-linking rate was followed by MALDI equipped with a high mass detector (HM1, CovalX). A bottom-up approach was then used to look for the cross-linked peptides and establish a linkage map (through identification of the spatially close lysines). For this, the cross-linked complex has been digested with trypsin (and/or chymotrypsin) and the resulting peptide mixture then directly analyzed by high resolution LC-MS/MS (Orbitrap-MS, Thermofisher).

Results: Although salt conditions required for the protein complex stability interferred with our protocol, few inter-protein cross-links could be assigned. We will now perform integrative modeling from a synergetic point of view. While cross-linking data can be employed to guide computational protein structure refinement, modeling will help for the optimization of the most appropriate cross-linkers.

Mots-Clés : cross, linking, retinoic acid receptor, structural analyse, protein, protein interaction

$\underline{\text { Programme }}$

*Intervenant 


\title{
Properties of different forms of small size cationized non-covalent systems formed by phospho-hexose and basic compounds in gas phase: interest for D labeling [P164.1]
}

\author{
Ekaterina Darii ${ }^{* \dagger}{ }^{1}$, Yves Gimbert ${ }^{2}$, Sandra Alves ${ }^{3}$, Alain Perret ${ }^{1}$, \\ Jean-Claude Tabet ${ }^{3,4}$ \\ ${ }^{1}$ CEA, DRF, Institut de biologie François Jacob - Université d'Evry - CNRS-UMR8030 - Université Paris Saclay, \\ Genoscope, France \\ ${ }^{2}$ Université Grenoble Alpes (DCM), CNRS-UJF 5250, Grenoble, France \\ ${ }^{3}$ Institut Parisien de Chimie Moléculaire, Université Pierre et Marie Curie, 75005 Paris, France \\ ${ }^{4}$ CEA, Laboratoire d'Etude du Métabolisme des Médicaments, DRF/JOLIOT/SPI, 91191 Gif-sur-Yvette, France
}

Understanding properties of small (NCC) is important for MS analysis of complex mixtures. Our work is focused on the gas phase (GP) study of deprotonated/cationized non-covalent complexes (NCC) between hexose-phosphates (HexP) and arginine (R) or arginine dipeptide (RR) desorbed in negative ESI mode. Stabilization of small size NCC in GP mainly involves interactions such as:

(i) hydrogen bond (HB) formally constituted by two monocharged anions solvating proton,

(ii) salt bridge (SB) between two functional groups with opposite charges possible if one partner is as zwitterion and

(iii) solvated salt (SS) where the metallic cation of salt is solvated by a second partner.

HB systems are characterized by the absence of free charge and dissociate under CID conditions yielding free charged partners in competition which is not the case of SB and SS systems. SS/SB forms carry free charge and dissociate under CID by covalent bond cleavages (CBC). The D labeled cationized NCC with alkali and earth-alkali were used for exploration of inter/intra H/D exchange (HDX) and dissociation mechanisms of $\mathrm{HB} / \mathrm{SB} / \mathrm{SS}$ systems under resonant excitation conditions. For this purpose very high resolution was chosen and LTQ-Orbitrap FT/MS was used.

Negative ESI mass spectra of HexP and R (or RR) mixtures in D2O display only expected HDX for deprotonated/deuterated free partners (i.e., d5, d6 and d11, respectively) and NCC systems (d12, and d17) corresponding to the mobile proton number in anions. Alkali/one $\mathrm{D}$ and earth alkali/2D exchanges take place. Under CID conditions, NCC parent ions with complete deuterium labeling yield fragment ions with expected and unexpected residual labeling. This is probably due to covalent bond cleavages (CBC) promoted by free charge carried by NCC within SS or SB forms. The incorporation of additional $\mathrm{D}$ in sugar rings takes place due to intermolecular HDX between HexP and RR RR before complex dissociation.

Mots-Clés : non-covalent interactions in gas phase, H/D exchange, fragmentation under CID

\footnotetext{
*Intervenant

${ }^{\dagger}$ Auteur correspondant: edariy@genoscope.cns.fr
} 


\section{Polymères, molécules synthétiques [P165-P166]}




\title{
Synchrotron UV photo-activation of trapped ions produced from synthetic polymers by atmospheric pressure photoionization or electrospray mass spectrometry [P165]
}

\author{
Véronique Legros ${ }^{1}$, Alexandre Giuliani ${ }^{2}$, William Buchmann ${ }^{* \dagger}{ }^{1}$ \\ ${ }^{1}$ Laboratoire Analyse et Modélisation pour la Biologie et l'Environnement (LAMBE - UMR 8587) - CEA : \\ DEN/DPC, Université d'Évry-Val-d'Essonne, Université Paris-Saclay, CNRS : UMR8587 - Bât. Mapertuis 1 \\ étage bd François Mitterrand 91025 Evry cedex, France \\ ${ }^{2}$ Synchrotron SOLEIL - CNRS : UMRUR1 - L'Orme des Merisiers Saint-Aubin \\ BP 4891192 Gif-sur-Yvette cedex, France
}

\begin{abstract}
Fragmentations experiments by tandem mass spectrometry (MS/MS) can be particularly useful when information about polymer end-groups, copolymer sequences are looked for. The research works dedicated to MS/MS analysis of polymers have until now, mainly involved collision induced dissociation (CID), but alternative activation methods have recently appeared by electron transfer or irradiation of trapped ions (UV or IR) in order to widen the range of fragmentations. The goal of this work was to evaluate the effects of a wavelength-tunable UV photo-activation of polymer ions stored in a linear ion trap during a variable time period. These polymers ions were produced from various model polymers by APPI or ESI. Our objective was to identify the most useful UV wavelengths and rationalize the effect of the photo-activation of ions by elucidating the dissociation pathways, as a function of the polymer structure, charge state, chain length and excitation wavelength. In this work, we began the exploration of the possible photo-fragmentations of synthetic polymers (PEG, PMMA, PS and PDMS...) using negative APPI. No fragment ion was detected from halogenated adducts whatever the polymer, the photon energy and irradiation time. The UV irradiation resulted simply in their neutralization by electron photo-detachment. In the positive APPI ion mode, photo-ionization of ions led to higher charge states accompanied or not by fragmentations. However, APPI could also lead to in-source fragmentations and suffered of a lack of sensitivity. In ESI, negative ion mode can provide complex isotopic distributions with multiple halogenated adducts so that the positive mode was preferred. Promising results have been obtained using positive ESI from a few polymers. It was established that the consequence of the UV irradiation of $(\mathrm{M}+\mathrm{n}$ cation $) \mathrm{n}+$ species above $10-12 \mathrm{eV}$ was mainly the production of higher charge states, accompanied or not by fragmentations.
\end{abstract}

Mots-Clés : Polymers, UV, photodissociation, fragmentations, tandem MS, ESI, APPI

$\underline{\text { Programme }}$

\footnotetext{
${ }^{*}$ Intervenant

${ }^{\dagger}$ Auteur correspondant: william.buchmann@univ-evry.fr
} 


\title{
Non-Targeted Screening of Extractables and Leachables in E-cigarettes using a Single Platform UPLC-APGC-QTOF-MS [P166]
}

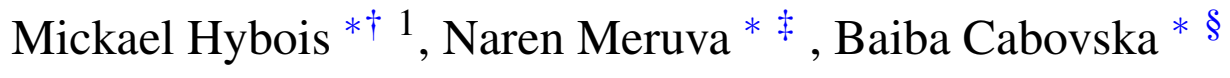 \\ ${ }^{1}$ Waters Corporation - Waters Corporation - Saint Quentin en Yvelines, France
}

\begin{abstract}
Characterization of extractables and leachables is essential for ensuring the safety, quality and efficacy of inhalation tobacco products such as e-cigarettes. The initial step for characterizing extractables from e-cigarettes involves targeted screening, i.e., testing the extracts for known compounds. This is a well-established process that can be performed using analytical techniques such as GC-MS and LCMS/MS. However the final extracts of e-liquids, refill cartridges and e-cigarette aerosol may have impurities present from the starting materials and other packaging and device components that need to be further evaluated. In this study, the various components of an e-cigarette (end caps, mouth piece, gauze, heating element and flavor formulation) were extracted separately and subjected to non-targeted high resolution screening using both UPLC and APGC analysis on a single QTOF-MS platform. Data was acquired using alternating high and low collision energy states (MSE) across the full analytical mass range, to generate the precursor and fragment ions (All Ions Fragmentation). The data from sample extracts was compared to reagent blank extracts to determine the differences and potential extractables. The potential candidate markers were screened against a known library of extractables and leachables compounds which was automatically interrogated using mass accuracy, isotopic fit and fragment matching. The structural elucidation of unknown contaminants present was performed by using elemental composition, database searching and fragment identification via in-silico fragmentation of a downloaded structure compared to accurate mass fragment ion data. This application demonstrates how non-targeted screening using LC and GC workflows can be adopted on a single MS and software platform for extractable and leachable testing in food, cosmetics and pharmaceutical packaging applications.
\end{abstract}

Mots-Clés : Extractables, Leachables, tobacco, cigarette, GCMS, LCMS

Programme

\footnotetext{
${ }^{*}$ Intervenant

†Auteur correspondant: mickael_hybois@waters.com

¥Auteur correspondant: $\overline{\text { narendra_meruva@ waters.com }}$

§Auteur correspondant: baiba_cabovska@waters.com
} 


\section{Présentation de plateforme [P167-P172]}




\title{
Overview of metabolomics directed sample preparation strategies for a range of biological matrices [P167]
}

\author{
Anne-Lise Royer * 1, Yann Guitton ${ }^{1}$, Gaud Dervilly-Pinel ${ }^{1}$, Jean-Philippe \\ Antignac ${ }^{1}$, Antoine Escourrou ${ }^{1}$, Nora Cesbron ${ }^{1}$, Karine Pouponneau ${ }^{1}$, \\ Fabrice Monteau ${ }^{1}$, Bruno Le Bizec ${ }^{1}$
}

${ }^{1}$ LUNAM Université, Oniris, Laboratoire d'Etude des Résidus et Contaminants dans les Aliments (LABERCA),
UMR 1329 (ONIRIS-Laberca) - Ministère de l'alimentation de l'agriculture et de la pêche - Nantes, France

Among areas revolutionized by metabolomics in the last decade, those having traits to public health in connection with the chemical safety of food are not outdone $(1,2)$. When dealing with the investigation of biomarkers of exposure/effect in relation with food producing animals exposure to chemical, although urine, feces and serum are fully relevant matrices at the farm level, tissue samples (muscle, liver, kidney...) offer the advantage over biofluids to investigate the food item itself. This is of prime importance for instance in the case of importation at the border.

Although the objective of the metabolomics strategies applied to these various matrices is the same, the nature of the matrix needs to be specifically and carefully considered in order to provide relevant extracts to be characterized. With such matrices dedicated process, the whole metabolome coverage is also greatly improved thanks to the wider and better coverage of the metabolic diversity gained trough matrices dedicated extraction process.

In this work, criteria for sample preparation will be developed according to the type of analysis expected (untargeted or targeted) in LC-HRMS. Some generalities on steps of sample preparation will be developed. Matrices analyzed by the platform will be presented explaining the specificities of preparations according to the matrix (feces, tissue ...). These points will be discussed in order to guarantee the quality of the samples and to limit the confounding factors.

(1) C. Le Boucher et al., Food Chemistry (2013) 1032-1040

(2) T. Peng et al., Metabolomics (2017) 13:77

Mots-Clés : metabolomics, sample preparation, matrices

Programme

${ }^{*}$ Intervenant 


\title{
La PFP, Plate-Forme Polyphénols de l'INRA à Montpellier [P168]
}

\author{
Nicolas Sommerer ${ }^{* \dagger}{ }^{1}$, Emmanuelle Meudec ${ }^{1}$, Arnaud Verbaere ${ }^{1}$, Luc \\ Verdier $^{1}$, Christine Le Guernevé ${ }^{1}$, \\ Jean-Claude Boulet ${ }^{1}$, Véronique Cheynier ${ }^{1}$
}

${ }^{1}$ INRA - UMR1083 SPO - Plateforme d'analyse des polyphénols (INRA - PFP) - INRA - UMR1083 SPO 2 place Viala 34060 Montpellier, France

Les polyphénols sont des métabolites secondaires ubiquitaires du règne végétal. Ils sont par exemple responsables de la couleur des fleurs (et jouent un rôle de signal pour les insectes pollinisateurs) et sont aussi des molécules de réponse à une bio-agression ou un stress abiotique. Les composés phénoliques se retrouvent dans les produits transformés (boissons comme le vin, les jus de fruits, le thé, le café, et les aliments, comme le chocolat par exemple). Ils ont dans les aliments des propriétés organoleptiques ou en lien avec la qualité (couleur, astringence, amertume...) et font l'objet d'allégations bio-santé (antioxydants).

Ces molécules (plusieurs milliers décrites à ce jour) se regroupent dans des familles (anthocyanes, flavan3-ols et tanins, acides benzoïques et hydroxycinnamiques et leurs dérivés, flavonols, flavones, flavanones, stilbènes...) réactives qui se polymérisent et se transforment (oxydation, condensation...). L'analyse des polyphénols et notamment des structures polymériques complexes, nécessite un haut niveau d'expertise et d'équipement.

La plateforme Polyphénols, créée en 2001, a pour mission de mettre à la disposition de la communauté scientifique et des partenaires industriels son expertise et ses ressources expérimentales en LC-MS, RMN et chimiométrie, pour des projets relatifs aux composés phénoliques et plus particulièrement à :

- la caractérisation rapide, à moyenne ou large échelle, de la composition phénolique fine d'un grand nombre d'échantillons complexes de végétaux (métabolomique, profilage) ou de produits dérivés des végétaux (authentification, suivi de procédés),

- l'analyse structurale des composés phénoliques (constituants des végétaux, produits formés au cours des opérations de transformation, métabolites végétaux).

Adossée à l'UMR Sciences pour l'œnologie (INRA, Montpellier SupAgro, Université de Montpellier), intégrée au LabEx Agro et soutenue par la région Occitanie Pyrénées-Méditerranée, la PFP a été labellisée par RIO puis IBiSA et la CNOC.

La PFP sera labellisée ISO9001 v.2015 au début de l'année prochaine.

https://www6.montpellier.inra.fr/spo/Structures-collectives/Plate-forme-Polyphenols

Mots-Clés : polyphénols, spectrométrie de masse, RMN, chimiométrie

$\underline{\text { Programme }}$

\footnotetext{
*Intervenant

${ }^{\dagger}$ Auteur correspondant: nicolas.sommerer@inra.fr
} 


\title{
Clic-Imaging, a mass spectrometry imaging platform for clinical studies [P169]
}

\author{
Maxence Wisztorski ${ }^{*} \uparrow 1$, Jean-Pascal Gimeno ${ }^{1,2}$, Soulaimane \\ Aboulouard ${ }^{1,2}$, $\overline{\text { Michel Salzet }}{ }^{1}$, Isabelle Fournier $* \sharp 1$ \\ ${ }^{1}$ Univ. Lille, Laboratoire de Protéomique Réponse Inammatoire Spectrométrie de Masse (PRISM) - INSERM : \\ U1192 - Université Lille, Sciences et Technologies Bat SN3, 1er étage 59655 Villeneuve d'Ascq Cedex, France \\ ${ }^{2}$ Plateforme Clic-Imaging (Clic-Imaging) - Université de Lille, Sciences et Technologies - Université Lille, \\ Sciences et Technologies Bat SN3, 1er étage 59655 Villeneuve d'Ascq Cedex, France
}

Clic-Imaging Core Facility at the University of Lille (www.Clic-Imaging.com) offers a wide range of Mass Spectrometry services for Private and Public laboratories. The main focus of our platform is to provide services around tissue analysis especially using Mass Spectrometry Imaging (MSI). The Clic-Imaging platform has built a strong knowledge and background in MALDI-MSI as well as tissue proteomics and so-called microproteomics (or Spatially Resolved Proteomics). The Clic-Imaging Platform is integrated to the INSERM U1192 PRISM Laboratory (www.laboratoire-prism.fr). Clic-Imaging will assist throughout all steps of the project from sample preparation to the data analysis. Clic-Imaging can propose conventional methodologies and strategies of tissue analysis by MS accordingly the state-of-the-art internationally recognized standards.

The service offer of Clic-Imaging is given below:

- Clinical or biological (animals, plants and human) sample preparation for MSI analysis (tissue section, washing steps, and matrix deposition, on tissue enzymatic digestion...)

- Mass spectrometry Imaging of metabolites, lipids, peptides and proteins from fresh frozen or formalin fixed and paraffin embedded (FFPE) tissue (clinical archived tissues)

- Surface sampling using LESA for small molecules analysis

- On tissue Spatially-Resolved MicroProteomics (Shotgun or Top-Down approach)

- Exogenous compounds localization to study potential effect on endogenous peptides and toxicity response.

- Specific data processing for MS Imaging (image reconstruction 2D and 3D images, statistical analysis by PCA/pLSA, spatial segmentation, classification model construction)

- Data mining by integrative Multi-Omics analysis

- Mass Spectrometry based analysis: MALDI-TOF/TOF, MALDI-LTQ-Orbitrap, nanoLC coupled with HR-MS \& MS/MS,

With respect to tissue samples, the platform has acquired along the time a unique know-how in France on the proteomics of Formalin-Fixed Paraffin Embedded Tissues (FFPE) allowing many retrospective study to be performed for clinics or biology. More conventional services, although using among the latest technologies available (Q-Orbitrap), are dedicated to large scale proteomics with relative label free quantification.

Mots-Clés : mass spectrometry imaging, proteomics, clinics

Programme

\footnotetext{
*Intervenant

†Auteur correspondant: maxence.wisztorski@univ-lille1.fr

$¥$ Auteur correspondant: isabelle.fournier@univ-lille1.fr
} 


\title{
Investigations of cancer metabolism using mass spectrometry based fluxomics [P170]
}

\author{
Hanna Kulyk Barbier * 1,2 ,Maud Heuillet ${ }^{1,2}$, Lara Galès ${ }^{1,2}$, Maria \\ Fatarova $^{1,2}$, Lindsay Peyriga ${ }^{-1,2}$, Jean-Charles Portais ${ }^{1,2}$, Floriant Bellvert ${ }^{1,2}$ \\ ${ }^{1}$ MetaToul-MetaboHUB, National Infrastructure of Metabolomics \& Fluxomics (ANR-11-INBS-0010) \\ 2 Laboratoire d'Ingénierie des Systèmes Biologiques et des Procédés (LISBP) - INSA, CNRS : UMR5504, \\ INRA : UMR0792 - 135 Avenue de rangueil, 31077 Toulouse cedex 04, France
}

Fluxomics has become a major approach in the fields of systems biology, biotechnology and cancer. Metabolic flows are used to quantify metabolic activity accurately. In many fields and in particular for biotechnologies (metabolic engineering, enzymatic engineering), the need for fluxomics is increasing in order to measure the quantitative impact of the changes introduced.

In this context, the MetaToul-MetaboHUB platform offers a broad range of services, including the design of isotope-labelling experiments, protocols for sampling of labelled material, the isotopic profiling of metabolites using NMR or mass spectrometry, the processing and interpretation of isotopic data, and the calculation of metabolic fluxes. The platform is also providing support and expertise to interpret the data in a biological context.

At MetaToul-MetaboHUB, mass spectrometry is used to measure both the absolute pool sizes of metabolites and their isotopic profiles in isotope-labelling studies. Due to its high sensitivity, this technique allows the isotopic profiling of metabolites belonging to central carbon metabolism (glycolysis, pentose phosphate pathway, TCA cycle and related pathways, etc.), amino-acid metabolism, and energy metabolism (nucleotides, etc.). A recently developed method is also available at MetaToul to quantify and analyze the labelling patterns of short-chain acyl-CoAs (e.g. acetyl-CoA, malonyl-CoA, succinylCoA, etc.) that play a key role in lipid metabolism and in the TCA cycle. Taken together, the LC-MS methods developed at MetaToul-MetaboHUB allow highly detailed investigation of the operation of the entire central metabolism and its connections to amino acid metabolism and lipid metabolism. Hence MS-based isotopic profiling allows a system-level investigation of cellular metabolism and can now be routinely applied to tackle the complexity of the biochemical processes.

Mots-Clés : fluxomics, metabolic flows

$\underline{\text { Programme }}$

*Intervenant 


\title{
Pôle d'Analyse et d'Imagerie des Biomolécules (PAIB) de la Plate-forme de Chirurgie et d'Imagerie pour la Recherche et l'Enseignement (CIRE) [P171]
}

\author{
Valérie Labas ${ }_{-}^{* 1,2}$ \\ ${ }^{1}$ Physiologie de la Reproduction et des Comportements [Nouzilly] (PRC) - INRA : URM085, Institut Français \\ du Cheval et de lÉquitation [Saumur], Université François Rabelais - Tours, CNRS : UMR7247 - Centre de \\ Recherches de Tours 37380 Nouzilly, France \\ 2 Plate-forme CIRE (Chirurgie-Imagerie-Recherche-Enseignement)-Pôle d'Analyse et d'Imagerie des \\ Biomolecules (PAIB) (CIRE-PAIB) - INRA : UMR85, CNRS : UMR7247, Université François Rabelais - Tours, \\ IFCE - INRA Centre Val de Loire 37380 Nouzilly, France
}

La plate-forme CIRE (Chirurgie-Imagerie-Recherche-Enseignement) offre, à l'ensemble de la communauté scientifique, un service unique pour la Recherche, la Formation et l'Innovation, dans les domaines de la santé animale et humaine et les systèmes d'élevage des animaux de rentes. CIRE regroupe notamment des moyens de chirurgie, un Pôle d'Imagerie in vivo appliqués aux grands modèles animaux et un Pôle d'Analyse et d'Imagerie ex vivo des Biomolécules (PAIB). Grâce à ses approches multidisciplinaires en imagerie biologique et sciences 'omiques', CIRE permet d'étudier des systèmes intégrés à différents niveaux allant de l'animal entier, du tissu, de la cellule jusqu'à la molécule. Dans ce cadre, CIRE s'est doté d'un parc instrumental constitué principalement d'un IRM 3 Teslas, d'un tomodensitomètre CT-Scan, d'un échographe doppler, d'un endo-miscroscope confocal Cell Vizio, d'un amplificateur de brillance et de plusieurs spectromètres de masses. En effet, le Pôle PAIB dispose d'un spectromètre de masse à haute résolution (LTQ Velos Orbitrap, Thermofisher) couplé à un système de nanochromatographie liquide et d'un spectromètre de masse MALDI-TOF-TOF (UltrafleXtreme, Bruker) et de différents outils bioinformatiques dédiés à la protéomique et à la lipidomique. PAIB propose des méthodes originales et novatrices basées sur le phénotypage cellulaire et tissulaire par MALDI-TOF telles que l'analyse directe de cellules eucaryotes pour la recherche de marqueurs (peptides et protéines, lipides) et la classification de populations cellulaires par modélisation, l'analyse directe de cellules procaryotes pour l'identification de micro-organismes et l'imagerie moléculaire par l'analyse directe de tissus. PAIB propose aussi l'identification et la caractérisation structurale fine de ces biomolécules endogènes par une approche Top-down (HRMS). PAIB propose également des approches protéomiques de type Bottom-up par GeLC-MS/MS ou shogun pour l'identification et la quantification des protéines avec la caractérisation de leurs modifications post-traductionnelles. Pour toutes demandes, veuillez contacter CIRE à l'adresse suivante : cire@inra.fr (Direction Yves Tillet, Catherine Taragnat).

Mots-Clés : CIRE, PAIB, imagerie in et ex vivo, phénotypage cellulaire et tissulaire, protéomique, lipidomique

\section{Programme}

\footnotetext{
*Intervenant
} 


\title{
MetaboHUB: Innovation, development and training dedicated to metabolomics and fluxomics [P172]
}

\author{
Camille Benard ${ }_{-}{ }^{1}$, Cécilia Berges ${ }^{2}$, Thierry Berton ${ }^{3}$, Raphael Bir ${ }^{4}$, Noémie Butin ${ }^{1}$, Salimata Diarrassouba ${ }^{3}$, Sylvain \\ Emery $^{4}$, Maria Fatarova ${ }^{2}$, Maud Heuillet ${ }^{2}$, Ulli Hohenester ${ }^{1}$, Hanna Kulyk-Barbier ${ }^{2}$, Sylvain Kenan ${ }^{3}$, Nadia Lamari ${ }^{3}$, \\ Marie Lefebvre ${ }^{3}$, Maria-Helena Meireles ${ }^{2}$, Nils Paulhe ${ }^{4}$, Laura Prouteau ${ }^{4}$, Fabien Riols ${ }^{2}$, Léa Roch ${ }^{3}$, Simon Roques ${ }^{3}$, \\ Pierrick Roger-Mele ${ }^{5}$, Spiro Khoury ${ }^{4}$, Samuel Terrier ${ }^{1}$, Laetitia Theron ${ }^{4}$, Fanny Viard ${ }^{2}$, Vanessa Zhendre ${ }^{3}$, \\ Jean-Emmanuel Sarry ${ }^{6}$, Christophe Caron ${ }^{7}$, Caroline Sautot ${ }^{8}$, Christophe Junot ${ }^{1}$, Dominique Rolin ${ }_{-}^{\dagger}$, And All Other \\ MetaboHUB Members ${ }^{9}$

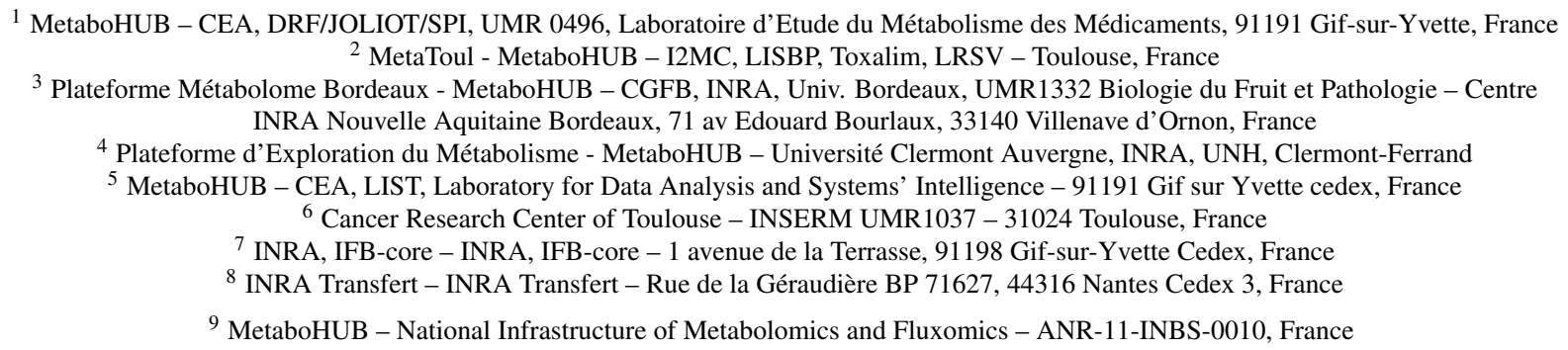

MetaboHUB (http://www.metabohub.fr) is a national infrastructure for metabolomics and fluxomics, which provides tools, services and training sessions to academic research teams and industrial partners in the field of health, nutrition, agriculture, environment and biotechnology. Metabolomics and fluxomics require several complementary analytical approaches and tools such as nuclear magnetic resonance (NMR), mass spectrometry (MS) and bioinformatics. To meet the metabolomics community needs involving large-scale programs, MetaboHUB is developing robotic workflows enabling high-throughput cell cultures and samples preparation, analytical procedures for metabolic profiling, and methods for absolute quantitation. Many training sessions and workshops are periodically organized on these rapidly evolving technologies: http://www.metabohub.fr/formationsa-venir.html. In addition, a spectral database (Peak Forest) is built for efficient metabolome annotation of biological matrices. Informatics and Bioinformatics resources are of prime importance for analyzing and handling the large amount of data generated in such studies. Four e-MetaboHUB tools were thus developed and are sustained: MAMA (MetaboHUB Analysis Manager; https://mama-webapp.metabohub.fr/): a web application, that centralizes and manages the user requests to fulfil the partner scientific requirements, Workflow4Metabolomics: a free and open-source metabolomic data-processing software tool for automatic peak detection, statistical analysis and annotation, developed in collaboration with the French Institute of Bioinformatics (IFB), (http://workflow4metabolomics.org/; Giacomoni et al., 2015), NMRProcFlow: an open-source software that provides a complete set of tools for processing and visualizing 1D-NMR data within an interactive interface (http://www.nmrprocflow.org/; Jacob et al. 2017), and MetExplore: a web server dedicated to the analysis of genome scale metabolic networks (https://metexplore.toulouse.inra.fr; Cottret et al., 2010). We illustrate here two proofs of concept projects designed to apply the MetaboHUB high value service in health and disease fields. An investigation of the links between nutrition and chronic metabolic diseases within the Canadian NuAge cohort, and metabolomic and fluxomic studies on acute myeloid leukemia (Boutzen et al., 2016; Farge et al. 2017).

Mots-Clés : metabolomics, fluxomics, bioinformatics, high-throughput, NMR, MS

\footnotetext{
*Intervenant

${ }^{\dagger}$ Auteur correspondant: dominique.rolin@inra.fr
} 


\section{Jeudi 5 octobre [P173-P257]}




\section{Santé et médecine: mécanismes et biomarqueurs [P173-209]}




\title{
Gut-derived metabolites study after a bariatric surgery on obese patients [P173]
}

\author{
Farid Ichou * 1 , Rohia Alili ${ }^{1,2}$, Christine Poitou ${ }^{1,2}$, Lyamine Hedjazy ${ }^{1}$, \\ Cécile $\bar{C}$ iangura ${ }^{1}$, Jean-Michel Oppert ${ }^{1}$, Karine Clement ${ }^{1,2}$
}

\footnotetext{
${ }^{1}$ Institute of Cardiometabolism and Nutrition (ICAN), Assistance Publique Hôpitaux de Paris, Nutrition department,,Pitié-Salpêtrière Hospital , 75013 Paris (ICAN) - APHP, Pitié-Salpêtrière university hospital, Sorbonne Université UPMC Paris VI - 50-52 boulevard V. Auriol, 75013 Paris, France

${ }^{2}$ Sorbonne Universités, UPMC Univ Paris 06, INSERM, UMR S 1166, NutriOMique, F-75013, Paris, France INSERM - 47-83 Boulevard de l'Hôpital, 75013 Paris, France
}

Among the 'unusual' risk factor, microbiota-derived metabolites, such as trimethylamine oxide (TMAO), a by-product from the choline metabolism, are correlated to coronary or cardiovascular risks. It has been demonstrated recently that an elevated level of TMAO increases the risk cardiovascular events. To our knowledge, level variations of TMAO and derived methylamine have not yet been studied kinetically in obese patients following surgery procedure. This study was performed in the framework of the PROMISE* cohort. A metabolome analysis was made in order to explore the metabolic changes associated with gastric surgery known to improve the cardiovascular risk.

65 women patients were recruited in PROMISE* study and split into 3 groups $(1=$ usual nutritional and physical activity advices after surgery, $2=$ protein supplementation, $3=$ protein supplementation and muscle training until 6 months after surgery). Serum before and 6 months after bariatric surgery, were analyzed by ultra-performance liquid chromatography coupled to a high resolution mass spectrometer (UPLC-HRMS) allowing the screening of more than 100 metabolites.

Our study demonstrates a significant impact of gastric surgery on gut-derived metabolites. In particular, a major decrease of branched chain amino acids and aromatic amino acids (q-value $<0.05$ ) and surprisingly an increase of TMAO level (q-value $<0.0001$ ) have been observed. Some correlations between several microbiota-derived metabolites and clinical parameters were also identified. Nevertheless, any significant difference in term of metabolite concentrations between the 3 groups has been observed. In conclusion, the effect of surgery-induced weight loss seems to prevail over that of protein supplementation and physical activity.

* PHRC PROMISE: PROtein supplementation and Muscle training Intervention In Surgery of obEse Patients

Mots-Clés : Metabolomics Microbiota, LC, HRMS, TMAO, gastric surgery

Programme

*Intervenant 


\title{
Temporally \& Spatially-Resolved Microproteomics and MALDI MSI Lipidomic Analysis for Traumatic Brain Injury Biomarker Identification [P174]
}

\author{
Khalil Mallah ${ }_{-}^{* 1,2}$, Jusal Quanico ${ }^{1}$, Firas Kobeissy ${ }^{3}$, Michel Salzet ${ }^{1}$, Kazem \\ Zibara_ $_{-}^{\dagger}$, Isabelle Fournier +1
}

${ }^{1}$ Univ. Lille, INSERM, U-1192 - Laboratoire Protéomique, Réponse Inflammatoire et Spectrométrie de Masse-PRISM, F-59000 Lille, France (PRISM) - INSERM U1192 - Bat SN3, 1er étage 59650 Villeneuve d'Ascq, France

${ }^{2}$ Laboratory of Stem Cells (ER045-PRASE) - Beirut, Liban

${ }^{3}$ Department of Biochemistry and Molecular Genetics, Faculty of Medicine American University of Beirut, Liban

\begin{abstract}
The major cause of Traumatic Brain Injury (TBI) is the direct mechanical damage to the brain tissue leading to an axonal disruption and wide spread neural dysfunction. TBI is characterized by a primary acute phase lasting from few hours up to few days, followed by a secondary phase due to the activation of the immune. Several studies have been conducted to assess potential TBI biomarkers such as GFAP and $\alpha$ II-spectrin. However, these studies have utilized complete brain tissue as well as biofluids (serum and CSF). We investigated TBI impact at the injury site and surrounding tissues, in order to connect TBI microenvironment dynamics with the underlying biological processes associated with the location and proximity of TBI lesion. Using an experimental TBI rat model of mild/moderate Controlled Cortical Impact (CCI) injury, we combined large scale proteomics identification and relative quantification using Spatially-Resolved Microproteomics along with MALDI MS Imaging of Lipids. Direct on-tissue micro-digestion followed by micoextraction from $0.25-1 \mathrm{~mm} 2$ surface area are subjected to an LC-MS $\&$ MS/MS analysis using HR MS. Data will involve protein regulation dynamics specific to the lesion area, or to the close environment, coupled with the related biological networks. Meanwhile, the lipid imaging will help in identification of injury specific lipid markers and distribution within surrounding tissue. Our analysis is focused on studying and identifying the different proteins and pathways involved in a spatial and temporal manner. Spatially by identifying unique markers prior and post TBI injury in a coronal view of the brain as well as the injury site itself, and temporally by better understanding the acute phase through focusing on the following time points post injury: 1, 3, 7, and 10 days. This will help in the identification of TBI markers as well as determining the time points which could be targeted for therapy.
\end{abstract}

Mots-Clés : TBI Biomarkers, Microproteomics, MALDI MSI lipidomic

\section{Programme}

\footnotetext{
* Intervenant

†Auteur correspondant: kz06@aub.edu.lb

$¥$ Auteur correspondant: isabelle.fournier@univ-lille1.fr
} 


\title{
Validation of LC-MS analysis of sub-microliter samples: metabolomics analysis of human perilymph fluid [P175]
}

\author{
Sylvie Mavel ${ }^{* \dagger}{ }^{1}$, Antoine Lefèvre ${ }^{\ddagger 1}$, David Bakhos ${ }^{2}$, Diane \\ Dufour-Rainfray ${ }^{1}$, Hélène Blasco ${ }^{1}$, Patrick Emond $* £ 1$ \\ ${ }^{1}$ Université François-Rabelais, INSERM U930 “Imagerie et Cerveau”, CHRU de Tours - INSERM : U930 - 10 \\ Bv Tonnellé, 37044 Tours, France \\ ${ }^{2}$ Service ORL et Chirurgie Cervico-Faciale, CHRU de Tours - CHRU Tours - Blvd Tonnellé \\ 37044 Tours, France
}

\begin{abstract}
Although there is some data from animal studies, the metabolome of inner ear fluid in humans remains unknown. Characterization of the metabolome of the perilymph would allow for better understanding of its role in auditory function and for identification of biomarkers that might allow prediction of response to therapeutics. There is a major technical challenge due to the small sample of perilymph fluid available for analysis (sub-microliter). The objectives of this study were to develop and validate a methodology for analysis of perilymph metabolome using liquid chromatography-high resolution mass spectrometry (LC-HRMS). Due to the low availability of perilymph fluid; a methodological study was first performed using low volumes $(0.8 \mu \mathrm{L})$ of cerebrospinal fluid (CSF) and optimized the LC-HRMS parameters using targeted and non-targeted metabolomics approaches. We obtained excellent parameters of reproducibility for about 100 metabolites. This methodology was then used to analyze perilymph fluid using two complementary chromatographic supports: reverse phase (RP-C18) and hydrophilic interaction liquid chromatography (HILIC). Both methods were highly robust and showed their complementarity, thus reinforcing the interest to combine these chromatographic supports. A fingerprinting was obtained from 98 robust metabolites (analytical variability < 30\%), where amino acids (e.g., asparagine, valine, glutamine, alanine, etc.), carboxylic acids and derivatives (e.g., lactate, carnitine, trigonelline, creatinine, etc.) were observed as first-order signals. This work lays the foundations of a robust analytical workflow for the exploration of the perilymph metabolome dedicated to the research of biomarkers for the diagnosis/prognosis of auditory pathologies.
\end{abstract}

Mots-Clés : LCR, fluide cochléaire, périlymphe, optimisation de méthodologie, petit volume d'échantillon, LC/HRMS.

$\underline{\text { Programme }}$

\footnotetext{
${ }^{*}$ Intervenant

$\dagger$ Auteur correspondant: mavel@univ-tours.fr

$¥$ Auteur correspondant: antoine.lefevre@ univ-tours.fr

$\S$ Auteur correspondant: patrick.emond@univ-tours.fr
} 


\title{
Alternative proteins : The hidden world of spinal cord injury? [P176]
}

\author{
Tristan Cardon * 1, Céline Mériaux ${ }^{1}$, Stéphanie Devaux ${ }^{1}$, Julien Franck, \\ Isabelle Fournier ${ }^{1}$, Michel Salzet ${ }^{1}$
}

\footnotetext{
${ }^{1}$ Laboratoire Protéomique, Réponse Inflammatoire et Spectrométrie de Masse (PRISM) - INSERM : U1192 bâtiment SN3 cite scientifique lille 1 villeneuve d ascq 59600, France
}

The commonly accepted dogma says that mature mRNA codes for a single protein. However the laboratory has revealed the existence of alternative proteins translated from alternative open reading frames. Indeed, it has been shown the possibility to observe proteins from the 5'UTR, 3'UTR and CDS domain according a $+1,+2$ or +3 reading frame. These proteins named alternative proteins in opposition to reference protein. Browsing newly predicted libraries containing the expected alternative proteins has led to the identification of more than 13,000 proteins. Despite the function of these proteins is not yet elucidated, preliminary data seem to show that they would have important role in the regulation of the reference proteins.

This new vision of the proteome was applied on the rat spinal cord injury (SCI) model to understand the role of alternative proteins as potential new biomarkers. Although several studies have been conducted to identify the molecular progression of injury sequel from the lesion site, the exact underlying mechanisms and pathways of injury development have not been elucidated. In previous proteomics studies we have demonstrated a regio-temporal specificity in the proteins regulation. Molecular and cellular processes occurring after SCI are altered differently according to the lesion proximity. Rostral and caudal segments nearby the lesion (R1-C1) express inflammatory factors whereas distant segments (R2-C2, R3-C3) coexpress factors implicated in neurogenesis. We also observed a discrepancy between $\mathrm{R} 1$ and $\mathrm{C} 1$ related to the delay in T-regulators recruitment and the presence in $\mathrm{C} 1$ of neurites outgrowth inhibitors that are absents in R1.

Here, we identified alternative proteins present in the rostral, caudal and lesion segments of injured rat spinal cords at 12 hours, $1,3,7$ and 10 days after the lesion. The regio-temporal pattern of the identified altprots tends to demonstrate their molecular function in limiting axonal repair including the inflammatory pathway.

Mots-Clés : Alternative proteins, Spinal Cord Injury

Programme

\footnotetext{
*Intervenant
} 


\title{
Trouble de stress post-traumatique : dosage de biomarqueurs et compréhension du processus biologique par analyses métabolomiques convergentes [P177]
}

\author{
Denis Desoubzdanne ${ }^{1}$, Nicolas Belverge ${ }^{1}$, Cyril Linard ${ }^{1}$, Emilie \\ Guilleminault ${ }^{1}$, Laura Desnouveaux ${ }^{1}$, Pierre Caillol ${ }^{1}$, Nicolas Taudon ${ }_{-}^{*}$ \\ ${ }^{1}$ Institut de recherche biomédicale des armées (IRBA) - Ministère des Armées - place Général Valérie André \\ 91220 Brétigny sur Orge, France
}

Le trouble de stress post-traumatique (TSPT) est un état pathologique particulier, s'apparentant à un syndrome de dépression survenant à distance d'un évènement traumatisant, le plus souvent lié à une expérience proche de la mort. Si les militaires sont particulièrement exposés dans le cadre de leurs missions (taux prévalence jusqu'à 30\% selon les études), la population civile n'est pas épargnée par le TSPT (taux prévalence jusqu'à 10\% selon les études) dont les origines sont multiples : accident, viol, attentat... Le diagnostic du TSPT est effectué au décours d'un entretien clinique avecun professionnel de santé. La référence en matière de diagnostic est le manuel diagnostique et statistique des troubles mentaux (DSM) qui permet, à travers un questionnaire, de donner un score de gravité.Dans le cas des militaires français, le Service de Santé des Armées a mis en place des questionnaires à compléter avant, au retour et trois mois après le retour de mission, afin de déceler et de suivre les personnes à risques. Néanmoins, la possibilité de ne pas déceler une personne en souffrance demeure (adhésion, sentiment d'infériorité...).Bien que de potentiels biomarqueursaient déjà été décrits dans la littérature, il n'existe à ce jour aucune méthode de diagnostic biologique validée ou reconnue. Face à cette lacune, l'Institut de recherche biomédicale des arméesdéveloppe un ensemble de méthodes d'analyses quantitatives qui seront validées selon les recommandations en vigueur. Ainsi, sont présentés les dosages ciblés de l'acide gammaaminobutyrique plasmatique par GC-MS, du cortisol dans les cheveux par HPLC-Fluo et des métabolites plasmatiques du tryptophane par UHPLC-HRMS. Ces méthodes seront éprouvées lors de l'étude d'une cohorte initiée en 2017. Parallèlement, une étude métabolomiqueglobale sur modèle rongeur visera à : i) identifier de nouveaux potentiels biomarqueurs et ii) mieux appréhender le processus biologique à l'origine de cet état pathologique.

Mots-Clés : Trouble de stress post, traumatique, métabolomique, tryptophane, cortisol, GABA

Programme

*Intervenant 


\title{
Intérêt de la RMN des solides haute résolution à l'angle magique pour modéliser l'infection pulmonaire à $P$. aeruginosa et tester de nouvelles thérapies [P178]
}

\author{
Audrey Le Gouellec ${ }^{* \dagger}{ }^{1,2}$, Elodie Meynet ${ }^{1,2}$, Bertrand Toussaint $\stackrel{*}{*}{ }_{-}, 2$, \\ Florence Fauvelle $* 3$ \\ ${ }^{1}$ Techniques de l'Ingénierie Médicale et de la Complexité - Informatique, Mathématiques et Applications \\ [Grenoble] (TIMC-IMAG) - CNRS : UMR5525, IMAG, Université Grenoble Alpes - Domaine de la Merci - \\ 38706 La Tronche, France \\ ${ }^{2}$ CHU Grenoble - CHU Grenoble - CS10217, France \\ ${ }^{3}$ Grenoble Institut des Neurosciences (GIN) - Université Joseph Fourier - Grenoble 1, CEA : DSV/IRTSV, CHU \\ Grenoble, INSERM : U836 - UJF - Site Santé La Tronche - BP 170 - 38042 Grenoble Cedex 9, France
}

Pseudomonas aeruginosa $(\mathrm{Pa})$ est une bactérie responsable d'infections sévères, nosocomiales, et est considérée comme un agent pathogène critique par l'organisation mondial de la santé, au regard de sa résistance aux antibiotiques. L'utilisation des modèles murins d'infection pulmonaire à Pa est un standard mais reste problématique quant à la souffrance des animaux lors des expériences de challenge infectieux réalisées pour valider la pertinence de facteur de virulence ou encore pour évaluer l'efficacité thérapeutique de nouveaux antibiotiques ou de nouvelles stratégies vaccinales. En effet, malgré 50 ans de recherche dans le domaine, aucun vaccin n'est à ce jour disponible pour les patients notamment mucoviscidosiques qui souffrent d'infections chroniques à Pa.

Dans ce travail, nous avons évaluer l'intérêt de la RMN des solides haute résolution à l'angle magique (HR-MAS RMN) sur biopsies de poumons prélevées 18h après le challenge infectieux par voie intranasale avec $\mathrm{Pa}$. Ceci nous a permis d'une part de construire un modèle à l'aide de statistique multivariés de l'infection pulmonaire à Pa mais également d'identifier un set de biomarqueurs de l'infection pulmonaire à Pa. Nous avons montré que les métabolites suivant Glycerophosphocholine, Succinate, Beta-hydroxybyturate, Valine, Leucine/Isoleucine, et Glycine, Ascorbate sont les plus affectés au cours de l'infection pulmonaire à $\mathrm{Pa}$. Ces biomarqueurs pourraient être validés dans un protocole de recherche clinique.

Par ailleurs, nous avons vu qu'une souche déletée de son principal facteur de virulence, DpopBD (appartenant au système de sécrétion de type 3) est intermédiaire dans le modèle contrairement à $D k y n A$ qui est autant virulent que la souche sauvage (CHA). Par conséquent, nous validons l'utilisation de cette technique HR-MAS RMN dans l'évaluation de facteur de virulence de Pa. Enfin, nous avons évalué une nouvelle stratégie vaccinale (bactéries mortes mais métaboliquement actives) à l'aide de la HR-MAS RMN et validons son utilisation pour montrer l'efficacité de traitement anti Pa.

Mots-Clés : Infection pulmonaire, Pseudomonas aeruginosa, metabolomique, Modélisation

\footnotetext{
*Intervenant

†Auteur correspondant: alegouellec@ @ chu-grenoble.fr

† Auteur correspondant: btoussaint@ chu-grenoble.fr
} 


\title{
Mass spectrometry and hydrophilic proteoform enrichment method-development for the characterization of Chorionic Gonadotropin glycosylation [P179]
}

\author{
Nicolas Eskenazi ${ }^{* 1}$, Chiara Giangrande ${ }^{1}$, Julien Camperi ${ }^{2,3}$, Nathalie \\ Delaūnay $^{2}$, Valerie Pichon ${ }^{2,4}$, Joëlle Vinh ${ }^{1}$ \\ ${ }^{1}$ ESPCI Paris, PSL Research University, Spectrométrie de Masse Biologique et Protéomique (SMBP), CNRS : \\ USR3149, ESPCI Paris, PSL Research University, 10 rue Vauquelin, F75231 Paris cedex 05, France \\ 2 Department of Analytical, Bioanalytical Sciences, and Miniaturization (LSABM), UMR CBI 8231 CNRS - \\ ESPCI Paris, PSL Research University, 10 rue Vauquelin 75005 Paris \\ ${ }^{3}$ Laboratory of PhysioPathology and PharmacoToxicology of the Human Placenta (L3PH), UMR-S 1139 \\ -INSERM - University Paris Descartes, Sorbonne Paris Cité, Paris, France (L3PH) - INSERM : UMR-S 1139 - \\ Faculté des Sciences pharmaceutiques et biologiques 4 avenue de l'Observatoire 75006 Paris, France \\ ${ }^{4}$ UPMC, Sorbonne Universités, Paris, France - 4 place Jussieu 75005 Paris, France
}

Protein glycosylation is at the origin of structural heterogeneity and has a key role in understanding their molecular functions. Thus, the characterization and quantification of glycoproteoforms is essential in many pathologies since genomic approaches are inadequate to address this question. Different cell types produce different glycoproteoforms, and some abnormal glycosylation profiles can be associated with pathologies. Their detection and relative quantification might be the basis of the discovery of new biomarker candidates.

The human Chorionic Gonadotropin (hCG) is a hormone physiologically produced by the placenta during pregnancy (1), and displays different biological activities and functions that are essential for gestation outcome. It is an $\alpha \beta$ hetero-dimeric glycoprotein with a molar mass of $25-60 \mathrm{kDa}$, and can be modified on up to $4 \mathrm{~N}$-linked Asn glycosylation sites ( 2 on each subunit) and 4 O-linked Ser glycosylation sites (on $\beta$ subunit). hCG levels have a clear pattern during embryonic and foetal development and hyperglycosylation might be a signature of an aberrant pregnancy.

In this study, we propose to characterize and quantify the different hCG proteoforms from drugs combining bottom-up and top-down approaches, to gather intact proteoforms exact masses, glycopeptides sequencing, and released glycans profiling. Glycopeptides are usually found in lower abundancies than their analogous unmodified counterpart, and tend to produce a less intense signal in MS due to the hydrophilic nature of their carbohydrate moieties. Therefore, an additional step was introduced using porous graphitized carbon in reverse phase mode or polar sorbents in HILIC mode as enrichment tools to increase glycopeptides concentration and enhance their detection in nanoLC-MS/MS. Glycosylated peptide sequencing and glycan profiling performed on micro-scale sample amounts are further combined to assess the microheterogeneity of hCG glycosylation.

(1) Fournier T. Human chorionic gonadotropin: Different glycoforms and biological activity depending on its source of production. Ann Endocrinol (Paris). 2016 Jun;77(2):75-81.

Mots-Clés : Glycopeptides, Glycosylated proteoform enrichment, MALDI, TOF/TOF, LC, MS/MS

*Intervenant 


\title{
ESA abuse detection in equine plasma and urine by NMR and LC-HRMS metabolomics [P180]
}

\author{
Céline Joré ${ }^{* 1,2}$, Benoît Loup ${ }^{2}$, Gilles Rautureau ${ }^{3}$, Patrice Garcia ${ }^{2}$, \\ Marie-Agnès Popot ${ }^{2}$, Michel Audran ${ }^{4}$, Ludovic Bailly-Chouriberry ${ }^{2}$, \\ Emmanuelle Varlet-Marie ${ }^{1}$, Yves Bonnaire ${ }^{2}$
}

\footnotetext{
${ }^{1}$ Institut des Biomolécules Max Mousseron (IBMM) - CNRS : UMR5247, Université Montpellier I, Université Montpellier II - Sciences et techniques - Faculté de pharmacie 15, Avenue Charles Flahault 34060 Montpellier

${ }^{2}$ Laboratoire des Courses Hippiques (LCH) - Laboratoire des Courses Hippiques - 15 rue de Paradis, 91370 Verrières-le-Buisson, France

${ }^{3}$ Institut des Sciences Analytiques (ISA) - CNRS : UMR5280, PRES Université de Lyon, École Normale Supérieure (ENS) - Lyon, Université Claude Bernard - Lyon I (UCBL)

5 rue de la Doua, 69100 Villeurbanne, France

${ }^{4}$ Association Française de Lutte Contre le Dopage (AFLD) - Association Française de Lutte contre le Dopage 143 avenue Roger Salengro, 92290 Châtenay-Malabry, France
}

Erythropoiesis Stimulating Agents (ESAs), developed for therapeutic use, stimulate red blood cell production and thus increase endurance by improving tissue oxygenation. Consequently, ESAs are one of the major substances of concern in doping control. This study aims at developing indirect methods using metabolomic fingerprinting approaches to improve the detection of ESAs misuse.

Our hypothesis is that the different ESAs could potentially have similar effects on the metabolome and by studying their variations following an administration, it could be possible to suspect the use of most of ESAs with a single method by targeting their effects.

An animal phase on horses ( $\mathrm{n}=3$ ) was carried out with the administration of a single dose of $4.2 \mu \mathrm{g} / \mathrm{kg}$ of Mircera $($. Blood and urine samples were collected before and after treatment. Haematological parameters were monitored and plasma and urine samples were analyzed by untargeted 1D 1H NMR and LC-HRMS metabolomics. After dedicated preprocessing, the data was normalized and then analyzed with multivariate statistical methods to develop models enabling ESAs administration suspicion and to find out candidate biomarkers.

Concerning the haematological parameters, an increase of the hematocrit was observed for all three horses but no significant results were obtained for the circulating reticulocytes. The rHuEPO concentration was measured by ELISA and was detected up to 31 days after Mircera $($ administration.

NMR and LC-HRMS datasets were analyzed by Orthogonal Partial Least Squares (OPLS). Various models were obtained for the different biological matrices (i.e. plasma and urine) allowing a discrimination between samples collected before and after Mircera $\AA$ administration up to 74 days.

The results obtained by metabolomics are promising compared to the direct detection of the rHuEPO. However further studies are needed to validate the models obtained. Furthermore structure identification of some interesting ions could possibly indicate some candidate biomarkers.

Mots-Clés : metabolomics, plasma, urine, horse, NMR, LC, HRMS, erythropoietin, doping control

$\underline{\text { Programme }}$

*Intervenant 


\title{
Role of the microbiota in the defense against multidrug-resistant Enterobacteriaceae using a NMR-based metabolomics approach [P181]
}

\author{
Cécile Canlet * 1,2, Ana Djukovic ${ }^{3}$, Marie Tremblay-Franco ${ }^{1,2}$, Salim \\ Makni ${ }^{1}$, Laurent Debrauwer ${ }^{1,2}$, Bernhard Kuster ${ }^{4}$, Jean Marc Rolain ${ }^{5}$, \\ Karina Xavier ${ }^{6}$, Miguel Angel Sanz ${ }^{7}$, Carles Ubeda ${ }^{3}$ \\ ${ }^{1}$ UMR Toxalim, Université de Toulouse - INRA - ENVT, INP-Purpan, UPS, F-31027 Toulouse, France \\ ${ }^{2}$ Axiom Platform - INRA - MetaToul-MetaboHUB, 31027 Toulouse, France \\ ${ }^{3}$ Centro de Investigacion en Salud Publica-FISABIO - Valencia, Espagne \\ 4 Technische Universität München - Freising, Allemagne \\ ${ }^{5}$ Fondation Méditerranée Infection (FMI), Faculté de Médecine et de Pharmacie - Aix Marseille Université - \\ Marseille, France \\ ${ }^{6}$ Instituto Gulbenkian de Ciência of the Fundação Calouste Gulbenkian (IGC-FCG) - Oeiras, Portugal \\ ${ }^{7}$ La Fe Medical Hospital - Valencia, Espagne
}

\begin{abstract}
Antibiotic resistant pathogens (ARPs) represent a major health concern, mostly in hospitalized patients. The difficulty of treating these pathogens makes them a real threat for the patient's life. Infections with ARPs usually begin by colonization of the intestinal epithelium. In normal conditions, the intestinal microbiota suppresses colonization by ARPs, a phenomenon known as 'colonization resistance' (CR). However, administration of antibiotics disrupts the microbiota and allows ARPs to colonize the intestine. Once established, ARPs can proliferate, which promotes their dissemination into the bloodstream and transmission to other patients. Thus understanding how the microbiota promotes CR and how antibiotics alter this state is mandatory to prevent infections by ARPs. Here, we propose to use a metabolomics approach on fecal samples for better understanding the microbiota complexity, which is essential to elucidate the CR mechanisms.

Patients with acute leukemia (AL) and treated with antibiotics are frequently colonized by ARPs. In this project, fecal samples from AL hospitalized patients colonized with multi-drug-resistant Enterobacteriaceae (MRE), were studied. Two consecutive fecal samples from 54 MRE colonized patients in which a significant difference in the MRE level was observed were analyzed by $600 \mathrm{MHz} 1 \mathrm{H}$ NMR spectroscopy. Because of paired samples, the " multilevel " method was used to divide the variability into two parts, namely intra-variability and inter-variability. Then intra-variability was used for multivariate statistical analyses. PLS-DA analyses showed a clear separation between samples with low and high MRE levels. Metabolites associated with higher MRE levels have been identified using 2D NMR experiments.

The results showed that the production of short-chain fatty acids (propionate, butyrate, caprylate, isovalerate) and amino acids (valine, lysine, alanine, and ornithine) is increased for patients with high MRE level. The biological interpretation of these observations is in progress.
\end{abstract}

Mots-Clés : metabolomics, NMR, MRE, microbiota

${ }^{*}$ Intervenant 


\title{
Une approche multi-échelle incluant la métabolomique décrit l'historique du développement de l'athérosclérose dans un modèle de mini-porc athéro-susceptible [P182]
}

\author{
Jean-Charles Martin * 1, Denis Lairon, Michel Bonneau, Chantal Kang, \\ Claire Bal Dit Sollier, Ludovic Drouet
}

${ }^{1}$ UMR INRA 1260 / INSERM 1060 (NORT) - Universités Aix Marseille, INRA - 27 Bvd Jean Moulin, Faculté de Médecine de la Timone, 13385 Marseille, France

\begin{abstract}
Nous avons suivi pendant 2 ans l'installation de l'athérosclérose chez 32 mini-porcs (16 femelles et 16 mâles castrés) à LDLr -/-, soumis à 4 régimes différents par leur ration lipidique (10\%) : végétale ou à base de 3 types de matière grasse laitière. Trente deux paramètres cliniques sanguins, 22 acides gras des lipides du plasma, ainsi que le métabolome du plasma et de l'urine des animaux mesuré par LC-HRMS ont été analysés à $0,6,12,18$ et 24 mois. A l'autopsie la moyenne du rapport intima sur média de l'ensemble de l'arbre aortique a été calculé comme indice d'athérosclérose. Les cochons dont la valeur d'indice était supérieure ou inférieure à la valeur médiane permettaient d'évaluer quelles variables étaient associées à l'athérosclérose par OPLSDA. 384 variables (dont 336 de masse avec 221 annotées) ont été associées à l'indice d'athérosclérose. Les régimes influaient de façon minoritaire sur l'athérogénicité des cochons (moins de 10\% de la variance). Pour faciliter l'interprétation, ces 384 variables ont été regroupés en 14 catégories ou fonctions, et cela pour chaque temps de prélèvement. Ces " fonctions " ont été scorées par analyse multi-bloc. L'analyse temporelle sur les 24 mois par ANOVA-PCA révélaient 6 grands groupes de cinétique pour ces 'fonctions' liées à l'histoire de l'athérosclérose : certaines étaient induites précocément (0-6 mois), d'autres tardivement (18-24 mois), d'autres de façon intermédiaire (12 mois), d'autres de façon oscillatoire à pas court ou long, d'autres en pointillés. Une analyse en réseau de corrélations partielles de ces fonctions permettait de visualiser la cascade temporelle de l'induction de ces fonctions conduisant à l'athérosclérose. En conclusion, une méthode de modélisation de données collectées à différents niveaux d'échelle et comprenant la métabolomique a permis de suivre la cascade d'évènements temporelles conduisant à l'athérosclérose dans un modèle de mini-porc athéro-susceptible.
\end{abstract}

Mots-Clés : athérosclérose, miniporc, métabolomique LCMS, intégration, modélisation

Programme

*Intervenant 


\title{
Impact of repeated dose of stable iodine in the rat using a metabolomic approach [P183]
}

\author{
Clément Rosique ${ }_{-}^{*}$, Dalila Lebsir , Maamar Souidi , Jean-Charles Martin ${ }^{1}$ \\ ${ }^{1}$ UMR INRA 1260 / INSERM 1060 (NORT) - Universités Aix Marseille, INRA - 27 Bvd Jean Moulin, Faculté \\ de Médecine de la Timone, 13385 Marseille, France
}

Accidents occurring on the core of a reactor at a nuclear power plant result in the release of large quantities of iodine-131. It can be inhaled by populations exposed to the plume and one of the main risks of exposure to radioactive iodine is the development of thyroid cancers, especially when exposure occurred during the foetal period. A counter-measure is to give iodine tablets to population, in order to saturate thyroid and prevent fixation of radioactive iodine.

The main goals of the PRIODAC (Prophylaxie Répétée par l'IODe stable en situation ACcidentelle) consortium is to determine the repeated modalities of administration of stable iodine in condition of chronic radioactive releases and to evaluate the potential undesirable effects on the individuals' physiological functions.

To determine these effects on the offspring, pregnant rats were given a repeated dose of potassium iodine (KI group : $1 \mathrm{mg} / \mathrm{kg}$ ) or water for injection (control group) for 8 days. The young rats were kept under standard conditions and sacrificed 30 days after the weaning and blood samples were harvested.

Using LC-MS and statistical tools, we aimed to determine the effects of KI by confronting the metabolite composition of blood between KI and control groups. Using an in-house databank, we identified 67 metabolites that can be mapped in regulation pathways.

Our findings suggest that many pathways - such as aminoacids, energy or lipid metabolisms - are impacted by the KI treatment. Moreover the L-tyrosine and L-Glutamine seem to be at the crossroad of regulation. Further metabolites identification will provide insight into the biological regulation impacted at middle term after birth by KI administration during the foetal period.

Mots-Clés : iodine, pathway, databank, cancer, thyroid

Programme

*Intervenant 


\title{
Etude du métabolome folliculaire bovin par RMN $1 \mathrm{H}$ [P184]
}

\author{
Marie Tremblay-Franco ${ }^{* \dagger}{ }^{1}$, Nicolas Cabaton ${ }^{1}$, David Allen ${ }^{2}$, Cécile \\ Canlet ${ }^{3}$, Roselyne Gautier ${ }^{3}$, Safouane Hamdi ${ }^{4}$, Daniel Zalko ${ }^{1}$, \\ Catherine Combelles ${ }^{2}$
}

${ }^{1}$ INRA Toxalim - Université de Toulouse (INRA Toxalim - Université de Toulouse) - INRA : UMR1331 - 180 chemin de Tournefeuille, 31027 Toulouse, France

2 Middlebury College, Biology Department - Middlebury, Vermont, États-Unis

${ }^{3}$ INRA Toxalim Axiom MetaToul MetaboHUB - Université de Toulouse (INRA Toxalim Axiom MetaToul MetaboHUB - Université de Toulouse) - INRA : UMR1331 - 180 chemin de Tournefeuille 31027 Toulouse, France

${ }^{4}$ Laboratoire de Biochimie Hormonale - CHU Toulouse - CHU de Toulouse, Toulouse, France

Le développement des follicules antraux comprend des étapes essentielles d'un point de vue dynamique et fonctionnel, comprenant la croissance, la sélection et la différentiation au support final, la maturation de l'ovocyte et l'ovulation. Les cellules de thèque sont essentielles pour la production d'hormones, de facteurs de signalisation et de croissance, et des substances nutritives qui influencent le développement du follicule et de l'ovocyte.

Dans ce projet, notre objectif était de caractériser le métabolome folliculaire, via l'étude des cellules de la thèque, et d'examiner si des marqueurs biologiques peuvent être utilisés pour évaluer le statut physiologique des follicules bovins.

Les ovaires de vaches (non gravides) ont été prélevés et l'étape du cycle oestral a été déterminée à partir de caractéristiques morphologiques des ovaires. Pour chaque individu, les cellules de thèque ont été prélevées sur le plus grand follicule disponible. Du liquide folliculaire a été obtenu à partir de chacun de ces follicules pour l'analyse d'hormones et les cellules ont été utilisées pour l'analyse métabolomique. Les extraits aqueux des cellules de thèque ont été analysés par RMN du proton à $600 \mathrm{MHz}$.

La Classification Ascendante Hiérarchique $(\mathrm{CAH})$ a été utilisée pour classer les individus en fonction de leur concentrations hormonales et de leur taille. La régression PLS-DA a ensuite été appliquée pour séparer les échantillons en fonction des clusters déterminés à l'étape précédente.

Un modèle PLS-DA valide et robuste a été construit à partir des profils métaboliques permettant de séparer les individus en fonction des trois clusters issus de la $\mathrm{CAH}$ : les métabolites discriminants sont en cours d'identification. Ces métabolites seront ensuite intégrés pour reconstruire le réseau métabolique : cette étape nous permettra d'identifier les voies métaboliques modulées pendant le développement des follicules, avec, en perspective, l'application aux situations de perturbations pathologiques.

Mots-Clés : Fluide folliculaire bovin, Cellules de thèque, RMN 1H, Statistiques multivariées

$\underline{\text { Programme }}$

\footnotetext{
*Intervenant

${ }^{\dagger}$ Auteur correspondant: marie.tremblay-franco@inra.fr
} 


\title{
Investigating Iron Oxide Nanoparticles Effects on Rat using Proteomic Tools [P185]
}

\author{
Dalel Askri ${ }^{*} 1,2$, Sylvia G Lehmann ${ }^{1,3}$, Valérie Cunin ${ }^{1}$, Souhir Ouni ${ }^{2}$, Walid \\ Rachidi ${ }^{4}$, Salem Amara ${ }^{2}$, Mohsen Sakly ${ }^{2}$, Michel Sève ${ }^{1}$ \\ ${ }^{1}$ Univ. Grenoble Alpes, LBFA and BEeSy, PROMETHEE Proteomic Platform, CHU Grenoble, IBP - Université \\ Grenoble Alpes - Grenoble, France \\ ${ }^{2}$ Univ. Carthage, College of Sciences of Bizerte, Unit of Integrated Physiology - Bizerte, Tunisie \\ ${ }^{3}$ Univ Grenoble Alpes, Isterre - Grenoble, France \\ ${ }^{4}$ CEA Grenoble, INAC/SCIB/LAN - Université Grenoble Alpes - Grenoble, France
}

Iron Oxide Nanoparticles (IONPs) are used in Biomedicine as theranostic agents for cancer, and also as Magnetic Resonance Imaging contrast agents because of their unique properties [1]. With the increasing production and use of these IONPs, there is an evident increasing risk that can affect the human and the environment. Thus, it is essential to study the effects of these nanoparticles to better understand their mechanisms [2]. In our study, we investigated the liver, lung and brain proteome changes to evaluate the effects of IONPs on mammals taking the Wistar rat as model. Two groups of rats $(n=6)$ were used. The first group, the control, received a physiological solution and the second group, the treated, received IONPs solution during 7 consecutive days by intranasal instillation. Depending on the total rat weight, the IONPs dose was adjusted at $10 \mathrm{mg} / \mathrm{kg}$ body weight. Liver, lung and brain proteins were extracted using the FASP (Filter Aided Sample Preparation) method combined with a Lys-C/Trypsin protease mix digestion before labelling the resulting peptides with iTRAQ 4-plex reagents for liver, lung and brain. Afterwards, the labelled peptides were fractionated in two dimensions, by OFFGEL and Reverse Phase nanoHPLC, before MALDI-TOF/TOF mass spectrometry analysis. MS and MS/MS data were analysed using ProteinPilotTM Software and quantitation was validated by the R package IsobarPTM. This proteomic approach led to the identification and quantitation of 1542 proteins in Brain and Lung, and 1124 proteins in Liver. Several proteins were dysregulated comparing treated samples to controls, in particular, proteins involved in the pathways of lipid and carbohydrate metabolism, immune system stimulation and inflammation process, response to oxidative stress, angiogenesis, and pathways related to neurodegenerative diseases. This study allows us to identify promising biomarkers according to IONPs and to predict the long-term impact of exposure.

Mots-Clés : Iron Oxide Nanoparticles, Rat, Proteomics, Biomarkers

$\underline{\text { Programme }}$

*Intervenant 


\title{
New insights in the pathophysiology of ADHD by studying the cerebral metabolome in a rat model [P186]
}

\author{
Camille Dupuy, Antoine Lefevre, Sylvie Bodard, Pierre Castelnau, Patrick \\ Emond ${ }_{-}^{*}$, Laurent Galineau ${ }^{\dagger}+1$
}

${ }^{1}$ Université François-Rabelais, INSERM U930 “Imagerie et Cerveau”, CHRU de Tours, 10 Bv Tonnellé, 37044 Tours, France - INSERM - 10 Bv Tonnellé, 37044 Tours, France

\begin{abstract}
Attention-Deficit/Hyperactivity Disorder (ADHD) is a neurodevelopmental disorder characterized by inattention, hyperactivity and impulsiveness. It is diagnosed in 7 to $8 \%$ of school-aged children and frequently persists through adulthood. Despite numerous neuroimaging studies, the neurobiological substrates underlying ADHD symptoms remain unclear. It is well accepted that abnormalities in frontostriatal, fronto-parietal, fronto-cerebellar and default mode networks are present in ADHD patients. In addition, modifications in catecholamine neurotransmission are historically thought to be involved in ADHD. However there is a lack of clinical evidences supporting this hypothesis, due to the phenotypic heterogeneity of ADHD, and to the lack of imaging probes targeting these systems. Our objective was to investigate the neurotransmission abnormalities involved in ADHD using metabolomics in a rat model of ADHD.
\end{abstract}

We used Spontaneously Hypertensive rats (SHR/NCrl) rats and their control (WKY/NHsd rats), which are one the most characterized animal model of ADHD. Eight rats of each group were sacrificed at 7 postnatal weeks, and their brain dissected to extract the orbitofrontal and prelimbic cortices, the dorsal and ventral striata, the amygdala, the hippocampus and the cerebellum that we previously found involved in the inattention, hyperactivity and impulsivity displayed by these animals. Each region was analyzed using targeted LC-HRMS-based approaches (ESI+ and ESI- on HILIC and C18 chromatography columns), and data were processed using multivariate and univariate analyses.

Our results revealed that SHR/NCrl rats could be discriminated from controls using multivariate and univariate analyses. Among all the detected modifications, abnormalities in metabolites related to catecholamine and serotonin biosyntheses were observed in the cortical and subcortical areas. This brings new evidences supporting the involvement in catecholamines but also serotonin in the pathophysiology of ADHD.

Mots-Clés : ADHD

Programme

\footnotetext{
* Intervenant

†Auteur correspondant: galineau@univ-tours.fr
} 


\title{
New Translational Metabolomics Exploration of Age-Related Macular Degeneration: From Patients to Functional Implication of Lactate [P187]
}

\author{
Matthieu Schoumacher *, Vincent Lambert, Sylvain Hansen , Justine \\ Leenders ${ }^{1}$, Bernadette Govaerts ${ }^{2}$, Bernard Pirotte ${ }^{3}$, Jean-Marie Rakic , \\ Agnès Noël , Pascal De Tullio ${ }^{1}$ \\ ${ }^{1}$ Centre Indisciplinaire de Recherche sur le Médicament (CIRM) - Institut de Pharmacie Quartier HOPITAL - \\ Av. Hippocrate, 15 (Bât. B36) Sart-Tilman B-4000 Liège, Belgique \\ ${ }^{2}$ Institut de Statistique, Biostatistique et Sciences Actuarielles (ISBA) (ISBA) - Voie du Roman Pays 20, 1348 \\ Louvain-La-Neuve, Belgique \\ ${ }^{3}$ University of Liège, Department of Medicinal Chemistry, Center for Interdisciplinary Research on Medicines \\ (CIRM) (University of Liège-CIRM) - 1 Avenue de l'Hôpital, B-4000 Liège, Belgium, Belgique
}

\begin{abstract}
Age-related macular degeneration (AMD) is a leading cause of vision loss in the western world in the elderly population. $90 \%$ of all vision loss due to AMD result from the exudative form, which is characterized by choroidal neovascularization (CNV). Age-related changes that induce pathologic $\mathrm{CNV}$ are incompletely understood. A successful application of anti-VEGF approaches in the clinic is obviously a turning point in AMD treatment. Nevertheless, despite such important advances, critical issues remain to be addressed. To better understand the etiology of this pathology, we decide to apply a NMR-based metabolomics approach on AMD patients and on a laser-induced murine choroidal neovascularization experimental model.

These experiments provide unique challenges to fulfill the goal of improving the current status of physiological information related to metabolome and in general to functional genomics.

For this purpose, sera from control and exudative AMD patients, induced and non-induced mice have been collected and the metabolic profiles of these samples were determined by NMR. After post-processing treatments, the different spectra were analyzed by statistical discriminant methodologies (PCA, ICA, PLS-DA, O-PLS-DA).

This approach allows the differentiation between control and AMD patients and between laser-induced mice and the control mice group. Moreover, the same discriminating spectral zones have been identified in human and mice model, leading to the emergence of different putative biomarkers. Among these markers, Lactate emerges as a key metabolite in both settings. Mechanistically, lactate produced locally and by inflammatory cells, plays a critical role in the onset of the inflammatory and angiogenic phases. In mice model of laser-induced $\mathrm{CNV}$, normalization of circulating lactate by dichloroacetate, decreases $\mathrm{CNV}$ development. Our data support the innovative concept of lactate as a parainflammation- and angiometabolite associated to AMD and CNV progression and metabolomics as a novel option for patients follow-up.
\end{abstract}

Mots-Clés : NMR, metabolomics, AMD, biomarker

*Intervenant 


\title{
A combined metabolomics and lipidomics approach enables the stratification of acute-on-chronic liver failure patients according to their severity [P188]
}

\author{
François Fenaille* 1, Noémie Butin ${ }^{\dagger}{ }^{1}$, Benoit Colsch ${ }^{1}$, Christophe Junot ${ }^{1}$, \\ Joan Clària ${ }^{2,3}$, Richard Moreau ${ }^{2,4}$, Vincente Arroyo ${ }^{2}$ \\ ${ }^{1}$ CEA-INRA UMR 0496/DRF/Institut Joliot/SPI/LEMM, Université Paris Saclay, MetaboHUB - CEA - Centre \\ d'Etudes Nucléaires de Saclay, 91191 Gif-sur-Yvette, France \\ ${ }^{2}$ European Foundation for the Study of Chronic Liver Failure (EF-CLIF), Barcelona, Spain - Travessera de \\ Gràcia, 11, Planta $7^{\mathrm{a}}, 08021$ Barcelona, Spain, Espagne \\ ${ }^{3}$ Department of Biochemistry and Molecular Genetics, Hospital Clinic, Institut d'Investigacions Biomèdiques \\ August-Pi-Sunyer (IDIBAPS), University of Barcelona - Carrer del Rosselló, 149, 08036 Barcelona, Espagne \\ ${ }^{4}$ Centre de recherche sur l'Inflammation (CRI) - Université Paris Diderot - Paris 7, INSERM : U1149, CNRS : \\ ERL8252 - Faculté de Médecine site Bichat - 16, Rue Henri Huchard, 75018 Paris, France
}

Acute-on-Chronic Liver Failure (ACLF) is a recently recognized syndrome characterized by acute decompensation (AD) of cirrhosis, an organ/system failure(s) and extremely poor survival. ACLF can be triggered by a precipitating event (e.g. bacterial infection) and is invariably associated with exacerbated systemic inflammation. According to the European Foundation for the study of Chronic Liver Failure (EF-CLIF), patients with ACLF can be classified into three groups, essentially according to the number of impaired organs. In the present project, we investigated whether metabolomics and lipidomics can identify potential new diagnostic biomarkers of ACLF.

In our study, a cohort of 89 serum samples from decompensated cirrhotic patients with and without ACLF were analyzed and compared to healthy subjects by liquid chromatography coupled to high resolution mass spectrometry (LC-HRMS). Two complementary methods involving both HILIC and C18 columns for metabolomics and C8 column for lipidomics were used in both positive and negative ionization modes. Data mining procedures using multivariate and univariate analyses were then performed to highlight discriminant metabolites.

Our data confirmed the metabolic and lipidomic cirrhosis signatures obtained in previous studies, especially regarding to the levels of glycerophosphatidylcholines, amino acids and energy metabolites. Furthermore, our approach enabled to discriminate between decompensated cirrhotic patients with ACLF and those without ACLF, and a specific metabolite signature associated with the ACLF grade has been obtained. Taken together, our findings indicate that metabolomic and lipidomic profiling using LCHRMS may contribute to describe the ACLF development in cirrhotic patients and provide new insights into the metabolomics changes detected.

Mots-Clés : metabolomics, lipidomics, mass spectrometry, cirrhosis, Acute, on, Chronic Liver Failure

\footnotetext{
*Auteur correspondant: francois.fenaille@cea.fr

${ }^{\dagger}$ Intervenant
} 


\title{
Relation entre maladie d'Alzheimer et perturbation de la voie de la kynurénine dans le métabolisme du tryptophane: exploration d'une étape clef vers la théranostic [P189]
}

\author{
Jean Escal $_{-}^{* 1,2}$, Sophia Sylla ${ }^{2}$, Audrey Le Gouellec ${ }^{1,2}$, Patrice Faure ${ }^{2}$, \\ Bertrand Toussaint ${ }^{1,2}$
}

\footnotetext{
${ }^{1}$ Techniques de lÍngénierie Médicale et de la Complexité - Informatique, Mathématiques et Applications [Grenoble] (TIMC-IMAG) - CNRS : UMR5525, Université Grenoble Alpes, Institut polytechnique de Grenoble Domaine de la Merci - 38706 La Tronche, France

${ }^{2}$ Institut de Biologie et de Pathologie (IBP) - CHU Grenoble - 38706, La Tronche, France
}

La maladie d'Alzheimer est une affection neurodégénérative, entraînant l'altération progressive des fonctions cognitives, en particulier la mémoire. Première cause de démence dans le monde, elle touche selon l'OMS plus de 30 millions de personnes. Son diagnostic peut s'avérer délicat à poser, en particulier pour les formes précoces de la maladie. De plus, malgré de nombreuses tentatives, il n'existe actuellement aucun traitement curatif.

Maladie d'origine plurifactorielle, il semblerait que le tryptophane joue un rôle majeur dans son développement. Le métabolisme de cet acide aminé s'opère par plusieurs voies, dont celle de la kynurénine. Des déséquilibres dans l'activation de certaines enzymes de cette voie métabolique (indoleamine-2,3dioxygenase, tryptophan-2,3-dioxygenase et kynurénine monooxygenase) conduisent à une surproduction de métabolites neurotoxiques (3-hydroxykynurénine, acide quinolinique et acide 3-hydroxyanthranilique ) et à une diminution de métabolite neuroprotecteur (acide kynurénique).

Le but de cette étude est de quantifier le tryptophane et sept de ses métabolites par spectrométrie de masse en tandem couplée à la chromatographie en phase liquide à haute performance, à partir de liquide céphalorachidien de malades et de sujets sains.

Ces dosages permettent d'évaluer l'implication du métabolisme du tryptophane dans la physiopathologie de la maladie d'Alzheimer. Ils permettent aussi d'évaluer la corrélation entre les concentrations de certains métabolites et le stade de la maladie.

Cette étude pourrait mener à des évolutions diagnostiques, par l'obtention de nouveaux biomarqueurs plus précoces, et thérapeutiques, par l'utilisation de ces biomarqueurs ou de certaines enzymes comme nouvelle cible pour de futurs médicaments.

Mots-Clés : maladie d'Alzheimer, métabolisme du tryptophane, kynurénine

$\underline{\text { Programme }}$

\footnotetext{
${ }^{*}$ Intervenant
} 


\title{
Brain PET-18FDG and metabolomics: exploration of a rat model of autism [P190]
}

\author{
Laurent Galineau ${ }^{* 1}$, Binta Diémé ${ }^{2}$, Clovis Tauber, Sophie Serrière, Sylvie \\ Mavel $^{2}$, Julie Busson, Sylvie Bodard, Zuhal Guhlan, Patrick Emond $*{ }^{\dagger}{ }^{2}$ \\ ${ }^{1}$ INSERM U930 - INSERM, Université François Rabelais Tours - Unité INSERM 930-Imagerie et Cerveau \\ UFR Médecine, 10 bd Tonnellé, BâtJ 4ème étage, 37000 Tours, France \\ ${ }^{2}$ Université François-Rabelais, INSERM U930 “Imagerie et Cerveau”, CHRU de Tours, 10 Bv Tonnellé, 37044 \\ Tours, France - INSERM - 10 Bv Tonnellé, 37044 Tours, France
}

\begin{abstract}
Autism spectrum disorders (ASD) are a group of neurodevelopmental disorders with lifelong consequences including pervasive impairments in social interactions, deficits in communication, and stereotyped, repetitive patterns of behaviors and interests. To date, ASD physiopathology remains largely unexplained and no biomarker is available for clinical purposes. In this context, our study aims at exploring modifications of the brain activity associated to the brain metabolome during the development in a rat model of ASD.

The animal model is obtained by exposing pregnant Wistar rats to valproic acid (VPA, $600 \mathrm{mg} / \mathrm{kg}$, i.p.) on the twelfth day of gestation. Experiments were conducted on the male progeny which was divided in two groups for imaging or metabolomics investigations. Two microPET scans with 2-deoxy-2-(18F)fluorod-glucose (18FDG) were performed for each rat $(\mathrm{n}=8)$ at 21 (P21) and 35 (P35) postnatal days and compared to controls. $18 \mathrm{FDG}$ was injected $(18.5 \mathrm{MBq} / 100 \mathrm{~g}$, i.p.) in freely moving rats placed for $45 \mathrm{~min}$ in a cage free of external stimulation. A list-mode microPET scan was then performed on anesthetized rats (isoflurane) for 30min starting 1hour post 18 FDG administration. Metabolomics study was realized on hippocampus, striatum, cerebellum, frontal and parietal cortices dissected from VPA rats at P21 $(n=19)$ and P35 $(n=16)$ and compared to controls by LC-High Resolution Mass Spectrometry. For all brain regions, around 130 metabolites were identified using an in house standard library.
\end{abstract}

18FDG scans revealed specific activity profiles between VPA and controls rats depending on the developmental stage, including modifications in the frontal cortex, striatum, hippocampus and cerebellum. In these brain regions, metabolomics analyses showed changes in metabolites implicated in neurotransmission, neuroinflammation, oxidative stress and amino acids metabolism.

Combining metabolomics to PET imaging gives the opportunity to extend the molecular exploration for a better understanding of the pathophysiological processes involved in this animal model of autism.

Mots-Clés : Autism Spectrum Disorders, Metabolomics, PET Imaging, Rat model, Valproic Acid

$\underline{\text { Programme }}$

\footnotetext{
${ }^{*}$ Intervenant

${ }^{\dagger}$ Auteur correspondant: emond@univ-tours.fr
} 


\title{
LC-HRMS Human Urine Metabolic Fingerprints for ESA Doping Control [P191]
}

\author{
Céline Joré ${ }^{* 1,2}$, Benoît Loup ${ }^{2}$, Patrice Garcia ${ }^{2}$, Marie-Agnès Popot ${ }^{2}$, \\ Michel Audran ${ }^{3}$, Ludovic Bailly-Chouriberry ${ }^{2}$, \\ Emmanuelle Varlet-Marie ${ }^{1}$, Yves Bonnaire ${ }^{2}$
}

\footnotetext{
${ }^{1}$ Institut des Biomolécules Max Mousseron (IBMM) - CNRS : UMR5247, Universités Montpellier I et II Sciences et techniques - Faculté de pharmacie 15, Avenue Charles Flahault 34060 Montpellier cedex 2, France

${ }^{2}$ Laboratoire des Courses Hippiques (LCH) - 15 rue de Paradis, 91370 Verrières-le-Buisson, France

${ }^{3}$ Association Française de Lutte Contre le Dopage (AFLD) - 143 avenue Roger Salengro, 92290

Châtenay-Malabry, France
}

Although prohibited by the WADA, some athletes abuse Erythropoiesis Stimulating Agents (ESAs) in high level competitions to enhance their endurance capability.

In order to improve ESA doping control, we aim at developing a method enabling the suspicion of any ESA misuse by targeting their metabolic effects. Our approach relies on the hypothesis that the different ESAs could have similar effects on the metabolome. In this objective a metabolomic fingerprinting approach was carried out to observe and analyze the variations induced by an administration of ESA.

In our study a single dose of Mircera $\mathbb{R}(2.7 \pm 0.7 \mu \mathrm{g} / \mathrm{kg})$ was injected to 10 young men (22 22 years) with a regular sport activity (between 5 to $10 \mathrm{~h} /$ week). Urine and blood were collected at days $-60,-53$, $-39,-18$ and 0 before administration and at days 2, 4, 7, 10, 17, 24, 31, 45, 56 after administration. Haematological parameters and total EPO concentration were monitored meanwhile urine samples were analyzed by untargeted LC-HRMS metabolomics.

After a simple sample preparation, urine metabolic fingerprints were recorded by LCHRMS in positive and negative modes. Raw data was preprocessed with XCMS package and multivariate statistical methods were conducted by Orthogonal Partial Least Squares (OPLS). The aim was to develop models allowing sample discrimination between before and after Mircera ${ }^{\circledR}$ administration and to find out interesting candidate biomarkers.

Human haematological parameters showed significant variations with an increase of the reticulocytes percentage (\%ret) and a decrease of the OFF-score with a peak at day 10 after administration. Total EPO concentrations (endogenous and exogenous) were measured by ELISA and were detected superior

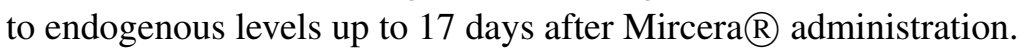

OPLS models were constructed by combining ESI positive and negative LC-HRMS datasets. The models obtained allowed discrimination between samples collected before and after Mircera $($ administration up to 56 days.

Mots-Clés : metabolomics, urine, human, LC, HRMS, erythropoietin, doping control

$\underline{\text { Programme }}$

\footnotetext{
*Intervenant
} 


\title{
MALDI Imaging and High Resolution Mass Spectrometry as a Lipidomic Approach to Assess Nonalcoholic Fatty Liver Disease Pathophysiology and Biomarkers [P192]
}

\author{
Julie Le Faouder ${ }^{* \dagger}{ }^{1}$, Noémie Butin ${ }^{2}$, Benoit Colsch ${ }^{2}$, Valérie Paradis ${ }^{1,3}$, \\ Pierre Bedossa 1,3 \\ ${ }^{1}$ UMR 1149, Centre de recherche sur l'Inflammation - INSERM, Université Paris Diderot - Paris 7 - Hopital \\ Beaujon, 100 bd du Général Leclerc 92110 Clichy, France \\ ${ }^{2}$ CEA-INRA UMR 0496/DRF/Institut Joliot/SPI/LEMM, Université Paris Saclay, MetaboHUB - CEA - Centre \\ d'Etudes Nucléaires de Saclay, 91191 Gif-sur-Yvette, France \\ ${ }^{3}$ Département de pathologie, Hôpital Beaujon - Assistance Publique - Hôpitaux de Paris (AP-HP) \\ Clichy, France
}

\begin{abstract}
Background: Nonalcoholic Fatty Liver Disease (NAFLD) encompass a wide spectrum of lesions including steatosis (nonalcoholic fatty liver, NAFL), steatohepatitis (NASH), fibrosis/cirrhosis, that may progress to cancer. Detailed mechanisms underlying disease progression remain poorly understood; in particular the potential relationship between in situ lipotoxicity and disease patterns. The aim of the study was to characterize profiles of lipids and their spatial distribution along the progression of NAFLD using complementary lipidomic approaches in order to identify relevant diagnostic markers of NASH and potential therapeutic strategies.

Methods: Twenty-seven human liver samples with NAFLD at various stages (normal, $n=10$; NAFL, $\mathrm{n}=7$; NASH, $\mathrm{n}=10$ ) were subjected to 2 complementary lipidomic methods. The liquid chromatography coupled to high-resolution mass spectrometry (LC-HRMS) method and its associated data processing workflow were first applied to tissue extracts. Then, the MALDI Imaging Mass Spectrometry (MALDI IMS) method coupled to analysis with SCiLS Lab 2016b software was applied to tissue slides.
\end{abstract}

Results: Partial least squares Discriminant Analysis (PLS-DA) of LC-HRMS data, from total lipid extracts of liver tissue sections, based on 21 classes of lipids and 406 unique lipid species, allowed the separation of the 3 groups (Normal, NAFL and NASH). Univariate analysis showed an increased level of diacylglycerols (DG), triacylglycerols (TG) and cholesteryl esters (CE) in NAFL and NASH samples compared to Normal samples. In addition, several glycerophospholipids species were discriminant between NASH and NAFL samples. ROC analyses of IMS data assessed several discriminant glycerophospholipids species between normal and pathological sections (NAFL+NASH) and between NAFL and NASH sections with specific zonation in zone 3 (centrolobular, Z3).

Conclusion: Combination of IMS and LC-MS methodologies allows localizing and characterizing discriminant lipid species of the different pathological patterns of NAFLD.

Mots-Clés : Nonalcoholic Fatty Liver Disease, MALDI imaging, lipidomics

\footnotetext{
*Intervenant

†Auteur correspondant: julie.lefaouder@inserm.fr
} 


\title{
Proteomic signature reveals modulation of human macrophage polarization and functions under differing environmental oxygen conditions [P193]
}

\author{
Arnaud Millet $* \dagger 1,2$, Magali Court ${ }^{2}$ \\ ${ }^{1}$ Team ATIP/Avenir "Mechanobiology, Immunity and Cancer" - INSERM, Université Grenoble Alpes - 17 rue \\ des martyrs, Bat 40.23, CEA de Grenoble, 38054 Grenoble, France \\ ${ }^{2}$ INSERM U1205 - Université Grenoble Alpes - 17 rue des martyrs, bât. 40.23, CEA de Grenoble \\ 38054 Grenoble, France
}

\begin{abstract}
Macrophages are innate immune cells which can react to a large number of environmental stimuli thanks to a high degree of plasticity. Macrophages' activation state, which determines their functional orientation, is strongly influenced by the cellular environment. A large body of macrophage literature is devoted to better defining polarizations from a molecular viewpoint. It is now accepted that a multidimensional model of polarization is needed to grasp the broad phenotype repertoire controlled by environmental signals. The study presented here aimed, among other goals, to provide a molecular signature of various polarizations in human macrophages at the protein level so as to better define the different macrophage activation states. To study the proteome in human monocyte-derived macrophages as a function of their polarization state, we used a label-free quantification approach on in-gel fractionated and LysC/Trypsin digested proteins. In total, 5106 proteins were identified and quantified for all polarization states. New polarization-specific markers were identified and validated by western-blot, flow cytometry and quantitative PCR. Because oxygen tension is an important environmental parameter in tissues, we explored how environmental oxygen tension, at either atmospheric composition (18.6\% O2) or "tissue normoxia" (3\% O2), affected our classification of macrophage polarization. The comparative results revealed new polarization-specific makers which suggest that environmental oxygen levels should be taken into account when characterizing macrophage activation states. The proteomic screen revealed various polarization-specific proteins and oxygen sensors in human macrophages. One example is arachidonate 15-lipoxygenase (ALOX15), an IL4/IL13 polarization-specific protein, which was upregulated under low oxygen conditions and is associated with an increase in the rate of phagocytosis of apoptotic cells. These results illustrate the need to consider physicochemical parameters like oxygen level when studying macrophage polarization, so as to correctly assess their functions in tissue.
\end{abstract}

Mots-Clés : LC MS/MS, Macrophages, Label free quantification, Hypoxia

$\underline{\text { Programme }}$

\footnotetext{
${ }^{*}$ Intervenant

${ }^{\dagger}$ Auteur correspondant: arnaud.millet@inserm.fr
} 


\title{
Etude sur l'identification de biomarqueurs prédictifs du risque du cancer du sein par RMN métabolomique [P194]
}

\author{
Agnès Victor Bala *1, Lucie Lecuyer, Nadia Bouchemal ${ }_{-}^{\dagger}$, Mohamed \\ Triba $_{-}^{\ddagger 3}$, Marie-Paule Vasson, Pilar Galan, Emmanuelle Kesse-Guyot, Paule \\ Latino-Martel, Serge Hercberg, \\ Mathilde Touvier ${ }_{-}^{\S}$, Philippe Savarin ${ }_{-}^{\text {Il } 3}$ \\ ${ }^{1}$ Chimie, Structures et Propriétés de Biomatériaux et d'Agents Thérapeutiques (CSPBAT) - Université Sorbonne Paris Cité \\ (USPC), Université Paris 13, CNRS : UMR7244 - 74 rue Marcel Cachin 93017 Bobigny, France \\ ${ }^{2}$ CSPBAT - CNRS : UMR7244 - Bobigny, France \\ ${ }^{3}$ Laboratoire Chimie, Structures, Propriétés de Biomatériaux et d'Agents Thérapeutiques (CSPBAT) - Université Paris-Nord \\ - Paris XIII - 74 rue Marcel Cachin, 93037, Bobigny, France \\ ${ }^{4}$ Equipe de Recherche en Epidémiologie Nutritionnelle (EREN) - Université Sorbonne Paris Cité (USPC), Université Paris \\ XIII - Paris Nord, INRA : UR1125, INSERM : U1153, 74 rue Marcel Cachin, 93017 Bobigny
}

Contexte : Dans le cadre d'une étude épidémiologique nutritionnelle sur une large cohorte de femmes, une approche métabolomique par RMN a été mise en place. L'objectif consiste à identifier de manière précoce des métabolites en lien avec le risque de développer un cancer du sein à long terme.

Matériels et méthodes : Une étude cas-témoins a été réalisée dans la cohorte SU.VI.MAX. 602 échantillons de plasmas de femmes prélevés à l'inclusion ont été sélectionnés correspondant aux plasmas de 206 femmes diagnostiquées d'un cancer du sein invasifs au cours de l'étude et de 396 plasmas de témoins. Les facteurs d'appariements (cas/témoins) sont l'âge, l'IMC, le statut ménopausique, la période de prélèvement sanguin. Les spectres de chacun de ces échantillons ont été obtenus en utilisant les séquences RMN NOESY 1D et CPMG. Les spectres ont été découpés en buckets à l'aide de l'algorithme optimized bucketing. Puis des régressions logistiques conditionnelles multivariées ont été calculées pour chacun des buckets.

Résultats : A partir des spectres RMN, nous avons respectivement 25 buckets significatifs (sur 237) pour l'expérience NOESY 1D, et 27 buckets significatifs (sur 228) pour la CPMG, dans les modèles logistiques. Nous avons montré que les métabolites lipidiques et glycoprotéiques sont associés à une diminution du risque d'apparition du cancer du sein tandis que les acides aminés tels que la valine, la leucine et la glutamine sont associés à une augmentation du risque.

Conclusion : Cette nouvelle approche a permis d'identifier des métabolites qui sont associés au risque de développer un cancer du sein à long terme. Cette même étude est menée en parallèle par spectrométrie de masse. L'objectif suivant serait d'étudier les métabolites en lien avec la nutrition et le risque de développer un cancer du sein.

Mots-Clés : RMN, métabolomique, biomarqueurs, cancer du sein, nutrition, SU.VI.MAX

\footnotetext{
${ }^{*}$ Intervenant

†Auteur correspondant: nadia.bouchemal@univ-paris13.fr

¥Auteur correspondant: mohamed.triba@univ-paris13.fr

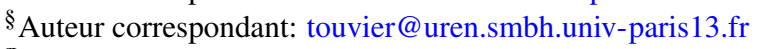

IIAuteur correspondant: philippe.savarin@univ-paris13.fr
} 


\title{
Development of proteomic methods on milk for ruminant phenotyping [P195]
}

\author{
Mylène Delosière ${ }^{* 1,2}$, Isabelle Cassar-Malek ${ }^{1,2}$, Laurence Bernard ${ }^{1,2}$, \\ Arnaud Delāaud ${ }^{1,2}$, Didier Viala ${ }^{1,2,3}$, Muriel Bonnet ${ }_{-}^{\dagger 1,2}$ \\ ${ }^{1}$ INRA (UMR1213 Herbivores) - F-63122 Saint-Genès-Champanelle, France \\ ${ }^{2}$ Clermont Université (VetAgro Sup) - Université Clermont Auvergne - BP 10448 \\ F-63000 Clermont-Ferrand, France \\ ${ }^{3}$ INRA (UMR 1019 Nutrition Humaine) - 63122 Saint-Genès-Champanelle, France
}

A challenge for livestock production is to improve animal performances and the quality and safety of their products while ensuring welfare and health. To face this challenge, tools are needed for assessing rapidly, efficiently and cheaply the multiple traits of performances. Proteomic screening of milk provides a good opportunity for discovering biomarkers to be adopted in such tools. Therefore, we aim at developping rapid and affordable proteomics of milk for dairy ruminants' phenotyping.

Raw milk is a complex fluid requiring fractionation techniques in order to enhance protein characterization. As a first step in milk fractions analysis, we focused on the subproteome of the milk fat globules membranes (MFGM). Two MFGM protein purification protocols were applied to fresh milk from Holstein cows. MFGM were Tris HCl-SDS washed during $1 \mathrm{~h}$, then proteins treated with acetone during 20 h (ACE) or MFGM were cristallized at $4 \circ \mathrm{C}$ overnight to harden the fat globules (CRI). Prior to nano LC-MS/MS analysis, two digestion protocols were tested: 1/ in-solution digestion (SD) and 2/ in-gel digestion after a concentration of proteins in one band stacking gel (GD).

The combination of all methods allowed identifying 218 unique proteins. From CRI extraction, we identified 179 and 65 proteins after GD and SD, respectively, but only 93 and 31 proteins from ACE extraction. Comparable results were obtained on frozen milk. The greatest protein identification with CRI compared to ACE extraction could be due to a higher preservation of proteins using cold cristallisation than aggressive acetone. GD allowed more protein identifications probably due to a higher lipid elimination compared to SD. A total of 88 proteins were specific of the combination of CRI extraction and GD protocol; this combination will be used for future investigation of the MFGM proteome. Similar developments are still under progress on the whey fraction.

Mots-Clés : phenotype, milk, ruminant

$\underline{\text { Programme }}$

\footnotetext{
* Intervenant

†Auteur correspondant: muriel.bonnet@inra.fr
} 


\title{
Multi-platform metabolomics and data fusion: application to chronic kidney disease [P197]
}

\author{
Yoric Gagnebin ${ }^{* \dagger}{ }^{-}$, Julian Pezzati ${ }^{1}$, Pierre Lescuyer ${ }^{2}$, Belen Ponte ${ }^{3}$, Julien \\ Boccard ${ }^{1}$, Serge Rudaz ${ }^{1}$ \\ ${ }^{1}$ Analytical Sciences, School of Pharmaceutical Sciences, University of Geneva, University of Lausanne - Rue \\ Michel-Servet 1, 1211 Genève, Suisse \\ 2 Department of Genetic and Laboratory Medicine, Geneva University Hospitals - Rue Gabrielle-Perret-Gentil 4 \\ 1205 Genève, Suisse \\ ${ }^{3}$ Service of Nephrology, Geneva University Hospitals - Rue Gabrielle Perret-Gentil 4, 1205 Genève, Suisse
}

\begin{abstract}
Metabolomics constitutes a potent approach for assessing biochemical alterations caused by diseases or environmental influences. For relevant untargeted metabolomics, large coverage of metabolites is required. As no analytical technique offers an exhaustive monitoring of all metabolites in a biofluid, the use of multiple platforms is needed. When coupled to mass spectrometry, reverse phase chromatography (RPLC) and hydrophilic interaction chromatography (HILIC) are complementary techniques commonly used for their coverage of apolar and polar metabolites, respectively. A strategy based on the combination of these two analytical approaches was applied to plasma samples collected from a clinical study designed to evaluate the metabolic impact of kidney failure. The cohort was composed of 160 patients and control samples. Moreover, samples were collected just before and after haemodialysis, to evaluate potential metabolome variations due to the latter. Each sample and quality control (QC) was analysed by RPLC and HILIC coupled to QTOF-MS in negative and positive ESI mode. Low-level data fusion was carried out using multiblock approaches to combine signals from the different data blocks, evaluate the complementary of the techniques and eliminate redundant information. Data fusion strategies were investigated based on (i) unambiguous metabolite identification based on authentic chemical standard analysis of more than 600 metabolites (in house database) and (ii) automatic annotation without standard using chemical classes and biochemical pathways (public databases). The workflow developed in this study allowed new biological hypotheses to be generated, leading to a better understanding of the pathology.
\end{abstract}

Mots-Clés : Multiplatform metabolomics, data fusion, chronic kidney disease

Programme

\footnotetext{
*Intervenant

†Auteur correspondant: yoric.gagnebin@ unige.ch
} 


\title{
Matrisome landscape of Head and neck squamous cell carcinoma (HNSCC) -associated fibroblasts [P198]
}

\author{
Luc Camoin * 1, Sandeep Gopal, Stéphane Audebert ${ }^{2}$, Dominique Grall , \\ Emilie Baudelet, Agata Radwanska, Stéphanie Beghelli-De La Forest \\ Divonne, Anne Sudaka, Ellen Van Obberghen-Schilling
}

${ }^{1}$ Marseille Protéomique - Centre de Recherche en Cancérologie de Marseille (MaP-CRCM) - Centre de Recherche INSERM : U1068, CNRS : UMR7258, Aix Marseille Université (Aix-en-Provence) : UM105 - Centre de Recherche en Cancérologie de Marseille INSERM U1068 - CNRS 7258 - AMU UM105 27 Bd Leï Roure - CS 3005913273 Marseille Cedex 09, France

2 Centre de Recherche en Cancérologie de Marseille, UMR1068 INSERM, UMR 7258 CNRS, Institut Paoli-Calmettes, Aix-Marseille Université, 27 Boulevard Lei Roure, 13009 Marseille, France

\begin{abstract}
Background: HNSCC is the sixth most common malignancy reported worldwide with a 5-year survival rate of 50\%, largely due to recurrent disease and locoregional spread following treatment failure. Malignant progression of these tumors is controlled by functional interplay between tumor cells and their pro-tumoural tissue environment thus a thorough understanding of these interactions is required for the development of effective therapies. The extracellular matrix (ECM) is a key component of the tumor microenvironment that shapes the tumor tissue and actively participates in tumor progression through complex signaling networks, not fully understood.
\end{abstract}

Methods: De-cellularised ECM was prepared from normal immortalized human skin fibroblasts (Telomeraseimmortalized fibroblasts (TIFs)) and from early passage HSNCC-derived fibroblasts (CAFs) isolated from fresh tumours. Two independent biological experiments were analysed using mass spectrometer (MS). ECM extracts were reduced, alkylated, and proteins digested before injection on LC-MS/MS. The protein profile of CAFs and TIFs were compared using label-free quantification.

Aims and Results: We set out to provide a comprehensive data set of the human HSNCC-associated fibroblast matrisome. We focused on fibroblasts, as they represent the major matrix-producing cells of the tumour stroma. CAF and TIF matrisomes were compared to validate the possible use of TIF-derived matrix for functional studies. Cellular FN was among the major ECM glycoproteins produced by CAFs and TIFs. Other matrix glycoproteins include transforming growth factor- 3 -induced (TGFBI), Emilin-1 and Tenascin C (TNC). Both matrisomes contained a similar set of core matrix components and matrisomeassociated proteins with comparable relative abundance.

Conclusions This dataset of ECM components present in the stroma of HNSCC provides valuable insights into the adhesion-dependent events that take place in the microenvironment of these tumours. The ECM of human TIFs and CAFs display a similar composition, thus TIF-derived ECM can be utilized for functional studies, including ECM-tumour cell interactions and interactions between the ECM immune cells.

Mots-Clés : Matrisome, HNSCC, FN, tandem MS/MS, Label, free

${ }^{*}$ Intervenant 


\title{
Mechanisms of IL-33 activation through proteolytic maturation by allergen proteases analyzed by mass spectrometry [P199]
}

\author{
Mylène Camus * 1 , Corinne Cayrol ${ }^{1}$, Anais Duval ${ }^{1}$, Pauline Schmitt ${ }^{1}$, \\ Stephane Roga ${ }^{1}, \overline{\text { Alexandre Stella }}{ }^{1}$, Odile Burlet-Schiltz ${ }^{1}$, Anne Gonzalez \\ De Peredo ${ }^{1}$, Jean-Philippe Girard ${ }^{1}$
}

${ }^{1}$ Institut de pharmacologie et de biologie structurale (IPBS) - Université Paul Sabatier - Toulouse 3, CNRS : UMR5089 - 205 Route de Narbonne, 31077 Toulouse cedex 4, France

Background: Environmental exposure to allergens plays an important role in the exacerbation of allergic diseases such as asthma. It is therefore important to understand why and how the immune system responds to allergens. Interleukin-33 (IL-33) is an epithelial cytokine involved in type 2 immunity and asthma. It contains a C-terminal bioactive IL1-like domain, and can be regulated through cleavage in its central domain by activator proteases. Here, we show that IL-33 detects proteolytic activities associated with various environmental allergens. Through mass spectrometry analyses we could map the cleavage sites for a large panel of allergen proteases, which generate highly active shorter mature forms responsible for airway inflammation.

Methods: Recombinant human IL-33 full-length protein samples, either untreated or incubated with allergens extracts, were digested using specific proteolytic enzymes and analyzed by nanoLC-MS/MS on a highly sensitive Orbitrap Fusion mass spectrometer, to map the central domain of the protein and identify neo $\mathrm{N}$-terminal peptides resulting from allergen cleavage in this region. Peptide mapping was performed with Mascot and the in-house-developed software Proline, allowing raw MS signal extraction of identified neo $\mathrm{N}$-terminal peptides across samples treated with different allergens.

Results: We found that all allergen proteases analyzed ( 9 distinct allergens, including fungi, house dust mite, cockroach and pollens) cleave IL-33 in the central "sensor" domain and generate mature forms containing the C-terminal IL-1 cytokine domain. Some of these forms can also be produced by inflammatory proteases from mast cells and neutrophils, while others are uniquely generated by allergen proteases. Maturated forms were shown to be potent inducers of type- 2 innate immune responses in vivo. Conclusion: Our data reveal a mechanism for the induction of allergic type 2 inflammation through the direct cleavage of IL-33 by many allergen proteases, which may explain the critical role of IL-33 in asthma susceptibility.

Mots-Clés : allergens, cytokine, Interleukin, 33, mass spectrometry, nanoLC, MS/MS

Programme

*Intervenant 


\title{
Préparation d'échantillon optimisée pour la protéomique urinaire [P200]
}

\author{
David Marx ${ }^{* \dagger}{ }^{1,2}$, Leslie Muller $^{2}$, Sophie Caillard ${ }^{1}$, Sarah Cianferani ${ }^{\ddagger}{ }^{2}$, \\ Christine Carapito $* £ 2$
}

\footnotetext{
${ }^{1}$ Service de Néphrologie-Transplantation - Hôpitaux Universitaires de Strasbourg - 1, place de l'Hôpital 67000 Strasbourg, France

${ }^{2}$ Laboratoire de Spectrométrie de Masse BioOrganique (LSMBO) - CNRS, université de Strasbourg, IPHC UMR 7178 - 25, rue Becquerel 67000 Strasbourg, France
}

Les maladies rénales sont insidieuses et les biomarqueurs actuels sont souvent pris en défaut. Les urines sont riches en protéines potentiellement informatives mais leur gamme dynamique et variabilité en rendent l'étude difficile. Afin de trouver des protéines urinaires renseignant sur des complications fréquentes de la transplantation rénale, nous avons comparé le protéome urinaire de 96 patients parfaitement phénotypés cliniquement et par biopsie. Quarante-huit avaient un greffon fonctionnel et quarante-huit avaient une complication parmi 9 entités courantes. Nous avons optimisé un protocole de préparation des urines pour l'analyse protéomique par FASP (Filter Aided Sample Preparation). Les urines décongelées ont été poolées par 3 puis aliquotées par 500 microlitres qui ont été centrifugées sur un filtre (cutoff $10 \mathrm{kDa}$ ) puis lavées, alkylées et réduites. Un autre aliquot a permis le dosage protéique total par technique de rouge pyrogallol sur automate hospitalier afin d'injecter $800 \mathrm{ng}$ pour chaque pool. Les principales étapes comportaient la digestion trypsique, le dessalage par extraction sur phase solide puis l'injection sur nano-chromatographie liquide en phase inverse avec un gradient de 140 minutes, couplée à un spectromètre de masse Quadrupole-Orbitrap opérant en mode Data Dependent Acquisition. Après analyse des données par quantification sans marquage par extraction des courants d'ions MS, 626 protéines en moyenne ont été quantifiées [de 400 à 741, écart-type 72], avec 257 protéines communes à l'ensemble des échantillons. Les 10 protéines les plus abondantes généraient 62\% du signal total. Des candidats biomarqueurs de rejet de greffe ont pu être identifiés et la durée de la préparation à l'analyse est inférieure à 36 heures ce qui rend ce protocole optimisé compatible avec une utilisation en routine clinique.

Mots-Clés : protéomique quantitative, approche sans marquage, urine, FASP, digestion, rejet de greffe, transplantation

$\underline{\text { Programme }}$

\footnotetext{
${ }^{*}$ Intervenant

† Auteur correspondant: Davmarx@ gmail.com

¥Auteur correspondant: sarah.cianferani@unistra.fr

$\S$ Auteur correspondant: ccarapito@unistra.fr
} 


\title{
Differential label free analysis to identify microtubule-associated proteins enriched in platelets versus brain or HeLa cells [P201]
}

\author{
Agnès Hovasse ${ }^{*} 1$, Morgane Batzenschlager ${ }^{2}$, Maria M. Magiera ${ }^{3}$, Catherine \\ Strassel $^{2}$, Alain Van Dorsselaer ${ }^{1}$, Carsten Janke ${ }^{3}$, François Lanza ${ }^{2}$, Christine \\ Schaeffer-Reiss ${ }^{1}$ \\ ${ }^{1}$ Laboratoire de Spectrométrie de Masse BioOrganique, Institut Pluridisciplinaire Hubert Curien, \\ CNRS-Université de Strasbourg (LSMBO-IPHC) - CNRS : UMR7178 \\ 25 rue Becquerel, 67087 Strasbourg, France \\ 2 UMR S 949 INSERM, EFS-Grand Est, Université de Strasbourg (EFS-Grand Est) - UMR S 949 INSERM - 10 , \\ rue Spielmann - BP 3667065 Strasbourg Cedex, France \\ ${ }^{3}$ Institut Curie, CNRS UMR3348 - Centre Universitaire, bât. 11091405 Orsay, cedex, France
}

Microtubules (MTs) play a major role in blood platelet formation and function. In the final stages of platelet biogenesis, microtubules (MTs) are arranged into circular submembranous structures (the marginal band), and show excessive bending that has so far not been observed in other mammalian cells. This striking functional adaptation of MTs could be achieved by the interaction with specific MT binding partners (MAPs and motors), and these interactions might depend on the particular tubulin composition of platelet MTs. To identify proteins that specifically interact with platelet MTs, we used in vitro cosedimentation experiments of platelet MAPs with MTs polymerized from platelet, brain or HeLa tubulin, and performed differential MS analysis to determine MT-binders that are enriched on platelet MTs.

Tubulin was purified from platelets, HeLa and brain tissue, and polymerized into MTs. A fraction of MAPs isolated from platelets was incubated with these different types of MTs. MTs with equilibriumbound MAPs were then separated by ultracentrifugation. The quantity of MAPs bound to the different MTs were determined by quantitative nanoLC-MS/MS analyses using a label-free approach on a QExactive Plus. MaxQuant was used for data validation and protein quantification.

We identified a series of MAP that were enriched on platelet MTs samples. Among these were cytoskeletalrelated proteins such as EML3 and EB2. These first results demonstrate the feasibility of our quantitative approach, and will allow us to pin down MAPs that play specific roles in the formation of the platelet marginal band.

Mots-Clés : label free, quantification, plaquettes, tubulines

Programme

\footnotetext{
*Intervenant
} 


\title{
Analyse par 'label free' du protéome de lésions pré-néoplasiques de cancer du côlon à partir de matériel fixé en formol et inclus en paraffine [P202]
}

\author{
Virginie Salnot *1,2, Pierre Sohier ${ }_{-}^{\dagger}$, Romain Sanson ${ }_{-}^{\ddagger}$, Marjorie Leduc ${ }^{1,2}$, \\ Cédric Broussard ${ }^{1,2}$, Evangéline Bennana ${ }^{1,2}$, Mārina Nkoyock ${ }^{1,2}$, \\ Pierre-Alexandre Just ${ }^{1}$, Patrick Mayeux ${ }^{\S 1,2}$, Benoit Terris ${ }^{1}$, \\ Christine Perret ${ }^{1}$, François Guillonneau ${ }^{1,2}$ \\ ${ }^{1}$ Institut Cochin - INSERM, U1016, Cnrs, UMR8104 \\ Université Paris Descartes, Sorbonne Paris Cité - Paris, France \\ 2 3P5 - Plate-forme protéomique (3P5) - Université Paris Descartes - Paris 5, INSERM U1016 \\ 22 rue Méchain 75014 Paris, France
}

Le cancer colorectal (CRC) se classe au 3ème rang des cancers les plus fréquents en France. La voie principale de développement de CRC est modélisée dans la Polypose Adénomateuse Familiale $(\mathrm{PAF})$, elle est associée à une mutation germinale du gène $A P C$ et à une dérégulation de la voie $\mathrm{Wnt} / \beta$ caténine. Plus récemment, une autre voie a été décrite, la voie festonnée. Elle comprend deux voies de développement, dont les événements génétiques et épigénétiques sont encore mal caractérisés : les adénomes festonnés sessiles (SSA) et les adénomes festonnés traditionnels (TSA). Le matériel tumoral concernant les SSA et les TSA est majoritairement disponible sous la forme de tissu fixé en formol et inclus en paraffine (FFPE). Nous avons mis en place une méthode permettant l'analyse protéomique de ces échantillons. Après déparaffinage et réhydratation, les protéines sont extraites des coupes histologiques par des étapes successives de sonication et de chauffage et les protéines sont digérées par la technique FASP. Les peptides sont préfractionnés sur StageTips SCX et chacune des 5 fractions SCX est analysée par LC-MS/MS. Dans un premier temps, nous avons validé cette technique de préparation en utilisant un jeu de 6 échantillons disponibles à la fois sous forme congelée et sous forme de blocs histologiques FFPE. Dans une seconde étape, 15 échantillons FFPE de chaque type (muqueuse normale, PAF, TSA et SSA) ont été analysés. Plus de 7000 protéines ont été identifiées et 600 d'entre-elles présentaient une expression différentielle. Une analyse en composante principale montre que les différents échantillons ségrégent conformément à leur groupe histologique. Une signature protéomique potentielle des SSA et des TSA est en cours de validation par immunohistochimie. Ce travail montre que les échantillons FFPE, stockés depuis de très nombreuses années dans les services d' anatomo-pathologie, sont accessibles à une analyse protéomique quantitative à grande profondeur.

Mots-Clés : Label free, cancer du colon, tissu fixé en formol et inclus en paraffine

$\underline{\text { Programme }}$

\footnotetext{
${ }^{*}$ Intervenant

† Auteur correspondant: pierre.sohier@aphp.fr

¥Auteur correspondant: romain.sanson@inserm.fr

$\S$ Auteur correspondant: $\overline{\text { patrick.mayeux@inserm.fr }}$
} 


\title{
Quantification absolue de protéines de globules rouges et de réticulocytes purifiés [P203]
}

\author{
Emilie-Fleur Gautier * ${ }^{\dagger} 1,2,3$, Sylvie Cochet ${ }^{3,4}$, Virginie Salnot ${ }^{1,2}$, Evangéline \\ Bennana ${ }^{1,2}$, Marjorie Leduc ${ }^{1,2,3}$, Cédric Broussard ${ }^{1,2}$, François Guillonneau \\ 1,2 , Sara El-Hoss ${ }^{3,4}$, Bérengère Khoel ${ }^{3,4}$, Emmanuelle \\ Maillard ${ }^{2,5}$, Karine Bailly ${ }^{2,5}$, Wassim El-Nemer ${ }^{3,4}$, Patrick Mayeux \\ 1 3P5- Plateforme protéomique, INSERM U1016, Université Paris Descartes, 22 rue méchain 75014 Paris \\ 2 Institut Cochin, INSERM U1016. CNRS UMR8104. Université Paris Descartes, 22 rue Méchain, 75014 Paris \\ ${ }^{3}$ GR-Ex - Laboratoire d'Excellence du Globule Rouge - Paris, France \\ ${ }^{4}$ INTS - INSERM UMR S 1134 - Universite Paris Diderot- Paris 7,INTS \\ 6 rue Alexandre Cabanel 75739 Paris Cedex 15, France \\ ${ }^{5}$ CYBIO- Plateforme de cytométrie - INSERM U1016 - CNRS UMR8104 - Université Paris Descartes - Groupe \\ Hospitalier Cochin, 27,Rue du Faubourg Saint-Jacques - 75014 Paris, France
}

Le corps humain produit 2 millions de globules rouges chaque seconde. Le processus d'érythropoï̀se donnant naissance à ces globules rouges se produit dans la moelle osseuse jusqu'à l'étape d'énucléation (perte du noyau) donnant naissance aux réticulocytes. Les réticulocytes sortent ensuite dans le sang et maturent pour donner des globules rouges, qui, durant 120 jours, apportent l'oxygène à l'ensemble des cellules du corps.

Diverses pathologies liées à un défaut protéique des globules rouges existent et sont largement étudiées afin d'en comprendre les mécanismes moléculaires. Cependant, les données de protéomiques des globules rouges publiées contiennent une importante quantité de protéines contaminantes liées à la présence d'autres types cellulaires ou de plasma. Ceux-ci peuvent donner lieu à des conclusions erronées lors d'analyses comparatives, notamment lorsqu'on s'intéresse à des pathologies du globule rouge avec une augmentation compensatoire du taux de réticulocytes dans le sang. De plus, les quantifications publiées sont uniquement des quantifications relatives.

Nous proposons un protocole d'analyse protéomique de réticulocytes et de globules rouges hautement purifiés avec quantification absolue des protéines en nombre de copies par cellule. Pour cela, les globules rouges et réticulocytes sont tout d'abord purifiés par colonne de cellulose, gradient de percoll et tri FACS. Une partie des cellules est directement lysée en tampon SDS et l'autre partie est soumise à une purification de membranes (ghosts) afin notamment d'en retirer l'hémoglobine, avant lyse en tampon SDS. La digestion des protéines est ensuite réalisée sur FASP. Les peptides sont factionnés en 5 fractions sur phase SCX et analysés en nLC-MS/MS avec un gradient de $3 \mathrm{~h}$ par fraction. La quantification absolue est réalisée à partir des signaux MS des globines dont la quantité par globule rouge est connue. Les premières analyses ont permis la quantification absolue de près de 1000 protéines avec une bonne corrélation avec les données de la littérature.

Mots-Clés : Label free, globule rouge, quantification absolue

\footnotetext{
*Intervenant

${ }^{\dagger}$ Auteur correspondant: emilie-fleur.gautier@ parisdescartes.fr

$\ddagger$ Auteur correspondant: patrick.mayeux@inserm.fr
} 


\title{
On the Discovery of Biomarkers for River Blindness - Lipidomics, Metabolomics, Proteomics [P204]
}

\author{
Ruben T'kindt ${ }^{*}$, Ole Lagatie ${ }^{2}$, Lucie Jorge ${ }^{1}$, Alexia Ortiz ${ }^{1}$, Jonathan \\ Vandenbussche $^{1}$, Lieven Stuyver ${ }^{2}$, Koen Sandra ${ }^{\dagger}{ }^{1}$ \\ ${ }^{1}$ Research Institute for Chromatography (RIC) - Kennedypark 26 B-8500 Kortrijk, Belgique \\ 2 Janssen Diagnostics - Turnhoutseweg 30 Beerse, Belgique
}

River blindness (Onchocerciasis) is a parasitic infection caused by the filarial parasitic nematode Onchocerca volvulus which is transmitted to humans through the blackfly vector. Worldwide, approximately 37 million people suffer from the disease, and an estimated 89 million are at risk, mostly in poor, rural communities near streams and rivers in Africa. A diagnostic test is available but it has a limited sensitivity and moreover, it is indirect since it measures antibodies generated against worm proteins. This study aims at the discovery of novel biomarkers for Onchocerciasis disease management. Therefore, a large-scale omics based biomarker discovery study involving plasma and urine samples of 102 subjects was conducted. 72 patients with Onchocerca nodules and positive in the diagnostic test were included next to 20 non-endemic controls which were negative in the in the Onchocerciasis diagnostic test. A small group of lymphatic filariasis infected patients was included as a negative control. The quality of the discovery study was monitored by the repetitive injection of aliquots from a mixed pool of study samples.

Robust comprehensive mass spectrometric (MS) methods were applied that allow non-targeted omics based measurement of parasite derived molecules and simultaneously allow to assess host response. Various one and two-dimensional LC- and GC-MS based methodologies were used to cover the diverse physicochemical properties of the molecules under investigation being metabolites, lipids and proteins. Several biomarkers were detected that showed excellent discrimination between Onchocerca volvulus positive and negative individuals with high statistical significance.

Mots-Clés : Biomarker, omics, mass spectrometry, river blindness

$\underline{\text { Programme }}$

\footnotetext{
*Intervenant

†Auteur correspondant: koen.sandra@ richrom.com
} 


\title{
Applying a Proteoform profiling method for neurological disorder biomarker discovery [P205]
}

\author{
Pierre-Olivier Schmit $* \dagger 1$, Christophe Hirtz $*^{2}$, Jérôme Vialaret $* 2$, \\ Sylvain Lehmann ${ }_{-}^{\ddagger 2}$, Audrey Gabelle ${ }^{3}$ \\ ${ }^{1}$ Bruker Daltonique (Bruker) - Bruker France SAS - 34, rue de l'industrie, 67160 Wissembourg, France \\ 2 1- Laboratoire de Biochimie et Protéomique Clinique, Institut de Médecine Régénératrice et de Biothérapie \\ (LBPC-IMRB) - CHU Montpellier \\ Hôpital Gui de Chauliac, Montpellier. Université Montpellier I, Montpellier, F-34000 France \\ ${ }^{3}$ Centre Mémoire Ressources Recherche (CMRR) - CHU Montpellier - CHU Montpellier, hôpital Gui de \\ Chauliac, Montpellier. Université Montpellier I, Montpellier, F-34000 France
}

The low abundance Tau protein is routinely used as a molecular biomarker for Alzheimer's disease (AD) through the quantification of total Tau and of the phosphorylated Tau peptide. As this approach has specificity and accuracy, a targeted proteomics method has been developed to enable the direct quantification of the six Tau isoforms in CerebroSpinal Fluid (CSF). Discriminating the various Tau isoforms requires good sequence coverage; combined with the low abundance of the targeted isoforms and the overall CSF complexity, this constitutes an analytical challenge and might reduce the viability of the approach in a clinical environment.

As Top-Down approaches reveal isoform distribution patterns while removing the hassle and variability of the digestion step in bottom-up methods, we are developing a targeted top-down proteomics approach. The purpose of this approach will be to deliver information on the relative abundance of the various Tau isoforms while being compatible with the requirements of the routine clinical laboratory.

Methods: The Tau protein isoforms are enriched from CSF samples by using an automated immunoprecipitation (IP)procedure. A proteoform profiling approach that uses a state-of-the-art UHR-Q-TOF is then used to generate the isoform profiles.

Results: After optimization of the LC-MS profiling method to increase the detectability of the various Tau isoforms, the method has been used to optimize the IP procedure. A Tau standard spiked in CSF has been used to verify that the process was not altering the isoforms distribution ratio. The proteoforms of the tau ladder, ranging from 36 to $45 \mathrm{Kda}$, are easily separated by the method and the reproducibility of the isoform ratio determination has been evaluated, before evaluating the method on endogenous Tau isoforms in CSF

In this communication, we are presenting the reproducibility test results as well as the first results obtained from patient samples.

Mots-Clés : Proteoforms, Top, Down, Biomarkers

Programme

\footnotetext{
*Intervenant

${ }^{\dagger}$ Auteur correspondant: pierre-olivier.schmit@bruker.com

¥Auteur correspondant: Lehmann.sylvain@ gmail.com
} 


\title{
Label-free quantification of T-cell proteome in nephrotic syndrome [P206]
}

\author{
Cérina Chhuon * ${ }^{1}$, Guerrera Chiara ${ }^{1}$, Pauline Vachin ${ }^{2}$, Kelhia Sendeyo, \\ André Pawlak ${ }^{2}$, Djillali Sahali ${ }^{2}$, Mario Ollero ${ }^{2}$ \\ ${ }^{1}$ Plateforme Protéomique 3p5-Necker, Université Paris Descartes-Structure Fédérative de Recherche Necker, \\ INSERM US24/CNRS UMS3633 - INSERM, CNRS, Université Paris Descartes \\ 14 rue Maria Helena Vieira Da Silva, 75014 Paris, France \\ ${ }^{2}$ INSERM U955 - INSERM, Université Paris-Est Créteil Val-de-Marne (UPEC) - 94040 Créteil, France
}

\begin{abstract}
CMIP is overexpressed in lymphocytes of idiopathic nephrotic syndrome (INS) patients. To dissect its role in INS pathogenesis, we generated a transgenic mouse overexpressing CMIP in peripheral mature T-cells. We aimed to evaluate the impact of CMIP on T-cell proteome in basal and stimulating conditions.

T-cells from transgenic $(\mathrm{Tg})$ and control $(\mathrm{Wt})$ mice $(\mathrm{n}=3)$ were purified by negative immunoselection, and subjected to anti-CD3/anti-CD28 stimulation. At 0 and $60 \mathrm{~min}$ post-activation, total proteins were extracted, digested, and peptides analyzed by nano-RSLC Q-Exactive-Plus MS. Protein quantification was performed by label-free using MaxQuant and Perseus softwares on three parallel technical replicates per sample.

Forty-six proteins were found differentially expressed between $\mathrm{Tg}$ and $\mathrm{Wt}$ as a function of T-cell activation (two-way ANOVA interaction, $\mathrm{p}<0.05$ ). In basal conditions, 9 proteins were highly expressed in $\mathrm{Wt}$ while strongly downregulated in Tg, including proteins involved in lipid remodeling (Pla2g16, Pcyt2). In activated T-cells, 13 proteins were depleted in Wt but increased or unchanged in Tg, including proteins involved in the organization of actin cytoskeleton, like cofilin-1 (Cfl1), and nucleotide metabolism (Ckb, Nampt, Guk1). Ten proteins were significantly downregulated in Wt relatively to Tg in basal conditions, including proteins involved in lipid uptake and metabolism (Tmeme30a, Abhd6). Finally, 14 proteins were dramatically increased after stimulation in $\mathrm{Wt}$, but depleted in Tg, including Ikbke, Csnk2a2, Anxa1 and Acp6. Based on these findings, we further analyzed by WB the expression of Cfl1, linking immunological synapse and cytoskeleton dynamics. Inactive phosphorylated Cfl1 was dramatically increased in $\mathrm{Tg}$ at $60 \mathrm{~min}$ post-stimulation as compared to Wt. Likewise, Cfl1 was hyperphosphorylated in CMIPtransfected HEK cells, suggesting an association between CMIP overexpression and Cfl1 inactivation. In conclusion, CMIP overexpression exerts profound changes in protein expression following T-cell activation in mice. This involves, in part, an altered link between T-cell activation and cystoskeleton organization and dynamics.
\end{abstract}

Mots-Clés : Label, free, lymphocytes, syndrome néphrotique

$\underline{\text { Programme }}$

\footnotetext{
${ }^{*}$ Intervenant
} 


\title{
HILIC-HRMS-based metabolite profiling of cerebrospinal fluid for advanced polar metabolome coverage: drawing baseline in aged population without neurological disorder [P207]
}

\author{
Ioana Konz ${ }^{*}{ }^{1}$, Héctor Gallart-Ayala ${ }^{1}$, Tony Teav ${ }^{1}$, Florence Mehl ${ }^{1}$, \\ Aikaterini Oikonomidi ${ }^{2}$, Gwendoline Peyratout ${ }^{2}$, Hugues Henry ${ }^{3}$, \\ Julius Popp ${ }_{-}^{\dagger} 2$, Julijana Ivanisevic $\$ 1$ \\ ${ }^{1}$ Metabolomics Platform, Faculty of Biology and Medicine, University of Lausanne \\ Rue du Bugnon 19 CH-1005 Lausanne, Suisse \\ 2 Old Age Psychiatry, Department of Psychiatry, Lausanne University Hospital \\ Mont Paisible 16 CH-1011 Lausanne, Suisse \\ ${ }^{3}$ Clinical Chemistry Laboratory, Department of Biomedicine, Lausanne University Hospital \\ Rue du Bugnon 19 CH-1005 Lausanne, Suisse
}

Cerebrospinal fluid (CSF) is a key body fluid in maintaining the homeostasis in CNS metabolism by regulation of the electrolyte balance, transport of active molecules, and removal of catabolites. As a biofluid whose content reflects the brain metabolic activity, the CSF is commonly profiled in the context of neurological diseases for diagnosis and to provide novel insights into the disease mechanisms. However, the CSF metabolite profiling suffers from the lack of an optimized technique for high-throughput measurement of water soluble metabolome. Although still avoided due to reputation of being challenging and less reproducible, hydrophilic interaction liquid chromatography (HILIC) has significantly evolved to offer the unprecedented coverage capacity of water-soluble metabolome, as a robust and versatile alternative to derivatization-assisted GC-MS methods and not-MS compatible ion pairing RPLC. Here, we evaluate and demonstrate the performance of combined HILIC profiling in acidic and basic $\mathrm{pH}$ on a high resolution Q-TOF instrument in both ESI (+) and ESI (-) for unbiased analysis of CSF polar metabolome. This optimized workflow is used to analyze the population of aged individuals without neurological disease (age and gender matched, $\mathrm{n}=34$ ) and allowed us to cover a broad range of central carbon metabolites ( $\mathrm{n}>300$, including amino acids, acylcarnitines, glycolysis and TCA cycle intermediates, nucleotides, energy currency metabolites, etc.) from a single biological extract. We provide the evaluation of unique metabolite coverage in positive mode and in negative mode together with the method sustainability in terms of within and between batch reproducibility. In addition, the cohort of patients is explored to draw the baseline differences in the metabolite levels between men and women, and with regards to specific life-style parameters. This case study is a proof of principle of HILIC performance for high-throughput untargeted profiling of CSF for clinical evaluation in large-scale cohort studies.

Mots-Clés : Metabolomics, CSF, HILIC, HRMS

\section{Programme}

\footnotetext{
*Intervenant

${ }^{\dagger}$ Auteur correspondant: Julius.Popp@ chuv.ch

¥Auteur correspondant: Julijana.Ivanisevic@unil.ch
} 


\title{
Tspan15 is a new stemness-related marker in hepatocellular carcinoma [P208]
}

\author{
Nazha Sid Ahmed-Adrar * ${ }^{\dagger} 1$, Jean-François Ottavi ${ }^{1}$, Nassima Benzoubir ${ }^{1}$, \\ Taous Ait Saadi ${ }^{1}$, Mohamed Bou Saleh ${ }^{1}$, Philippe Mauduit ${ }^{2}$, Catherine \\ Guettier $^{3}$, Christophe Desterke ${ }^{4}$, François Le Naour $\stackrel{*}{*} 1$ \\ ${ }^{1}$ Unité 1193 - INSERM, Université Paris Sud - Paris XI - 14, Avenue Paul Couturier 94800 Villejuif, France \\ ${ }^{2}$ Unité 1197 - INSERM, Universtié Paris XI - 14, Avenue Paul vaillant Couturier 94800 Villejuif, France \\ ${ }^{3}$ Unité 1193 - INSERM, Université Paris Sud - Paris XI \\ 14, Avenue Paul Vaillant Couturier Villejuif, F-94800, France \\ ${ }^{4}$ UMS33 - INSERM, Université Paris XI - Paris Sud - 14, Avenue Paul Vaillant Couturier, France
}

\begin{abstract}
Hepatocellular carcinoma (HCC) is the second cause of cancer-related deaths worldwide and its incidence is still increasing. A clearer understanding of the molecular mechanisms underlying tumor growth and invasiveness remains crucial for the development of new therapies. Here, we have addressed the expression of tetraspanins, a family of plasma membrane organizers involved in the regulation of cell proliferation and migration. Integrative approaches combining transcriptomics and bioinformatics allowed demonstrating the induced and heterogeneous expression of Tspan15 in HCC. Tspan15 positive tumors exhibited the gene expression signatures related to HCC derived from hepatic progenitor cells as well as to early recurrence. Immunohistochemistry experiments were performed on normal liver $(n=6)$ and HCC $(n=42)$ from various aetiologies. On the normal liver, Tspan 15 was not detected on hepatocytes whereas a high expression was observed on cholangiocytes in biliary ducts. In HCC, Tspan 15 expression was confirmed only in the subset of HCC expressing stemness-related markers such as EpCAM and Cytokeratin-19. In addition, Tspan15 expression was significantly correlated with morphological criteria of macro-invasion. Functional networks based on the gene set expressed in correlation to Tspan 15 revealed that most of these genes support cell proliferation. Furthermore, Tspan 15 overexpression in the hepatoma cell line HepG2 significantly increased cell proliferation. A quantitative proteomic analysis of the secretome revealed a higher abundance of the protein Connective Tissue Growth Factor (CTGF) in HepG2/Tspan 15 cells as compared to the parental cells HepG2. Interestingly, CTGF is a pleiotropic matricellular signaling protein that has been involved in cell proliferation, adhesion, migration and ductular reaction. Proteomic profiling of Tspan 15 complexes allowed identifying numerous membrane proteins including several growth factor receptors. Finally, Tspan15 increased ERK1/2 phosphorylation that directly controlled CTGF expression and secretion. In conclusion, we established that Tspan 15 is a new stemness-related marker in HCC which exhibit high potential of tumor growth and recurrence.
\end{abstract}

Mots-Clés : Hepatocellular carcinoma, cancer stem cell, membrane proteins, integrative biology, SILAC

$\underline{\text { Programme }}$

\footnotetext{
*Intervenant

†Auteur correspondant: nazha.sid-ahmed-adrar@inserm.fr

¥Auteur correspondant: francois.le-naour@inserm.fr
} 


\title{
A two-step PRM strategy reveals a new biomarker signature of multiple sclerosis in cerebrospinal fluid [P209]
}

\author{
Philippe Marin*1 , Geoffrey Hinsinger ${ }^{1}$, Serge Urbach ${ }^{\dagger}{ }^{1}$, Oana Vigy ${ }^{1}$, \\ Sylvain Lehmann ${ }^{2}$, Martial Séveno $₫ 3$, Eric Thouvenot ${ }^{4}$ \\ ${ }^{1}$ Functional Proteomics Platform (FPP) - CNRS : UMR5203 - c/o Institut de Génomique Fonctionnelle (IGF), \\ CNRS, INSERM, 34094 Montpellier Cedex 5, France \\ 2 CHU de Montpellier - CHU Montpellier - 34295 Montpellier Cedex 5, France \\ ${ }^{3}$ Functional Proteomics Platform (FPP) - CNRS : UMS3426 - c/o Institut de Génomique Fonctionnelle (IGF), \\ CNRS, INSERM, 34094 Montpellier Cedex 5, France \\ ${ }^{4}$ CHU de Nîmes - CHU de Nimes - 30029 Nîmes Cedex 9, France
}

Background: Multiple sclerosis (MS) is an inflammatory disease characterized by an initial demyelinating event (CIS), followed by remission periods and relapses occurring at irregular intervals. Clinical symptoms and brain imaging allow diagnosis with a good sensitivity. However, there is still a need for prognostic biomarkers of conversion to MS and disease progression after a CIS. Using quantitative proteomics, we previously identified $\sim 60$ candidate MS biomarkers exhibiting differences in abundance in the cerebrospinal fluid (CSF) from patients with MS and symptomatic controls or from patients with rapid (2 years) conversion to MS after a CIS. These proteins were combined with previously described biomarker candidates to generate a list of 87 CSF proteins that were quantified by Parallel Reaction Monitoring (PRM) in different patient cohorts.

Methods: We implemented a two-step strategy consisting in i) monitoring all selected candidate biomarkers (226 peptides corresponding to the 87 proteins) in CSF samples from symptomatic controls and MS patients at different disease stages $(n=60)$; ii) verifying biomarkers that passed this qualification step (16 peptides corresponding to 12 proteins) in a new PRM assay using shorter gradient and high-purity, heavy isotope-labelled peptides (AQUA Ultimate, ThermoFisher), in a larger cohort $(\mathrm{n}=189)$ comprising patients with MS at different disease stages or with other inflammatory or non-inflammatory neurological disorders.

Results: These studies identified a combination of five biomarkers allowing i) positive diagnosis of MS at any disease stage, ii) discrimination between MS and the other inflammatory or non inflammatory neurological diseases and iii) prognosis of conversion to MS for patients with radiologically-isolated syndrome, a presymptomatic form of MS.

Conclusion: The identified biomarker signature may not only improve MS diagnosis and prognosis but also reveal new mechanisms underlying MS pathogenesis and new therapeutic targets for its management.

Mots-Clés : Multiple sclerosis, biomarker, cerebrospinal fluid, PRM

\footnotetext{
*Auteur correspondant: philippe.marin@igf.cnrs.fr

$\dagger$ Intervenant

¥Auteur correspondant: serge.urbach@fpp.cnrs.fr
} 
Modifications post-traductionnelles
[P210-P216] 


\title{
Reductive Di-methylation for Improvements of Mass Spectrometry Acetylation Identification [P210]
}

\author{
Issa Diallo ${ }^{1}$, Valérie Cunin ${ }^{1}$, Sylvie Michelland ${ }^{1}$, Frédéric Minassian ${ }^{2}$, \\ Jean-François Poisson ${ }^{2}$, Michel Seve ${ }^{1}$, Sandrine Bourgoin-Voillard ${ }^{* \dagger}{ }^{1}$ \\ ${ }^{1}$ LBFA et BEeSy, PROMETHEE Proteomic Platform, Grenoble, France - Université Grenoble Alpes, Centre de \\ Recherche INSERM, CHU Grenoble, Institut de Biologie et Pathologie \\ Boulevard La Chantourne, 38700 La Tronche France \\ 2 DCM, Grenoble, France - Université Grenoble Alpes, CNRS : UMR5250 - Université Grenoble Alpes \\ Bâtiment NanoBio Campus 570, rue de la Chimie BP 5338041 Grenoble Cedex 09 France
}

Protein acetylation is one of the most widespread post-translational modifications which is involved in many cellular physiologies and pathologies such as cancers. Regarding the important biological effect of protein acetylation and a non-negligible number of proteins bearing this PTM, several methods emerged last decade to investigate such PTM. But the detection of acetylations is still limited and target mostly one kind of acetylation (K-acetylation). Herein, we present a novel approach based on reductive di-methylation strategy to improve the detection of the three kind of acetylation: N-ter, $\mathrm{K}$ - and $\mathrm{O}-$ acetylations.

Yeast protein samples were digested with trypsin prior di-methylation of resulting peptide mixture. Then, di-methylated peptide mixtures were fractionated by OFFGEL and reverse phase liquid chromatography followed by MALDI-TOF/TOF mass spectrometry analysis. Data analysis was performed by using Mascot as search engines.

Our results showed that OFFGEL fractionation is a useful step to increase detection of acetylations. Indeed, when comparing an experiment without and an experiment with OFFGEL fractionation, the number of identified acetylated peptide without OFFGEL fractionation gave the 50 unique acetylated peptides while with OFFGEL fractionation we identified 157 unique acetylated peptides. Moreover, we showed that our di-methylation treatment improved significantly detection of acetylation. After dimethylation treatment, 445 unique acetylated peptides were identified while 185 unique acetylated peptides were detected without di-methylation treatment. The improvement of acetylation detection using our di-methylation strategy is observed for each of acetylations : N-ter, K- and O-acetylations. Thus, this new proteomic method is promising to enhance $\mathrm{N}$-ter, $\mathrm{K}$ - and $\mathrm{O}$-acetylation detection.

Mots-Clés : Acetylation, Posttranslational modification, Reductive dimethylation, Mass spectrometry

Programme

\footnotetext{
* Intervenant

${ }^{\dagger}$ Auteur correspondant: sandrine.bourgoin@univ-grenoble-alpes.fr
} 


\title{
Enhancing the vision of signal transduction using PTMScan $®$ affinity proteomics [P211]
}

\author{
Sriram Aravamudhan _ 1 \\ ${ }^{1}$ Cell Signaling Technology (CST) - Schuttersveld 2, 2316 ZA Leiden, Pays-Bas
}

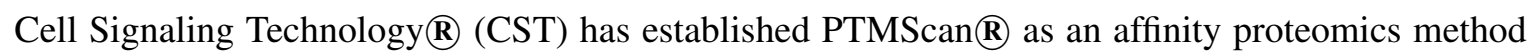
which employs validated PTM- and motif- specific antibodies developed by CST to enrich PTM contain-

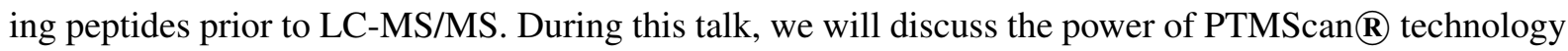
to profile and quantify even low abundant post-translational modifications that provide insights into signaling events in normal and disease biology, enabling a more focused enrichment of PTM peptides than the classical abundance-driven approaches like IMAC. We will begin with the principle and applications of PTMScan ß technology and then discuss the power of antibody-based enrichment in profiling post-translational modifications in cancer serum without immunodepletion, as a case study. Finally we

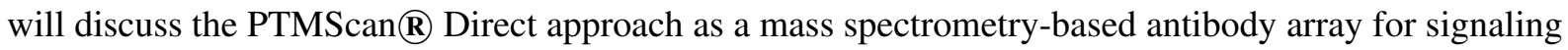
pathway enrichment.

Gu H, et al. (2016) Quantitative Profiling of Post-translational Modifications by Immunoaffinity Enrichment and LC-MS/MS in Cancer Serum without Immunodepletion. Mol. Cell Proteomics 15(2), 692-702.

Stokes M, et al. (2015) Complementary PTM Profiling of Drug Response in Human Gastric Carcinoma by Immunoaffinity and IMAC Methods with Total Proteome Analysis. Proteomes. 3(3), 160-183.

Stokes MP, et al. (2012) PTMScan direct: identification and quantification of peptides from critical signaling proteins by immunoaffinity enrichment coupled with LC-MS/MS. Mol. Cell Proteomics 11(5), 187-201.

Mots-Clés : PTMScan, post translational modifications, affinity proteomics, mass spectrometry, signal transduction

$\underline{\text { Programme }}$

\footnotetext{
*Intervenant
} 


\title{
Characterization of a disulfide bridge in LC-CDR3 of monoclonal antibody [P212]
}

\author{
Hélène Diemer * ${ }^{1}$, Elsa Wagner-Rousset ${ }^{2}$, Olivier Colas ${ }^{2}$, Alain Beck ${ }^{2}$, \\ Sarah Cianférani ${ }^{1}$ \\ ${ }^{1}$ Laboratoire de Spectrométrie de Masse BioOrganique (LSMBO) - Université de Strasbourg, IPHC, CNRS, \\ UMR 7178 - 25, rue Becquerel 67087 Strasbourg, France \\ ${ }^{2}$ Centre d'Immunologie Pierre Fabre (CIPF) - Institut de Recherche Pierre Fabre - 5 Av. Napoléon III BP 60497 \\ 74164 Saint-Julien-en-Genevois, France
}

Monoclonal antibodies have taken on an increasing importance for the treatment of various diseases including cancers, immunological disorders, and other pathologies. The Complementary-Determining Regions (CDRs) are a part of the variable sequence of the monoclonal antibody and are related to its antigen-binding specificity. Presence of cysteine residues in the CDRs is rare in human antibodies but may be critical for the antigen-binding (Almagro et al.) or deleterious for therapeutic antibody development (Beck et al.).

Here, we report the characterization by mass spectrometry of a disulphide bridge in CDR3 of a hzIgG4. This mAb contains two additional cysteines in CDR3 of the light chain: Cys91 and Cys100. In silico peptide mapping by trypsin provides two peptides T2 and T7 linked by a bridge between Cys 23 and Cys88. The mass of T2-T7 is more than $5 \mathrm{kDa}$. First, the presence of potential disulfide bridges in T2-T7 is checked by LC-MS after digestion by trypsin with or without reduction. As its mass is very high, the peptide is collected and digested by pepsin in order to reduce his mass. Then, the new short peptide T2-T7 is fragmented by CID or ETD in order to attribute the disulfide bridges between the four cysteines. All in all, the interpretation of the MS/MS spectra highlights the presence of a disulfide bridge in the CDR3 of the light chain.

Almagro JC, Raghunathan G, Beil E, Janecki DJ, Chen Q, Dinh T, LaCombe A, Connor J, Ware M, Kim PH, Swanson RV, Fransson J. Characterization of a high-affinity human antibody with a disulfide bridge in the third complementarity-determining region of the heavy chain. J Mol Recognit. 2012;25: 125-35.

Beck A, Wagner-Rousset E, Ayoub D, Van Dorsselaer A, Sanglier-Cianférani S. Characterization of therapeutic antibodies and related products. Anal Chem. 2013 Jan 15;85(2):715-36.

Mots-Clés : monoclonal antibody, disulfide bridge, CID, ETD

$\underline{\text { Programme }}$

${ }^{*}$ Intervenant 


\title{
Localisation des sites de O-GIcNAcylation des 'odorant-binding protein' par ESI-ETD-MS/MS [P213]
}

\author{
Patricia Nagnan-Le Meillour * ${ }^{1}$, Alexandre Joly ${ }^{2}$, Paul Cann ${ }^{2}$, Chrystelle Le \\ Danvic ${ }^{3}$, Séverine Zirah ${ }^{4}$ \\ ${ }^{1}$ Unité de Glycobiologie structurale et fonctionnelle - UMR 8576 CNRS/Univ. Lille1/USC INRA 1409 (UGSF) \\ - CNRS : UMR8576, Université Lille I - Sciences et technologies - Bâtiment C9 Cité Scientifique, avenue \\ Mendeleiev - 59655 Villeneuve d'Ascq cedex, France \\ ${ }^{2}$ Unité de Glycobiologie Structurale et Fonctionnelle, UMR 8576 CNRS/Univ. Lille1/USC INRA 1409 (UGSF) \\ - CNRS : UMR8576, Université des Sciences et Technologies de Lille - Lille I, INRA : USC1409 - Cité \\ Scientifique, avenue Mendeleiev - 59655 Villeneuve d'Ascq cedex, France \\ ${ }^{3}$ Unité de Glycobiologie Structurale et Fonctionnelle (ALLICE) - Allice - Cité Scientifique, avenue Mendeleiev \\ -59655 Villeneuve d'Ascq cedex, France \\ ${ }^{4}$ Muséum National d'Histoire Naturelle - UMR 7245 CNRS / MNHN (MNHN) - Muséum National d'Histoire \\ Naturelle (MNHN), CNRS : UMR7245 - 57 rue Cuvier (CP 54) - 75005 Paris, France
}

La $O$-b-N-acétylglucosaminylation ( $O$-GlcNAcylation) est une modification post-traductionnelle qui concerne de nombreuses protéines nucléaires, cytoplasmiques, mitochondriales et sécrétées. Elle consiste en l'ajout d'une N-acétylglucosamine (GlcNAc) sur les groupements hydroxyles des résidus de sérine et thréonine par une liaison $b$. Cette modification post-traductionnelle module la fonction des protéines, souvent en balance avec la phosphorylation. Bien que connue depuis 30 ans, sa caractérisation reste délicate, car le pourcentage d'isoformes $O$-GlcNAcylées est très faible, moindre que celui des isoformes de phosphorylation. De plus, le groupement GlcNAc est labile lorsque de hautes énergies de collision sont utilisées en spectrométrie de masse. Ainsi, la localisation des sites de $O$-GlcNAcylation est loin d'être triviale, et très peu d'équipes dans le monde sont capables de publier de telles données. Un état des lieux des différentes stratégies utilisées montre que l'utilisation d'une cellule de collision de type ETD (Electron Transfer Dissociation) après enrichissement des peptides issus de digestions enzymatiques (Bottom-Up), est la seule méthode efficace. Pour localiser les sites de $O$-GlcNAcylation des OBP porcines, nous avons procédé à différents enrichissements à partir de fractions HPLC, par Click-Chemistry et colonnes d'affinité (sWGA). Nous présenterons les résultats préliminaires obtenus par spectrométrie de masse ESI-ETD-MS/MS.

Mots-Clés : O, GlcNAc, OBP, ESI, ETD, MS/MS

Programme

*Intervenant 


\title{
Characterization of $\mathrm{N}$ - and $\mathrm{O}$-glycosylations of immunoglobulin IgA using NanoLC-MS/MS and Byonic software [P214]
}

\author{
Katell Bathany ${ }^{* \dagger}{ }^{1}$, Stéphane Claverol ${ }^{2}$, Christelle Oblet ${ }^{3}$, Jean-Claude \\ Aldigier $^{3}$, Anne Druilhe ${ }^{3}$, Marc Bonneu ${ }^{1,2}$, Jean-Marie Schmitter \\ ${ }^{1}$ Chimie et Biologie des Membranes et des Nanoobjets (CBMN) - CNRS : UMR5248, Université de Bordeaux, \\ Bordeaux INP - 146 rue Léo Saignat, 33076 Bordeaux, France \\ ${ }^{2}$ Plateforme Protéome du Centre Génomique Fonctionnelle Bordeaux (CGFB) - Université de Bordeaux - 146 \\ rue Léo Saignat 33076 Bordeaux, France \\ ${ }^{3}$ Contrôle de la Réponse Immune B et des Lymphoproliférations (CRIBL) - Université de Limoges, CNRS : \\ UMR7276 - 2 Rue du docteur Marcland 87025 LIMOGES cedex, France
}

Immunoglobulin A nephropathy (IgAN) the most frequent form of glomerulonephritis that affects about $1 \%$ of the world population is characterized by deposits of circulating polyclonal IgA1 in kidneys. The pathophysiology of IgAN is still poorly understood, but IgAN is putatively linked to abnormal glycosylation of circulating IgA1, and not to renal defects. Characterization of the heterogeneity of the $\mathrm{O}$-linked glycans in the hinge region of the IgA1 is fundamental for understanding the pathogenesis of the IgA nephropathy.

After purification of circulating IgA1 from plasma by affinity chromatography, a mass spectrometry strategy was set up to identify the glycome of the IgA1 hinge region: the reduction/ alkylation of the protein followed by the proteolytic cleavage with trypsin prior to mass analysis by MALDI-ToF-ToF (Ultraflex III, Bruker) and NanoLC-MS/MS (Orbitrap Fusion Lumos, Thermo Scientific).

The heavy chain of IgA1 has a short hinge region with $9 \mathrm{Ser} / \mathrm{Thr}$ residues that are potential O-glycosylation sites. MALDI-MS revealed the complex distribution of $\mathrm{O}-$ and $\mathrm{N}$-glycopeptides of IgA1. A detailed characterization of the micro-heterogeneity of these glycopeptides was undertaken by means of nanoLCMS/MS. Byonic software (Protein Metrics) was used to identify the light and heavy chains proteins and for MS/MS data processing. Byonic's internal tables containing the most common N- and O-linked glycan compositions were used, allowing several glycans per peptide. CID data did not allow identifying all possible O-glycans on the nine potential sites. Therefore, we used the HCD and ETD fragmentation modes to characterize aberrant IgA1 O-glycans. In order to find markers of IgA1 deposits and/or predictive of disease evolution, a full characterization of IgA1 glycoforms in healthy volunteers versus IgAN patients has been undertaken.

Mots-Clés : glycosylation, immunoglobulin

$\underline{\text { Programme }}$

\footnotetext{
* Intervenant

†Auteur correspondant: k.bathany@cbmn.u-bordeaux.fr

$¥$ Auteur correspondant: jm.schmitter@cbmn.u-bordeaux.fr
} 


\title{
E4F1-mediated control of pyruvate metabolism: impact on protein acetylation [P215]
}

\author{
Michela Di Michele *1, Eric Bonneil, Pierre Thibault, Matthieu Lacroix , \\ Laurent Le Cam
}

${ }^{1}$ Institut de Recherche en Cancérologie de Montpellier (IRCM) - INSERM U1194 - 208 rue des Apothicaires, 34298 Montpellier cedex 5, France

Our lab recently identified the multifunctional protein E4F1 as a crucial regulator of mitochondrial activity and pyruvate metabolism. More specifically, we found that E4F1 controls the expression of essential subunits and regulators of the pyruvate dehydrogenase (PDH) complex (PDC), a key metabolic enzyme that catalyzes the oxidative decarboxylation of pyruvate into Acetyl-Coenzyme A (AcCoA). In agreement with our findings, a homozygote mutation in the human E4F1 gene was recently identified in a family presenting clinical symptoms that resembles those of Leigh syndrome patients. The Leigh syndrome is a rare neurodegenerative disorder that results from mitochondrial defects in pyruvate metabolism or in the electron transport chain. We found that the metabolic reprogramming of E4F1/PDCdeficient cells associates with defects in the production of glucose-derived AcCoA, a key donor of acetyl groups used for protein acetylation. Preliminary data revealed that these cells display decreased protein acetylation, including that of histones. Our project aims at determining the acetylome of primary mouse adipocytes and neurons derived from E4fl knock-out animals using MS. Briefly, we will determine by LC-MS the acetylome of E4F1 deficient/proficient cells upon immunopurification of acetylated peptides using a mixture of anti-acetyl lysine antibodies with a special focus on histones. This should shed light on the epigenetic changes associated with impaired PDH activity that may translate into specific gene expression signatures. Potential candidates that are differentially acetylated in E4F1-deficient cells will be validated using our genetically engineered mouse models that display E4fI inactivation specifically in the central nervous system, skeletal muscles or adipose tissue. This work should improve our understanding of the molecular defects associated with PDH deficiency and may lead to the development of more efficient therapeutic strategies for Leigh syndrome patients.

Mots-Clés : Acetyl Coenzyme A, Acetylome, E4F1, Leigh syndrome, Mass Spectrometry, Pyruvate Dehydrogenase Complex

$\underline{\text { Programme }}$

*Intervenant 


\title{
Quantitative Analysis of Post Translational Modifications of Proteins: Data Mining and Interpretation [P216]
}

\author{
Giovanni Chiappetta ${ }^{* \dagger}{ }^{1}$, Shakir Shakir ${ }^{1}$, \\ Isabelle Rivals ${ }^{2}$, Joëlle Vinh $* \$ 1$ \\ ${ }^{1}$ ESPCI Paris, Spectrométrie de Masse Biologique et Protéomique. (SMBP) - PSL Research University, CNRS : \\ USR3149 - 10 rue Vauquelin, 75231 Paris Cedex 05, France \\ ${ }^{2}$ ESPCI Paris, Équipe de Statistique Appliquée, Neurophysiologie respiratoire expérimentale et clinique, \\ UMRS1158, Paris, France - PSL Research University, PSL Research University \\ 10 rue Vauquelin 75231 Paris cedex 05, France
}

\begin{abstract}
Relative quantification of Post-Translational Modifications (PTMs) is a complex issue in comparison with relative quantification of proteins. The information of fold change between modified peptides in two conditions is indeed a necessary but not sufficient condition to depict the post translational state of the protein. First the fold change observed for the modified peptides could result from the expression level variation of the associated protein itself. Second, even if the comparison of protein and modified peptide relative fold changes between two conditions could lead to find possible specific changes in the extent of a PTM, this approach provides partial and relative information only. Indeed, the estimation of relative variation of a PTM occurrence does not provide any information about the proportion of protein undergoing the PTM event. For example, measuring a significant 2-fold change of a given PTM could indicate major increase from $45 \%$ to $90 \%$ of modified protein or a slight variation from $0.1 \%$ to $0.2 \%$ of modified protein.

Since this information might be a key factor to address biological questions involving the role of PTMs in cell signaling, the concept of site occupancy was introduced (1). The PTM site occupancy is the proportion of the protein which is modified with this PTM. Mass spectrometry-based proteomics workflows could provide information about PTM site occupancy. However, conventional proteomics workflows do not provide a direct information for this complex estimation. The major risk is underestimating this difficulty, if we consider multiple modifications for example. With this contribution, we would like to review the pitfalls of PTMs quantification, and to open the discussion about some conceptual hypotheses that are found in the literature. We will illustrate this study with our revised pipeline for the quantitative PTM data mining and interpretation applied to various PTMs.
\end{abstract}

(1) Olsen et al. 2010, Sci.Signal. doi: 10.1126/scisignal.2000475.

Mots-Clés : Quantitative proteomics, site occupancy, peptides, proteins

\section{Programme}

\footnotetext{
*Intervenant

†Auteur correspondant: giovanni.chiappetta@espci.fr

¥Auteur correspondant: joelle.vinh@espci.fr
} 


\section{Méthodes de quantification ciblée [P217-P225]}




\title{
Improvement of specificity for multiplex mAbs DMPK triage studies using LC-MRM3 [P217]
}

\author{
Quentin Enjalbert* 1, Elsa Wagner ${ }^{2}$, Chloé Bardet ${ }^{1}$, \\ Alain Beck ${ }^{2}$, Tanguy Fortin ${ }^{1}$ \\ ${ }^{1}$ ANAQUANT - 5 rue de la Doua 69100 Villeurbanne, France \\ ${ }^{2}$ Pierre Fabre - 5 Avenue Napoléon III, 74160 Saint-Julien-en-Genevois, France
}

\begin{abstract}
Through the different development phase of new Biologics, quantitative analysis of mAbs in biological fluids is mainly conducted with ligand binding assays (LBAs). Ligand-binding-assays (LBAs), such as ELISA, offer a high degree of specificity, sensitivity and throughput. However, for pre-clinical phase, when dozens of putative new biologics are studied, specific and dedicated LBAs suffer from lengthy assay development. They also can be affected by matrix effect and are antibody dependent with poor multiplexing possibility. Over the past 10 years, Liquid chromatography-mass spectrometry coupling in Selected Reaction monitoring mode (LC-MS-SRM assays) have increased capacity and selectivity compared with LBAs. LC-MS-SRM is conducted to support data collection during pharmacokinetic (PK), pharmacodynamics (PD) or toxicokinetic(TK) studies. Meanwhile, R\&D strategies and development phases have to be performed with limited cost and time. Thus, one approach would consist in co-injecting several putative biologics within rodents and then comparing their PK properties in rodentbased triage study, with the objective to limit the number rodent animals used for the study. However, in pre-clinical studies, mAbs are mainly quantified in very complex matrices such as plasma or serum. To reach low sensitivity levels, heavy sample preparations are mainly developed to make less complex the sample matrix thanks to immune capture or precipitation. Heavy sample preparation can be time and money consuming. In this study, we investigate the use of a highly specific MRM3 method for the multiplexed quantitation of 5 FDA and EMA approved mAbs within a 20 min analysis directly in total serum. We reach sub $1 \mu \mathrm{g} / \mathrm{mL}$ on LOQ for the $5 \mathrm{mAbs}$.
\end{abstract}

Mots-Clés : mAbs, PKPD, DMPK, SRM, multiplex analysis

$\underline{\text { Programme }}$

${ }^{*}$ Intervenant 


\title{
Mise au point d'une méthode de quantification dans le sang de 3 plastifiants suspectés de jouer un rôle dans le déclenchement de certains cancers du sein par $\mu$-LLE suivie d'une analyse par UHPLC-MS/MS [P218]
}

\author{
Barbara Giroud * 1, Loïc Spinner * 1, Audrey Buleté ${ }^{1}$, Julie Deverchère ${ }^{2}$, \\ A $\overline{\text { rnaud Vigneron }}{ }^{2}$, Emmanuelle Vulliet $* \nmid 1$ \\ ${ }^{1}$ Institut des Sciences Analytiques (ISA) - CNRS : UMR5280, École Normale Supérieure (ENS) - Lyon, \\ Université Claude Bernard - Lyon I (UCBL) - 5 rue de la Doua, 69100 Villeurbanne, France \\ 2 Centre de Recherche en Cancérologie de Lyon (CRCL) - Centre Léon Bérard [Lyon], Université Claude \\ Bernard Lyon 1, INSERM : U1052, CNRS : UMR5286 \\ 28 rue Laennec, Bât. Cheney 69373 Cedex 08 Lyon, France
}

Les additifs plastiques largement utilisés dans les emballages alimentaires ou à usage pharmaceutique peuvent migrer dans leur contenu puis dans le corps humain. L'examen approfondi de l'exposition humaine et du risque sur le cancer associé n'ont jamais été réalisés. Le projet PLASTOC, soutenu par l'INSERM dans le cadre du plan Cancer, vise à étudier l'impact potentiel sur la santé humaine de trois additifs plastiques, le triphényl-phosphate (TPP), le diphénylphosphate (DPP), produit de dégradation du TPP et l'irgafos 168, choisis pour leurs capacités à modifier les réponses de facteurs de transcription AhR impliqués dans la réponse à certains xénobiotiques perturbateurs endocriniens sur des modèles de cellules mammaires.

L'étude de ces molécules représente un véritable défi analytique. Afin de quantifier ces composés à l'état de traces dans le sang de souris, organisme modèle dans les premières étapes du projet, une méthode basée sur une extraction liquide-liquide miniaturisée ( $\mu$ LLE) suivie d'une analyse par UHPLC-MS/MS a été développée et validée. Les seuils de détection et de quantification sont de l'ordre du $\mathrm{ng} / \mathrm{ml}$. La méthode appliquée à une pré-étude chronique afin de déterminer les concentrations résiduelles de ces plastifiants 1 heure après l'administration de différentes doses par intraveineuse et gavage oral ont montré des résultats similaires et confirment la dégradation de TPP en DPP. La sensibilité de la méthode permet de détecter le DPP dès 0,001mg de TPP administré.

Remerciements : INSERM pour le financement du projet PLASTOC (PLastic Additives Study Of the POtential risk for Cancer), PLAN CANCER 2014-2019

Mots-Clés : additifs plastiques, quantification, ultra, traces, sang

$\underline{\text { Programme }}$

\footnotetext{
*Intervenant

${ }^{\dagger}$ Auteur correspondant: emmanuelle.vulliet@isa-lyon.fr
} 


\title{
Quantification of therapeutic monoclonal antibody using ImmunoCapture coupled to Liquid Chromatography- High Resolution Mass Spectrometry (IC-LC-HRMS) [P219]
}

\author{
Pauline Bros $*^{* \dagger}$, Aline Cournut, Stéphane Muccio, Alain Roccon, Laurent \\ Vermet, Olivier Fedeli, Gilles Miscoria \\ ${ }^{1}$ Sanofi RD - SANOFI Recherche : Biomarkersand Clinical Bioanalyses - 371, Rue du Professeur Joseph \\ Blayac - 34184 Montpellier, France
}

In the pharmaceutical field, the development of therapeutic monoclonal antibodies (mAb) is drastically increasing in order to address new targets in inflammatory or oncology diseases. The quantification of these biologics is crucial to evaluate their pharmacokinetic and pharmacodynamic properties. Nowadays, mAbs are quantified using a Bottom Up approach. In this strategy, mAb is digested by trypsin enzyme into tryptic peptides, which are detected and quantified by Liquid Chromatography coupled with Mass Spectrometry High Resolution (LC-HRMS). The mAb of interest, called mAb1, is an IgG1 type immunoglobulin targeting a receptor located in blood cell membranes. In this work, our goal was to assess the benefits of human plasma purification using immunocapture (IC) versus raw plasma analysis. In Order to achieve this work, the first crucial step was the selection of specific tryptic peptides. After in silico prediction of potential tryptic peptides, and the evaluation of their uniqueness, in vitro Peptide Mapping and analysis of different human plasmas were performed. The result of this work was that 4 specific peptides were selected. At this step, two approaches were tested in order to quantify them: with or without ImmunoCapture (IC). With IC, the specific target of mAb1 was used to purify human plasma and concentrate only $\mathrm{mAb}$ of interest. In both cases, after tryptic digestion, extracts were analyzed using LC-HRMS. A Scheduled Parallel Reaction Monitoring (PRM) method was created in order to increase sensitivity. Compared to direct analysis, IC improved sensitivity and specificity resulting in a lower limit of quantification. The combination of IC and LC-HRMS is an efficient way to quantify $\mathrm{mAb}$ at $\mathrm{ng} / \mathrm{mL}$ level. This robust IC method could be used in routine during clinical assays to support the development of $\mathrm{mAb}$ and would give new perspectives in isotyping experiments.

Mots-Clés : quantification, monoclonal antibody, LC, HRMS, immunocapture

$\underline{\text { Programme }}$

\footnotetext{
*Intervenant

†Auteur correspondant: pauline.bros@sanofi.com
} 


\title{
Ancient tooth proteomes [P220]
}

\author{
Carine Froment ${ }^{* \dagger}{ }^{1}$, Mathilde Hourset ${ }^{2}$, Nancy Saenz ${ }^{2}$, Claire Willmann ${ }^{2}$, \\ Alexandre Stella ${ }^{\top}$, Emmanuelle Mouton-Barbosa ${ }^{1}$, Clément Zanolli ${ }^{2}$, Rémi \\ Esclassan ${ }^{2,3}$, Catherine Thèves ${ }^{2}$, Odile Burlet-Schiltz ${ }^{1}$, Catherine \\ Mollereau-Manauté_ 2
}

\footnotetext{
${ }^{1}$ Institut de Pharmacologie et Biologie Structurale (IPBS), UMR5089 CNRS - Université de Toulouse (IPBS) - CNRS :

UMR5089 - 205 route de Narbonne, 31077 Toulouse, France

${ }^{2}$ Laboratoire d'Anthropologie Moléculaire et Imagerie de Synthèse (AMIS), UMR5288 CNRS - Université de Toulouse

(AMIS) - CNRS : UMR5288 - 37 allées Jules Guesde, 31073 Toulouse Cedex 3, France

${ }^{3}$ Faculté de chirurgie dentaire de Toulouse - Université Paul Sabatier - Toulouse III 3 Chemin des Maraîchers, Toulouse, France
}

Teeth are a remarkable source of information in paleoanthropological research. Investigation of ancient dental proteomes has the potential to provide complementary biomolecular data such as sex and taxonomic determination, phenotype and disease marker identification, or diet composition, that are essential to understand morphostructural signatures of fossils remains and to get insight on human phylogeny and ancient physiopathology.

In the frame of setting up paleoproteomic approaches, human teeth from different archeological periods (present-day to Neolithic) and geographical areas have been compared and analyzed by online nanoflow liquid chromatography coupled to tandem mass spectrometry (nanoLC-MS/MS) using Q Exactive $\mathrm{e}^{\mathrm{TM}}$ Plus and Orbitrap Fusion ${ }^{\mathrm{TM}}$ Tribrid $^{\mathrm{TM}}$ mass spectrometers. At each step, protocols and procedures have been adapted to the particular case of ancient samples, i.e. low content proteins and contamination by modern or environmental materials, by careful manipulation in cleanrooms and by insertion of appropriate blank controls. The degraded and modified proteins are another major issue. Therefore, a protein identification workflow using iterative searches with home-build protein databases and Proteome DiscovererTM software has been optimized to take into account the high events of modifications (deamination, oxidation, carbamoylation) and missed cleavages as well as the non-tryptic and the variant peptides containing diagenetic amino-acid substitutions.

Among the proteins identified in dental tissues, some of them such as amelogenin, ameloblastin, enamelin, amelotin, dentin sialophosphoprotein, are very specific to enamel or dentin, ensuring therefore the reliability of the analyzed samples. In addition, the detection of the two forms of amelogenin encoded by the chromosomes X (AMELX) and Y (AMELY) potentially offers the opportunity to characterize male specimens, an essential information for paleoanthropologists when confronted to sexual dimorphism. For this purpose, PRM-based targeted mass spectrometry approaches have been implemented to systematically and precisely detect and identify the sex discrimination peptides of amelogenin as well as quantify them.

Mots-Clés : Paleoproteomics, Database iterative searches, Tooth, Palaeoanthropology

\footnotetext{
* Intervenant

$\dagger$ Auteur correspondant: carine.froment@ipbs.fr

¥Auteur correspondant: catherine.mollereau-manaute@ipbs.fr
} 


\title{
Extraction à l'eau subcritique des composés phénoliques de deux espèces du genre Glebionis de Corse [P221]
}

\author{
Marion Brunel*1, Franck Renucci ${ }_{-}^{\dagger}$, Jean Costa ${ }_{-}^{\ddagger}$, \\ Xavier Vitrac ${ }_{-}^{\S}$, Alain Muselli ${ }_{-}^{\text {If }} 1$ \\ ${ }^{1}$ Université de Corse, UMR-CNRS 6134 SPE, Laboratoire Chimie des Produits Naturels - Université de Corse - \\ Campus Grimaldi, BP 52, 20250 Corte, France \\ ${ }^{2}$ Laboratoire PHENOBIO SAS - Laboratoire PHENOBIO SAS - Centre Montesquieu, 1 Allée Jean Rostand, \\ 33650 Martillac, France
}

A l'instar de l'éco-extraction, le procédé utilisant l'eau à l'état subcritique (ESC) est une méthode innovante et prometteuse pour l'extraction de produits naturels à partir de végétaux. Dans cette étude, nous nous sommes intéressés à deux espèces du genre Glebionis poussant à l'état spontané en Corse : G. coronaria et $G$. segetum. Considérées comme plantes messicoles, elles sont abondantes en région Corse et les produits transformés qui en sont issus pourraient trouver des applications dans le secteur de la cosmétique. Notre travail visait l'étude de la composition chimique des extraits préparés à l'eau subcritique à partir des parties aériennes des deux espèces. La caractérisation qualitative et quantitative des composés phénoliques a été réalisée par une approche ciblée en mode MRM par Chromatographie Liquide/Spectrométrie de masse en tandem (LC-MS/MS). L'activité antioxydante des extraits a également été évaluée par des tests spectrophotométriques (ORAC et DPPH). Parmi les composés phénoliques identifiés dans les extraits ESC, on retrouve principalement des acides caféylquiniques (acide chlorogénique, acide 4,5-di-O-caféylquinique) et des flavonoïdes tels que le kaempérol-7-O-glucoside. Les extraits de G. segetum sont particulièrement marqués par la présence d'herniarine, une coumarine simple. L'identification de ces composés illustre l'apport de la chimie comme outil taxonomique utile à la classification plutôt controversée des deux espèces.

Mots-Clés : Glebionis coronaria, Glebionis segetum, extraction eau subcritique, LC, MS/SM, acides caféylquiniques, coumarine

Programme

\footnotetext{
*Auteur correspondant: marionbrunel.mb@gmail.com

† Auteur correspondant: $\overline{\text { franck.renucci@univ-corse.fr }}$

$¥$ Auteur correspondant: costa@ univ-corse.fr

$\S$ Auteur correspondant: xavier.vitrac@phenobio.fr

IIntervenant
} 


\title{
Analysis of chlorogenic acids profile in green coffee leaves by liquid chromatography coupled to an electrochemical detector [P222]
}

\author{
Rocio Rodríguez-Gómez ${ }^{1}$, Bastien Dauvergne ${ }^{* \dagger}{ }^{1}$, Florence Souard, \\ Caroline Stévigny, Piet Stoffelen , \\ Kris De Braekeleer ${ }^{1}$, Jean-Michel Kauffmann ${ }^{1}$ \\ ${ }^{1}$ Chimie analytique instrumentale et bioéléctrochimie \\ 151 boulevard du triomphe, 1050 Ixelles, Belgique
}

Coffee is a beverage widely consumed in the world. The coffee species most commercialized worldwide are Coffea arabica and Coffea canephora. Coffee beans contain several antioxidants, mainly the chlorogenic acids (CQA = caffeoylquinic acids) [1]. In the present work, we developed a liquid chromatography-electrochemical detection (LC-EC) method for the analysis of three main chlorogenic acids isomers, 5-, 4- and 3- CQA, (Neochlorogenic acid, 5-CQA, Cryptochlorogenic acid, 4-CQA and Chlorogenic acid, 3-CQA) in coffee leaves. Samples from eight coffee species Coffea arabica, canephora, liberica, humilis, mannii, charrieriana, anthonyi and liberica var. liberica were collected. Aqueous extracts have been analysed. Linearity of the calibration graphs was observed in the range LOQ-10-5 M with R2 equal to $99.9 \%$ in all cases. The limits of detections were 1.0 x10-8 M for 3-CQA and 5-CQA and 2.0 x 10-8 M for 4-CQA. Differences in the chlorogenic acids profile between the samples harvested of each Coffea in tropical greenhouses in January and July were studied. The samples were extracted in triplicate and injected three times. Obtained raw data were processed using multivariate statistical analysis (Principal Component Analysis, PCA). According to the results high differences between two groups of Coffea were found. The Coffea liberica and liberica var. liberica contained the highest amount of chlorogenic acids mainly 3- and 4-O-CQA. Also differences between January and July were remarked. In July, the amount of chlorogenic acids increased more than twice compared to January. The concentrations of CQAs ranged from 5.3 to $49.6 \mathrm{mg} \mathrm{g}-1$ (January) and from 12.7 to $106.3 \mathrm{mg}$ g-1 (July). The others Coffea species contained a lower amount of chlorogenic acid. C mannii contains very low concentration in chlorogenic acids.

Mots-Clés : coffe, chlorogenic acid, LC, EC

$\underline{\text { Programme }}$

\footnotetext{
*Intervenant

${ }^{\dagger}$ Auteur correspondant: bastien.dauvergne@ulb.ac.be
} 


\title{
Étude du mécanisme de rétrocontrôle négatif dans la transmission du message nociceptif : Dosage de la sérotonine et du GABA par microdialyse spinale suite à l'injection d'antalgiques [P223]
}

\author{
Jeremy Pinguet ${ }^{*} 1,2$, Roberto Cadeddu ${ }^{2}$, Christophe Mallet ${ }^{2}$, \\ Alain Eschalier ${ }^{2}$, Christine Courteix ${ }^{2}$, Damien Richard ${ }^{1,2}$ \\ ${ }^{1}$ CHU Clermont-Ferrand, Service de Pharmacologie Médicale - CHU Clermont-Ferrand, Service de \\ Pharmacologie Médicale, F-63003 Clermont-Ferrand, France \\ ${ }^{2}$ Neuro-Dol INSERM 1107 (Neuro-Dol) - INSERM : U1107, Université Clermont Auvergne - Université \\ d'Auvergne Place Henri Dunant - 63001 Clermont-Ferrand, France
}

La régulation de la transmission du message nociceptif passe, entre autre, par les voies descendantes bulbo-spinales. L'utilisation empirique de la fluoxétine (antidépresseur inhibiteur sélectif de la recapture de la sérotonine) est objectivée à l'aide d'une étude cinétique des concentrations de l'acide $\gamma$-aminobutyrique (GABA), de la sérotonine (5-hydroxytryptamine, 5-HT) et de son métabolite principal, l'acide 5-hydroxyindolacétique (5-HIAA) à partir de prélèvements spinaux de microdialyse sur des animaux douloureux vigiles. Les microprélèvements de microdialyse ont ensuite été analysés par LC/LMS/MS. Pour cela, des étapes de préparation des échantillons associant une dérivation par le 5Nsuccinimidoxy-5-oxopentyl) triphenylphosphonium bromide (SPTPP) suivie d'une préconcentration et d'un dessalage en ligne ont été optimisées. Couplée à une analyse chromatographique et un spectromètre de masse (5500Qtrap, Sciex), cette méthode permet d'atteindre des limites de quantification compatibles avec les concentrations basales de ses neurotransmetteurs au niveau spinal ; soit de $5 \mathrm{pg} / \mathrm{mL}, 0.1 \mathrm{ng} / \mathrm{mL}$ et $0.5 \mathrm{ng} / \mathrm{mL}$ pour la 5 -HT, le GABA et le 5 -HIAA respectivement. Cette méthode robuste, sensible et spécifique permet l'étude chez l'animal vigile du suivi cinétique des concentrations simultanées de ces médiateurs après administration de fluoxétine (molécule de référence) ainsi que d'autres médicaments antalgiques (ex : le paracétamol). L'association des techniques de microdialyse spinale avec une analyse multiparamétrique par LC/MS/MS des médiateurs endogènes permet d'apporter la preuve des voies mécanistiques de régulation et des mécanismes d'action de certains antalgiques sur des modèles animaux douloureux. Cette connaissance physiopathologique ouvre la porte à l'utilisation de nouvelles thérapeutiques antalgiques qui pourront être extrapolées aux pathologies humaines.

Mots-Clés : quantification, microdialyse, sérotonine, GABA, nociceptif, antalgiques

$\underline{\text { Programme }}$

${ }^{*}$ Intervenant 


\title{
Quantitative profiling of endogenous polar metabolites from low volumes of blood samples [P224]
}

\author{
Miranda Kok ${ }^{* \dagger}{ }^{1}$, Marianne Fillet ${ }^{1}$ \\ ${ }^{1}$ Laboratory for the Analysis of Medicines, University of Liège \\ Avenue Hippocrate 15, 4000 Liège, Belgique
}

The etiology of many diseases is not yet completely understood. The involved biological processes might be resolved using a metabolomics approach, because metabolomics provides unique challenging opportunities to correlate the metabolome with a physiological or pathophysiological status and provides a vision on the relationships between genes, gene expression, environment and lifestyle.

Here, we present the development of two ultra-high performance liquid chromatography (UHPLC) methods coupled to mass spectrometry (MS) for the separation and quantitation of polar metabolites in blood samples. A reversed-phase UHPLC-MS/MS method has been developed to quantify anionic energetic metabolites, whereas hydrophilic interaction chromatography (HILIC)-MS/MS has been used to determine amino acids. Two sample pretreatment procedures have been developed for an optimal recovery of the respective metabolites from whole blood samples. One method involved the precipitation of proteins with acetonitrile and acids. In addition, volumetric absorptive microsampling has been used for the sample preparation. Small and accurate quantities of biological fluids (10 or $20 \mu \mathrm{L})$ can be collected with this sampling technique, which is of great interest for volume-limited samples or serial collection of samples.

The developed methods have been validated and will be applied to determine differences in metabolite concentrations between plasma samples from patients and controls. This can lead to a breakthrough in the understanding of diseases and can open new therapeutic perspectives.

Mots-Clés : Quantitative profiling, polar metabolites, ultra high performance liquid chromatography, mass spectrometry, volumetric absorptive microsampling

$\underline{\text { Programme }}$

\footnotetext{
*Intervenant

†Auteur correspondant: miranda.kok@ulg.ac.be
} 


\title{
A generic steroidomic approach: analysing steroid perturbations in serum using a workflow combining untargeted and targeted metabolomics methods with automated annotation [P225]
}

\author{
Arnaud Garcia ${ }^{* \dagger}{ }^{1}$, Emilie Reginato ${ }^{1,2}$, Isabelle Stevant ${ }^{3}$, Randazzo \\ Giuseppe Marco ${ }^{1}$, Julien Boccard ${ }^{2,1}$, Serge Nef $_{-}^{\ddagger}$, Serge Rudaz ${ }^{1,2}$ \\ ${ }^{1}$ Section des Sciences Pharmaceutiques - University of Geneva, \\ 1 Rue Michel Servet, 1211 Genève 4 -, Suisse \\ ${ }^{2}$ Swiss Center of Applied Human Toxicology (SCAHT) - University of Basel, Suisse \\ ${ }^{3}$ Department of Genetic Medecine Development - University of Geneva, \\ 1 Rue Michel Servet, 1211 Genève 4, Suisse
}

\begin{abstract}
Dysregulation in steroids is implied in numerous health problems ranging from cancer to endocrine disruption; a generic monitoring method would facilitate diagnostics and generate more exhaustive information about steroids content in a biological object. Routine in steroids analysis is originally achieved using GC-MS, or immunoassays (IA) techniques. However, IA results are often prone to cross-reactivity issues, while GC-MS is limited by the mandatory derivatisation of steroids which reduces throughput and full coverage of steroids. LC-MS can nowadays overcome these hurdles and provide robust results. In this study mice were injected with Human Chorionic Gonadotropin to stimulate testosterone production, and compared with control mice injected with $\mathrm{NaCl}$. After sacrifice, serum were spiked with deuterated standards and were extracted using SLE and analysed using a 16.8 min gradient of increasing $\mathrm{ACN}$ in $\mathrm{H} 2 \mathrm{O}$ and a $15 \mathrm{~cm}$ Kinetex $\mathrm{C} 18$ column. The UHPLC was hyphenated to a Q-Exactive Focus, a hybrid quadrupole Orbitrap MS, in sequential Full Scan - SIM acquisition mode.

The untargeted analysis was performed with Full scan data processed with Progenesis thanks to a new dynamic steroids database based on retention time compound annotation. Retention time are predicted for any gradient conditions at fixed temperature, stationary phase and mobile phase type using linear solvent strength theory (LSS) parameters. The database facilitates level 2+ and 2 annotations, obtained by recalculating retention times from experimental data and by predicting LSS parameters using a QSRR model, respectively.

SIM data were processed with the Quan Browser software from Thermo and quantified using the isotope dilution quantification method. The Q-Exactive allows enhanced selectivity of ions through the SIM mode while the Orbitrap detector displays high resolution mass spectra, leading to stronger identification and more accurate quantification.

This combined workflow is intended to provide quantitative and qualitative data from the same experiments and in optimized time conditions.
\end{abstract}

Mots-Clés : Steroidomics, Mouse, Orbitrap, automated annotation, untargeted, targeted

\footnotetext{
*Intervenant

†Auteur correspondant: Arnaud.Garcia@unige.ch

¥Auteur correspondant: Serge.Nef@unige.ch
} 


\section{Lipidomique [P226-P234]}




\title{
Development of a LC-MS-based method for quantifying alkyl hydroxycinnamates [P226]
}

\author{
Pierre Van Delft ${ }^{1,2}$, Camille Delude ${ }^{2}$, \\ Frédéric Domergue ${ }^{2}$, Laetitia Fouillen * 1,2
}

\begin{abstract}
${ }^{1}$ Plateforme Métabolome Bordeaux (PMB-MetaboHUB) - CNRS : UMR5200, Université de Bordeaux - Centre INRA de Bordeaux-Aquitaine, IBVM, CS 20032, 33140 Villenave d'Ornon, France

${ }^{2}$ Laboratoire de biogenèse membranaire (LBM) - CNRS : UMR5200, Université de Bordeaux - Bâtiment A3 INRA Bordeaux Aquitaine, 71 Avenue Edouard Bourlaux, CS 20032, 33140 Villenave d'Ornon, France
\end{abstract}

Suberin is a complex hydrophobic polymer that acts as a barrier controlling water and solute fluxes and restricting pathogen infections. Suberin is a complex heteropolymer made up of aliphatics, phenolics, and glycerol. Some of the fatty alcohols not covalently linked to the suberin polymer are in the form of alkyl hydroxycinnamates (AHCs): alkyl caffeates, alkyl coumarate and alkyl ferulate.

Fatty alcohols, hydroxycinnamic acids and AHC are typically analyzed by GC-MS. However, AHC quantification is not very sensitive. We therefore developed a more sensitive method with LC-MS in positive MRM mode for AHC absolute quantification. The dynamic range of concentration and detection limit obtained by our LC-MS method are 2 to 3 times better than with the classical GC-MS method.

We applied this method to Arabidopsis roots and showed that soluble fatty alcohols not extracted by rapid dipping in chloroform are predominantly in the form of alkyl caffeates and therefore represent suberin-associated waxes

Mots-Clés : LC/MS, Lipid, Suberin

$\underline{\text { Programme }}$

${ }^{*}$ Intervenant 


\title{
Method development for lipidomic approaches using supercritical fluid chromatography coupled to high resolution mass spectrometry [P227]
}

\author{
Carlos Rincon Aguilar* 1, Laurent Laboureur ${ }^{1}$, \\ Benoit Colsch ${ }^{2}, \bar{D}_{\text {David Touboul }}^{\dagger} 1$ \\ ${ }^{1}$ Institut de Chimie des Substances Naturelles (CNRS-ICSN) - CNRS : UPR2301 - ICSN, CNRS UPR2301, \\ Université Paris-Sud, Université Paris-Saclay, Avenue de la Terrasse, 91198 Gif-sur-Yvette, France \\ ${ }^{2}$ Laboratoire d'Etude du Métabolisme des Médicaments - CEA - Saclay, France
}

This study aims to develop a rapid and efficient analytical method for detecting several classes of lipids in human blood plasma using supercritical fluid chromatography coupled to high resolution mass spectrometry (SFC-HRMS). Lipid separation is performed using an Agilent 1260 Infinity Analytical SFC system equipped with an Electrospray Dual Jet Stream (ESI JS) ion source, and coupled to a Q-TOF 6540 Quadrupole-Time-of-Flight mass analyzer from Agilent. A two steps workflow is proposed. First, the best chromatographic conditions are investigated to obtain a separation of lipids by classes. Second, a modification of the hyphenation interface is proposed to reduce extra-column dead volumes and improve the response. The separation was carried out with a column ACQUITY UPC2 Torus DEA functionalized with a propyloxy bridge and a 1-(diethylamino)2-hydroxypropyl group at the end, and a mixture of methanol/isopropanol/water/ammonium acetate as a modifier. The identification was performed according to retention times and high resolution mass spectra in both positive and negative ionization of standards from each lipid class. Optimized conditions give access to the separation of eight lipids classes from polar to nonpolar ones in 10 minutes of analysis, comprising four main families of lipids: glycerolipids, glycerophospholipids, sphingolipids, and sterols. The modification of the interface using a splitter allows obtaining peaks with an increase of chromatographic resolution by factor of 2 without the loss of sensitivity. In addition, the new interface led to the separation of 1,2 and 1,3-diglycerides. This SFC-HRMS method could contribute to the discovery of lipid biomarkers in various metabolic diseases.

Mots-Clés : Supercritical fluid chromatography, High resolution mass spectrometry, Lipids determination, Hyphenation interface

$\underline{\text { Programme }}$

\footnotetext{
*Intervenant

${ }^{\dagger}$ Auteur correspondant: david.touboul@icsn.cnrs-gif.fr
} 


\title{
Development of lipidomic profiling by SFC-HRMS [P228]
}

\author{
Pauline Le Faouder ${ }^{*}$, Sarah Guez ${ }^{1}$, Marion Regnier ${ }^{2}$, \\ Hervé Guillou ${ }^{2}$, Justine Bertrand-Michel ${ }^{1}$
}

\footnotetext{
${ }^{1}$ Institut des Maladies Métaboliques et Cardiovasculaires (I2MC) - Université Paul Sabatier - Toulouse 3, Hôpital de Rangueil, INSERM : U1048 - 1 avenue du Prof Jean Poulhes - BP 84225 - 31432 Toulouse Cedex 4, France

2 ToxAlim (ToxAlim) - Institut National Polytechnique [Toulouse], INRA : UMR1331, Université Paul Sabatier Toulouse 3, Ecole Nationale Vétérinaire de Toulouse - 23 ch. Capelles 31076 Toulouse, France
}

Lipids are essential cellular constituents that have many critical roles in physiological functions. They are involved in energy storage, cell signaling as second messengers, and are major constituents of cell membranes including lipid rafts (1). Their crucial role is highlighted by their involvement in a large number of heterogeneous diseases such as cancer, diabetes, neurological disorders and inherited metabolic diseases $(2,3)$.

Due to the high structural diversity of lipid species arising from various combinations of fatty acyls and functional headgroups, the presence of isomeric and isobaric lipid species and their occurrence at a large concentration scale, a complete lipidomic profiling of biological matrices remains a challenge. In this context, the aim of our study presented in this poster is to develop an untargeted lipidomic approach by using supercritical fluid chromatography high resolution mass spectrometry to be able to propose a relative quantification of main lipids class in various biological sample.

To develop the method, the optimization of the separation and the detection of lipid species were performed on pure standards and then on liver lipid extract from 12-weeks-old C57BL6/J mice exposed to a control or an HFD (60\% lipids in the diet) during 14 weeks. These analyses allowed the building of a homemade lipid data bank. An automatic process was then developed to produce the relative quantification of lipids species belonging to the 6 main class of lipids. The optimization of this method will be present with the first results obtained on liver disease model.

(1) Simons, K., \& Toomre, D. (2000). Nature Reviews Molecular Cell Biology, 1(1), 1-39.

(2) Wenk, M. (2005). Nature Reviews Drug Discovery, 4(9), 594-610.

(3) Lamari, F., (2013). Journal of Inherited Metabolic Disease, 36(3), 411-425.

Mots-Clés : lipidomic profiling, SFC, HRMS

$\underline{\text { Programme }}$

${ }^{*}$ Intervenant 


\title{
Caracterisation du processus de démyelinisation accompagnant un traumatisme cranien chez la souris : étude du lipidome du corps calleux par UHPLC-HRMS [P229]
}

\author{
Anne Regazzetti *1, Toufik Taib ${ }^{2}$, Dominique Lerouet ${ }^{2}$, Bérard Coqueran ${ }^{2}$, \\ Catherine Marchand-Leroux ${ }^{2}$, Valérie Besson ${ }^{2}$, \\ Nicolas Auzeil $* \nmid 1$, Olivier Laprévote ${ }^{1}$ \\ ${ }^{1}$ Université Paris Descartes Université Sorbonne Paris Cité, Paris, France - CNRS : UMR8638 équipe Chimie - \\ Toxicologie Analytique et Cellulaire - Faculté de pharmacie de Paris \\ 4 avenue de l'Observatoire 75006 PARIS, France \\ ${ }^{2}$ Université Paris Descartes Université Sorbonne Paris Cité, Paris, France - EA4475 - Pharmacologie de la \\ Circulation Cérébrale - Faculté de pharmacie de Paris \\ 4 avenue de l'Observatoire 75006 PARIS, France
}

Le traumatisme crânien s'accompagne d'altérations au niveau de la substance blanche. On observe en particulier une démyélinisation liée à la mort des oligodendrocytes, les cellules responsables de la production de myéline. La myéline est majoritairement constituée de lipides. Afin d'évaluer si les modifications du lipidome sont un reflet du processus de démyélinisation une étude a été menée pour caractériser chez la souris l'effet d'un traumatisme crânien sur le lipidome du corps calleux.

Les lipides ont été extraits à partir d'un homogénat de corps calleux prélevé chez des souris Black 6 $(n=12)$ trois et sept jours après induction d'un traumatisme crânien. Les extraits lipidiques de corps calleux prélevés chez des souris non traumatisées $(n=12)$ ont été utilisés comme contrôles. L'analyse lipidomique a été réalisée par UHPLC couplée à la spectrométrie de masse haute résolution. Après retraitement des données obtenues, des analyses statistiques multivariées ont permis de mettre en évidence des changements marqués concernant plusieurs familles de lipides. Ainsi, on observe chez les souris traumatisées entre autre la diminution de glycérophospholipides (phosphatidylacides, phosphatidylcholines, phosphatidyléthanolamines, phosphatidylglycérols, phosphatidylinositols, phosphatidylsérines), céramides, glycérolipides et sphingomyélines. On constate chez ces mêmes souris la forte augmentation de certains cholestérylesters.

Nos résultats font apparaitre de profonds changements du profil lipidique affectant le corps calleux à la suite d'un traumatisme crânien en faveur d'un processus de démyélinisation.

Mots-Clés : traumatisme crânien, corps calleux, myéline, analyse lipidomique, UHPLC, HRMS, démyélinisation.

Programme

\footnotetext{
${ }^{*}$ Intervenant

${ }^{\dagger}$ Auteur correspondant: nicolas.auzeil@ parisdescartes.fr
} 


\title{
Toxicité de l'oxaliplatine et démyelinisation : analyse lipidomique par UHPLC-HRMS dans un modele de cellule de Schwann [P230]
}

\author{
Pauline Cassan ${ }^{1}$, Delphine Dargere ${ }^{1}$, Anne Regazzetti * 1 , France \\ Massicot $^{1}$, Anne-Laure Schang ${ }^{1}$, Nicolas Auzeil $\stackrel{*}{+}{ }^{1}$, Olivier Laprévote ${ }^{1}$ \\ ${ }^{1}$ Université Paris Descartes Université Sorbonne Paris Cité, Paris, France - CNRS : UMR8638 équipe Chimie - \\ Toxicologie Analytique et Cellulaire - Faculté de pharmacie de Paris \\ 4 avenue de l'Observatoire, 75006 Paris, France
}

Le cis-[oxalato(trans-1-1-1,2-diaminocyclohexane)] ou oxaliplatine est un agent anticancéreux du groupe des dérivés du platine de plus en plus utilisé. Il est indiqué notamment dans le traitement du cancer colorectal métastatique. Toutefois, l'oxaliplatine est responsable de nombreux effets indésirables, notamment l'apparition de neuropathies périphériques, en particulier des paresthésies transitoires et/ou dysesthésies. Au niveau physiologique, ces troubles pourraient être dus à une altération de la gaine de myéline induisant un trouble de la conduction au niveau des fibres nerveuses sensitives.

Les cellules de Schwann étant responsables de la synthèse de la myéline au niveau du système nerveux périphérique, l'étude présentée concerne l'effet de l'oxaliplatine sur un modèle in vitro de cellules de Schwann murines, la lignée MSC80. Les lipides étant les constituants majoritaires de la myéline, l'effet de l'oxaliplatine sur le processus de myélinisation a été évalué en caractérisant les changements lipidiques induits par l'exposition des cellules de Schwann à l'oxaliplatine. Pour cela, une analyse lipidomique non ciblée ainsi que le dosage d'oxystérols, connus pour être impliqués dans le processus de myélinisation a été effectué par chromatographie liquide couplée à la spectrométrie de masse haute résolution. Le choix de la dose d'exposition à l'agent anticancéreux a été déterminé par une étude de viabilité cellulaire. Des cellules non exposées ont été utilisées comme contrôles. Les lipides ont été extraits à partir de lysats cellulaires selon la méthode de Bligh et Dyer et analysés par ESI-UPLC-HRMS. Après retraitement des données, des analyses statistiques multivariées et univariées ont été effectuées afin de rechercher les lipides dont le taux est modifié suite au traitement avec l'oxaliplatine.

Les résultats montrent un changement important au niveau de certains phospho et glycérophospholipides, constituants clés de la myéline.

Mots-Clés : oxaliplatine, cellule de Schwann, démyélinisation, analyse lipidomique non ciblée, UHPLC, HRMS

Programme

\footnotetext{
*Intervenant

${ }^{\dagger}$ Auteur correspondant: nicolax.auzeil@ parisdescartes.fr
} 


\title{
Mechanistic re-visitation of phospholipid fragmentations under low energy collision conditions [P231]
}

\author{
Benoit Colsch ${ }^{* \dagger}{ }^{1}$, François Fenaille ${ }^{1}$, Anna Warnet ${ }^{1}$, \\ Christophe Junot ${ }^{1}$, Jean Claude Tabet ${ }^{1}$ \\ ${ }^{1}$ CEA-INRA UMR 0496/DRF/Institut Joliot/SPI/LEMM, Université Paris Saclay, MetaboHUB - CEA - Centre \\ d’Etudes Nucléaires de Saclay, 91191 Gif-sur-Yvette, France
}

\begin{abstract}
Glycerophospholipids (GPLs) are the major amphiphilic molecules found in the plasma membrane bilayer of all vertebrate cells. Involved in many biological processes, their huge structural diversity and large concentration scale make their thorough characterization extremely difficult in complex biological matrices. Mass spectrometry (MS) techniques are now recognized as being among the most powerful methods for the sensitive and comprehensive characterization of lipids. Depending on the experimental conditions used during electrospray ionization MS experiments, GPLs can be detected as different molecular species (e.g. protonated, sodiated species) when analyzed either in positive or negative ionization modes or by direct introduction or hyphenated MS-based methods. The observed ionized forms are characteristic of the corresponding phospholipid structures, and their formation is highly influenced by the polar head group. Although the fragmentation behavior of each phospholipid class has already been studied but there is no real "consensus" regarding the processes by which fragment ions are formed. In this work, we emphasize the crucial roles played by ion-dipole complexes and salt bridges within charge-induced dissociation processes. Under these conditions, we were able to readily explain almost all the fragment ions obtained under low-energy collision-induced dissociation (CID) for particular GPLs and Lyso-GPLs species including phosphatidylcholines (PCs), phosphatidylethanolamines (PEs). Thus, in addition to providing a basis for a better comprehension of phospholipid fragmentation processes, our work also highlighted some potentially new relevant diagnostic ions to sign the presence of such particular lipid species.
\end{abstract}

Mots-Clés : Phospholipids, high resolution mass spectrometry, fragmentation, mechanisms, ion, dipole complexes, salt bridges.

\section{Programme}

\footnotetext{
*Intervenant

${ }^{\dagger}$ Auteur correspondant: benoit.colsch@ @ea.fr
} 


\title{
Lipidomics reveals cerebrospinal-fluid signatures of amyotrophic lateral sclerosis [P232]
}

\author{
Helene Blasco $* \dagger 1$, Chalotte Veyrat, Cinzia Bocca ${ }^{*}$, Franck Patin, Patrick \\ Vourch, Judith Kouassin Zoughet, Guy Laeners, Christian Andres, Gilles \\ Simard, Philippe Corcia, Pascal Reynier ${ }^{2}$ \\ ${ }^{1}$ Imagerie et cerveau - Université François Rabelais - Tours, INSERM : U930, CNRS : ERL3106 - Hôpital \\ Bretonneau 1 Bd Tonnelle 37044 Tours, France \\ 2 Institut MITOVASC, UMR CNRS6015-INSERM1083, - Université d'Angers, Angers, France
}

Background: Amyotrophic lateral sclerosis (ALS), the most common adult-onset motor neuron disorder, is characterized by a survival span of only 2-5 years after onset. Relevant biomarkers would provide powerful tools for the management of ALS. The objectives of this study were to investigate the cerebrospinal fluid (CSF) lipidomic signature of ALS patients to evaluate the diagnostic and predictive values of the profile and to identify pathophysiologic biomarkers.

Methods: We performed an untargeted lipidomic analysis in 40 ALS patients compared to 45 controls. We robustly determined 122 lipids by liquid chromatography coupled to high-resolution mass spectrometry. Parameters of disease progression were collected at baseline and again one year later (ALSFRS-r, FVC, BMI), as well as survival. Lipidome profiles were then subjected to powerful statistical modelling based on training and test sets, to compare ALS and controls and to model the rate of progression.

Findings: ALS displayed a highly significant specific CSF lipidomic signature. Phosphatidylcholine PC(36:4), higher in ALS ( $\mathrm{p}=0.0003$ ) was the most strongest biomarker. Analysis of lipids in the brain cortex of ALS mice confirmed the role of some discriminant lipids such as PC. We also obtained very performant models from baseline lipidome for predicting the variation of the ALSFRS-r score on the test sets (accuracy at 71\%). Significant predictions of clinical evolution were found to be correlated to sphingomyelins and triglycerides with long-chain fatty acids.

Interpretation: Our study, which shows extensive lipid remodelling in the CSF of ALS patients, provides new biomarkers of the disease and its evolution with good performances of prediction on test sets. These findings highlighted phosphatidylcholines, that merit to be further explored.

Mots-Clés : lipidomics, diagnosis biomarkers, neurodegenerative disease

$\underline{\text { Programme }}$

\footnotetext{
*Intervenant

${ }^{\dagger}$ Auteur correspondant: heleneblasco@yahoo.fr
} 


\title{
Lipidomic analysis of bovine embryos and oviductal fluids to optimize production of in vitro embryo [P233]
}

\author{
Charles Banliat ${ }^{* \dagger}{ }^{1}$, Valérie Labas ${ }^{1}$, Daniel Tomas ${ }^{1}$, Florine Dubuisson ${ }^{2}$, \\ Justine Saulnier ${ }^{2}$, Marie Saint-Dizier ${ }^{2}$ \\ ${ }^{1}$ Plate-forme d'Analyse Intégrative des Biomarqueurs Laboratoire de Spectrométrie de Masse (PAIB) - INRA, \\ CNRS : UMR7247, Université François Rabelais - Tours, Institut Francais du Cheval et de l'Equitation - Centre \\ de Recherches INRA de Nouzilly 37380 Nouzilly, France \\ 2 Physiologie de la reproduction et des comportements [Nouzilly] (PRC) - INRA : UR0085, Institut Français du \\ Cheval et de lÉquitation [Saumur], Université François Rabelais - Tours, CNRS : UMR7247 - Centre de \\ Recherches de Tours 37380 Nouzilly, France
}

Currently, in vitro produced bovine embryos (IVBE) present lower quality than in vivo embryos. Indeed, IVBE are less viable and more cryosensitive. Therefore, in order to better understand the molecular mechanisms implicated in embryo development and to characterize the biomolecules which could increase pregnancy rates, we propose phenotyping of intact embryo and screening of its natural environment through the cycle (before and after ovulation). Several researches reported the relationship of lipids with fertility, their role in embryo development and cryosensitivy. Therefore, herein we report qualitative lipidomic analysis of individual in vitro embryos by ICM-MS (Intact Cell MALDI-TOF MS) and direct quantitative profiling of oviductal fluids ipsi-lateral to ovulation collected at four different stages (I (post-ov), II (mid-luteal phase), III (late luteal phase) and IV (pre-ov)) for 15 cows per stage.

Lipid spectral profiles were acquired (5000 shots per spectra) from each sample co-crystallized with THAP (2,4,6-Trihydroxyacetophenone monohydrate) matrix using an Ultraflextreme MALDI-TOF instrument in positive reflector mode, in the mass range 400-1200 m/z. From aligned ICM-MS spectra (three individual in vitro embryos), around 300 peaks corresponding to glycerophospholipids and sphingolipids were detected.

For each oviductal fluid, 5 spots were analysed in duplicate. All spectra were integrated to ClinProTools 3.0 software for statistical analyses (ANOVA, 2D peak distribution, PCA, ROC...). Among the $232 \mathrm{~m} / \mathrm{z}$ peaks detected in all samples, the largest differences were found between stage II and IV. $24 \mathrm{~m} / \mathrm{z}$ were differential using a p value $<0.01$ with a fold change $<0.5$ and $>2.0$. The lipid contents were also signifying different between intermediary stages.

In this work, we showed for the first time, that global lipid mass fingerprint of oviductal fluids can yield information around the occurrence of produced molecules which could influence development of embryo and therefore its quality.

Mots-Clés : bovine embryo, oviductal fluids, lipidomic, MALDI, TOF MS

$\underline{\text { Programme }}$

\footnotetext{
*Intervenant

${ }^{\dagger}$ Auteur correspondant: charles.banliat@inra.fr
} 


\title{
Characterization of diet-induced molecular changes in ovarian reserves of Aedes aegypti using 3D-MSI-TOF-SIMS and MALDI FT-ICR [P234]
}

\author{
Anthony Castellanos ${ }^{1}$, Quentin Vanbellingen ${ }^{* \dagger}{ }^{1}$, Paolo Benigni ${ }^{1}$, Veronika \\ Michalkova $^{2}$, Marcela Nouzova ${ }^{2}$, \\ Fernando Noriega ${ }^{2,3}$, Francisco Fernandez-Lima \\ ${ }^{1}$ Department of Chemistry and Biochemistry - AHC 4 Florida International University \\ 11200 SW 8th St, Miami, FL 33199, États-Unis \\ 2 Department of Biological Sciences - AHC4 Florida International University \\ 11200 SW 8th St, Miami, FL 33199, États-Unis \\ ${ }^{3}$ Biomolecular Science Institute - AHC4 Florida International University \\ 11200 SW 8th St, Miami, FL 33199, États-Unis
}

Female mosquitoes are subject to 'trade-offs' between the energetic demands of reproduction and the energy required to survive. The mobilization of nutrient reserves within the ovaries during previtellogenic development is thought to play a vital role in the reproductive viability of Aedes aegypti. In the present work, mass spectrometric tools were used to characterize ovarian follicles from mosquitoes raised with (20\%) and without a sucrose diet.

A. aegypti strain were raised at $28{ }^{\circ} \mathrm{C}$ with $80 \%$ humidity, at a 16-hour light and 8-hour dark cycle. Following eclosion, adult mosquitoes were fed from either a cotton pad soaked with and without $20 \%$ sucrose solution. On the fifth day, specimens were sacrificed. A TOF-SIMS was used to localize and quantify relative changes in lipid reserves on the single follicle level. Using MALDI-FT-ICR, a large sample set of follicles $(\mathrm{n}=58$ ) were probed, allowing for exact mass accuracy based molecular assignments and Principal Components Analysis to be performed. HPLC-MS/MS analysis of whole ovary liquid-liquid extractions enabled secondary chemical verification.

Processing of MALDI-FT-ICR data permitted a good separation of Principal Components. This result permits further implementation of this technology as a criterion for follicle fitness and fate for large follicle populations with high throughput allowing a measure of apoptosis or previtellogenic development in A. aegypti females. 3D-MSI-TOF-SIMS results suggested that intact glycerides were present in ovarian follicles $(n=5)$ and were more abundant in the $20 \%$ sucrose fed specimen.

The major advantages of using these methods for the characterization of A. aegypti ovarian follicle nutrient reserves is that, for the first time, individual lipid species can be defined by their structure, localization, and relative abundance compared in ovarian follicles as a result of carbohydrate availability. Here, MSI is applied to characterize follicular fitness in order to predict fate in A. aegypti oocytes using molecular markers.

Mots-Clés : Aedes aegypti, TOF, SIMS, LC, MS/MS, MALDI, FT, ICR

\footnotetext{
*Intervenant

${ }^{\dagger}$ Auteur correspondant: quentin.vanbellingen@gmail.com

¥Auteur correspondant: franciscoalberto.fernandezlima@ fiu.edu
} 
Microbiologie: bactérie, virus,
champignon et méta-omiques 


\title{
A pilot study for the identification of biomarkers of Ehrlichia ruminantium infection in natural host [P235]
}

\author{
Bernard Fernandez $*$, Guylaine Miotello* ${ }^{*}$, Rosalie Aprelon $*$, Ken \\ Giraud-Girard $*^{1}$, Nathalie Vachiery ${ }^{2}$, Jean Armengaud $* 3$, \\ Philippe Holzmuller $* \uparrow$ \\ ${ }^{1}$ Centre de Coopération Internationale en Recherche Agronomique pour le Développement (CIRAD) - UMR 15 \\ CMAEE, Site de Duclos, 97117 Petit-Bourg, Guadeloupe \\ ${ }^{2}$ Contrôle des maladies animales exotiques et émergentes [Montpellier] (CMAEE) - INRA, Centre de \\ coopération internationale en recherche agronomique pour le développement [CIRAD] : UMR15 - Campus \\ international de Baillarguet - TA A-15 / G - 34398 Montpellier Cedex 5, France \\ ${ }^{3}$ Laboratory «Innovative technologies for Detection and Diagnostics» (CEA/Li2D) - CEA Marcoule, \\ DRF/JOLIOT/DMTS/SPI/Li2D, BP17171, F-30207 Bagnols-sur-Cèze, France
}

Heartwater, caused by the Rickettsiales Ehrlichia ruminantium, is one of the most important tickborne diseases of livestock in Africa, but also in the Caribbean from where it threatens the American mainland. All domestic and wild ruminants can be infected by E. ruminantium, a small pleomorphic gram-negative obligate intracellular bacterium invading the cytoplasm of vascular endothelial cells. Clinical diagnosis of heartwater is based on the presence of Amblyomma sp. ticks, nervous signs, and presence of transudates in the pericardium and thorax on post-mortem examination, and efficient molecular diagnostics allow reliable heartwater confirmation but not early detection. The objective of the present study was to evaluate modifications in serum composition in animals infected by E. ruminantium and define new diagnostic biomarkers. For this, sera from goats experimentally infected by intravenous injection of E. ruminantium cultured in bovine aortic endothelial cells in vitro were sampled. Sera at Day 0 and Day 14 post-infection (occurrence of clinical signs) were pre-fractionated by SDS-PAGE and analysed by shotgun next-generation proteomics by means of high-throughput analysis of peptides with a Q-Exactive HF mass spectrometer incorporating an ultra-high-field Orbitrap analyzer. Preliminary data obtained against the Capra hircus and Ehrlichia ruminantium theoretical molecular databases evidenced 6 and 2 proteins of interest for which abundances were increased or decreased, respectively, at Day 14. These proteins could represent a molecular signature of E. ruminantium infection. Here, we demonstrated the relevance of such proteomic approach to propose candidate diagnostic biomarkers of heartwater. Further investigations will be performed for monitoring more precisely the whole kinetics of E. ruminantium infection for delineating biomarkers for early diagnosis.

Mots-Clés : diagnostic, biomarkers, proteomic approach, infection, tick, borne diseases.

Programme

\footnotetext{
*Intervenant

†Auteur correspondant: philippe.holzmuller@cirad.fr
} 


\title{
SHIMADZU Excellence in Science [P236]
}

\author{
Cynthia Le Roux *1, Julie Liang ${ }^{1}$ \\ ${ }^{1}$ Shimadzu - marketing - Bld Salvador Allende, Le Luzard II, 77448 Marne-la-Vallée, France
}

\section{SHIMADZU, UNE ENTREPRISE PÉRENNE}

Shimadzu est le groupe japonais leader mondial spécialisé dans l'instrumentation analytique et physique, le diagnostic médical et l'aéronautique. Son histoire débute en 1875 au Japon, avec son fondateur Genzo Shimadzu Sr., fabricant d'instruments de physique et de chimie. Aujourd'hui coté à la bourse de Tokyo, Shimadzu dégage un chiffre d'affaires annuel de plus de 3 miliards de dollars.

\section{DES COLLABORATEURS EXPERTS ET PASSIONNÉS}

Shimadzu a toujours misé sur le talent de ses collaborateurs passionés pour transformer l'industrie, à l'image de Genzo Shimadzu Jr., récompensé comme l'un des dix plus grands inventeurs japonais de tous les temps ou encore de Koichi Tanaka, lauréat du prix Nobel de Chimie en 2002 pour ses travaux de recherche sur la spectrométrie de masse et les macromolécules.

\section{UN PIONNIER DANS L'INNOVATION}

Tout au long de son histoire, cette entreprise japonaise n'a jamais cessé d'innover et a été à l'origine de nombreuses découvertes et premières mondiales. Aujourd'hui, Shimadzu est présent à l'international dans plus de 100 pays avec des centres de Recherche \& Développement ou de production en Europe, au Japon, en Chine, en Australie et aux Etats-Unis. Plus de 11000 collaborateurs Shimadzu se mobilisent chaque jour autour d'un seul but : contribuer à l'amélioration de la socié société à travers la Science et la Technologie.

\section{DES SOLUTIONS ADAPTÉES À VOS BESOINS}

Notre effort en Recherche \& Développement est constant, nos nouvelles technologies sont le fruit d'une collaboration avec différentes institutions universitaires et centres de recherche. Cela nous permet de mettre au point des solutions

Mots-Clés : spectrométrie, chromatographie gazeuse, chromatographie liquide, analyse élémentaire, analyse de carbone organique total, azote total, machines d'essais, essais statiques, essais dynamique, caméra ultra, rapide, essais de dureté

Programme

\footnotetext{
*Intervenant
} 


\title{
Fréquence des bactéries isolées de laits de mammites bovines à LABEO Manche en 2015 et 2016 par spectrométrie de masse MALDI-TOF avec un focus particulier sur les staphylocoques non-aureus [P237]
}

\author{
Fabienne Benoit $* \uparrow 1$, Elodie Cauvin $* 1$ \\ ${ }^{1}$ LABEO - 1352 avenue de Paris 50000 Saint-Lô, France
}

\begin{abstract}
La connaissance de la fréquence des pathogènes de mammites cliniques et/ou subcliniques au niveau d'une région est une information épidémiologique qui permet de définir des priorités pour l'élaboration des plans de prévention et dans une moindre mesure pour les stratégies de traitement. L'originalité de l'étude présentée repose sur une identification précise des Staphylocoques Coagulase Négative (SCN) par un spectromètre de masse MALDI-TOF. Ceci est d'un intérêt réel pour les vétérinaires car derrière l'appellation SCN se cache une multitude d'espèces avec des origines, des modes de contamination et des conséquences sur la maîtrise des cellules et des mammites très différentes selon les espèces. Cette connaissance fine de l'espèce bactérienne peut contribuer à définir de nouveaux axes de prévention spécifiques pour les vétérinaires. Les données utilisées sont issues de 333 élevages différents et comporte 851 souches de bactéries issues de prélèvements reçus entre le 30 décembre 2014 et le 30 septembre 2016.

Au final, 704 souches ont été sélectionnées pour aborder la répartition des bactéries. Le premier pathogène isolé est Streptococcus uberis (27\% des isolats). Les staphylocoques non-aureus (96\% minimum de $\mathrm{SCN}$ ) sont le deuxième type de pathogènes isolés, suivis par E. coli (19\%) et $S$. aureus $(9 \%)$. A noter que dans les 40 élevages avec au moins 5 prélèvements, $E$. coli n'est prépondérant que dans $10 \%$ des élevages.

Pour les SCN, parmi les 14 taxons identifiés, on isole essentiellement les espèces suivantes : S. chromogenes (5\%), S. haemolyticus (4\%), S. xylosus (3\%), puis S. epidermidis (2\%).

La connaissance précise de leur taxon est donc utile pour prodiguer des conseils mieux adaptés afin d'améliorer la situation cellulaire, la production laitière ainsi que la persistance des vaches dans le troupeau laitier.
\end{abstract}

Mots-Clés : mammites, épidémiologie, Staphylocoques coagulase négative

$\underline{\text { Programme }}$

\footnotetext{
*Intervenant

${ }^{\dagger}$ Auteur correspondant: fabienne.benoit@laboratoire-labeo.fr
} 


\title{
Analyse par métabolomique et protéomique de la bactérie marine Pseudoalteromonas lipolytica TC8 cultivée en mode planctonique versus biofilm [P238]
}

\author{
Laurie Favre ${ }^{1}$, Carole Pichereaux ${ }^{* \dagger}{ }^{2}$, Audrey Gargaros ${ }^{3}$, Odile \\ Burlet-Schiltz ${ }^{3}$, Valérie Cotelle ${ }^{4}$, \\ Annick Ortalo-Magné ${ }^{1}$, Gérald Culioli $* \ddagger 1$ \\ ${ }^{1}$ Université de Toulon, MAPIEM EA 4323 - Université de Toulon - CS 60584, 83041 Toulon Cedex 9, France \\ ${ }^{2}$ Fédération de Recherche Agrobiosciences, Interaction et Biodiversité (FR AIB) - CNRS : FR3450 - Pôle de Biotechnologies Végétales 24, \\ chemin de Borde Rouge BP 42617 Auzeville, 31326 Castanet-Tolosan, France \\ ${ }^{3}$ Institut de pharmacologie et de biologie structurale (IPBS) - Université Paul Sabatier - Toulouse 3, CNRS : UMR5089 - 205 Route de \\ Narbonne 31077 Toulouse cedex 4, France \\ ${ }^{4}$ Laboratoire de Recherche en Sciences Végétales (LRSV) - CNRS : UMR5546, BP 42617, 31326 Castanet-Tolosan, France
}

Toute surface immergée est rapidement colonisée par un large panel d'organismes parmi lesquels les bactéries jouent un rôle prépondérant. Ces microorganismes peuvent se développer sous forme libre (planctonique) ou en communautés (biofilms). L'organisation en biofilm est considérée comme le mode de vie naturel le plus favorable pour les bactéries, leur permettant de survivre et de se développer dans des environnements très contrastés (1). La formation de biofilms sur une surface est considérée comme une étape déterminante dans la colonisation ultérieure par d'autres organismes (2).

Dans cette étude, la bactérie Pseudoalteromonas lipolytica TC8, isolée à partir d'un biofilm marin formé sur une surface artificielle, a été choisie comme organisme-modèle (3). Les espèces du genre Pseudoalteromonas sont très répandues en milieu marin et ont été étudiées du fait de leur facilité de mise en culture et de leur faculté à produire des molécules avec des rôles écologiques marqués. Dans ce contexte, une approche couplant métabolomique et protéomique a été utilisée afin d'analyser les modifications de la production métabolique de cette souche bactérienne en fonction du mode de culture utilisé (biofilm ou planctonique).

Les résultats obtenus par ces deux approches montrent une nette distinction entre les deux phénotypes de TC8. L'étude métabolomique réalisée par LC-MS indique que des phosphatidylethanolamines sont caractéristiques des biofilms tandis que des aminolipides sont spécifiquement produits en mode planctonique. L'analyse protéomique révèle que la biosynthèse de certains acides aminés et les voies d'assimilation de nutriments sont régulées différemment selon le phénotype. Enfin, une confrontation des résultats a permis l'établissement de liens entre les modifications observées au niveau du métabolome et celles issues de l'analyse protéomique.

(1) Flemming H.-C. \& Wingender J. Nat. Rev. Microbiol. 2010, 8: 623.

(2) Qian P.Y. et al. Mar. Biotechnol. 2007 9: 399.

(3) Favre L. et al. J. Proteome Res. 2017 16: 1962.

Mots-Clés : bactérie marine, biofilm, planctonique, metabolomique

\footnotetext{
*Intervenant

${ }^{\dagger}$ Auteur correspondant: Carole.Pichereaux@ipbs.fr

† Auteur correspondant: culioli@univ-tln.fr
} 


\title{
Les plantes et les organismes du sol sont bien bavards ! [P239]
}

\author{
Virginie Puech Pages * 1, Adeline Bascaules Bedin, Patricia Jargeat, \\ Guillaume Bécard
}
${ }^{1}$ LRSV (UMR5546) - CNRS : UMR5546, Université Paul Sabatier-Toulouse III - UPS - 24, chemin de Borde Rouge - Auzeville, B.P. 42617, 31326 Castanet-Tolosan cedex, France

La symbiose mycorhizienne est une symbiose plante-champignons très ancienne et très répandue. La nutrition hydrique et minérale ainsi que la résistance aux maladies des plantes mycorhizées sont fortement améliorées. Nous avons étudié les mécanismes qui contrôlent cette symbiose, en particulier les signaux échangés entre les deux partenaires, analysés par spectrométrie de masse. Les molécules d'origine végétale ont été identifiées comme étant des strigolactones (Gomez-Roldan et al. 2008), puis les signaux d'origine fongiques ont été identifiés comme appartenant à deux familles de molécules chitiniques, des lipochitooligosaccharides (Maillet et al. 2011) et les chitooligosaccharides (Genre et al. 2013).

D'autres microorganismes produisent des molécules à base de chitine, dont des bactéries fixatrices d'azote (bactéries en symbiose avec les légumineuses), des champignons et des oomycètes pathogènes. Nous souhaitons déterminer si d'autres microorganismes du sol produisent ces molécules chitiniques et leurs rôles dans les interactions plantes-microorganismes. Les résultats en cours seront détaillés.

L'objectif appliqué consistera à ajouter de faibles quantités de molécules chitiniques aux cultures, pour favoriser les symbioses végétales, tout en augmentant les défenses naturelles des plantes. Ce travail est soutenu par l'ANR" Nice crops", implique la plateforme Metatoul et l'infrastructure MetaboHUB.

Genre et al. (2013) Short-chain chitin oligomers from arbuscular mycorrhizal fungi trigger nuclear Ca2+ spiking in Medicago truncatula roots and their production is enhanced by strigolactone. New Phytologist, 198, 179-189.

Gomez-Roldan et al. (2008) Strigolactone inhibition of shoot branching. Nature, 455, 189-U122.

Maillet et al. (2011) Fungal lipochitooligosaccharide symbiotic signals in arbuscular mycorrhiza. $\mathrm{Na}$ ture, 469, 58-U1501.

Mots-Clés : plante, champignon, symbioses, interactions, molecule verte, activite biologique

$\underline{\text { Programme }}$

*Intervenant 


\title{
Dynamiques métaboliques lors de l'inhibition de la digestion anaérobie par le phénol par DI-HRMS (Direct-Introduction High-Resolution-MassSpectrometry [P240])
}

\author{
Lénaïck Rouillac ${ }^{* \dagger}{ }^{1}$, Olivier Chapleur ${ }^{\ddagger}$, Celine Madigou ${ }^{1}$, Angéline \\ Guenne ${ }^{1}$, Laurent Mazeas ${ }^{\S} 1$ \\ ${ }^{1}$ Hydrosystèmes et bioprocédés (UR HBAN) - Institut National de Recherche en Sciences et Technologies pour \\ l'Environnement et l'Agriculture (IRSTEA) - 1 rue Pierre-Gilles de Gennes 92761 Antony Cedex, France
}

La digestion anaérobie (DA) est un processus biologique de dégradation de la matière organique en biogaz. Ce processus est réalisé par un écosystème microbien complexe en différentes étapes successives. Cette technologie peut être inhibée par divers composés chimiques tel que le phénol et ses dérivés. Pour comprendre les mécanismes d'inhibition de la DA par le phénol, 27 digesteurs de laboratoire ont été inoculés en présence de neuf concentrations d'inhibiteur ( 0 à $2 \mathrm{~g} / \mathrm{L})$. Des prélèvements réalisés au cours de l'expérience ont été analysés pour suivre plusieurs paramètres indicateurs de l'avancement de la dégradation : la quantité de biogaz produite, les acides gras volatils, le taux de carbone dissous, les communautés microbiennes présentes et actives. Le surnageant a été analysé après dilution, par DIHRMS avec une source ESI en mode positif et négatif, pour une approche métabolomique. L'acquisition a été faite sur 250 scans moyennés avant un traitement par XCMS avec la méthode MSW. Les spectres montrent une forte présence de molécules inférieures à $600 \mathrm{~m} / \mathrm{z}$ et ont une allure similaire dans les deux modes d'ionisation. Cela semble indiquer une redondance d'information, le mode positif ayant une plus grande richesse d'information. Une première analyse statistique par ACP présente une classification des échantillons en fonction du niveau d'inhibition par le phénol. Ensuite, une sparse PCA (package mixOmics) a permis de ne sélectionner que les variables les plus influentes sur chaque axe de l'ACP afin d'affiner la discrimination entre les groupes d'échantillons. La même classification est obtenue avec seulement 200 et 100 variables au lieu de 1033 initialement. Trois groupes d'échantillons se distinguent de façon plus nette en cohérence avec les niveaux d'inhibitions mesurés par les indicateurs de performance. L'objectif suivant sera d'assigner les molécules associées à cette classification afin d'identifier les voies métaboliques les plus sensibles à une inhibition par le phénol.

Mots-Clés : Digestion anaérobie, inhibition, DI HRMS, méta omiques

$\underline{\text { Programme }}$

\footnotetext{
${ }^{*}$ Intervenant

$\dagger$ Auteur correspondant: lenaick.rouillac@irstea.fr

¥Auteur correspondant: olivier.chapleur@irstea.fr

§Auteur correspondant: $\overline{\text { laurent.mazeas@irstea.fr }}$
} 


\title{
Reduced membrane fluidity of a SigX deficient strain results in altered carbon catabolic repression response in Pseudomonas aeruginosa [P241]
}

\author{
Maud Fléchard, Rachel Duchesne, Emeline Bouffartigues, Ali Tahrioui, \\ Gwendoline Gicquel, Julie Hardouin * 1, Manuella Catel-Fereira, Olivier \\ Maillot1 , Olivier Lesouhaitier, Nicole Orange, Marc Feuilloley, éric Déziel, \\ Pierre Cornelis , Sylvie Chevalier ${ }_{-}^{\dagger}$ \\ ${ }^{1}$ CNRS UMR 6270 - Université de Rouen, Université de Rouen - Plateforme PISSARO, IRIB, \\ Mont-Saint-Aignan, France
}

The extracytoplasmic sigma factor $\operatorname{SigX}$ is a master regulator of bacterial adaptation that is involved in fatty acids biosynthesis and membrane homeostasis in $P$. aeruginosa. The growth of a sigX mutant was strongly affected in LB broth, but not in M9-glucose minimal medium. Through comparative transcriptomics and proteomics conducted in LB medium, we show that the absence of SigX results in strong dysregulation of genes, the products of which are mainly involved in transport, carbon and energy metabolisms. The CbrA/B two components system was strongly activated in a sig $X$ mutant, leading to a higher production of $c r c Z$ and a reduced activity of the major translational repressors $\mathrm{Hfq}$ and $\mathrm{Crc}$ compared to the wildtype strain. Remarkably, growth as well as genes, the expression of which was dysregulated in the mutant strain, were restored when the C18D9-structurally related detergent Polysorbate 80 was supplemented to LB medium. Anisotropy data further showed that the $\operatorname{sig} X$ mutant displayed a less fluid membrane than the WT strain, a phenotype that was restored by adding Polysorbate 80. Altogether, our data show that the altered membrane fluidity of the sigX mutant strain could be the leading cause of the strong metabolic alterations and the reduced carbon catabolic repression response (CCR) encountered by this mutant strain. Thus, by controlling and increasing membrane fluidity, SigX behaves as a master regulator of the nutritional stress response, in addition to its involvement in $P$. aeruginosa adaptation, virulence and biofilm formation.

Mots-Clés : Pseudomonas aeruginosa, quantification, carbon catabolism

$\underline{\text { Programme }}$

\footnotetext{
*Intervenant

${ }^{\dagger}$ Auteur correspondant: Sylvie.Chevalier@univ-rouen.fr
} 


\title{
Proteogenomic characterization of Escherichia coli ATCC 8739 used for MALDI-TOF calibration in VITEK-MS [P242]
}

\author{
Frédéric Jauffrit ${ }_{-}{ }^{1,2}$, Corinne Beaulieu ${ }^{2}$, Pierre-Jean Cotte-Pattat ${ }^{3}$, Victoria \\ Girard $^{3}$, Martin Welker ${ }^{3}$, Céline Brochier-Armanet ${ }^{1}$, \\ Jean-Pierre Flandrois ${ }^{1}$, Jean-Philippe Charrier ${ }^{2}$ \\ ${ }^{1}$ Laboratoire de Biométrie et Biologie Evolutive (LBBE) - Université Claude Bernard Lyon 1, Institut National \\ de Recherche en Informatique et en Automatique, CNRS : UMR5558 - 43 Bld du 11 Novembre 1918 \\ 69622 Villeurbanne cedex, France \\ ${ }^{2}$ Microbiology Research Department, bioMérieux S.A. - BIOMERIEUX \\ 376 Chemin de l'Orme, Marcy l'Etoile, France \\ ${ }^{3}$ RD Microbiology, bioMérieux S.A. - BIOMERIEUX - 3 Route de Port Michaud, La Balme-les-Grottes, France
}

In clinical microbiology, linear MALDI-TOF is the new gold standard for microorganism identification. Accurate identification at the species level relies on correct mass calibration, which is achieved in the Vitek MS instrument using 13 peaks of Escherichia coli strain ATCC8739. These peaks have been related to proteins (e.g. ribosomal proteins), but other peaks remain uncharacterized. Their identification can increase the number of possible calibration points and therefore improve the calibration accuracy. Unfortunately, the whole Escherichia coli proteome contains too many candidates to unambiguously match protein sequences with MALDI-TOF peaks. On the other hand, small sequences are frequently poorly annotated. To circumvent these difficulties, we propose a proteogenomics approach.

The complete genome of ATCC8739 was downloaded from GenBank and de novo annotated using high resolution LC-MS/MS data dependent acquisition. The 6 frame translation of the genome was used as a pseudo-protein database. Peptides were identified using MS-GF+ and ORFs were inferred by expanding the identified peptide sequences. Possible protein $\mathrm{m} / \mathrm{z}$ were calculated according to gene sequences, potential posttranslational modifications and charges. Mass candidates were filtrated according to the protein production observed by LC-MS/MS and eventually matched with peaks from MALDI-TOF spectra. Evidences of few expressed genes were found by LC-MS/MS in supposedly non-coding regions, mainly for small proteins having masses lower than $10 \mathrm{kDa}$. However, the main benefit was the limitation of protein candidates. From the 4000 genes found in the E.coli genome, little more than 1000 were correctly semi-quantified by LC-MS/MS.

Restriction to proteins with proven abundant production lead to unambiguous matches with the MALDITOF spectrum. This strategy allowed us to characterize peaks of ribosomal and non-ribosomal origin in the Escherichia coli spectrum and to propose new calibration masses. The approach can prove to be especially useful in the study of non-model organisms, which usually have lower quality protein annotations.

Mots-Clés : proteogenomics, MALDI, TOF, LC, MS/MS

${ }^{*}$ Intervenant 


\title{
Untargeted metabolite discovery in co-cultivation of fungal endophytes Botryosphaeria mamane and Fusarium solani: a time-scale metabolomics method in multi-well plates design [P243]
}

\author{
Asih Triastuti ${ }^{* \dagger}$, Marieke Vansteelandt ${ }^{1}$, Gabriel Rabouille, Fatima Barakat, \\ Nicolas Fabre ${ }^{1}$, Carlos Amasifuen, Alexis Valentin, Mohamed Haddad \\ ${ }^{1}$ Pharmacochimie et Pharmacologie Pour le Développement (PHARMA-DEV) - CNRS : UMR152, Université \\ Paul Sabatier (UPS) - Toulouse III, Institut de recherche pour le développement (IRD) \\ 35 Chemin des Maraîchers 31400 Toulouse, France
}

Co-cultivation of microorganisms in order to induce the production of secondary metabolites is a well-known method which has shown its interest in the discovery of new compounds (1). By mimicking the natural microbial environment, it allows microbial crosstalk leading to the expression of cryptic biosynthesic gene clusters, which can be silent in axenic cultures (2). In a preliminary study, the coculture of two fungal endophytes isolated from medicinal plants, Botryosphaeria mamane from Bixa orellana and Fusarium solani from Plantago lanceolata showed an inhibition zone between the two fungi, implying the production of potential bioactive compounds as a result of their interaction. However this zone disappeared with time. In this work, in order to explain our observation, we investigated the kinetics of metabolite production using a time series-based analysis during ten days of culture. The mono-culture and co-culture of the fungal endophytes were performed in 6-multiwell plates in order to enable the rapid and efficient generation of a large number of replicates for cultures. Every day, the morphological features and chemical composition of the different extracts through LC-HRMS analysis were evaluated. A depth data processing using Xcalibur and XCMS online was then performed in order to highlight the differences between mono and co-cultures, and the production of compounds through the time of culture incubation. Early findings showed a variation in the metabolism of the fungi through time, and an induction of de novo metabolites in co-culture starting after three days of incubation. This experiment emphasize that co-culture in time-frame analysis is an interesting method to unravel hidden metabolome in the investigation of fungal chemical diversity.

Mots-Clés : Fungal endophyte, Time, scale metabolomics, Co, cultivation, LC, HRMS

Programme

\footnotetext{
*Intervenant

${ }^{\dagger}$ Auteur correspondant: asih.triastuti@univ-tlse3.fr
} 


\title{
Analyse métabolomique de Listeria monocytogenes : vers une meilleure compréhension des mécanismes de pathogénicité [P244]
}

\author{
Samuel Terrier * 1 , Juan J. Quereda ${ }^{2}$, Patricia Lamourette ${ }^{1}$, Christophe \\ Junot $^{1}$, François Fenaille ${ }^{1}$, Javier Pizarro-Cerda ${ }^{2}$, Florence Castelli ${ }^{1}$ \\ ${ }^{1}$ CEA-INRA UMR 0496 DRF/Institut Joliot/SPI, Université Paris Saclay, MetaboHUB \\ 91191 Gif-sur-Yvette cedex, France \\ ${ }^{2}$ Unité des Interactions Bactéries-Cellules, Institut Pasteur, 25-28 Rue du Dr Roux, 75015 Paris, France
}

\begin{abstract}
Listeria monocytogenes est une bactérie pathogène opportuniste, ubiquitaire, causant des épisodes infectieux allant de la gastro-entérite à des infections plus graves, avec un taux de mortalité de 20 à $30 \%$ chez des patients fragiles ou à risques. Des études récentes montrent l'existence de niveaux variables de pathogénicité en fonction des sérotypes de L. monocytogenes. Par exemple, la souche F2365 produit in vivo une toxine modifiant localement le microbiote intestinale, facilitant ainsi sa diffusion dans les tissus et sa propagation. Néanmoins, les mécanismes biochimiques impliqués dans la pathogénicité de cette souche restent mal connus.

Dans ce contexte, l'objectif de ce travail est d'utiliser l'analyse métabolomique non ciblée afin de mieux appréhender le phénotype de pathogénicité de L. monocytogenes. Ainsi, les profils métaboliques de deux souches présentant des niveaux variables de pathogénicité ont été étudiés et comparés, afin de préciser les mécanismes biochimiques sous-jacents.

Nous avons tout d'abord mis en place un protocole expérimental non biaisé d'extraction des métabolites de bactéries cultivées in vitro. Les extraits métaboliques ainsi obtenus ont ensuite été analysés par chromatographie liquide (C18/HILIC) couplée à la spectrométrie de masse à haute résolution en combinant deux modes d'ionisation afin de maximiser la couverture métabolique.

Des résultats préliminaires obtenus après séparation chromatographique sur colonne HILIC en mode d'ionisation négatif, révèlent 27 métabolites annotés putativement et statistiquement discriminants. Ces données semblent indiquer des différences métaboliques fortes entre ces deux souches, dont les voies métaboliques les plus impactées étant le métabolisme central énergétique, la biosynthèse des acides aminées et des nucléotides.

Des analyses supplémentaires sont en cours afin de mieux caractériser la signature métabolique distinguant la souche pathogène de la non pathogène. Ces résultats permettront ainsi une meilleure compréhension des mécanismes biochimiques liés à la pathogénicité de L. monocytogenes.
\end{abstract}

Mots-Clés : Listeria monocytogenes, Métabolomique, Spectrométrie de masse, Pathogénicité, Virulence

Programme

${ }^{*}$ Intervenant 


\title{
Purification et analyse LC-MS/MS de molécules chitiniques fongiques [P245]
}

\author{
Adeline Bascaules-Bedin ${ }^{* \dagger}{ }^{1}$, Virginie Puech-Pagès ${ }^{1}$, Guillaume Bécard ${ }^{1}$ \\ ${ }^{1}$ Laboratoire de Recherche en Sciences Végétales (LRSV) - CNRS : UMR5546, Université Paul Sabatier (UPS) \\ - Toulouse III - 24 Chemin de Borde-Rouge BP 42617 Auzeville 31326 Castanet Tolosan cedex, France
}

Les plantes interagissent avec un grand nombre de micro-organismes du sol et ont développé des mécanismes sensibles et complexes pour distinguer les micro-organismes bénéfiques des nuisibles, via les signaux qu'ils produisent.

Parmi les interactions bénéfiques, se distingue la symbiose mycorhizienne à arbuscules. Cette symbiose ancestrale, concerne $80 \%$ des plantes terrestres. Le champignon forme un organe particulier à l'intérieur de la racine de la plante, un arbuscule, qui est le lieu d'échange entre les deux partenaires. La plante fournit au champignon, biotrophe obligatoire, les sucres indispensables à son développement. En retour, le champignon transfère de l'eau et des sels minéraux à la plante partenaire, favorisant ainsi sa nutrition et sa croissance. La symbiose mycorhizienne permet de limiter l'irrigation et l'ajout d'engrais chimiques aux cultures et permet une agriculture plus respectueuse de l'environnement.

Notre principal objectif, est d'étudier les mécanismes cellulaires et moléculaires impliqués dans l'établissement de cette symbiose, depuis la germination des spores jusqu'à la formation des arbuscules. Ainsi, il a été montré que les champignons produisent des lipochitooligosaccharides (LCO) simples, molécules qui stimulent la mycorhization (Maillet et al., 2011) et des chitooligosacharides (CO) qui activent la cascade de signalisation végétale (Genre et al., 2013). La détection et l'analyse structurale de ces composés chitiniques est complexe car ils sont présents le plus souvent à l'état de trace dans des échantillons biologiques complexes.

Afin de gagner en sensibilité de détection, il a été nécessaire de développer et d'optimiser plusieurs étapes de purification, de séparation LC et d'analyse MS ce qui a déjà permis la détection de LCOs possédant des structures plus complexes, dans différents types d'échantillon mycorhizien. L'objectif sera maintenant d'évaluer l'étendue du spectre des micro-organismes (symbiotiques et pathogènes), interagissant plus ou moins étroitement avec les plantes, capables de produire ces molécules chitiniques, afin de définir leurs rôles dans les interactions plantes-microorganismes.

Mots-Clés : symbiose, champignons mycorhiziens à arbuscules, signaux symbiotiques, analyse LC, MS/MS

$\underline{\text { Programme }}$

\footnotetext{
*Intervenant

$\dagger$ Auteur correspondant: adeline.bascaules@1rsv.ups-tlse.fr
} 


\title{
Caractérisation de micro-organismes endophytes par analyse de protéines en spectrométrie de masse MALDI-TOF [P246]
}

\author{
Vincent Guérineau ${ }^{* \dagger}{ }^{1}$, Morgane Barthélemy ${ }^{1}$, Mélanie Roy ${ }^{2}$, Didier \\ Stien $^{3}$, Jérôme $\overline{\text { Chave }}{ }^{2}$, Véronique Eparvier ${ }^{1}$, David Touboul ${ }^{1}$ \\ ${ }^{1}$ Institut de Chimie des Substances Naturelles - CNRS : UPR2301 - Avenue de la terrasse \\ 91198 Gif sur Yvette cedex, France \\ ${ }^{2}$ Laboratoire Evolution et Diversité Biologique - CNRS : UMR5174 - Université Toulouse III Paul Sabatier \\ Bâtiment 4R1 118, route de Narbonne 31062 Toulouse cedex 9, France \\ ${ }^{3}$ Laboratoire de Biodiversité et Biotechnologies Microbiennes - CNRS : USR3579 - Observatoire \\ Océanologique Ave du Fontaulé 66650 Banyuls/Mer France
}

Depuis quelques années, la spectrométrie de masse MALDI-TOF s'est imposée dans les milieux hospitaliers comme la technique de choix pour le diagnostic microbiologique. Ainsi, l'identification de bactéries/levures pathogènes se fait de manière routinière par comparaison des empreintes spectrales MALDI-TOF de l'extrait protéique de la souche analysée avec des bases de données (1).

Depuis peu, des études s'intéressent également au développement de bases de données couvrant les champignons filamenteux mais celles-ci se focalisent sur l'analyse d'isolats cliniques (pathogènes humains ou souches environnementales opportunistes) (2). A ce jour, très peu d'études utilisent cette technique pour l'identification de souches environnementale (phytopathogènes, micro-organismes mutualiste, endophytes...) et aucune base de données commerciale n'est disponible pour ce type de microorganisme.

Dans le cadre d'un projet portant sur l'étude d'endophytes isolés de huit spécimens de palmier de l'espèce Astrocaryum sciophilum, les spectres MALDI-TOF de 197 endophytes ont été générés selon le protocole standardisé en clinique : extraction des protéines $(\mathrm{CH} 3 \mathrm{CN} / \mathrm{H} 2 \mathrm{O} / \mathrm{HCOOH}: 50 / 15 / 35)$ puis analyse MALDI-TOF (matrice $\alpha$-CHCA à $10 \mathrm{mg} / \mathrm{ml}, \mathrm{H} 2 \mathrm{O} / \mathrm{CH} 3 \mathrm{CN} / \mathrm{CF} 3 \mathrm{COOH}: 47,5 / 50 / 2,5$ ).

Ces résultats ont été mis en parallèle avec les résultats de séquençage Sanger d'ADN sur les régions ITS, $16 \mathrm{~S}$ et/ou $28 \mathrm{~S}$ permettant ainsi d'identifier génétiquement les micro-organismes. Les premières analyses confirment bien la présence sur les spectres de biomarqueurs caractéristiques permettant d'identifier les souches au rang de l'espèce. Avec ce travail, une base de données MALDI TOF sur les souches environnementales est en cours de construction et facilitera les futures identifications de micro-organisme au laboratoire.

(1) Rahi, P. et al. Frontiers in Microbiology. 7, 1359 (2016).

(2) Santos, C. et al. Journal of Applied Microbiology. 108, 375-385 (2010).

Ce travail a bénéficié d'une aide de l'Agence Nationale de la Recherche au titre du programme Investissement d'avenir portant la référence ANR-15-CE21-0016.

Mots-Clés : endophytes, protéines, MALDI, TOF

\footnotetext{
${ }^{*}$ Intervenant

${ }^{\dagger}$ Auteur correspondant: vincent.guerineau@cnrs.fr
} 


\title{
Analyse du profil lipidique par spectrométrie de masse MALDI-TOF pour l'identification de micro-organismes [P247]
}

\author{
Morgane Barthélemy ${ }^{* \dagger}{ }^{1}$, Vincent Guérineau ${ }^{1}$, Mélanie Roy ${ }^{2}$, Didier \\ Stien $^{3}$, Jerome Chave ${ }^{2}$, Véronique Eparvier ${ }^{1}$, David Touboul ${ }^{1}$ \\ ${ }^{1}$ Institut de Chimie des Substances Naturelles - CNRS : UPR2301 - Avenue de la terrasse \\ 91198 Gif sur Yvette cedex, France \\ ${ }^{2}$ Laboratoire Evolution et Diversité Biologique - CNRS : UMR5174 - Université Toulouse III Paul Sabatier \\ Bâtiment 4R1 118, route de Narbonne 31062 Toulouse cedex 9, France \\ ${ }^{3}$ Laboratoire de Biodiversité et Biotechnologies Microbiennes - CNRS : USR3579 - Observatoire \\ Océanologique Ave du Fontaulé, 66650 Banyuls/Mer France
}

L'analyse de profil protéique par spectrométrie de masse MALDI-TOF est devenu la méthode de choix pour l'identification de micro-organismes dans les laboratoires de microbiologie clinique. Cette technique présente notamment un gain de temps et un coût relativement faible comparée aux techniques conventionnelles d'identification basées sur l'ADN. Néanmoins, si la procédure d'extraction des protéines à l'acide formique est facilement applicable sur les bactéries, elle peut donner de mauvais résultats avec les champignons du fait de leur structure membranaire plus rigide. Il y a donc un potentiel certain à développer de nouvelles méthodes basée sur la spectrométrie de masse MALDI-TOF pour l'identification de micro-organismes. En ce sens les lipides présentent un intérêt d'étude étant des constituants majeurs des membranes cellulaires (1).

L'analyse MALDI-TOF de la composition lipidique de 197 endophytes isolés de palmier de l'espèce Astrocaryum sciophilum est réalisée. Les lipides de chaque souche sont extraits après macération de celle-ci dans un mélange MTBE/MeOH (2:1) puis récupération de la phase organique et évaporation du solvant. Ces extraits lipidiques sont solubilisés dans un mélange $\mathrm{CHCl} 3 / \mathrm{MeOH}(2: 1)$ puis analysés par MALDI-TOF en mode réflectron positif (matrice DHB à $20 \mathrm{mg} / \mathrm{mL}$ dans du THF) et négatif (matrice 9-AA à $10 \mathrm{mg} / \mathrm{ml}$ dans du $\mathrm{MeOH}$ ).

Chaque empreinte spectrale donnée par ces extraits lipidiques est associée au résultat d'identification donné par la génétique (séquençage Sanger) et par l'analyse de protéine par MALDI-TOF. Les premiers résultats indiquent une composition lipidique dépendante au rang de l'espèce du micro-organisme. Ces compositions lipidiques pourront également montrer de possibles relations chimiotaxonomiques entre les micro-organismes.

(1) Stübiger, G. et al. Journal of Microbiological Methods. 130, 27-37 (2016).

Ce travail a bénéficié d'une aide de l'Agence Nationale de la Recherche au titre du programme Investissement d'avenir portant la référence ANR-15-CE21-0016.

Mots-Clés : Lipides, Identification, micro, organismes, MALDI, TOF

\footnotetext{
*Intervenant

${ }^{\dagger}$ Auteur correspondant: Morgane.Barthelemy@cnrs.fr
} 


\title{
Caractérisation des protéines du système BAC impliqué dans la formation de biofilms et la production de rhamnolipides chez Pseudomonas aeruginosa [P248]
}

\author{
Brahim Saffiedine * 1, Mohamed Amine Ben Mlouka , Rémy Agniel, Julie \\ Hardouin, Emmanuelle Dé, Patrick Di Martino, \\ Thierry Jouenne, Pascal Cosette \\ ${ }^{1}$ Polymères Biopolymères Surfaces - Plateforme PISSARO (PBS) - Universté de Rouen, CNRS : UMR6270, \\ CURIB - 25 rue Lucien Tesnières, 76130 Mont Saint Aignan, France
}

\begin{abstract}
P. aeruginosa est un pathogène opportuniste, principal responsable des surinfections broncho-pulmonaires chez les patients atteints de mucoviscidose, en raison de sa capacité à former des biofilms, lui conférant une résistance exceptionnelle aux antimicrobiens. Des travaux antérieurs d'analyse protéomique différentielle ont permis d'identifier plusieurs protéines accumulées par $P$. aeruginosa cultivée en biofilm, parmi lesquelles la protéine hypothétique PA3731.

Nos travaux ont comme objectif une meilleure caractérisation du système protéique impliquant la protéine PA3731 et les protéines voisines PA3729, PA3730 et PA3732 (baptisé système BAC), afin d'évaluer son implication dans la formation de biofilm et la sécrétion de rhamnolipides, indispensables à l'adhésion bactérienne. Des travaux de mutagénèse ont validé le rôle du système BAC dans ces phénotypes. De façon intéressante, des tests complémentaires ont également mis en évidence l'implication des rhamnolipides sur la sensibilité de la bactérie à la tobramycine. Nous réalisons des études protéomiques suite à la mutation des différents gènes afin d'évaluer l'effet de ces mutations sur la machinerie cellulaire bactérienne.

Par ailleurs, les études bioinformatiques suggèrent des interactions potentielles entre certaines de ces protéines. Pour initier ces études interactomiques ciblées, la première étape consiste à surproduire et purifier les protéines. Pour l'instant, la protéine PA3732 a été purifiée, ce qui en a fait un premier candidat idéal pour ces études. La mise en présence de cette protéine avec des rhamnolipides a démontré une très forte interaction par calorimétrie, confortant notre hypothèse. Enfin, une approche le " cross-linking " des protéines pour l'étude des interactions protéine/protéine est en train d'être mise en place. Dans un premier temps, différents cross-linker sont en phase de développement pour aboutir à la maitrise du protocole élaboré et étudier les interactions entre les protéines du système BAC.
\end{abstract}

* Ce projet de recherche est soutenu par le programme de financement CPER/FEDER DO-IT

Mots-Clés : Pseudomonas aeruginosa, Biofilm, Protéomique, Rhamnolipides, Système BAC

$\underline{\text { Programme }}$

*Intervenant 


\title{
Identification of metabolic biomarkers to follow wound evolution [P249]
}

\author{
Kévin Berrou ${ }^{* \dagger}{ }^{1}$, Catherine Dunyach-Remy ${ }^{2}$, Jean-Philippe Lavigne ${ }^{2}$, \\ Benoit Roig ${ }^{1}$, Axelle Cadiere $\$ 1$ \\ ${ }^{1}$ Détection, évaluation, gestion des risques CHROniques et éMErgents (CHROME), Université de Nîmes : \\ EA7352 - Rue du docteur Georges Salan, 30021 Nîmes cedex 01, France \\ 2 Virulence bactérienne et maldies infectieuses - INSERM : U1047 - Faculté de médecine, 186 chemin du \\ carreau de lanes, CS83021, 30908 Nîmes Cedex 02, France
}

Chronic wounds like diabetic foot ulcers, bedsores, venous or pressure ulcers are an important clinical problem, leading to infections and sometimes loss of limbs. The current clinical diagnoses are based on bacterial culture and the molecular methods are very sensitive but still little used due to their cost. In this context, we propose a study based on characterization of metabolites produced by bacteria with the aim to establish a metabolic profile that could serve as fingerprint of bacteria.

In a first approach, five species (S. aureus, S. epidermidis, P. aeruginosa, E. faecalis, P. mirabilis) usually find in chronic wounds were selected. The level of knowledge on the metabolism of these strains is variable and for some of them nothing is described in the literature.

To identify specific metabolites of each strain, a funel and non a priori approach is used. Metabolite production is followed during the growth by HPLC with a refractometry or UV detection using three different columns. Evolution of pic area over time is determined and pics are classifed as primary or secondary metabolites. By this method, between 4 and 9 primary metabolites and between 1 and 4 secondary metabolites were detected in the different species. Among them, some appears to be speciesspecific: 5 are only fund in P. aeruginosa, 4 in S. aureus and P. mirabilis, S. epidermidis and E. faecalis exhibited each 1 specific metabolite.

In order to determine species-specific biomarkers, a biostatistical approach will be developed. Candidate compounds will be identified by LC/MSMS and by RMN.

Moreover, a research of volatile metabolites produced has been performed using a Solid Phase MicroExtraction (SPME) method. Specific pattern of volatile metabolites have been highlighted.

This fine-tuned analysis of metabolites opens to oriented and well-promising diagnosis of chronic wound infections.

Mots-Clés : chronic wound, biomarker, metabolite

\section{$\underline{\text { Programme }}$}

\footnotetext{
* Intervenant

${ }^{\dagger}$ Auteur correspondant: kevin.berrou@unimes.fr

¥Auteur correspondant: $\overline{\text { axelle.cadiere@ unimes.fr }}$
} 


\title{
Studies by LC- MS/MS on the phosphorylation sites on the $P$ protein from a fish rhabdovirus [P250]
}

\author{
Céline Henry ${ }_{-}^{*}$, Emilie Merour ${ }^{2}$, Anna Alencar ${ }^{2}$, Annie Lamoureux ${ }^{2}$, Julie \\ Bernard $^{2}$, Michel Bremont ${ }^{2}$ \\ ${ }^{1}$ PAPPSO, Micalis Institute, INRA, AgroParisTech, Université Paris-Saclay - 78350, Jouy-en-Josas, France \\ ${ }^{2}$ VIM, INRA, Université Paris-Saclay - 78350 Jouy-en-Josas, France
}

The viral hemorrhagic septicemia virus (VHSV) is a virus infecting fish that belongs to the Rhabdoviridae family as the vesicular stomatis virus (VSV) whose biology and structure are very well known. Previous reports on the VSV phosphoprotein $\mathrm{P}$ which is part of the replication complex together with the large polymerase $\mathrm{L}$ protein and the nucleoprotein $\mathrm{N}$, have demonstrated that some phosphorylation sites are involved in viral mRNA synthesis and genome replication. In the current study, we analyzed the P protein of semi-purified VHSV. First, we analyzed the wild-type VHSV to determine the potential phosphorylation sites on the P protein. Phosphorylation site were characterized by PAPPSO platform using $50 \mathrm{~cm}$ column with sensitive mass spectrometers : Orbitrap Fusion ${ }^{\mathrm{TM}}$ Lumos $^{\mathrm{TM}}$ Tribrid $^{\mathrm{TM}}$ (Thermo Fisher scientific). HCD fragmentation mode was used to identify 6 major phosphorylation sites on serine residue of the $\mathrm{P}$ protein in position 7, 33, 37, 38, 40 and 42. Following alanine scanning mutagenesis to replace these serine residues, we generated the respective recombinant viruses by reverse genetics. These recombinant VHSV were used to infect fish cells and the replication kinetics were measured to evaluate the impact on the P dephosphorylation on the viral cycle. Altogether, 11 recombinants VHSV were generated with either a single dephosphorylation mutation S33A, S37A, S38A, S40A and S42A, or in combination S33/38A, S38/40A, S33/37/38A, S37/38/40A, S33/38/42A, S38/40/42A. All these recombinant mutants have been validated by LC $-\mathrm{MS} / \mathrm{MS}$.

Mots-Clés : rhabdovirus, $\mathrm{P}$ protein, phosphorylation

$\underline{\text { Programme }}$

*Intervenant 


\title{
The eukaryotic-like protein kinase is not the only player in the Streptococcus thermophilus serine/threonine phosphorylation process [P251]
}

\author{
Celine Henry ${ }^{*}{ }^{1}$, Lucia Haller ${ }^{1}$, Mélisande Blein-Nicolas ${ }^{2}$, Morgane \\ Verbrugghe $^{3}$, Christine Mezange ${ }^{3}$, Mylène Boulay ${ }^{3}$, Véronique Monnet $^{3}$ \\ ${ }^{1}$ Plate-forme PAPPSO, Micalis Institute, INRA, AgroParisTech, Université Paris-Saclay \\ 78350 Jouy-en-Josas, France \\ 2 Plate-forme PAPPSO, Génétique Quantitative et Évolution -Le Moulon, INRA, Université Paris-Sud, CNRS, \\ AgroParisTech, Université Paris-Saclay - Ferme du Moulon, 91190 Gif-sur-Yvette, France \\ ${ }^{3}$ Micalis Institute, ComBac team, INRA, AgroParisTech, Université Paris-Saclay - 78350, Jouy-en-Josas, France
}

To quickly adapt to variable environments, bacteria modify their proteins via post-translational modifications (PTMs). Understand the role of these modifications needs first to characterize, localize and quantify them via proteomics. However, despite dramatic technological advances, PTMs studies remain a major technological challenge. Among PTMs, serine, threonine and tyrosine phosphorylation is recognized as an important regulatory mechanism which still requires intense research to fully understand its complexity and impacts. This study was conducted to discern the influence of serine/threonine (S/T) phosphorylation by the eukaryotic-like protein kinase PknB on Streptococcus thermophilus LMD-9 signaling pathways.

To study the effects and targets of PknB, a knock-out mutant was constructed and analysed using LCMS/MS. The proteome as well as the phosphoproteome were both established in one growth condition, using phosphopeptide enrichment and dimethyl-tag labeling for the phosphoproteome.

A combined 881 proteins were found for wild type and the mutant, representing around $50 \%$ of the genome. The phosphoproteome identifications covered around $6 \%$ of the genome with 106 identified proteins. Therein, the occurrences of serine, threonine and tyrosine were 43/33/23\%, respectively. 90 phosphoproteins were found in the WT, while 55 could be identified in the Mut. Statistical variance analysis determined 14 significantly variable proteins in the phosphoproteome, all either diminished or absent in the mutant. Of the variable phosphopeptides, 6 were phosphorylated on serine, 7 on threonine and 3 on tyrosine.

PknB is not solely responsible for the S/T phosphoproteome of St. thermophilus and might also be involved in phosphorylation of tyrosine residues.

Mots-Clés : phosphorylation, kinase, Streptococcus thermophilus

$\underline{\text { Programme }}$

${ }^{*}$ Intervenant 


\title{
Etude longitudinale du métabolome de Pseudomonas aeruginosa au cours des infections pulmonaires chroniques dans la mucoviscidose [P252]
}

\author{
Oriane Moyne $* \dagger 1$, Benoit Cournoyer ${ }^{2}$, Florence Castelli ${ }^{3}$, François \\ Fenaille $^{3}$, Patricia Lamourette ${ }^{3}$, Christophe Junot ${ }^{3}$, Claire Léger ${ }^{4}$, \\ Dominique Bicout ${ }^{5}$, Max Maurin ${ }^{4}$, \\ Bertrand Toussaint ${ }_{-}^{\ddagger}$, Audrey Le Gouëllec ${ }_{-}^{\S 4}$

\footnotetext{
${ }^{1}$ Univ. Grenoble Alpes, CNRS, Grenoble INP, Laboratoire TIMC-IMAG équipes TheRex et EPSP (TIMC-IMAG), Grenoble, France ${ }^{2}$ Laboratoire d'Ecologie Microbienne, équipe Bactéries Pathogènes Opportunistes et Environnement - CNRS, INRA, Marcy l'Etoile ${ }^{3}$ Institut de Biologie et de Technologies de Saclay, CEA - 91191 Gif-sur-Yvette cedex, France ${ }^{4}$ Univ. Grenoble Alpes, CNRS, Grenoble INP, Laboratoire TIMC-IMAG équipe TheREx, Grenoble, France

${ }^{5}$ Univ. Grenoble Alpes, CNRS, Grenoble INP, VetAgroSup, Laboratoire TIMC-IMAG équipe EPSP, Grenoble, France
}

L'infection pulmonaire chronique par Pseudomonas aeruginosa (P.a.) est considérée comme la principale cause de morbidité et de mortalité liée à la mucoviscidose. Au cours de cette infection persistante, P.a. s'adapte à l'environnement pulmonaire caractéristique de ces patients et évolue avec son hôte pendant des décennies. Bien que plusieurs études aient tenté d'évaluer les mécanismes génétiques d'évolution chez cette bactérie, il demeure difficile aujourd'hui d'expliquer les relations entre les mutations accumulées dans le génome bactérien et l'expression de phénotypes cliniquement pertinents, ou encore de corréler ces mutations avec l'état de santé du patient.

Afin de mieux appréhender le niveau d'expression phénotypique des processus de régulation biologique, nous proposons d'étudier l'évolution du métabolome de P.a. dans ces infections chroniques.

Pour cela nous avons constitué une banque longitudinale d'isolats cliniques de P.a. prélevés chez 32 patients adultes atteints de mucoviscidose et suivis au CHU Grenoble-Alpes sur une période de 1 à 5 ans. Cette banque a ensuite été génotypée afin de sélectionner, pour chaque patient, deux isolats représentant différents stades d'évolution du clone ayant initié l'infection chronique.

Les empreintes métabolomiques des 66 isolats sélectionnés seront obtenues par chromatographie liquide couplée à la spectrométrie de masse, après croissance dans un milieu mimant l'environnement pulmonaire de la mucoviscidose. Les résultats préliminaires obtenus à partir d'isolats prélevés chez un même patient ont permis la détection de 1893 variables, dont 173 annotées putativement, et de mettre en évidence un profil discriminant les isolats selon leur date de prélèvement.

L'objectif de notre étude est en premier lieu de mettre en évidence des convergences adaptatives du métabolome de souches de P.a. infectant différents patients. Nous étudierons également les corrélations entre les signatures métabolomiques observées et $1 /$ l'expression de phénotypes bactériens cliniquement pertinents (cytotoxicité, antibiorésistance...), et 2/ la sévérité de l'atteinte respiratoire des patients infectés, modélisée d'après les données cliniques. Mots-Clés : Métabolomique non ciblée, mucoviscidose, Pseudomonas aeruginosa, adaptation, évolution, LC, MS

\footnotetext{
${ }^{*}$ Intervenant

† Auteur correspondant: oriane.moyne@univ-grenoble-alpes.fr

†Auteur correspondant: btoussaint@chu-grenoble.fr

$\S$ Auteur correspondant: $\overline{\text { alegouellec@chu-grenoble.fr }}$
} 


\title{
$\mathrm{N}$-terminomics as a tool for identifying proteolytic cleavage of Toxoplasma gondii [P253]
}

\author{
Justine Schneider ${ }^{*}{ }^{1}$, Ludivine Esteves Gloria ${ }^{1}$, Sabrina Marion ${ }^{2}$, \\ Christine Schaeffer-Reiss ${ }_{-}^{\dagger} 1$ \\ ${ }^{1}$ Laboratoire de Spectrométrie de Masse BioOrganique (LSMBO, IPHC) - Université de Strasbourg, CNRS : \\ UMR7178 - 25 rue Becquerel, 67087 Strasbourg, France \\ ${ }^{2}$ Center for Infection and Immunity of Lille (CIIL) - Université de Lille, CNRS : UMR8204, INSERM : \\ UMRU1019 - 1 Rue du Professeur Calmette 59800 Lille, France
}

Apicomplexan parasites such as Toxoplasma gondii cause significant mortality and morbidity in humans and livestock. These parasites employ specialized secretory organelles (micronemes, rhoptries and dense granules) to invade and survive within host cells. T. gondii Sortilin-Like Receptor (TgSORTLR) is an essential receptor for protein trafficking and biogenesis of apical secretory organelles (1). Formation of those organelles is correlated with proteolytic maturation of ROP/MIC proteins. Proteolytic processing events occurring in this parasite are still poorly understood but remain central to the development of therapeutic strategies.

To address these questions, we have undertaken an $\mathrm{N}$-terminome analysis on the lysate and secreted fraction of parasites depleted for TgSORTLR using the doublet $\mathrm{N}$-terminal oriented proteomics $(\mathrm{dN}$ TOP) approach (2) based on a double light/heavy trimethoxyphenylphosphonium (TMPP) labeling of alpha-amines. Protein extracts were submitted to TMPP labeling followed by 1D SDS-PAGE separation. Gel bands were digested in parallel with a combination of different enzymes (trypsin, chymotrypsin and Asp-N) prior to nanoLC-MS/MS analysis (nanoUPLC-Q-TOF Impact II).

This N-terminome analysis of the lysate allowed us to identify more than 2500 parasite proteins and 400 $\mathrm{N}$-terminal peptides among which more than $75 \%$ were found to be acetylated. N-terminal maturation and degradation products of ROP, MIC and GRA proteins were detected. For the secreted fraction, more than 550 parasite proteins were identified and $85 \mathrm{~N}$-terminal peptides among which more than $65 \%$ were found to be acetylated.

Our preliminary results showed a first map of the proteolytic processing events and highlighted the importance of the $\mathrm{N}$-terminal acetylation of processed proteins. N-terminome study of $T$. gondii deficient in key trafficking proteins will provide novel insights into the proteolytic processing events of key virulent factors.

(1) Sloves et al., Cell Host \& Microbe, 2012.

(2) Bertaccini et al., J Proteom Res, 2013.

Mots-Clés : Toxoplasma gondii, parasite, N, terminomic, TMPP labeling, proteolytic processing

$\underline{\text { Programme }}$

\footnotetext{
*Intervenant

${ }^{\dagger}$ Auteur correspondant: christine.schaeffer@unistra.fr
} 


\title{
Apport de la métabolomique pour appréhender les mécanismes de régulation et d'export des peptides lasso [P254]
}

\author{
Séverine Zirah $* \dagger 1$, Laetitia Niemo, Jimmy Mevaere, Christophe Goulard, \\ Lionel Dubost, Sylvie Rebuffat, Yanyan Li
}

\footnotetext{
${ }^{1}$ Molécules de Communication et Adaptation des Micro-Organismes (MCAM) - Sorbonne Universités, Muséum National d'Histoire Naturelle (MNHN), CNRS : UMR7245 - CP 54, 57 rue Cuvier, F-75005 Paris, France
}

Les peptides lasso sont des peptides bactériens de structure entrelacée, produits à partir d'un précurseur issu de la voie de biosynthèse ribosomale, soumis à des modifications post-traductionnelles. Ils possèdent un cycle macrolactame $\mathrm{N}$-terminal dans lequel est enchâssée et piégée stériquement la queue Cterminale. Leurs activités biologiques variées (notamment en tant qu'antimicrobiens ou antagonistes de récepteurs) leur confèrent un potentiel biotechnologique important. Toutefois, les mécanismes qui gouvernent leur production sont mal connus, en particulier chez les Actinobactéries. Comprendre les mécanismes qui gouvernent la production des peptides lasso représente un enjeu majeur puisque ces peptides sont à ce jour non accessibles par synthèse chimique et puisque les clusters de biosynthèse s'avèrent souvent cryptiques. Nous avons examiné le rôle de différents gènes du cluster de biosynthèse d'un peptide lasso, la svicéucine, produite par Streptomyces sviceus, afin d'examiner les mécanismes de régulation et d'export de ce peptide. La souche sauvage et les mutants inactivés pour les gènes codant deux régulateurs (DR1 et DR2) et deux transporteurs (DD1-D2 et DD3-D4) ont été cultivées, puis les extraits issus des surnageants et culots ont été soumis à une analyse par chromatographie liquide - spectrométrie de masse (U-HPLC-MS) sur un instrument de type electrospray - temps de vol (ESIQ-TOF). Une analyse métabolomique des profils LC-MS a été conduite sous R à l'aide des librairies xcms et mixOmics. Les expériences LC-MS/MS ont été analysées par réseaux moléculaires (GNPS) afin d'aider à l'identification des pics discriminant les différents mutants. Les différentes souches ont montré des profils chimiques clairement différents, permettant d'assigner différents composés d'intérêt pour appréhender les mécanismes de production et le rôle physiologique de la svicéucine.

Mots-Clés : métabolomique, peptides lasso, Streptomyces, substances naturelles

$\underline{\text { Programme }}$

\footnotetext{
*Intervenant

${ }^{\dagger}$ Auteur correspondant: szirah@mnhn.fr
} 


\title{
Adaptation of Listeria monocytogenes to temperature: exploration of intracellular subproteome through shotgun proteomics [P255]
}

\author{
Tiago Santos $* 1$, Christophe Chambon ${ }^{2}$, Didier Viala ${ }^{2}$, Julia Esbelin ${ }^{1}$, \\ Michel Hébraud_ 1,2 \\ ${ }^{1}$ Université Clermont Auvergne, INRA, UMR MEDiS (MEDiS) - INRA Clermont-Ferrand-Theix, Université \\ Clermont Auvergne - 63122 Saint-Genès Champanelle, France \\ ${ }^{2}$ Plateforme d'Exploration du Métabolisme, composante protéomique (PFEMcp) - INRA \\ Clermont-Ferrand-Theix - F-63122 Saint-Genès Champanelle, France
}

Listeria monocytogenes is a foodborne pathogen that can cause serious invasive human illness (listeriosis) in susceptible patients. Most human listeriosis cases appear to be caused by consumption of refrigerated ready-to-eat foods. Although initial contamination levels in foods are usually low, the ability of these bacteria to survive and multiply at low temperatures allows it to reach levels high enough to cause disease. It is able to grow in a broad spectrum of temperatures, between 1 and $45 \circ \mathrm{C}$. Bacteria are able to modify their cell envelope composition and their metabolism to maintain cell homeostasis and match their fitness to environmental thermal conditions. This study explores which cytoplasmic proteins might have an association to L. monocytogenes adaption to different temperatures and the potential advantageous differences shown by the biofilm mode of growth. Cultures were grown in planktonic and biofilm mode; the latter being the most widespread mode of growth in natural and industrial realms. Protein extractions were performed from three different growth temperatures $(10 \circ \mathrm{C}, 25 \circ \mathrm{C}$, and $37 \circ \mathrm{C})$ and two stages of growth (exponential and stationary phase). The intracellular subproteomes were isolated by fractionation using a cell disrupter to broke cells. After trypsin digestion of proteins, peptides separation and identification were performed by shotgun proteomics using high performance liquid chromatography combined with tandem mass spectrometry (LC-qTOF-MS/MS) and MS data analysis by LC-Progenesis. Many of the identified proteins are connected to basic cell functions but some are related to the temperature adaptation. Among the thermoregulated proteins, some are particularly overexpressed at $37 \circ \mathrm{C}$, the temperature at which L. monocytogenes is virulent, and others at low-temperature condition, as those prevailing in food workshops. These comparisons of protein expression throughout several conditions (temperatures, mode/phase of growth) will enrich databases and help to model regulatory circuitry that drives adaptation of L. monocytogenes to environments.

Mots-Clés : Shotgun proteomics, Intracellular Subproteome, Listeria monocytogenes, Temperature adaptation

$\underline{\text { Programme }}$

\footnotetext{
*Intervenant

${ }^{\dagger}$ Auteur correspondant: michel.hebraud@inra.fr
} 


\title{
MALDI Imaging and Profiling Mass Spectrometry approach for the analysis of Listeria monocytogenes biofilms exposed to desiccation [P256]
}

\author{
Tiago Santos * 1, Laëtitia Théron ${ }^{2}$, Christophe Chambon ${ }^{2}$, Didier Viala ${ }^{2}$, \\ Delphine Centeno $^{2}$, Michel Hébraud ${ }_{-}^{\dagger, 2}$ \\ ${ }^{1}$ Université Clermont Auvergne, INRA, UMR MEDiS (MEDiS) - INRA Clermont-Ferrand-Theix \\ 63122 Saint-Genès Champanelle, France \\ 2 Plateforme d'Exploration du Métabolisme, composante protéomique (PFEMcp) - INRA \\ Clermont-Ferrand-Theix - F-63122 Saint-Genès Champanelle, France
}

MALDI-TOF IMS is a surface-sampling technology that can determine spatial information and relative abundance of analytes directly from biological samples. IMS has broad applications in clinical and pharmaceutical research, food science and microbiology. Combining IMS with methods such as liquid chromatography (LC) allows their chemical identification. The identity of the measured IMS $\mathrm{m} / \mathrm{z}$ values can then be assigned using mass matching to the calculated $\mathrm{m} / \mathrm{z}$ of the proteins identified by LC-MS/MS. Human listeriosis cases are due to the ingestion of contaminated foods with the pathogenic bacteria Listeria monocytogenes. The control of L. monocytogenes is an ongoing challenge in food processing workshops because of its high adaptability to hostile environments and its ability to form biofilms. The presence of water is essential for microorganism life and reducing its availability by decreasing the air relative humidity $(\mathrm{RH})$ in food workshops, particularly after cleaning-disinfection operations, is part of a strategy to improve the control of bacterial contamination. This study aims to implement the IMS approach on L. monocytogenes biofilms to explore the molecular mechanisms by which sessile cells are able to adapt and persist to a dehumidification treatment. IMS allowed to examining the in situ distribution of low molecular weight proteins within biofilms, either grown in suitable conditions $\left(48 \mathrm{~h}\right.$ at $\left.25^{\circ} \mathrm{C}\right)$ or in an isolated desiccation environment $\left(24 \mathrm{~h}\right.$ at $\left.10^{\circ} \mathrm{C}, 75 \% \mathrm{RH}\right)$. Furthermore, a LC-MS/MS approach, with in situ trypsic digestion, was made to link the dots between IMS and protein identification. Spectral data were processed using the SCiLS software allowing to distinguish protein localization patterns between the two conditions and chose target mass peaks of interest for further LC-MS/MS analysis. These data demonstrate how imaging can be used to dissect the spatial proteome of an intact bacterial biofilm giving new insights into protein expression relating to a dehumidification stress adaptation.

Mots-Clés : MALDI Imaging MS, Listeria monocytogenes, Biofilms, Food plants, Desiccation

Programme

\footnotetext{
${ }^{*}$ Intervenant

†Auteur correspondant: michel.hebraud@inra.fr
} 


\title{
A pipeline dedicated to Metaproteomics for large cohorts [P257]
}

\author{
Céline Henry $* 1$, Ariane Bassignani $* 2,3$, Mélisande Blein-Nicolas $* 3$, \\ Olivier Langella $* 3$, Catherine Juste $* 4$ \\ ${ }^{1}$ Plate-forme PAPPSO, Micalis Institute, INRA, AgroParisTech, Université Paris-Saclay \\ 78350, Jouy-en-Josas, France \\ ${ }^{2}$ MetaGenoPolis, INRA, Université Paris-Saclay, - Jouy-en-Josas, France \\ ${ }^{3}$ PAPPSO, GQE - Le Moulon, INRA, Univ. Paris-Sud, CNRS, AgroParisTech, Université Paris-Saclay \\ 91190 Gif-sur-Yvette, France \\ ${ }^{4}$ Micalis Institute, INRA, AgroParisTech, Université Paris-Saclay - 78350 Jouy-en-Josas, France
}

The human body is colonized by a vast number of microbes, collectively referred to as the human microbiota. The link between these microbes and our health is the focus of a growing number of research initiatives. However, the application of gut metaproteomics has largely been limited due to the low efficiency of protein identification. PAPPSO platform works since a long time with complex samples in the Metaproteomic field with sensitive mass spectrometers. Metaproteomic samples are extremely complex which makes the mass spectrometry analysis more difficult than with others samples. In the national research agency (ANR) "ProteoCardis" 250 patients subjects, generating 250 cytosolic fractions and as many envelope-enriched fractions are analyzed with Orbitrap Fusion ${ }^{\mathrm{TM}}$ Lumos $^{\mathrm{TM}}$ Tribrid $^{\mathrm{TM}}$. Proteins are identified using the specific metagenome of each patient or MetaHIT databases (3,3 or 9.9 millions entries), using X!TandemPipeline, a software developed by the PAPPSO platform and designed to perform protein inference and manage the redundancy of peptides identifications. This software is the only one able to deal with very large raw data sets and huge databases. We grouped the identified proteins to produce the shorter list of proteins explaining the mass spectrometry results. We compared the number of peptides and proteins identified with specific metagenomes with those obtained with the MetaHIT gene catalog. To go further in the analysis, we quantified the peptides using two quantification methods: Spectral Counting and eXtracted Ion Chromatogram with the dedicated house made software MassChroQ. A new generation mass spectrometer, a longer column and an efficient analysis software allowed us to anlyze the intestinal metaproteome of an unusually large cohort. Investigations of the microbiome from this cohort, may open new avenues for reducing cardiovascular risk, including the discovery of biomarkers, new targets and new therapeutic molecules.

Mots-Clés : Metaproteomic, mass spectrometry, PAPPSO, microbiome

Programme

\footnotetext{
${ }^{*}$ Intervenant
} 


\title{
Exploration de la face cachée du métabolisme bactérien [P257.1]
}

\author{
Marcel Salanoubat ${ }^{1-3}$, Alain Perret ${ }^{1-3}$, Ekaterina Dariy ${ }^{1-3}$, \\ Marion Thomas $* \dagger 1-3$
}

\author{
Laboratoire de Génomique et Biochimie du Métabolisme \\ ${ }^{1}$ CEA, DRF, Institut de biologie François Jacob, Genoscope \\ ${ }^{2}$ CNRS (UMR 8030 Génomique Métabolique), 2 rue Gaston Crémieux, CP5706 91057 Évry cedex, France \\ ${ }^{3}$ Université d'Évry Val d'Essonne (UEVE), Boulevard François Mitterrand, 91000 Évry, France
}

\begin{abstract}
Dans ce projet, nous développons une nouvelle stratégie basée sur l'exploitation de ressources biologiques existantes chez la bactérie du sol Acinetobacter baylyi ADP1 (banque complète de mutants de délétion (1), collection d'enzymes purifiées...) et des avancées récentes du laboratoire dans l'exploration de son métabolome. Cette étude prend sa source dans un travail de thèse précèdent (2), où ont été étudiées les modifications du contenu en métabolites intracellulaires en réponse à un stress biotique (changement de source de carbone). Une vingtaine de métabolites d'identité inconnue ont été mis en évidence à la suite du changement de source de carbone. Ces composés ne sont pas reliés à notre connaissance du métabolisme. Ils ne sont donc aujourd'hui pas rattachés à des gènes. Ces métabolites orphelins (MO) participent probablement à des voies métaboliques nouvelles, mises en place lors du changement de source de carbone et représentent des points d'entrée dans la partie obscure du métabolisme bactérien. Le but du projet est de déterminer la structure de différents MO et d'identifier les gènes impliqués dans leur synthèse. L'ensemble des résultats devrait permettre de reconstituer les voies métaboliques qui permettent la synthèse de ces nouveaux métabolites.
\end{abstract}

(1) de Berardinis, V. et al. (2008). A complete collection of single-gene deletion mutants of Acinetobacter baylyi ADP1. Molecular Systems Biology, 4:174

(2) Stuani, L. et al. (2014). Novel metabolic features in ADP1 revealed by a multiomics approach. Metabolomics, 10:1223-1238.

Mots-Clés : Métabolisme, voie métabolique, identification, traitement de données, résonance magnétique nucléaire, spectrométrie de masse

$\underline{\text { Programme }}$

\footnotetext{
*Intervenant

${ }^{\dagger}$ Auteur correspondant: mthomas@genoscope.cns.fr
} 


\section{Liste des auteurs}

Álvarez-Ortí, Manuel, 251

Abdallah, Jad, 111

Abergel, Daniel, 280

Abi Ghanem, Joséphine, 109

Abou Hammoud, Aya, 108

Aboulouard, Soulaimane, 336

Adriaensen, Hans, 201

Adrian, Marielle, 302

Afonso, Carlos, 73, 174, 219, 261

Agniel, Rémy, $\underline{420}$

Aguesse, Audrey, 103

Aidoud, Nacima, $\overline{131}$

Aimond, Axelle, $\underline{306}$

Ait Saadi, Taous, $\underline{376}$

Ait-Belkacem, Rima, 203

Akbal, Laura, 286

Alali, Mellis, 71

Alava, Thomas, $\frac{80}{6}$

Alban, Claude, 96

Aldigier, Jean-Claude, 383

Alencar, Anna, 422

ALEXANDRE-GOUABAU, Marie-Cécile, 51

Alexandrov, Theodore, 45, 66

Alili, Rohia, 342

Allane, Taous, 167

Allanic, Marianne, 196

Allard, Pierre-Marie, 227, 297

Allen, David, 353

Allouche, Abdul-Rahman, $\underline{82}$

Alvarez, Jean-Claude, $\underline{266}$

Alves, Sandra, 329

Amara, Salem, 354

Amasifuen, Carlos, 415

Amato, Pierre, 218

Amiel, Aurélien, 292

Amouri, Adel Amar, 294

Amrane, Samir, 262

Amzil, Zouher, 212

Andersson, Frédéric, 201

Andreas, Huhmer, 316

Andres, Christian, 124, 403

Andres, Christian R., 282

Andriot, Isabelle, 162

Antignac, Jean-Philippe, 51, 334

Antona, Claudine, 131

Aprelon, Rosalie, 407

Aravamudhan, Sriram, 380

Arhaliass, Abdellah, 52

Arivalagan, Jaison, $2 \overline{15}$
Arnoux, Lucie, 131

Array, Tabiwang, 264

Arrivault, Stéphanie, 97

Arroyo, Vincente, $35 \overline{7}$

Askri, Dalel, 354

Astruc, Thierry, 202

Aubriet, Frédéric, 216, 319

Audebert, Stéphane, 126, 327, 366

Audoin, Coralie, 306

Audran, Michel, 349,360

Auzeil, Nicolas, $\underline{400}, \underline{401}$

Aveline, Nicolas, $\underline{302}$

Azémard, Clara, 271

Bécard, Guillaume, 411, 417

Baillet, Valentin, 174

Bailly, Karine, 371

Bailly-Chouriberry, Ludovic, 176, 182, 265, 349, $\underline{360}$

Bakhos, David, 344

Bakiri, Ali, 113

Bal dit Sollier, Claire, 351

Balabaud, Charles, 108

Balliau, Thierry, 301

Balvay, Daniel, 196

Banliat, Charles, 201, 404

Barakat, Fatima, 415

Barbier Saint Hilaire, Pierre, 229

Barcelo, Damia, 34

Bardet, Chloé, 387

Barham, Siamak, 107

Barnes, Loïc, 82

Barraud, Nicolas, 127

Barthélemy, Morgane, 418, 419

Bartolo, François, 133

Bascaules Bedin, Adeline, 305, 411

Bascaules-Bedin, Adeline, 417

Bassignani, Ariane, 429

Bastide, Bruno, 126

Batailler, Brigitte, 310

Batailler, Martine, $\overline{201}$

Bathany, Katell, 383

Batzenschlager, Morgane, 369

Baudelet, Emilie, 327, 366 
Baudry, Charlotte, 131

Bayer, Emmanuelle, 300

Beaulieu, Corinne, $4 \overline{14}$

Becher, François, 117

Beck, Alain, 57, 58, 172, 226, 232, 381, 387

Beck, Scarlett, 268

Bedossa, Pierre, 361

Beghelli-de la Forest Divonne, Stéphanie, 366

Bellati, Jorge, 298

Bellvert, Floriant, 100, 141, 337

Belmudes, Lucid, 93

Belouah, Isma, 97

Belverge, Nicolas, 346

Ben Mlouka, Mohamed Amine, 420

Benamara, Salem, 167

Benard, Camille, 339

Bendahmane, Abdelhafid, 102

Beniddir, Mehdi, 227

Benigni, Paolo, 405

Bennana, Evangéline, 370, 371

Bennouna, Djawed, 299

Benoit, Fabienne, 409

Bentrad, Najla, 259

Benzoubir, Nassima, 376

Berardocco, Solenne, $\underline{98}$

Berdeaux, Olivier, 178

Berenger, Caroline, 72

Berge, Alexandre, $1 \overline{86}$

Berges, Cécilia, 339

Berhow, Mark, 240

Berland, Sophie, 215

Bernard, Julie, 422

Bernard, Laurence, 364

Bernardeau, Karine, 103

Bernhardt, Oliver M., 255

Bernillon, Stéphane, 97, 311

Berrou, Kévin, 421

Bertile, Fabrice, 121

Bertolino, Pascal, 173

Berton, Thierry, 97, 311, 339

Bertrand, Cédric, $217,221,247$

Bertrand, Frédéric, 107

Bertrand, Marylène, 106

Bertrand-Michel, Justine, 399

Bertsch, Christophe, 248

Besaury, Ludovic, 218

Besson, Valérie, 400

Biacchi, Michael, 172

Bicout, Dominique, 424

Bienvenut, Willy, 194

Bijot, Teddy, 241

Billard, Hélène, 51
Bioulac-Sage, Paulette, 108

Bir, Raphael, 339

Birman, Serge, 106

Bisson, Jonathan, 227

Bitar, Tania, 282

Bizouerne, Elise, 98

Blanc, Jean-Frédéric, 108

Blanc, Stéphane, 121

Blanchard, Valentin, 103

Blasco, Hélène, 282,

Blasco, Helene, $124, \underline{403}$

blasco, helene, 284

Blein-Nicolas, Mélisande, 97, 301, 423, 429

Boberieth, Lise, 177

Bocca, Cinzia, 403

Boccard, Julien, $\underline{48}, 63,153,365, \underline{395}$

Bodard, Sylvie, 355, 359

Bogliotti, Nicolas, 275

Bohl, Jan, 237, 326

Boireau, Wilfrid, 105

Bol, Vanesa, 203

Bolbach, Gérard, 263

Bolbach, Gerard, 215

Bomgarden, Ryan, 323

Bonnaire, Yves, 176, 182, 265, 349, 360

Bonneau, Michel, 351

Bonnefille, Bénilde, 71, 208

Bonnefoy, Christelle, 186, 187

Bonneil, Eric, 384

Bonnel, David, 204

Bonnet, Antoine, 222

Bonnet, Muriel, 364

Bonneu, Marc, 205, 383

Bons, Joanna, 188

Bonvallot, Nathalie, 70

Bookhari, Abbes, 303

Boquien, Clair-Yves, 51

Bordes, Claire, $\underline{186}, \underline{187}$

Bormans, Myriam, 212

Botzanowski, Thomas, 232

Bou Nader, Charles, 234

Bou Saleh, Mohamed, 376

Boualem, Adnane, 102

Bouatrous, Yamina, 158

Boubakri, Hasna, 95

Boubred, Farid, 131

Bouchemal, Nadia, 285, 363

Bouchereau, Alain, 98

Bouchonnet, Stéphane, 72, 163, 242

Bouclon, Julien, 274

Boudah, Samia, 155

Boudra, Hamid, $\underline{87,} 224$ 
Bouffartigues, Emeline, 413

Boulanger, Pascale, 80

Boulanger, Renaud, $\overline{16} 2$

Boulay, Mylène, 423

Boulet, Jean-Claude, 296, 335

Bouloc, Philippe, 111

Boumaza, Houda, 92

Bourcier, Sophie, 72, 163, 242

Bourgain, Catherine, 33

Bourgoin-Voillard, Sandrine, 78, 173, 249, 379

Bournais, Sylvain, 96

Bousbata, Sabrina, $\overline{295}$

Bousset, Luc, 239

Boustie, Joël, 220

Boutinaud, Philippe, 196

Bouyssié, David, 189,191

Bouyssiere, Brice, 116

Boychenko, Oleksandr, 257

Boyen, Catherine, 156

Brachi, Benjamin, $\overline{311}$

Brandolini-Bunlon, Marion, 153

Bravo-Veyrat, Sophie, 77

Bray, Fabrice, 132, 274, 312

Bremont, MIchel, 422

Briand, Enora, 212

Brochier-Armanet, Céline, 414

Bros, Pauline, 389

Broussard, Cédric, $\underline{370}, \underline{371}$

Broutin, Isabelle, 137

Bruley, Christophe, 129, 189, 191, 192, 253

Brun, Virginie, $93, \overline{154}, 253$

Bruneel, Arnaud, 289

Brunel, Marion, 391

Brunelle, Alain, 190,193

Brunius, Carl, 195

Buchmann, William, 324, 331

Buemi, Antoine, $\underline{88}$

Bugnazet, Dawid, 252

Bulau, Patrick, 55

Buleté, Audrey, 186, 187, 388

Burel, Alexandre, 189

Burger, Thomas, 93

Burlet-Schiltz, Odile, 75, 128, 189, 191, 367, 390, $\underline{410}$

Burnouf, Thierry, 105

Busson, Julie, 359

Butin, Noémie, $339,357,361$

Cabaton, Nicolas, $211, \underline{353}$

Cabovska, Baiba, 332

Cabrera-Bosquet, Llorenc, 301

Cadène, Martine, 233, 241
Cadeddu, Roberto, 393

Cadiere, Axelle, 421

Cahoreau, Edern, $\underline{315}$

Caillard, Sophie, $\underline{368}$

Cailleu, Dominique, 86

Caillol, Pierre, $\underline{346}$

Cajetan, Neubauer, 316

Camadro, Jean-Michel, 76

Camel, Valérie, 160

Camoin, Luc, 126, 327, 366

Camperi, Julien, 348

Camus, Mylène, $\overline{75,} 367$

Canet, Isabelle, 218

Canlet, Cécile, 87, 112, 197, 211, 350, 353

Cann, Paul, 382

Canonge, Julie, 58

Cantel, Sonia, $11 \overline{16}$

Cantonny, Valérie, 291

Carapito, Christine, 107, 188, 191, 368

Carapito, Raphaël, 107

Cardasis, Helene, $2 \overline{73}$

Cardon, Tristan, 345

Cariou, Véronique, 51

Caron, Christophe, 154, 197, 339

Caroux, Emilie, 239

Carr, Steven, 61

Carré, Vincent, 216, 319

Carrasco, Nathalie, 219

Carvalho, Paulo Costa, 138

Cascante, Martha, 78

Casewell, Nicholas, 152

Cassan, Pauline, 401

Cassar-Malek, Isabelle, 364

Castellanos, Anthony, $6 \overline{5,405}$

Castelli, Florence, $416, \underline{424}$

Castelnau, Pierre, 355

Catel-Fereira, Manuella, 413

Cauvin, Elodie, 409

Cayrol, Corinne, 75, 367

Cazals, Guillaume, $\underline{53}$

Cazier, Hélène, 67

Centeno, Delphine, 164, 202, 428

Cerina, Chhuon, 272

Cersoy, Sophie, 270

Cesbron, Nora, $\underline{334}$

Chabot, Benjamin, 176

Chaillou, Elodie, 201

Chalvin, Camille, 102

Chambers, Jeremy, 65

Chambert, Stéphane, 82

Chambon, Christophe, 161, 202, 427, 428

Chamot-Rooke, Julia, 138,171 
Champeyroux, Chloé, 298

Champion, Thierry, 226

Chanon, Stéphanie, $\overline{121}$

Chapel, Soraya, 296

Chapleur, Olivier, 412

charbit, Pierre-Albert, 194

Charcosset, Alain, 301

Charrié-Duhaut, Armelle, 230

Charrie-Duhaut, Armelle, $\underline{81}$

Charrier, Benoît, 279

Charrier, Jean-Philippe, 414

Chartier, Agnès, 302

Chaurand, Pierre, 193

Chave, Jerome, 418,419

Chazalviel, Maxime, 317

Chazarin, Blandine, 121

Chaze, Thibault, 171

Cherkaoui, Mehdi, 304

Chevalier, Mickael, 139

Chevalier, Stephan, 267

Chevalier, Sylvie, 413

Cheynier, Véronique, 335

Chhuon, Cérina, 374

Chhuon, Cerina, 90

Chiappetta, Giovanni, 127, 215, 254, 385

Chiara, Guerrera, 90, 374

Chiari, Marcella, 175

Chirot, Fabien, 275

Choi, Changmin, 275

Cholet, Sophie, 289

Chong, Julie, 248

Chris, Mullen, 273

Christophe, Bruley, 96

Cianférani, Sarah, $1 \overline{07}, 381$

Cianferani, Sarah, 57, 188, 189, 191, 225, 226, $231,232, \underline{368}$

Ciangura, Cécile, $\underline{342}$

Cieniewski-Bernard, Caroline, 126

Cifkova, Eva, 42

Cissé, Madi, $\overline{100}$

Clària, Joan, $\underline{357}$

Cladière, Mathieu, 160

Claude, Welcker, 301

Claverol, Stéphane, 300, 383

Clavier, Hervé, 260

Clavier, Séverine, 252

Clement, Karine, 342

Clermont, Dominique, 138

Clodic, Gilles, 263

Coat, Rémy, 52

Cobbs, Archie, 269

Cochet, Sylvie, 371
Cocquet, Julie, 129

Colas, Olivier, $\underline{57,}$ 58, 226, 232, $\underline{381}$

Coll, Jean-Luc, 249

Collard, Marie, $\underline{182}$

Collen, Jonas, 156

Collomb, Laetitia, 76

Colombie, Sophie, $\overline{97}$

Colombo, Mélissa, $\overline{177}$

Colsch, Benoit, 67, 229, 357, 361, 398, 402

Com, Emmanuelle, 45

Combelles, Catherine, 353

Combes, Florence, 93, 154

Combes-soia, Lucie, 201

Comby-Zerbino, Clothilde, 275

Compagnon, Isabelle, 82

Comte, Blandine, 153

Concordet, Didier, 112

Coqueran, Bérard, 400

Corcia, Philippe, 124,403

Corcia, philippe, 284

Cordeau, Emmanuelle, 116

Cordelieres, Fabrice, 183

Cordier, Florence, 252

Cornelis, Pierre, $\underline{413}$

Cornu, David, 169, 234

Corre, Erwan, 156

Cortéjade, Aurélie, 187

Cortes, Roldan, $\underline{78}$

Corti, Hélène, 301

Corvaïa, Nathalie, 226

Cosette, Pascal, 137, 420

Costa, Jean, 114, 236

costa, Jean, 391

Cotelle, Valérie, 410

Cotte-Pattat, Pierre-Jean, 414

Cottret, Ludovic, $\underline{317}$

Courant, Frédérique, 71, 208

Cournoyer, Benoit, $4 \overline{24}$

Cournut, Aline, 389

Court, Magali, 362

Courteix, Christine, 393

Couté, Yohann, 253

Coute, Yohann, 93

Couzijn, Erik, 264

Covindarassou, Sangeetha, 328

Cravedi, Jean Pierre, 70

Crespo, Marion, 129

Crone, Catherina, 264

Crossouard, Stephanie, 103

Croyal, Mikaël, 51

Croyal, Mikael, $\overline{103}$

Cucchetti, Margot, 327 
Culioli, Gérald, $\underline{410}$

Culioli, Gerald, $\underline{136}$

Cunin, Valérie, $\underline{78}, 173,249, \underline{354}, \underline{379}$

Curien, Gilles, $\underline{96}$

D'Atri, Valentina, $\frac{58}{57}$

D'atri, Valentina, 57

D'Hulst, Christophe, 312

Dé, Emmanuelle, 137, 420

Déchaumet, Sylvain, 98

Déziel, Éric, 413

Da Silva, David, 267

Daire, Xavier, 302

Dairou, Julien, 111

Dalle, Céline, 164

Damoc, Eugen, 264

Damont, Annelaure, 129, 235

Daniel, Régis, 321, 324

Danoun, Saïda, 305

Dargere, Delphine, 401

Darii, Ekaterina, 329

Dariy, Ekaterina, 322, 430

Darmaun, Dominique, $\frac{131}{08}$

Dartigues, Benjamin, 108

Dauly, Claire, $141,25 \overline{7,273}$

Dauvergne, Bastien, 308, 392

David, Bouyssié, 192

David, Matthieu, $\underline{60}$

David-Souchard, Agnès, 51

De Braekeleer, kris, 392

De Marco, Federica, 310

De Pauw, Edwin, 139

de Tullio, Pascal, $\underline{88,} 356$

de Vaugelade, Ségolène, 72, 163

Debaene, François, 226

Debaine-Francfort, Corinne, 271

Debise, Grégoire, 208

Debrauwer, Laurent, 70, 87, 112, 350

Debruyne, Régis, 271

Decourcelle, Mathilde, 198

Decoville, Martine, 106

Deffressigne, Sylvie, 230

Dejean, Sebastien, 133

Delabriere, Alexis, $\overline{197}, 235$

Delage, Ludovic, 156

Delaporte, Grégoire, 160

Delaunay, Nathalie, $\overline{348}$

Delavaud, Arnaud, $\overline{364}$

Delcambre, Adéline, 70

Delcourt, Vivian, 91

Delepee, Raphael, 148

Deleu, Carole, 98
Delort, Anne-Marie, 218

Delosière, Mylène, 364

Delplanque, Bernadette, 131

Delporte, Cédric, 307, 308

Delsuc, Marc-André, 274

Delude, Camille, 397

Demey-Thomas, Emmanuelle, 287

Deo, Claire, 275

Deota, Shaunak, 128

Deracinois, Barbara, 126

Derosier, Sandra, 154

Dervilly-Pinel, Gaud, 133, 334

Desbenoit, Nicolas, 205

descat, amandine, 284

Deschasaux, Mélanie, 164

Desjobert, Jean-Marie, 114

Desnouveaux, Laura, $3 \overline{46}$

Desoubzdanne, Denis, 346

Destandau, Emilie, 207, 283, 293

Desterke, Christophe, 376

Deuscher, Zoé, 162

Devaux, Stéphanie, 345

Deverchère, Julie, $3 \overline{88}$

Dhaou, Dounia, 95

Dhulster, Pascal, 46

Di Martino, Patrick, 420

Di Michele, Michela, 384

Diémé, Binta, 359

Diallo, Issa, 379

Diarrassouba, Salimata, 97, 339

Diemer, Hélène, 381

Dinant, Sylvie, 310

Distler, Ute, 255

Dittami, Simon, 156

Dive, Vincent, 67

Djukovic, Ana, 350

Domergue, Frédéric, 397

Dominguez Medina, Sergio, 80

Dos Reis, Sylvie, 142

Dossmann, Héloïse, 210,260

Doucet, Jean-Louis, 307

Douillet, Antonin, 302

Douix, Suzie, 210

Dovgan, Igor, 225

Drake, Penelope, 232

Drevensek, Stéphanie, 102

Dron, Michel, 102

Drouet, Ludovic, 351

Drouin, Nicolas, 179,181

Drouyé, Freddy, 146,168

Druilhe, Anne, 383

Dubillot, Emmanuel, 222 
Dubois, Cecile, 213

Dubost, Lionel, 426

Dubuisson, Florine, 404

Duchateau, Magalie, 138

Duchesne, Rachel, 413

Dufour, Anthony, 319

Dufour, Elise, 271

Dufour-Rainfray, Diane, 344

Dufresne, Christelle, 302

Dugot-Senant, Nathalie, 108

Dugourd, Philippe, 275

Duhamel, Marie, 123

Dumez, Jean-Nicolas, 280

Duminil, Jérôme, 307

Dumont, Emmie, 165

Dunyach-Remy, Catherine, 421

Duperier, Christophe, 197

Dupierris, Véronique, $\overline{191}, 192$

Dupont, Erwan, 126

Dupre, Mathieu, $\overline{138}$

Dupuy, Camille, $\overline{355}$

Dupuy, Jean-William, 108, 183

Durand, Stéphane, 327

Durand, Stéphanie, 164, 238

Durand, Thierry, 208

Dutertre, Sébastien, 152

Duval, Anais, $\underline{75}, \underline{367}$

Edelman, Aleksander, 90

Egertson, Jarrett, 61

Ehkirch, Anthony, 57, 231, 232

El Jadid, Sara, 185

El Kennani, Sara, 129

El-Hoss, Sara, 371

El-Nemer, Wassim, 371

Elena-Herrmann, Benedicte, 92

Elfakir, Claire, 283, 293

Elie, Nicolas, 193

Elie-Caille, Céline, 105

Eloy, Richard, 201

Emery, Sylvain, 339

Emond, Patrick, 124, 282, 344, 355, 359

Enjalbal, Christine, 53, 68, 116, 152

Enjalbert, Quentin, 250,387

Eparvier, Véronique, 418,419

Erb, Stéphane, 225, 232

Esbelin, Julia, 427

Escal, Jean, $\underline{358}$

Eschalier, Alain, 393

Esclassan, Rémi, 390

Escourrou, Antoine, 334

Eskenazi, Nicolas, 348
Esposito, Mélissa, 236

Esteves Gloria, Ludivine, 425

Eveillard, Sandrine, $\underline{310}$

Eydoux, Cécilia, 297

Ezzoukhy, Zakaria, 183

Ezzoukry, Zakaria, $\overline{108}$

Fabre, Bernard, 292

Fabre, Nicolas, $\underline{292}, \underline{415}$

Fadel, Ismail, 303

Faes, Pascal, 98

Fall, Fanta, 103,266

Fanuel, Mathieu, $\underline{200}$

Farenc, Mathilde, 73

Farigoule, Alexandre, 177

Fatarova, Maria, $337, \overline{339}$

Fatou, Benoit, 122

Faure, Patrice, 358

Fauvelle, Florence, 347

Favre, Laurie, $136, \underline{410}$

Fayeulle, Noémie, 296

Fedeli, Olivier, 389

Fenaille, François, 67, 117, 129, 175, 229, 235, $289,357, \underline{402}, \underline{416}, \underline{424}$

Fenet, Hélène, 71

Fernandez, Bernard, 407

Fernandez, Olivier, 311

Fernandez, Samantha, 131

Fernandez-Lima, Francisco, 65, 405

Fernando, Laurent, 47

Ferrand, Yann, 325

Ferrari, Roselyne, 209

Ferro, Myriam, 96

Fertin, Guillaume, 60

Feuilloley, Marc, $4 \overline{13}$

Fildier, Aurélie, 186, 187

Fillet, Marianne, 394

Fine, Frédéric, 299

Fiore, Frédéric, 327

Fiorini-Puybaret, Christel, 292

Fléchard, Maud, 413

Flahaut, Christophe, 139

Flamant, Frederic, 92

Flandrois, Jean-Pierre, 414

Focsa, Cristian, 122

Fontaine, edma, 203,204

Fontaine, Jean Xavier, 86

Fontaine, Jean-Xavier, $\underline{48}$

Fornecker, Luc-Matthieu, 107

Fortin, Tanguy, 250, 387

Fostner, Shawn, $\underline{80}$

Fouché, Mathieu, 300 
Fougere, Laëtitia, 207, 267, 283, 293

Fouillen, Laetitia, $\overline{397}$

Fournier, Isabelle, $\underline{91}, \underline{122}, \underline{123}, \underline{336}, \underline{343}, \underline{345}$

Fournier, Sylvie, 305

Frainay, Clément, 317

Francin-Allami, Mathilde, 304

Franck, Julien, 91, 345

Francois, Yannis, 172

Francois, Yannis-Nicolas, 58

Fresnais, Margaux, 81

Fritz, Carole, 190

Froment, Carine, 390

Fromont-Hankard, Gaëlle, 214

Fulzele, Amitkumar, 128

Fumex, Maud, 321

Gabant, Guillaume, 233, 241

Gabelica, Valérie, 109, 228, 262, 325

Gabelle, Audrey, 373

Gaceb-Terrak, Rabéa, 259

Gadaj, Anna, 166

Gagne, Didier, 116

Gagnebin, Yoric, 179, 181, 365

Gahoual, Rabah, 55

Gakière, Bertrand, 291, 309

Galan, Pilar, 164

galan, pilar, 363

Galano, Jean-Marie, 208

Gales, Lara, 337

Galineau, Laurent, 355, 359

Gallart-Ayala, Héctor, 375

Gallart-Ayala, Hector, 195

Garcia, Arnaud, 395

GARCIA, Camille, 76

Garcia, Cyrielle, 131

GARCIA, Patrice, 360

Garcia, Patrice, 176, 182, 265, 349

garcon, guillaume, 284

Gargaros, Audrey, $\overline{410}$

Garin, Jérôme, 189,191

Garric, Jeanne, 187

Gasperi, Johnny, 186

Gassner, Anne Laure, 283

Gatineau, David, 260

Gaudin, Mathieu, $\underline{203}, 204$

Gaudin, Valérie, 159

Gaudreau, Pierrette, 153

Gauquelin-Koch, Guillemette, 121

Gauthier-Vanacker, Karine, 92

Gautier, Emilie-Fleur, 256, 371

Gautier, Roselyne, 87, 211, 353

Gaviard, Charlotte, 137
Geairon, Audrey, 220, 304

Gele, Patrick, 284

Genet, Bruno, 252

Genta-Jouve, Grégory, 227, 306

Genty, Christophe, 242

Georges, Béatrice, $\overline{182}$

Georgin, Dominique, 67

Gewinner S., 36

Ghigo, Jean-Marc, 127

Giacomoni, Franck, 197, 238

giai gianetto, Quentin, 171

Giangrande, Chiara, 348

Giannakopulos, Anastassios, 264

Gibon, Yves, 97, 311

Gicquel, Gwendoline, 413

Giglione, Carmela, 194

Gil, Mélodie, 53

Gilard, Françoise, 102, 291, 309

Giles, Kevin, 243

Gilles, Rautureau, 92

Gimbert, Yves, 260, 329

Gimeno, Jean-Pascal, 336

Giorgetti, Jeremie, 58

Girard, Jean, 156

Girard, Jean-Philippe, 367

Girard, jean-philippe, $\overline{75}$

Girard, Victoria, 414

Giraud-Girard, Ken, 407

Giraudeau, Patrick, 133, 279

Giribaldi, Julien, 152

Giroud, Barbara, 388

Giuliani, Alexandre, 210, 331

Giuseppe Marco, Randazzo, 395

Giusti, Pierre, 73

Gloaguen, Pauline, 96

Gloaguen, Yoann, $\overline{317}$

Goddard, Mary-Lorène, 248

Goepfert, Nicolas, 271

Gomes, Bruno, 203

Gomez, Elena, 71

Goncalves Menoita, Marisa, $\underline{327}$

Goncalves, Olivier, 52

Gonnet, Florence, 321,324

González Flórez, A.I., 36

González, Esther M., 294

González-Ruiz, Víctor, 63, 179

Gonzalez de Peredo, Anne, 75, 128, 191, 367

Gonzalez Duque, Sergio, 119

Gonzalez Ruiz, Victor, 181

Gopal, Sandeep, 366

Gorel, Anais, 307

Gouilleux, Boris, 279 
Goulard, Christophe, $\underline{426}$

Goupille, Caroline, 267

Gourrat, Karine, 162

Govaerts, Bernadette, $\underline{62}, \underline{356}$

Govin, Jérôme, 129

Goyon, Alexandre, 57

Graber, Marianne, $\overline{222}$

Grall, Dominique, 366

Grison, Magali, 300

Grolet, Florine, $\underline{296}$

Grote, Jens, 264

Guérard, Florence, 291, 309

Guérineau, Vincent, 418,419

Guével, Blandine, 45

Guduff, Ludmilla, $\underline{280}$

Guenne, Angéline, 412

guermouche, saliha, 278

Guerrera, Chiara, 272

Guettier, Catherine, 376

Guez, Sarah, 399

Guhlan, Zuhal, 359

Guichard, Elisabeth, 162

Guillarme, Davy, 57, 58

Guilleminault, Emilie, 346

Guillemot, Jean-Claude, 297

Guillet, Benjamin, 131

Guillon, Fabienne, $\overline{200}, 304$

Guillonneau, François, 256, 276, 370, 371

Guillot, Xavier, 48

Guillou, Hervé, $\overline{399}$

Guimaraes, Cyrille, 267

Guitton, Yann, 51, 98, 133, 197, 238, 334

Gutierrez, Craig, 323

Hébraud, Michel, 427, 428

Hédou, Céline, 159

Hériter, Lauirent, 221

Haberger, Markus, 55

Haddad, Mohamed, 415

Hadjadj Aoul, Seghir, 294

Hahm, H.S., 36

Halgand, Frédéric, 237, 326

Haller, Lucia, 423

Halushkina, Anastasiia, 324

Hamdi, Safouane, $\underline{353}$

Hamm, Gregory, 203

Hanozin, Emeline, 139

Hansen, Sylvain, 356

Hao, Jingfang, 309

Harder, Alexander, 257, 264

Hardouin, Julie, 137, 413, 420

Hardy, Olivier, 307
Hautbergue, Thaïs, 235

Hay, Anne-Emmanuelle, 95

Heaven, Michael, 269

Hedjazy, Lyamine, 342

Heidenreich, Anna-Katharina, 55

Heinisch, Sabine, $\underline{57}$

Helle, Stanislas, $\underline{312}$

Hem, Sonia, 298

Henriet, Elodie, 108, 183

Henry, celine, 422, 423, 429

Henry, Hugues, 375

Hentz, Sébastien, $\underline{80}$

Hercberg, Serge, 164,363

Hercul, Eslande, 234

Hernandez Alba, Oscar, 231, 232

Hernandez-Alba, Oscar, 57

Herrera-Belaroussi, Aude, $\underline{95}$

Hertzog, Jasmine, 319

Hervé, Pierre-Yves, 196

Hess, Philipp, 212

Hesse, Anne-Marie, 191, 192, 253

Hessmann, Steve, 225

Heuillet, Maud, 100, 315, 337, 339

Hinsinger, Geoffrey, 377

Hirtz, Christophe, 373

Hleihel, Walid, 282

Hodges, Mickael, 309

Hoffmann, W., $\underline{36}$

Hofmann, J., 36

Hohenester, Ulli, 339

Hohenester, Ulli M., 224

Holcapek, Michal, 42

Holzmuller, Philippe, 407

Hopfgartner, Gérard, $\overline{77,2} 86$

Hourset, Mathilde, $\underline{390}$

Hovasse, Agnès, 369

Huber, Gaspard, $\underline{209}$

Huc, Ivan, 325

Hughes, Chris, 255

Huguet, Romain, 240, 273

Hupin, Sébastien, 261

Hurbin, Amandine, 249

Hurtaud-Pessel, Dominique, 159

Husson, Gauthier, 188

Hybois, Mickael, 332

Ichou, Farid, 342

Iman, Haddad, 180

Immel, Françoise, 300

Isabel, Vandenheede, 165

Ivanisevic, Julijana, 195, 375

Izzet, Guillaume, 261 
Jacob, Jérémy, 207

Jacques, Philippe, 139

Jaffe, Jacob D., 61

Jamet, Elisabeth, 39

Jamin, Emilien, 70, 235

Janke, Carsten, 369

Jaquinod, Michel, 93

Jargeat, Patricia, $4 \overline{11}$

Jarroux, Nathalie, 324

Jaubert, Murielle, 265

Jauffrit, Frédéric, $\underline{414}$

Jean Francois, Gossens, 284

Jesse, Canterbury, 240

Jeudy, Jérémy, 143

Jia, Liangyuan, 319

Jirasko, Robert, 42

Joly, Alexandre, 382

Joly, Charlotte, $\overline{153}$

Joly, Nicolas, 111

Jonard, Catherine, $\underline{98}, \underline{310}$

Joré, Céline, $\underline{349}, \underline{360}$

Jorge, Lucie, 372

Jouan-Rimbaud Bouveresse, Delphine, 160

Jouenne, Thierry, 137, 420

Joulia, Philippe, 292

Jourdan, Fabien, 47, 317

Jouret, François, $\overline{88}$

Jousse, Cyril, $17 \overline{7,} 218$

Joutel, Anne, 180

Jung, Vincent, 90, 272

Junot, Christophe, 67, 117, 175, 229, 235, 339, $\underline{357}, \underline{402}, \overline{416}, \overline{424}$

Jurkunas, Ula V., 111

Just, Pierre-Alexandre, 370

Juste, Catherine, $\underline{429}$

Kalli, Anastasia, 316

Kamissoko, Adama, 216

Kang, Chantal, 351

Kaoma, Tony, 47

Kauffmann, Jean-Michel, 308, 392

Kaur-Atwal, Gushinder, 255

Kazmierczak, Théophile, 309

Kenan, Sylvain, 339

Kernalléguen, Angéline, 68

Kesse-Guyot, Emmanuelle, 70, 164, 363

Khalikova, Maria, 42

Khoel, Bérengère, 371

Khoury, Spiro, 134, 339

khoury, Spiro, 178

Knebelmann, Bertrand, 90

Kobeissy, Firas, 343
Kok, Miranda, $\underline{394}$

Kolthur-Seetharam, Ullas, 128

Konz, Ioana, $\underline{375}$

Kosinski, Thomas, 269

Kouassin Zoughet, Judith, 403

Kraut, Alexandra, 253

Krempf, Michel, 103

Krouk, Gabriel, 298

Krug, Karsten, 61

Kruppa, Gary, $\overline{269}$

Kuharev, Jörg, 255

Kulyk Barbier, Hanna, 337

Kulyk-Barbier, Hanna, $\overline{339}$

Kuntz, Marcel, 96

Kuprov, Ilya, 280

Kurzbach, Dennis, 280

Kuster, Bernhard, $\underline{350}$

Léger, Claire, 424

Léger, Thibaut, 76, 111

Labas, Valérie, $\overline{201}, \underline{338}, 404$

Labouré, Hélène, 162

Laboureur, Laurent, 398

Lacombe, Maud, 93, 154

Lacroix, Elodie, 156

Lacroix, Matthieu, 384

Laeners, Guy, 403

Lafitte, Daniel, $\underline{68}$

Lagarrigue, Mélanie, 45, 214

Lagatie, Ole, 372

Lagrée, Marie, 177, 218

Lairon, Denis, $\underline{351}$

Laloue, Hélène, 248

Lamari, Foudil, 117

Lamari, Nadia, 339

Lambert, Gilles, 103

Lambert, Matthias, 126

Lambert, Vincent, 356

Lamothe-Sibold, Marlène, 291

Lamourette, Patricia, 416, 424

Lamoureux, Annie, 422

Lamouri, Aazdine, 111

Landon, Céline, 106

Lange, Olivier, 264

Langella, Olivier, 429

Langlade, Nicolas, 311

Lanza, François, 369

Laprévote, Olivier, 400, 401

Larre, Colette, 304

Latino-Martel, Paule, 164, 363

Laurent, François, 214

Lavanant, Hélène, $\overline{261}$ 
Lavigne, Jean-Philippe, 421

Lavigne, Régis, 45, 66, 214

Lazard, Myriam, 169

Lazarus, Mathieu, 247

Lazouk, Melha-Amel, 48

Le Bail, Brigitte, 108

Le Beller, Dominique, 46

Le Bizec, Bruno, 133, $\overline{334}$

Le Cahérec, Françoise, 98

Le Cam, Laurent, 384

Le cam, Laurent, $\frac{100}{100}$

Le Corguillé, Gildas, 197

Le Danvic, Chrystelle, 270, 382

Le Faouder, Julie, 361

Le Faouder, Pauline, 399

Le Gouëllec, Audrey, 424

Le Gouellec, Audrey, $\overline{347}, 358$

Le Guernevé, Christine, 335

Le Hir, Rozenn, 310

Le Lamer, Anne-Cécile, 220

Le Meillour, Louise, 270

Le moyec, Laurence, 285

Le Naour, François, $3 \overline{76}$

Le Pogam, Pierre, 220

Le Quéré, Jean-Luc, 162

Le Roux, Cynthia, 408

Le Ruyet, Pascale, $\overline{131}$

Lebeau, Diane, 324

Leblanc, Catherine, 156

Lebon, Matthieu, 270

Lebsir, Dalila, 352

Leclère, Valerie, 139

Leconte, Patrick, 98

Lecuyer, Lucie, $1 \overline{64}, 363$

Leduc, Marjorie, 256, 370, 371

Leenders, Justine, $\frac{88}{28}, \frac{356}{344}$

Lefèvre, Antoine, $282, \underline{344}$

Lefai, Etienne, 121

Lefebvre, Marie, 339

Lefevre, Antoine, $\underline{355}$

Lefort, Gaëlle, 112

Leger, Thibaut, 209

Legouin, Béatrice, 220

Legoupil, Thierry, $\overline{148}$

Legrand, Jack, 52

Legros, Véronique, 331

Lehmann, Sylvain, 373,377

Lehmann, Sylvia G, 354

Lehmann, Sylvia G., 249

Leize, Emmanuelle, $\underline{328}$

Leize-Wagner, Emmanuelle, 58, 81, 172

Lemaitre-Guillier, Christelle, $\underline{302}$
Lenglet, Timothee, 284

Lennon, Sarah, 255

Lenuzza, Natacha, 197, 266

Leonard, Susan, 168

Leonetti, Georges, 68

Leport, Laurent, 98

Lerouet, Dominique, 400

Leroux, Cédric, 156

Leroy, Marc, 230

Lesage, Denis, 260

Lescuyer, Pierre, 365

Lesouhaitier, Olivier, $\underline{413}$

Lesquame, Guillaume, 46

Leste-Lasserre, Thierry, 108

Lesur, Joséphine, 270

Letellier, Guillaume, $\underline{46}$

Leyssen, Pieter, 236

LI, Yanyan, 426

Liang, Julie, $\underline{408}$

Liebart, Jean-Claude, 111

Lima, Diogo Borges, 138

Linard, Cyril, 346

Linares, Laetitia, 100

Lipecka, Joanna, 90, 272

Lippens, Guy, $\underline{315}$

Lisa, Miroslav, $\underline{42}$

Lisacek, Frederique, 139

Litaudon, Marc, 236, 297

Liu, Cailing, 111

Liuu, Sophie, 287

Livet, Sandrine, 262

Locard-Paulet, Marie, 128

Loeder, Martin, 205

Lollier, Virginie, 60, 304

Lopez de Alda, Miren, 34

Loup, Benoît, 349, 360

Loup, Benoit, $\overline{176}, \overline{265}$

Loussouarn, Aurelie, 103

Loutelier-Bourhis, Corinne, 174

Loux, Valentin, 154

Lubeck, Markus, 268

Lucas-Torres, Covadonga, 251

Lucchi, Géraldine, 105

Ludwig-Papst, Carmen, 147

Lyan, Bernard, 164, 218, 224

lyan, bernard, 134

Mériaux, Céline, $\underline{345}$

Mašek, Ondřej, 319

MacAleese, Luke, 275

MacCoss, Michael, 61

Mackay, Logan Colin, 319 
Madigou, celine, 412

Madiona, Karine, $\overline{239}$

Madji Hounoum, Blandine, 124

Magiera, Maria M., 369

Mahious, Lila, 295

Maillard, Emmanuelle, 371

Maillard, Julien, 219

Mailler, Romain, 186

Maillot1, Olivier, $\underline{413}$

Maitre, Marlène, 183

Makni, Salim, 350

Malgorn, Carole, 67

Malissen, Bernard, 327

Malissen, Marie, 327

Mallah, Khalil, 343

Mallet, Christophe, 393

Mallone, Roberto, 119

Malosse, Christian, 138

Manach, Claudine, 164

Mandavid, Hugues, 46

Maniyadath, Babukrishna, 128

Marceau, Sabrina, 73

Marcellin, Marlène, 128

Marcellin-Gros, Rémy, 95

Marchand, Jérémy, 133, 279

Marchand-Leroux, Catherine, 400

Marchioni, Eric, 313

Marianski, M., 36

Marie, Arul, 215, 270, 271

Marie, Benjamin, 215

Marin, Philippe, $1 \overline{98,} 377$

Marion, Sabrina, $\overline{425}$

Markossian, Suzy, 92

Markov, Gabriel, $1 \overline{56}$

Marnet, Nathalie, 98

Martens, Lennart, 35

Marti, Guillaume, $\underline{292}$

Martin, Cécile, 87

Martin, Jean-Charles, 131, 299, 351, 352

Martin, Jean-François, 70

Martin, Jean-Francois, $\overline{197}, 307$

Martin, Manon, 62

Martin-Bernabe, Alfonso, 78

Martin-Magniette, Marie Laure, 310

Martineau, Estelle, 133

Martinez, Jean, 116

Marx, David, 368

Masotti, Nicole, 131

Masselon, Christophe, 80, 253

Massicot, France, 401

Masson, Elodie, 178

Matheron, Lucrèce, 263
Matheront, Lucrèce, 215

Matondo, Mariette, 171

Matringe, Michel, 96

Mattar, Hanna, 282

Matthieu, Bourderioux, 90

Mauduit, Philippe, 376

Maunit, Benoit, 267

Maurel, Christophe, 298

Maurin, Max, 424

Maurizot, Victor, 325

Mauve, Caroline, 102, 291

MAVEL, Sylvie, 344

Mavel, Sylvie, 124, 282, 359

Mayeux, Patrick, 256, 276, 370, 371

Mazeas, Laurent, $\underline{412}$

Mc Call, Eimear, 168

Mehl, Florence, 375

mehl, florence, 195

Meier, Florian, 268

Meininger, Vincent, 284

Meinnel, Thierry, 194

Meireles, Maria-Helena, 339

Melichar, Bohuslav, $\underline{42}$

Melki, Ronald, 239

Memboeuf, Antony, 260

Merlet, Benjamin, 317

Merour, Emilie, 422

Meruva, Naren, 332

Mesnard, François, 48

MetaboHUB members, and all other, 339

MetaSpace, Consortium, 66

Meudal, Hervé, 106

Meudec, Emmanuelle, 335

Mevaere, Jimmy, 426

Meynet, Elodie, $3 \overline{47}$

mezange, christine, 423

meziere, marie, 171

Michalkova, Veronika, 405

Micheau, Pierre, 164

Michelland, Sylvie, 78, 173, 249, 379

Miesh-Fremy, Sandrine, 93

Migaud, Martine, 201

Migné, Carole, 238

Mihoub, Mouadh, 111

Milet, Anne, 260

Millard, Pierre, 100, 315

Millet, Arnaud, 362

Minassian, Frédéric, 379

Mintz, Elisabeth, 93

Miotello, Guylaine, 407

Mirmont, Elodie, 182

Miscoria, Gilles, $\underline{389}$ 
Modzelewska, Karolina, 45

Moehring, Thomas, 257, 264

Moing, Annick, 97, $\underline{311}$

Molinié, Roland, 48

Molinie, Roland, $\underline{86}$

Mollereau-Manauté, Catherine, $\underline{390}$

Mompelat, Sophie, 159

Mondeguer, Florence, 212

Monnerie, Stéphanie, $\overline{153}$

Monnet, Véronique, $4 \overline{23}$

Monnet-Tschudi, Florianne, 63

Monteau, Fabrice, 334

Montecucco, Fabrizio, 283

Mooney, Mark, 166

Morais, José, 153

Morand, Christine, 164

Morani, Marco, 175

Moreau, Richard, 357

Moreau, Violaine, 183

Moreira, Cynthia, 177

Moreno, Andrés, $\underline{251}$

Morgavi, Diego, 87

Morgavi, Diego P., 224

Morio, Cédric, 207

Morlet, Bastien, 76

Moulard, Yves, 265

Moumne, Roba, 263

Mourad, Michel, 88

Mourier, Gilles, $\underline{321}$

Moussa, Ahmed, 185

Mouton-Barbosa, Emmanuelle, 128, 191, 390

Moyne, Oriane, 424

Moyon, Thomas, 51

Muccio, Stéphane, 389

Mucha, E., $\underline{36}$

Mullen, Christopher, 240

Muller, Leslie, $\underline{107}, \underline{368}$

Multigner, Luc, 214

Muselli, Alain, $\underline{114}, \underline{391}$

Nadal, Marc, 111

Nadal-Desbarats, Lydie, 124, 282

Nagnan-Le Meillour, Patricia, 270, 382

Nahon, Laurent, 210

Nauleau, Fabrice, 186

Ndiaye, Sega, 264, 323

Nef, Serge, 395

Negro, Sandra, 301

Neil, Kelleher, $\overline{273}$

Nesi, Nathalie, 98

Neyts, Johan, 236

Nguyen, Lien, 154
Nguyen-khoa, Thao, 90

Nick, Peter, 248

nicol, edith, $\underline{72}, 163,242$

Nicolas, Stéphane, 301

Nicolini, Brigite, $13 \overline{31}$

Niemo, Laetitia, $\underline{426}$

Nikolski, Macha, 108

Niogret, Marie-Françoise, 98

Nishiyama, Yusuke, 85

Nkoyock, Marina, $3 \overline{70}$

Noël, Agnès, 356

Noret, Nausicaa, 307,308

Noriega, Fernando, 405

Nothias-Scaglia, Louis-Félix, 236

Nouet, Julius, 193

Nouzova, Marcela, 405

Nuzillard, Jean-Marc, $\underline{244}$

Obeid, Sameh, 105

Oblet, Christelle, $\underline{383}$

Officer, Adam, 61

Oger, Camille, 208

Oikonomidi, Aikaterini, 375

Olivier, Marie-Françoise, 235

Olivon, Florent, 297

Ollero, Mario, 374

Oppert, Jean-Michel, 342

Orange, Nicole, 413

Ortalo-Magné, Annick, 136, 410

Ortiz, Alexia, 165, 372

Ory, Pascaline, 222

Ottavi, Jean-François, 376

Ouni, Souhir, 354

Pélissier-Alicot, Anne-Laure, 68

Pétéra, Mélanie, 153, 164, 197

Pagel, Kevin, 36

Pagnon, Remi, 221

Palama, Tony, $\overline{47}$

palaric, cécile, $\overline{86}$

Pallares-Lupon, Nestor, 108

Palmer, Andrew, 45

Pannequin, Anais, 114

Paolini, Julien, 236

Paradis, Valérie, 361

Pardo, José Emilio, 251

Partula, Valentin, 164

Patin, Franck, 403

patin, franck, 284

Paudel, Iru, 65

Paul, Nicodème, 107

Paulhe, Nils, 238, 339 
Paupy, Benoit, 73

Pavageau, Marie-Pierre, 240, 316

Pawlak, André, 374

Payette, Hélène, 153

Peake, David, 316

Pecorari, Frédéric, 103

Pellizzaro, Anthoni, 98

Perdu, Elisabeth, 211

Perret, Alain, 329, 430

Perret, Christine, 370

Perus, Lisa, 154

Petera, Mélanie, 238

Petit, Alain, 86

Petit, Emmanuel, 48

Peyratout, Gwendoline, 375

Peyriga, Lindsay, $315,3 \overline{37}$

Peyron, Marie-Agnes, $\frac{161}{165}$

Pezzati, Julian, 181,365

Pezzatti, Julian, $\underline{63}, \underline{179}$

Pflieger, Delphine, 129

Piccolo, Stefano, 228

Pichereaux, Carole, 410

Pichon, Valerie, $\underline{348}$

Pilard, Serge, 86

Pinard, Ludovic, 319

Pinault, Michelle, 267

Pineau, Charles, 45, 66, 214

Pinguet, Jeremy, 161, 393

Pinochet, Xavier, 299

Piot, Madeleine, 261

Piotto, Martial, 144

Pirnay, Stéphane, 163

Pirotte, Bernard, 356

Pizarro-Cerda, Javier, 416

Plainchont, Bertrand, $\underline{244}$

Planchon, Mariane, 209

Pleurdeau, David, 270

Poisat, Julie, 189

Poisson, Jean-François, 379

Poitou, Christine, $\underline{342}$

Polomé, Andy, 295

Pons, Simon, 305

Ponte, Belen, $\underline{365}$

Pontet, Célia, 299

Popot, Marie-Agnès, 176, 182, 265, 349, 360

Popp, Julius, 375

Portais, Jean-Charles, 100, 315, 337

Potier, Noëlle, 328

Poupin, Nathalie, 47, 317

Pouponneau, Karine, $\overline{334}$

pouyet, corinne, 134

Poyer, Salomé, 275
Prache, Nolween, 116

Pradat, Pierre Francois, 284

Preys, Sébastien, 162

Prouteau, Laura, $\overline{339}$

Puech Pages, Virginie, 305

puech pages, virginie, $\overline{411}$

Puech-Pagès, Virginie, $\overline{417}$

Pujos-Guillot, Estelle, 134, 153, 164, 202, 238

Pupin, Maude, 139

Qannari, El Mostafa, 51

Quanico, Jusal, 91, $3 \overline{43}$

Quereda, Juan J., 416

Quintana, Sabine, $\overline{247}$

Quinton, Loïc, 152

Rabilloud, Thierry, 50

Rabin, Clémence, $\overline{109}$

Raboudi, Amel, 196

Rabouille, Gabriel, $\underline{415}$

Rabuka, David, 232

Rachidi, Walid, $\underline{354}$

Radwanska, Agata, 366

Raether, Oliver, 268

Rageot, David, 105

Rahmania, Fatma, 259

Rakic, Jean-Marie, $\underline{356}$

Raoul, Cédric, 124

Rautureau, Gilles, 349

Ravanel, Stéphane, 96

Raviglione, Delphine, 217, 221

Raymond, Anne-Aurélie, 108,183

Rebuffat, Sylvie, 426

Redeker, Virginie, 169, 234, 239

Regazzetti, Anne, $\overline{400}, 401$

Reginato, Emilie, $\overline{395}$

Regnier, Marion, $\overline{399}$

Reiter, Lukas, 255

Remaud, Gérald, 279

Remy, Pierre, 176

Remy, Simon, $\overline{297}$

Renaud, Tristan, 86

Renois Predelus, Gina, 82

Renucci, Franck, 391

Repoux, Marie, 162

Retailleau, Pascal, 236

Rety, Maxime, 207

Reubrecht, Sébastien, 212

Reusch, Dietmar, 55

Reversat, Guillaume, 208

Rey, Marjolaine, 95

Reynes, Christelle, 53 
Reynier, Pascal, 403

Rezaei, Human, $\overline{237}$

Rhazi, Larbi, $\underline{48}$

Rhino, Béatrice, 293

Ricart, Emma, 139

Richard, Damien, 161, 393

Richardin, Pascale, 81

Richardson, Keith, 255

Richarme, Gilbert, 111

Riches, Eleanor, 73

Rincon Aguilar, Carlos, 398

Riols, Fabien, 339

Ripoche, Alexis, 166

Rivals, Isabelle, $\overline{385}$

Roccon, Alain, $\underline{389}$

Roch, Léa, 339

Rochel, Natacha, 328

Rocher, Amandine, 208

Rocher, Vincent, 186

Rodet, Franck, 123

Rodríguez-Gómez, Rocio, 392

Rodriguez-Silva, Monica, 65

Roempp, Andreas, 205

Roest, Hannes, 255

Rofidal, Valérie, 298

Roga, Stephane, 367

Roger, Jean-Michel, 296

Roger-Mele, Pierrick, 197, 339

Rogniaux, Hélène, 60, 200, 220, 304

Roig, Benoit, 421

Rolain, Jean Marc, 350

Rolando, Christian, 132, 274, 312

Rolin, Dominique, 339

Rolland, Norbert, 96

Rolland, Sophie, 98

Rollet-Cohen, Virginie, 90

Rombaut, David, 276

Roncagalli, Romain, 327

Rondel, Karine, 214

Ropartz, David, 200

Roques, Simon, $\overline{339}$

Rosique, Clément, 352

Rossato, Maxime, 116

Rosu, Frédéric, 262

Rosu, Frederic, $\underline{325}$

Roucou, Xavier, 91

Rouillac, Lénaïck, 412

Roulard, Romain, 48

Roussi, Fanny, 236

Rouvière, Florent, 57

Roy, Mélanie, 418, 419

Royer, Anne-Lise, $\overline{334}$
Rué, Olivier, 154

Rudaz, Serge, 63, 179, 181, 283, 365, 395

RUEL, Coralie, 175

Ruel, Coralie, 289

Süssmuth, Roderich, 46

Séveno, Martial, 198, 377

Sève, Michel, 354

Sabatier, Robert, 53

Sachon, Emmanuelle, 263

Saenz, Nancy, 390

Saffiedine, Brahim, 420

Sago, Laila, 234

Sahali, Djillali, 374

Said, Nassur, 172

Saint-Dizier, Marie, 404

Sakly, Mohsen, 354

Sakthivelou, Felindra, 326

Salanoubat, Marcel, 430

Salnot, Virginie, 370, 371

Salpin, Jean-Yves, 275

Saltel*, Frédéric, 108

Saltel, Frédéric, 183

Salvia, Marie-Virginie, 217

Salzet, Michel, 91, 122, 123, 288, 336, 343, $\underline{345}$

Sancelme, Martine, 218

Sandra, Koen, $165, \underline{372}$

Sandra, Pat, 165

Sandstrom, Jenny, 63

Sansa Perna, Marc, 80

Sanson, Romain, 370

Santé-Lhoutellier, Veronique, 161

Santerre, Cyrille, 56

Santoni, Véronique, 298

Santos, Tiago, 427, 428

Sanz, Miguel Angel, 350

Sarrut, Morgan, 57

Sarry, Jean-Emmanuel, 47, 339

Saucier, Cédric, 53

Saudemont, Philippe, 122

Saulnier, Justine, 404

Saulnier, Luc, 200

Sautot, Caroline, 339

Savarin, Philippe, 285, 363

Sayd, Thierry, 161

Scarpelli, Jean-Pierre, 194

Schölkopf, W., 36

Schaeffer-Reiss, Christine, 369, 425

Schang, Anne-Laure, 401

Schappler, Julie, 181

Scheier, Rico, 205

Schindler, Baptiste, 82 
Schmidt, Heiner, 205

Schmit, Pierre-Olivier, 144, 268, 269, 373

Schmitt, Alain, 90

Schmitt, Pauline, 367

Schmitter, Jean-Marie, 205, 383

Schmitz-Afonso, Isabelle, 219

Schneider, Bernd, 37

Schneider, Justine, 425

Schoumacher, Matthieu, 356

Scipion, Maureen, 214

Searle, Brian, 61

Seeberger, P.H., 36

Seigneurin-berny, Daphné, 96

Semon, Etienne, 162

Sendeyo, Kelhia, 374

Sermet-Gaudelus, Isabelle, 90

Serrière, Sophie, 359

Servent, Denis, $\underline{321}$

Servien, Rémi, 112

Seta, Nathalie, 289

Seve, Michel, 78, 173, 249, 379

Shakir, Shakir, 254, 385

Shameer, Sanu, 317

Sharma, Seema, 240

Shlomi, Tomer, 38

Sibat-Dubois, Manoella, 212

Sid Ahmed-Adrar, Nazha, 376

Siegel, Anne, 156

Simard, Gilles, 403

Singhal, Kratika, 323

Siroit, Christophe, 146, 243

Slais, Karel, 173

Smargiasso, Nicolas, 139

Snovida, Sergei, 323

Sohier, Pierre, 370

Sola, Laura, 175

Sommerer, Nicolas, 335

Somsen, Govert, 55

Souard, Florence, 392

Souard, florence, $\underline{307}, \underline{308}$

Soufia, Michel, 282

Souidi, Maamar, 352

Sourdon, Joevin, 196

Spalla, Olivier, 209

Spinner, Loïc, 388

Srour, Bernard, 164

Stévigny, Caroline, 307, 308, 392

Stanislas, Grassin-Delyle, 266

Stark, Ann-Kathrin, 80

stauber, Jonathan, 203, 204

Steenbeke, Mieke, 165

Stella, Alexandre, $\underline{367}, \underline{390}$
Stevant, Isabelle, $\underline{395}$

Stien, Didier, 418, 419

Stoffelen, Piet, $\underline{308,392}$

Stojiljkovic, Natali, $\frac{182}{369}$

Strassel, Catherine, $\underline{\underline{369}}$

Stratton, Tim, 240

Strupat, Kerstin, 264

Struwe, W.B., 36

Stuani, Lucille, $\underline{47}, \underline{101}$

Stuyver, Lieven, 372

Subra, Gilles, $11 \overline{6}$

Sudaka, Anne, 366

Suryawanshi, Rahul, 217

Svilar, Ljubica, 299

Swart, Remco, 257

Sylla, Sophia, 358

Szydlowski, Nicolas, 312

t'Kindt, Ruben, 372

Tabet, Jean Claude, 402

Tabet, Jean-Claude, 83, 235, 322, 329

Tahrioui, Ali, 413

Taib, Toufik, 400

Tapissier, Nathalie, 247

Taran, Frédéric, 67

Tardieu, François, 301

Tardif, Marianne, $\overline{96}$

Tardivel, Patrick, $\underline{112}$

Tarnus, Céline, 248

Tarrago-Celada, Josep, 78

Tauber, Clovis, 359

Taudon, Nicolas, 346

Taverna, Myriam, 175

Tavernier, Reynald, 48

Tavitian, Bertrand, $\overline{196}$

Teav, Tony, 118, 195, 375

Teixeira-Gomes, Ana-Paula, 201

Tenzer, Stefan, 255

Terral, Guillaume, 226

Terrier, Samuel, $339, \underline{416}$

Terris, Benoit, 370

Tessier, Dominique, 60

Théron, Laëtitia, 428

Thévenot, Etienne, 197, 235, 266, 308

Thèves, Catherine, $\underline{390}$

Theron, Laetitia, 202, 339

Thibault, Pierre, $\underline{384}$

Thiebault, Thomas, 207

Thoeing, Christian, 264

Thomé, Jean-Pierre, 214

Thomas, D.A., 36

Thomas, Marion, 430 
Thomasset, Brigitte, 48

Thouvenot, Eric, 377

Ting, Sonia, 61

Tintaru, Aura, 114

Tirat, Sophie, 46

Tognetti, Vincent, 261

Tokarski, Caroline, $\underline{40}, \underline{132}, \underline{312}$

Tollance, Axel, 173

Tomas, Daniel, $\overline{404}$

Tosello, Gilles, $\underline{190}$

Touahni, Rajaa, 185

Touboul, David, 56, 236, 297, 398, 418, 419

Touhami, Aicha, 303

Toussaint, Bertrand, $\underline{358}, \underline{424}$

toussaint, bertrand, 347

Touvier, Mathilde, 164,363

Trévisiol, Stéphane, 265

Traïkia, Mounir, 218

Tran, Thuy, 175

Tran-Maignan, Thuy, 289

Trauchessec, Mathieu, 250

Tremblay-Franco, Marie, 112, 197, 211, 307, 350, $\underline{353}$

Triastuti, Asih, 415

Triba, Mohamed, $285, \underline{363}$

Trottier, Camille, 156

Ubeda, Carles, $\underline{350}$

Ujma, Jakub, 243

Um, Khémary, 93

Urbach, Serge, 198, 377

Vénien, Annie, 202

Vaca, Sebastian, 61

Vachiery, Nathalie, 407

Vachin, Pauline, $\underline{37 \overline{4}}$

Valenduc, Marjorie, 46

Valentin, Alexis, $\underline{415}$

Vallet, Marion, 177

VALLET, Nadine, 56

Vallverdu-Queralt, Anna, 296

Valois, Ludivine, 313

Van Antwerpen, Pierre, 307, 308

van Delft, Pierre, 397

van der Rest, Guillaume, 237, 326

Van Dorsselaer, Alain, $\underline{369}$

Van Gheluwe, Louise, $\underline{109}$

van Heijenoort, Carine, 280

Van Nuffel, Sebastiaan, $\overline{190}, 193$

Van Obberghen-Schilling, Ellen, 366

Vanbellingen, Quentin, 65, 405

Vandenbrouck, Yves, $9 \overline{6,}, 1$
Vandenbussche, Jonathan, $\underline{372}$

Vanhoenacker, Gerd, 165

Vansteelandt, Marieke, $\underline{415}$

Vanwonterghem, Laetitia, 249

Varlet-Marie, Emmanuelle, 349, 360

Vasson, Marie-Paule, $\underline{363}$

Velickovic, Dusan, 200

Verbaere, Arnaud, 335

Verbrugghe, Morgane, 423

Vercauteren, Joseph, 208

Verdier, Luc, 335

Verdier, Yann, 119

Vermet, Laurent, 389

Verneau, Olivier, 221

Vernhes, Emeline, 80

Veyrat, Chalotte, 403

Viala, Didier, $364, \underline{42} 7,428$

Vialaret, Jérôme, 373

Viard, Fanny, 339

Victor Bala, Agnès, 363

Vigneron, Arnaud, 388

Vigor, Claire, 208

Vigy, Oana, 198,377

Vilaine, Françoise, 310

Viner, Rosa, 323

Vinh, Joëlle, 254, 385

Vinh, Joelle, 119, 127, 180, 215, 287, 348

Vinson, Florence, 317

Viode, Arthur, 117

Vissers, Johannes PC, 255

Vitrac, Xavier, 391

Vlad, Zabrouskov, 240, 273

von Helden, G., 36

Vourc'h, Patrick, 282

Vourch, Patrick, $\underline{403}$

Vrana, David, $\underline{42}$

Vujovic, Svetlana, 72, 163

Vulliet, Emmanuelle, 186, 187, 388

Wagner - Rousset, Elsa, 58

Wagner, Alain, 225

Wagner, Elsa, $3 \overline{87}$

Wagner-Rousset, Elsa, 226, 232, 381

Walter, Philippe, 190

Warnet, Anna, 235

warnet, anna, $\underline{402}$

Welker, Martin, 414

Wiebach, Vincent, $\underline{46}$

Wilhelm, Kim, 248

Willmann, Claire, $\underline{390}$

Wirgot, Nolwenn, 218

Wisztorski, Maxence, 91, 122, 123, 336 
Wolfender, Jean-Luc, 297

Wong, Alan, 85

Wuhrer, Manfred, 55

Xavier, Karina, 350

Xie, Juan, 275

Xuan, Yue, 257

Yahiaoui-Zaidi, Rachida, 295

Yanibada, Bénédict, 87

Yen-Nicolay, Stéphanie, 289

Zagiel, Benjamin, 263

Zala, Ninon, 93

Zalko, Daniel, 211, 353

Zanolli, Clément, $\underline{390}$

Zazzo, Antoine, 270, 271

Zhendre, Vanessa, 339

Zhou, Yuxiang, 217

Zibara, Kazem, $\overline{343}$

Zirah, Séverine, 270, 271, 382, 426

Ziskind, Michael, 122

Zivy, Michel, 97, 301

Zonja, Bozo, 34

Zuo, Xuan, $\underline{2 \overline{42}}$ 


\section{Table des matières}




\section{Table des matières}

$\begin{array}{ll}\text { Introduction } & 7\end{array}$

$\begin{array}{ll}\text { Programme détaillé } & 14\end{array}$

$\begin{array}{ll}\text { Ateliers, tables rondes et club jeunes } & 27\end{array}$

Club Jeunes : Réunion annuelle des trois clubs jeunes $[\mathrm{CJ}] \ldots \ldots \ldots$

Atelier 1: Méthodes rapides en RMN 2D pour l'analyse quantitative de mélanges [A1] . 29

Atelier 2: La métabolomique appliquée aux communautés (meta-métabolomique [A2] ․ 30

Atelier 3: Outils d'analyse des spectres de fragmentation pour l'identification des petites

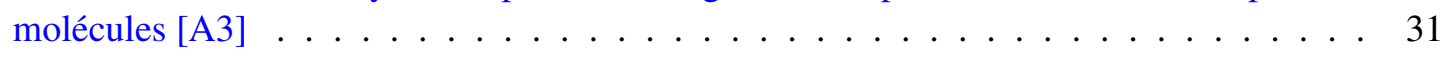

Conférenciers invités

Enjeux sociétaux des technologies omiques [I1], Catherine Bourgain $\ldots \ldots \ldots$. . . . 33

Smart Suspect Screening and Related HRMS Approaches for Detection of Pharmaceuticals and their Transformation products in Real-World Water samples [I2], Damia

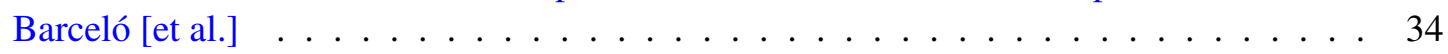

The power and promise of a thousand and one proteomes [I3], Lennart Martens $\ldots \ldots$

Gas-phase structural analysis of complex carbohydrates [14], Kevin Pagel [et al.] … 36

NMR- and MS-based micrometabolic profiling of plants [I5], Bernd Schneider $\ldots . .37$

Cancer cellular metabolism at a spatio-temporal resolution [I6], Tomer Shlomi . . . . . . 38 
Towards a functional plant cell wall proteome atlas: from protein identification to characterization of post-translational modifications [I7], Elisabeth Jamet $\ldots \ldots$. . . . . . . 39

Art and Cultural Heritage natural polymers by bottom up and top down approaches [I8], Caroline Tokarski . . . . . . . . . . . . . . . . . . 40

Cerebrospinal fluid proteomics in multiple sclerosis [19], Frode Berven . . . . . . . . . . 41

Accurate lipidomic quantitation: a case study of kidney cancer [I10], Michal Holčapek [et

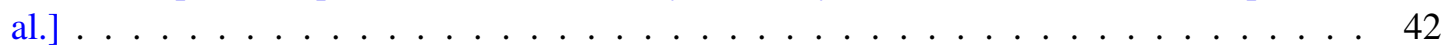

Intégration des données et approches multi-omiques [S1a]

Metabolite imaging and shotgun proteomics to decipher the role of epididymis in sperm maturation [O1], Karolina Modzelewska [et al.] . . . . . . . . . . . . . . . . . . 45

Identification d'une nouvelle classe de lanthibiotiques : utilisation combinée de l'exploration de données génomiques et de la spectrométrie de masse MALDI et HRMS [O2], Sophie

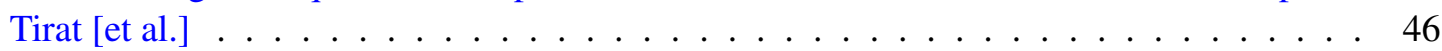

Modélisation du réseau métabolique des cellules de Leucémies Aiguës Myéloïdes pour comprendre les différences métaboliques liées à la mutation sur IDH1 [O3], Laurent

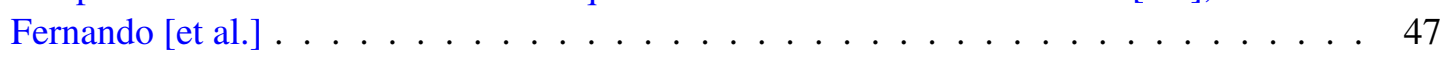

Multiblock Omics data fusion: an efficient strategy to understand climatic effect on flaxseed (Linum usitatissimum) composition [O4], Roland Molinié [et al.] . . . . . . . . 48

Alimentation et santé [S1b]

Input of proteomic analyses for understanding cellular responses to nanoparticles: toward mechanistic data and evidence for cross-toxic effects [O5], Thierry Rabilloud … 50

Breast milk lipidome as a predictive component of postnatal growth trajectory in preterm infants [O6], Marie-Cécile Alexandre-Gouabau [et al.] $\ldots \ldots \ldots \ldots$. . . . . . . 51

Découverte de marqueurs précoces de l'altération des ovoproduits au cours de leur procédé de fabrication par des approches de prises d'empreintes métabolomique utilisant des techniques combinées (RMN et MS) [O7], Rémy Coat [et al.] . . . . . . . . . . . . . 52

Shotgun polyphenomics of rosé wines [O8], Mélodie Gil [et al.] $\ldots \ldots \ldots \ldots$ 
Characterization of monoclonal antibodies - receptor interaction using affinity liquid chromatography coupled to native mass spectrometry [09], Rabah Gahoual [et al.] $\ldots .55$

Flowers absolute fingerprint with SFC-HRMS non targeted method [O10], Cyrille San-

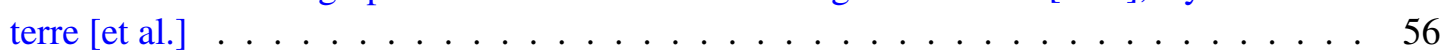

An online four-dimensional HICxSEC-IMxMS methodology for in-depth characterization of antibody drug conjugates [O11], Anthony Ehkirch [et al.] $\ldots \ldots \ldots \ldots$

Analysis of Monoclonal Antibody Fc-glycosylation profiles using Capillary electrophoresis - mass spectrometry [O12], Jeremie Giorgetti [et al.] $\ldots \ldots \ldots \ldots$

Traitement et analyse statistique des données

SpecOMS permet d'obtenir le profil des modifications portées par un échantillon analysé en MS/MS en quelques minutes [O13], Dominique Tessier [et al.] . . . . . . . . . . . 60

Combattre le feu par le feu: Comprehensive DIA spectral libraries improve phosphopeptide identification and quantification by DIA [O14], Sebastian Vaca [et al.] . . . . . . . . 61

Complex designs combining ASCA/APCA-derived methods and mixed models [O15], Manon

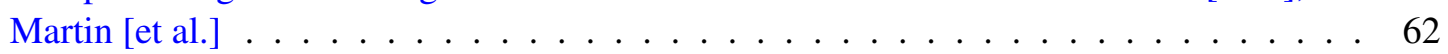

Two birds, one stone: ANOVA multiblock OPLS supports data analysis and method comparison in toxicant-induced neuroinflammation observed in 3D rat neural cell cultures [O16], Víctor González-Ruiz [et al.] . . . . . . . . . . . . . . . . . 63

Imagerie in vitro et in vivo

Analysis of Chemotherapeutic Drug Delivery at the Single Cell Level Using TOF-SIMS [O17], Quentin Vanbellingen [et al.] $\ldots \ldots \ldots \ldots \ldots \ldots$

MetaSpace: A molecular annotation engine for metabolite imaging mass spectrometry [O18], Régis Lavigne [et al.] . . . . . . . . . . . . . . . . . . . 66

Development of a dual imaging strategy combining radio- and mass spectrometry imaging to study the biodistribution of 14C-graphene oxide [O19], Hélène Cazier [et

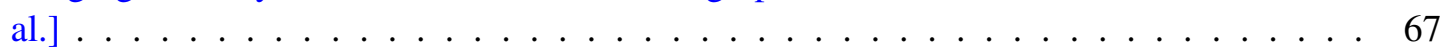

Characterization and localization of synthetic cannabinoid isomers in hair using MALDI-

MSn imaging [O20], Angéline Kernalléguen [et al.] . . . . . . . . . . . . . . . 68 
Apport et limites des approches non ciblées de spectrométrie de masse à haute résolution pour la caractérisation de l'exposome : cas des pesticides [O21], Emilien Jamin [et al.] · $\quad 70$

LC-HRMS based metabolomics to highlight biotransformation products and unexpected effects of diclofenac in Mytilus galloprovincialis [O22], Bénilde Bonnefille [et al.] . . . 71

Ecotoxicity of sunlight irradiated marketed mixtures of acetamiprid and structural characterisation of unknown photoproducts [O23], Edith Nicol [et al.] . . . . . . . . . 72

Intrinsic ion mobility peak width as an indicator of isomeric species distribution in petroleum using ion mobility - mass spectrometry [O24], Mathilde Farenc [et al.] . . . 73

Approches omiques quantitatives

Proteomic analysis reveals strong secretion of IL-9 by group2 innate lymphoid cells upon IL-33/TL1A co-stimulation [O25], Anne Gonzalez De Peredo [et al.] . . . . . . . . . . . 75

Carbon 12 metabolic labeling for high-throughput quantitative proteomics [O26], Thibaut

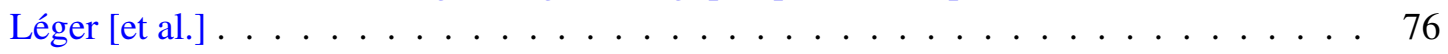

Ultra-Short Column-Differential Mobility Spectrometry-Mass Spectrometry for Monitoring Oxidative Stress Markers in Human Whole Blood [O27], Sophie Bravo-Veyrat [et

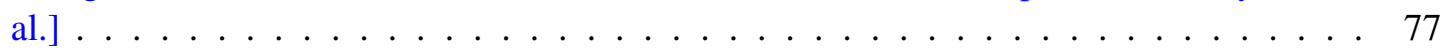

Regulation of Metabolic Enzymes by Lysine Deacetylase Inhibitors in A549 Non-Small Cell Lung Cancer Cells [O28], Alfonso Martin-Bernabe [et al.] . . . . . . . . . . . . . 78

Développements méthodologiques et fondamentaux MS

Weighing intact viral capsids using nanomechanical resonators mass spectrometry [O29], Shawn

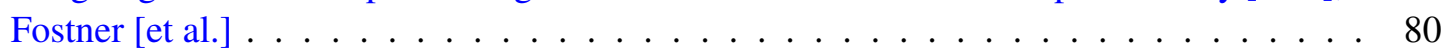

Etude de la préservation des kératines de cheveux de momies par une approche protéomique spécifiquement dédiée [O30], Armelle Charrié-Duhaut [et al.] $\ldots \ldots . . .81$

Bridging the technological gap between mass spectrometry and spectroscopy for the structural resolution of isomers: application to glycomics [O31], Baptiste Schindler [et al.] 82

De la formation des ions sous ESI à leur dissociation: une histoire différemment perçue

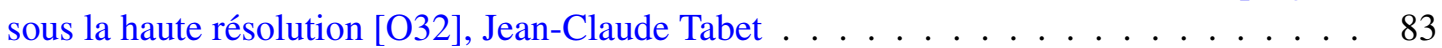


Mise en place d'une approche combinée MS-RMN pour aider à l'interprétation des données de stabilité des médicaments [O34], Cécile Palaric [et al.] . . . . . . . . . . 86

Recherche des marqueurs de la production de méthane chez la vache laitière [O35], Béné-

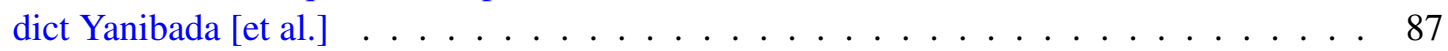

Développement d'un protocole de pré-traitement analytique pour l'analyse métabolomique par RMN d'échantillons rénaux congelés dans l'OCT (Optimal Cutting Temperature compound) [O36], Justine Leenders [et al.] $\ldots \ldots \ldots \ldots$. . . . . . . . . . . . . 88

Clinique et diagnostic

Proteomic analysis of exosomes for biomarker research in rare genetic diseases[O37], Bour-

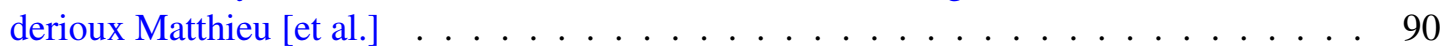

MALDI-MSI based top down micro-proteomics: evidence of a hidden proteome [O38], Julien

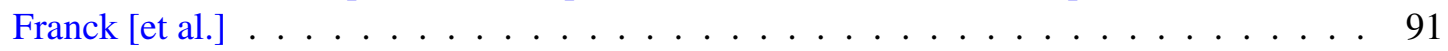

A Proton NMR Metabolomic Investigation of an Emerging Genetic Disease [O39], Houda

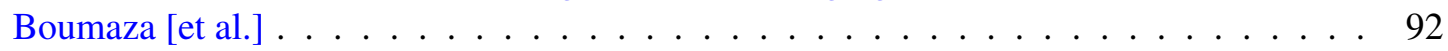

Proteomics investigation of Wilson's disease pathophysiology using the ATP7B-/- murine model [O40], Maud Lacombe [et al.] . . . . . . . . . . . . . . . . . . 93

Plantomics

Caractérisations chimique et biologique de composés discriminants au sein du métabolome symbiotique Alnus viridis-Frankia [O41], Dounia Dhaou [et al.] . . . . . . . . . . . 95

ChloroKB: a web-application for the integration of knowledge related to chloroplast metabolic network [O42], Myriam Ferro [et al.] . . . . . . . . . . . . . . . . 96

Description of developmental transitions of tomato fruit through Proteome and Metabolome quantitative analysis [O43], Isma Belouah [et al.] $\ldots \ldots \ldots \ldots . \ldots \ldots 7$

Leaf ageing imprinting on metabolism and nitrogen nutrient recycling in oilseed rape (Brassica napus L.), a metabolomic and fluxomic view [O44], Sylvain Déchaumet [et al.] 98

A novel approach for simultaneous absolute quantification and isotopic analysis of metabolome [O45], Floriant Bellvert [et al.] … . . . . . . . . . . . . . . . 100 
IDH mutation dictates a global redirection of catabolic and redox pathways towards 2HG biosynthesis leading to mitochondrial OxPHOS dependency and chemoresistance in acute myeloid leukemia $[\mathrm{O} 46]$, Lucille Stuani . . . . . . . . . . . . . . . . . . . 101

Study of sclareol biosynthesis for clary sage metabolic engineering [O47], Camille Chalvin [et

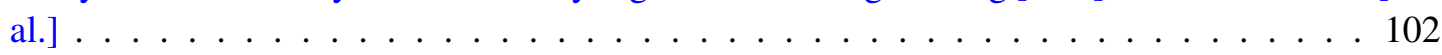

Analyse multiplexe des flux protéiques par l'utilisation d'isotopes stables et de la LCMS/MS : applications aux apolipoprotéines [O48], Mikaël Croyal [et al.] . . . . . . . . 103

Santé et médecine: mécanismes et biomarqueurs

On chip detection and proteomics of platelet-derived microparticles [O49], Géraldine

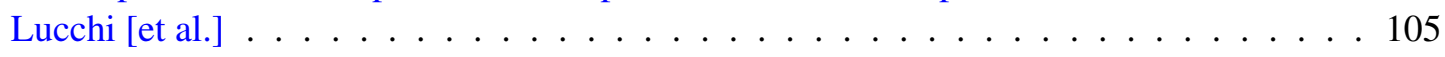

Metabolomic NMR studies \& Huntington's disease: models in transgenic drosophila [O50], Marylène Bertrand [et al.] . . . . . . . . . . . . . . . . . 106

Développement d'une approche multi-omique pour la recherche de biomarqueurs associés à la réponse au traitement dans les lymphomes [051], Luc-Matthieu Fornecker [et

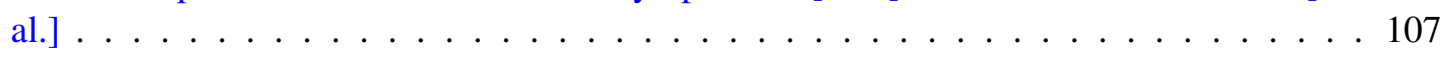

Combined laser microdissection and proteomic analysis for identification of tumor signatures [O52], Elodie Henriet [et al.] . . . . . . . . . . . . . . . 108

A native MS Study of RNA kissing complexes and their interaction with magnesium cations [053], Clémence Rabin [et al.] . . . . . . . . . . . . . . . . . . . . . . 109

\section{Identification structurale et annotation}

Elucidation of the Parkinsonism-associated protein DJ-1/Park7 function as a major protein and DNA deglycase [O54], Gilbert Richarme [et al.] . . . . . . . . . . . . . 111

ASICS: an automatic method for identification and quantification of metabolites in complex 1D 1H NMR spectra [055], Patrick Tardivel [et al.] . . . . . . . . . . . . 112

Computer-aided dereplication of natural products: 13C NMR-based strategies [O56], Ali

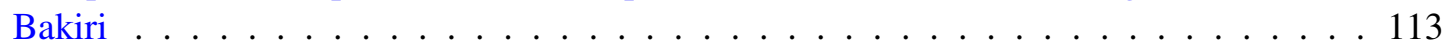

Développement de stratégies analytiques originales pour l'étude des actifs volatils de Frullania tamarisci [O57], Anais Pannequin [et al.] . . . . . . . . . . . . . . . 114 
Mass spectrometry and chemical labeling as a powerful tool for peptide quantitation in pharmacology [O58], Christine Enjalbal [et al.] . . . . . . . . . . . . . 116

Top-down and bottom-up mass spectrometry approaches for Alpha-synuclein analysis in biological fluids [O59], Arthur Viodé [et al.] … . . . . . . . . . . . 117

Altered brain energy metabolism in Alzheimer disease: Linking peripheral and central metabolic changes $[\mathrm{O} 60]$, Tony Teav $\ldots \ldots \ldots \ldots \ldots$

Identifying autoimmune beta-cell epitopes in type 1 diabetes by HLA-peptidomics [O61], Sergio Gonzalez Duque [et al.] . . . . . . . . . . . . . . . . . . . . . . . 119

Prix Junior et Doctorants

Compared effects of beta-hydroxybutyrate and bear serum on the proteome of human muscle cells [O62-P99], Blandine Chazarin [et al.] . . . . . . . . . . . . . . . 121

Development of microsampling tools by laser ablation and mass spectrometry for the characterization of biological tissues [O63], Benoit Fatou [et al.] . . . . . . . . . 122

De la classification moléculaire des gliomes à une nouvelle stratégie thérapeutique de réactivation des macrophages au sein de la tumeur [O64], Marie Duhamel [et al.] . . . . 123

Evaluation of metabolic alterations induced by glutamate in a cellular model of amyotrophic lateral sclerosis using a metabolomics approach [O65], Blandine Madji Hounoum [et

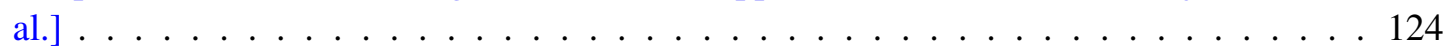

Modifications post-traductionnelles

Intensive fractionation and Click chemistry as a powerful method for identification of O-GlcNAcylation sites [O66], Barbara Deracinois [et al.] . . . . . . . . . . . 126

Quantitative analysis of redox modifications of protein cysteines in biofilm and planktonic Escherichia coli [O67], Giovanni Chiappetta [et al.] . . . . . . . . . . . . . 127

Large-scale proteomic analysis of SIRT1- and tissue-dependent acetylproteome in mouse liver, testis and muscle [O68], Marie Locard-Paulet [et al.] . . . . . . . . . . . . . . 128

Proteomic study of histone acylations [O69], Marion Crespo [et al.] … . . . . . . 129 
Une approche combinée de lipidomique, d'imagerie MS et d'imagerie TEP-Scan révèle des différences de fonctionnement cérébral chez le raton selon le contenu lipidique de formules infantiles [O70], Jean-Charles Martin $\ldots \ldots \ldots 131$

Two-dimensional mass spectrometry patterns as a tool for lipidomics: application to human blood plasma with different oxidation states [O71], Fabrice Bray [et al.] . . . . . 132

Multilevel statistics applied to NMR/MS lipidomics [O72], Jérémy Marchand [et al.] . 133

Apport de la spectrométrie de masse dans la caractérisation structurale et l'analyse des phospholipides oxydés [O73], Spiro Khoury [et al.] . . . . . . . . . . . . . . 134

Microbiologie: bactérie, virus, champignon et méta-omiques

Discrimination de biofilms marins par métabolomique [O74], Gérald Culioli [et al.] . . 136

Lysine modifications in Pseudomonas aeruginosa PA14 [O75], Charlotte Gaviard [et al.]

An integrated innovative top-down proteomics workflow for the rapid discrimination of enterobacterial pathogens [O76], Mathieu Dupre [et al.] . . . . . . . . . . . . . 138

NRPomics : Kendrick mass defect for molecular formula assignment of non ribosomal peptides (NRPs) [O77], Mickael Chevalier [et al.] . . . . . . . . . . . . . . . . . 139

Workshops

Thermo Fisher Scientific: Orbitrap MS- repousser les limites de la recherche Omics [W1], Claire Dauly et Floriant Bellvert . . . . . . . . . . . . . . . . 141

Optimisez le cœur de votre laboratoire grâce à un générateur de gaz Peak Scientific [W2], Sylvie Dos Reis $\ldots \ldots \ldots \ldots \ldots \ldots \ldots \ldots$. . . . . . . . . . . . . . . . . . .

Agilent 6545XT AdvanceBio LC/Q-TOF: Designed for BioPharma Workflows [W3], Jérémy

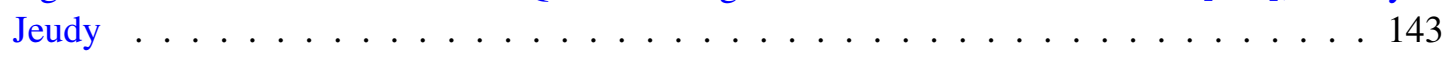

Workshop Bruker [W4], Pierre-Olivier Schmit et Martial Piotto . . . . . . . . . . . . . 144

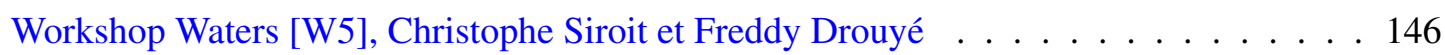

The benefits of targeted, standardized procedures in metabolomics [W6], Carmen Ludwig-

Papst ............................ 147

Workshop Shimadzu [W7], Thierry Legoupil ～. . . . . . . . . . . . . . . . . . 148 
Mardi 3 octobre [P1-P88]

Intégration des données et approches multi-omiques [P1-P5]

Integrated proteomic and transcriptomic approaches towards the high-throughput discovery of new bioactive molecules in venoms [P1], Julien Giribaldi [et al.] . . . . . . . . . 152

Evaluation de méthodes statistiques pour l'intégration de données métabolomiques, cliniques et alimentaires [P2], Marion Brandolini-Bunlon [et al.] . . . . . . . . . . . . 153

ProteoRE, a Galaxy-based infrastructure for interpreting and exploring mass spectrometrybased proteomics data [P3], Lien Nguyen [et al.] $\ldots \ldots \ldots \ldots$

Omics meets metabolic engineering for the production of light olefins by recombinant microorganisms : a highway to renewable plastics, synthetic rubber and fuels [P4], Samia

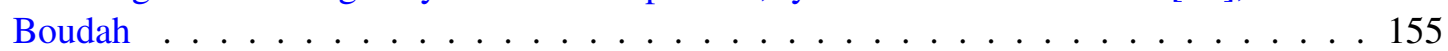

Patchwork evolution of metabolic pathways in red and brown macroalgae [P5], Gabriel

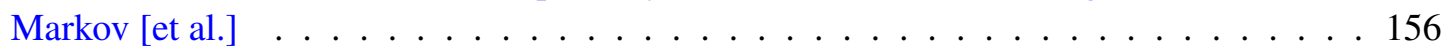

Alimentation et santé [P6-P17]

Transgénèse et leurs effets sur la santé humaine [P6], Yamina Bouatrous . . . . . . . 158

Application d'une stratégie non ciblée par LC-HRMS pour l'identification d'interférences aux fluoroquinolones dans le miel révélées lors du dépistage immunochimique [P7], Sophie Mompelat [et al.] . . . . . . . . . . . . . . . . . 159

Towards a foodomics approach of food chemical safety assessment [P8], Grégoire Dela-

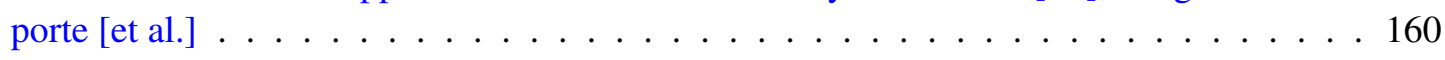

Peptidomic approach to evaluate meat digestion in elderly conditions using combined in vitro mastication and gastric digestion [P9], Thierry Sayd [et al.] . . . . . . . . . . . . 161

Organoleptic properties of dark chocolates investigated by direct-injection mass spectrometry (PTR-ToF-MS) and GC-MS-Olfactometry [P10], Jean-Luc Le Quéré [et al.] . . 162

Consequences of sunlight-induced aging on a personal care emulsion containing $\alpha$ tocopherol as antioxidant [P11], Ségolène De Vaugelade [et al.] . . . . . . . . . . . . 163

Identification of food intake biomarkers using metabolomics in the Metabo-Breast cancer project [P12], Céline Dalle [et al.] . . . . . . . . . . . . . . . . . . . 164 
One-Dimensional and Two-Dimensional LC-MS Applied to the Characterization of Monoclonal Antibodies and Antibody-Drug Conjugates [P13], Vandenheede Isabel [et al.] . . 165

Liquid chromatography coupled to high resolution mass spectrometry based metabolomics profiling of serum responses to dietary supplementation [P14], Alexis Ripoche [et al.] . . 166

Capacité de l'huile d'olive à extraire les molécules bioactives de différentes espèces végétales alimentaires et non alimentaires : Cas particulier de l'absinthe (Artemisia absinthium) [P15], Taous Allane [et al.] . . . . . . . . . . . . . . . . . 167

I knew you were trouble: Expanding LC methods to include difficult GC compounds using a Novel Ionization Technique [P16], Freddy Drouyé [et al.] . . . . . . . . . . 168

Exposition de la levure Saccharomyces cerevisiae à la sélénométhionine : caractérisation des acides aminés séléniés incorporés dans les protéines et agrégation des protéines [P17], David Cornu [et al.] . . . . . . . . . . . . . . . . . . . . . . . . 169

Evaluation of different Stage Tip fractionation strategies to increase proteome coverage at low cost [P18], Marie Meziere [et al.] . . . . . . . . . . . . . . . 171

Top-down and middle-down approach by fraction collection enrichment using Off-line capillary electrophoresis - mass spectrometry coupling: application to monoclonal antibody $\mathrm{Fc} / 2$ charge variants [P19], Michael Biacchi [et al.] . . . . . . . . . . . 172

A low-molecular-weight color $\mathrm{pI}$ markers to monitor on-line the peptide focusing process in OFFGEL fractionation [P20], Sylvie Michelland [et al.] . . . . . . . . . . . . . 173

Comparaison de différentes sources d'ionisation sous vide en GC-MS haute résolution pour l'analyse de derivés de gaz de combat [P21], Valentin Baillet [et al.] . . . . . . . . 174

Apport de l'électrophorèse capillaire couplée à la spectrométrie de masse pour l'étude de la N-glycosylation [P22], Coralie Ruel [et al.] . . . . . . . . . . . . . . . . . 175

Detection of human insulins in horse plasma samples by MSIA technology and nLC-QEx

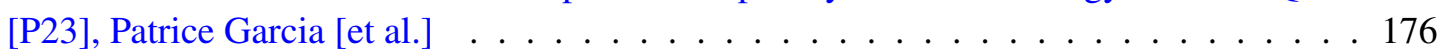

Ionic liquids as super-solvent to improve metabolic extraction? [P24], Alexandre Farigoule [et

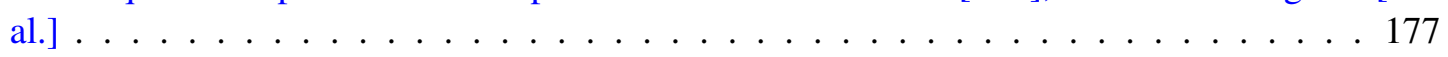

Méthode monophasique pour l'extraction simultanée des lipides polaires et non polaires d'un homogénat de cerveau avant leur analyse par chromatographie liquide couplée à la spectrométrie de masse [P25], Olivier Berdeaux [et al.] . . . . . . . . . . . 178 
Analytical Coverage Investigation of a Database of Reference Compounds for Metabolomic

Studies [P26], Julian Pezzatti [et al.] . . . . . . . . . . . . . . . . . . . 179

An in-solution digestion method to improve Proteome coverage from small samples of Extracellular Matrix and Membrane extracts [P27], Haddad Iman [et al.] . . . . . . . . . 180

CE-MS for metabolomic analysis [P28], Nicolas Drouin [et al.] . . . . . . . . . . . . . 181

Evaluation de l'intérêt de la FAST-GC pour le screening des anabolisants dans l'urine de cheval [P29], Elodie Mirmont [et al.] . . . . . . . . . . . . . . . . . . 182

Laser capture and mass spectrometry combination for subcellular proteomics [P30], Za-

karia Ezzoukhy [et al.] . . . . . . . . . . . . . . . . . . 183

Traitement et analyse statistique des données [P31-P44]

Protein identification using MS/MS data under R [P31], Sara El Jadid [et al.] . . . . . . 185

Exploitation de données HRMS via W4M pour la comparaison de signatures en entrée/sortie d'un traitement tertiaire [P32], Aurélie Fildier [et al.] . . . . . . . . . . . . . 186

Exploitation de données HRMS via Galaxy pour la mise en évidence de métabolites chez Gammarus fossarum exposé à 2 composés pharmaceutiques [P33], Aurélie Fildier [et al.] 187

Data-Independent Acquisition workflow optimizations: from chromatographic conditions to data processing [P34], Joanna Bons [et al.] . . . . . . . . . . . . . . 188

MS-Angel: a solution for real-time proteomics workflows [P35], Julie Poisat [et al.] . . . 189

Visualisation of Residual Bioorganic Compounds in an Archaeological Mollusc Shell Sample using Imaging Mass Spectrometry [P36], Sebastiaan Van Nuffel [et al.] . . . . . 190

Proline label free quantification algorithm evaluation and abundance measurement accuracy [P37], David Bouyssié [et al.] . . . . . . . . . . . . . . . . 191

mzScope: fast MS data visualization and exploration tool based on the mzDB file format [P38], Christophe Bruley [et al.] . . . . . . . . . . . . . . . . 192

Understanding MALDI through 3D ToF-SIMS Imaging [P39], Nicolas Elie [et al.] • . 193

EN-TerPred: A new tool for predicting protein N-terminal modifications and plastid transit-peptide cleavage sites [P40], Willy Bienvenut [et al.] . . . . . . . . . . . . . . . 194

True or False Experience: Going after well-behaved features and biologically relevant information in metabolomics data [P41], Florence Mehl [et al.] . . . . . . . . . . . . . 195 
Integration and provenance of proteomics data using SWOMed, a Product Lifecycle

Management framework for biomedical research [P42], Amel Raboudi [et al.] . . . . . . 196

Workflow4Metabolomics: new services and contributions for the metabolomics community [P43], Yann Guitton [et al.] ． . . . . . . . . . . . . . . . . . . . . . . . 197

Leading tool: a "proteinGroups.txt" post-processing file to highlight representative "leading" proteins among protein groups [P44], Oana Vigy [et al.] . . . . . . . . . . . 198

Imagerie in vitro et in vivo [P45-P50]

A new image of cereal cell walls provided by MALDI MS imaging [P45], Fanuel Math-

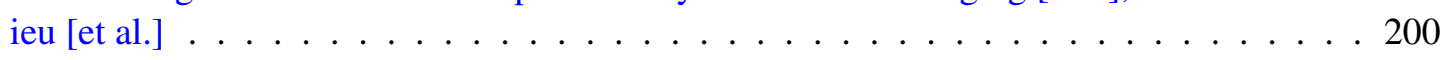

2.5 D whole sheep brain representation combining in vivo 3D Magnetic Resonance Imaging and ex vivo 2D Mass Spectrometry Imaging and lipidomic in selective areas [P46], Valérie Labas [et al.] . . . . . . . . . . . . . . . . . . . 201

Muscle Mass Spectrometry Imaging for myofiber metabolic type determination [P47], Laeti-

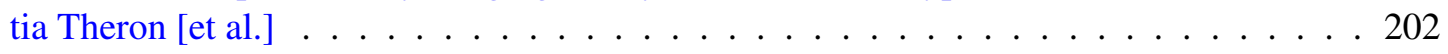

Biomarker Monitoring by Quantitative MALDI Imaging: Application to the TryptophanKynurenine Pathway in Immuno-Oncology [P48], Edma Fontaine [et al.] . . . . . . . . 203

Mass spectrometry imaging: a game changer in the pharmaceutical industry [P49], Edma

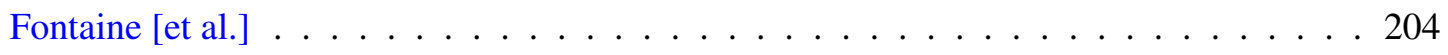

Label-free multimodal imaging for biological applications: toward a molecular investigation without a priori [P50], Nicolas Desbenoit [et al.] . . . . . . . . . . . . . 205

La dynamique quotidienne des polluants émergents en amont de station d'épuration par UHPLC/MRM [P51], Laëtitia Fougere [et al.] . . . . . . . . . . . . . . . . . . . 207

Profils isoprostanoiques de mollusques lamellibranches marins exposés à un contaminant émergeant, le diclofénac [P52], Vigor Claire [et al.] . . . . . . . . . . . . . . 208

Metabolomic and proteomic investigations of impacts of titanium dioxide nanoparticles on Escherichia coli [P53], Gaspard Huber [et al.] . . . . . . . . . . . . . . . . . 209

Analysis of perfluorocarbons compounds (PFCs), potent greenhouses gases by action

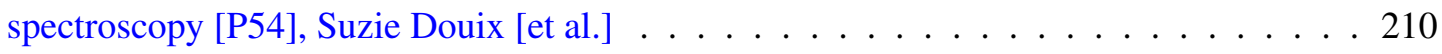


Toxicologie des contaminants émergents : étude du métabolisme in vitro et de la modulation du métabolome des cellules hépatiques HepaRG par les bisphénols A chlorés [P55], Nicolas Cabaton [et al.] . . . . . . . . . . . . . . . . . . . . . 211

Preliminary metabolomic approach on cyanobacterial co-cultures: Chemically mediated interactions between Microcystis and Planktothrix [P56], Florence Mondeguer [et al.] . . 212

Proteome modulation as an early marker of gamma irradiation effect on Caenorhabditis elegans egg hatchability? [P57], Cecile Dubois $\ldots \ldots \ldots \ldots$

Localisation and quantification of Chlordecone in a rat model of prostatic adenocarcinoma by MALDI imaging [P58], Mélanie Lagarrigue [et al.] . . . . . . . . . . . . . 214

Insights into biomineralization and environmental adaptation of bivalves through shell matrix proteins [P59], Arul Marie [et al.] . . . . . . . . . . . . . . 215

Étude de la composition de particules du courant principal de fumée de cigarette en fonction de la nature de la cigarette par LDI-FTICRMS [P60], Adama Kamissoko [et al.] 216

Evaluation of the environmental impact of a natural herbicide, Myrigalone and its extract from Myrica gale using Environmental Metabolic Footprinting (EMF) [P61], Rahul

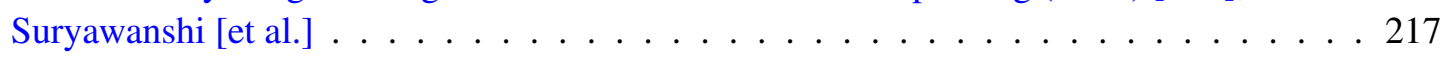

Modulation and resilience of the metabolome of Pseudomonas graminis, a cloud bacterium, facing $\mathrm{H} 2 \mathrm{O} 2$ atmospheric stress [P62], Nolwenn Wirgot [et al.] . . . . . . . . . 218

Composition chimique du brouillard de Titan par spectrométrie de masse haute résolution [P63], Isabelle Schmitz-Afonso [et al.] . . . . . . . . . . . . . . . . . . . . 219

L'imagerie par spectrometrie de masse MALDI appliquée à l'étude des metabolites des lichens [P64], Audrey Geairon [et al.] . . . . . . . . . . . . . . . . 220

Etude de l'impact d'une formulation commerciale de glyphosate sur Trachemys scripta elegans par profilage métabolomique non ciblé [P65], Remi Pagnon [et al.] . . . . . . . 221

High resolution LCMS analysis of metabolic cycles in the intertidal bivalve Mimach-

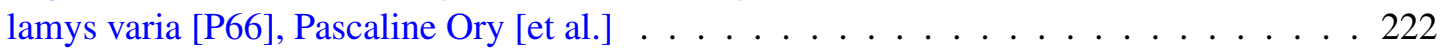

Hydride shifts in gas phase ions influence the release of hydroxide as $\mathrm{H} 2 \mathrm{O}, \mathrm{CO}$ and H2CO [P67], Ulli M. Hohenester [et al.] . . . . . . . . . . . . . . . . . . 224

Benchmarking mAb bioconjugation strategies using a combination of native MS and peptide mapping approaches [P69], Stéphane Erb [et al.] . . . . . . . . . . . . 225 
Epitope characterization of anti-JAM-A antibodies using orthogonal Mass Spectrometry and Surface Plasmon Resonance approaches [P70], Guillaume Terral [et al.] . . . . . . . 226

Deep metabolome annotation and the necessity of a thought experiment [P71], PierreMarie Allard [et al.] . . . . . . . . . . . . . . . . . . . . . 227

RNA Aptamers and their ligand complexes: Shape and KD determination by native mass spectrometry [P72], Stefano Piccolo [et al.] $\ldots \ldots \ldots \ldots \ldots \ldots$

M+2 Relative Isotopic Abundance on Orbitrap Fusion: input of 18O/13C2 separation on annotation for metabolomics [P73], Pierre Barbier Saint Hilaire [et al.] . . . . . . . . . . 229

Characterization by mass spectrometry of plant adhesives from the Iron Age discovered on the site "Cité d'Affrique" (Messein, France) [P74], Armelle Charrié-Duhaut [et al.] . 230

Size-exclusion chromatography coupled to native ion mobility mass spectrometry (SECnative IM-MS) for therapeutic protein aggregation studies [P75], Oscar Hernandez Alba [et

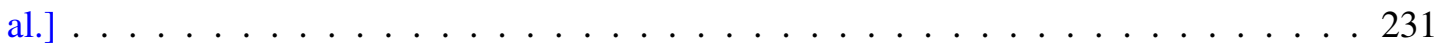

Insights from native mass spectrometry approaches for top- and middle- level characterization of site-specific antibody-drug conjugates [P76], Thomas Botzanowski [et al.] . 232

Assessing chemical labeling of proteins by mass spectrometry: MALDI-TOF to the rescue of ESI-HRMS [P77], Guillaume Gabant [et al.] . . . . . . . . . . . . . . 233

Identification de l'extrémité $\mathrm{N}$-terminale des protéines par marquage chimique [P78], Laila

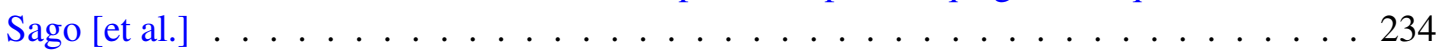

Automated detection of chemical patterns to mine MS/MS spectral libraries and facilitate de novo spectrum elucidation [P79], Alexis Delabriere [et al.] . . . . . . . . . . . 235

Isolation of anti-chikungunya diterpenoids from Euphorbia pithyusa extract: premyrsinane, myrsinane and tigliane diterpene analogues annotated by molecular networking

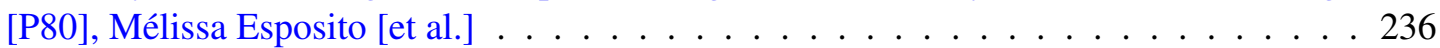

Investigation of the conformational dynamics of the human prion protein and its interaction with the $\mathrm{A} \beta$ peptide by ion mobility mass spectrometry [P81], Jan Bohl [et al.] $\ldots 237$

Analyses métabolomiques non ciblées par GC-QToF : de la basse à la haute résolution [P82], Carole Migné [et al.] . . . . . . . . . . . . . . . . . . 238

Structural characterization of distinct Tau strains [P83], Emilie Caroux [et al.] … . . 239

UVPD as a unique fragmentation tool for complete structure determination and substructure identification of small molecules [P84], Marie-Pierre Pavageau [et al.] . . . . . . . . 240 
Towards a faster localization of non-covalent ligand binding sites using an original foot-

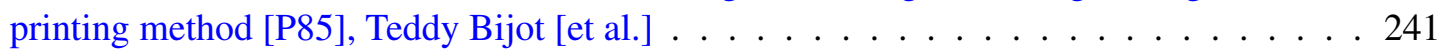

Etude des mécanismes impliqués dans la photodégradation d'un polluant organique, le cyprodinil, par LC-HR MS/MS [P86], Xuan Zuo [et al.] . . . . . . . . . . . . . . . . . 242

Native Ion Mobility Mass Spectrometry for the Characterization of Biotherapeutics [P87], Christophe

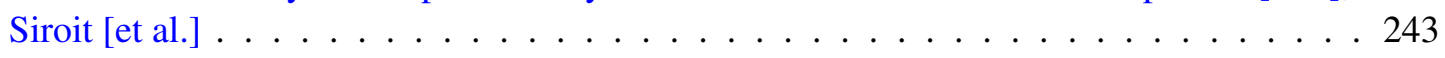

Structure elucidation and validation of small molecules: the LSD and CASA software [P88], Jean-Marc Nuzillard [et al.] . . . . . . . . . . . . . . . . . . . . . 244

Utilisation d'une approche métabolomique pour l'analyse des composés organiques volatils du cacao fermenté séché en provenance de Côte d'Ivoire [P89], Mathieu Lazarus [et al.] . 247

Impact des Botryosphaeriaceae sur la production de métabolites de la vigne [P90], Mary-

Lorène Goddard [et al.] . . . . . . . . . . . . . . . . . . . . . . . 248

Overcoming Gefitinib Resistance By HDAC Inhibition In Mutant KRAS Lung Adenocarcinoma [P91], Sylvia G. Lehmann [et al.] . . . . . . . . . . . . . . . . . . . . 249

Host Cell Proteins accurate quantification using MS-based assay coupled to label-free strategy [P92], Tanguy Fortin [et al.] . . . . . . . . . . . . . . . . 250

NMR-based metabolomic in study on fruit-oils: Determination of optimal treatment on fruits and differences on oil composition [P93], Covadonga Lucas-Torres [et al.] . . . . . 251

Monitoring of Host Cell Proteins clearance through therapeutic monoclonal antibodies

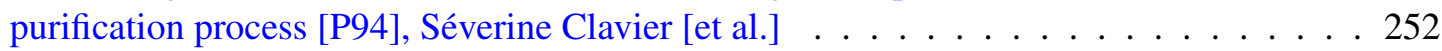

Performance evaluation of Data Independent Acquisition and Data Dependent Acquisition workflows [P95], Alexandra Kraut [et al.] . . . . . . . . . . . . . . . . 253

Quantitative analysis of the cysteine redoxome by iodoacetyl tandem mass tags [P96], Shakir

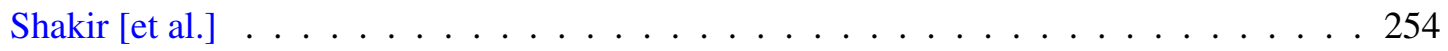

Scanning quadrupole data independent acquisition: a novel workflow for discovery and targeted quantitative proteomics [P97], Sarah Lennon [et al.] . . . . . . . . . . . . . 255

Evolution des histones au cours de l'érythropoïèse murine [P98], Marjorie Leduc [et al.] 256 
Revolutionary Proteome Profiling and Quantitation without Compromising Speed, Sensitivity, and Selectivity [P100], Claire Dauly [et al.] . . . . . . . . . . . . . . . 257

Développements méthodologiques et fondamentaux MS [P101-P117]

Identification and evaluation of antibacterial agents present in lipophilic fractions isolated from date seeds and pollen of Phoenix dactilyfera L [P101], Najla Bentrad [et al.] . 259

VUV study of the electronic effects of phosphine ligands bound to a Molybdenum complex [P102], Héloïse Dossmann [et al.] . . . . . . . . . . . . . . . . . . 260

Collision Cross Sections of Polyoxometalates : linking experimental and theoretical values [P103], Sébastien Hupin [et al.] . . . . . . . . . . . . . . . . . . 261

Study of DNA i-motif folding in gas phase by ion mobility spectrometry coupled to native mass spectrometry [P104], Sandrine Livet [et al.] . . . . . . . . . . . . . . . 262

Optimization of the design of cyclic peptides scaffolds for characterization by MALDITOF/TOF mass spectrometry [P105], Benjamin Zagiel [et al.] $\ldots \ldots . \ldots 263$

New innovations implemented on the Q Exactive HF mass spectrometer [P106], Tabi-

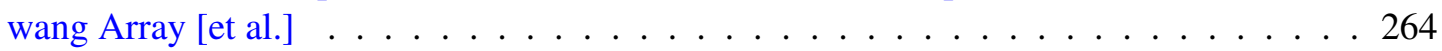

Étude in vitro et in vivo chez le cheval du métabolisme du FG4592 (Roxadustat), un stabilisateur du facteur induit par l'hypoxie 1 alpha (HIF1- $\alpha$ ), dans le contexte de la lutte anti-dopage [P107], Stéphane Trévisiol [et al.] . . . . . . . . . . . . . 265

Optimization of source and acquisition parameters for HILIC-HRMS metabolomic analysis of human plasma [P108], Fanta Fall [et al.] . . . . . . . . . . . . . . 266

Analysis of sterols and steroids using HPTLC- MS: influence of ionization parameters [P109], David Da Silva [et al.] . . . . . . . . . . . . . . . . . . . 267

2D-precursor selection for trapped ion mobility with parallel accumulation - serial fragmentation (TIMS-PASEF) [P110], Pierre-Olivier Schmit [et al.] $\ldots \ldots . . . . .268$

microDIA acquisition combined to a novel software tool enables direct identification of peptides in pseudo-SRM MS/MS spectra from sequence databases [P111], Pierre-Olivier

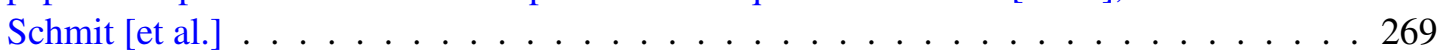

Paléoprotéomique pour retracer l'introduction de petits bovidés en Afrique australe [P112], Louise Le Meillour [et al.] . . . . . . . . . . . . . . . . . . . 270

Identification de fibres animales archéologiques par protéomique [P113], Clara Azé-

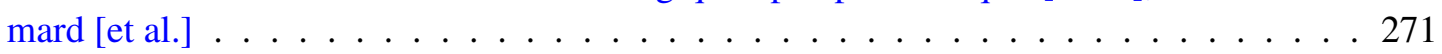


Optimized Protein Digestion for Immunoprecipitation Samples [P114], Vincent Jung [et

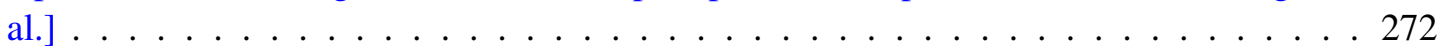

In-Depth Characterization Of Intact Protein Standards Using Top Down Mass Spectrometry With Multiple MSMS Strategies [P115], Claire Dauly [et al.] . . . . . . . . . . 273

Two-dimensional (2D) FT-ICR MS at high resolution on both precursor and fragment ions [P116], Fabrice Bray [et al.] . . . . . . . . . . . . . . . . . 274

Conformational Dynamics in Ion Mobility Data [P117], Salomé Poyer [et al.] . . . . . 275

Exclusion en temps réel de précurseurs MS en fonction de la signature des protéines identifiées [P117.1], David Rombaut [et al.] . . . . . . . . . . . . . . . 276

Stability-indicating HILIC Method for Determination of Citicoline and Characterization of its Degradation Products by LC-MS/TOF [P118], Saliha Guermouche . . . . . . . . . 278

Ultrafast 2D NMR on a benchtop spectrometer for high-throughput foodomics [P119], Boris

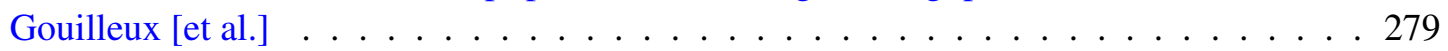

Spatially encoded diffusion-ordered NMR spectroscopy [P120], Ludmilla Guduff [et al.] 280

Clinique et diagnostic [P121-P129]

Multiplatform metabolomics study of urine in autism spectrum disorders in a Middle

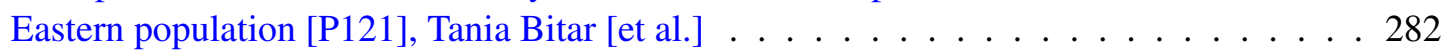

De la caractérisation à la quantification de Méthyle- $\beta$-Cyclodextrine dans des échantillons biologiques de souris [P123], Laëtitia Fougere [et al.] $\ldots \ldots \ldots$. . . . . . . . . 283

A pharmacometabolomics approach in ALS: proof of concept in a clinical trial of olesoxime [P124], Helene Blasco [et al.] … . . . . . . . . . . . . . . . 284

Empreintes métabolomiques par RMN sur la cirrhose et ses complications [P125], Philippe

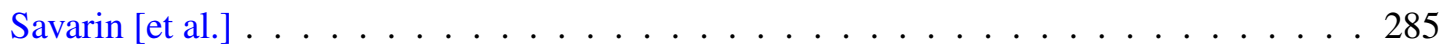

Hyphenation of Online Supercritical Fluid Extraction - Supercritical Fluid Chromatography with SWATH Mass Spectrometry for Metabolomics [P126], Laura Akbal [et al.] . 286

Targeted MS and power ultrasound sample treatment allow robust and rapid amyloidosis diagnosis [P127], Emmanuelle Demey-Thomas [et al.] . . . . . . . . . . . . . 287

Shedding new light on Spinal Cord injury [P128], Michel Salzet $\ldots \ldots . \ldots .288$ 
MALDI-TOF MS analysis of serum N-glycans and glycoproteins: an essential analytical tool in the diagnosis scheme of congenital disorders of glycosylation [P129], Arnaud

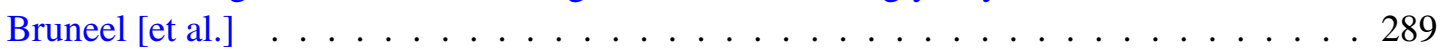

Plantomics [P130-P153]

Platform Metabolism-Metabolome : various analytical techniques based on stable isotopes and metabolomics for plant biology [P130], Françoise Gilard [et al.] . . . . . . . . 291

Développement d'une méthode de profilage par LC-HRMS/MS du lipidome total des extraits lipidiques de Serenoa repens (W.B. Bartram) Small (ARECACEAE) [P131], Au-

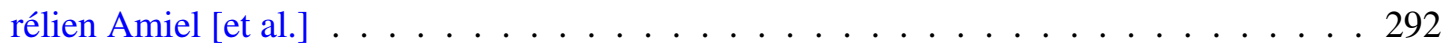

Métabolomique ciblée par UHPLC/MRM pour l'aide à la sélection variétale de plante piège [P132], Laëtitia Fougere [et al.] . . . . . . . . . . . . . . . . . . 293

Antioxydants and proteome analysis of root response to salt stress in the plant model Medicago truncatula Gaertn [P133], Adel Amar Amouri [et al.] . . . . . . . . . . . . . . 294

Differential protein expression in potato tubers infected with pectobacterium atrosepticum pathogen induced by chitosan treatment [P134], Lila Mahious [et al.] . . . . . . . 295

Fast discrimination of chocolates from mass spectrometry fingerprints of cocoa polyphenols [P135], Noémie Fayeulle [et al.] . . . . . . . . . . . . . . . . 296

Chemical diversity and antiviral potential of tropical Euphorbiaceae [P136], Simon Remy [et

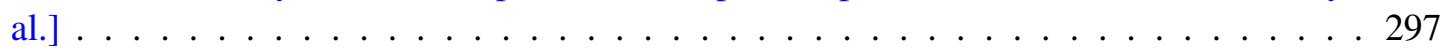

Interactomics reveals novel regulatory mechanisms of plant aquaporins [P137], Jorge

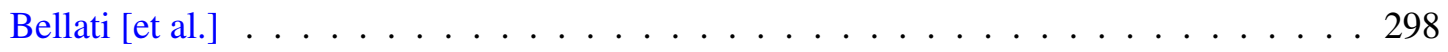

The impact of interactions between environment, cultural management and rapeseed oil varieties on health promoting molecules using a metabolomic approach [P138], Djawed

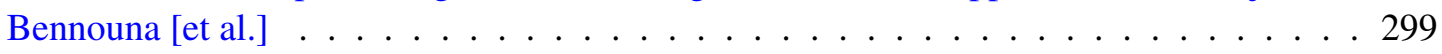

How nano-LC-MS/MS methods improve plasmodesmata proteome knowledge [P139], Françoise

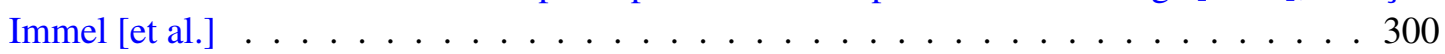

Genome wide association study for protein expression under normal and water deficit conditions in maize leaves [P140], Mélisande Blein-Nicolas [et al.] . . . . . . . . . . . 301

Volatilomics in the vineyard [P141], Christelle Lemaitre-Guillier [et al.] . . . . . . . . 302

Activité antimicrobienne des huiles essentielles du genre Thymus numidicus et Thymus algériensis vis-à-vis les souches bactériennes responsables des infections nosocomials [P142], Aicha Touhami . . . . . . . . . . . . . . . . . . 303 
Etude protéomique des parois de grains de blé au cours du développement [P143], Mehdi

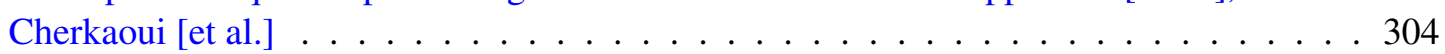

Extraction et analyse de phytohormones par U-HPLC-MS : rôle des phytohormones dans la symbiose mycorhizienne [P144], Simon Pons [et al.] . . . . . . . . . . . . . 305

Identification of specific molecules of two Mentha species by a converging metabolomics/molecular networking approach [P145], Axelle Aimond [et al.] $\ldots \ldots \ldots 306$

Does wild plant metabolomic diversity correlate with neutral genetic diversity? [P146], Flo-

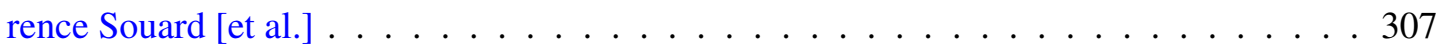

Coffee's leaf: an untargeted metabolome profiling determined by LC-HRMS [P147], Florence Souard $[\mathrm{et}$ al.] $\ldots \ldots \ldots \ldots \ldots \ldots \ldots$

Plants with increased yield: from metabolomic to field [P148], Théophile Kazmier-

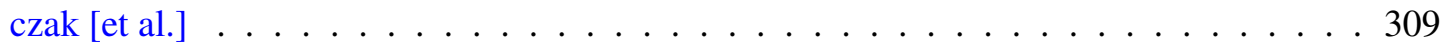

Metabolic profile of phloem sap of tomato plants in response to phytoplasma infection [P150], Federica De Marco [et al.] . . . . . . . . . . . . . . . . 310

Développement d'une méthode haut débit pour le profilage métabolomique non ciblé par

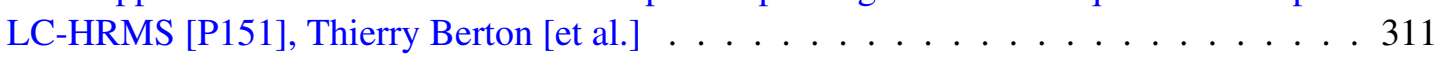

Towards proteomics of single-starch granules [P152], Stanislas Helle [et al.] . . . . . . 312

Les réseaux moléculaires comme moyen d'exploration rapide du contenu phytochimique d'extraits hydro-alcooliques de plantes [P153], Ludivine Valois [et al.] . . . . . . . . . . 313

Fluxomique [P154-P155]

A 15N-NMR based approach for amino acids based 13C-metabolic flux analysis of microbial metabolism [P154], Lindsay Peyriga [et al.] . . . . . . . . . . . . . . . 315

High Resolution Orbitrap Mass Spectrometry for the Analysis of Deuterium-Labeled Lipids in E. Coli [P155], Marie-Pierre Pavageau [et al.] . . . . . . . . . . . . . . . 316

Visualization of metabolic subnetwork with MetExploreViz [P155.1], Maxime Chaza-

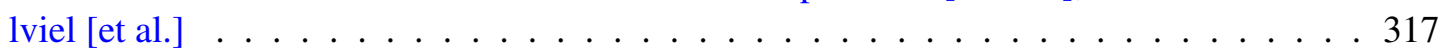

Géochimie / pétroéolomique / astrochimie [P156]

Determination of the efficiency of two deoxygenation catalysts for the upgrading of pyrolysis bio-oil by petroleomic approach [P156], Jasmine Hertzog [et al.] . . . . . . . . 319 
Affinity capillary electrophoresis hyphenated to mass spectrometry to study synthetic sulfated peptides and their non-covalent interactions with the chemokine SDF-1 [P157], Maud

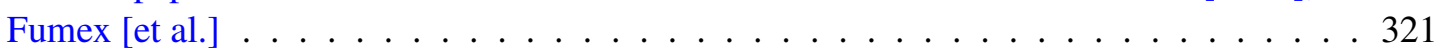

Properties of different forms of small size cationized non-covalent systems formed by phospho-hexose and basic compounds in gas phase: interest for D labeling [P158], Eka-

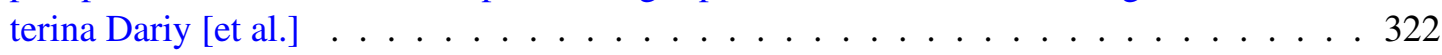

Enrichment strategies for improvement of mass spec analysis of chemical cross-linked

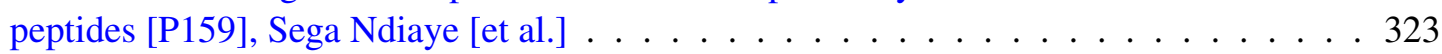

New biochip functionalizations for the SPR-MS coupling [P160], Anastasiia Halushk-

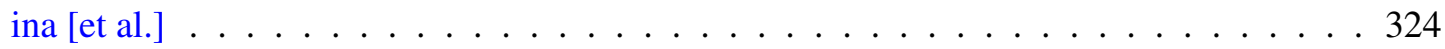

Ion mobility spectrometry of foldamers and foldaxanes. Optimization of parameters used for theoretical CCS calculation [P161], Frederic Rosu [et al.] . . . . . . . . . . . . . 325

Measurement of energy resolved collision induced dissociation and collision induced unfolding in a TWIMS device: critical parameters that need to be assessed [P162], Felindra

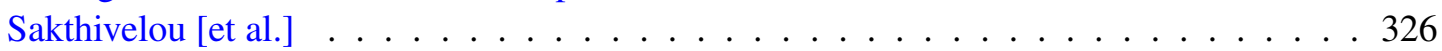

Interactome analysis of the RLTPR protein reveals its essential role in T cells [P163], Luc

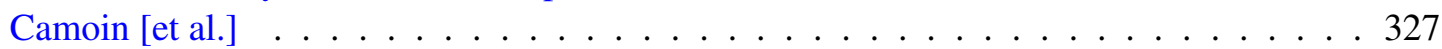

Chemical cross-linking and Mass spectrometry for the structural characterization of retinoic acid receptor complexes [P164], Noëlle Potier [et al.] $\ldots \ldots \ldots 328$

Properties of different forms of small size cationized non-covalent systems formed by phospho-hexose and basic compounds in gas phase: interest for D labeling [P164.1], Eka-

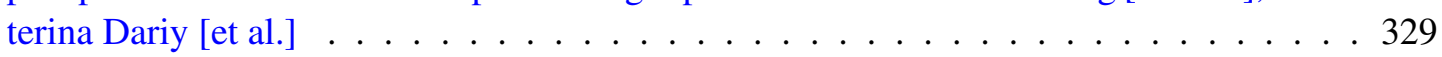

Polymères, molécules synthétiques [P165-P166]

Synchrotron UV photo-activation of trapped ions produced from synthetic polymers by atmospheric pressure photoionization or electrospray mass spectrometry [P165], Véronique

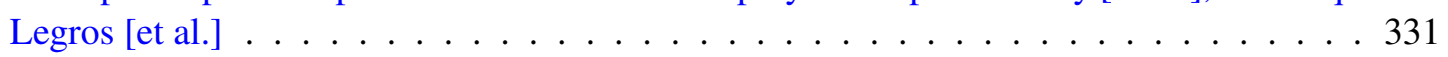

Non-Targeted Screening of Extractables and Leachables in E-cigarettes using a Single Platform UPLC-APGC-QTOF-MS [P166], Mickael Hybois [et al.] . . . . . . . . . . . . 332 
Overview of metabolomics directed sample preparation strategies for a range of biological matrices [P167], Anne-Lise Royer [et al.] $\ldots \ldots \ldots \ldots 34$

La PFP, Plate-Forme Polyphénols de l'INRA à Montpellier [P168], Nicolas Sommerer [et

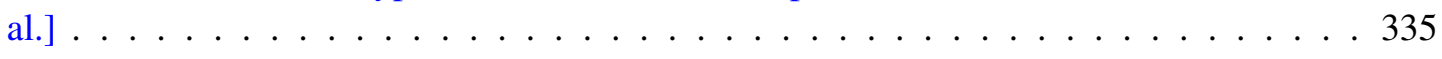

Clic-Imaging, a Mass Spectrometry Imaging platform for clinical studies [P169], Max-

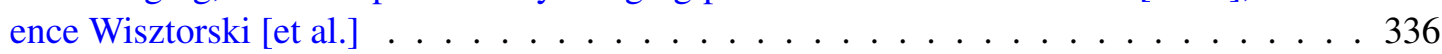

Investigations of cancer metabolism using mass spectrometry based fluxomics [P170], Hanna

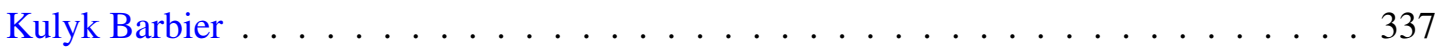

Pôle d'Analyse et d'Imagerie des Biomolécules (PAIB) de la Plate-forme de Chirurgie et d'Imagerie pour la Recherche et l'Enseignement (CIRE) [P171], Valérie Labas . . . . 338

MetaboHUB: Innovation, development and training dedicated to metabolomics and fluxomics [P172], Camille Benard [et al.] $\ldots \ldots \ldots \ldots 339$

Jeudi 5 octobre [P173-P257]

Santé et médecine: mécanismes et biomarqueurs [P173-209]

Gut-derived metabolites study after a bariatric surgery on obese patients [P173], Farid

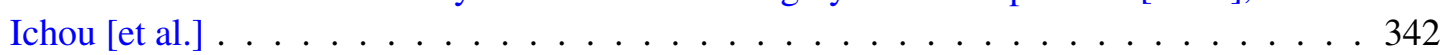

Temporally \& Spatially-Resolved Microproteomics and MALDI MSI Lipidomic Analysis for Traumatic Brain Injury Biomarker Identification [P174], Khalil Mallah [et al.] . 343

Validation of LC-MS analysis of sub-microliter samples: metabolomics analysis of human perilymph fluid [P175], Sylvie Mavel [et al.] . . . . . . . . . . . . . . . . 344

Alternative proteins : The hidden world of spinal cord injury? [P176], Tristan Cardon [et

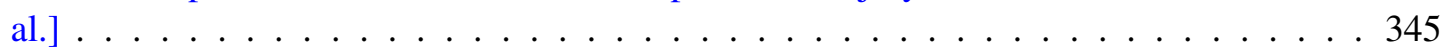

Trouble de stress post-traumatique : dosage de biomarqueurs et compréhension du processus biologique par analyses métabolomiques convergentes [P177], Denis Desoubz-

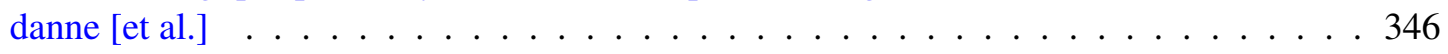

Intérêt de la RMN des solides haute résolution à l'angle magique pour modéliser l'infection pulmonaire à P. aeruginosa et tester de nouvelles thérapies [P178], Audrey Le Gouel-

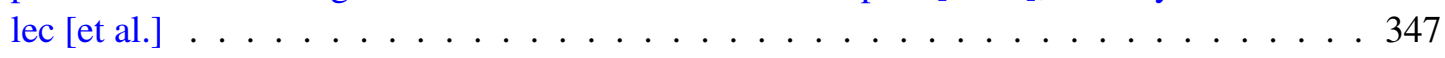

Mass spectrometry and hydrophilic proteoform enrichment method-development for the characterization of Chorionic Gonadotropin glycosylation [P179], Nicolas Eskenazi [et al.] 348 
ESA abuse detection in equine plasma and urine by NMR and LC-HRMS metabolomics [P180], Céline Joré [et al.] . . . . . . . . . . . . . . . . . . . . . 349

Role of the microbiota in the defense against multidrug-resistant Enterobacteriaceae using a NMR-based metabolomics approach [P181], Cécile Canlet [et al.] . . . . . . . . . 350

Une approche multi-échelle incluant la métabolomique décrit l'historique du développement de l'athérosclérose dans un modèle de mini-porc athéro-susceptible [P182], JeanCharles Martin [et al.] . . . . . . . . . . . . . . . . . . . . . . . . . . 351

Impact of repeated dose of stable iodine in the rat using a metabolomic approach [P183], Clément Rosique [et al.] . . . . . . . . . . . . . . . . . . 352

Etude du métabolome folliculaire bovin par RMN 1H [P184], Marie Tremblay-Franco [et al.]............................. 353

Investigating Iron Oxide Nanoparticles Effects on Rat using Proteomic Tools [P185], Dalel Askri [et al.] . . . . . . . . . . . . . . . . . . . . . 354

New insights in the pathophysiology of ADHD by studying the cerebral metabolome in a rat model [P186], Camille Dupuy [et al.] . . . . . . . . . . . . . . . . 355

New Translational Metabolomics Exploration of Age-Related Macular Degeneration: From Patients to Functional Implication of Lactate [P187], Matthieu Schoumacher [et

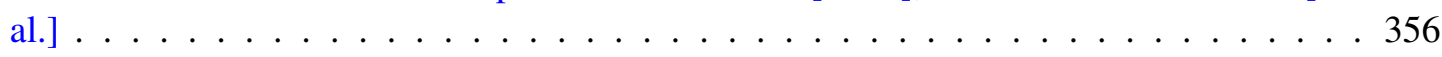

A combined metabolomics and lipidomics approach enables the stratification of acuteon-chronic liver failure patients according to their severity [P188], François Fenaille [et

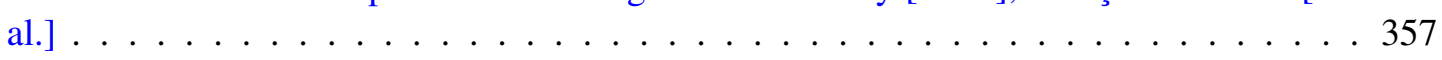

Relation entre maladie d'Alzheimer et perturbation de la voie de la kynurénine dans le métabolisme du tryptophane: exploration d'une étape clef vers la théranostic [P189], Jean Escal [et al.] . . . . . . . . . . . . . . . . . . . 358

Brain PET-18FDG and metabolomics: exploration of a rat model of autism [P190], Laurent Galineau [et al.] . . . . . . . . . . . . . . . . . . . . 359

LC-HRMS Human Urine Metabolic Fingerprints for ESA Doping Control [P191], Céline Joré $[$ et al.] . . . . . . . . . . . . . . . . . . . . 360

MALDI Imaging and High Resolution Mass Spectrometry as a Lipidomic Approach to Assess Nonalcoholic Fatty Liver Disease Pathophysiology and Biomarkers [P192], Julie Le Faouder [et al.] . . . . . . . . . . . . . . . . . . . . 361

Proteomic signature reveals modulation of human macrophage polarization and functions under differing environmental oxygen conditions [P193], Arnaud Millet [et al.] . . . . . 362 
Etude sur l'identification de biomarqueurs prédictifs du risque du cancer du sein par RMN métabolomique [P194], Agnès Victor Bala [et al.] . . . . . . . . . . . . . . 363

Development of proteomic methods on milk for ruminant phenotyping [P195], Mylène Delosière [et al.] . . . . . . . . . . . . . . . . . . . . . . . . . 364

Multi-platform metabolomics and data fusion: application to chronic kidney disease [P197], Yoric Gagnebin [et al.] . . . . . . . . . . . . . . . . . . 365

Matrisome landscape of Head and neck squamous cell carcinoma (HNSCC) -associated fibroblasts [P198], Luc Camoin [et al.] . . . . . . . . . . . . . . . . . . . 366

Mechanisms of IL-33 activation through proteolytic maturation by allergen proteases analyzed by mass spectrometry [P199], Mylène Camus [et al.] . . . . . . . . . . . . 367

Préparation d'échantillon optimisée pour la protéomique urinaire [P200], David Marx [et

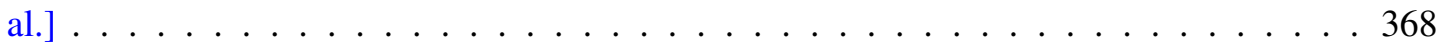

Differential label free analysis to identify microtubule-associated proteins enriched in platelets versus brain or HeLa cells [P201], Agnès Hovasse [et al.] . . . . . . . . . . . 369

Analyse par " label free " du protéome de lésions pré-néoplasiques de cancer du côlon à partir de matériel fixé en formol et inclus en paraffine [P202], Virginie Salnot [et al.] . 370

Quantification absolue de protéines de globules rouges et de réticulocytes purifiés [P203], Emilie-

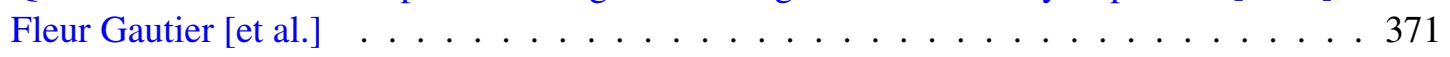

On the Discovery of Biomarkers for River Blindness - Lipidomics, Metabolomics, Proteomics [P204], Ruben T'kindt [et al.] . . . . . . . . . . . . . . . . 372

Applying a Proteoform profiling method for neurological disorder biomarker discovery [P205], Pierre-Olivier Schmit [et al.] . . . . . . . . . . . . . . . . 373

Label-free quantification of T-cell proteome in nephrotic syndrome [P206], Cérina Chhuon [et

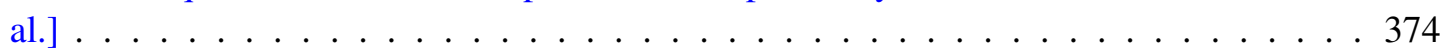

HILIC-HRMS-based metabolite profiling of cerebrospinal fluid for advanced polar metabolome coverage: drawing baseline in aged population without neurological disorder [P207], Ioana

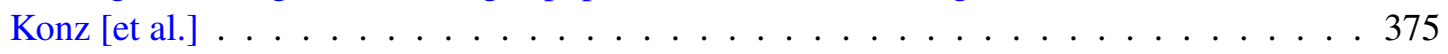

Tspan15 is a new stemness-related marker in hepatocellular carcinoma [P208], Nazha

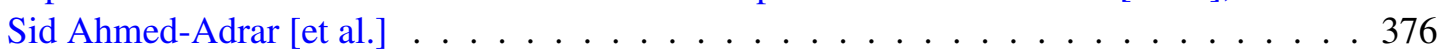

A two-step PRM strategy reveals a new biomarker signature of multiple sclerosis in cerebrospinal fluid [P209], Philippe Marin [et al.] . . . . . . . . . . . . . . 377 
Reductive Di-methylation for Improvements of Mass Spectrometry Acetylation Identification [P210], Issa Diallo [et al.] $\ldots \ldots \ldots$. . . . . . . . . . . . . . . . . . . . . . . . . . . .

Enhancing the vision of signal transduction using PTMScan $\AA$ affinity proteomics [P211], Sriram Aravamudhan . . . . . . . . . . . . . . . . . . 380

Characterization of a disulfide bridge in LC-CDR3 of monoclonal antibody [P212], Hélène

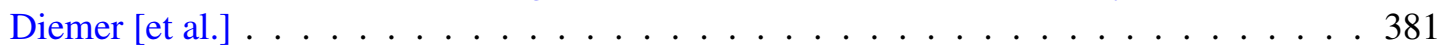

Localisation des sites de O-GlcNAcylation des " odorant-binding protein "par ESI-ETD-

MS/MS [P213], Patricia Nagnan-Le Meillour [et al.] $\ldots \ldots \ldots 382$

Characterization of N- and O-glycosylations of immunoglobulin IgA using NanoLC-

MS/MS and Byonic software [P214], Katell Bathany [et al.] . . . . . . . . . . 383

E4F1-mediated control of pyruvate metabolism: impact on protein acetylation [P215], Michela

Di Michele [et al.] . . . . . . . . . . . . . . . . . . . . 384

Quantitative Analysis of Post Translational Modifications of Proteins: Data Mining and Interpretation [P216], Giovanni Chiappetta [et al.] . . . . . . . . . . . . . 385

Méthodes de quantification ciblée [P217-P225]

Improvement of specificity for multiplex mAbs DMPK triage studies using LC-MRM3

[P217], Quentin Enjalbert [et al.] . . . . . . . . . . . . . . . . . 387

Mise au point d'une méthode de quantification dans le sang de 3 plastifiants suspectés de jouer un rôle dans le déclenchement de certains cancers du sein par $\mu$-LLE suivie d'une analyse par UHPLC-MS/MS [P218], Barbara Giroud [et al.] . . . . . . . . . . . . 388

Quantification of therapeutic monoclonal antibody using ImmunoCapture coupled to Liquid Chromatography- High Resolution Mass Spectrometry (IC-LC-HRMS) [P219], Pauline Bros [et al.] $\ldots \ldots \ldots \ldots \ldots \ldots \ldots \ldots$

Ancient tooth proteomes [P220], Carine Froment [et al.] … . . . . . . . . . 390

Extraction à l'eau subcritique des composés phénoliques de deux espèces du genre Glebionis de Corse [P221], Marion Brunel [et al.] . . . . . . . . . . . . . . . . . . 391

Analysis of chlorogenic acids profile in green coffee leaves by liquid chromatography coupled to an electrochemical detector [P222], Rocio Rodríguez-Gómez [et al.] . . . . . 392 
Étude du mécanisme de rétrocontrôle négatif dans la transmission du message nociceptif : Dosage de la sérotonine et du GABA par microdialyse spinale suite à l'injection d'antalgiques [P223], Jeremy Pinguet [et al.] . . . . . . . . . . . . . . . . . 393

Quantitative profiling of endogenous polar metabolites from low volumes of blood samples [P224], Miranda Kok [et al.] . . . . . . . . . . . . . . . . . . . . . . . . . 394

A generic steroidomic approach: analysing steroid perturbations in serum using a workflow combining untargeted and targeted metabolomics methods with automated annotation [P225], Arnaud Garcia [et al.] . . . . . . . . . . . . . . . . . . 395

Development of a LC-MS-based method for quantifying alkyl hydroxycinnamates [P226], Pierre

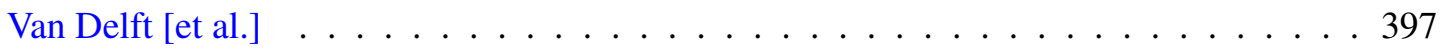

Method development for lipidomic approaches using supercritical fluid chromatography coupled to high resolution mass spectrometry [P227], Carlos Rincon Aguilar [et al.] . . . 398

Development of lipidomic profiling by SFC-HRMS [P228], Pauline Le Faouder [et al.]

Caracterisation du processus de démyelinisation accompagnant un traumatisme cranien chez la souris : étude du lipidome du corps calleux par UHPLC-HRMS [P229], Anne

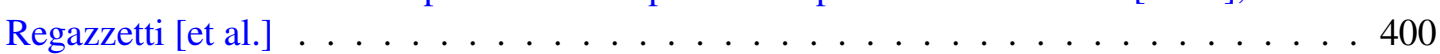

Toxicité de l'oxaliplatine et démyelinisation : analyse lipidomique par UHPLC-HRMS dans un modele de cellule de Schwann [P230], Pauline Cassan [et al.] . . . . . . . . . . 401

Mechanistic re-visitation of phospholipid fragmentations under low energy collision con-

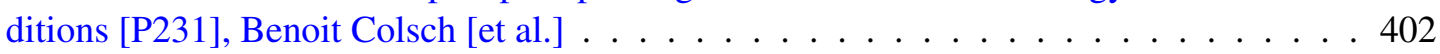

Lipidomics reveals cerebrospinal-fluid signatures of amyotrophic lateral sclerosis [P232], He-

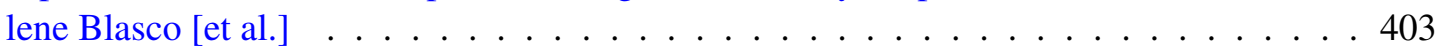

Lipidomic analysis of bovine embryos and oviductal fluids to optimize production of in vitro embryo [P233], Charles Banliat [et al.] . . . . . . . . . . . . . . . . . . 404

Characterization of diet-induced molecular changes in ovarian reserves of Aedes aegypti using 3D-MSI-TOF-SIMS and MALDI FT-ICR [P234], Anthony Castellanos [et al.] . 405

A pilot study for the identification of biomarkers of Ehrlichia ruminantium infection in natural host [P235], Bernard Fernandez [et al.] . . . . . . . . . . . . . . 407 
SHIMADZU Excellence in Science [P236], Cynthia Le Roux [et al.] . . . . . . . . . . . 408

Fréquence des bactéries isolées de laits de mammites bovines à LABEO Manche en 2015 et 2016 par spectrométrie de masse MALDI-TOF avec un focus particulier sur les staphylocoques non-aureus [P237], Fabienne Benoit [et al.] . . . . . . . . . . . . . . 409

Analyse par métabolomique et protéomique de la bactérie marine Pseudoalteromonas lipolytica TC8 cultivée en mode planctonique versus biofilm [P238], Laurie Favre [et al.] 410

Les plantes et les organismes du sol sont bien bavards ! [P239], Virginie Puech Pages [et

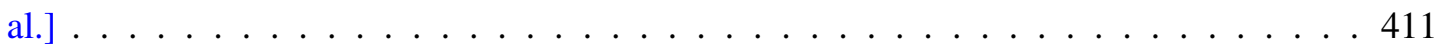

Dynamiques métaboliques lors de l'inhibition de la digestion anaérobie par le phénol par DI-HRMS (Direct-Introduction High-Resolution-MassSpectrometry) [P240], Lénaïck Rouil-

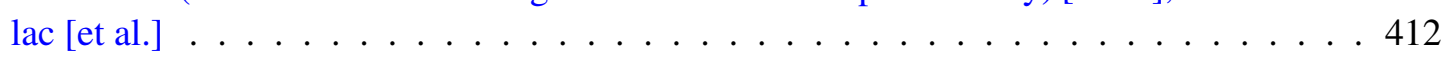

Reduced membrane fluidity of a SigX deficient strain results in altered carbon catabolic repression response in Pseudomonas aeruginosa [P241], Maud Fléchard [et al.] . . . . . 413

Proteogenomic characterization of Escherichia coli ATCC 8739 used for MALDI-TOF calibration in VITEK-MS [P242], Frédéric Jauffrit [et al.] . . . . . . . . . . . . . . . . . 414

Untargeted metabolite discovery in co-cultivation of fungal endophytes Botryosphaeria mamane and Fusarium solani: a time-scale metabolomics method in multi-well plates design [P243], Asih Triastuti [et al.] $\ldots \ldots \ldots \ldots . \ldots \ldots 4 \ldots$

Analyse métabolomique de Listeria monocytogenes : vers une meilleure compréhension des mécanismes de pathogénicité [P244], Samuel Terrier [et al.] . . . . . . . . . . . 4416

Purification et analyse LC-MS/MS de molécules chitiniques fongiques [P245], Adeline

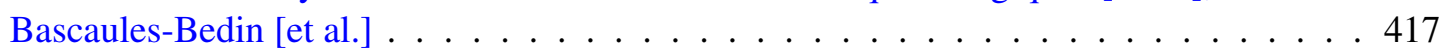

Caractérisation de micro-organismes endophytes par analyse de protéines en spectrométrie de masse MALDI-TOF [P246], Vincent Guérineau [et al.] . . . . . . . . . . . . . . 4418

Analyse du profil lipidique par spectrométrie de masse MALDI-TOF pour l'identification de micro-organismes [P247], Morgane Barthélemy [et al.] . . . . . . . . . . . . . . 419

Caractérisation des protéines du système BAC impliqué dans la formation de biofilms et la production de rhamnolipides chez Pseudomonas aeruginosa [P248], Brahim Saffiedine [et

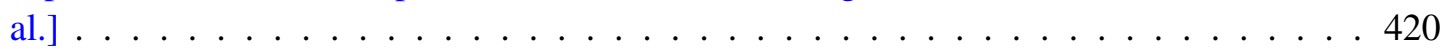

Identification of metabolic biomarkers to follow wound evolution [P249], Kévin Berrou [et

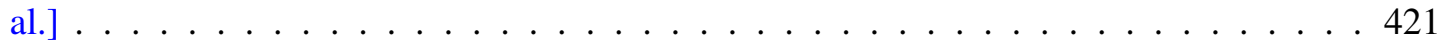

Studies by LC- MS/MS on the phosphorylation sites on the P protein from a fish rhab-

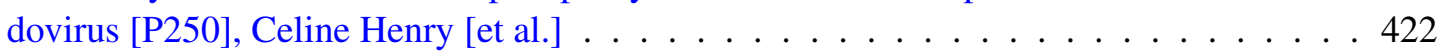


The eukaryotic-like protein kinase is not the only player in the Streptococcus thermophilus serine/threonine phosphorylation process [P251], Celine Henry [et al.] . . . . . . . . . 423

Etude longitudinale du métabolome de Pseudomonas aeruginosa au cours des infections pulmonaires chroniques dans la mucoviscidose [P252], Oriane Moyne [et al.] . . . . . . 424

$\mathrm{N}$-terminomics as a tool for identifying proteolytic cleavage of Toxoplasma gondii [P253], Justine Schneider [et al.] . . . . . . . . . . . . . . . . . . 425

Apport de la métabolomique pour appréhender les mécanismes de régulation et d'export des peptides lasso [P254], Séverine Zirah [et al.] . . . . . . . . . . . . . . . . 426

Adaptation of Listeria monocytogenes to temperature: exploration of intracellular subproteome through shotgun proteomics [P255], Tiago Santos [et al.] . . . . . . . . . . . 427

MALDI Imaging and Profiling Mass Spectrometry approach for the analysis of Listeria monocytogenes biofilms exposed to desiccation [P256], Tiago Santos [et al.] . . . . . . . 428

A pipeline dedicated to Metaproteomics for large cohorts [P257], Celine Henry [et al.] . 429

Exploration de la face cachée du métabolisme bactérien [P257.1], Marcel Salanoubat [et

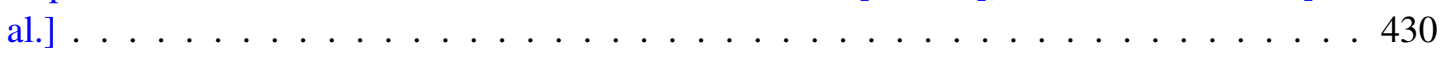

